\author{
Universidade de São Paulo \\ Faculdade de Filosofia, Letras e Ciências Humanas \\ Departamento de Geografia
}

\title{
O Lugar da Fronteira na Geografia de Pierre Monbeig
}

Carlo Eugênio Nogueira

São Paulo

2013 


\author{
Universidade de São Paulo \\ Faculdade de Filosofia, Letras e Ciências Humanas \\ Departamento de Geografia \\ Programa de Pós-Graduação em Geografia Humana
}

\title{
O Lugar da Fronteira na Geografia de Pierre Monbeig
}

Carlo Eugênio Nogueira

Tese apresentada ao Programa de Pós-Graduação em Geografia Humana do Departamento de Geografia da Faculdade de Filosofia, Letras e Ciências Humanas da Universidade de São Paulo, para a obtenção do título de Doutor em Geografia.

Orientador: Prof. Dr. Antônio Carlos Robert Moraes

São Paulo 
Nome: NOGUEIRA, Carlo Eugênio

Título: O lugar da fronteira na geografia de Pierre Monbeig

Aprovado em:

Tese apresentada ao Programa de Pós-Graduação em Geografia Humana do Departamento de Geografia da Faculdade de Filosofia, Letras e Ciências Humanas da Universidade de São Paulo, para a obtenção do título de Doutor em Geografia.

\section{Banca Examinadora}

Prof. Dr.

Instituição:

Julgamento:

Assinatura:

Prof. Dr.

Instituição:

Julgamento:

Assinatura:

Prof. Dr.

Instituição:

Julgamento:

Assinatura:

Prof. Dr. Instituição:

Julgamento:

Assinatura:

Prof. Dr. Instituição:

Julgamento:

Assinatura: 
Para o Eugênio e a Lígia, meus pais.

Para a Juliana: porque existe. 


\section{AGRADECIMENTOS}

O trabalho de pesquisa é sempre solitário, mas não se faz sozinho. Por isso, é necessário agradecer todos aqueles que contribuíram de algum modo para a feitura desta tese ao longo dos últimos quatro anos. Primeiramente, agradeço à minha família: Eugênio e Lígia, por tudo, que é sempre tão acima do que se espera, e os irmãos Érico, Maíce, Rodrigo e Adriana, responsáveis pelas novas estrelas da casa, a Elis e a Joana. Sem a confiança e o amor de todos eles jamais teria conseguido sequer iniciar a caminhada que por ora cessa: esta pesquisa só existe por causa de vocês. Em detalhe, uma menção especial deve ser feita ao poeta Érico Nogueira, que ajudou muito mais do que deveria com a correção gramatical e a organização dos assuntos. Desse modo, fica imediatamente creditado a ele qualquer improvável traço de qualidade no texto, restando unicamente a mim as responsabilidades pelos erros. Assim é porque assim foi.

Parte mais significativa da minha vida, esse trabalho é também da Juliana, que me aguenta (e ponto!), sendo importante lembrar com grande carinho da nova família que me aceitou sem demora. No campo ainda das afinidades, não poderia esquecer de mencionar os amigos de sempre - e os de vez em quando - mandando um abraço para a caravana de Bragança Paulista, de Bueno Brandão, Sampa, Rio de Janeiro, Curitiba, Santos (sempre Santos) e outras paragens menos recomendáveis.

Capítulo à parte, lembro que a pesquisa não seria a mesma sem o professor Antônio Carlos Robert Moraes, para quem ofereço cordialmente os parcos resultados deste trabalho. Sua orientação sincera e sua amizade generosa, que tenho o prazer de compartilhar já há mais de 10 anos, tornaram as dificuldades do trajeto mais palpáveis: Tonico, é sempre bom contar com o guia certo para indicar os atalhos. Obrigado!

Ao professor Manoel Fernandes de Souza Neto fica aqui uma nota especial pela inestimável ajuda e pelas palavras de incentivo na reta final. Aproveitando o ensejo, agradeço também ao pessoal do Laboratório de Geografia Política do Departamento de Geografia da Universidade de São Paulo, o nosso GEOPO, com um beijo grande para a excepcional Clenes Loureiro, amiga sempre disponível para ajudar no que for necessário.

Por fim, agradeço à Fundação de Amparo à Pesquisa do Estado de São Paulo (FAPESP) pelo auxílio financeiro concedido durante a vigência da bolsa de doutoramento entre 2009 e 2013, sem a qual não conseguiríamos desenvolver essa pesquisa à contento. 
"A Totalidade está sempre em movimento, num incessante processo de totalização, nos diz Sartre. Assim, toda totalidade é incompleta, porque está sempre buscando totalizar-se. Não é isso mesmo o que vemos na cidade, no campo ou em qualquer outro recorte geográfico? Tal evolução retrata o movimento permanente que interessa à análise geográfica: a totalização já perfeita, representada pela paisagem e pela configuração territorial e a totalização que se está fazendo, significada pelo que chamamos de espaço. Se o ser é a existência em potência, segundo Sartre, e a existência é o ser em ato, a sociedade seria, assim, o Ser e o espaço, a Existência. É o espaço que, afinal, permite à sociedade global realizar-se como fenômeno. Assim, o espaço é, antes do mais, especificação do todo social, um aspecto particular da sociedade global. A produção em geral, a sociedade em geral, não são mais que um real abstrato, o real concreto sendo uma ação, relação ou produção específicas, cuja historicidade, isto é, cuja realização concreta somente pode dar-se no espaço." 


\section{RESUMO}

Este trabalho procura avaliar a relação existente entre a expansão espacial do povoamento ocorrida no Brasil na primeira metade do século XX e o processo de formação territorial do país, trazendo a lume a importância das relações sociais que ocorriam na fronteira para a composição de uma explicação geográfica sobre o fenômeno do pioneirismo. Tomando como ponto de partida a análise da noção de frente pioneira explicitada na obra do geógrafo francês Pierre Monbeig entre as décadas de 1930 e 1950, busca-se apontar de que maneira a descrição explicativa das áreas de movimentação de fronteiras dinamizadas pela expansão espacial da colonização, que impulsionou a fundação de cidades, o desmatamento de florestas e a abertura de campos de cultivo e pastos, comporta uma análise sobre o processo de construção dos sistemas de engenharia que conseguiram consolidar nexos de solidariedade entre distintos lugares, garantindo maior fluidez e integração a um território que modificava sua organização espacial para se adequar às novas necessidades surgidas com a expansão do capitalismo no Brasil.

Figura de destaque no ensino e pesquisa em geografia desenvolvidos no Brasil nas décadas de 1930 e 1940, especialmente na Faculdade de Filosofia, Ciências e Letras da Universidade de São Paulo, onde foi um dos fundadores do curso de Geografia e História, Pierre Monbeig é um dos protagonistas da institucionalização acadêmica do campo geográfico no país, influenciando diretamente a formação da primeira geração de geógrafos brasileiros saídos dos bancos universitários. Assim sendo, este trabalho colocou como objetivo específico rastrear a influência do enquadramento oferecido por Monbeig em seus trabalhos sobre o pioneirismo nas pesquisas de autores como Ary França, José Ribeiro de Araújo Filho, Renato da Silveira Mendes, Nice Lecocq Müller e Pasquale Petrone, discípulos do francês que assumiram uma posição institucional de relevo no cenário da geografia brasileira a partir da década de 1950, tornando-se os continuadores do curso de Geografia da FFCL/USP.

Palavras-chave: Frentes Pioneiras - Território - Pierre Monbeig - Fronteira - História do Pensamento Geográfico 


\begin{abstract}
The aim of this work is to analyze the relation between the spatial expansion of Brazilian settlement occurred in the first half of the twentieth century and the process of territorial formation, with a focus on the role of the frontier's social relations in the construction of a geographic approach for the pioneering phenomena. Based upon the analysis of the pioneer fringe as it is expounded in the work of French geographer Pierre Monbeig between the 1930's and the 1950's, we intend to point out in what ways the descriptive explanation of the moving frontier, which impelled, for its turn, the foundation of cities, the deforestation and the formation of agriculture fields and pastures, reveals an interpretation about the construction of engineering systems planned to consolidate spatial relations among different places in the Brazilian territory, ensuring the territorial integration necessary for the expansion of capitalism in Brazil.

Pierre Monbeig is a distinguish figure of the Brazilian geographic movement, fulfilling an important role in the institutionalization of the geographic scientific field as one of the greatest scholar figures that ever worked in this country. The analysis of the influence brought together with his activities as a teacher and researcher developed in the Department of Geography of the São Paulo University during the 1930's and the 1940's, which he helped to organize and establish, can be taken in consideration as a demonstration of the reach of his works for the generation of students that came after him in the University. Thus, this work seeks to examine the influence of the explicative frame held in Monbeig's studies of the pioneer fringe on the research developed by authors like Ary França, José Ribeiro de Araújo Filho, Renato da Silveira Mendes, Nice Lecocq Müller and Pasquale Petrone, all of them future teachers in the same Department of Geography in São Paulo.
\end{abstract}

Key words: Pioneer Fringe - Territory - Pierre Monbeig - Frontier - History of Geographical Tough 


\section{SUMÁRIO}

APRESENTAÇÃo

\section{CAPÍTULO I}

O BRASIL QUE ENCONTRA PIERRE MONBEIG

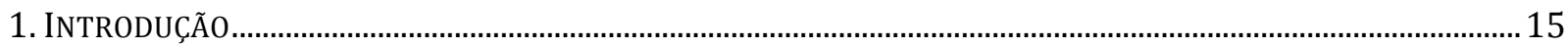

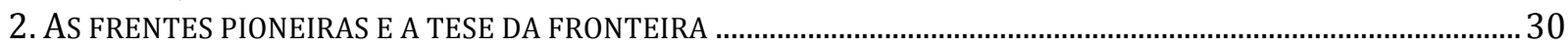

3. INTEGRAÇÃO TERRITORIAL, OS INTELECTUAIS E O DEBATE POLÍTICO ………...................................................... 43

4. A APROPRIAÇÃO TECNOCIENTÍFICA DO TERRITÓRIO: O IBGE E AS EXPEDIÇõES CIVILIZATÓRIAS....................... 67

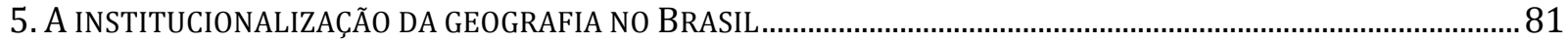

6. AS NUANCES DE UMA TENTATIVA DE REGIONALIZAÇÃO ....................................................................................... 111

\section{CAPÍTULO II}

A MOBILIDADE DO POVOAMENTO E A PSICOLOGIA BANDEIRANTE

1. INTRODUÇÃO 121

2. VISÕES 'TRADICIONAIS' DA OBRA DE PIERRE MONBEIG 123

3. OS FATORES PSICOLÓGICOS E A ORGANIZAÇÃO DAS PAISAGENS PIONEIRAS....................................................... 133

4. A EXPANSÃO DA COLONIZAÇÃO E OS VETORES DE MODERNIZAÇÃO DO TERRITÓRIO ............................................ 167

\section{CAPÍTULO III}

A GEOGRAFIA DAS FRENTES PIONEIRAS: ANTECENDENTES E DEFINIÇÕES

1. A CRISE DE 1929 E OS NOVOS TEMAS DE PESQUISA DA GEOGRAFIA ACADÊMICA ............................................ 195

2. ALBERT DEMANGEON, ISAIAH BOWMAN E A GEOGRAFIA DO PIONEIRISMO …................................................ 222

3. O PIONEIRISMO SEGUNDO PIERRE MONBEIG............................................................................................. 256

\section{CAPÍTULO IV}

A GEOGRAFIA FRANCESA FAZ ESCOLA

1. INTRODUÇÃO

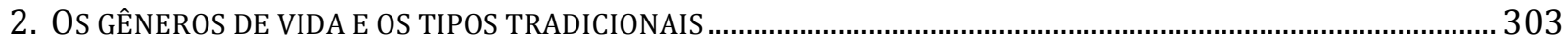

3. A IMPORTÂNCIA DAS TÉCNICAS: O CAFÉ COMO FATOR DE REGIONALIZAÇÃO................................................... 312

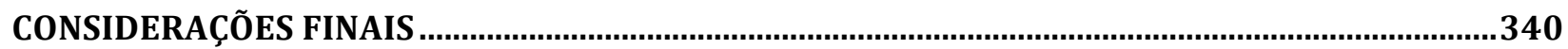

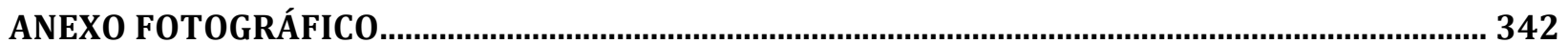

BIBLIOGRAFIA 


\section{APRESENTAÇÃo}

A história deste trabalho iniciou-se em 2003, quando o professor Antônio Carlos Robert Moraes recrutou um conjunto de alunos de graduação para iniciar um grupo de estudos sobre geografia histórica, naquilo que foi o estopim para a organização do Laboratório de Geografia Política no Departamento de Geografia da Faculdade de Filosofia, Letras e Ciências Humanas da Universidade de São Paulo (GEOPO - DG/FFLCH/USP). Na época, esse grupo de geógrafosaprendizes tinha o objetivo de contribuir para a reconstrução da geografia material dos anos que antecederam o processo de emancipação política do Brasil, buscando mais elementos para equacionar algumas dúvidas que ainda se colocam para a historiografia brasileira, tais como: qual era o espaço construído herdado com que contava o Brasil no momento em se desvencilhava de sua condição de colônia? E qual foi o papel do território para a formação do Estado e da Nação?

Apresentou-se então, pela primeira vez, o tema da formação territorial. Continuando os estudos no campo da geografia histórica durante o mestrado, cujas pesquisas de gabinete e de campo versando sobre as antigas províncias de Goiás e Mato Grosso na passagem do século XVIII para o XIX foram feitas entre 2005 e 2008, certas questões de cunho teórico que haviam sido apenas tangenciadas anteriormente foram aprofundadas, principalmente às que se referiam ao papel da expansão da fronteira no processo de formação do território brasileiro. De fato, a relação existentes entre a expansão do povoamento para os sertões goiano e mato-grossense impulsionada pela economia mineradora, e o desenvolvimento de políticas territoriais com o intuito de consolidar a soberania da coroa portuguesa por áreas que excediam em muito as terras efetivamente ocupadas em seus três séculos de dominação, apresentava-se como o eixo de maior interesse para o momento, principalmente pela necessidade de justificar a diferença existente entre a borda do povoamento dinamizada pela rede de cidades construída em Goiás, que demarcava os limites ao território usado da colônia, e as áreas de fronteira ligadas aos núcleos avançados do Mato Grosso, que conferiam certa materialidade ao espaço de soberania formal da América portuguesa, sendo alvo prioritário de ações de cunho geopolítico.

Ao final, o interesse no conceito geográfico de fronteira ganhou corpo, e foi novamente por sugestão do professor Antônio Carlos Robert Moraes que saímos da geografia histórica para enveredarmos no campo da história do pensamento geográfico. No caso, a obra de Pierre Monbeig foi de pronto definida como o objeto de estudo, visto que a exiguidade de estudos específicos sobre o geógrafo francês contrasta com sua importância para a consolidação do 
campo disciplinar no país. Na verdade, pode se contar nos dedos das mãos os livros e artigos em português que têm Pierre Monbeig como objeto de estudo pormenorizado, sendo ainda relevante observar que os geógrafos das gerações mais recentes desconhecem quase por completo a noção de franja pioneira cunhada por Monbeig, uma vez que é muito comum encontrar referências às definições que sociólogos antropólogos e economistas fazem do fenômeno pioneiro na bibliografia de trabalhos geográficos que se utilizam do termo.

Seja como for, a leitura aprofundada dos textos do autor que analisam o fenômeno da expansão pioneira ocorrida em São Paulo e no Paraná na primeira metade do século XX foi o caminho escolhido aqui para o desenvolvimento do tema. Especificamente, avaliamos igualmente a influência de Monbeig no trabalho de seus discípulos brasileiros, procurando estabelecer se houve no Brasil a formação de uma linhagem intelectual dentro do campo geográfico. Realmente, a falta de estudos pormenorizados que refazem em detalhe o processo de organização institucional da geografia em São Paulo, a exemplo do trabalho que Mônica Sampaio (2009) esboçou para a geografia universitária no Rio de Janeiro, demonstrou-se uma lacuna incontornável, pois uma pesquisa desse tipo demandaria um esforço de levantamento documental das atas e decisões internas de departamentos e universidades que excederia em muito a proposta dessa pesquisa. Some-se então a conhecida desorganização existente nos arquivos mortos do meio universitário, que preza pouco a preservação da memória viva nos documentos, à pouca disposição dos geógrafos para a labuta quase braçal da leitura de fontes primárias e temos então o cenário perfeito para a inexistência de estudos de história do pensamento geográfico que privilegiem a história institucional pela via dos documentos. Esperamos que o avanço da digitalização mude esta situação em um futuro próximo.

De volta à nossa pesquisa, para a consecução dos objetivos colocados dividimos o trabalho em três grandes capítulos, que podem ser lidos como três partes, ao que se segue um capítulo final de conclusão. Assim sendo, no primeiro capítulo, de cunho mais historiográfico, apresentamos um painel que tenta reconstruir a realidade política, econômica e intelectual com a qual Pierre Monbeig se defrontou quando chegou ao país. Dividido em seis partes, esse painel é unificado pelo tema da formação territorial e da integração do território, pois analisa tanto os projetos políticos que tinham o território como objeto principal, como por exemplo o programa "Marcha para o oeste", implantado por Getúlio Vargas durante seu período de ditador no Estado Novo, quanto determinadas concepções sobre o território que eram comuns no ambiente 
intelectual nacional, retroalimentando as políticas territoriais. Ao final, apresentamos a trajetória de institucionalização da geografia no país, tentando estabelecer o protagonismo de Monbeig na estruturação de um grupo de geógrafos na Universidade de São Paulo.

De fato, no primeiro capítulo são levantadas diversas questões que serão retomadas e aprofundadas posteriormente, uma vez que o contexto histórico da época foi pensado como um embasamento para esclarecer o modo como o autor ora apreciado interpretou as transformações estruturais pela qual passava o território brasileiro em seu processo de formação, influenciado então decisivamente pela expansão das relações capitalistas de produção. Logo, como os discursos geográficos produzidos à época tinham como referência básica a materialidade expressa na organização, localização e disposição dos objetos na superfície terrestre, espera-se que a reconstrução da geografia histórica do capitalismo em nosso país possa ser capaz de fornecer boas ferramentas de análise para acedermos a uma dimensão de feição metageográfica (MORAES, 2000), que toma a produção teórica da geografia universitário-acadêmica por si como objeto de análise.

Nessa direção, J.B. Arrault (2007) esmiúça o trajeto de construção de um problema intelectual dentro da comunidade científica dos geógrafos, questionando o modo como, entre 1890 e 1930, os geógrafos franceses entretidos na estabilização dos Annales de Géographie elevaram o processo de mundialização que percebe e concebe a Terra como uma totalidade à condição de objeto de estudo. Apoiado nos escritos de Lewis e Wigen (1997), a definição para o termo metageografia completa o significado acima descrito: trata-se não só de tomar a produção acadêmica interna ao campo disciplinar como objeto, mas de problematizar a própria formação de certos modos de pensar e firmar imagens acerca da realidade. Assim, as metageografias referir-se-iam às diferentes maneiras como os indivíduos e grupos imersos numa determinada realidade sociocultural organizam o conhecimento do mundo por meio de categorias espaciais, fato exemplificado na divisão dos "Três Mundos" operada pelo contexto da Guerra Fria, no atual redimensionamento do mundo em "regiões globais" ou mesmo nas clássicas divisões do planeta em continentes ou em Estados-nação: "by metageography we mean a set of spatial structures through which people order their knowledge of the world: the often unconscious frameworks that organize studies of history, sociology, anthropology, economics, political science, or even natural history" (LEWIS e WIGEN, 1997, p. IX). 
No caso aqui em questão, toma-se por princípio que a noção de franja pioneira é a forma pela qual a geografia acadêmica analisa o processo de expansão territorial do capitalismo no Brasil. Desse modo, a análise de como certos projetos políticos concebiam as terras interiores do território brasileiro como "sertões", espaços vazios à espera de desenvolvimento, são a base contextual para o desenvolvimento de uma análise metageográfica da noção de frente pioneira. Já no segundo capítulo, para avaliar o lugar comum que considera a obra de Pierre Monbeig sobre as frentes pioneiras como uma justificativa científica para os anseios de uma fração da burguesia paulista que o trouxe a São Paulo, como se seus escritos pudessem ser reduzidos a uma específica ideologia de classe, analisamos de que modo o francês trata a questão da "psicologia bandeirante" em suas obras. Nesse caso, sustenta-se que a preocupação de Monbeig com a chamada geografia das mentalidades revela a abertura do francês a temas que eram incomuns na literatura geográfica de então, pois, para ele, os fatores subjetivos que poderiam ser identificados em alguns traços da mentalidade dos pioneiros brasileiros, ajudariam a compor de maneira mais completa o complexo geográfico, que é o conceito com o qual Monbeig verdadeiramente trabalha.

Em muitas passagens de sua obra, Monbeig realmente se aproximava da retórica territorialista do Estado Novo, considerando a expansão da colonização e do povoamento catalisada pelas lavouras de café e algodão como a forma mais acaba assumida pela "Marcha para oeste" no Brasil. Desse modo, ao elaborar uma explicação que combinava a expansão das lavouras, a fundação de cidades, o desenvolvimento de indústrias e a implantação um novo tipo de economia, Monbeig forneceu uma explicação adequada ao projeto de poder dos círculos de intelectuais, políticos e empresários que ele frequentava. Assim, mesmo que não represente a assunção do geógrafo a nenhum específico projeto político, seja o do governo federal, seja o da burguesia cafeeira de São Paulo, ao tratar da psicologia bandeirante Monbeig indica as possibilidades de relacionamento e acomodação entre a burguesia paulista e Getúlio Vargas após os embates de 1932. Contudo, do ponto de vista do campo geográfico, a valorização dos fatores subjetivos que influem na organização do complexo geográfico não deve ser ofuscado.

No terceiro capítulo analisamos de forma aprofundada a noção de franja pioneira, discutindo os autores que mais influenciaram Monbeig no tratamento desse tema, como Albert Demangeon e Isaiah Bowman, bem como certas modificações pelas quais passou o entendimento do próprio autor com o passar dos anos. Como um todo, nesse capítulo expressa-se de maneira eloquente a importância que Monbeig conferia à circulação na construção de seu arranjo 
explicativo, pois vemos de que maneira as vias de comunicações que tomaram forma nas ferrovias e rodovias definem em grande parte as direções da expansão pioneira. Entendida como um aspecto no limite acidental da busca por novas terras férteis, essas próteses territoriais conseguiram estabelecer nexos de solidariedade entre regiões que até então encontravam-se ilhadas, sem contato um com a outra. A maior fluidez do território, como define Milton Santos, incentiva o desenvolvimento econômico e o crescimento demográfico nas cidades, estabilizando em certa medida o povoamento móvel que caracterizava a expansão pioneira, que ficava assim atrelado às fundações urbanas, principalmente pela formação de um mercado interno.

Esse entrelaçamento entre a expansão dos campos de cultivo e a fundação de cidades, paradoxos aparentes que unificam em um mesmo movimento a mobilidade da população ocupada com uma atividade agrária e a imobilidade do povoamento da cidade, a expansão do espaço agrícola e o crescimento das indústrias, podem ser vistos como manifestações territorializadas do crescimento geograficamente desigual que marca a expansão do capitalismo no Brasil. Ao final, a explicação geográfica sobre as franjas pioneiras elaborada por Monbeig, a despeito de como ele descrevia tais fenômenos, exemplifica a maneira como a geografia acadêmica participava do debate mais amplo colocado no pensamento político-social, tratando ao seu modo de questões sobre o desenvolvimento econômico e a fixação do povoamento.

Por fim, no quarto e último capítulo, um pouco mais curto que os demais, retomamos com mais vagar as obras dos geógrafos uspianos escritas nas décadas de 1940 e 1950, apontando em cada uma delas algumas passagens que ilustram a influência do enquadramento de Monbeig sobre o fenômeno do pioneirismo em suas análises. De fato, segundo queremos crer, a expansão do capitalismo que é pano de fundo das movimentações pioneiras constituiu-se em um padrão ideal para a apreciação do nível de desenvolvimento das diferentes regiões paulistas. Nesse caso, quando os geógrafos uspianos qualificam uma área como atrasada ou decadente o que eles tinham em mente era exatamente o processo de desenvolvimento então experimentado pelas cidades dos planaltos ocidentais. Com isso, as modificações introduzidas em determinadas regiões pela implantação de um novo produto agrícola com fins comerciais ou a adoção de novas técnicas de exploração do solo seriam considerados como fatores de evolução das paisagens a partir do que havia ocorrido nas áreas de movimentação de fronteira. Finaliza o trabalho um breve anexo fotográfico, sendo então esses, em linhas gerais, os aspectos que tentamos mostrar ao longo deste trabalho. 


\section{CAPÍTULO I}

\section{O BRASIL QUE ENCONTRA PIERRE MONBEIG}

"A análise e a reflexão da obra e do pensamento do geógrafo francês Pierre Monbeig são da maior importância para os estudiosos de Geografia do Brasil. Pierre Monbeig foi o geógrafo estrangeiro que permaneceu por maior espaço de tempo em nosso pais, num momento em que a geografia brasileira passava a ser pensada de forma científica e autônoma; exercendo o magistério na Universidade de São Paulo e realizando pesquisas, teve uma grande influência sobre a primeira geração de geógrafos brasileiros, participando direta ou indiretamente dos primeiros trabalhos cientificos, especialmente geográficos, no nosso país."

Manuel Correia de Andrade

\section{Introdução}

É comum encontrar nos textos clássicos que tratam da história do pensamento geográfico brasileiro - como o capítulo escrito por José Veríssimo da Costa Pereira (1955) para a obra "Ciências no Brasil", dirigida por Fernando de Azevedo; a contribuição de Pasquale Petrone (1979) na coleção "História das Ciências no Brasil"; o opúsculo precursor de Carlos Augusto de Figueiredo Monteiro (1980); ou mesmo o artigo de Nilo Bernardes (1982), que analisa as influências estrangeiras na geografia brasileira - a referência destacada ao papel de Pierre Monbeig na formação e desenvolvimento da ciência geográfica e da profissão do geógrafo no Brasil. Enfatizando esta sua proeminência na estruturação do campo disciplinar em nosso país, atribui-se à sua atuação profissional como professor e pesquisador a formação de um círculo de discípulos progressivamente dilatado ao longo da década de 1940, o que culminou com o florescimento, em São Paulo, de "um certo espírito de grupo profissional então praticamente inexistente nas áreas geográficas das demais universidades" (BERNARDES, 1982, p. 522) e, pois, da tendência de colaboração expressa sobretudo nas excursões de campo que esses mesmos discípulos, ao assumirem as cátedras organizadas por Monbeig na Faculdade de Filosofia, Ciências e Letras da USP, mantiveram nas décadas subsequentes.

Nascido em Marissel, no departamento de Oise, em 15 de setembro de 1908, e falecido em Cavalaire, no Var, em 22 de setembro de 1987, Monbeig fez os estudos primários em casa, sob orientação de seus pais, e os estudos secundários nos liceus parisienses Montaigne e Louis-leGrand. Por essa época, na década de 1920, frequenta o Instituto de Geografia da Universidade de Paris, na Sorbonne, obtendo por esta instituição, sucessivamente, a Licence em História e 
Geografia, em 1927, o Certificat e o Diplôme d'Etudes Supérieures, em 1928, e o título de Agrégé de l'Université (História e Geografia), que possibilitava sua entrada como professor no sistema de educação francês, aos 21 anos, em $1929^{1}$.

De posse de sua Agrégation, Monbeig parte para a Espanha, onde permanecerá de 1929 a 1931, como bolsista da École de Hautes Études Hispaniques / Casa de Velázquez, em Madrid, dando início aos trabalhos de pesquisa necessários para a confecção de sua tese de doutoramento, projetada inicialmente para se desenvolver sob a orientação de Albert Demangeon. Elegendo como terrain as ilhas Baleares, dedica-se integralmente ao seu objeto de estudo nesses primeiros dois anos, reservando os períodos de férias escolares para outras viagens de campo entre 1931 e 1934, quando é designado e assume o cargo de professor secundário no Liceu Malherbe, em Caen, na Normandia ${ }^{2}$.

Em 1935, após convite feito por Georges Dumas, desde o início do século XX o principal animador das relações culturais encetadas entre o Brasil e a França ${ }^{3}$, Monbeig chega ao Brasil, tendo como destino a cadeira de Geografia da Faculdade de Filosofia, Ciências e Letras da USP, criada no ano anterior por Pierre Deffontaines (PEIXOTO MASSI, 1991). Substituindo este discípulo de Jean Brunhes, que fora requisitado no Rio de Janeiro para fundar o novo curso de geografia a ser implantado na Universidade do Distrito Federal (UDF), instituição de vida breve que antecede a instalação da Universidade do Brasil (UB) (SAMPAIO, 2009), Monbeig, que assinou inicialmente um contrato de dedicação exclusiva com duração de 3 anos, permaneceria

\footnotetext{
${ }^{1}$ As informações biobibliográficas aqui compiladas têm como principais fontes as entrevistas e artigos publicados por Théry e Droulers (1991), bem como a coletânea organizada por Salgueiro (2006), que trabalhou diretamente com o arquivo pessoal de Monbeig lotado no Instituto de Estudos Brasileiros (IEB - USP), e os trabalhos de Dantas (2002; 2005). Vale também deixar como referências de base os estudos de Manuel Correia de Andrade (1987; 1994) e a notícia necrológica de Olivier Dollfus (1987), além das informações contidas nos relevantes depoimentos de Aziz Ab'Saber (1994) e Pasquale Petrone (1994), ex-alunos que conviveram com Monbeig durante sua estadia no Brasil.

${ }^{2}$ Dessa época que antecede sua vinda ao Brasil, Heliana Angotti Slagueiro (2006) localizou uma série de 10 artigos. A maioria (seis) foi publicada nos Annales de Geographie, o que por si só bastaria para tornar evidentes os liames que o prendiam ao círculo de afinidades intelectuais hegemonizado pelas figuras de Emmanuel De Martonne e Albert Demangeon no Instituto de Geografia da Sorbonne, que detinha o controle editorial dos Annales. Digno de nota, de todo modo, são os dois artigos publicados no futuramente prestigioso periódico Annales d'Histoire Économique et Sociale, veículo de divulgação da nova corrente historiográfica, o que indica uma contínua colaboração de Monbeig com o campo da história que seria estreitada ao longo dos anos vindouros, mas que nesse momento revela a ascendência preponderante dos historiadores Lucien Febvre e Marc Bloch, seus professores na Universidade de Paris e influências posteriormente reconhecidas por Monbeig como capitais para sua formação.

${ }^{3}$ Georges Dumas (1866-1946), médico e filósofo que fez sua carreira sempre em trânsito por essas duas áreas, foi por décadas chefe do Laboratório de Psicologia Patológica da Faculdade de Medicina, em Paris, além de responsável pela cátedra de Psicologia Experimental da Sorbonne. Como veremos, Dumas será um dos principais responsáveis pelo recrutamento dos professores franceses para a Faculdade de Filosofia, Ciências e Letras da USP (PEIXOTO MASSI, 1991).
} 
no Brasil por longos 10 anos, retornando à França somente em 1946, após o término da II Guerra Mundial (1939-1945).

As circunstâncias que envolvem a mudança de tema de Monbeig, que deixa de lado sua tese sobre as ilhas Baleares, já em fase avançada de redação, para tratar das franjas pioneiras paulistas, conta com decisiva participação de Henri Hauser (1866-1948), historiador de renome, professor e antigo orientador de sua esposa, Juliette Monbeig. De fato, Hauser era amigo do físico e matemático Paul André Marie Janet, que iria se tornar sogro de Monbeig, e ambos, Hauser e Janet, colegas de Georges Dumas, que os havia trazido ao Brasil, em 1925, numa das conferências do Groupament ocorrida quando a criação de uma universidade nos moldes da USP era ainda projeto embrionário no país. Por uma dessas coincidências que assumem grande significado numa visão retrospectiva construída a posteriori, a jovem Juliette Janet esteve com seus pais durante essa viagem, guardando do Brasil lembranças que certamente ajudaram-na a fazer propaganda do país a seu futuro esposo, como revelou em entrevista o próprio Monbeig (BATAILLON, 1991).

Sobre o Groupement, sabe-se que foi criado por um grupo de professores universitários liderados por Henry Le Châtelier e Paul Appel, ao final do ano de 1907, no Collège de France, em Paris, e dissolvido durante a ocupação alemã, em 1940, sendo um dentre outros inúmeros organismos culturais subvencionados pelo Ministério de Relações Exteriores francês para gerir as políticas culturais do país centradas na América Latina, e atuando com desenvoltura principalmente no Brasil, no México e na Argentina, onde organizava, por intermédio dos Institutos Franceses, liceus e outros centros de atração de francófonos, conferências com intelectuais e cientistas franceses de renome ${ }^{4}$. Tido inicialmente como um órgão autônomo ocupado tão-somente com a cooperação universitária e científica, ao longo da década de 1920 o

\footnotetext{
4 "O final do século XIX e as primeiras décadas do século XX, particularmente o período anterior à I Guerra Mundial, podem ser descritos como um momento de intenso contato com a França. No plano científico, são as idéias de evolução, o darwinismo, o positivismo, o materialismo que encontram eco nas elites políticas e intelectuais brasileiras (...). Se a cultura francesa teve um grande impacto em todo o mundo neste período, é preciso lembrar que na América Latina tal trânsito de ideias esteve amparado por um sólido suporte institucional, principalmente no que diz respeito à cooperação científica. Em 1908, se reunia pela primeira vez, em Paris, o comitê fundador do Groupement des Universités et Grandes Écoles de France pour les relations avec l'Amérique Latine, visando desenvolver as relações intelectuais entre a França e a América Latina de modo geral e, em particular, promover a Universidade e a ciência francesas no exterior (...). A origem dos contatos de Dumas com o Brasil remonta a 19071908, quando ele é convidado por um dos seus alunos brasileiros para dar conferências no Rio e em São Paulo. Paul Appel, ao tomar conhecimento da viagem, pede a Dumas que viabilize a atuação do Groupament no país. Quando retorna ao Brasil em 1917-1918, enviado pelo Governo francês como médico do exército (é dessa época a criação do Hospital Brasileiro), aproveita para detalhar o plano de criação de liceus franceses no Brasil." (PEIXOTO MASSI,1991, pp. 28-29/31.)
} 
escopo de suas ações vai sendo paulatinamente deslocado do âmbito universitário para o campo estritamente político e diplomático, para o que sem dúvida contribuiu a visão da ciência como uma atividade antes de tudo cultural e a retórica acerca da latinidade, que focava as operações desenvolvidas no ensino e na difusão da língua francesa (PETITJEAN, 1996; SUPPO, 2000):

Os organismos para as "relações intelectuais" que se constituem na França, como em outros países, cobrem diferentes aspectos culturais e científicos. Mais freqüentemente, eles são de iniciativa do Estado, tomando, às vezes, a forma de uma estrutura nos ministérios: o Service des Ouevres do Ministério das Relações Estrangeiras da França, ou o Service pour l'Expansion Scientifique do Ministério da Instrução Pública, nos primeiros anos do século XX. Esses dois organismos asseguram o controle político geral do Estado sobre a expansão intelectual, particularmente pelo viés do financiamento. Eles são completados por organismos autônomos, como a Aliança Francesa no domínio cultural (da aprendizagem da língua), criada no fim do século XIX. É o caso também do Office National des Universiés et Écoles Françaises (Onuef). Esse organismo, encarregado da cooperação escolar e universitária, foi criado em 1910 por parlamentares e professores. Seus objetivos recuperam os do Groupement, e os dois organismos colaborarão cada vez mais estreitamente, sendo reservada para o segundo a América Latina. Mas o Groupement diferencia-se sob dois aspectos: concentra-se na cooperação universitária e científica (e só se interessa marginalmente pelos intercâmbios escolares, ao contrário do Onuef) e seus animadores são universitários e não políticos. Isso evoluirá, aliás, após a Primeira Guerra, e a história do Groupement se caracterizará pela perda de sua autonomia. Não se deve deixar de notar que, iniciativa autônoma, a criação do Groupement precederá a do Onuef, em três anos. (PETITJEAN, 1996, p. 96.)

De todo modo, fora Henri Hauser quem indicara a Dumas o nome de Monbeig para fazer parte da segunda missão francesa ocupada com a consolidação dos cursos da Faculdade de Filosofia, Ciências e Letras da USP. Se a questão dos contratos assinados com a USP, que impediam sua volta à Europa antes do final do ano letivo brasileiro, atrapalhou o andamento de suas pesquisas de campo, a eclosão da Guerra Civil Espanhola (1936-1939) obstou totalmente a continuidade de seu doutorado tal como ele o havia inicialmente projetado em conjunto com Albert Demangeon, seu diretor de tese. Como quer que seja, nesse mesmo ano de 1936, de passagem pelo Brasil, Henri Hauser, sempre interessado nas questões de história econômica, sugeriu a Monbeig que se dedicasse aos estudos do fenômeno paulista da expansão das lavouras de café e algodão, o que fez em definitivo somente em 1937, após Demangeon, que ficou severamente contrariado com a vinda de seu jovem pupilo ao Brasil, ter acenado com a continuidade da orientação a despeito do novo tema e da distância que ele necessariamente iria manter de Paris (DROULER E THÉRY, 1991; SALGUEIRO, 2006). 
Expressivamente, a década de 1930 pode ser tomada como um ponto de inflexão da geografia brasileira, principalmente pela atuação de algumas figuras de inconteste proeminência, como Pierre Monbeig, cuja obra é de algum modo continuada por discípulos mais próximos - o que indica a rotinização da produção científica da geografia, que a partir de então passa a ser praticada e consagrada fundamentada em novos parâmetros. Sua atuação como pesquisador, aliada às suas preocupações didáticas enquanto docente, fez com que sua obra aparecesse como um modelo de escrita dentro do espaço acadêmico-universitário brasileiro, isto é, fez com que a forma de fazer ciência por ele defendida fosse tomada como o exemplo acabado do que deveria ser um trabalho científico de geografia, do qual a monografia regional descritivo-explicativa, apoiada em farto material cartográfico e iconográfico conseguido por meio das observações diretas efetuadas no campo, seria o epítome. Por outro lado, seus escritos catalisaram a emergência de alguns temas que logo se considerariam incontornáveis a uma análise geográfica do real, direcionando estudos e consolidando linhas de pesquisa aparentadas que contavam com um vocabulário conceitual único, circunstância que expressa a formação de alguns denominadores comuns entre sua obra e as que a sucedem temporalmente.

Em vista disso, a categoria formação, tal como aparece num esclarecedor ensaio de Paulo Arantes (1997) sobre Antonio Candido, talvez possa ser tomada como o giro explicativo que permite reconhecer um ponto de convergência a unificar a discussão. Comentando o uso metodológico que o crítico paulista dá a essa categoria em sua obra "Formação da Literatura Brasileira”, Paulo Arantes sublinha a diferenciação levada a cabo por Candido entre literatura e manifestação literária:

Ao distinguir entre manifestações literárias avulsas - a cifra mesma da tenuidade brasileira - e literatura propriamente dita, encarada como um sistema de obras ligadas por denominadores comuns que fazem dela um aspecto orgânico da civilização, um fato de cultura que não surge pronto e acabado, antes se configura ao longo de um processo cumulativo de articulação entre sociedade e adensamento artístico, ao rever nesses termos a constituição de uma continuidade literária no Brasil, Antonio Candido dava enfim forma metódica ao conteúdo básico da experiência intelectual brasileira. Mais exatamente, pondo em evidência elementos da assim chamada formação nacional, que alimentavam as escolhas estéticas dos escritores, acabava desentranhando do fato bruto, a que se resumia a referida formação nacional, o fio condutor de uma outra linha de força formativa, vir-a-ser de um sistema cultural que na sua trajetória ia aos 
poucos convertendo surtos desgarrados em vida literária efetiva. (ARANTES, 1997 , pp. 21-22. $)^{5}$

No esquema interpretativo de Antonio Candido visto por Paulo Arantes, a contribuição isolada de um ou vários autores, ainda que seja relevante do ponto de vista estético, social ou qualquer outro parâmetro de avaliação crítica que se adote, não forma um sistema literário, e isso principalmente pela falta dos importantes denominadores comuns, que teriam a função de estabelecer um elo de ligação entre as distintas obras, articulando entre elas um ar de família que permitiria a identificação de uma tradição, observada principalmente no aspecto de continuidade e rotinização da produção artística, a partir do qual as obras produzidas em um dado momento influiriam na elaboração de outras, fechando a tessitura do sistema. Alçada à sua expressão metodológica, a categoria formação ultrapassaria o conjunto ensimesmado das manifestações literárias ditas de alta cultura, adentrando o universo cultural da acumulação da produção literária como um todo por um viés que indaga a própria possibilidade de existência de atividade intelectual na periferia da economia-mundo capitalista (ARANTES, 1997; ARRUDA, 2004; CANDIDO, 1989).

Posto isso, a hipótese aqui trabalhada revela a possibilidade de compreender a obra de Pierre Monbeig e seus discípulos nos termos básicos da chave interpretativa utilizada por Antonio Candido para identificar a consolidação do sistema literário brasileiro, pois a influência que o trabalho de Monbeig indiscutivelmente exerceu para a primeira geração de geógrafos formados nas universidades brasileiras, principalmente em São Paulo, pode ser sem dúvida entendida como um marco que permite diferenciar essa fase da geografia brasileira dos períodos anteriores, marcados pela presença de contribuições isoladas e esparsas que, embora relevantes e passíveis de análise em si mesmas, não chegaram a gerar uma tradição dentro do pensamento geográfico. Assim, da mesma maneira que Candido diferencia um sistema literário das manifestações literárias avulsas, pode-se também distinguir, tendo como parâmetro o campo geográfico, as manifestações artísticas, literárias e filosóficas que formulam um discurso culto sobre o espaço,

\footnotetext{
5 "Para compreender em que sentido é tomada a palavra formação, e porque se qualificam de decisivos os momentos estudados, convém principiar distinguindo manifestações literárias, de literatura propriamente dita, considerada aqui como um sistema de obras ligadas por denominadores comuns, que permitem reconhecer as notas dominantes duma fase. Estes dominadores são, além das características internas (língua, temas, imagens), certos elementos de natureza social e psíquica, embora literariamente organizados, que se manifestam historicamente e fazem da literatura aspecto orgânico da civilização. Entre eles se distinguem: a existência de um conjunto de produtores literários, mais ou menos conscientes de seu papel; um conjunto de receptores, formando os diferentes tipos de público, sem os quais a obra não vive; um mecanismo transmissor (de modo geral, uma linguagem, traduzida em estilos), que liga uns a outros." (CANDIDO, 1997, p. 23.)
} 
do discurso mais coeso da geografia científica ou acadêmica stricto sensu, que aparece como uma modalidade discursiva passível de ser apreendida enquanto produto social delimitado histórica e culturalmente (ESCOLAR, 1996; MORAES, 1988).

$\mathrm{O}$ sentido de grupo professado de um modo particular pelos geógrafos vinculados à FFCL/USP (ANDRADE, 1987; BERNARDES, 1982), perceptível nas escolhas temáticas, nos procedimentos de pesquisa e no arcabouço metodológico de predominante sotaque francês, permite que se enxergue ali a germinação de um sistema de obras interligadas por certos denominadores comuns, tais como a predileção pelos conceitos de paisagem, região e habitat, a concepção da geografia como ciência de síntese que privilegia as relações homem-meio, a importância conferida ao trabalho de campo e as metáforas organicistas que estabelecem analogias entre os fenômenos físicos-naturais e as relações sociais, já que as últimas, esvaziadas de sentido crítico, seriam em grande medida condicionadas pelos primeiros. Os resultados concretos da chamada "geografia moderna" assim praticada, conforme foi observado por outros comentadores (MONTEIRO, 1980), adquirem plena maturidade tanto nas teses defendidas na USP nas décadas de 1940 e 1950, quanto nos trabalhos dos geógrafos brasileiros apresentados durante o encontro internacional de geografia da União Geográfica Internacional (UGI), ocorrido no Rio de Janeiro, em 1956, sendo pois absolutamente factível que se compreenda a geografia acadêmica surgida com a consolidação institucional dos cursos universitários como uma componente do imaginário espacial professado abertamente no Brasil durante o período enfocado ${ }^{6}$.

\footnotetext{
${ }^{6}$ Do ponto de vista mais amplo do pensamento político-social brasileiro, a primeira metade do século XX destaca-se pela existência de um movimento de afirmação de um ambiente intelectual no qual a defesa do caráter moderno da identidade nacional em formação (ORTIZ, 1994) demandava, entre outras dimensões igualmente fundamentais, a instrumentalização simbólica de categorias espaciais, mobilizadas na produção de discursos que questionavam o desajuste brasileiro a um mundo capitalista em expansão com o intuito de refletir acerca das possibilidades de desenvolvimento da modernidade em condições periféricas: "A mobilização do espaço na produção de discursos sobre homens, culturas e sociedades guarda duas dimensões: por um lado, o espaço é variável determinante, como em boa parte do pensamento geográfico do século XIX, preocupado em classificar os meios físicos que pudessem produzir tipos específicos. Por outro lado, o tema espacial pode ser mobilizado por meio de metáforas e analogias, como fonte para a produção de imagens e comparações sobre o mundo social (...). o espaço é cenário físico, por certo, geografia povoada de referentes. Mas é também metáfora ou imagem capaz de dar sentido às experiências sociais. Ou seja, mesmo quando diretamente referenciada numa realidade física imediata, uma imagem pode extrapolar essa dimensão e operar como uma ideia que encarne temas e problemas mais amplos. Não se trata, portanto, de postular apenas a dimensão cultural e simbólica envolvida na apreensão da paisagem ou do espaço (passo imprescindível para o encaminhamento do problema), mas de sustentar que esse simbolismo pode mesmo servir não só de representação de um lugar, mas a uma discussão teórica na qual o espaço se associe a certas qualidades ou propriedades de fenômenos de outra ordem." (MAIA, 2008, pp. 24/28.)
} 
Sendo assim, tomando a obra do geógrafo francês Pierre Monbeig como ponto de partida, pretende-se avaliar sua contribuição para a geografia brasileira rastreando sua influência na formação da primeira geração de geógrafos saídos do curso de geografia e história da antiga Faculdade de Filosofia, Ciências e Letras da Universidade de São Paulo (FFCL/USP), com o objetivo de compreender como o tema das franjas pioneiras foi analisado no Brasil pela comunidade dos geógrafos ao longo da primeira metade do século XX. Dito de outro modo, ao longo deste trabalho buscaremos esclarecer se realmente é possível falar de uma linhagem comum entre o mestre e os alunos que, sob sua orientação direta ou inspiração básica, defenderam trabalhos de pós-graduação ao longo das décadas de 1940 e 1950, a saber, Ary França (1945; 1951), Nice Lecocq Müller (1946), Renato da Silveira Mendes (1948), José Ribeiro do Araújo Filho (1950) e Pasquale Petrone (1961), todos futuros professores dessa mesma casa.

No geral, esta pesquisa preocupou-se em esclarecer as eventuais modificações nas maneiras pelas quais o fenômeno das frentes ou zonas pioneiras foi pensado e enunciado a partir do temário, conceitos e tópicos tradicionalmente reconhecidos como integrados a esse específico campo do saber entre os anos de 1934 a 1956, quando o curso universitário de Geografia é organizado e passa a funcionar como uma única graduação em conjunto com o curso de História. Essa circunstância expressa o desenvolvimento de uma sensibilidade historiográfica que influenciou sobremaneira a feitura das pesquisas desenvolvidas posteriormente pelos geógrafos, que assumiram a forma de monografias regionais descritivo-explicativas próximas dos clássicos trabalhos de geografia histórica elaborados na França no início do século XX (DOSSE, 2004) ${ }^{7}$. Fazendo desde já um ajuste na periodização, a opção por esse recorte temporal, além de trazer a lume uma época de grandes mudanças no país, que sofreu alterações em sua estrutura demográfica, que passa a ter uma população crescente com um perfil cada vez mais urbano, e no padrão de acumulação da economia, que deixa de ser fundamentada unicamente na exportação de

\footnotetext{
${ }^{7}$ É relevante lembrar que no currículo do curso de Geografia e História vigente na época, as disciplinas especificamente geográficas reduziam-se aos cursos de Geografia Física e Geografia Humana, ministrados nos dois primeiros anos, e ao curso de Geografia do Brasil, oferecido no terceiro e último ano. A reforma curricular instituída no ano de 1946, que tornou obrigatório o quarto ano e criou a especialização, que era uma espécie de mestrado, não modificou muito essa situação, pois apenas adicionou o curso de Elementos de Cartografia no primeiro ano, além de aumentar em um ano a duração dos cursos de Geografia do Brasil, que se iniciaria no segundo ano, e dos cursos de Geografia Física e Humana, que seriam oferecidos também no terceiro ano do curso. Contudo, a partir do segundo ano os alunos poderiam escolher a sua área preferencial de atuação, desobrigando-se de alguns trabalhos pedidos pelas cadeiras. As informações referentes ao curso de Geografia e História da USP foram retiradas dos Anuários da Faculdade de Filosofia, Ciências e Letras.
} 
produtos primários, passando por um processo de industrialização, justifica-se na medida em que se sabe que a primeira geração de geógrafos brasileiros formados em universidades foram alunos exatamente durante esse intervalo temporal, quando não havia separação entre as áreas da geografia e da história ${ }^{8}$.

Como quer que seja, vale ter em mente que a referência aos anos de 1934 e 1956 serviu apenas como base para delimitar a escolha dos textos aqui avaliados de forma mais aprofundada, sendo oportuno dizer que sempre que foi necessária uma melhor contextualização das discussões, não hesitamos em efetuar avanços e recuos que não respeitaram estritamente o intervalo temporal mencionado. Com efeito, embora os trabalhos de Silveira Mendes (1948) e Araújo Filho (1950) tenham sido orientados, respectivamente, por Pierre Gourou e Aroldo de Azevedo, o fato de eles terem sido discípulos diretos de Monbeig avaliza sua inclusão no conjunto de autores analisados, tornando-se ainda mais importante para apreciar as eventuais diferenças que apresentam em relação aos trabalhos orientados pessoalmente por Monbeig durante sua estadia no país, que durou de 1935 até 1946. Na mesma direção, Pasquale Petrone, que igualmente frequentou a universidade na década de 1940, mas defendeu sua tese de doutorado somente em 1961, foi orientado por Ary França, que assumiu a cátedra de Geografia Humana na década de 1950 em substituição ao mestre francês, de quem sempre foi muito próximo. Logo, a avaliação do trabalho do geógrafo ítalo-paulista emerge como uma ferramenta interessante de análise para verificarmos as continuidades, rupturas e atualizações que o legado da geografia francesa sofreu no Brasil.

\footnotetext{
${ }^{8} \mathrm{~A}$ análise das formas como os geógrafos conceberam o fenômeno das zonas pioneiras, supõe reconhecer a geografia como uma disciplina cuja rotinização dos problemas, procedimentos e linguagem teórica própria são reiteradamente firmados e reafirmados em meio ao processo mais amplo de sua institucionalização, que ao fim e ao cabo confere existência a um campo científico-disciplinar que apresenta uma dinâmica própria e relativa autonomia (BORDIEU, 1989; CAPEL, 1977; 1981). Desenvolvido pelo pensador francês Pierre Bourdieu, o campo científico, entendido como um lugar de lutas que produz e supõe formas específicas de interesse em busca do monopólio da autoridade científica, da competência e da capacidade de falar e agir legitimamente, diz respeito à construção de tradições acadêmicas que articulam historicamente, a partir de certas filiações, uma produção teórica e um quadro conceitual próprios que confluem para erigir uma perspectiva discursiva na qual alguns temas e problemas recebem um modo específico de enunciação por uma comunidade com relativa autonomia (ORTIZ, 2003). Esta comunidade, funcionando como uma corporação, apresenta regras e hierarquias definidas e redefinidas internamente, com locais e rituais exclusivos de difusão, reprodução e legitimação do conhecimento produzido: "Digo que para compreender uma produção cultural (literatura, ciência, etc.) não basta referir-se ao contexto social contentando-se em estabelecer uma relação direta entre o texto e o contexto (...). Minha hipótese consiste em supor que, entre esses dois polos, muito distanciados, entre os quais se supõe, um pouco imprudentemente, que a ligação se possa fazer, existe um universo intermediário que chamo o campo literário, artístico, jurídico ou científico, isto é, o universo no qual estão inseridos os agentes e instituições que produzem, reproduzem ou difundem a arte, a literatura ou a ciência. Esse universo é um mundo social como outros, mas obedece a leis sociais mais ou menos específicas." (BOURDIEU, 2004, p.20.)
} 
Colocadas em linhas gerais o caminho a ser seguido em nossa argumentação, focaremos neste primeiro capítulo dois aspectos sobremaneira imbricados, examinando tanto a conjuntura histórica vivida pelo país a partir da década de 1930, quanto o nível de desenvolvimento institucional da geografia no mesmo período, isto é, reconhecendo o papel ocupado pelas pesquisas elaboradas por Monbeig no processo de amadurecimento do campo disciplinar, é interessante que a contextualização histórica das alterações pelas quais passou o ambiente intelectual brasileiro desde a época em que aportou por aqui anteceda a análise mais detida de seus textos. Assim, ainda que nas próximas seções deste capítulo a figura de Monbeig apareça apenas pontualmente, a reconstrução do contexto histórico do país é uma operação necessária para que se possa estabelecer, nos capítulos subsequentes, uma aproximação mais bem fundamentada com diversos aspectos de sua obra. Além disso, ao notar as modificações pelas quais passou a organização institucional do ensino e da pesquisa do campo geográfico nacional, esclarecendo algumas das discussões que estavam postas no ambiente político e intelectual brasileiro e paulista no momento em que o geógrafo francês se estabelece no Brasil como um dos professores ocupados com a fundação dos cursos da FFLC/USP, abre-se um caminho seguro para que possamos estimar em que medida sua atuação realmente merece ser considerada como um marco para a geografia brasileira.

Para tanto, esse capítulo foi dividido em mais cinco seções que, formando um painel, objetivam mapear as maneiras pelas quais o imperativo da conquista e o tema da integração territorial, que do ponto de vista da consolidação do aparato de controle estatal sobre o espaço relacionam a expansão do povoamento e o desenvolvimento econômico do país ao espraiamento da sociedade brasileira dentro de seu território, aparecem em programas oficiais desenvolvido por órgãos do governo ou em certos círculos de debates acadêmicos, influenciando de distintas formas a organização institucional de centros ocupados com a elaboração e a difusão dos saberes geográficos, mas também pesando na própria implementação de políticas territoriais.

Desse modo, para melhor avaliarmos as informações preliminares que disponibilizamos acerca de Pierre Monbeig e sua atuação no Brasil, que refazem em contornos genéricos o trajeto que o trouxe ao Brasil, funcionando como uma breve introdução que traz a lume o protagonista da argumentação a ser desenvolvida, seria produtivo fornecer alguns subsídios que permitam fazer uma breve contextualização do estágio organizacional do ensino superior na época de sua chegada a São Paulo, principalmente para questionar o significado dos esforços que sustentavam 
o projeto político e pedagógico em torno da criação da USP dentro do quadro mais geral dos debates e das reformas por que passava a educação brasileira desde o início da década de $1920^{9}$.

Sobre esse assunto, poderíamos trazer à baila as discussões empreendidas por Fernando Limongi (1988), que em sua análise do processo de criação da Universidade de São Paulo revê o posicionamento assumido por boa parte da bibliografia especializada, a qual insiste em estabelecer um vínculo entre o projeto político liberal encampado pelo "grupo do Estado" e a organização da dita universidade ${ }^{10}$. Acompanhando a trajetória de Júlio de Mesquita Filho na década de 1930, peça-chave que era nas articulações políticas antecedentes e subsequentes ao levante armado de nove de julho de 1932, Limongi conclui que o tema da reforma educacional, segundo a posição que concebia a Universidade como o instrumento que iria garantir a posição privilegiada de São Paulo - questões tão presentes nos textos de Mesquita da década de 1920 -, não faz parte do cerne das preocupações do "grupo do Estado" no momento mesmo de organização e início dos trabalhos da USP, quando as discussões em torno da nova Carta Constitucional, promulgada em 1934, mesmo ano de fundação da Universidade, e a centralidade que nesses debates assume o problema da autonomia regional paulista, dominavam as atenções de todos.

Para esse autor, a questão da expansão do mercado cultural em São Paulo, aliada à atuação fundamental dos educadores profissionais (MICELI, 2001) integrados ao "grupo do Estado" na disputa pelo controle do aparelho de ensino paulista - embate fundamentado nos princípios gerais

\footnotetext{
${ }^{9}$ Para uma discussão aprofundada acerca da história das ideias pedagógicas no Brasil, que inclusive questiona a validade de utilização do termo "sistema educacional" para definir a situação vivenciada pelo país nesse momento, consultar os trabalhos de Demerval Saviani $(2005 ; 2008)$.

${ }^{10}$ Segundo Irene Cardoso (1982), cujo consistente trabalho é alvo de reparações por parte de Limongi, a expressão "grupo do Estado" pode ser compreendida como a definição que o grupo de políticos e intelectuais atuantes no jornal O Estado de São Paulo oferece de si mesmo. Seu núcleo era formado pelos diretores e principais redatores do jornal, como Júlio de Mesquita Filho, Francisco Mesquita, Armando Salles de Oliveira, Nestor Rangel Pestana, Plínio Barreto, Paulo Duarte e Amadeu Amaral, entre ourtos. Para além dos limites estritos do pessoal ocupado com a publicação diária do jornal, intelectuais de renome podem também ser tomados como integrantes do "grupo do Estado", a saber, Fernando Azevedo, Lourenço Filho, Oliveira Vianna e Afrânio Peixoto. Em uma época anterior, ou numa escala diversa de envolvimento, também Monteiro Lobato e Olavo Bilac. Sobre as relações entre o projeto político desse grupo e a criação da Universidade de São Paulo, Cardoso afirma que: "O entendimento da Universidade como uma forma de poder para formar e reproduzir as elites dirigentes conduz à interpretação do seu projeto como parte integrante de um projeto de hegemonia cultural e política. O controle da Universidade e a possibilidade da formação e reprodução ideológica de uma elite dirigente, com uma dada concepção do mundo, apresenta-se como um meio de conquista ou de conservação do poder. Mesmo que se configure a impossibilidade daquela hegemonia, a Universidade é criada num momento em que esta impossibilidade não é evidente (...). A Universidade como parte de um projeto de hegemonia, projeto este conduzido por um grupo com pretensões a estado-maior dirigente da nacionalidade, acaba também por constituir uma outra "marca ideológica" que impregna a história posterior da Universidade, esvaziada no entanto de seu conteúdo histórico específico." (CARDOSO, 1982, p. 59.)
} 
defendidos em órgãos de representação política aparentados ao grupo por afinidades de interesses, como a Liga Nacionalista ${ }^{11}$-, mostra um deslocamento das ações de boa parte dos intelectuais do "grupo do Estado" intimamente ligados à expansão das atividades de cunho cultural, que se veem cada vez mais desapegados das disputas diretas pelo poder e, vale dizer, próximos de uma elite cultural até certo ponto afastada da política militante praticada dentro do Partido Republicano Paulista (PRP). Essas circunstâncias revelam o relativo fechamento da carreira política, que se tornava mais e mais profissionalizada, para sujeitos como Mesquita Filho e outros integrantes do grupo, que, embora mantivessem uma influência política e a capacidade de refletir sobre as condições sociais e econômicas do país, dependiam menos das disputas internas próprias do dia a dia do PRP, organização sempre ávida em conseguir acesso a verbas e cargos públicos, não importando o governante de turno (CARONE, 1974; LIMONGI, 1988).

É à luz desse contexto histórico que efetuaremos uma breve reconstrução do processo de institucionalização da geografia no Brasil, procedimento importante caso se queira compreender a realidade encontrada aqui por Pierre Monbeig. O intuito básico seria o de verificar em que medida as iniciativas elaboradas após a institucionalização universitária da disciplina, feitas sob o estímulo e incentivo de novas associações profissionais, como a Associação dos Geógrafos Brasileiros (AGB) e o Conselho Nacional de Geografia (CNG/IBGE), indicam a permanência de imagens e ideias sobre o país que permitem estabelecer uma comparação com as apropriações simbólicas do espaço verificadas em outras épocas e ambientes institucionais, como no âmbito da Sociedade de Geografia do Rio de Janeiro (SGRJ). Realmente, as construções discursivas que mobilizam conceitos de base espacial para explicar o país, associando qualidades mesológicas à sociedade como um todo, são informadas por diferentes concepções do espaço, apropriações simbólicas cujo exame possibilita sublinhar a centralidade que o tema da expansão territorial da

\footnotetext{
${ }^{11}$ Um dos movimentos precursores do Partido Democrático paulista, organizado em 1926, a Liga foi fundada em São Paulo cerca de 1 ano após o surgimento, em 1916, de sua congênere carioca, sendo extinta, em 1924, após muitos de seus membros terem expressado simpatia à violenta revolta tenentista ocorrida neste ano. A Revolta de 1924, aliás, continua sendo, até os dias de hoje, o maior confronto bélico que a cidade de São Paulo já presenciou: “A Liga Nacionalista de São Paulo, criada em 1917, foi um dos movimentos que se originaram da Liga de Defesa Nacional. Ao ideário já consagrado foram acrescentados objetivos de ordem política. A verdade eleitoral, o combate à abstenção e à fraude, e a demanda do voto legítimo levaram a Liga Nacionalista de São Paulo a promover campanhas de alfabetização. Seria através da alfabetização que a maior parte da população brasileira poderia participar do jogo político e corrigir suas distorções (...) Constatamos assim a existência de duas orientações: uma, mais ligada ao serviço militar e à construção de uma consciência cívico-patriótica, configurada na Liga de Defesa Nacional, e outra, mais preocupada com questões políticas, particularmente com a verdade do voto, exemplificada pela Liga Nacionalista de São Paulo. Havia ainda uma terceira tendência, que tinha raízes no Rio de Janeiro e que se expressou através de dois movimentos: a Propaganda Nativista e a Ação Social Nacionalista”. (LIPPI, 1990, pp.147-148.)
} 
sociedade brasileira tem para a prática e difusão da ciência geográfica, consolidando importantes espaços institucionais (MORAES, 1991).

Seja como for, convém reiterar que neste trabalho não se confunde a história disciplinar da geografia com a história de sua institucionalização (QUAINI, 1983), uma vez que pesquisas recentes iluminaram os variados caminhos pelos quais os saberes geográficos foram produzidos e difundidos no Brasil (PEREIRA, 1997; RUDZIT, 1997), com especial destaque reservado para os currículos do ensino e a prática da geografia escolar (PEREIRA, 1990; ROCHA, 1996). Aprofundando o debate, é importante discutir, para o caso brasileiro, a validade da ressalva feita por Horacio Capel $(1977 ; 1981)$ no tocante à geografia europeia, segundo quem deve-se atentar no fato de que a consolidação de uma comunidade científica especializada, se não monopoliza integralmente, influi decisivamente na produção e divulgação das reflexões sobre o espaço, constituindo-se a geografia e a comunidade dos geógrafos, a partir daí, em locus privilegiado de legitimação dessa modalidade discursiva.

Considerando que o conjunto dos estudos geográficos sobre as frentes pioneiras pode ser visto como uma modalidade discursiva que se utiliza preponderantemente de conceitos de base espacial, tais como fronteira, paisagem e região, para elaborar explicações sobre o Brasil, convém fazer uma sucinta diferenciação do tipo de abordagem representada pela análise geográfica das frentes pioneiras, mais preocupada com questões atinentes ao espraiamento espacial do povoamento, à exploração econômica dos recursos naturais e à integração do território, em relação a outros tipos de estudos que igualmente valorizam o espaço a partir de aspectos como o identitário ou o cultural (MAIA, 2008). Efetivamente, Lúcia Lippi Oliveira, que desde a década de 1990 vem insistindo na importância de categorias espaciais na consolidação dos Estados nacionais, aponta para a constituição de uma tradição, dentro do pensamento político-social brasileiro, que considera certos atributos naturais do território como a matriz fundamental na construção da identidade brasileira. Essa linha de pensamento, que remontaria aos viajantes estrangeiros que visitaram o Brasil ao longo do século XIX, passaria pelos escritores do romantismo e desembocaria nos cientistas nacionais que, como Oswaldo Cruz e Cândido Rondon, perscrutaram os sertões no início do XX (LIMA, 1999), revela uma ação recorrente que expressa a relevância, abrangência e permanência do tema da identidade nacional correlacionado à questão das representações geográficas (OLIVEIRA, 2011) $)^{12}$.

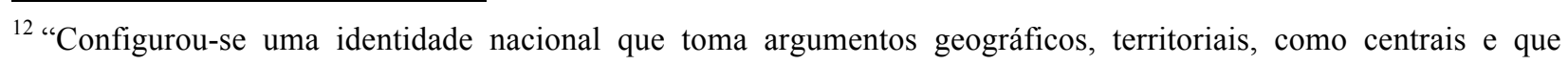


Dentre as diversas formas de relacionamento das representações geográficas do país com as questões que envolvem a constituição da identidade nacional, a problemática da fronteira merece por certo um lugar de destaque (SOUZA, 1998; WEGNER, 2000), visto que, no Brasil, uma das vertentes mais influentes a problematizar o espaço no pensamento político-social toma a expansão territorial levada a cabo a partir dos movimentos bandeirantes como o "marco zero" da construção do país. Entendendo o processo expansivo das entradas e bandeiras como "o evento histórico original que fez nascer a nação" (OLIVEIRA, 2000, p. 80), os autores partícipes dessa vertente da fronteira no pensamento político-social retomam simbolicamente a epopeia bandeirante, fundada objetivamente no apresamento de povos indígenas e na busca de pedras preciosas, para a construção de um robusto mito de identidade, se esforçando por nacionalizar um mito de alcance regional e estabelecendo uma relação complementar entre espaço, geografia e nacionalismo que ultrapassa a mera assunção de que os bandeirantes teriam sido os principais artífices do patrimônio territorial herdado dos portugueses (RAIMUNDO, 2001; VELLOSO, $1990)^{13}$.

Daí, pois, abrir-se a possibilidade de construir, no Brasil, um entendimento da relação entre o tema da conquista do espaço e a formação da nacionalidade bem próximo à função que, nos EUA, normalmente se atribui ao "mito da fronteira", especialmente quando tal mito aparece

integra o imaginário nacional. Isto se faz presente em trabalhos e livros de historiadores como Capistrano de Abreu, em seu Capitulos da história colonial (1907), em livros fundamentais da cultura nacional, como Os sertões (1902) de Euclides da Cunha. Continuará a se fazer presente em obras voltadas à explicação do Brasil mesmo em épocas mais recentes, como em Celso Furtado na Formação econômica do Brasil (1959), onde cada ciclo econômico se passa em distinto espaço geográfico do país. Estes exemplos servem para confirmar como, no Brasil, a nação foi pensada como espaço territorial, como natureza, e cabendo ao Estado a responsabilidade por garantir as fronteiras nacionais, mapear as riquezas e fomentar sua ocupação, assim como pela manutenção da unidade entre diferentes áreas isoladas e, mais tarde, pela integração entre tais áreas no todo nacional (...). Concordando que o mito fundador mais importante no Brasil seja este - o papel da natureza tropical - a pergunta a ser respondida, o enigma a ser decifrado, é como foi e como é possível que ele consiga se atualizar e permanecer forte e fornecer sentimentos de identidade durante tanto tempo? Como, de que maneira, quem, através de que instituições isto foi possível? A força do mito não é reconhecida positivamente por todos, ao contrário, recebe crítica principalmente de muitos acadêmicos, já que a preponderância do papel da natureza na formação brasileira traz a equação: natureza maravilhosa logo civilização precária!”. (OLIVEIRA, 2011, pp. 11-12.)

13 "No Brasil do início do século XX, a ideia de nação formou-se a partir de um debate estabelecido entre os criadores de matrizes de identidade de caráter local-regional. Diferentes intelectuais, inseridos no mesmo campo cultural, alimentaram uma discussão para definir qual seria o melhor modelo de identidade nacional: se Tiradentes e as montanhas de Minas Gerais, se a "casa-grande e senzala" do Nordeste, se o olhar contemplativo da capital federal ou se as bandeiras dos paulistas. Exemplares, sob o aspecto de terem estabelecido no meio político e cultural um campo de disputas entre modelos de brasilidade, as diferentes visões foram elaboradas a partir da história, da geografia e da experiência social de um determinado local. Por isso a temática da região e o sentimento a ela associado, presentes nas investigações realizadas nas ciências sociais, como tentativa de entendimento dos diversos constructos imaginários acerca da elaboração de uma identidade nacional, podem ser bastante reveladores" (RAIMUNDO, 2004, p. 79). Ver também: Oliven (1992). 
vinculado à tese de Turner, que defende ter sido a experiência da fronteira em expansão a responsável por modificar as instituições e populações europeias que se aventuravam no Novo Mundo, catalisando as virtudes do individualismo, da igualdade social e o espírito empreendedor, predicados típicos do homem fronteiriço de tipo turneriano que embasariam a excepcionalidade da história, da democracia e do povo americano (SILVA, 2001). Sendo assim, vê-se que a tentativa de aproximar os pioneiros americanos dos bandeirantes luso-brasileiros, reinterpretando suas ações para forjar um mito que reforça o caráter nacional da expansão territorial por eles engendrada, ganha corpo ao longo do século XX, especialmente durante a Era Vargas (19301945), quando autores como Cassiano Ricardo conferem a essa vertente da fronteira uma versão atualizada, pensada como fundamento ideológico das ações do Estado (OLIVEIRA, 2000; VELHO, 1979) ${ }^{14}$.

Como pode se inferir, a interpretação geográfica sobre as frentes pioneiras ganhou corpo dentro de um ambiente intelectual no qual as discussões sobre o processo de formação do Brasil não abdicavam de conceitos espaciais, já que na época era comum o uso de abundantes referências à natureza e ao território brasileiro para marcar as singularidades que envolviam a construção da identidade nacional. Em vista disso, vislumbra-se a possibilidade de discutirmos melhor o modo como a frontier thesis foi apropriada por diferentes autores no Brasil, sendo ainda válido notar que, a propósito da concepção geográfica de pioneirismo, a relação fundamental estabelecida entre os termos fronteira, frente pioneira e frontier segue sendo assunto mais citado do que estudado, restando ainda por ser feita uma apreciação mais acurada do tema nos trabalhos de geógrafos brasileiros.

\footnotetext{
14 “Tem-se que a produção do espaço expressa determinações econômicas (ligadas à tecnologia, aos materiais e às funções), mas também todo um rol de outros condicionantes (manifestos na tradição, na simbologia, no estilo, etc.), e que explicá-la redunda em articular essa rede de mediações no movimento histórico-concreto. A historicidade engata os vários planos em uma trama una, na qual o próprio espaço é apenas uma dimensão. A paisagem resulta dessa trama (histórica, de múltiplas determinantes), sendo mais do que a materialização da produção imediata na superfície da Terra. Acatando a circularidade desse processo, percebe-se que o espaço produzido propicia leituras. Estas, em si momentos de produção dos lugares, retroalimentam o processo ao veicularem projetos e interpretações, ao realizarem a valorização subjetiva do espaço. A manifestação da consciência, que diretamente nos interessa. Neste ponto, delineia-se claramente o lugar enquanto representação. Não mais a paisagem tomada - na tradição da Geografia Cultural - como registro histórico e antropológico, mas a própria leitura da paisagem como elemento revelador de uma época e de uma cultura. O discurso sobre o espaço em si mesmo apreendido enquanto produto histórico e cultural, pré-ideação básica na produção do próprio objeto sob o qual se exercita. Resgata-se, então, a consciência do espaço diretamente como tema de análise. Tema cuja compreensão traz luz ao debate maior da valorização do espaço.” (MORAES, 1988, pp. 24-25.)
} 


\section{As frentes pioneiras e a tese da fronteira}

Numa primeira consideração do fenômeno pioneiro no Brasil, a análise de diferentes autores e perspectivas nos deixaria inclinados a atestar a existência de um juízo comum, bem ou mal generalizado pelas classes letradas até meados do século XX, segundo o qual a explicação das particularidades nacionais aparece como decorrência do relacionamento íntimo entre a conquista de novas terras, o avanço do povoamento, a busca do desenvolvimento econômico e a consolidação da identidade, numa operação que insiste em estabelecer um vínculo de cunho essencialista entre o conhecimento sistemático do território, o domínio da natureza tropical, sua exploração produtiva e a origem da singularidade do povo brasileiro ${ }^{15}$.

Realmente, um ponto em aberto no tratamento geográfico das frentes pioneiras é sua relação ambígua com a chamada "tese da fronteira". Enunciada primeiramente pelo supramencionado historiador Frederick Jackson Turner, em 1893, e desde então tomada em consideração por diversos autores, a chamada frontier thesis associa a fronteira a uma extensão variável de terras onde ocorreria a expansão e consequente perenização da colonização, isto é, a fronteira serviria para designar o avanço civilizatório da população americana por sobre espaços considerados vazios, o que acaba por conferir uma centralidade à expansão territorial na formação da nacionalidade e na consolidação da democracia estadunidense, pois foi a partir da experiência social da fronteira, sempre em movimento, que as instituições que caracterizam distintamente o processo americano de construção de uma identidade nacional tomaram forma.

\footnotetext{
${ }^{15}$ Em seus estudos sobre o processo brasileiro de formação territorial, Antônio Carlos Robert Moraes vem trabalhando com um argumento que reconhece a existência de uma espécie de razão de Estado, presente sobretudo nos países de formação colonial, que sói identificar o Brasil ao seu território, e não à sua sociedade. Reverberando uma visão instrumental dos segmentos populares e servindo como justificativa à elaboração de diferentes estratégias de apropriação territorial, essa concepção espacialista do Brasil, continuamente reposta em formulações diversas desde ao menos meados do século XIX, enraíza-se na ideia de construção do país, mote ideológico que passa a informar um projeto nacional imiscuído em uma ótica geopolítica: "O padrão discursivo básico do século XIX que conforma essa concepção estrutura-se em torno do conceito de civilização, atribuindo portanto à monarquia brasileira uma missão civilizadora. Construir o país é levar a civilização aos sertões, ocupar o solo é subtrair os lugares da barbárie, o que cabe a uma elite que se auto-define como 'representante das idéias da Ilustração' (...). O papel catalisador que a noção de 'civilização' cumpriu para a antiga mentalidade será agora ocupado pelo conceito de modernização. Tal conceito, central no pensamento brasileiro do século XX, reveste-se também de densa espacialidade. Pode-se dizer que modernizar é, entre outras coisas, reorganizar e ocupar o território, dotá-lo de novos equipamentos e sistemas de engenharia, conectar suas partes com estradas e sistemas de comunicação. Enfim, modernização implicava no caso brasileiro necessariamente valorização do espaço. Nesse sentido, o país podia ser novamente equacionado como âmbito espacial no qual o Estado devia agir para instalar o novo projeto nacional: a construção do Brasil moderno". (MORAES, 2002, pp. 118/121.)
} 
Para a América Latina, afora a coletânea de textos organizada por David Weber e Jane Rausch (1994), que revisita textos clássicos, como o de Sarmiento, e traz contribuições de intelectuais de renome, como Emilio Willems e Clodomir Viana Moog, a tentativa mais conhecida de aplicar a tese de Turner num viés comparativo com o caso paradigmático dos EUA permanece sendo o livro de Alistair Hennessy (1978), que aponta para a ausência, na história dos países latino-americanos, das condições necessárias - a saber, "terras livres" e uma legislação adequada que incentivasse uma política pública de imigração e ocupação, permitindo um amplo acesso à propriedade da terra - para que a experiência da fronteira cumprisse o exato papel descrito por Turner. Na opinião deste autor, a inexistência de tais condições teria obstado, por corolário, que fosse desenvolvida na região uma interpretação sobre a expansão do povoamento algo parecida com o mito da fronteira (HENESSY, 1978).

Na mesma direção, Lígia Maria Osório Silva (2001), que já havia trabalhado com a questão da formação da propriedade da terra no Brasil numa perspectiva histórica (SILVA, 1996), conclui que, embora diversos países da América Latina tenham passado por experiências similares de conquista e colonização de novas áreas, a fronteira, incorporada ao patrimônio territorial dos novos Estados politicamente emancipados no século XIX a partir de situações de domínio colonial muito distintas, não teria ocupado o mesmo lugar que teve em certa historiografia norteamericana, principalmente aquela que se apropria do entendimento desse processo de expansão territorial na forma de um mito que reforça a identidade nacional ao mesmo tempo que empresta tal caráter nacionalista ao Estado:

Isto não impediu que em diferentes momentos históricos, governos de diferentes tendências fizessem um esforço no sentido de promover a mito certos episódios da ocupação do interior do país. Foi assim com a arrancada do café no final do século XIX, começo do XX, com a 'Marcha para o Oeste' do primeiro governo Vargas e a colonização da Amazônia na época dos governos militares. Mas, tratava-se de incutir, através da propaganda governamental, uma visão idealizada dos processos de ocupação em curso ou de épocas passadas, mas com vistas a objetivos políticos imediatos. Em consequência, por não ter surgido espontaneamente da generalização de algumas experiências concretas, não se fixou no imaginário da população com a mesma força que o mito turneriano. (SILVA, 2001, p. 167.)

Segundo a autora, a grande originalidade da tese de Turner foi tomar o processo de ocupação fronteiriça como ponto de partida para os trabalhos de história econômica dos EUA, uma vez que os estudos de fronteira deveriam ressaltar não só as características singulares do espaço físico no qual a fronteira se movia, mas igualmente as modificações que esse novo espaço 
impunha aos grupos humanos e instituições mobilizados em uma dinâmica expansiva. A bem dizer, Silva observa que, analisado de um viés histórico e historiográfico, o estudo das estratégias de colonização e povoamento, na época de Turner, não era exatamente uma novidade na Europa - o novo, no caso, é o fenômeno mais amplo de expansão de uma sociedade em movimento que, a partir do XIX e dos estudos de inspiração turneriana, passou a ser designado pelo conceito de fronteira (SILVA, 2001). Comparando as políticas públicas de apropriação de terras desenvolvidas ao longo do século XIX no Brasil, na Argentina e nos EUA, Silva lembra que a noção de vazio territorial ligada ao vocábulo "terras livres" não foi tomada na América do Sul como algo positivo, originando mesmo mitos negativos que qualificavam esses espaços ainda não ocupados produtivamente como lugares onde dominavam o primitivismo e a barbárie - eram os sertões, figura primordial na estruturação de uma tradição no pensamento político-social brasileiro (AMADO, 1995; ALMEIDA, 2001; OLIVEIRA, 2000). Ao final de suas observações, a autora admite que no processo de ocupação e apropriação territorial que incorporou terras então qualificadas como vazias ao patrimônio do Estado americano, houve uma alteração no significado do termo fronteira, que a partir daí deixa de se referir exclusivamente aos limites políticos entre duas áreas de jurisdição territorialmente delimitadas, passando a designar algo novo, a saber, as áreas caracterizadas por movimentos migratórios associados à instalação e permanência de assentamentos com fins agrícolas (SILVA, 2001) ${ }^{16}$.

Como quer que seja, é também digno de nota os trabalhos de estrangeiros que versam especificamente sobre o Brasil, tentando enquadrar o caso brasileiro de movimentação das fronteiras nos termos gerais propostos pela historiografia de cariz turneriano, como o livro de Roy Nash (1926) e o sempre citado estudo de J. F. Normano (1935), ambos traduzidos para o

\footnotetext{
16 "Sem perder de todo esse sentido [de limite político], a partir da experiências de ocupação dos 'espaços vazios' na América do Norte, a fronteira ganhou uma acepção própria para designar a zona móvel de assentamento ou colonização (implicando aproveitamento agrícola e povoamento) no limite das áreas 'desconhecidas', 'não desbravadas' ou até mesmo 'selvagens'. Nesse sentido forte, a palavra fronteira designa a zona de contato entre uma região onde vigoram os padrões de ocupação considerados 'civilizados' e a região ainda a ser incorporada (...). Mas a verdade é que a visão que se tem desses processos antigos de colonização como sendo 'de fronteira' é posterior ao estudo da fronteira americana. Quer dizer que foi preciso que o processo ocorrido em torno da ocupação de terras americanas 'revelasse' a peculiaridade dos fenômenos de fronteira, para que se começasse a tratar aspectos da história europeia em termos de avanço de fronteira." (SILVA, 2001, pp. 138/141.) Entretanto, ao analisar o uso e o emprego da palavra frontier ao longo da história americana, Juricek (1966) confere menor importância à novidade representada por essa mudança de significado, ocorrida plenamente no final do XIX, pois desde o século XVI a frontier era utilizada para designar seja os limites políticos, seja os espaços de colonização agrária, havendo até mesmo a possibilidade de se pensar os aspectos políticos e econômicos de forma integrada, pois uma área poderia ser intencionalmente colonizada para se garantir sua soberania política. Ao final, essa mudança de sentido, reforçada no inicio do século XX, aproxima-se mais de uma estratégia discursiva empregada por Turner para sustentar sua hipótese acerca da singularidade da civilização criada na América ante as nações da Europa.
} 
português na década de 1930 e largamente utilizados como obras de referência pelos que se dedicaram ao tema, mormente durante os anos de 1940 e 1950. Além desses, seria importante lembrar os artigos de Lombardi (1975) e de Katzman (1975), que tentam rastrear o papel da fronteira na história econômica do Brasil tendo como contraponto o enquadramento conceitual de Turner, e o livro de Joe Foweraker (1981), que após um período de quase 10 anos de pesquisas de campo, estruturou um bem embasado estudo que sublinha a extrema violência presente no processo de expansão da fronteira no Brasil entre 1930 e 1970:

So it must be clear at the outset that the pioneer frontier is a process of occupation of new lands which is historically specific. The period of the process correspond to the period of Brazil's most rapid rates of industrialization and urbanization, and begins at the moment when the Brazilian economy grows 'in depth' in the industrial and financial centers so it grows 'in breadth' through the extension of the pioneer frontier. The frontier expresses not any and all economic activities directed to the world Market, but the particular activity which integrates unexplored region into national economy. The process is propelled by the forces and contradictions of this economy (...). While the mechanisms of accumulation on the frontier may not themselves be capitalist, the surplus is expropriated not only by speculatory and commercial but also industrial capital. Within this perspective the frontier cycle is primarily determined by the capitalist social relations which dominates the social formation, and is achieved through a wide range of political, legal and ideological interventions by a particular form of the capitalist State. (FOWERAKER, 1981, pp. 3-4.)

Como se depreende do trecho acima, o processo de incorporação de novas terras ao espaço econômico brasileiro, executado por meio da abertura de amplas áreas dedicadas ao cultivo de produtos voltados para o comércio internacional, como o café e o algodão, ou mesmo pela formação de imensas pastagens também orientadas para a produção de carne para o mercado externo, epítome das movimentações demográficas e econômicas integradas à expansão das frentes pioneiras (MONBEIG, 1952), permite que identifiquemos, nesse fenômeno, um processo de acumulação primitiva mediado pela exploração e valorização dessas novas terras (MARTINS, 1979; 1995), ou seja, entre as décadas de 1930 e 1960, a expansão territorial do capital logrou transformar espaços considerados vazios em áreas economicamente ativas do território nacional.

De maneira similar ao trabalho de Foweraker, cuja preocupação básica recai na análise de como o desenvolvimento do capitalismo no Brasil comportou uma acirrada disputa pela posse da terra entre os diversos sujeitos sociais envolvidos nesse processo, não poderíamos deixar de citar as contribuições fundamentais de Otávio Guilherme Velho $(1972 ; 1979)$ e de José de Souza Martins $(1975 ; 2009)$, que também alertam para o fato de o processo de consolidação do 
capitalismo ter sido impulsionado por um movimento expansivo que, em sua incessante dinâmica de incorporação de novas terras na esfera do espaço econômico nacional, ia colocando cada vez mais áreas do território brasileiro na órbita de influência de um sistema econômico internacionalizado. Tanto no caso de José de Souza Martins quanto na argumentação de Otávio Guilherme Velho, o realce dado à exploração da força de trabalho camponesa, com amplo uso de formas de remuneração não especificamente capitalistas, como a peonagem e os distintos tipos de parceria, e, mais importante, a referência à subordinação dos camponeses ao capital no processo de formação das fazendas - as etapas do desmatamento, preparação e cultivo das unidades de produção agropecuárias, identificadas como um momento da acumulação primitiva (a formação do capital), e não como parte da reprodução ampliada do capital -, é um ponto de fundamental relevância na análise da via trilhada pelo desenvolvimento do capitalismo no Brasil, e aspecto absolutamente fundamental para se compreender como o processo de expansão territorial do capital encontra-se mediado por um movimento de incorporação de terras e produção de mercadorias que nem sempre é executado a partir de relações de produção especificamente capitalistas:

A produção capitalista de relações não-capitalistas de produção expressa não apenas uma forma de reprodução ampliada do capital, mas também a reprodução ampliada das contradições do capitalismo - o movimento contraditório não só de subordinação de relações pré-capitalistas, mas também de criação de relações antagônicas e subordinadas não-capitalistas. Nesse caso, o capitalismo cria a um só tempo as condições de sua expansão, pela incorporação de áreas e populações às relações comerciais, e os empecilhos à sua expansão, pela não mercantilização de todos $\mathrm{s}$ fatores envolvidos, ausente $\mathrm{o}$ trabalho caracteristicamente assalariado (...). O capitalismo engendra relações de produção não-capitalistas como recurso para garantir a sua própria expansão, como forma de garantir a produção não-capitalista do capital, naqueles lugares e naqueles setores da economia que se vinculam ao modo capitalista de produção através de relações comerciais. A primeira etapa da expansão do capitalismo é a produção de mercadorias e não necessariamente a produção de relações de produção capitalistas. (MARTINS, 1998, p. 21.)

Outros autores que desenvolvem uma perspectiva comparativa, tentando atualizar a discussão conceitual para verificar a possibilidade de aplicar o referencial de Turner em outros lugares e contextos, como Gerhard (1959), Mikessel (1960) e Bassin (1993), e o recente debate travado por Hevilla (1998; 1999) e Escamilla (1999) em torno das relações da tese de Turner com o conceito geográfico de fronteira, oportunamente resenhado em suas implicações por Perla Zusman (1999), que reforça a influência das representações e do caráter simbólico da fronteira na produção da realidade, relacionando seus aspectos materiais com a elaboração de imagens que 
visam promover diferentes estratégias estatais de ocupação territorial, definitivamente recolocam a importância da temática da fronteira na ordem do dia. Em vista disso, a definição do conceito de franja pioneira proposta por Pierre Monbeig em 1966, depois, portanto, de seu périplo de mais de 10 anos pelo Brasil, não se distancia muito da chave interpretativa normalmente associada à tese turneriana da fronteira que vimos descrevendo, enxergando a frente pioneira como homônimo do avanço de um grupo humano que se encontraria num "estágio superior de civilização" por sobre espaços "vazios" pouco ou não habitados, num movimento de colonização e povoamento que integra novas áreas a um dado espaço econômico ao mesmo tempo em que pode catalisar a formação de identidades nacionais:

L'extension de l'œkoumène continue de s'accomplir par la pénétration de groupes humains pionniers dans les secteurs de la planète encore peu habités. Une région pionnière peut se définir comme l'un des ces secteurs en cours d'incorporation à l'œkoumène. Puisque, à l'exception des grands déserts glacés des zones polaires, il n'y a pas de partie des continents qui soit totalement vide d'hommes, la région pionnière est le théâtre de contacts et de conflits entre des sociétés humaines techniquement, économiquement, démographiquement et politiquement inégales. On y assiste à la disparition du paysage naturel qui, sous l'action des pionniers, fait place à un paysage humanisé : naissance et formation de campagnes, fondation et croissance de villes, construction d'un réseau de communications. En même temps se constituent de nouveaux foyers de production, de nouveaux courants d'échanges, des régions humaines qui oblitèrent les cadres naturels antérieurs, des sociétés originales par leur composition ethnique et démographique autant que par leurs modes de penser. Tels sont les grands thèmes d'intérêt qu'offrent au géographe les régions pionnières du globe. (MONBEIG, 1966, p. 974.)

Par une contradiction qui n'est qu'apparente, l'époque récente des grands défrichements fut celle où naquirent et où s'affirment des sentiments nationaux vite jaloux. Les pionniers contribuèrent dans une très large mesure à la formation du sentiment national en Australie comme en Argentine ou au Brésil comme au Canada, en Nouvelle-Zélande et en Afrique du Sud. Aux Etats-Unis la part du monde pionnier dans l'élaboration de 1 communauté américaine a été considérable. Il y naquit comme un mythe de la frontier et d'un frontier's man, citoyen émérite. Le mot frontier n'a évidemment pas ici le sens politique habituel. Il désigne la frange pionnière, zone imprécise séparant Blancs et Indiens, nature brute et zone civilisée. Une littérature considérable crut pouvoir affirmer la responsabilité de la frontière comme creuset à la fois du peuple et de la démocratie nord-américaine. On lui reconnaissait en outre une fonction de soupape de sûreté car la marche vers l'Ouest aurait évité le gonflement des villes et, du coup, l'exaspération des rivalités sociales. (Ibidem, p. 980.)

A citação desse texto de Monbeig, que define o verbete franges pionnières no tomo sobre geografia geral da conceituada Encyclopédie de la Pléiade, obra editorial de imenso prestígio que reuniu em seus 49 volumes, publicados entre 1956 e 1991, uma vasta gama de contribuições 
dedicadas aos mais variados ramos das ciências, da literatura à música, da psicologia à zoologia, merece mais alguns comentários, mesmo que ultrapasse os limites cronológicos do período que consideramos. Assim sendo, é representativo notar que no final da década de 1950 e início de 1960, Monbeig galgou a postos-chave na estrutura universitária francesa: em 1957, foi um dos fundadores do Instituto de Altos Estudos da América Latina (IHEAL, na sigla em francês), assumindo pouco depois o lugar de Charles Robequain como professor da cadeira de geografa colonial da Sorbonne, onde seria, em 1961, efetivado como professor de geografia humana, mesmo ano em que adentra, como diretor adjunto, a estrutura do afamado Centre Nationale de Recherches Sociales (o CNRS).

A bem dizer, alguns dos caracteres típicos sempre lembrados na definição das franjas pioneiras são exemplarmente citados no trecho acima. Em primeiro lugar, o movimento pioneiro define-se ali como um processo de expansão do ecúmeno, palavra grega adaptada da biologia darwinista, utilizada em alusão às áreas do globo consideradas capazes de fornecer suporte para o desenvolvimento da vida humana, que se transformou numa noção consagrada das geografias de sotaque francês ou alemão entre o final do século XIX e início do XX - em uma palavra, a noção de ecúmeno é sinônimo da ideia de espaço habitado pelo homem (SORRE, 1951) ${ }^{17}$. Desse modo, seguindo uma tradição há muito presente na geografia, as regiões pioneiras poderiam ser definidas como as áreas da superfície terrestre em vias de ocupação pelos grupos humanos, que, ao conquistá-las, libertam-nas da dominação dos meios naturais e as incorporam ao ecúmeno. Além disso, as regiões pioneiras do globo se apresentam como palcos onde se assiste ao desenrolar de contatos e conflitos entre sociedades que apresentam níveis de desenvolvimento técnico, econômico, político e demográfico desiguais, o que indica que a frente pioneira pode ser vista como uma corrente que modifica não apenas as paisagens, mas igualmente as populações das áreas apropriadas em sua dinâmica de expansão.

\footnotetext{
${ }^{17}$ O geógrafo Max Sorre (1880-1962), um dos mais diletos discípulos de Vidal de La Blache, considerava que a tarefa da Geografia Humana era a descrição do ecúmeno. No capítulo III do primeiro tomo de sua obra magna, Les fondaments de la Géographie Humaine, dedicado inteiramente aos fundamentos biológicos das atividades humanas, Sorre persegue o processo de formação do ecúmeno, notando que a variabilidade do espaço terrestre originou diferentes adaptações dos grupos humanos, formando distintos gêneros de vida que desenvolveram técnicas próprias nesse processo de adaptação: de fato, o espaço habitado - a "morada do homem" - caracterizava-se, para Sorre, por seus aspectos diferenciais, seja do ponto de vista do embasamento físico da vida, seja da perspectiva da apropriação dessa base natural pelos grupos humanos: "Nous venons de définir les limites de la terre habitée, ou si l'on veut de l'espace humain. Ce qu'il y a d'un peu surprenant dans cette dernière façon de parler disparait si l'on considère avec les naturalistes modernes que la notion d'aire d'extension est inséparable de l'idée de groupement spécifique. Il faut maintenant insister sur les deux propriétés fondamentales de cet espace: il est discontinu et il n'est pas homogène." (SORRE, 1951, p. 85.)
} 
Há, então, como pano de fundo da dinâmica posta pelas frentes pioneiras, um desvelo com a dominação de espaços e homens, que se põem, ambos, à disposição das vontades daqueles que controlam o movimento. $\mathrm{O}$ saliente aspecto de luta entre os homens e o meio natural presente nessa definição traduz-se no processo de transformação de paisagens naturais em paisagens humanizadas, que resulta na fundação de cidades, no surgimento de novos campos de cultivo e na conformação de uma rede de caminhos. Ademais, a definição das franjas pioneiras como uma zona de limites imprecisos que separa os "brancos" dos "indígenas", praticamente sinônima da antinomia estabelecida entre a "natureza bruta" e os espaços naturais apropriados e conquistados pela "civilização", imprime ao termo um sentido de dominação de povos e terras que recoloca a subordinação de grupos considerados inferiores ou primitivos, e a construção de cidades, campos e redes de transporte demandados por uma economia estruturalmente exógena, como as qualidades gerais comuns a todas as regiões pioneiras do mundo. Mas isso lá é assunto para outro capítulo.

No momento, cumpre asseverar que do ponto de vista da formação territorial o fenômeno do pioneirismo brasileiro define-se como o avanço do povoamento impulsionado por uma colonização de base eminentemente agrária por sobre áreas pouco ou nada habitadas, sendo frequente aos sujeitos que pretendem controlar ou comandar a direção de tais movimentos expansivos - em geral proprietários de terras, empresas ligadas à colonização e exploração agrícola, ou mesmo órgãos ligados ao Estado - qualificar tais áreas como "vazias", o que implica reconhecer não apenas a aptidão real ou sugerida de tais áreas para a implantação de projetos de colonização, mas sobretudo a disponibilidade das terras ainda não incorporadas política e economicamente na órbita estatal para a fixação populacional, posição que revela a invisibilidade dos habitantes que porventura lá se encontrassem antes do início do processo de ocupação, via de regra povos indígenas, posseiros e pequenos agricultores, concebidos como os portadores de técnicas primitivas e os principais símbolos do atraso que se quer superar.

Desdobrando essa proposição, é oportuno sublinhar dois aspectos sobremaneira relevantes para o caso brasileiro: de um lado, o fato de tais "espaços vazios" serem normalmente identificados como "sertão" (LIMA, 1999; LOMBARDI, 1975; OLIVEIRA, 2000; SOUZA, 1997); de outro lado, a operacionalidade de um tratamento econômico da questão, que busca relacionar o avanço da fronteira com o aumento das terras efetivamente apropriadas e cultivadas dentro de um território e, pois, entende as movimentações de fronteira como parte de um 
processo de desenvolvimento econômico e demográfico mais amplo do país ou região onde estas ganham dinamismo - o que nos leva a distinguir dois tipos distintos de movimentação de fronteiras, um associado à pequena propriedade e à agricultura de subsistência, e outro ligado à agricultura de exportação praticada em grande escala (KATZMAN, 1975).

Sem nos determos em demasia no imenso cabedal de trabalhos que tratam do tema do sertão, basta por ora assinalar que este pode ser tomado como um dos mais significativos conceitos espaciais mobilizados no pensamento político-social para a explicação das singularidades nacionais (AMADO, 1995; ALMEIDA, 2001; MAIA, 2008; OLIVEIRA, 2000; SOUZA; 1998). Expressivamente, entre 1870 e 1940, o sertão constituiu-se numa das categorias centrais das construções literárias e ensaísticas que tinham a nação e seu processo de formação como tema. Entretanto, o termo sertão não se refere a uma realidade fático-material, nem a uma paisagem típica presente no universo empírico da geografia clássica, pois o espaço denominado como sertão não se apresenta como uma área localizável e cartografável dotada de certa homogeneidade e individualidade, "não podendo ser estabelecido como um tipo de meio natural singular nem como uma modalidade própria de paisagem humanizada" (MORAES, 2003, p. 12). Isso nos leva a asseverar que o sertão não é um lugar, mas uma condição atribuída, em circunstâncias determinadas, a diversos lugares. Em outros termos, a definição do sertão inclui a projeção de uma valorização futura que irá mudar a condição atual da área assim qualificada:

Enfim, o sertão é uma figura do imaginário da conquista territorial, um conceito que ao classificar uma localização opera uma apropriação simbólica do lugar, densa de juízos valorativos que apontam para sua transformação. Nesse sentido, a designação acompanha-se sempre de um projeto (povoador, civilizador, modernizador, integrador), o qual almeja - no limite - a superação da condição sertaneja. Trata-se de um espaço a ser conquistado, submetido, incorporado à economia nacional: uma área de expansão. Por essa característica, é possível estabelecer paralelos entre o papel desempenhado pela idéia de sertão na formação brasileira e o uso similar da noção de "deserto" na história da Argentina. No plano conceitual, mas mais distante de conteúdo em função de seu componente democrático (não presente nos conceitos anteriores), estaria a "fronteira" - tal como analisada por Turner - na colonização dos Estados Unidos. Tem-se o sertão como um qualificativo de lugares, um termo da geografia colonial que reproduz o olhar apropriador dos impérios em expansão. $\mathrm{Na}$ verdade, tratam-se de sertões, que qualificam caatingas, cerrados, florestas, campos. Um conceito nada ingênuo, veículo da difusão da modernidade no espaço. (MORAES, 2003, pp. 20-21.) ${ }^{18}$

\footnotetext{
${ }^{18}$ Ao perscrutar o itinerário de construção semântica do termo ao longo do período colonial, Janaína Amado concluiu ser o sertão uma categoria que adquiriu, como a palavra frontier no caso dos EUA, novos significados ao longo do processo de colonização, pois a partir do sentido usual do termo em Portugal, que remonta ao século XIV e o atrela à
} 
Nesse sentido, o sertão, ou melhor, o processo de sua conquista por meio do avanço das fronteiras, estaria mesmo próximo do significado atribuído ao termo frontier, principalmente se atentarmos para a circunstância de que este termo pode ser tomado como expressão de forças centrífugas, ou seja, como resultado de correntes expansivas impulsionadas num território por alterações demográficas e econômicas em certa medida passíveis de serem intencionalmente orientadas de maneira estratégica para a manutenção de limites políticos (KRISTOF, 1959) ${ }^{19}$. Essa última condição geral aponta para a possibilidade de se instrumentalizar politicamente uma corrente migratória, se adequando bem ao caso brasileiro do período aqui analisado, mormente quando se pensa nos objetivos elaborados por Getúlio Vargas durante a década de 1930 e 1940 para o programa "Marcha para o oeste" (LENHARO, 1986; SECRETO, 2007). Visto como um slogan que revelava uma política territorial de alto valor estratégico, a "Marcha" indicava a necessidade de se dinamizar a ocupação do interior pela via de uma colonização dirigida ou planejada. Assim, ao integrar os espaços "vazios" do interior na órbita de influência do Estado, este poderia assegurar um desenvolvimento econômico ao país ao mesmo tempo em que garantiria a soberania não disputada de amplos espaços ainda não efetivamente integrados ao território do ponto de vista demográfico, político, econômico e cultural (DINIZ FILHO, 1994). Nesse sentido, o domínio do sertão, ao garantir uma maior fluidez aos fluxos internos encetados

noção de espaços vastos, desconhecidos e pouco habitados, criaram-se na América portuguesa parâmetros de definição adequados à situação de conquista e consolidação do território colonial: "Sertão, já se viu, designava não apenas os espaços interiores da Colônia, mas também aqueles espaços desconhecidos, inacessíveis, isolados, perigosos, dominados pela natureza bruta, e habitados por bárbaros, hereges, infiéis, onde não haviam chegado as benesses da religião, da civilização e da cultura (...). Para o colonizador, 'sertão', constitui o espaço do outro, o espaço por excelência da alteridade. Que outro, porém, senão o próprio eu invertido, deformado, estilhaçado? A partir da construção de alteridades, durante os processos de colonização, os europeus erigiram e refinaram as próprias identidades (...). Como o conceito de 'sertão' foi construído pelos portugueses, dependendo, para ser expresso, da localização do seu enunciante - geralmente um colonizador -, disso decorreu outra conseqüência importante: durante a época colonial (à medida, portanto, que a colonização avançava sobre as terras), 'sertão' foi empregado para nomear áreas tão distintas quanto, por exemplo, o interior da capitania de São Vicente, a atual Nova Iguaçu, no Rio de Janeiro, a Amazônia, a cidade do Recife e a capitania de Minas Gerais.” (AMADO, 1995, p. 149.)

${ }^{19}$ A dificuldade de promover uma separação entre os aspectos internos das fronteiras em movimento e os aspectos externos que envolvem a definição dos limites políticos é há muito reconhecida pelos geógrafos que se debruçaram sobre esse assunto (FOUCHER, 1991). Ao empreender uma análise aprofundada dos significados do termo fronteira com o objetivo de definir os processos aos quais ele se refere, Kristof (1959) aproveitou-se de uma especificidade linguística e cultural dos Estados Unidos e atribuiu alcances diversos aos termos boundary e frontier, associando o primeiro ao sentido clássico de limites políticos, e reservando ao segundo o significado de avanço de fronteira, processo mais afeito à expansão espacial de uma atividade ou setor econômico. Seguindo essa senda, Stephen Jones avaliou de maneira panorâmica os diversos usos dados ao conceito de fronteira, tal como definido em sua acepção de limites, mas antes notou a espinhosa tarefa de estabelecer uma tipologia que excluísse o sentido político do econômico: "I am focusing on boundaries rather than frontiers, but anyone who has delved into the subject knows that it is impossible completely to separate the two. I am dealing with both external and internal boundaries, partly in response to the availability of materials, partly because, for some times and places, it is difficult to distinguish the two kinds sharply." (JONES, 1959, p. 241.) 
no território brasileiro, tornar-se-ia um fator de integração nacional, atuando como veículo de difusão da modernidade no espaço ${ }^{20}$.

Em resumo, embora o imaginário da conquista territorial seja um elemento presente em distintos momentos da história brasileira, influenciando a elaboração de políticas territoriais ao assumir múltiplas expressões desde ao menos o final do XIX (MACHADO, 1995; MORAES, 2011), há dentro do pensamento político-social, notoriamente no intervalo entre as décadas de 1930 e 1960, uma significativa mudança no entendimento do que era ou deveria ser o sertão que paulatinamente acompanha as alterações nas formulações discursivas preocupadas em ajustar a construção identitária nacional ao processo de formação territorial estatal. Permeadas por uma interpretação globalizante da relação sociedade-natureza, essas formulações trazem consigo avaliações negativas ou positivas dos espaços considerados "vazios", ou seja, das áreas ainda não exploradas de maneira produtiva, que normalmente assumem a denominação de sertões $(\text { MORAES, 2003) })^{21}$. Assim, o sertão surge como uma qualidade atribuída a um espaço que se quer dominar e ocupar, pois, se eram os espaços sertanejos os destinados a passar por um processo de civilização no XIX, são também os sertões, agora refuncionalizados (SANTOS, 1997), as áreas percebidas como as mais aptas a receberem os fluxos modernizantes do século

20 "The frontier is a manifestation of centrifugal forces. On the other hand, the range and vigor of centripetal forces is indicated by the boundary. True, the frontier has, and always had, also a strategic meaning - the defensive line which keeps enemies out - and in this it depends on support from the hinterland. But precisely in order to be able to maximize its strategic forces the central government must mobilize and integrate all the available resources. All efforts and loyalties must be concentrated and coordinated under the banner of the state idea and interest. Consequently, the frontier lands, too, have to be controlled and bound to the state; they must be subordinated to the imperative and overriding demands of the sovereign raison d'etre of the state as a whole. In other words, an effort is made to draw somewhere a line of effective control over both ingress and egress: not only the enemy has to be kept out but one's own citizens and resources have to be kept in. It is in the interest of the central government to substitute a boundary for the frontier. The frontier is an integrating factor. Being a zone of transition from the sphere (ecumene) of one way of life to another, and representing forces which are neither fully assimilated to nor satisfied with either, it provides an excellent opportunity for mutual interpenetration and sway. Along the frontier life constantly manipulates the settled patterns of the pivotally organized socio-political and cultural structures. It is precisely this watering down of loyalties and blurring of differences that the central governments attempt to forestall by substituting the semi-autonomous frontiers with a controlled and exact borderline." (KRISTOF, 1959, pp. 272273.)

21 "Nos países de formação colonial, a conquista de espaços aparece como um elemento estruturador da sociabilidade política, fornecendo não apenas um projeto prático para a organização e atuação do Estado e das elites, mas também um forte argumento ideológico de legitimação de suas ações e objetivos. 'Construir o território' emerge nestes contextos da periferia como um apelo orientador da vida social, o qual disponibiliza uma meta comum que se sobrepõe aos horizontes de atuação local de elites geralmente bastante regionalizadas. Nesse processo, o território acaba por substituir a sociedade na própria identificação do país, que passa a ser tomado como um espaço a ser conquistado num movimento onde o 'povo' é visto como mero instrumento de realização desse projeto nacional. A história da formação brasileira exemplifica bem tais determinações da condição periférica, com a ideia de construir o país consolidando-se numa reiteração dos princípios coloniais agora aplicados na tarefa de edificação da nova nacionalidade." (MORAES, 2009, p. 78.) 
XX. Vislumbra-se então a existência de uma linhagem interpretativa que esboça imagens do país em registros que descrevem a natureza brasileira e seus atributos, dentre eles o território e a população, ora como positividade, a reserva identitária da nação, ora como negatividade, o entrave ao nosso progresso, a antítese da nação desejada ${ }^{22}$.

Retomando o ponto, percebe-se que a menção a exemplos que revelam outras formas de concepção e tratamento do espaço no pensamento político-social brasileiro, mesmo que feita apenas tangencialmente, atenua sobremodo a proposição de Capel (1977), pois mostra que, no Brasil, a constituição da comunidade científica dos geógrafos não lhes facultou uma posição de comando nas discussões sobre o espaço, sendo mesmo necessário admitir que, dentro do pensamento político-social como um todo, o papel ocupado pelos que se denominavam geógrafos não foi assim tão fundamental para o desenvolvimento de uma argumentação embasada precipuamente em conceitos de base espacial, já de longa data presentes nas discussões sobre o país. Ademais, a intenção dessa digressão foi também frisar o duplo caráter material e simbólico de que pode revestir-se o entendimento do processo de ocupação territorial (MORAES, 2011), o que quer dizer que a expansão do povoamento e da colonização dentro de um território sob inconteste jurisdição estatal comporta sempre duas faces. Uma face empírica, expressão das alterações sofridas na geografia material pela organização do território, seja por conta da influência de fenômenos econômicos, seja como resultado de movimentos migratórios que incidem em mudanças do perfil demográfico, e outra face por assim dizer ideológica, mais evidente nas construções narrativas que buscam se apropriar simbolicamente dos processos históricos, econômicos e demográficos para construir discursos que objetivam embasar mitos de identidade ou apenas justificar diferentes estratégias de apropriação territorial:

\footnotetext{
22 "O lugar geográfico ou social identificado como sertão acompanha este caminho, que recebe ora uma avaliação positiva, ora negativa. As definições de sertão fazem referência a traços geográficos, demográficos e culturais: região agreste, semiárida, longe do litoral, distante de povoações ou de terras cultivadas, pouco povoada e onde predominam tradições e costumes antigos. Lugar inóspito, desconhecido, que proporciona uma vida difícil, mas habitado por pessoas fortes. A força de seu habitante aparece relacionada à capacidade de interagir com a natureza múltipla. O cabra - o cangaceiro - aparece como a encarnação do herói sertanejo. Para além destes atributos, aparece no imaginário social a idéia de que não há um sertão mas muitos sertões e que o sertão pode e deve ser tomado como metáfora do Brasil (...). Duas perspectivas na conotação de sertão podem ser identificadas com a tradição romântica e a realista no trato do espaço geográfico e do homem que o habita. Na perspectiva romântica, o sertanejo aparece como símbolo da nacionalidade pelo seu admirável modo de vida, caracterizado pela destreza e simplicidade. Natureza e organização social se fundem na base deste julgamento positivo, opondo-se à vida degradada e corrompida do litoral, ou seja, das cidades. Na perspectiva realista, a vida interior perde esta visão idealizada. O sertão passa a ser visto como um problema para a nação e se opõe à urbanidade do litoral. Sob a visão cientificista do final do século XIX, as explicações raciais sustentam uma suspeita sobre os tipos miscigenados portadores da degeneração." (OLIVEIRA, 2000, pp.70-71.)
} 
Por ejemplo, en Brasil la visión turneriana fue inspiradora de algunos trabajos en torno del tema de la frontera. Historiadores y geógrafos se valen de las particularidades que el proceso de incorporación del territorio de este país a la economía mundial, tanto en su período colonial como en el independiente, a partir de ciclos simultáneos o secuenciales de monoproducción (palo brasil, azúcar, café, cacao, caucho, oro) para explicar los movimientos de la población migrante de avance sobre el sertão. Este avance es descrito como un proceso discontinuo y hasta truncado, ya que el mismo estaría signado por los avatares que dichos productos sufren en el mercado mundial. Quien migra al "sertão" es presentado como sucesor de la figura pionera por excelencia: el bandeirante. Como ya lo hemos señalado, la historiografía oficial suele presentar al bandeirante como el principal colaborador de la política oficial portuguesa en su expansión por los territorios de América Meridional. (ZUSMAN, 2000, pp.7879.)

Nesta seção tentamos entrelaçar três pontos básicos: primeiramente, reconheceu-se que a chamada tese da fronteira comporta de modo geral um entendimento acerca do processo de expansão territorial das sociedades, que nos Estados Unidos pôde ser apropriado intelectualmente como forma de explicar as singularidades que envolveriam a formação da identidade nacional norte-americana (ÁVILA, 2006). No geral, tal apropriação simbólica foi efetuada numa chave interpretativa que conjuga o desenvolvimento econômico de um grupo social, tomado como o portador dos signos da "civilização", com o espraiamento espacial desse mesmo grupo em um espaço considerado vazio. Posteriormente, buscou-se mostrar que tais "espaços vazios" qualificados pelo domínio da natureza hostil e de povos bárbaros foram normalmente identificados no Brasil com o vocábulo sertão, que incorpora em seu significado uma vontade de controle estatal por sobre espaços que não foram nem apropriados economicamente nem colocados sob a órbita de uma jurisdição política incontestável - em uma palavra, que incorpora em sua definição o ser alvo de fluxos expansivos que irão integrá-los ao espaço nacional. Por fim, no esboço de explanação do sentido conferido pelos geógrafos ao termo franjas pioneiras, aqui passado rapidamente em revista por meio da alusão feita a um trabalho de Pierre Monbeig, pudemos acompanhar a presença de alguns dos termos básicos acima arrolados em sua definição, uma vez que o geógrafo francês descrevia as franjas pioneiras como as áreas do mundo que se encontravam em via de incorporação ao ecúmeno, ou seja, como os lugares ainda dominados pela natureza bruta e por populações que apresentavam baixos níveis de desenvolvimento cultural, político e econômico que seriam apropriados e explorados por sociedades tecnicamente avançadas. 
No caso, como se pensava que as dificuldades encontradas por essas sociedades em expansão poderiam ser minoradas a partir das soluções propostas nos inquéritos de campo que dariam fundamento científico às correntes de povoamento e colonização dinamizadas ao redor do mundo, a distinção entre civilização e barbárie constante na noção turneriana de frontier é reposta nos trabalhos geográficos mais recentes em termos que se vinculam aos debates que envolvem o desenvolvimento econômico e a colonização planejada dos lugares, com o que a interpretação geográfica do pioneirismo afasta-se sensivelmente do enquadramento desenvolvido por Turner, que ainda cultuava a figura do desbravador isolado lutando sozinho contra as agruras do meio e a ameaça dos povos indígenas, para se aproximar das disciplinas de ação e de planejamento que se consolidavam nas bordas do aparato decisório estatal no início do século XX (ROBIC, 2006). Para Monbeig, que foi nisso influenciado pelo geógrafo estadunidense Isaiah Bowman, o maior expoente a tratar do tema, o pioneirismo moderno seria assunto de interesse estratégico dos governos, e não uma corrente de povoamento deixada para se desenvolver por esforços individuais de particulares.

Continuando agora o esforço de reconstrução da conjuntura histórica do Brasil no início do século XX, a próxima seção, um tanto mais extensa do que as demais, analisará certos caracteres das décadas de 1930 e 1940 que revelam a importância dos temas da integração territorial e da expansão do povoamento para o debate político e intelectual efetuado no momento, circunstância que, como iremos acompanhar até o final do capítulo, sugere a existência de um ambiente propício para o desenrolar do processo de institucionalização acadêmica da geografia no país, funcionando como eficiente indicador do processo de amadurecimento daquilo que podemos chamar de "cultura geográfica” (CARDOSO, 2009).

\section{Integração territorial, os intelectuais e o debate político}

Dentre os fatores que corroboram a hipótese de que haveria no Brasil do início do século XX um ambiente intelectual amadurecido para a consolidação institucional da geografia, é importantíssimo citar o papel que a Sociedade de Geografia do Rio de Janeiro (SGRJ) cumpriu na elaboração de um projeto de saber disciplinar que visava fundamentar o conhecimento geográfico num corpo teórico específico. Com efeito, o esforço de socialização dos valores pátrios com vistas à adoção de um imaginário nacionalista por novos grupos e setores da sociedade através do 
ensino demandava sua transmissão por disciplinas consideradas "científicas" e, pois, exigia a renovação da geografia (ESCOLAR, 1996). A bem dizer, o período de 1910 a 1920, caracterizado decisivamente pela eclosão dos conflitos armados na Europa, em 1914, e pela Revolução Russa, em 1917, se distingue pela vulgarização do sentimento cívico e pela reafirmação dos interesses nas questões nacionais, que seguem identificando o sentimento de nacionalidade com o território, fato explícito, por exemplo, no chamado patriotismo à moda de 1914, que defendia o princípio das nacionalidades e a vontade de autodeterminação dos povos, sendo encontrado tanto nas intervenções do presidente americano Woddrow Wilson como nas falas de Lênin nas conferências de paz de Paris, ocorridas entre 1919 e 1920 (WALLERSTEIN, 1993).

No caso brasileiro, o período da I Grande Guerra (1914-1919), que impulsionou uma revisão de nossos padrões intelectuais, reacendendo as discussões sobre o nacionalismo para além do simples ufanismo, marca o estabelecimento de um novo patamar de legitimação das intervenções nesse tema, agora definitivamente afastado dos cânones românticos. Imersa no clima generalizado de transformação cultural vivido no despontar dos anos 1920, que impunha a "necessidade de pensar o Brasil do ponto de vista brasileiro" (LIPPI, 1990, p. 126), a SGRJ entra numa nova fase, com o fim da gestão de Francisco Marcondes Homem de Mello, o barão Homem de Mello, e o início de uma sucessão de militares na presidência do grêmio, como o marechal Gregório Thaumaturgo de Azevedo (1914-1920), o almirante Antônio Coutinho Gomes de Pereira (1920-1925), o general José Maria Moreira Guimarães (1920-1945) e o almirante Raul Tavares (1940-1945). Para eles, o foco de interesses não estaria de maneira alguma restrito às minudências da questão pedagógica, senão que a geografia se colocava exatamente como um elemento estratégico na defesa da soberania nacional, vista, essa soberania, basicamente como resultado da integridade do território. De fato, a Grande Guerra chamara atenção para o uso de argumentos históricos como justificativa das reivindicações territoriais:

A proporção tomada pelo conflito europeu suscitou interesse crescente pela confecção de mapas e outras formas de representação espacial, uma vez que a maioria das reivindicações políticas sobre territórios nacionais assentava-se em argumentos históricos (...). No Brasil, desde o final do século XIX, as autoridades republicanas preocupavam-se com a soberania e a preservação do espaço nacional. Se, por um lado, a vasta extensão territorial era motivo de ufanismo, por outro, o isolamento de algumas regiões, afastadas dos grandes centros e situadas nas faixas de fronteira, daria ensejo a diversos projetos de integração do território, a exemplo do da Comissão de Construção das Linhas Telegráficas, formada por militares, que integrou as comunicações entre Rio de 
Janeiro, São Paulo e Triângulo Mineiro à Amazônia. Paralelamente, o governo passou a conferir maior importância a entidades como a Sociedade de Geografia do Rio de Janeiro, reconhecida como órgão de utilidade pública [em 1917] por decreto do presidente Wenceslau Braz Pereira Gomes. (CARDOSO, 2010, p. 73.)

O pragmatismo dos trabalhos desenvolvidos e incentivados pela SGRJ, dentre os quais destacam-se as expedições promovidas pela entidade, que visavam esclarecer questões ainda sem consenso dentro da comunidade científica, como a definição das nascentes dos grandes rios, a exaltação da beleza e unicidade de um acidente geográfico, ou a atenção à fixação dos limites fronteiriços (internos e externos), coadunam bem com as "obsessões geográficas" segundo o ideário positivista dominante na época. Afinal, entre o final do XIX e início do XX, a objetivação do nacional passava pela geografia e por categorias espaciais tanto ou mais do que a construção de uma memória comum passava pela história (PEREIRA, 2002).

Como quer que seja, embora houvesse flagrante heterogeneidade $\mathrm{e}$ falta de correspondência entre os objetivos e os resultados da maioria dos empreendimentos patrocinados pela SGRJ, uma vez que boa parte das iniciativas não foram encaminhadas conforme o pretendido - lembre-se, por exemplo, o "Dicionário de Geografia" de Alfredo M. Pinto, discutido como obra grandiosa desde 1884, mas publicado, em modestos 3 volumes, entre 1894 e 1899 , e o compêndio "Geografia do Brasil Comemorativa do Centenário", projeto de natureza enciclopédica integrante das comemorações do centenário da Independência, que foi planejado em 10 volumes para atingir o grande público, mas que foi editado, sem a periodicidade almejada, em incompletos 4 volumes -, não se pode subestimar o alcance dos projetos encampados pelo grêmio na difusão de um conhecimento geográfico sobre o país. Para avaliar esse fato, bastaria fazer referência à organização, em 1926, do Curso Superior Livre de Geografia, voltado fundamentalmente para o aprofundamento da formação dos professores do ensino primário, ou então descortinar os estímulos dados para a realização dos Congressos Brasileiros de Geografia (CBG), que costumam ser apontados como as iniciativas mais importantes da SGRJ, sendo forçoso reconhecer que seus oito eventos, realizados entre 1909 e 1926, congregaram os esforços dos sujeitos interessados no desenvolvimento de saberes identificados com a geografia, sobretudo aqueles passíveis de serem aproveitados pelo poder público ${ }^{23}$.

\footnotetext{
${ }^{23}$ O dois últimos Congressos, ocorridos em Florianópolis e no Rio de Janeiro em 1940 e 1944, respectivamente, são um caso à parte, e devem ser analisados em separado por inscreverem-se num contexto sobremodo diferenciado dos anteriores, já que foram realizados num momento em que se estava assistindo à convivência inédita da SGRJ com as universidades, a AGB e o IBGE, instituições que hegemonizam a organização da geografia em moldes acadêmicos e
} 
O Curso Livre de Geografia, que reunia em seu corpo docente figuras expressivas da SGRJ e do Colégio Pedro II, tendo como principais artífices Everardo Backheuser, Carlos Delgado de Carvalho e Fernando Raja Gabaglia, conferia o diploma de "Laureado em Geografia e Ciências Correlatas" aos que o concluíssem, sendo uma notória manifestação da tentativa de organizar um projeto disciplinar para a geografia antes de sua efetiva institucionalização universitárioacadêmica. Mesmo não tendo sido reconhecido oficialmente pelo governo, suas aulas inaugurais conformam um discurso unitário e coerente para a disciplina, alinhando-se ao que se chamava então de "geografia moderna", na medida em que tentava subsumir a geografia no rol das ciências naturais, o que, imaginava-se, iria contribuir para reafirmar seu caráter científico. Daí a oportunidade de caracterizar o Curso Superior Livre como "uma das primeiras evidências de um projeto de legitimação da geografia como campo disciplinar referenciado num corpo teórico definido e em construções conceituais próprias" (PEREIRA, 2002, p. 170) ${ }^{24}$. Esse plano de cunho pedagógico, destinado à atualização de professores do ensino primário, destacava a importância da relação homem-meio através da difusão das ideias de Ratzel e La Blache, sendo em tudo similar ao empreendimento educacional nacionalista tentado anteriormente pelo Instituto Histórico e Geográfico Brasileiro, o IHGB, que entre 1916 e 1921 empreendeu a iniciativa de estabelecer uma "Academia de Altos Estudos", transformada posteriormente na Faculdade de Filosofia e Letras do IHGB, também não reconhecida oficialmente pelas autoridades. Ao fim e ao cabo, ambos os projetos encapavam a ideia de que a educação feita a partir de um efetivo

profissionais ao longo da década de 1930, mas que nem por isso deixam de recorrer à SGRJ, em crise de identidade e em pleno processo de renovação, para consolidar seu espaço institucional e se legitimarem como os novos centros difusores dos saberes geográficos no país, sendo peculiar ao caso brasileiro de institucionalização da geografia que uma entidade já antiga, esvaziada e sem maiores perspectivas de alteração de seu status se colocasse como referência obrigatória para a organização desses encontros de caráter nacional. Seja como for, a preocupação dos promotores dos eventos era estabelecer uma ideia uniforme de país, construindo uma concepção que fizesse do "Brasil" uma representação mental de síntese que permitiria unificar as grandes desigualdades objetivamente observadas entre as diversas regiões. O propósito seria sedimentar uma imagem única e positiva do país que pudesse ser veiculada não só internamente, mas sobretudo no exterior: "uma tentativa de apreender todos os fatos e conhecimentos do país em um encontro de estudiosos e diletantes. Numa época de comunicações precárias, fazia-se um esforço de reunir todos os aspectos do país, divulgando as mais recentes descobertas e os últimos trabalhos realizados; através do contato entre estudiosos de diversas partes do Brasil pretendia-se chegar ao 'todo nacional'”. (PEREIRA, 2002, p. 144.)

${ }^{24}$ Comentando sobre a preleção dada por Everardo Backheuser na inauguração do Curso Livre, Perla Zusman reafirma esse juízo, dizendo que: "A apresentação de Backheuser dá à Geografia um "status científico" fundamentado nas normas de justificação e validade do conhecimento do campo natural, uma especificidade ontológica outorgada pela apropriação das relações de interdependência localizadas entre o solo, o clima e o homem. Estas inter-relações, apoiadas numa teoria específica (aquela sustentada pela escola alemã), permitem a produção de um discurso substantivo particular onde o conceito de paisagem e de região têm papel fundamental. São estes os fundamentos epistemológicos da Geografia Moderna, que, opondo-se a uma Geografia enciclopédica, memorística, tornam-se a estratégia epistemológica utilizada a partir dos anos 1930 pelas novas instituições e pelos discursos produzidos nelas para justificar sua necessidade de constituição”. (ZUSMAN, 1996, p. 139.) 
conhecimento do território nacional era um dos caminhos mais seguros para alterar as condições precárias do ensino da disciplina no país. Além disso, personalidades como Basílio de Magalhães, José Maria Moreira Guimarães e mesmo Delgado de Carvalho, quadros integrantes da SGRJ, participaram ativamente do empreendimento educacional do IHGB, o que reforça a convergência entre os projetos, que evidenciavam as tendências teóricas mais recentes da época:

Ao que tudo indica, o esforço dos coordenadores e o brilhantismo daquele grupo de professores não foi o suficiente para manter o funcionamento do Curso, pois, sabe-se que no segundo ano de atividades houve uma redução considerável do número de alunos. Embora na documentação disponível na Sociedade de Geografia do Rio de Janeiro não exista nenhuma relação dos alunos laureados em Geografia e Ciências Correlatas, é viável supor que houve quem concluísse o Curso, uma vez que na Revista informa-se que a entrega dos diplomas poderia ser realizada em sessão solene na Sociedade ou diretamente na secretaria. De qualquer forma, tratava-se de um projeto educacional afinado com as idéias vigentes, ou seja, percebia o estudo da geografia e da história como instrumentos para a disseminação do patriotismo e para exaltação da grandeza nacional. (CARDOSO, 2009, p. 252.)

A referência a essas iniciativas científico-pedagógicas, com destaque às que envolviam de algum modo a modernização do ensino pela incorporação das novas teorias e conceitos da geografia, que seriam aplicados à explicação dos problemas nacionais, ressalta a inexistência de um sistema organizado de educação pública no Brasil, pois mesmo com a cultura e a ciência sendo consideradas ferramentas para a construção de uma nação moderna desde ao menos o final do século XIX, somente a partir da década de 1920 os debates em torno da necessidade de se criar uma estrutura pública e universal de ensino adquirem maior expressão, como atesta a fundação, no Rio de Janeiro, em 1922, da Academia Brasileira de Ciências, e em 1924, da Associação Brasileira de Educação, ambas com ativa participação dos já citados Everardo Backheuser e Delgado de Carvalho (SCHWARTZMAN, 2001) ${ }^{25}$.

\footnotetext{
25 "Nos anos iniciais do século XX, passa a se compor uma via de institucionalização da Geografia, que tem no ensino de primeiro e segundo graus a sua fundamentação. É nesse período também, que se funda o primeiro ensaio brasileiro de ensino superior em Geografia: o Curso Livre de Geografia Superior fundado em 1926, por Everardo Backheuser e Carlos Delgado de Carvalho (...). Backheuser e Delgado de Carvalho representam em nossa opinião, as duas principais vertentes epistemológicas da Geografia na década de 1920. Os dois tiveram ativa participação na implementação da Geografia Moderna em termos de pesquisa e ensino. Na década de 20 - que é considerada, com justa razão, um momento de profundas transformações para a Geografia, refletindo as transformações sofridas pela sociedade - tanto Backheuser como Delgado trabalharam diretamente na divulgação e na oficialização de novos paradigmas geográficos, tanto no ensino secundário como no primário. Sendo assim, o diálogo estabelecido entre estes dois geógrafos é algo extremamente valioso para a compreensão do processo histórico de construção da Geografia, no Brasil. O Curso Livre de Geografia Superior que se constituiu num primeiro passo para a institucionalização definitiva da Geografia, no país, tem nestes dois intelectuais seus primeiros diretores Backheuser dirige o Curso em 1926, Delgado, em 1927. A institucionalização da Geografia em nível superior ocorre em 1934, em São Paulo e, em 1935, no Rio de Janeiro. Portanto, a compreensão da veiculação das idéias geográficas
} 
Embora o horizonte pedagógico assuma grande preponderância na narrativa que vimos construindo até o momento, visto que o presente capítulo objetiva fornecer um embasamento da conjuntura histórica que cerca o processo de institucionalização da geografia no Brasil a fim de avaliar a contribuição de Monbeig para o sucesso de tal empreitada, faz-se necessário notar que a discussão estratégica e geopolítica é sem dúvida fundamental na caracterização do ambiente intelectual nas décadas de 1920 e 1930. No geral, os discursos geoestratégicos tomavam o território e seus componentes, tais como a dimensão, as fronteiras, os recursos naturais e de população, a posição, a situação e as condições de deslocamento internas, entre outros, como temas centrais das discussões que intentavam elaborar verdadeiros projetos nacionais para o Brasil. De fato, haveria até a coincidência de certos nomes, pois Everardo Backheuser, Carlos Delgado de Carvalho e, em certo sentido, até mesmo o capitão do Exército Mário Travassos, precursores das discussões e pesquisas geopolíticas em nosso país, frequentavam de modo simultâneo associações como a Associação Brasileira de Ensino (ABE), o Itamaraty e a SGRJ, desempenhando um papel de destaque nos círculos intelectuais mais próximos dos debates de cunho geoestratégico, mas também participando das atividades que esboçaram uma sistematização da geografia acadêmica antes da institucionalização universitária da disciplina (ANSELMO, 2000; VLACH, 2007).

Na verdade, no início do século XX, a vertente geopolítica do pensamento político-social brasileiro já colocava as questões associadas da coesão territorial e da circulação interna do território como fatores fundamentais a serem resolvidos para que o desenvolvimento e a consequente modernização do país fossem bem encaminhados (COSTA, 1992; MIYAMOTO, 1981). Assim, dentre as principais ações pensadas para resolver os problemas postos pelo paradoxo que opunha as potencialidades do território (leia-se sua natureza) ao atraso da população, interessa-nos sobretudo a promoção de uma série de políticas governamentais voltadas para a organização de uma renovada configuração territorial, pois o planejamento e execução de medidas visando uma tal reorganização dos fixos e fluxos (SANTOS, 1988) ${ }^{26}$ no

\footnotetext{
no meio escolar acaba assumindo uma expressiva relevância para a compreensão mais ampla da importância que essa ciência representa para o desenvolvimento da sociedade brasileira.” (ANSELMO e BRAY, 2002, p. 115.)

26 "A paisagem é o conjunto de todas as coisas que se dão diretamente aos nossos sentidos; a configuração territorial é o conjunto total, integral, de todas as coisas que formam a natureza em seu aspecto superficial e visível; e o espaço é o resultado de um matrimônio ou um encontro, sagrado enquanto dura, entre a configuração territorial, a paisagem e a sociedade. O espaço é a totalidade verdadeira, porque dinâmica, resultado da geografização da sociedade sobre a configuração territorial. Podem as formas, durante muito tempo, permanecer as mesmas, mas, como a sociedade está sempre em movimento, a mesma paisagem, a mesma configuração territorial oferecem-nos, no transcurso histórico,
} 
espaço brasileiro apresentavam-se, nessa ótica, como a solução dos problemas relativos ao atraso social e econômico, que seriam atenuados pelo estímulo à ocupação, povoamento e consequente indução do desenvolvimento industrial e agrário no Brasil, temas que compõem a vertente geopolítica que informava o núcleo do pensamento autoritário disseminado na época (BOMFIM, 2001).

Como é fartamente reconhecido na historiografia dedicada ao período, os anos de 1930 marcam o início de um período de muitas mudanças políticas, econômicas e culturais no Brasil. Em verdade, sob o comando de Getúlio Vargas (1930-1945), grandes transformações atingiram a organização do Estado e da sociedade brasileira, valendo destacar a criação, pelo governo federal, de inúmeros institutos, conselhos, ministérios, departamentos, companhias, fundações - enfim, aparelhos burocráticos que tinham como finalidade a centralização das ações administrativas apoiada na cooptação e formação de quadros intelectuais de burocratas de perfil mais técnico, que viriam dar corpo e contornos científicos aos projetos do governo.

A proeminência de uma visão espacializada do país, percebida por exemplo na vulgarização das leituras que qualificavam como benéficas ou deletérias as características físicas e mesmo sociais (estas vistas por um prisma naturalizador) do território, parece solidificar-se como um dos cernes explicativos da realidade nacional, erigindo uma espécie de determinismo bio-mesológico que questiona o papel do meio tropical e da população miscigenada no desenvolvimento do país ao formular um enunciado que traz consigo um intrigante paradoxo: o território brasileiro e a população nele fixada encerrariam um potencial de riquezas ainda não exploradas pelo Estado nacional ou seriam mesmo a motivação principal de nosso atraso? Com qual povo contamos para alavancar nosso progresso $?^{27}$.

espaços diferentes. O espaço é, também e sempre, formado de fixos e de fluxos. Nós temos coisas fixas, fluxos que se originam dessas coisas fixas, fluxos que chegam a essas coisas fixas. Tudo isso, junto, é o espaço. Os fixos nos dão o processo imediato do trabalho. Os fixos são os próprios instrumentos de trabalho e as forças produtivas em geral, incluindo a massa dos homens. Não é por outra razão que os diversos lugares, criados para exercitar o trabalho, não são idênticos e o rendimento por eles obtido está em relação com a adequação dos objetos ao processo imediato de trabalho. Os fluxos são o movimento, a circulação e assim eles nos dão também a explicação dos fenômenos da distribuição e do consumo. Desse modo, as categorias clássicas - isto é, a produção propriamente dita, a circulação, a distribuição e o consumo - podem ser estudadas através desses dois elementos: fixos e fluxos.” (SANTOS, 1988, pp. 77-78.)

${ }^{27}$ Essa questão, em termos um tanto quanto distintos, já fora posta, ao longo do XIX, nas discussões do Instituto Histórico e Geográfico Brasileiro (IHGB) sobre o problema racial e as populações indígenas (KODAMA, 2009; SCHWARCZ, 1993). Decerto, ao se colocar a tarefa de construir a identidade nacional, ocupou-se o IHGB em construir também a história e a geografia nacionais. Assim, a análise de algumas das posições assumidas no desempenho dessa empreitada revelam a tendência do imaginário culto do Brasil de incorporar o território como parte inerente, natural até, da formação da nação, o que reforça a permanência de conceitos de base espacial no 
No que diz respeito à formação territorial, ao longo da primeira metade do século XX ocorreram mudanças substantivas na configuração espacial do país, dentre as quais ganha importância o processo de industrialização sequente à urbanização das principais cidades fenômenos que não ocorriam apartados do processo de expansão das fronteiras agrícolas representado pelas movimentações pioneiras, é bom que se diga, pois essas funcionavam como um polo de atração para as centenas de milhares de migrantes nacionais e estrangeiros que se dirigiram para o Brasil, e especialmente para São Paulo, desde o final do século XIX. A progressiva relevância de tais processos ao longo das décadas de 1930 e 1940 acompanha o surgimento de novos padrões de organização social e econômica, que se justapõem ao movimento de modernização do país e ao surgimento de novas relações de poder, ficando esses pontos evidenciados até mesmo numa rápida descrição das principais linhas de conflito que permearam o período que se inicia após a chegada de Getúlio Vargas ao poder. De modo objetivo, a Revolução de 1930 ficou marcada, em boa parte dos inúmeros trabalhos que versam sobre o assunto, como um momento no qual há um efetivo realinhamento de forças na esfera política, uma fase que inaugura um novo padrão de relacionamento entre sociedade e Estado, com a rearticulação do poder e a consolidação de novos grupos de influência identificados bem ou mal com a crescente população urbana, que passou a disputar com as tradicionais oligarquias agrárias extremamente regionalizadas da I República a condição privilegiada de grupo dirigente (AGGIO, BARBOSA e COELHO, 2002).

Salta aos olhos, nessa caracterização do ambiente político-ideológico do período, a alusão a temas caros aos clássicos da geografia política - pense-se, a propósito, em Friedrich Ratzel e Camille Vallaux, ou, no pensamento brasileiro, nos já citados Mário Travassos e Everardo Backheuser -, como a questão das condições de circulação interna e a descrição das vantagens que adviriam da construção de uma vasta rede de comunicações interligando os mais remotos pontos do território, objetivo comum entre os pensadores brasileiros que perpassa diferentes

pensamento brasileiro: "No Novo Mundo é da mais alta relevância a representação que os homens fazem sobre a natureza, sobre o espaço. O Novo Mundo é ele mesmo o resultado do alargamento do espaço do Ocidente. A relação dos homens com a natureza implica uma consciência do espaço, e o discurso a respeito do espaço é ele também histórico (...). Se o que nos sobrava era a natureza, o que nos faltava era o conhecimento, a descrição, a análise desta natureza e do homem que a habitava, nos dirá a geração de 1870, comprometida com a integração do Brasil ao mundo moderno (...). Haveria, assim, uma competição entre as bases de construção da identidade nacional, uma mais geográfica, outra mais histórica, envolvendo duas matrizes metafóricas do conhecimento: a contemplação e a recordação." (LIPPI, 1990a, pp. 56-57-58.) 
períodos e fundamenta uma práxis sempre em busca do fortalecimento do poder nacional (COSTA, 1992; MIYAMOTO, 1981):

O problema da coesão interna, tão exaustivamente debatido pela geografia política desde Ratzel, e eleito pelos geopolíticos como um dos principais alvos da ação dos Estados em geral, adquire no Brasil um caráter particular. A imensidão do território, o povoamento disperso e o fraco poder de articulação inter-regional da economia agrário-exportadora, ao lado de um poder central baseado na composição política com as oligarquias locais e regionais, representaram, desde a formação do Estado nacional, em 1822, um quadro distante de um federalismo clássico (como o norte-americano) e mais próximo de um conjunto político-administrativo-territorial unitário extremamente desarticulado em nível nacional. Esse era o pano de fundo que, sob vários matizes, marcaram o discurso político-territorial de muitos setores do poder estatal ou próximos deste. Daí porque a base técnico-científica fornecida pela geografia tornou-se elemento importante para a formulação dessas políticas. Nesse sentido, não são de estranhar as muitas coincidências entre uma dada concepção geográfica do país (explicitada pelos geopolíticos) e o discurso expresso, por exemplo, pelos próceres do novo regime que se instalou em $1930 \mathrm{e}$ que passou a ser conhecido como Estado Novo a partir de 1937. (COSTA, 1992, pp. 186-187.)

O bom entendimento dos pontos até agora arrolados demandam, em todo caso, uma primeira avaliação do papel central ocupado pelo planejamento estatal, e por certos profissionais e órgãos ligados à execução e elaboração das políticas territoriais oficiais, na elaboração de um conjunto de indagações e proposições de cunho marcadamente geopolítico que giravam em torno das dificuldades de dar uma resposta satisfatória ao problema da coesão interna do território, fundamento que informa a imagem comum que se fazia do Brasil, visto como um "arquipélago" regional cercado de vazios demográficos por todos os lados. Se bem que a participação efetiva de geógrafos na formulação das políticas territoriais oficiais não pareça ter sido relevante, uma retórica que se utilizava fartamente de conceitos de base espacial era comum nos textos de intelectuais que contribuíram com a edificação do regime varguista, como Almir de Andrade, Azevedo Amaral e Francisco Campos, todos de grande influência no período. Outrossim, os estudos de Adriana Simas (2008) e de Alexandre Rio Camargo (2009) sobre o papel da Revista Brasileira de Geografia (RBG) na estruturação do campo geográfico, que fazem um balanço dos temas tratados nos artigos publicados nesse periódico, esboçam uma visão mais ampla do alcance da publicação como forma de "mobilizar a classe política e as elites intelectuais em torno do ideário do regime" (RIO CAMARGO, 2009, p. 26), revendo sua importância no circuito da produção, recepção e difusão do discurso oficial e permitindo considerar os geógrafos entre os 
intelectuais preocupados com a realidade nacional e com racionalização da organização política do Estado (CONDATO e GUANDALINI JR., 2003):

Artigos que tinham por temas fronteiras, território e povoamento, regiões naturais, recursos minerais, cidades, levantamentos cartográficos e cartografia geral, bastante frequentes entre 1930 e 1947 , se coadunavam muito bem com os esforços de integração do ecúmeno nacional, os projetos de colonização de áreas afastadas, valorização do homem rural e sua fixação no campo e, sobretudo, a bandeira da "Marcha para o oeste". Do ponto de vista da justificativa ideológica do Estado Novo, tratava-se da ocupação efetiva de nossos limites territoriais, não apenas para a salvaguarda de nossa segurança nacional, como, principalmente, para o pleno desenvolvimento da consciência do povo brasileiro, como se essa estivesse adormecida em uma nação que restava desconhecida (...). Neste sentido, para o intervalo de 1939-1947, há uma profusão de uma produção alinhada com as questões geopolíticas focadas no argumento da segurança nacional. O tema "fronteiras, território e povoamento" predomina de longe, respondendo por 24 artigos nesse período e praticamente desaparecendo a partir daí. Seu conteúdo é programático, estabelecendo, em linhas gerais, a importância dos transportes e da comunicação para a integração do espaço territorial, iniciando-se pela conquista do interior, isolado entre o litoral e as fronteiras. São estudos que frequentemente exploram o potencial de regiões de fronteira, focos de imigração e de investimentos econômicos, ferrovias de integração política e geográfica com os países sul-americanos e a questão da saída para o Oceano Pacífico. (RIO CAMARGO, 2009, pp. 26/30.)

A propósito do pensamento geopolítico, a partir de meados da década de 1940, notadamente após a II Guerra, desenvolveu-se e se afirmou no Brasil, principalmente influenciados pela Escola Superior de Guerra (ESG), uma doutrina ou projeto geopolítico que, apoiado numa explícita intenção ordenadora do território, tinha dentre suas preocupações centrais a construção de uma rede de comunicações que interligasse os pontos lindeiros do território e garantisse, por meio desses eixos de circulação, a indução da industrialização, o desenvolvimento de um mercado consumidor interno e a integração dos espaços fronteiriços (BOMFIM, 2007).

Nessa perspectiva, a associação entre o exercício do poder político e as condições internas de deslocamento experimentadas por um território confere à circulação tanto um sentido político - o deslocamento de tropas, ideias e ordens -, quanto um sentido econômico, referido à circulação de mercadorias, bens e capitais. Sendo assim, a análise do desenvolvimento e consolidação das relações capitalistas, que poderiam em tese garantir a promoção do progresso do Brasil por meio da expansão e manutenção dos fluxos econômicos, vincula o exercício do poder político às condições de deslocamento dentro do território nacional, na medida em que vê nessa integração o mais adequado instrumento através do qual o Estado afirmaria seu poder geoestratégico: 
A preocupação central dos geopolíticos brasileiros e dos tecnoburocratas, em relação às políticas territoriais, passava pela construção de vias de circulação e pela exploração, à exaustão, dos recursos naturais, desde a mineração até o uso do solo. Ora, em todos esses aspectos está presente a questão da técnica. O próprio conceito de recurso natural, como valor de uso que uma riqueza natural adquire perante as necessidades de certo grupo social, já traria à baila o conceito de circulação, pois a produção - exatamente para adquirir significado econômico - exigiria movimento, contato, deslocamento e troca social (...) se o espaço e o tempo seriam categorias básicas no desenvolvimento dos grupos humanos, a circulação não seria mais do que uma das formas desse movimento histórico no tempo e no espaço -, cuja importância estaria em seu papel precursor na formação dos Estados, implicando em conseqüências políticas, estratégicas e de organização do território pelos mecanismos estatais (BOMFIM, 2007, pp. $31 / 34.)^{28}$

As vantagens que a otimização do sistema de transportes traria à circulação, vista como um fator geográfico que preocupa a prática política dos Estados, transformam a coesão política de um Estado em tributária da intensidade dos fluxos encetados no sentido de comprimir as tendências centrífugas presentes no território. Desse ângulo, a questão da ineficiência da rede de transportes, ou de sua ausência, decerto erigiu-se, a partir dos anos 1930, em uma barreira para o desenvolvimento do comércio inter-regional, afetando até a ligação de cidades não tão distantes umas da outras. Contudo, é mesmo na interligação entre os pontos extremos do território nacional que o problema adquire imenso potencial estratégico, articulando o desenvolvimento de um sistema de comunicações com os objetivos das políticas de povoamento, de integração econômica e do ideal da segurança nacional (MIYAMOTO, 1981).

Sem dúvida, os esforços para racionalizar o planejamento do setor de transportes, alvo de inquietação por parte do governo desde 1934, quando se elabora um Plano Geral de Viação, podem ser tomados como um dos mais evidentes exemplos da generalização dos anseios centralizadores do Estado na era Vargas. Em 1937, a organização do Departamento Nacional de Estradas de Rodagem, o DNER, primeiro órgão a pensar a implementação de uma política de transportes em escala nacional, representa um avanço nos aspectos técnicos e administrativos,

\footnotetext{
${ }^{28}$ Entre os fatores geográficos que definem um território, o de maior importância não diz respeito à sua extensão ou localização, mas à coesão e articulação interna do espaço político considerado: "De tous les caractères du territoire, il semble que le plus important soit la position. C'est aussi le plus difficile à définir, le plus complexe, parce qu'il exprime le rôle dudit territoire dans le système de relations qui détermine sa personnalité politique aussi bien que sa situation géographique. Ce qui permet de définir la position et aussi de suivre l'évolution de la définition, c'est la circulation. L'ensemble des mouvements, des transports, des échanges d'hommes, de choses, d'idées à travers le monde, c'est qui en détermine le compartimentement, la signification de chaque compartiment par rapport aux autres et donc, en grande partie, ce que le peuple peut faire de son territoire. Le fait fondamental de notre univers est qu'il bouge, que tout y est mouvement, fluidité: l'atmosphère, les eaux, les homes, la pensée. C'est pourquoi la circulation est à la base de toute géographie et de toute politique". (GOTTMAN, 1952, pp. 119-120.)
} 
sendo exemplar dessa evolução o conjunto de artigos escritos na RBG pelo engenheiro Moacir Malheiros F. Silva, consultor técnico do CNG. A série de onze escritos sobre o tema dos transportes, que deu origem ao livro "Geografia dos Transportes no Brasil”, editado em 1949, remonta aos anos de 1939 e 1941, e ilustra bem a forma como a questão da circulação era tratada no ambiente institucional em que gravitavam os geógrafos ${ }^{29}$. Tomando como pano de fundo as preocupações com a segurança nacional, que se resolveria pela integração do território, os artigos propõem uma avaliação exaustiva sobre o desenvolvimento das diferentes matrizes de transporte (marítimas, terrestre, fluviais e aéreas), que são apreciadas conjuntamente com o histórico de ocupação do território e as condições do meio físico-natural, desenhando um quadro referencial que deveria ser encarado como ponto de partida para a execução de projetos que intentassem remediar a situação.

Em sua dimensão espacial, o diagnóstico da fragilidade da unidade nacional por parte do Estado Novo comportava a integração e a homogeneização do território em seus aspectos econômicos e culturais. Para tanto, as políticas desenvolvidas no âmbito do governo que tinham em comum a finalidade da ocupação demográfica e econômica do interior do país podem ser agrupadas dentro do conjunto heterogêneo de ações governamentais designadas como "Marcha para o oeste", que em realidade era pouco mais que um slogan derivado da estratégia geoeconômica de valorização dos sertões, uma ação intencional do regime que visava atrair a

\footnotetext{
${ }^{29}$ Comentando criticamente o temário da geografia política estudado por Camille Vallaux a partir da estrutura argumentativa pioneiramente desenvolvida por Ratzel, Wanderley Messias da Costa (1992) chama a atenção para as inovações que o geógrafo francês institui quando analisa os problemas relativos à circulação, iluminando interessantes aspectos sobre o tema em debate: "Vallaux aborda o fenômeno da circulação em sua dimensão essencialmente política. Para ele, muitos geógrafos da época mostraram-se perplexos com as idéias de Ratzel a respeito, porque estavam, no fundo, presos a uma forte concepção historicista-economicista do problema. Custavalhes pensar a circulação sob outro prisma que não fosse o movimento de mercadorias e pessoas, dentro, portanto, dos quadros do comércio, das migrações, das necessidades de ir e vir, etc. Trata-se de concepção estreita, diz ele, em primeiro lugar porque o fenômeno da circulação não se restringe às 'coisas', abarcando também o movimento das idéias pelos meios de comunicação. Segundo, porque a 'rede de circulação' e o quadro de relações que se estabelecem são fenômenos que se desenvolvem em geral sob a 'sombra dos Estados' (...). Essa projeção estaria fortemente presente, porém, ao nível da circulação terrestre, cuja estrutura obedeceria a uma lógica coletiva e política posta em ação pela sociedade através do Estado. Mesmo no caso dos caminhos e estradas construídos por companhias de colonização, por exemplo, em que a finalidade econômica é precípua, o seu traçado não pode fugir às imposições do problema da segurança e, conseqüentemente, das estratégias do Estado. Apesar disso, reconhece que um verdadeiro 'sistema de circulação terrestre' só se desenvolve em Estado complexos. Nestes, a 'rede de caminhos', malgrado a aparência de que se destinam unicamente ao comércio, obedece em geral a uma estratégia estatal definida a priori ou a posteriori para o território em seu conjunto. Como exemplo, ele discorre sobre casos de vias de penetração inaproveitáveis economicamente fora das rotas comerciais, que se destinam unicamente a exercer o papel de levar essas regiões as 'forças de coesão interna' do estado, a fim de contrabalançar as eventuais 'forças centrífugas' aí presentes. Daí, para ele, a via terrestre ser antes de tudo 'obra política e militar”. (COSTA, 1992, pp. 50-51.)
} 
participação política de amplos setores da opinião pública (DINIZ FILHO, 1994). As políticas de colonização do governo, regulamentadas oficialmente pelo Decreto-Lei 3059, de 14 de fevereiro de 1941, direcionariam a solução da questão agrária para o estímulo à expansão da pequena propriedade e à produção de alimentos, com privilégios na distribuição dos lotes aos agricultores pobres nascidos no Brasil, o que, é bem verdade, tentou-se realizar sem que houvesse danos aos privilégios dos grandes proprietários de terras. No que concerne aos estratagemas que envolviam a definição de onde seriam instalados esses empreendimentos, a localização das colônias expressa uma organização complementar da produção por meio da integração inter-setorial e da divisão territorial do trabalho, visto que as indústrias foram projetadas para se localizar nas proximidades das áreas destinadas à produção de matérias-primas: por exemplo, a colônia de Dourados, no Mato Grosso (hoje Mato Grosso do Sul), e a de Goiás, miravam, via estradas de ferro, o mercado paulista, já as colônias que seriam localizadas nos estados do Amazonas, Pará, Maranhão, Piauí e Paraná, destinar-se-iam ao abastecimento das respectivas capitais (LENHARO, 1986) ${ }^{30}$.

A criação das colônias agrícolas, que certamente representavam o ápice da política colonizadora do regime, acelerada desde a proclamação do "Marcha para o oeste", em 1941, deve ser compreendida em conjunto com os decretos que regulamentavam a criação das colônias militares e das vilas planejadas nos territórios federais fronteiriços, uma vez que as discussões acerca da ameaça do inimigo estrangeiro, sempre agudas em momentos de tensão bélica como o vivido no período em tela, levaram à expropriação de propriedades de alto valor geopolítico, consideradas estratégicas por estarem localizadas nas zonas de fronteiras. O caso do estado do Mato Grosso, principalmente as cidades de Cáceres e Corumbá (esta no atual estado do Mato

\footnotetext{
${ }^{30}$ As especificidades das colônias agrícolas nacionais (CAN) em relação às figuras jurídicas dos núcleos agrícolas, das granjas-modelo e dos núcleos agroindustriais não diz respeito apenas à envergadura dos projetos, mas refere-se sobretudo às finalidades de cada empreendimento - no caso das colônias, a de criar e sustentar todo um novo conjunto de relações sociais, e nos últimos, a não desprezível função de minorar os problemas de abastecimento: “As colônias agrícolas nacionais foram pensadas como verdadeiras 'autarquias', réplicas, em miniatura, do mercado nacional, microcosmos econômicos do país (...). A organização do auto-abastecimento era pensada estrategicamente como uma etapa inicial a ser superada quando a colônia se firmasse e tendesse a irradiar-se pelas áreas próximas. Daí a armação de um 'rosário de colônias', pontos avançados de penetração, impulsionadores da Marcha para o oeste e da conquista da Amazônia". (LENHARO, 1986, pp. 47-48). De todo modo, é interessante notar a maneira como, na campanha da "Marcha para o oeste", o objetivo de nivelar economicamente as áreas interiores, aproximando-as nesse detalhe das áreas mais desenvolvidas do litoral, ligava-se à meta de impedir a formação de "quistos étnicos" no país, ação que atingia em cheio a maior parte dos motivos apontados pelos intelectuais orgânicos do regime como sendo os causadores da fragilidade de nossa unidade política: a descentralização do governo, a débil integração comercial entre os Estados, a ausência de um mercado interno robusto, o regionalismo de cunho separatista e as áreas sujeitas à influência dos colonos estrangeiros. Esse tema, que por si só pediria uma discussão aprofundada, integrava as discussões sobre os "quistos" a uma política demográfica mais ampla, sendo ainda oportuno lembrar que a preocupação generalizada com os imigrantes era favorecida, nesse momento, pela efetiva entrada de um grande contingente de estrangeiros no país.
} 
Grosso do Sul), que tinham seus vastos pastos e campos ervais na mira de empresas e grupos estrangeiros, como a Companhia Matte Laranjeira, desde o final do século XIX (GARCIA, 2005), era preocupante, como comprova o desdobramento de tal situação, que culminou na criação dos territórios federais do Guaporé e Ponta-Porã.

Enfim, a conquista do oeste sustentaria, para Vargas, o substrato simbólico de união de todos os brasileiros, articulando os pares antípodas sempre utilizados na explicação do Brasil, como campo e cidade, litoral e sertão, tradicional e moderno, agricultura e indústria. A criação da brasilidade, sentido último da "Marcha para o oeste", assentava-se, portanto, numa proposta que combinava colonização e industrialização, abrindo espaço para o exercício do "imperialismo brasileiro", agente construtor da nação que faria coincidir as fronteiras econômicas com as fronteiras políticas, conforme posteriormente defendeu em artigo Arthur Hehl Neiva (1949):

A ocupação dos espaços ditos vazios significava não simplesmente a ocupação econômica da terra, transformada em geradora de riqueza; sua pretendida ocupação seria procedida de maneira especial, a ponto de fixar o homem na terra através de métodos cooperativos, que redimensionassem as relações sociais, de acordo com a orientação política vigente (...). O imperialismo brasileiro consistia na expansão demográfica e econômica dentro do próprio país, que fazia a conquista de si mesmo e promovia a sua integração ao Estado, "tornando-o de dimensões tão vastas quanto o país" (...). Eis o desafio que o Estado Novo lança para si mesmo: se o Estado é a extensão territorial do país; se o país encontra-se talhado em duas partes opostas - uma que produz, exporta manufaturas e capitais, a outra que os recebe e remete matéria-prima de volta - cabia, através do imperialismo interno, fazer com que as ilhas de prosperidade industrial ocupassem os espaços despovoados, desfizessem o arquipélago e rearticulassem o país continental. (LENHARO, 1986, pp. 18/23-24.)

Vê-se por aí que o projeto de construção de uma nação moderna envolvia também as respostas dadas à crise mundial vivenciada entre 1930 e 1945: do ponto de vista econômico, abria-se a possibilidade de implantação de um modelo urbano-industrial baseado numa forte política de substituição de importações, e, nesse detalhe, sobressai-se a forma como o regime pós1937 interpretava a relação da sociedade brasileira com seu território no aproveitamento dos recursos naturais. O texto clássico que explicita os termos básicos da tese da substituição de importações, vista como a via específica de industrialização para a América Latina, foi lançado em 1964, no âmbito da CEPAL, por Maria da Conceição Tavares, que retornou ao tema inúmeras outras vezes ao longo de sua carreira, destrinchando suas consequências para o caso brasileiro:

Entende-se, no entanto, que essa designação [substituição de importações] será aplicada, daqui por diante, em um sentido lato, para caracterizar um processo de desenvolvimento interno que tem lugar e se orienta sob o impulso de restrições 
externas e se manifesta, primordialmente, através de uma ampliação e diversificação da capacidade produtiva industrial (...). A nossa tese central é de que a dinâmica do processo de desenvolvimento pela via de substituição de importações pode atribuir-se, em síntese, a uma série de respostas aos sucessivos desafios colocados pelo estrangulamento do setor externo, através dos quais a economia vai-se tornando quantitativamente menos dependente do exterior e mudando qualitativamente a natureza dessa dependência. Ao longo desse processo, do qual resulta uma série de modificações estruturais da economia, vão-se manifestando sucessivos aspectos da contradição básica que lhe é inerente entre as necessidades de crescimento e a barreira que representa a capacidade para importar. Tentaremos mostrar qual a mecânica da superação de alguns desses aspectos, chegando à conclusão de que os problemas de natureza externa e interna tendem a se avolumar de forma a frear o dinamismo do processo. (TAVARES, 2000, pp. 230-231.)

A tarefa de invenção do Brasil moderno (IANNI, 1992), destino manifesto do Estado nacional, reveste-se de um caráter épico no período varguista, assumindo um aspecto religioso que aponta para o "tempo das origens", uma vez que a conquista do sertão surge na ideologia oficialista fartamente divulgada com feições de uma "nova cruzada" (LENHARO, 1986) ${ }^{31}$. Essa espécie de apologia do Estado forte, que toma forma nos mecanismos de centralização políticoadministrativa operados pelo governo federal, emerge claramente quando nos deparamos com a progressiva ocupação dos espaços institucionais pelas novas agências burocráticas estatais, que a partir da criação de autarquias e conselhos nacionais dedicados ao controle, planejamento e regulação dirigida de setores, produtos e serviços considerados estratégicos, ia absorvendo paulatinamente o controle das esferas decisórias (PENHA, 1993).

A surpreendente eficácia política dos discursos de Getúlio Vargas, que articulavam num mesmo eixo de argumentação os estímulos ao desenvolvimento econômico, a ocupação demográfica sustentada do território e a homogeneização da população, todos garantidos pela função estratégica da ocupação nacionalizadora do Hinterland, pode ser talvez atribuída ao entrelaçamento que o presidente concebia entre os avanços da agricultura e o desenvolvimento da indústria, que nas ações do "Marcha para o oeste" poderiam afiançar de modo integrado a exploração dos recursos naturais, o fornecimento de alimentos a baixo custo, a elevação do nível

\footnotetext{
${ }^{31}$ Nos dizeres de Getúlio Vargas: "O imperialismo do Brasil consiste em ampliar as suas fronteiras econômicas e integrar num sistema coerente, em que a circulação das riquezas e utilidades se faça livre e rapidamente, baseada em meios de transportes eficientes, que aniquilarão as forças desintegradoras da nacionalidade. $\mathrm{O}$ sertão, o isolamento, a falta de contato são os únicos inimigos terríveis para a integridade do país. Os localismos, as tendências centrífugas são o resultado da formação estanque de economias regionais fechadas. Desde que o mercado nacional tenha sua unidade assegurada, acrescendo-se a sua capacidade de absorção, estará solidificada a federação política. A expansão econômica trará o equilíbrio desejado entre as diversas regiões do país, evitando-se que existam irmãos ricos ao lado de irmãos pobres. No momento nacional só a existência de um governo central, forte, dotado de recursos suficientes, poderá trazer o resultado desejado". (VARGAS apud SCHWARTZMAN, 1983, pp. 422-423.)
} 
de renda da população rural e a decorrente criação de um mercado interno para absorver a produção industrial. Por conseguinte, a definição do sertão como o objeto de um movimento expansivo que busca incorporá-lo numa ordem preestabelecida, à qual os lugares e as populações sertanejas escapariam completamente, aponta para o estabelecimento de uma relação entre a colonização e o sertão que se torna relevante neste trabalho quando lembramos que, na compreensão do processo de consolidação do capitalismo brasileiro, é comum estabelecer um laço de complementaridade entre a formação do complexo industrial nacional e a economia cafeeira, sempre ávida por conquistar novos solos, mas também responsável por costurar nexos de solidariedade territorial entre distintas regiões do país ${ }^{32}$.

Em resumo, a obsessão com a integração do território e com a unidade nacional pode ser compreendida, em uma primeira aproximação, como a razão de Estado que comandava, pela via da colonização dos sertões, a solidificação da soberania estatal em sua pretendida área de jurisdição exclusiva, buscando, para isso, o desenvolvimento econômico, a homogeneização da população e a afirmação dos dispositivos de controle político-militar sobre as fronteiras. Por sua vez, o estímulo à unificação dos mercados, entendido como uma forma de atingir o ideal da integração nacional, não aparece como elemento auxiliar do desenvolvimento econômico, mas como um meio através do qual a ocupação induzida do território cimentaria a unidade do país e, pois, uma arma potente contra os desiquilíbrios regionais em busca da uniformização social e econômica do território, uma vez que "integrar o mercado interno requeria a eliminação, se possível, de todas as barreiras existentes à livre movimentação econômica entre as regiões do país. Mais que isso, haveria que aumentar-se o grau de interdependência regional através de um significativo aumento da complementaridade econômica inter-regional” (CANO, 1985, p. 186).

\footnotetext{
${ }^{32}$ Escusando de fornecer maiores detalhes acerca desse intrincado e ainda atual debate, o que demandaria muito tempo e poderia alterar os rumos deste trabalho, lembremos apenas os termos básicos do relacionamento entre o capital cafeeiro e o capital industrial, base da transição da economia brasileira para o capitalismo, exposto de maneira sucinta por João Manuel Cardoso de Mello: "A economia cafeeira capitalista cria, portanto, as condições básicas ao nascimento do capital industrial e da grande indústria ao: 1) gerar, previamente, uma massa de capital monetário, concentrada nas mãos de determinada classe social, passível de se transformar em capital produtivo industrial; 2) transformar a própria força de trabalho em mercadoria; e, finalmente, 3) promover a criação de um mercado interno de proporções consideráveis (...). Em suma, o complexo exportador cafeeiro, ao acumular, gerou o capital-dinheiro que se transformou em capital industrial e criou as condições necessárias a essa transformação: uma oferta abundante no mercado de trabalho e uma capacidade para importar alimentos, meios de produção e bens de consumo e de capitais, o que só foi possível porque se estava atravessando um auge exportador.” (MELLO, 1982, pp. 99/101.) Para uma visão geral do debate que envolveu economistas e políticos entre 1930 e 1964, vide Bielschowsky (1996). Sobre as relações entre a economia cafeeira, a criação do parque industrial brasileiro e estruturação das disparidades regionais, consultar as obras de Wilson Cano (1978; 1985).
} 
A propósito, a instauração do Estado Novo, em 1937, elevou a construção da unidade nacional à condição de projeto político de consenso. Compreendido como o objetivo principal do novo regime, percebe-se que a unidade nacional somente seria alcançada pela via da integração econômica, política, demográfica e cultural das afastadas regiões do Brasil, único remédio para que a ameaça do esfacelamento territorial do país não se consubstanciasse. Em outras palavras, afirmava-se a ideia de unidade do país como sinônimo de integração territorial, com a centralização autoritária do poder expressando-se exatamente no estabelecimento da padronização e uniformização da legislação processual, civil, penal e financeira, que definia o território nacional como uma unidade econômica, comercial e alfandegária ${ }^{33}$.

A percepção de que havia um vínculo entre a organização do território e a reforma na estrutura político-administrativa do país, somada à grande preocupação com a integração, sobretudo econômica, das afastadas regiões brasileiras, respondem em parte pela recorrência com que a extensão territorial do Brasil era apontada como empecilho para a construção da unidade do país. De fato, a grande dimensão do território, nesse pormenor, era vista como problemática, tendo uma ação dispersiva que seria resolvida somente através de um povoamento homogêneo e da organização de um sistema de transportes e comunicação que abarcasse eficientemente a totalidade do espaço político brasileiro.

Em vista disso, a marcha incompleta da conformação de um mercado interno coeso expressaria, por seu turno, a débil complementaridade econômica vivenciada naqueles anos, com a integração do território passando necessariamente pelo esforço governamental de reduzir as disparidades socioeconômicas regionais. Explicadas principalmente pela ocupação incompleta do país, tais desigualdades seriam o resultado do sub-aproveitamento do território do ponto de vista

\footnotetext{
33 “A perspectiva geopolítica de atuação do Estado Novo fica evidente em vários programas governamentais e na criação de órgãos e normas que interessavam diretamente o ordenamento territorial. O projeto 'Marcha para o Oeste', de colonização estatal, é um claro exemplo dessa visão, também a instalação dos parques nacionais do Itatiaia e de Foz do Iguaçu, e a publicação dos códigos das águas, mineral e florestal. Modernizar a economia brasileira povoando e equipando o território era uma meta explícita da ditadura varguista, que também fez intensa utilização simbólica da representação do espaço para legitimação de suas ações. Na visão do país difundido por seu Departamento de Imprensa e Propaganda o Brasil era definido como a somatória de suas culturas regionais e a autenticidade do 'caráter nacional' era localizada nas áreas distantes do interior e, por tanto, o sentimento da verdadeira brasilidade residiria nos sertões (...). Enfim, a ditadura Vargas além de concentrar o poder no executivo federal, realizou uma divisão no território a partir da ótica do centro, fundamentada em critérios naturais e objetivada por culturas próprias. Nesse entendimento, a diversidade das regiões brasileiras foi equacionada como pura positividade, a partir do qual o Estado forte construiria a nação. O Estado Novo inaugurou o período posteriormente denominado de 'nacional-desenvolvimentismo', no qual se propunha o planejamento estatal como agente indutor do progresso, entendido basicamente como a industrialização do país. Nessa formulação a questão social (até então vista como um 'caso de polícia') começou a ganhar corpo, associando-se aos desígnios geopolíticos ainda preponderantes.” (MORAES, 2011, pp. 90-91.)
} 
econômico, quer dizer, da falta de plena exploração econômica dos recursos naturais oferecidos pelo território, o que restringiria o uso produtivo do espaço, criando desigualdades entre os níveis de desenvolvimento das áreas de ocupação mais antiga quando comparadas com aquelas de povoamento mais recente, que normalmente apresentavam uma ocupação rarefeita do ponto de vista econômico.

As políticas de povoamento do interior que sustentariam, por meio da ocupação produtiva de novas terras, a integração econômica do território formam a base, associada com a exploração futura dos espaços ainda "vazios" do país, do núcleo essencial que dirige as políticas territoriais do Estado Novo, já que o imenso estoque de terras disponíveis e a expectativa de exploração das riquezas potencialmente advindas da incorporação desses fundos territoriais (MORAES, 2002) ao circuito do capital justificariam, em grande parte dos discursos veiculados por intelectuais orgânicos do regime, a peculiaridade do expansionismo brasileiro como um "imperialismo pacífico" resolvido sem conflitos por voltar-se para dentro de si mesmo, tal como constava nos objetivos da "Marcha para o oeste",34.

$\mathrm{Na}$ ótica autoritária compartilhada pelo governo e seus próceres, a existência de amplos fundos territoriais, que definem as áreas internas a um território que ainda não foram aproveitadas economicamente pelo Estado, ficando de fora dos fluxos colonizadores de povoamento e exploração, verdadeiras reservas territoriais à espera de uma valorização, colocaria a ocupação racional do território pela via do planejamento dirigido como corolário do projeto estatal de reestruturação da economia e da sociedade brasileiras ${ }^{35}$. O objetivo seria enaltecer, fundamentalmente, a capacidade humana de ação teleológica sobre o espaço, isto é, a intencionalidade da criação de uma nova organização geográfica, o que facultaria aos

\footnotetext{
${ }^{34}$ Essa maior capacidade de intervenção do Estado, aliada a um movimento de progressiva integração regional, revela a existência de uma correlação entre o processo de amadurecimento do capitalismo e as mudanças no padrão de organização territorial brasileiro: "É significativo notar como as ideologias geográficas do Estado Novo serviram como elementos mediadores entre as transformações postas pelo processo de consolidação do capitalismo e a necessidade de implantar um novo modelo de produção do espaço. Essas ideologias permitiam pensar a forma de encaminhamento das políticas territoriais do Estado e, ao mesmo tempo, colocar essas políticas como instrumentos para a própria resolução das 'questões' postas pela transição capitalista". (DINIZ FILHO, 1994, pp. 202-203.)

35 "O Estado Novo foi um período de intensa formulação oficial de políticas territoriais explícitas. Pode-se dizer que nesse período foi criado (e territorializado) o próprio aparelho de Estado brasileiro. Construía-se assim urna nova geografia material do país, e esta se fazia acompanhar de uma nova construção simbólica da identidade nacional: o nacional agora claramente expresso como estatal e oficial. Por isso, o período também foi rico no que tange à formulação de representações do espaço, uma época de ampla difusão de ideologias geográficas. $\mathrm{O}$ exposto permite levantar uma segunda hipótese: seguindo certa similaridade com o processo europeu, a centralidade da geografia no contexto brasileiro estaria apoiada em sua eficácia ideológica na conjuntura de afirmação não da nacionalidade em si, mas do Estado nacional? Repousaria tal eficácia na possibilidade aberta por essa disciplina no que se refere à construção de uma identidade pelo espaço?" (MORAES, 1991, p. 173)
} 
propagandistas oficiais amplamente subvencionados pelos órgãos oficiais de cultura converter as migrações interiores e a conquista de terras numa obrigação patriótica continuamente reposta.

A título de exemplo, poderíamos citar as ações da Fundação Brasil Central (FBC), órgão estatal organizado em 1943 a partir da experiência da Expedição Roncador-Xingu, que havia tido por objetivo o reconhecimento e a exploração geocartográfica do chamado maciço central brasileiro, tarefas efetuadas com o intuito de facilitar a construção de pistas de pouso e de estradas que servissem de base para a futura integração dos estados do centro-sul com a Amazônia, projetada para ser feita a partir das cabeceiras do rio Xingu. Chefiada pelo antigo comandante da guarda pessoal de Getúlio Vargas, o coronel Flaviano Vanique, e contando com outros 23 homens do chamado alto escalão do governo e das forças armadas: "Esse bandeirantismo estatal inscrevia-se num contexto de preocupações geopolíticas, já que se temia que os expansionismos germânicos e nipônicos requisitassem 'espaços vazios' para o crescimento orgânico de seus Estados” (MAIA, 2009, p. 3).

Em suas diversas atividades, a FBC, criada como um dos eventos da "Marcha para o oeste" para consolidar o processo de territorialização estatal do interior profundo do Brasil, utilizava-se de imagens, categorias e conceitos espaciais sobre o interior do país que eram muito comuns à época (MAIA, 2010), apresentando-se como uma das muitas ações políticas do Estado Novo que visavam a integração territorial do país, ou seja, que buscavam dinamizar as fronteiras econômicas por meio da colonização, ocupação e apropriação de terras comandada pelo Estado. Ao colocar as terras interiores sob a órbita de poder do Estado, as ações da FBC articulariam os interesses econômicos da exploração de recursos naturais com a perspectiva geopolítica que se preocupava com a segurança nacional, fato reforçado após a entrada do Brasil na II Guerra, em 1942, e a assinatura dos Acordos com os EUA, que tinham a intenção de garantir o fornecimento de matérias-primas brasileiras aos EUA, principalmente o ferro e o látex:

À medida que a Expedição percorria seu trajeto pelos interiores de Goiás e Mato Grosso e construía estradas, campos de pouso e redes de comunicação, o governo Vargas se preocupava em dar maior estabilidade à empreitada. Assim, o Decreto $\mathrm{n}^{\mathrm{o}} 5.801$ de 8 de setembro de 1943 declarava a Expedição como de interesse militar, o que evidencia uma das motivações geralmente citada por comentadores para a Marcha para o Oeste: a preocupação geopolítica com a segurança nacional no contexto da Segunda Guerra. Em março de 1942, o Brasil assinou os Acordos de Washington, que previam a integração da Amazônia ao esforço de guerra por intermédio da intensificação da produção de borracha. $\mathrm{O}$ acordo previa a compra de estoques, quotas de produção e a injeção de capital americano para criar condições seguras de coleta. No âmbito dos Acordos, o 
governo federal construiu numerosas agências e órgãos responsáveis pela racionalização produtiva da região, evidenciando uma tentativa de modernizar a gestão de terras e pessoas naquele espaço. Assim, é possível associar a Expedição a esse esforço de guerra, embora a preocupação com a integração nacional e com a dinamização das fronteiras econômicas antecedesse os Acordos, traduzindo-se numa lógica de gestão característica do Estado Novo. (MAIA, 2010, p. 630.)

É relevante, pois, delinear os círculos intelectuais ocupados com as questões relativas à ocupação do território. Em trabalho já clássico sobre o Estado Novo, Mônica Pimenta Velloso (1982) analisa o papel da imprensa e dos intelectuais na elaboração de uma imagem positiva do governo ditatorial de Getúlio Vargas. Detendo-se nas ações do Departamento de Imprensa e Propaganda (DIP) e nos textos publicados em duas revistas de grande circulação na passagem dos anos 1930 aos 1940, a "Cultura Política" e a "Ciência Política", Velloso diferencia as funções exercidas por cada uma delas, pois enquanto a primeira, aparelhada por grandes nomes do meio acadêmico que professavam proximidade com Vargas, como Cassiano Ricardo, Oliveira Vianna, Azevedo Amaral, Francisco Campos e Almir de Andrade, estaria voltada mais especificamente para a produção do discurso ideológico de sustentação do regime, a segunda, veículo de divulgação do trabalho dos chamados "intelectuais médios", como Pedro Vergara, Paulo Filho, Renato Travassos e Sabóia Lima, voltar-se-ia sobretudo para a difusão desse discurso, funcionando como um órgão cultural que reverberava as doutrinas mais densas produzidas pelos primeiros (VELLOSO, 1982). Em ambos os casos, a celebração da centralização autoritária levada a cabo por Vargas valorizava as ações tomadas pelo governo no sentido de garantir a unidade do território ante as ameaças separatistas (reais ou imaginadas) que se interpunham ao regime, e a argumentação em favor do ideário constante na "Marcha para o oeste" foi decerto um dos pontos cuja defesa efetuou-se a partir de múltiplos vieses, dado o caráter heterogêneo do grupo de intelectuais que escreveram sobre a questão, que inclui nomes como Péricles de Melo Carvalho, Nelson Werneck Sodré, Ademar Vidal e Herberto Sales (MAIA, 2009; SECRETO, 2007).

A complementaridade entre certas ações do governo federal fundamentadas em elaborações ideológicas já consagradas e as políticas territoriais realmente implantadas para fomentar a colonização e o povoamento do país foi também notada, no que diz respeito às questões demográficas, por Endrica Geraldo (2007) e Giralda Seyferth (2002; 2008), que apontam a circunstância de os artigos e textos presentes na "Revista de Imigração e Colonização", que verbalizava as decisões do Conselho de Imigração e Colonização, esclarecerem como a "raça" e o 
ideal do branqueamento continuavam a pautar os critérios de seleção étnica, localização e composição dos núcleos de imigrantes estrangeiros na época do Estado Novo:

A partir da década de 1930 não é possível dissociar a legislação restritiva sobre imigração da campanha de nacionalização planejada para impor a assimilação, cerceando as etnicidades e suas manifestações através da intervenção direta na organização comunitária e na cultura dos grupos imigrados (...). Percebem-se, então, as motivações da campanha de nacionalização, cujas intenções iam além do processo sociológico de assimilação, julgada imprescindível para dar homogeneidade à nação diante das irredutibilidades étnicas de grupos refratários à idéia de melting pot. Segundo seus idealizadores e implementadores - em grande parte pertencentes ao exército nacional - a assimilação sociocultural devia ser atingida pela educação cívica, pela obrigatoriedade da língua portuguesa, pela imposição do espírito nacional; ocorre que a nação estava definida também pela mestiçagem, devendo os alienígenas concorrer para a formação do povo brasileiro. Não interessa analisar a campanha em si mesma: ela foi imposta especialmente aos grupos considerados mais enquistados alemães e japoneses - embora dirigida a todos os classificados como alienígenas, inclusive os portadores de latinidade. Esse fato simplesmente revela a preocupação com a unidade nacional, muito além da definição política e territorial do Estado-Nação. (SEYFERTH, 2002, p. 140.)

Apesar de a autora afirmar, talvez apoiada num dos sentidos do termo "etnicidade", que as políticas relativas à imigração revelam uma preocupação com a unidade nacional que ia "além da definição política e territorial do Estado-Nação", pensamos mesmo que seja possível compreender a construção da identidade brasileira, ao menos a que foi alvo de uma vontade de controle estatal, como uma componente do processo de formação territorial. Em outras palavras, a própria definição das fronteiras políticas do território nacional, por indicar os limites da atuação soberana de um Estado-nação, ajuda em grande medida a selecionar e separar aqueles que serão considerados como parte do "nós" daqueles identificados como "os outros" (ANDERSON, 1991). Na fórmula conhecida de Eric Hobsbawm (1990), a coincidência dos limites políticos do Estado com a abrangência dos caracteres distintivos da nação, colocada pelo moderno princípio das nacionalidades, faz com que se conceba como congruentes o âmbito espacial da dominação estatal e a extensão geográfica das qualidades socialmente compartilhadas que permitem definir, em uma dada população, aqueles a serem considerados como "os nacionais".

Nessa direção, Maria Verônica Secreto (2007) afirma que as políticas demográficas do período Vargas não podem ser compreendidas apartadas dos objetivos estratégicos colocados nos projetos de ocupação dos "espaços vazios". Sendo assim, a imigração, a colonização e a ocupação dos "vazios demográficos" assumiam no discurso de intelectuais próximos do regime uma perspectiva geopolítica, com objetivos e teores diferentes segundo os veículos de difusão, a 
elaboração ideológica e os órgãos de execução das políticas, como a Fundação Brasil Central. Em seu conhecido "Discurso do rio Amazonas", realizado em 1940, Getúlio Vargas expressava o alcance estratégico da propaganda de recrutamento de trabalhadores do Nordeste para os seringais, tecendo um argumento que combinava o flagelo da seca, especialmente cruel naqueles anos, à necessidade de povoar a floresta: "na dimensão nacional, a batalha pela borracha se encaixava no programa de ocupação e colonização dos 'espaços vazios' e nos esforços de guerra do Brasil. Na esfera local, a emigração de nordestinos para a Amazônia era uma questão que contava com uma longa tradição e alguns debates" (SECRETO, 2007, p. 125). Expressivamente, após a assinatura dos acordos de cooperação entre o Brasil e os EUA, a ideia de um recrutamento de famílias que iriam povoar os vazios amazônicos foi sendo paulatinamente substituída pela imagem dos "soldados da borracha", homens pobres que durante o esforço de guerra estariam ocupando um território ao mesmo tempo em que se integravam, como trabalhadores, no corpo social da nação:

Pelo resgate do passado bandeirante-caboclo, podemos perceber como esse programa de "inclusão" dos habitantes do campo recolhia alguma coisa que estava muito internalizada no mundo das representações populares. Há uma reapropriação de signos e significados. O discurso oficial do Estado Novo apropriou-se de um conjunto de idéias que faziam parte do "senso comum" e as reelaborou na forma de um projeto político que cristalizava também uma reivindicação tão secular quanto as entradas e bandeiras, o "destino" amazônico do nordestino: a do direito à terra, à ocupação dos "espaços vazios". Esta última elaboração passaria ainda por novas apropriações. No caso do Estado Novo, a sua cuidadosa geração de idéias faz parte de um discurso hegemônico articulado nos mínimos detalhes. Mas esse discurso, pelo menos no caso que nos ocupa, retoma idéias arraigadas no imaginário das classes médias urbanas como as de ingenuidade, autenticidade, simplicidade e paciência do homem rural. O discurso gerado desde o Estado, em torno da "Marcha para Oeste", é acolhido favoravelmente porque satisfaz expectativas e reproduz idéias há muito consensuais. Responde às expectativas, talvez urbanas, do que deve ser o campo e às expectativas rurais do que deve ser a cidade. Retoma, para corrigir, o mito dos "dois Brasis". O "sucesso" dessa construção poder ser avaliado a partir do grande número de trabalhadores recrutados na campanha da borracha, e também da apropriação que de seus slogans fizeram tanto os soldados como suas mulheres, na correspondência trocada entre eles e na que elas encaminharam ao presidente da República, reclamando, quando em junho de 1944 foi suspendida a assistência familiar. (SECRETO, 2007, p. 122.)

A reavaliação do conjunto dos discursos sobre a "Marcha para o oeste", quando referidos às políticas concretas de interiorização, revela a intenção estatal de criar uma base de apoio ao regime, na qual os benefícios aos pequenos trabalhadores rurais apareciam como uma espécie de "populismo" adaptado às condições do meio rural. Integrando o rol das estratégias utilizadas para 
a consolidação do Estado nacional, tais discursos, em sua faceta ideológica, revelam o desejo de controle sobre a produção, difusão e manipulação dos símbolos e representações passíveis de formarem a base para a construção de identidades coletivas (GOMES, OLIVEIRA e VELLOSO, 1982). Contudo, do ponto de vista da geografia, afora a presença de textos de autores como o militar Nelson Werneck Sodré, que em inúmeros escritos familiares ao campo geográfico tratou da temática da integração territorial na revista "Cultura Política", acentuando a necessidade de buscar um desenvolvimento econômico atrelado à construção de um sistema de comunicações, não nos afigura clara a participação direta de geógrafos na montagem das ações do regime varguista, se bem que, conforme já foi apontado, a permanência de uma concepção espacializada do país fosse comum a amplos setores letrados, que compartilhavam assim determinadas imagens sobre o Brasil, principalmente no que tange ao relacionamento da população brasileira com seu território e sua natureza.

Avaliando os efetivos resultados obtidos por meio dessas políticas territoriais, teríamos que as políticas de colonização não induziram movimentos expressivos de ocupação do interior, tampouco sendo alterada a concentração fundiária e a organização do espaço rural no período em foco - isto é, o varguista -, o que só ocorreria nas décadas seguintes. No que tange à unificação dos mercados, porém, resultados sensíveis foram obtidos, como o fim dos impostos interestaduais e a melhoria nas condições de planejamento e financiamento. Por fim, na questão estratégica dos transportes, os resultados tiveram um alcance restrito regionalmente às demandas da industrialização concentrada:

Apesar de toda a retórica a respeito da fronteira, não parece que Vargas imaginasse a "Marcha para o Oeste" como um movimento massivo que ocuparia e desenvolveria metade do país em um curto período de tempo. De certa maneira ainda se tratava da política de novos rótulos em velhas garrafas, mesmo que as velhas garrafas não representassem o imobilismo, visto como um certo movimento de fronteira estava se dando "espontaneamente". Quando falava em termos concretos, Vargas parecia ter em mente, em termos de política governamental, sobretudo as "medidas elementares", tais como saneamento, educação e transportes, que constituiriam os pré-requisitos e o suporte para a ocupação (...). Houve, no entanto, sem dúvida desenvolvimentos importantes na fronteira. Este foi o caso, por exemplo, no Centro-Oeste, mais facilmente conectado aos principais centros de produção do que a Amazônia. Estradas de ferro foram construídas ou estendidas (como no caso da Estrada de Ferro Noroeste) e antecipando Brasília, uma nova capital foi construída para o Estado de Goiás. Além disso, o movimento "espontâneo" vindo da direção de São Paulo e Minas Gerais para o Sul do Mato Grosso e Goiás (inicialmente reocupando terras que depois do período do ouro colonial haviam sido deixadas a uma 
pecuária dispersa, prosseguindo posteriormente para terras de mata) encontrou um certo apoio estatal. (VELHO, 1979, pp.141-142.)

Vejamos, como amostra da força de convencimento de uma argumentação sustentada por uma concepção politicamente orientada do espaço, um discurso de Getúlio Vargas, feito em 1940, que explicava à população os propósitos e justificativas para o desenvolvimento de seu programa de conquista do oeste:

Após a reforma de 10 de Novembro de 1937, incluímos essa cruzada no programa do Estado Novo, dizendo que o verdadeiro sentido de brasilidade é o rumo ao oeste. Para bem esclarecer a idéia, devo dizer-vos que o Brasil, politicamente, é uma unidade. Todos falam a mesma língua, todos têm a mesma tradição histórica e todos seriam capazes de se sacrificar pela defesa do seu território. Considerando-a uma unidade indivisível, nenhum brasileiro admitiria a hipótese de ser cedido um palmo desta terra, que é o sangue e a carne do seu corpo. Mas se politicamente o Brasil é uma unidade, não o é economicamente. Sob este aspecto assemelha-se a um arquipélago formado por algumas ilhas, entremeadas de espaços vazios. As ilhas já atingiram um alto grau de desenvolvimento econômico e industrial e as suas fronteiras políticas coincidem com as fronteiras econômicas. Continuam, entretanto, os vastos espaços despovoados, que não atingiram o necessário clima renovador, pela falta de toda uma série de medidas elementares, cuja execução figura no programa do Governo e nos propósitos da administração, destacando-se, dentre elas, o saneamento, a educação e os transportes. No dia em que dispuserem todos esses elementos, os espaços vazios se povoarão. Teremos densidade demográfica e desenvolvimento industrial. Deste modo, o programa de "Rumo ao Oeste" é o reatamento da campanha dos construtores da nacionalidade, dos bandeirantes e dos sertanistas, com a integração dos modernos processos de cultura. Precisamos promover essa arrancada, sob todos os aspectos e com todos os métodos, a fim de suprimirmos os vácuos demográficos do nosso território e fazermos com que as fronteiras econômicas coincidam com as fronteiras políticas. Eis o nosso imperialismo. Não ambicionamos um palmo de território que não seja nosso, mas temos um expansionismo, que é o de crescermos dentro das nossas próprias fronteiras. (VARGAS apud VELHO, 1979, p. 138.)

A propósito da centralização e concentração decisória, a reestruturação da máquina de governo federal, com a criação de conselhos e agências preocupadas com a gestão e controle de serviços específicos, teria como pano de fundo a organização e disciplinarização da sociedade com vistas a reforçar a identificação e o grau de exploração dos recursos naturais disponíveis, passando ainda pela necessidade de se produzir diagnósticos científicos sobre a realidade brasileira, vale dizer, sobre o potencial de exploração do território, com destaque para os estudos sobre as propriedades físicas do solo e subsolo e a preocupação com o padrão de ocupação econômica e humana (ALMEIDA, 2000). Nessa conjuntura, o papel do IBGE é visto como fundamental, pois representa o coroamento dos esforços que intentavam firmar, em nível federal, 
um órgão de planejamento territorial baseado na sistematização de dados estatísticos acerca do território. Entendida como uma agência do poder central capilarizada, o IBGE, com seus integrados Conselhos Nacionais de Estatística (CNE) e de Geografia (CNG), era um órgão de informações que embora estivesse diretamente subordinado ao Gabinete da Presidência da República, e, pois, sob a tutela do poder central, tinha como objetivo alcançar, por meio de informantes diretos e pesquisas de campo, as instâncias estaduais e municipais, unificando o conjunto de dados e informações disponíveis sobre o país.

Enfim, esta seção subdividiu-se em duas partes. De um lado, ao lembrarmos a importância da SGRJ no processo de institucionalização do campo geográfico, tivemos o intuito de ressaltar o modo como sua atuação na renovação do ensino poderia veicular concepções do território que expressavam visões politicamente orientada do espaço não incomuns ao momento. Por outro lado, ao tratarmos de uma miríade de projetos governamentais oficiais que tinham a coesão e a integridade do território como horizonte básico, nosso objetivo foi conferir importância às ideologias geográficas (MORAES, 1988) que bem ou mal poderiam informar os sujeitos responsáveis pela elaboração de tais políticas territoriais, influindo na tomada de decisões relativas à implantação de colônias agrícolas, na escolha dos imigrantes a serem alocados em projetos de colonização ou mesmo nas avaliações que envolviam a construção de um sistema de comunicações pensado para remediar os problemas de fluidez enfrentados pelo país. Numa tal realidade, a necessidade de reconhecimento do território demandava a consolidação órgãos oficiais voltados para a produção e a sistematização das informações imprescindíveis com as quais o Estado trabalharia, fornecendo o embasamento quantitativo e cartográfico básico para o exercício de sua soberania. Vejamos então como algumas dessas ações de apropriação intelectual do território também trabalhavam com conceitos e imagens espaciais do país.

\section{A apropriação tecnocientífica do território: o IBGE e as Expedições Civilizatórias}

A mobilização de forças para a criação de um sistema centralizado de informações estatísticas no Brasil, necessidade básica para a prática do poder estatal, antecede a chegada de Getúlio Vargas ao poder, mas foi decisivamente impulsionada ao desfraldar a década de 1930, quando assumem posições de liderança Mário Augusto Teixeira de Freitas, que havia organizado uma seção de estatísticas em sua passagem pelo governo de Minas Gerais, na década de 1920, e o 
diplomata José Carlos de Macedo Soares, primeiro presidente do Instituto Brasileiro de Geografia e Estatística. Congregando o trabalho de outros homens públicos de renome, como Juarez Távora, Rafael Xavier, Heitor Bracet, Rubens Porto e Waldemar Lopes, é costume tomar-se o ano de 1936 como o "marco zero" do IBGE, até por ser essa a data de criação do sistema estatístico brasileiro unificado:

Em 6 de julho de 1934, ainda no Governo Provisório, pelo Decreto n ${ }^{\circ} 24.609$, é criado o Instituto Nacional de Estatística - INE. Antes, desde 1930, Teixeira de Freitas lutara pela criação do Instituto Nacional de Estatística e Cartografia, mas, por razões políticas, tivera que ajustar sua proposta para conseguir aprová-la. Então, tendo-a aprovada, na forma do Instituto Nacional de Estatística, empenha-se por sua efetivação, o que só se daria em 29 de maio de 1936, com Macedo Soares assumindo sua presidência, perante Getúlio Vargas, no Palácio do Catete, onde seria instalado. Ato contínuo, Macedo Soares dará posse a uma Junta Executiva provisória, à qual caberia formatar o Instituto Nacional de Estatística. Por sua ação, logo se daria a Convenção Nacional de Estatística, aprovada pelo Decreto $\mathrm{n}^{\mathrm{O}}$. 1.022, de 11 de agosto de 1936, pela qual criou-se, entre outras coisas, o Conselho Nacional de Estatística, cujo início formal de operação ocorreria pelo Decreto $\mathrm{n}^{\mathrm{O}}$. 1.200 , de 17 de novembro de 1936 , no contexto da sua primeira Assembléia Geral. Em 24 de março de 1937, pelo Decreto $\mathrm{n}^{\mathrm{O}}$. 1.527, seria criado um Conselho Brasileiro de Geografia agregado ao Instituto; pouco depois, a 26 de janeiro de 1938, pelo Decreto-lei $\mathrm{n}^{\mathrm{O}} .218$, este Conselho seria nacional, ao mesmo tempo que o Instituto passava a ser o Instituto Brasileiro de Geografia e Estatística - IBGE. (SENRA, 2008, p. 50.)

Amparados pelo Decreto-Lei 311, de 02 de Março de 1938 - conhecido como a "Lei Geográfica do Estado Novo" -, vemos que dentre os objetivos iniciais da agência estariam: a) a atualização e reedição da Carta do Brasil ao Milionésimo, com a determinação das coordenadas das sedes de todos os municípios, o que se coaduna com a necessidade fundamental de se obter bases cartográficas confiáveis para o Censo de 1940; b) o planejamento de uma nova divisão administrativa do país em regiões, que buscava construir uma perspectiva regional de abordagem do país, transcendendo os limites territoriais das antigas políticas oligárquicas; c) a organização de um sistema nacional de estatísticas, fundando uma base de dados quantitativa para as ações políticas que, a partir de então, seriam cientificamente informadas; d) a definição de regras específicas sobre a toponímia dos municípios, proibindo homônimos; e) o estabelecimento de diretrizes técnicas comuns para se efetuar futuros mapeamentos (ALMEIDA, 2000; PENHA, 1993; SENRA, 2008):

As atividades do IBGE entre 1937 e 1945 foram orientadas desde cedo como suporte para a implantação de um importante instrumental técnico-científico de administração do território, visando, em última instância, contribuir para o avanço das políticas governamentais no campo econômico e a efetivação de suas 
práticas atinentes ao rearranjo político. Isso ocorreu com a instituição funcionando principalmente como suporte de funcionamento da máquina estatal no tocante à implementação de políticas públicas e como núcleo administrativo central responsável pelas formulações e execução de políticas territoriais. (ADAS, 2006, p. 37.)

Ocasião de debater mais a fundo o conjunto de objetivos do IBGE acima arrolados, a defesa em favor do municipalismo realizada por figuras importantes dentro da estrutura ibegeana, como Mário Augusto Teixeira de Freitas e Rafael Xavier, remete à importância do princípio da cooperação interadministrativa na conformação dos levantamentos estatísticos do IBGE. Segundo Nelson Senra (2008a), a questão da normalização de procedimentos de coleta, uniformização e integração estatística nas três esferas administrativas foi talvez o grande problema dos primeiros anos de existência do IBGE, visto que a ingerência do novo órgão federal nos dados primários antes sob a responsabilidade de estados e municípios era não raro considerada uma afronta à independência administrativa destes. Por isso, a criação dos agentes municipais de estatísticas, que iriam buscar as informações diretamente nos locais onde elas se encontravam, atuando simultaneamente como pesquisadores e educadores (pois que marcariam procedimentos e estabeleceriam regras para a produção e coleta dos dados), foi considerada uma grande vitória para os que se encontravam à testa dos movimentos geográfico e estatístico brasileiro, já que finalmente estruturava-se um sistema centralizado de informações com atuação capilar nos estados e municípios, instrumento basilar para o exercício do controle e do poder do Estado, que a partir daí poderia melhor fundamentar suas informações sobre o potencial quantitativo do país na execução de políticas estratégicas, como as ações de ocupação do interior do território:

Este "diálogo" assimétrico entre governo federal e municípios, visando à autonomia destes em relação à esfera estadual, foi em grande parte construído a partir da estrutura administrativa ramificada e complexa do IBGE, com suas unidades espalhadas em quase todas as cidades do País (...). Assim, o IBGE, em sua origem, foi a agência de informação por excelência, ensejando a desconcentração espacial da burocracia, em benefício da dimensão nacional da governabilidade, na Era Vargas. Este papel de mediação entre o central e o local se fez presente em diferentes ocasiões, nas variadas atuações do IBGE. As tabelas, os censos, os mapas e os cartogramas produzidos pelo Instituto afirmavam a referência a um coletivo nacional, fixavam o poder do Estado sobre o espaço físico e sua população, em sociedade, num território. Estas tecnologias de distância, ajustadas às tecnologias de governo, contribuíam decisivamente para esvaziar as representações espaciais que com elas concorressem (...). Para os trabalhos estatísticos, o município importava, antes de tudo, por ser a base primária de coleta e divulgação de informações estatísticas e geográficas (na qual era imprescindível o conhecimento sistematizado de seus limites e a racionalização de seus topônimos) (...). Concebido como "agência capilarizada 
do poder central", presente em todos os municípios do Brasil, o Instituto deveria promover não apenas o recrutamento e a formação de seus agentes municipais permanentes, mas sua instalação e integração à vida local - com suas hierarquias e chefes políticos -, fundamental à rede de obtenção e transmissão da informação. Por isso, a bandeira do municipalismo seria a mesma do IBGE (...). Seus técnicos, em especial Teixeira de Freitas como o maior e mais influente dentre eles, desenhariam políticas que passavam ao largo da experiência do self government, conhecido da tradição municipalista liberal. Ao contrário, em seu ideário, muitas vezes sistemático, a racionalização da administração, da economia e da cultura de base municipal passava pelo reforço da presença e do controle do Estado centralizado. (RIO CAMARGO, 2008, pp. 40/42.)

A relação ambígua do Estado Novo com as esferas municipais de poder combinava a defesa dos municípios com um projeto político de centralização autoritária do poder em tudo oposto ao autonomismo comum ao ideário municipalista (MELO, 1993). O incentivo à articulação direta entre o município e o governo central, numa imbricação entre as escalas local e central que não necessitaria de outras instâncias territoriais de mediação, como os estados ou regiões, ganhava força em ações de grande repercussão na opinião pública, como a arbitragem que o IBGE passou a fazer acerca das históricas disputas fronteiriças interestatais ou intermunicipais, e os projetos de uniformização cartográfica e toponímica dos municípios, que culminaram na Exposição de Mapas Municipais, ocorrida em 1940, e no projeto da Enciclopédia dos Municípios Brasileiros, editada entre 1957 e 1964. Ocorrida em 29 de maio de 1940, a Exposição de Mapas foi um momento de grande celebração patriótica, oportunidade única para propagandear as qualidades do regime muito bem aproveitada pelas autoridades, conforme se pode observar no conjunto de discursos e notas da imprensa imediatamente publicados (IBGE, 1940):

Entre vozes oficiais e discursos técnico-científicos, a exposição foi saudada como a consagração de um esforço sem precedentes do país na produção de um mapa padronizado de todos e de cada um dos municípios brasileiros que, pela sua linguagem homogênea, constituiria em sua soma o tecido cartográfico do território nacional (...). Neste contexto, a campanha dos mapas municipais foi programada como um grande empreendimento patriótico que objetivava, através do reforço a um municipalismo uniformizador, conhecer e controlar as realidades locais assim como fortalecer a unidade federal através da configuração de um tecido cartográfico homogeneizador (...). Se o conjunto de mapas municipais produzidos pela campanha de 1940 foi desenvolvido para responder aos programas cartográficos oficiais, fundados nos discursos racionalistas e científicos da elite intelectual do IBGE, o seu desfile teatral destinou-se a construir e divulgar uma imagem do território cartografado no plano simbólico, dentro de um rito celebrativo da idéia de unidade nacional. Entre os muitos artefatos retóricos inventados pelo Estado Novo para construir seu discurso unificador, centralizador e modernizante, a representação 
cartográfica alcançou uma posição singularmente importante. No que tange à questão territorial, talvez a mais importante no conjunto das políticas públicas da história do país. (GOMES, 2010, pp. 2/5/9.)

Outro dos objetivos gerais do IBGE que afiançam essa relação hesitante dos municípios com o poder central é o esforço de Vargas para esvaziar o poder das antigas elites estaduais, feito exatamente a partir da construção, ou ressignificação, do conceito de região, utilizado pelo governo muito mais num sentido de regionalismo cultural, e não como escala de divisão políticoadministrativa. No caso, a primeira divisão territorial oficial do país, proposta por Fábio de Macedo Soares Guimarães (1942), geógrafo do CNG, embasava-se no critério fisiográfico já utilizado por Delgado de Carvalho, partindo das diferenças observadas entre os elementos naturais, tais como vegetação, relevo e clima, para delimitar as grandes regiões do país, que se tornariam, a partir daí, a base territorial básica utilizada para a apresentação e tabulação dos dados estatísticos levantados pela agência de informações do governo.

$O$ reposicionamento da relação estabelecida entre o sertão e a nacionalidade na primeira metade do século XX, catalisando maneiras diversas de apreensão do espaço, frutificou em influentes ideologias geográficas (MORAES, 1988) que serviram para embasar diversas políticas territoriais, inflexão que permitiu "a emergência da categoria de fronteira para a descrição dos processos econômicos de incorporação de 'vazios demográficos' (...) oferecendo orientações ideológicas que transformam a concepção do agir sobre esse espaço" (SOUZA, 1998, p. 57). Esse desdobramento semântico do sertão em fronteira, como resultado da mudança de perspectiva das narrativas do pensamento político-social, embasou, a partir da década de 1930, uma instrumentalização do conceito de região que combinava os termos sertão, fronteira e nação a partir de uma definição renovada do que quer que fosse a identidade regional. Na verdade, o regime de Vargas combatia a exacerbação do sentimento regionalista, acusado de ser uma corruptela do separatismo, como forma de se contrapor às práticas políticas das antigas elites regionais oligárquicas, mas não se opunha ao regionalismo, tomado como expressão de formas específicas de manifestação cultural, isto é, como arranjos culturais espacialmente localizados que, vistos em conjunto, exprimiriam localmente a diversidade do caráter nacional. Desse modo, a ditadura varguista conferia novo significado ao conceito de região ao tentar definir o conteúdo do nacional a partir do regional, filtrando-o por sua concepção autoritária e centralizadora da sociedade: "no discurso de Getúlio Vargas o cerne da identidade nacional era localizado nos hábitos e símbolos tradicionais do Brasil 'profundo', com a cultura brasileira sendo apresentada 
como a somatória de identidades regionais visualizadas como folclore" (MORAES, 2011, p.125). É por esse motivo que Mônica Velloso chega a afirmar, em seu estudo sobre os intelectuais do movimento verde-amarelo, que:

As ideias regionalistas desse grupo vão ser absorvidas pelo regime, que as integra como dimensão constitutiva do nacional. O regionalismo deixa de ser visto como uma ameaça ao sentimento de unidade nacional ao sintetizar a própria brasilidade. O Estado Novo aparece como o Estado nacional, capaz de integrar as diversidades trazendo-as para o conjunto. De acordo com essa perspectiva, o regime passa a incentivar os intelectuais a escreverem sobre as origens da nação. Não importa que as interpretações sejam diferentes. Importa que elas abordem a mesma questão: a fundação do Estado nacional. No interior do projeto ideológico estadonovista, o que interessa resgatar é a ideia de organização nacional, tornando-se tudo o mais o seu corolário. (VELLOSO, 1990, p. 13.)

De volta à regionalização do país proposta pelo IBGE, uma vez entendido que o tema da divisão territorial colocava-se como um desdobramento dos problemas da coesão e da integração do território - problemas sempre lembrados pelos geopolíticos próximos do regime na sua cruzada contra as oligarquias regionais -, percebe-se que "a criação das Grandes Regiões Naturais representou, neste sentido, uma forma de intervenção técnico-administrativa sobre os estados, ao mesmo tempo que incentivava o municipalismo" (PENHA, 1993, p. 108). Aliás, num trecho que demonstra com clareza a concepção corrente sobre os limites do trabalho intelectual do geógrafo, visto mais como auxiliar da deliberação e ação políticas do que responsável por elas, Fábio de Macedo Soares Guimarães expõe os porquês de ser o natural o critério mais adequado para efetuar a delimitação regional do Brasil para fins estatísticos, o que vem a reafirmar aquela despolitização do conceito de região, pois, na definição oficial, a região se referia ou a fenômenos naturais ou a manifestações culturais:

A divisão regional mais adequada, mesmo do ponto de vista prático, é a que mais se aproximar das realidades geográficas; ou, em outras palavras, tais regiões devem assemelhar-se o mais possível às "regiões naturais". Cabe assim ao geógrafo fornecer a base para a solução do problema prático, resolvendo previamente o teórico, do ponto de vista científico, com o estabelecimento duma divisão em "regiões naturais". Com tal base, estará apto o administrador a encontrar a melhor solução prática, modificando convenientemente, de acordo com as necessidades administrativas, a divisão que lhe é apresentada pelo geógrafo (...). A uniformidade se impõe, indiscutivelmente, de maneira mais forte, quando se trata de divisão regional para fins estatísticos (...). É urgente, por conseguinte, que seja adotada uma divisão regional única para fins estatísticos, e que esta permaneça estável por um largo período, abrangendo diversos recenseamentos que se forem realizando, afim de que se possam comparar as situações do país em diferentes épocas (...). Como já fizemos notar, 
a divisão política ideal é a que se aproxima o mais possível da divisão em "regiões naturais". Mesmo, porém, que tal aproximação ideal não seja possível, por motivos de ordem administrativa e econômica, o que é sobretudo essencial é que haja uniformidade, principalmente para fins estatísticos. (GUIMARÃES, 1942, pp. 5/7-8.)

Mencionada, pois, a necessidade de se consolidar um sistema centralizado de informações geográfico-estatísticas que atuariam como auxiliares no processo de elaboração das políticas territoriais do governo, vale nos determos um pouco na comunicação "O Instituto Brasileiro de Geografia e Estatística e a Segurança Nacional”, escrita por Teixeira de Freitas e publicada no primeiro número da "Revista Brasileira de Estatísticas", em 1940, porquanto revela algumas das premissas básicas presentes no ideário político dos envolvidos diretamente na estruturação do IBGE. Considerando que a segurança dos agrupamentos humanos é condicionada pela adaptação dos seres vivos ao meio em que vivem, afirmação que não saberíamos distinguir de outras tantas feitas à época pelos geógrafos acostumados aos argumentos de cariz naturalista da geografia tradicional, Teixeira de Freitas atrela a segurança do Estado - em sua expressão, "a mais perfeita forma de solidariedade humana" - ao grau de conhecimento que este dispunha "de um lado, do seu 'espaço vital' ou 'ambiente telúrico', e de outro lado, da composição e estruturação, bem como das necessidades e possibilidades do grupo social a que der expressão política" (TEIXEIRA DE FREITAS, 1940, p. 100).

"Conhecer para prever" e "prever para prover" eram os axiomas da atividade estatística que para ele assumiriam o caráter de verdadeiros "imperativos categóricos" para as nações desenvolvidas (TEIXEIRA DE FREITAS, 1940). Logo, o conhecimento da ambiência geográfica do Estado, de suas características físicas, econômicas, culturais e humanas, da composição quantitativa dos diferentes aspectos e virtualidades que compõem seu território, é tomado como premissa básica para o estabelecimento de um governo comprometido com os destinos da coletividade política que ele quer representar. É a partir do enquadramento que concebe a segurança nacional como condicionada pelo conhecimento geográfico do território que Teixeira de Freitas confere ao IBGE um lugar estratégico de destaque no edifício estatal brasileiro. Para justificar um tal juízo, o grande incentivador da organização estatística nacional dedica-se à defesa da ampliação das atribuições do IBGE, que para ele não deveria ficar restrito à alimentação estatística dos órgãos civis de governo, oferecendo também as informações essenciais da construção dos dados privativos com que trabalham os órgãos dos Estados Maiores: 
Por conseguinte, não somente aconselhável, mas necessário será que, já possuindo o país um aparelho estatístico de significação verdadeiramente nacional, cuja atuação se estende a todos os recantos do território pátrio e a todos os aspectos da vida brasileira, congregando atividades das três órbitas governativas, a seu cargo devem também ficar as particularizações da estatística geral necessárias aos fins da defesa militar do país, nessa tarefa incluído o tratamento primário dos elementos que forem coletados especialmente para esse fim, de modo que, nos centros técnicos incumbidos dessa manipulação, tenham os Estados Maiores das Regiões eficientes agências civis em conexão adequada com a organização militar. Há, portanto, uma ampliação lógica para o atual esquema do Instituo Brasileiro de Geografia e Estatística: é a que venha atribuir à instituição uma atividade complementar dos seus objetivos normais, no sentido de lhe dar o papel que em princípio já lhe cabe em face da segurança nacional. E tudo indica que essa verdade, já evidenciada pela própria atuação do Instituto, não tardará a exprimir-se em efetivo desenvolvimento prático do pensamento do governo que integrou, tornou eficientes e articulou em um grande sistema os dispersos e escassos elementos que compunham a organização nacional nos setores da estatística e da geografia. (TEIXEIRA DE FREITAS, 1940, pp. 102103.)

Como se infere das linhas finais, a unificação total da produção estatística, que incluiria a produção das informações estratégicas a serem utilizadas pelos Estados Maiores militares, era ainda apenas um desejo de Teixeira de Freitas, vontade quiçá alimentada, por um lado, pelo momento de guerra então vivenciado, e por outro, por uma disputa por espaços de atuação especializados que o órgão recém-organizado talvez estivesse empreendendo ao lado dos tradicionais Serviços Geográficos Militares. Nessas circunstâncias, sabe-se que a criação de uma divisão de estatísticas militares dentro do sistema estatístico nacional, debatida desde 1939, foi executada apenas em 16 de março de 1942, quando finalmente foram criadas as Seções de Estatística Militar, agências municipais de informações localizadas em todas as capitais de estado cujas atividades eram subordinadas ao controle direto do IBGE (SENRA, 2008). Com efeito, nas primeiras resoluções tomadas pelo Conselho Nacional de Estatísticas, no ano de 1936, já se podem notar as disputas entre militares e civis, que então discutiam os limites de atuação da nova agência oficial de estatísticas, bem como a competência de um órgão civil para pautar as decisões geoestratégicas que, por tradição, eram da alçada dos serviços geográficos militares:

É de imaginar que naquele tempo os levantamentos de área, caracterização de território e afins fossem feitos pelo Serviço Geográfico do Exército, órgão com o necessário conhecimento técnico para isto e provavelmente a única referência no assunto. Com a criação do Conselho Nacional de Geografia, o que foi realizado para as estatísticas, no que tange à sua sistematização em escala nacional, conglomerando os órgãos produtores em todos os níveis: municipal, estadual e federal, também foi feito para os serviços geográficos. Desta forma, o Serviço Geográfico do Exército passou a ser integrante deste sistema, como órgão 
cooperador, em mesmo pé de igualdade, no organograma do sistema (conforme se vê no Anuário Estatístico do Brasil [1937]), de outras repartições ministeriais. Claro, ele continuaria com suas atribuições, pelo menos naqueles primeiros anos, mas, evidentemente, com a consolidação do sistema suas atribuições passariam para o novo órgão chamado IBGE. E não temos como saber como esta perda de espaço chegou aos militares daquele órgão do Exército. (SENRA, 2008, p. 140.)

Desse modo, conclui-se da análise do conteúdo dos artigos presentes no Decreto-Lei $\mathrm{n}^{\mathrm{O}}$ 4.181, que organizou as tais Seções Militares, em 1942, que a entrada em cena das Forças Armadas serviu sobretudo para harmonizar o relacionamento das agências municipais de estatísticas com os órgãos do poder central, uma vez que a penetração das Forças Armadas nos governos locais, associada à visão estratégica das estatísticas instrumentalizadas para a defesa nacional, permitiu uma maior flexibilização no que diz respeito ao fornecimento dos dados ao IBGE:

As agências, pouco a pouco foram criadas, mas eram ainda precárias. Seus vínculos ao prefeito dificultavam a obediência às regras vindas dos órgãos estaduais de estatística e do Instituto, donde o trabalho era feito quase sempre com atrasos. Os agentes, providos pelas prefeituras, eram escolhidos politicamente, e só raramente se ocupavam unicamente da atividade estatística; seus salários eram pequenos, e nada estimulantes. Dessa forma, restava, ainda, envidar os esforços de integração dos municípios àquele sistema cooperativo, o que ainda levaria bastante tempo, exigiria permanente inventividade; ajuda em material de consumo, em recursos financeiros, prêmio aos agentes operosos, ensino técnico aos agentes, tudo, por certo ajudava, mas não resolvia (...). Para o sucesso dessa atividade estatística expandida, no interesse da segurança nacional, "senão também [d]o normal rendimento da estatística nacional, como fundamento para toda a obra de governo, administração e progresso do país", foi declarada imperativa a "uniforme organização dos serviços municipais de estatística", vale dizer, devendo ser eles providos de "pessoal competente, bem remunerado e submetido a uma só direção". Dava-se, então, fundamento (imperativo categórico) à nacionalização (e posterior ibegeização) das agências municipais de estatística, ou seja, sua integração ao esquema de cooperação interadministrativa do sistema estatístico encabeçado pelo Instituto. (SENRA, 2008, pp. 171/174-175.)

Reconhecendo o avanço que representa o IBGE para a formação de um discurso técnicocientífico a respeito do território, há, porém, que observar que o esquadrinhamento instrumental

\footnotetext{
${ }^{36}$ Seria possível até supor que a crise desencadeada no IBGE quando da ascensão do general Djalma Polli Coelho à presidência do órgão, em 1952, contenha resquícios dessa disputa surda entre a ala civil do IBGE e os órgãos geográficos militares, dada a sua condição de oficial atuante de longa data no Serviço Geográfico do Exército, que presidira entre 1946 e 1951. Além disso, vale lembrar que Polli Coelho já havia entrado em confronto com os geógrafos do IBGE na época da Comissão de Estudos para a localização da nova capital do Brasil (1946-1948), chefiada por ele durante o governo Dutra (PEREIRA, 2008; VESSENTINI, 1986).
} 
do território não se iniciou, no Brasil, com a fundação do dito instituto. Na verdade, em seus diversos estudos sobre a Comissão Geográfica e Geológica (CGG) de São Paulo, Silvia Figueirôa (1987; 1997) é bem sucedida em demonstrar a maneira como, desde a sua fundação, em 1886, "a ocupação e integração do sertão de São Paulo aos fluxos da economia cafeeira e do complexo agroexportador" (FIGUEIRÔA, 2008, p. 765) era já alvo de preocupações por parte do governo paulista. Realmente, com a organização da CGG, ao final do século XIX, o governo de São Paulo mobilizou um grupo heterogêneo de cientistas, instrumentalizando um conjunto de saberes geográficos, cartográficos e geológicos então praticados de forma ainda muito dispersa no país num discurso que no limite flerta com o utilitarismo, pois que tinha a intenção de otimizar a exploração econômica de potenciais recursos naturais e humanos presentes no território, reforçando o papel fundamental da ciência e da técnica na elaboração de estratégias de apropriação territorial (FIGUEIRÔA, 2008).

Idealizada e dirigida em seu início pelo geólogo e naturalista Orville A. Derby (18511915), que propôs seu plano institucional e científico, a CGG sintetizava a vitória de um caminho tecnocientífico como alternativa viável para solucionar os problemas que a economia do café vivia ao final do século XIX. Os relatórios produzidos pelas expedições patrocinadas pela CGG se inscreviam em diversas áreas do conhecimento - geografia, geologia, botânica, meteorologia e hidrologia, entre outras -, o que permite compreendê-los, e à própria CGG, como uma espécie de matriz para o ensino e a prática de inúmeros ramos das ciências naturais e geológicas, fato reconhecível na influência que exerceu na organização de diversas instituições até hoje existentes e atuantes no sistema científico e tecnológico paulista, tais como o Instituto Geológico, o Instituto Geográfico e Cartográfico, o Instituto de Botânica, o Instituto Florestal, o Instituto Astronômico e Geofísico, o Museu Paulista e o Museu de Zoologia. Ricos em descrições, fotografias e documentos cartográficos, esses relatórios eram pensados como dispositivos que permitiriam a valorização de áreas ainda não ocupadas pelos fazendeiros, de preferência aquelas que apresentavam condições de solos e clima consideradas ideais para a atividade agrícola predominante, a cultura do café:

A exploração do 'extremo sertão' de São Paulo foi objeto específico de decreto governamental (1.278) em 23 de março de 1905, que também instruía o modo como os trabalhos deveriam se desenvolver. Foram organizadas quatro expedições que, percorrendo os rios Tietê, Feio, Peixe e Paraná, realizariam o mapeamento da região 'desconhecida', cujos limites eram: ao norte, a margem esquerda do Tietê até a confluência com o rio Paraná; a oeste, desta confluência 
até a barra do rio Santo Anastácio; das vertentes da margem direita do Santo Anastácio até o ribeirão Laranja Doce e, subindo a Serra dos Agudos, até o rio Feio, no limite sul; e, a leste, por uma linha do rio Paranapanema ao salto do Avanhandava, cortando o rio Feio e a Serra dos Agudos (...). Os relatórios publicados dessas expedições constituem um minucioso inventário do meio e dos recursos naturais das áreas palmilhadas e demonstram obediência fiel às instruções contidas no decreto, visando a apropriação dos espaços em futuro não muito distante (...). Diferentes tipos de informação são destacados nos textos, conforme a função exercida pelo engenheiro (ou médico) que reúne os dados no impresso. Em que pesem as variações entre os quatro relatórios de exploração, merecem destaque alguns pontos comuns, cuja simples presença reveste-se de grande significado. São eles: a exaltação à exuberância e à riqueza do meio natural, em especial as cachoeiras e quedas d'água; a superioridade da ciência e da técnica em detrimento dos saberes indígenas e 'caboclos'; a inexorável 'marcha do progresso' e conseqüente assimilação dessas regiões à 'civilização', como se fora um desdobramento futuro 'natural'; a presença de farta documentação fotográfica, que não apenas ilustra ou confere status de prova ao que foi visto, mas produz um discurso visual próprio, que reverbera e reforça o discurso textual. (FIGUEIRÔA, 2008, pp. 768/769/770.)

Além das atividades da Comissão Geográfica e Geológica, poder-se-iam citar outros exemplos de expedições que, ao estabelecerem uma apropriação científica do território, elaboravam imagens nas quais subjaz a ideia de construir o país, entendendo-o mais como um espaço a ser conquistado, e não como uma sociedade. Nísia Trindade Lima (1999), analisando as expedições de intelectuais e cientistas que se dirigiam ao interior do país no início do período republicano, com destaque para as viagens dos médicos sanitaristas partícipes do movimento higienista na década de 1910, afirma o dualismo entre sertão e litoral como integrante de um campo semântico que entendia o sertão como um lugar afastado do poder público e de seus projetos modernizadores, um lugar a ser incorporado ao Estado e à nação por processos de civilização e conquista que garantiriam o progresso ${ }^{37}$. Essas “missões civilizatórias" eivadas de um ideário cientificista operaram um esforço de valorização do sertão, "seja enquanto espaço a ser incorporado ao esforço civilizatório das elites políticas do país, seja como referência da

\footnotetext{
37 "Projetos cujas origens podem muitas vezes ser localizadas no Império, não apenas se intensificam durante a República, como ganham nova expressão, associando-se ao ideário cientificista dominante entre a intelectualidade. É possível falar de uma atitude de maior intervenção diante da natureza, cada vez mais ligada à idéia de recurso natural, e do movimento de auto-atribuição de uma missão civilizatória, da parte das elites intelectuais, que se viam como responsáveis pela formação da nacionalidade. Sertão e viagens, estas vistas como expedições civilizatórias, são termos que se interpenetram. O desbravamento do sertão pode ser visto como um movimento de forte conteúdo simbólico, que acompanhou os projetos oficiais de delimitação de fronteiras, saneamento, utilização de recursos naturais, povoamento e integração econômica e política. Este movimento missionário, fortemente associado à expansão da presença do Estado, encontrou como atores sociais agentes informados pelo cientificismo (...). Desta forma, ações diferenciadas mas que apresentaram elementos em comum integram esse movimento. Sertão, povoamento, civilização, integração à nacionalidade constituem termos recorrentes em diferentes documentos das três primeiras décadas do século XX.” (LIMA, 1999, p. 67.)
} 
autenticidade nacional" (LIMA, 1999, p. 65), o que indica a permanência do tema da integração do interior do território nacional no pensamento político-social brasileiro, uma vez que, como foi visto acima, o problema da coesão interna do território continuaria a incitar debates durante o período Vargas.

Nesse sentido, a campanha pela reforma da saúde pública e pelo saneamento dos sertões, que sensibilizou estratos cada vez mais amplos de diferentes grupos políticos e intelectuais, operacionaliza novas percepções do território, compondo imagens fortes que recusavam as versões ufanistas da natureza e associavam os sertões ao abandono, ao atraso e à doença, comprovando a fragilidade do homem diante da natureza tropical. Aliás, a constatação das dificuldades de adaptação do europeu e seus descendentes aos trópicos, que ecoa esse sentimento geral de inanição dos grupos humanos ante a natureza tropical, percebida como inferno ou obstáculo permanente à ocupação racional, será um tema caro à geografia da época, visto que os geógrafos brasileiros que tratam da questão do povoamento pelo prisma das frentes pioneiras o retomam inúmeras vezes, principalmente na avaliação que fazem das populações tradicionais que habitavam as áreas centrais das movimentações pioneiras.

Tendo como referência o fato de o conceito de formação territorial conceber o território simultaneamente como materialidade e representação, relacionando o processo de sua efetiva ocupação material com os discursos e projetos que o têm como objeto (MORAES, 2000), pode-se observar de que modo o imperativo da conquista, posto como questão de fundo para diferentes governos em diversos momentos históricos do Brasil, aclara a maneira pela qual o imaginário da expansão territorial da sociedade brasileira, que atrela vulgarmente a compreensão do processo de formação do país à integração do território, isto é, ao imperialismo interiorizado exercido nas áreas qualificadas como sertões, aparece como tema polarizador da comunidade geográfica nas contribuições concretas dos autores que se dedicaram à análise da difusão espacial do povoamento em nosso país.

A concepção do sertão como lugar insalubre e "enfermo" que retardava o avanço do país ajudou a compor uma imagem na qual metáforas organicistas serviam indistintamente para qualificar a sociedade e o território, repondo em novos termos a questão da população com que o Brasil contaria para se modernizar. Enfim, o sertão e sua população, fatores indissociáveis, eram compreendidos como patologias nacionais, problemas que somente seriam superados pelas ações de saneamento e educação comandadas, evidentemente, pelo cientificismo da maior parte dos 
envolvidos, o qual em muitos casos podia resvalar num discurso em que a noção de raça aparece em um viés eugenista:

Entre os intelectuais que aderem à campanha pelo saneamento dos sertões no final de 1910, a despeito de persistirem estereótipos e afirmações em que aparecem idéias associadas a diferenças raciais, pode-se afirmar o claro predomínio de um discurso que refutava a atribuição de inferioridade étnica à população brasileira. O próprio recurso à noção de raça revela muita imprecisão, e muitas vezes o termo parece indicar o conjunto do povo brasileiro, observado de um ponto de vista biológico. A integração dos sertões à civilização do litoral, por meio de políticas de saúde e educação, representaria uma alternativa para o país. O grande problema encontrava-se nas doenças e a solução era possível com os recursos da ciência. (LIMA, 1999, p. 115.)

Seja como for, pode-se observar, na primeira metade do século $\mathrm{XX}$, uma relativa persistência da elaboração de inúmeras interpretações do Brasil apoiadas na ideia de um contraste entre litoral e sertão, antinomia que também pode ser lida na base tradição versus modernidade, já que essas imagens surgem no pensamento político-social brasileiro referidas a duas ordens sociais de organização estruturalmente distintas, espelhando uma concepção linear do desenvolvimento e do tempo histórico que carrega consigo uma representação geográfica da realidade na qual uma parcela do território é concebida como atrasada e estagnada, enquanto a outra, mais civilizada e desenvolvida, seria suscetível de receber os fluxos de cunho modernizante (SANDES, 2000; SOUZA, 1997). Por meio desse dualismo com o qual se qualifica o território, a representação do processo histórico de construção da nacionalidade segundo a ótica do surgimento de novas formas de solidariedade social - formas essas que acompanham, no Brasil, o movimento de territorialização da dominação política do espaço pelo Estado e seus órgãos burocráticos - abarca o tanto a dimensão espacial, na qual uma determinada concepção de espaço atua, mediada pela política, no sentido de imprimir certa direção na construção material do território, quanto a integração social, que projeta os interesses pretensamente comuns da população na manutenção da integridade territorial, concebendo o povo como instrumento na construção do país ${ }^{38}$.

\footnotetext{
38 "Por nation-building entende-se o processo de constituição de novas formas de solidariedade social que acompanhariam a expansão da dominação política de tipo burocrático. A integração territorial diz respeito ao processo por meio do qual uma nação concebe a si própria como unidade geográfica, enquanto a integração dos estratos sociais é vista aqui como processo em que uma sociedade nacional assimila seus diferentes grupos e setores sob uma ideologia de participação (...). No caso brasileiro, sertão e litoral podem ser vistos como imagens espaciais e simbólicas que guardam estreita relação com essa idéia de dois tipos de ordem social. Aqui o contraste ocorreria não entre formas distintas e historicamente sucessivas, mas pela justaposição de épocas históricas, numa sociedade em que, segundo Roger Bastide, a geografia não se separa da história. O caráter conservador, de resistência à mudança, historicamente atribuído ao termo 'sertão', pode adquirir conotação negativa ou positiva, aproximando-se de
} 
Em suma, a necessidade de implantação de mecanismos de controle técnico e científico sobre o território, da qual decorrem as propostas de reconhecimento e saneamento das terras interiores do território nacional, encetadas inúmeras vezes ao longo da primeira metade do século $\mathrm{XX}$ - pois ao dominar a natureza tropical e intocada dos sertões estaríamos construindo o país ao mesmo tempo em que o inseríamos na modernidade -, pode ser entendida como parte de um movimento de forte conteúdo simbólico que acompanhava os projetos políticos então em desenvolvimento. Dentre esses projetos, ganha destaque o já citado programa "Marcha para o oeste", que, como dissemos, combinava uma política de colonização pensada para integrar ao ecúmeno nacional os espaços vazios e as regiões de desenvolvimento retardado, com a elaboração de representações ideológico-discursivas sobre o tema da conquista, que por meio de mapas, fotos, cinejornais e toda uma série de materiais canalizados por uma estratégia de propaganda buscariam um como substrato de união de todos os brasileiros, demonstrando visualmente a consecução do projeto estatal de ocupação territorial e mimetizando a obra transformadora do Estado na imagem do território: o corpo da nação que se expande e amadurece (LENHARO, 1986). Ademais, a permanência de uma abordagem que concebe o país como sinônimo de seu território, e o interior do território como um espaço a ser apropriado e conquistado do ponto de vista intelectual e material, aponta para a existência, dentro do pensamento político-social, de uma demanda pela sistematização de diagnósticos precisos acerca dos problemas enfrentados pelo país, circunstância que abriria a possibilidade de a geografia acadêmica aparecer no horizonte do ambiente intelectual brasileiro como uma modalidade discursiva que tenta apreender a realidade a partir de ferramentas analíticas e metodológicas voltadas para esse fim. Desse modo, o tipo de análise da realidade surgido a partir da consolidação do campo disciplinar em nível universitário, que defende para a geografia a missão de descrever explicativamente a superfície terrestre, localizando e comparando os fenômenos observados num determinado lugar com eventos similares ocorridos em outras localidades, vai dar início à formação de um discurso que do ponto de vista histórico se mostrou bem sucedido na criação de uma expressiva tradição dentro do pensamento político social.

Até aqui, fizemos um esforço de reconstrução da conjuntura histórica e intelectual vivida pelo país ao longo das três ou quatro primeiras décadas do século XX, enfatizando a importância

antinomias clássicas das sociedades ocidentais: civilização e barbárie; cultura de folk e civilização ocidental; tradição e modernidade; cultura e civilização.” (LIMA, 1999, pp.13/23.) 
da chamada Era Vargas tanto para as modificações da geografia material do Brasil, quanto para a alteração das formas de apreensão desta realidade por certos círculos de intelectuais que mantinham com a geografia uma certa relação de proximidade, que era perceptível quando menos por conta do uso de conceitos e imagens espaciais para o entendimento das questões então colocadas. Não perdendo de vista o objetivo principal deste trabalho, que consiste em mapear a influência da noção de frente pioneira, tal como esta aparece na obra de Pierre Monbeig, na conformação de um perceptível modo de fazer geografia dentro das universidades brasileiras, pensamos que o caminho até agora percorrido fornece um embasamento para que se possa compreender as diversas formas através das quais os problemas envolvendo o processo de formação e integração do território apareciam enquanto temas de interesse para a classe política e intelectual no Brasil. Caminhando para o final, restaria agora tratar mais acuradamente do processo de institucionalização da geografia. É a isso que nos dedicaremos nas próximas linhas.

\section{A institucionalização da geografia no Brasil}

É nesse contexto histórico que devem ser lidas as mudanças no ensino superior ocorridas no Brasil a partir de 1931, quando da elaboração do estatuto das Universidades Brasileiras por Francisco Campos, primeiro Ministro da Educação de Getúlio Vargas. Durante o Estado Novo, Campos iria assumir o Ministério da Justiça, ocupando posição de destaque como redator da Constituição que inaugura o regime ditatorial, outorgada em 1937, a "Polaca", que substituiu a Carta de 1934. Quanto ao estatuto das universidades, contrastando com a situação anterior, quando a educação era atribuição dos estados, sabe-se que o estatuto integrava um conjunto de decretos que visava estabelecer a padronização do ensino secundário e superior em nível nacional, dispondo sobre a criação do Conselho Nacional de Educação, sobre a adoção do regime universitário no país e regulamentando as atribuições do ensino técnico e comercial. Já em 1932, com a publicação do "Manifesto dos Pioneiros da Educação Nova", elaborado por Fernando de Azevedo com auxílio de Anísio Teixeira, sedimenta-se um projeto pedagógico que defendia, de modo geral, a não subvenção estatal ao ensino religioso e a implementação de uma escola pública leiga, universal e gratuita, cujos objetivos seriam a formação de cidadãos livres e capazes de se incorporar ao Estado nacional em formação. 
Demerval Saviani escreve longas páginas acerca do aparente paradoxo que representa o fato de um representante do movimento Escola Nova, Francisco Campos, autor das medidas que reorganizaram o edifício educacional brasileiro, ter inserido, em meio à renovada legislação brasileira relativa à educação, o Decreto 19.941, de 30 de abril de 1931, que introduziu, de maneira inédita no país, a obrigatoriedade do ensino religioso nas escolas oficiais, atendendo assim a uma reivindicação das lideranças católicas. Essa aliança de Francisco Campos com os educadores católicos, como Alceu Amoroso Lima e Gustavo Capanema, que o iria substituir como ministro da educação no governo Vargas, não pode ser compreendida sem fazer referência ao seu alinhamento com o pensamento autoritário, na esteira das ideias defendidas por Alberto Torres, Azevedo Amaral e Oliveira Vianna, cabendo ainda observar que à época do decreto de 1931, o conflito entre educadores católicos e escolanovistas ainda não se havia deflagrado, pois foi somente em 1933, depois, portanto, da publicação do "Manifesto", que os educadores católicos acirraram suas divergências com os liberais, se retirando da Associação Brasileira de Educação (ABE) e fundando a Confederação Católica Brasileira de Educação (SAVIANI, 2008).

No geral, entre as décadas de 1930 e 1940, a elaboração das ideias pedagógicas no Brasil é marcada por um equilíbrio tenso advindo dessa disputa entre educadores católicos, representantes da pedagogia tradicional, e a pedagogia nova, inspirada fundamentalmente na obra de John Dewey. Outrossim, é importante verificar a polarização que se dá com a crescente politização dos católicos, que, receosos de perder espaço no controle da formação intelectual da população com as reformas laicas de cunho liberal inspiradas no movimento da Escola Nova, passam a demandar cada vez mais espaço na direção pedagógica que iria orientar as retificações a serem implantadas no sistema público de ensino, o que seria conseguido plenamente durante a gestão de Gustavo Capanema (1934-1945) no Ministério da Educação:

A característica mais saliente das reformas educacionais empreendidas por Campos e Capanema traz a marca do pacto com a Igreja Católica costurado por Francisco Campos no início da década de 1930. Por esse pacto, Vargas, apesar de sua origem castilhista, se dispôs a apoiar a inclusão das teses católicas na Constituição de 1934, recebendo em troca o apoio político da Igreja (...). Do referido pacto decorreu uma forte influência da liderança católica, em particular de Alceu Amoroso Lima, na formulação da política educacional e especialmente na composição do quadro de pessoal. Além da função de aconselhamento, as cartas de Alceu dirigidas a autoridades governamentais, em especial a Campos e Capanema, revelam sua influência na indicação de determinados nomes e no veto a outros para o exercício de cargos públicos, em especial no magistério. Essa circunstância, ao aproximar a Igreja do aparelho de Estado, diluiu as críticas dos católicos ao chamado monopólio estatal do ensino, de que eram 
acusados os renovadores (...). Mas a "derrota do movimento renovador" representada pelo pacto com a Igreja, pelo desfecho da Constituinte, pelo afastamento de Anísio Teixeira da vida pública e pela orientação que se imprimiu às reformas de ensino precisa ser relativizada. Para a "trindade governamental" (Vargas, Campos e Capanema), os princípios da educação cristã assim como os princípios pedagógicos renovadores não tinham valor em si, mas eram vistos como instrumentos de ação política. E não viam incompatibilidade entre uma visão educacional centrada na preservação da ordem social e a renovação pedagógica. Para Campos, aderir à Escola Nova não significava renunciar à "recuperação dos valores perdidos", tarefa que, a seu ver, teria que ser desempenhada pelo ensino religioso. (SAVIANI, 2008, p. 270.)

Como quer que seja, é nessa época que as primeiras universidades brasileiras finalmente emergem da estrutura educacional do país, pensada agora como nacional e unificada. Vejamos dois exemplos. Em 1935, implanta-se no Rio de Janeiro, então capital da República, a Universidade do Distrito Federal, que não seguiu à risca a exigência da nova legislação de integrar necessariamente duas das três mais tradicionais instituições profissionais de ensino superior - medicina, engenharia e direito - a uma nova Faculdade de Filosofia, Ciências e Letras, pensada para exercer uma dupla função, pois deveria incentivar a pesquisa livre e desinteressada ao mesmo tempo em que fornecia bases sólidas de formação para o professorado secundário. Essa situação só seria alterada em 1939, após a fundação da Universidade do Brasil (UB), que se seguiu à extinção da UDF. Na verdade, o edifício organizacional conferido à UDF dá a ela um lugar único no processo de estruturação do ensino superior universitário no país, visto que essa instituição era composta por cinco Escolas (a de Ciências, a de Economia e Direito e a de Filosofia e Letras), dois institutos (o de Educação e o de Artes) e outros centros de experimentação pedagógica e de prática de ensino. No caso, o curso de geografia alocou-se na Escola de Economia e Direito, que primava pelo estudo do Brasil, sendo na prática uma das únicas seções de tal Escola (a outra foi a seção de Ciências Sociais) a efetivamente funcionar (MACHADO, 2009).

Estando à frente do cargo de direção da Instrução Pública do Distrito Federal o líder da Escola Nova Anísio Teixeira, que não escondia sua predileção por uma orientação pedagógica próxima do ensino liberal, foi inevitável o embate do grupo que estava à testa da UDF com a nata dos educadores católicos, que congregava em sua seara nomes de peso dentro do governo Vargas, como Alceu Amoroso Lima e Gustavo Capanema, o que levou ao ocaso a iniciativa, enfraquecida pelos fortes laços estabelecidos entre a Igreja e o Estado (SAVIANI, 2008; SCHWARTZAN, BOMENY e COSTA, 2001). Assim, haveria dois momentos iniciais da geografia universitária no 
Rio de Janeiro: entre 1935 e 1938, quando a UDF surge como proposta educacional nacional mais próxima dos parâmetros defendidos pelos educadores liberais, e após 1939, quando a influência do governo federal e da Igreja Católica fornece um novo contorno aos trabalhos já empreendidos, surgindo daí a Universidade do Brasil, compreendida como instituição modelo do ensino superior no país (MACHADO, 2009).

A tutela federal e o controle doutrinário da Igreja Católica exercidos no Rio de Janeiro ficam claros na indicação de Amoroso Lima para o cargo de direção da nova Faculdade Nacional de Filosofia (FNFi), bem como na questão da incorporação ou não dos alunos, professores e funcionários da UDF, pois, para o novo diretor, os cerca de cem professores e mil alunos vindos dessa instituição liberal poderiam comprometer o projeto da nova Faculdade. Após insistir no nome de Amoroso Lima até 1941, as delicadas negociações envolvendo o patrimônio da UDF levam o ministro Gustavo Capanema a indicar San Tiago Dantas para o cargo de diretor da FNFi. Assim, mesmo sem terem suas reivindicações plenamente atendidas, a nomeação de San Tiago Dantas não deixava de representar uma vitória dos educadores católicos. As indefinições e dificuldades do período, aliás, é fato passível de ser observado na trajetória universitária de Orlando Valverde, que ingressando no curso de geografia da UDF no início de 1936, formou-se pela Universidade do Brasil em data até hoje indefinida, provavelmente só no início de 1940, incerteza diretamente ligada às alterações curriculares impostas pelas mudanças estruturais do ensino superior carioca (ADAS, 2006).

Em 1934 - um ano antes, pois, da experiência carioca -, por esforço conjunto do governo estadual e do grupo político, intelectual e econômico que fazia ecoar seus projetos de poder nas páginas do jornal O Estado de São Paulo, organiza-se a Universidade de São Paulo, resultado da criação da nova Faculdade de Filosofia, Ciências e Letras com a integração de outras faculdades e institutos superiores de ensino estadual já existentes, com destaque para as Faculdades de Medicina, a Faculdade de Direito, a Escola Politécnica e a Faculdade de Farmácia e Odontologia, além do Instituto Biológico, o Museu Paulista e o Instituto de Higiene, instituições já consolidadas que contavam com um número razoável de alunos.

A despeito dos debates que envolvem o processo de criação da USP, pode-se afirmar sem receios que a motivação básica de sua constituição transita entre dois campos bastante intrincados. De um lado, deve-se realmente a uma articulação de grupos políticos paulistas de tendências liberais alijados do poder após a derrota da revolução constitucionalista de 1932, isto 
é, a Universidade pode ser vista, em parte, como uma espécie de resposta paulista à ascensão de Vargas (CARDOSO, 1982). De outro lado, como já notado, sua fundação liga-se igualmente às reformas pelas quais passava a educação brasileira no período, fato reconhecido pelo envolvimento direto de figuras ligadas ao movimento pedagógico da Escola Nova, como Fernando Azevedo e Lourenço Filho, na organização da USP. Ao fim e ao cabo, em vez de opor os desígnios políticos stricto sensu aos interesses dos empresários culturais e educadores profissionais, certamente ansiosos por controlar um grande mercado em expansão, garantindo novos campos de atuação para o seu grupo, pode-se mesmo enxergar, no foco dispensado às reformas educacionais, uma forma de reação política. Assim, ainda que por outros meios, e estando clara a necessidade de atenuar o controle do "grupo do Estado" no sentido de imprimir à universidade uma marca ideológica que fosse apenas desdobramento de um seu projeto de hegemonia, a USP não deixa de ser o resultado de um embate político (LIMONGI, 1988) ${ }^{39}$.

Nesse caso, seria importante notar as dificuldades que as novas universidades enfrentaram em seus primeiros anos, visto que os filhos das elites continuavam a se direcionar para os cursos tradicionais de medicina, engenharia e direito, o que no caso da USP por certo atenua a importância que o próprio Júlio de Mesquita Filho conferiu à criação da FFCL, considerada $a$ posteriori a medula sem a qual ruiria o edifício universitário paulista. Sem dúvida, é o próprio Fernando de Azevedo, um dos protagonistas do momento, quem já notara a oposição das antigas escolas profissionais, que proviam um ensino prático voltado aos problemas de "interesse da profissão", a esse novo modelo de organização superior:

É que a camada intelectual, recrutada através de mais de um século, nas escolas profissionais (direito, medicina e engenharia) e que desfrutava, numa sociedade estática, o monopólio na formação tanto das elites como da concepção de

\footnotetext{
39 "Todo bloco de poder, composição de forças sociais ou classe dominante exerce alguma ou muita influência sobre as produções culturais. Há sempre uma reinterpretação da história em marcha, segundo os governantes, os que detêm os meios de poder. A classe social, ou composição de forças sociais, que conquista o aparelho estatal pode expandir a sua influência cultural. O controle do sistema educacional, a influência nas igrejas, as relações com a indústria cultural, a disponibilidade de recursos materiais e organizatórios para mobilizar intelectuais segundo os seus interesses, tudo isso permite às forças sociais, ou classe social dominante, influenciar muito, ou decisivamente, as produções culturais. As artes, ciências e filosofias podem ser levadas a novos temas, linguagens, experiências. Em síntese, a cultura é uma dimensão fundamental da hegemonia que pode ser construída por uma classe, composição de forças sociais, bloco de poder, Estado. Toda configuração hegemônica é necessariamente cultural. Para exercer-se, a capacidade dirigente, ou hegemônica, compreende valores, ideais, princípios, modos de fazer, pensar e dizer, visão do mundo. Se é verdade que a hegemonia tem muito a ver com a consciência de classe , compreende também uma visão da sociedade, nação, estado, história. Como capacidade de interpretar e expressar os interesses de classe, composição, bloco ou Estado, a hegemonia conjuga também interesses, reivindicações e produções culturais de outros grupos e classes que não se acham necessariamente presentes nas esferas de poder.” (IANNI, 1992, pp. 154155.)
} 
cultura, apresentava um pensamento "escolástico', isto é, acadêmico e sem vida, que se opunha, pela indiferença ou pela hostilidade às transformações profundas do sistema de cultura e do ensino superior no país (...). Elas nunca tiveram, por isso, uma consciência viva e muito menos, profunda, da necessidade de criação de instituições universitárias no Brasil (...) essas duas Universidades - a de São Paulo, cuja Faculdade de Educação foi extinta em 1938 e na qual a Faculdade de Filosofia esteve a ponto de perecer à míngua de recursos (1938-1940) e a Universidade do Distrito Federal, absorvida em 1938 [sic] pela Universidade do Brasil -, tiveram a sua evolução atropelada de dificuldades, em parte decorrentes da mentalidade utilitária e profissional, ainda dominante no sistema de ensino superior, e em parte resultantes do próprio "clima histórico" em que nasceram (...). A profunda inquietação do espírito, cujas origens remontam à ruptura da unidade de pensamento e do monopólio intelectual da Igreja, atingiu ao máximo com as descobertas científicas e transformações econômicas, e o conflito de ideologias externadas. (AZEVEDO, 1976, pp. 186/188.)

Segundo Fernando Limongi (1988), que efetuou um levantamento comparando o número de matriculados com o total de formados nos cursos da FFCL, a pretendida célula central da USP quase fechou as portas em seus primeiros anos de funcionamento, tamanha a falta de procura pelos cursos que oferecia. Essa circunstância ajuda a desfazer o mito da nova Faculdade de Filosofia como uma obra feita pela e para as elites, que não afluiu aos novos cursos com o peso que seria de se esperar caso as intenções grandiosas dos fundadores fossem minimamente condizentes com a realidade. Era essa também a impressão de Pierre Monbeig, que assim escreveu no "Anuário da FFCL” do biênio 1934-1935:

Quando de sua instalação, a Faculdade atraíra alguns moços já nutridos de boa cultura, alguns dos quais, graças à sua idade, já com uma soma regular de conhecimentos ou, em todo caso, com inegável maturidade de espírito. $\mathrm{O}$ contingente do segundo ano, composto, na sua maior parte, de professores comissionados, de moças sobretudo, mais jovens que os primeiros, ofereceu ao professor um material completamente diferente. De um lado, uma minoria desejosa sobretudo de completar sua cultura geral. Tendo o gosto das idéias e das discussões; de outro lado, um grupo de jovens, animado de grande ardor para o trabalho, conhecendo perfeitamente as suas possibilidades, mas sabendo também que, antes de mais nada são professores e que é por esta razão que foram enviados à Faculdade. Os desejos de uns e de outros são diferentes, e esta situação formula o problema da Faculdade. (MONBEIG, 1936, p. 106.)

As memórias de Maria Conceição Vicente de Carvalho, Alice Piffer Canabrava e Olga Pantaleão, alunas das primeiras turmas da FFCL e futuras intelectuais de renome nos campos da história e da geografia, reafirmam a assertiva de Monbeig. Colocando em primeiro plano a importância do "comissionamento" na abertura dos bancos universitários para um público maior do que o aventado num projeto elitista, todas são unânimes em apontar a intervenção do governo em favor dos professores primários e secundários como um ponto de inflexão dentro do processo 
de consolidação da universidade. Em depoimento organizado posteriormente em livro por Eva Blay e Alice Gordo Lang, diz a certa altura Alice Canabrava:

Como tantas outras, fui uma das professoras do magistério primário beneficiadas pelo ato do Governo Estadual que facultou o comissionamento das interessadas junto à recém-criada Faculdade de Filosofia, Ciências e Letras da Universidade de São Paulo, desde que aprovadas em concurso de provas. A medida visava preencher o grande número de vagas. Desde 1933, a Reforma Fernando Azevedo [que modificou o sistema educacional paulista] havia proporcionado equivalência entre todos os cursos de segundo grau, pondo fim, desta forma, ao privilégio que usufruíam os ginásios, como cursos propedêuticos às escolas de nível superior. Não obstante, já no segundo ano de seu funcionamento (1935), a Faculdade de Filosofia não lograva despertar o interesse esperado. (CANABRAVA, 2004, p. 87.)

Aliás, a questão da falta de alunos somente seria resolvida após o governo paulista, numa ação deliberada de incentivo, regulamentar o comissionamento de professores oriundos da Escola Normal, que a partir de então passariam a frequentar os cursos sem necessidade de passar pelo vestibular e, o que era mais importante, sem prejuízo de seus vencimentos no magistério:

Muitas mulheres e homens que frequentavam a USP, quando de sua criação em 1934, puderam fazê-lo através do "comissionamento". As mulheres que trabalhavam, não tinham posses, de modo geral dependiam de seus salários. Para poder frequentar uma faculdade não podiam abrir mão do salário. Assim, foi por um ato governamental que estas professoras, mulheres na maioria, moradoras do interior do Estado de São Paulo, puderam vir estudar na capital. (BLAY e LANG, 2004, p. 88.)

A ação do governo paulista, que passou a incentivar e subvencionar a entrada dos alunos da Escola Normal na estrutura universitária, já foi considerada uma verdadeira "revolução dos normalistas" (CORRÊA, 1988). O uso dessa expressão por Mariza Corrêa não diz respeito somente ao franqueamento da entrada dos alunos normalistas na universidade, referindo-se, mais exatamente, à sólida herança que as políticas culturais incentivadas em todos os níveis de governo (municipal, estadual e federal) pelos educadores identificados com a Escola Normal deixou nos anos subsequentes, especialmente no cenário institucional e acadêmico dos anos 1950, quando os beneficiários diretos das ações tomadas na década de 1930 assumiram cargos relevantes dentro das diversas instituições de ensino e pesquisa então em pleno funcionamento. De todo modo, sabe-se que, em vista do comissionamento, o perfil dos alunos da FFCL/USP foi de fato modificado, deixando de ser um ambiente dominado exclusivamente por membros da "alta sociedade" paulistana, que lá estavam somente para prestigiar os cursos, e arregimentando 
um grande contingente de jovens, mulheres e filhos de imigrantes, que viam na carreira universitária uma possibilidade a mais de crescimento pessoal e de ascensão social:

Os alunos que se encaminhavam para a FFCL e para as Faculdades Profissionais já existentes tinham perfis sociais claramente distintos. Para estas últimas, encaminhavam-se os filhos da elite, possuidores de diplomas secundários obtidos nas melhores escolas, aqueles que saiam diretamente do secundário para a Faculdade. Alunos deste tipo são raros na FFCL. Se o objetivo da FFCL era de se constituir em uma alternativa às escolas existentes para formar "elites", se, portanto, pretendia "concorrer" com estas, os anos iniciais da vida da FFCL são anos que trazem expressos os sinais do fracasso de suas pretensões. Os filhos das elites continuaram a se encaminhar para as mesmas Faculdades que seus pais e estas Faculdades continuaram a ser responsáveis pela formação das "elites". (LIMONGI, 1988, pp. 201-202.)

Sem entrar em pormenores de sua conflituosa escalada inicial, sabemos que o primeiro impulso da Universidade de São Paulo tem a ver com o que se convencionou chamar de "missão estrangeira", composta por professores de diversas áreas do saber, em sua maioria franceses. Entre eles, Pierre Deffontaines é o escolhido por Georges Dumas, ainda em 1934, para fundar a cadeira de Geografia, sendo ajudado nessa tarefa pelo jovem Pierre Monbeig, que chega ao Brasil na segunda leva da missão, em 1935, assumindo de vez a cadeira somente em 1936, quando Deffontaines é designado para lecionar no Rio de Janeiro, para onde voltaria somente em 1938, após ter passado o ano de 1937 na França.

A bem dizer, considerando as missões de professores estrangeiros que lecionaram em São Paulo, pode-se distinguir ao menos três fases dentro dos cursos de humanidades da Faculdade de Filosofia, Ciências e Letras, que concentraram a maior parte dos de nacionalidade francesa. A primeira fase, correspondente ao ano de 1934, confere destaque àqueles que assinaram contratos curtos, de seis meses a um ano, e fundaram as primeiras cadeiras em ciências humanas, constituídas por professores de maior renome ou com cargos fixos na estrutura universitária francesa, como Étienne Borne (filosofia), Émile Coornaert (história), Paul Arbousse-Bastide (sociologia) e Pierre Deffontaines (geografia). A segunda fase, iniciada com os que vieram em 1935, conta com jovens professores em início de carreira, que buscavam se afirmar dentro de suas respectivas áreas de atuação e acabaram, por motivos diversos, permanecendo no país temporadas mais ou menos longas. Para esses, o "período brasileiro" que vivenciaram representa uma mudança de status em suas vidas intelectuais, influindo diretamente na feitura de seus trabalhos posteriores. Podem ser incluídos nessa segunda fase nomes como Claude Lévi-Strauss (sociologia), Fernand P. Braudel (história), Pierre Monbeig (geografia), Jean Magüe (filosofia) e 
alguns que chegaram em 1938 como substitutos daqueles que retornaram à Europa, como Roger Bastide (sociologia, substituindo Lévi-Strauss) e Jean Gagé (história, ocupando o lugar de Braudel). Já na terceira fase, iniciada após o término da II Guerra Mundial, temos a chegada de professores visitantes, uma vez que não se justificava mais a contratação fixa de estrangeiros, visto que a universidade se encontrava estruturada e em pleno funcionamento (PEIXOTO MASSI, 1991) ${ }^{40}$.

Mesmo com essas diferenças, a USP, a UDF e a UB podem ser consideradas os primeiros resultados práticos da nova legislação federal de organização do ensino superior em nível universitário, sendo oportuno sublinhar que essas instituições tornaram-se sólidos centros de incentivo à prática e ao desenvolvimento da produção científica nacional, o que inclui obviamente a geografia (AZEVEDO, 1976; MOTOYAMA, 2006; MACHADO, 2009). Essa breve descrição acerca do surgimento das universidades no Brasil serve como ponto de partida para que se possa indicar as ligações existentes, por um lado, entre a cadeira de Geografia da Faculdade de Filosofia, Ciências e Letras da Universidade de São Paulo e o surgimento da Associação de Geógrafos Brasileiros, e por outro, entre o curso de Geografia da Faculdade Nacional de Filosofia da Universidade do Brasil e os interesses diretos do governo federal,

\footnotetext{
${ }^{40}$ Em trabalho elaborado como parte das comemorações dos 70 anos de fundação da Universidade de São Paulo, Shozo Motoyama refaz o itinerário de arregimentação de professores europeus para a USP, relembrando, além dos já citados, outros nomes importantes desse momento inicial de estruturação do corpo docente, sendo importante notar, para o caso que nos interessa, a absoluta predominância de franceses nas cadeiras dos cursos de ciências humanas: "A tarefa de recrutar professores estrangeiros ficou a cargo do professor da Escola Politécnica, Theodoro Ramos, o primeiro diretor da recém-criada Faculdade de Filosofia, Ciências e Letras, que cumpriu com grande êxito a missão. Tratando diretamente com os governos italianos e francês, o professor Ramos conseguiu uma série de vantagens para os mestres, daqueles países, que aquiescessem em vir para o Brasil. Por exemplo, havia a garantia de que esses docentes teriam todas as vantagens e direitos de seus cargos, inclusive a remuneração e a contagem do tempo de serviço durante o período de vigência do contrato. Outro centro que forneceu grande número de docentes foi a Alemanha, em parte por causa dos graves distúrbio sociais e políticos que ocorriam naquele país na década de 1930, com o advento do nazismo. Buscou-se, sobretudo, a contratação de assistentes e jovens professores de grande potencial, capazes de desenvolver o seu talento no Brasil, fato esse que colaborou para o êxito da empreitada. Lecionaram na Faculdade de Filosofia, Ciências e Letras, nesse período: Luigi Fontappié (Análise Matemática e Geometria); Gleb Wataghin (Física Geral e Experimental); Heinrich Reinboltd (Química); Ettore Oronato (Mineralogia e Geologia); Felix Rawistscher (Botânica Geral); Ernst Breslau (Zoologia Geral); Pierre Deffontaines (Geografia); Michel Berveiller (Filologia Grega e Latina); Robert Garric (Literatura Francesa); Francesco Piccolo (Língua e Literatura Italiana); Paul Arbousse-Bastide (Sociologia); Claude Lévi-Strauss (Sociologia); Edgard Otto Gotsch (Economia Política); Francisco Rebelo Gonçalves (Filologia Portuguesa); Pierre Hourcade (Língua e Literatura Francesa); Jean Magüe (Filosofia); Pierre Monbeig (Geografia); Fernand P. Braudel (História); Ernst Marcus (Zoologia Geral); Paul Vanorden Shaw (História da Civilização Americana); François Perroux (Economia Política, Finanças e História das Doutrinas Econômicas); Luigi Galvani (Estatística); Giacomo Albanese (Geometria Projetiva e Analítica; História da Matemática); Giuseppe Ungaretti (Literatura Italiana); Georges Readers (Filologia e Literatura Latina); Ottorino de Fiore Cropani (Geologia, Paleontologia); Heinrich Hauptmann (Físico-Química); Jean Gagé (História); Roger Bastide (Sociologia); Pierre Froment (Economia Política); Atílio Venturini (Filologia Grega e Latina); Fidelino de Figueiredo (Literatura Luso-Brasileira); Alfred Bonzon (Literatura Francesa)". (MOTOYAMA, 2006, pp. 125-126.)
} 
veiculados, no caso específico desse campo disciplinar, pelas ações do Conselho Nacional de Geografia e do IBGE. Nessas circunstâncias, vale seguir o caminho sugerido por Mônica Machado (2009) e Roberto S. Almeida (2005), que compreendem que a estruturação do IBGE, órgão afinado com os interesses do governo federal, principalmente na sistematização das informações de base que poderiam ser utilizadas na elaboração das políticas territoriais demandadas pelas ações governamentais, acabou criando um nicho de atuação para os geógrafos e demais técnicos ligados ao $\mathrm{CNE}$ e ao $\mathrm{CNG}$, que garantia aos egressos dos bancos universitários uma opção por um destino profissional mais ou menos estável. Ademais, a imbricação entre os estudantes do curso de geografia e o CNG permite que enxerguemos o Conselho como um lugar de treinamento, que completava a formação universitária com suas excursões de campo, fornecendo pessoal, recursos e infraestrutura de pesquisa para estagiários e profissionais.

No caso da AGB, uma instituição privada surgida fora da capital federal, que não possuía os recursos financeiros, a estrutura material e nem o pessoal técnico especializado que autorizasse uma comparação com o CNG num patamar de igualdade - visto que não contava com a visibilidade experimentada pelo órgão geográfico do governo central -, a possibilidade de se analisar sua história (ou parte dela) em conjunto com a consolidação da FFCL da USP não deve de fato extrapolar as especificidades de cada situação institucional, que certamente revelam singularidades e diferenças. Contudo, o fato de até hoje a sede da AGB estar no prédio de geografia e história da USP, aliado à imagem que faziam dela os geógrafos paulistas, que na época a viam como a "sua" entidade de representação, permite que se estabeleçam certos laços entre a AGB e a universidade. Além disso, as publicações e os trabalhos de campo patrocinados por ela nas décadas de 1940 e 1950 fazem da Associação, quando menos, um centro de qualificação profissional, já que em suas reuniões efetuavam-se trabalhos de reconhecimento e descrição em diferentes pontos do território nacional, bem como cursos de especialização (MONTEIRO, 1980).

Analisando em detalhe o que acabamos de dizer, sabe-se que com a ida definitiva de Deffontaines para o Rio de Janeiro, em 1936, Pierre Monbeig assume a cátedra que congregava os cursos de Geografia Física e Humana. Nesse ano de 1936, ainda com a cadeira unificada, João Dias da Silveira, primeiro, e Conceição Vicente de Carvalho, pouco depois, são convidados a participar das atividades de docência como assistentes. Em 1937, Monbeig acabará desdobrando a cadeira fundada por Deffontaines. De início ainda relutante em seguir uma sugestão aventada 
por De Martonne, que viera por alguns meses a São Paulo para lecionar um curso de geomorfologia, cria a cadeira de Geografia Física, confiada em caráter interino a João Dias da Silveira, em 1938. Este teria seu contrato renovado até 1949, quando toma posse como catedrático defendendo a tese "Baixadas Litorâneas Quentes e Úmidas" (1950). Desde 1942, Elina de Oliveira Santos prestava auxílio à cadeira de Geografia Física, assumindo como primeira-assistente em 1944, mesmo ano em que Maria de Lourdes Pereira Radesca passa a exercer as funções de auxiliar de ensino. Em 1949, o então licenciado Aziz Ab'Saber aparece no relatório do Anuário decenal da FFCL (1939-1949) como técnico de laboratório ligado a essa cadeira.

Após o desdobramento da primeira cadeira em Física e Humana, foi criada, em 1942, a cadeira de Geografia do Brasil, sendo nomeado como professor interino Aroldo de Azevedo, que assume definitivamente como catedrático em 1945, após ter sido submetido a concurso público de títulos no qual apresentou a tese "Subúrbios Orientais de São Paulo". Em 1944, Aroldo de Azevedo já nomeara como seu primeiro assistente José Ribeiro de Araújo Filho, e em 1945, Antônio Rocha Penteado assume como auxiliar de ensino, ocupando o cargo deixado por Regina Carneiro. Ainda na âmbito das atividades docentes da cadeira de Geografia do Brasil, a licenciada Ely Goulart Pereira, que viria a se casar com Araújo, é nomeada assistente extranumerária em 1949. Apenas como curiosidade, no caso da cartografia, sabe-se que João Soukoup, desenhista e topógrafo nascido em Viena, que era agrimensor lotado na Procuradoria de Patrimônio Imobiliário do Estado de São Paulo e professor de cartografia no curso de geografia da Faculdade "Sedes Sapientiae" desde 1943, passa a oferecer, a partir de 1947, com um cargo de técnico de laboratório, o primeiro curso de Elementos de Cartografia da USP, sendo ele o professor responsável por essa disciplina até 1960, quando é arbitrariamente afastado de suas funções no Departamento de Geografia da USP.

A cadeira de Geografia Humana continuou atrelada a Monbeig até seu retorno a França, em 1946. Depois disso, assumiram, sucessivamente, Roger Dion (1947), Pierre Gourou (1948), Louis Papy (1950) e, de forma interina, Aroldo de Azevedo (1949), que se tornou o catedrático nominalmente responsável pela cadeira, embora tenha sido a equipe de auxiliares recrutados por Monbeig entre os alunos egressos do curso, todos com o título de doutor, conquistados ao longo da década de 1940, nos cursos de pós-graduação da própria USP, os que mais diretamente ficaram responsáveis pelas aulas. Foram eles: Maria da Conceição Vicente de Carvalho, 
doutorada em 1944, auxiliar de ensino a partir de 1937, e primeira assistente entre 1939 e 1945, quando deixa a Universidade de São Paulo; Renato da Silveira Mendes, doutorado em 1948, ocupou a função de auxiliar de ensino desde 1938; e Nice Lecocq Müller, doutorada em 1946, que exercia desde 1941 a função de auxiliar de ensino, quando ajudava nas traduções das aulas de Monbeig. Posteriormente, no início da década de 1950, Nice Lecocq Müller tornou-se primeira assistente da cadeira de Geografia Humana. Ela e Renato da Silveira Mendes continuaram exercendo suas atividades de ensino e pesquisa na cadeira de Geografia Humana ininterruptamente ao menos até 1956, quando Pasquale Petrone assume o posto de auxiliar de ensino no lugar de Renato da Silveira Mendes, então designado como professor responsável pela disciplina de Geografia Regional, criada também em 1956 - o mesmo ano, a propósito, que marca a separação definitiva dos cursos de Geografia e História em São Paulo.

O outro nome ligado à cadeira de Geografia Humana, Ary França, doutorado em 1945, foi auxiliar de ensino entre 1943 e 1946. A partir desse ano, depois que Conceição Vicente de Carvalho deixou a USP para seguir sua carreira em outras universidades, subiu de posto, e passou à condição de primeiro assistente. Em 1949, Ary França, que anos antes permanecera em Paris para uma temporada de estudos com uma bolsa do governo francês, quando chegou a trabalhar como assistente de Max Sorre e a se aproximar de um já decano Emmanuel De Martonne, toma lugar como professor interino "de fato", tornando-se um dos mais jovens catedráticos da USP após a defesa pública da tese "A Ilha de São Sebastião: Estudo de Geografia Humana", apresentada à cadeira de Geografia Humana em 1951.

Como exemplo das dificuldades de ascender profissionalmente dentro da estrutura fechada das cátedras, vejamos mais a fundo o caso de Aziz Ab'Saber. Contrapondo dois de seus depoimentos espaçados em exatos 30 anos, vemos que ele relembra de maneira diferenciada as circunstâncias de sua entrada no quadro de funcionários da USP. Num depoimento de 2007, o eminente geógrafo de São Luís do Paraitinga parece contrariado com o fato de sua entrada não ter seguido os trâmites regulares de indicação formal pelo responsável da cátedra:

Quando já tinha terminado a especialização, o professor Kenneth Caster (departamento de Geologia e Paleontologia) disse para mim: "Olha, tem uma vaga de jardineiro aqui; se você aceitar, não vai ser jardineiro, vai ser meu assistente". Eu entraria no cargo de jardineiro para poder ingressar oficialmente no quadro fechado da universidade, mas nunca cuidei de jardim nenhum (...). O salário de jardineiro era o menor possível. Três meses depois, os geógrafos do Departamento de Geografia, ao descobrirem que eu já era bacharel, licenciado e especialista e tinha sido nomeado jardineiro, acharam aquilo aviltante, brigaram 
e conseguiram me pôr como prático de laboratório. Fiquei nesse cargo de prático de laboratório até prestar exame para a livre-docência, em 1965 (...). Virei doutor (1956) e continuei prático de laboratório... para poder lecionar como doutor sendo prático de laboratório, os outros tinham que assinar os boletins e as aulas para mim. Por isso tudo, pode-se perceber o quanto foi humilhante e trabalhoso o começo de minha carreira, e economicamente difícil. (AB'SABER, 2007, pp. 73-74.)

Comparando-o com um outro depoimento, feito em 1977, mas publicado somente em 2010, pode-se perceber um tom mais ameno de Ab'Saber em relação ao caminho por ele seguido para adentrar o restrito quadro de docentes da USP, embora o fato de ele ter iniciado sua carreira acadêmica em uma posição inferior à de outros colegas continuasse a incomodá-lo. Importante notar, aqui, a deferência que Aziz demonstra ao professor Aroldo de Azevedo, que o animou "num momento de crise em que, depois de lutar por muitos anos, eu permanecia na Universidade com funções de professor, mas dentro do meu humilde cargo inicial de técnico de laboratório" (AB'SABER, 2010, p. 35). Isso é relevante, pois em documentos internos da década de 1950, Aziz aparece como auxiliar-técnico da cadeira de Geografia do Brasil, sob responsabilidade de Azevedo, e não, como seria de se esperar, como técnico ligado à cadeira de Geografia Física, cujo catedrático era João Dias da Silveira:

$\mathrm{Eu}$, que já tinha terminado o curso básico e não tinha sido nunca contactado para permanecer na Universidade, acabei entrando por mero acaso, porque o professor Caster reparou em mim. Naquele momento, muito introvertido e muito tímido como pessoa do interior, eu jamais teria coragem de me aproximar de um professor visando um lugar na Universidade, ainda que o sistema só pudesse ser esse. O sistema de cátedra, apesar de não ter sido substituído ainda por nada melhor, devia realmente estar morto desde há muito tempo, porque é muito ruim. Eu não considero que tenha sido resolvido o problema de substituição da cátedra, porque nesse caso particular, sabemos disso, os problemas são mais do homem do que do sistema (...). O Caster me disse: "Aziz, nós queríamos aproveitar você, mas não temos lugar. Acontece que existe no quadro desse Departamento um absurdo lugar de jardineiro. Se você estiver de acordo, você entraria para a Universidade contratado como jardineiro e viria trabalhar conosco. Enquanto eu estiver aqui, você exerceria realmente o papel de um orientador de alunos, de um homem que cuidasse daqui do laboratório - que na época se reduzia a uma biblioteca - e seria considerado um assistente". Embora a gente tenha seus princípios, nunca tive vaidade nesse setor. Não tive a menor dúvida e aceitei o cargo de Jardineiro. Isso causou um certo mal-estar entre os professores do grupo de Geografia, porque eles perceberam que eu, que era um elemento potencialmente razoável para ser experimentado na Universidade, acabei por ser capturado para ela através da visão de um professor norteamericano. Não agradou muito e, inclusive, no início do processo de contratação, aí pela primeira vez, outras pessoas vieram me dizer que não deveria ser esse o caminho, que poderia ser outro e tal. Porém, eu já tinha dito que sim ao professor Caster, aceitei e por alguns anos permaneci no 
Departamento de Geologia e Paleontologia. Ali, eu desenvolvi uma atividade curiosamente paradoxal: transformei-me num bibliotecário. Eu, que tinha verdadeira sede de livros numa época em que os livros estavam muito curtos para os alunos mais pobres, cuidava de catalogar, arrumar as coisas e ao mesmo tempo ler. Foi um período de muita leitura, porque foi o lugar onde, pela primeira vez, encontrei um estoque de bibliografia reunido e à minha disposição. Tornei-me um pequeno rato do setor, por muito tempo aproveitando desses livros. (AB'SABER, 2010, pp. 15-16.)

Sobre as condições da mudança de Pierre Deffontaines de São Paulo para o Rio de Janeiro, valeria transcrevermos alguns trechos de duas cartas enviadas por ele a Caio Prado Jr. quando do retorno do primeiro à França. Nessas cartas, recentemente publicadas, Deffontaines manifesta seu receio em aceitar o cargo que lhe fora proposto no Rio de Janeiro. Na primeira das que tratam diretamente da questão de sua mudança para a antiga capital federal brasileira, escrita em 2 de outubro de 1935, diz assim a certa altura:

Em relação a 1936, ainda não sei tudo o que será decidido; pediram-me para fundar, na futura universidade do Rio, o ensino de Geografia. Eu insisti que tinha começado muitas coisas em São Paulo para abandoná-las, e recusei. Insistiram muito no Ministério dos Negócios Estrangeiros, e eu aceito ir para o Rio somente com a condição de poder ficar nas duas universidades, de São Paulo e do Rio. O senhor Dumas chegou recentemente do Brasil e deve ver como a coisa pode arranjar-se. Não vi Dumas desde seu retorno, e não sei nada de preciso ainda. Mas não aceitarei voltar ao Brasil a não ser com a condição expressa de não abandonar meu trabalho em São Paulo. Acho que há muitas possibilidades de estar com vocês no próximo ano e regozijo-me profundamente. Vejo de longe tantas coisas por fazer e por fazer, e não perderia tanto tempo no início como no ano passado. (DEFFONTAINES, 2008, p. 235.)

$\mathrm{Na}$ outra carta, escrita em $1^{\circ}$ de janeiro de 1936, quando a ditadura do Estado Novo estava já em acelerada carreira de ascensão, o impasse de sua ida ou não ao Rio de Janeiro parece estar já solucionado. O mais interessante, entretanto, para além do fato de a carta ter sido censurada na prisão política de Getúlio Vargas, onde Caio Prado Jr. se encontrava, é perceber a sincera preocupação do francês com a recente prisão do amigo, que poderia comprometer as atividades

\footnotetext{
${ }^{41}$ A história de João Soukup assemelha-se, nesse pormenor, com os relatos de Ab'Saber, visto que também ele lecionou por muitos anos no Departamento de Geografia da USP numa posição subalterna de técnico de laboratório. Entretanto, ao contrário de Aziz, Soukup foi deixado de lado, saindo do Departamento de Geografia, no início dos anos 1960, por manobras regimentais, e isso a despeito de sua imensa contribuição aos geógrafos uspianos, que sempre requisitavam seus mapas nos artigos, teses e livros que escreviam. Dentre seus trabalhos mais conhecidos, está o Mapa-múndi em projeção azimutal, oblíqua e equidistante, tendo como centro a cidade de São Paulo, apresentado em 1949, os mapas e cartogramas da obra coletiva "A cidade de São Paulo", organizada por Aroldo de Azevedo (1958) e o desenho da capa do Boletim Paulista de Geografia. Informações detalhadas disponíveis em: <http://cartografiajoaosoukup.com.br> Acessado: 30/12/2012.
} 
da ainda embrionária Associação dos Geógrafos Brasileiros, é claro, mas também atrapalhar o desenvolvimento intelectual de Caio Prado Jr. Escreve Deffontaines:

Soube pelo jornal que você está preso, e estou muito inquieto sobre o futuro de sua atividade científica. Sabe que um pouco por mim é que você foi descoberto, e tenho por você uma consideração toda especial. Temo que sua atividade política venha a entravar seu trabalho científico. Sempre considero a política, qualquer que seja, um grande elemento de decadência. Assim, estou muito alarmado a seu respeito! (...) Quanto ao meu retorno ao Brasil, aqui na França insiste-se muito para que eu vá para o Rio de Janeiro. Dizem-me que tenho mentalidade de fundador, e há uma fundação a ser efetuada no Rio; em São Paulo dei o impulso, e já existe uma Geografia desenvolvendo-se bem, eu poderia ter dois empregos, e, enfim, que, uma vez assegurada a criação da cadeira de Geografia no Rio, eu poderia voltar a São Paulo. Aliás, o governo francês delega-me oficialmente para o Rio e não São Paulo. Aceitei, pois. Mas eis que os movimentos políticos colocaram tudo em questão. Acabam de me dizer, nos Negócios Estrangeiros de Paris, que a Universidade continuava, mas não estou certo disso. Você sabe as novidades antes de mim e poderia, de preferência, indicar-me o que fazer, mais do que eu mesmo dizer-lhe. De todo modo, desejo manter minha atividade na Associação dos Geógrafos, cujos primados estão em São Paulo. Irei a São Paulo tantas vezes quantas forem necessárias. Escrevi sobre o assunto a Monbeig, seja para assistir às reuniões, seja para combinar o trabalho de toda a nossa equipe que somente quer avançar. Conto muito com você especialmente (...). Não paro de fazer conferências sobre o Brasil e asseguro-lhe que não me canso. Sinto-me, neste ano, muito mais apto a apoiá-los. No primeiro ano, trouxe-lhes apenas um método, agora vejo bem melhor o que há para fazer (DEFFONTAINES, 2008, pp. 238-239.) ${ }^{42}$

A apreciação dessas correspondências deixa claro que Deffontaines estava se esforçando para continuar sua vida em São Paulo, não considerando estar fora da USP e tampouco da AGB, entidade que ele mesmo havia fundado. A partir daí, se tivermos em conta as turbulências e mútuas trocas de acusação nas quais se envolveram alguns dos membros da segunda missão francesa durante suas estadias no Brasil, sempre ávidos que estavam em discutir posições de chefia, melhores salários e flexibilidade no calendário escolar, Monbeig inclusive - que por aqui

\footnotetext{
${ }^{42}$ As datas nas quais essas cartas foram escritas ajudam a completar uma informação fornecida linhas atrás. Apoiado no trabalho de Mônica Machado, dissemos que Deffontaines lecionou no Rio de Janeiro nos anos de 1936 e de 1938, passando o ano de 1937 na França: "Na verdade, a documentação levantada indicou que Pierre Deffontaines parece ter lecionado na UDF apenas nos anos de 1936 e 1938. As correspondências mantidas entre Deffontaines e Odette Toledo apontam sua atuação no Brasil apenas nesses dois anos. Durante o ano de 1937, o francês Philippe Arbos, que chega com a missão francesa de 1937, encarrega-se do curso de geografia Humana, que era de responsabilidade de Deffontaines, o que pode ser confirmado pelo relatório de atividades do Diretor da Escola de Economia e Direito, de 1937". (MACHADO, 2009, p. 87). O documento referido por Mônica Machado realmente dá fé a essa versão: "A cadeira de Geografia Humana foi lecionada em 1936 pelo eminente professor francês Pierre Deffontaines, continuou esse ano sob a direção do Prof. Philippe Arbos. Pierre Deffontaines deu um impulso novo ao curso de Geografia Humana, não só pelas suas admiráveis lições, como pelas pesquisas e estudos que realizou com interesse invulgar pelo nosso meio e pelas nossas coisas". (PROEDES/UFRJ-UDF - Relatório do Diretor da Escola de Economia e Direito ao Reitor, 1937 apud MACHADO, 2009, p. 87).
} 
chegou a tomar providências para evitar o retorno de Deffontaines a São Paulo, mantendo sob seu controle a cátedra de Geografia da USP, que muito a contragosto desdobrou em duas em 1938 -, teremos uma imagem mais nítida acerca das ferrenhas disputas por cargos de prestígio que envolveram os estrangeiros aqui lotados como professores:

A questão do desdobramento das cadeiras foi um problema que envenenou a atmosfera da missão desde o fim de 1934 (...). Sem ter dado origem a um conflito tão violento como aquele com Braudel e Lévi-Strauss, o desdobramento da cadeira de geografia é o folhetim das primeiras missões. Deffontaines, que tinha ocupado a cadeira em 1934, se bem que vítima de uma campanha de calúnias, permanece bastante popular. E, várias vezes, os brasileiros exigem Deffontaines para criar uma segunda cadeira. Desde janeiro de 1936, ArbousseBastide nota que o retorno de Deffontaines traria um problema para Monbeig. Deffontaines é iniciador da geografia na USP, e não o continuador. É necessário então que "a independência das cadeiras no plano didático seja garantida", para que esse retorno seja aceitável para Monbeig. Felizmente, Deffontaines não voltará a São Paulo, preferirá ensinar na Universidade do Rio de Janeiro. Assim Monbeig conseguirá evitar o desdobramento de sua cadeira, às vezes desencorajando os candidatos potenciais. Ele só terá de suportar a presença de De Martonne durante dois meses em 1937. (PETITJEAN, 1996, p. 313.)

A propósito da Associação dos Geógrafos Brasileiros, a relação umbilical estabelecida entre o curso de geografia da USP e a AGB, ao menos nesses anos iniciais de existência da geografia universitária em São Paulo, ainda que não deva ser exagerada, é de fato referendada, entre outros, pelo próprio Deffontaines, que em texto escrito em 1935, no primeiro número da revista "Geografia", publicação científica organizada pela AGB, diz ter fundado esta Associação como forma de impulsionar o desenvolvimento do curso de geografia, reunindo alguns "notáveis locais" interessados no estudo das realidades do país "em redor da cadeira de Geografia da Universidade de São Paulo" (DEFFONTAINES, 1935, p.8) para fortalecer o funcionamento da cátedra e dar mais prestígio ao curso. Expressão de um ambiente propício para o amadurecimento da comunidade geográfica, a AGB teve em sua fundação decisiva participação de Deffontaines, que, conforme consta no livro de atas, reuniu, em 17 de Setembro de 1934, em sua casa, situada à avenida Angélica, número 133, em São Paulo, um grupo de intelectuais interessados em desenvolver os estudos em geografia no país. Foram eles: Luiz Flores de Moraes Rego, geólogo e professor da Escola Politécnica da USP, o bibliógrafo e futuro diretor da Biblioteca Municipal de São Paulo; Rubens Borba de Moraes; e o intelectual de orientação marxista Caio Prado Jr., pertencente a uma das famílias mais ricas, influentes e tradicionais da cidade de São Paulo.

Nesse momento inicial, sobressaem alguns aspectos curiosos: primeiro, a situação incomum de termos uma entidade profissional autônoma de caráter privado sendo fundada fora da capital 
federal; segundo, e relacionada com a anterior, a circunstância ímpar de os interesses e mesmo dos associados da nova associação ficarem praticamente restritos aos limites da realidade paulista, remetendo-se ao círculo de afinidades (BERDOULAY, 1981) políticas e intelectuais enredados com a fundação da Faculdade de Filosofia, Ciências e Letras e com o próprio funcionamento da cátedra de geografia desta faculdade. Todavia, a importância inicial da AGB não pode de maneira nenhuma ser superestimada, sendo muito ilustrativo, nesse sentido, um depoimento feito por Pasquale Petrone, em 1994. Palestrando sobre o papel da AGB na consolidação das pesquisas e do ensino de geografia no Brasil, pode-se identificar nesta fala uma típica análise anacrônica, visto que a importância da criação da AGB é referendada por aquilo que ela se tornou depois. Com efeito, nos primeiros 10 anos de sua existência, sobretudo antes da mudança dos estatutos e do processo de efetiva nacionalização da entidade, as reuniões quinzenais da AGB não logravam atrair um público muito superior a 20 pessoas, conforme o registrado nas atas originais (SEABRA, 2008), fato que revela o alcance limitado de suas discussões e resoluções, praticamente restritas ao universo dos alunos e professores do curso de geografia da USP, que formavam o grosso dos entusiastas. Veja-se o registro anacrônico de Pasquale Petrone, que apreende e reconstrói o passado com os olhos no presente:

Foi importante assim como o foi a revista Geografia a que já me referi, a primeira publicação científica significativa voltada para a Geografia no país todo. A Associação dos Geógrafos Brasileiros, fundada em São Paulo, foi a primeira entidade voltada para uma Geografia científica. Não se trata, com a afirmação acima, de menosprezar ou menoscabar o que já existia, a exemplo do Instituto Histórico e Geográfico, no Rio de Janeiro, em São Paulo, ou em outras partes do país. Mas é que as atividades dessas entidades tinham outro significado, embora freqüentemente de inegável importância, e sobre isso parece que não caibam dúvidas. Porém, dentro de uma perspectiva rigorosamente científica, a Associação dos Geógrafos Brasileiros inovou. Como organização foi pioneira, sob vários aspectos, dado que posteriormente outras entidades, voltadas para outros campos científicos, surgiram a partir do paradigma representado pela Associação dos Geógrafos Brasileiros. Parece-me importante, também, o fato de tal entidade ter surgido em São Paulo, de certa forma no bojo da Faculdade de Filosofia, e que tenha crescido sempre estreitamente vinculada à Universidade. Cabe insistir, embora autônoma, entidade particular e, portanto, não oficial, a Associação dos Geógrafos Brasileiros funcionou sempre em sintonia com a USP. Foram muitos os alunos da Universidade que tiveram a oportunidade de crescer intelectualmente frequentando a Associação. (PETRONE, 1994, p. 144.)

Por tudo isso, a prudência pede que não se assevere sem ressalvas a relevância e a abrangência da AGB naquela época como uma nova forma de organização profissional da 
comunidade geográfica, uma vez que o perfil dos primeiros associados se mostrava extremamente heterogêneo, congregando alunos matriculados no curso de geografia e história, professores de outras áreas do conhecimento e um bom número de figuras da intelectualidade paulista, num agrupamento que, grosso modo, não estava muito distante da elite francófona que anos antes animara as atividades do Groupament na cidade. Seja como for, a atuação de Monbeig como presidente da AGB, cargo que ocupou por mais de 10 anos, foi fundamental para a verdadeira nacionalização da instituição, uma vez que foi ele o principal articulador, em 1945, da reforma do estatuto que permitiu a criação das seções regionais, resolução que finalmente conseguiu reunir os dois grupos distintos então existentes no Rio de Janeiro e em São Paulo:

Atuando separadamente, mas percorrendo caminhos semelhantes, os grupos de São Paulo e Rio de Janeiro logo decidiram congregar esforços, surgindo daí a idéia de se reunirem periodicamente para discutir em conjunto aquilo que já faziam paroquialmente (...). O papel dessa AGB nacional na formação do pensamento geográfico brasileiro foi tão importante que, a partir de 1946, deixaram os geógrafos de freqüentar os congressos da antiga Sociedade Brasileira de Geografia, que passou, inclusive, a ser por eles alcunhada de 'veneranda'. E não podia ser de outra forma, já que as propostas que orientavam a AGB eram radicalmente diferentes daquelas que orientavam a ação das antigas sociedades de geografia (ABREU, 2006, p. 141.)

Após a volta de Monbeig à França, observa-se na AGB uma divisão do poder que marca uma progressiva diminuição do controle direto exercido por seu núcleo paulista, circunstância que indica de certo modo o afrouxamento dos laços que mantinha com as cadeiras de geografia da FFCL/USP, ou seja, a reforma estatutária de 1945, ainda que tenha mantido os cargos diretivos fundamentais obrigatoriamente sob o controle dos catedráticos uspianos, intencionava fornecer realmente um alcance nacional à Associação, seja pela abertura proporcionada com a alteração da estrutura organizacional da entidade, que permitia agora a fundação das seções regionais e a formação de núcleos municipais, seja também, e sobretudo, pela nova forma proposta para as assembleias ordinárias e congressos da AGB (ANTUNES, 2008), que passam a

\footnotetext{
${ }^{43}$ Cite-se aqui a parte da ata que define a mudança de estatuto da AGB, transcrita por Caio Prado Jr, seu relator, da leitura em voz alta feita por Pierre Monbeig nas reuniões ocorridas na Biblioteca Municipal de São Paulo, que definiram as alterações estatutárias: "após demorada troca de idéias entre diversos membros da associação e geógrafos do Rio de Janeiro, havia sido deliberado oferecer à casa um projeto de reforma dos Estatutos, afim de que pudesse, no futuro, a associação receber mais facilmente a colaboração dos geógrafos de outras regiões do país (...). A associação tem tido o seu campo de ação praticamente limitado à cidade de São Paulo, uma vez que os núcleos filiados não produziram os esperados resultados e que a sugestão de mais estreita colaboração, apresentada pelo grupo de geógrafos do Rio de Janeiro, abria uma oportunidade para se colocar a associação dentro de um âmbito mais largo, de modo a poder receber a colaboração de estudiosos de geografia residentes noutros pontos do país". Atas das reuniões de 21.5.1945 e de 4.6.1945. In: Iumatti et alii (2008, Anexos).
} 
ser anuais e itinerantes, dando uma nova dinâmica à entidade e permitindo que ela funcionasse como um centro de qualificação profissional para os estudantes e geógrafos recém-saídos dos bancos universitários:

Uma reunião da AGB impunha aos seus organizadores uma logística muito sofisticada, pois envolvia, além dos espaços tradicionais onde se realizavam as apresentações e os cursos especializados, a preparação de uma pesquisa de campo em alguma área do conhecimento geográfico físico ou humano, com todas as etapas possíveis que uma pesquisa requeria, isto é, equipamentos e pessoal treinado para auxiliar o pesquisador que coordenaria a pesquisa (geralmente um líder inconteste em sua área, podendo ser dos quadros do IBGE ou de alguma universidade considerada de primeiro nível). Essas eram variáveis cruciais nessa logística de preparação, e é importante lembrar que as assembléias da AGB sempre ocorriam em cidades médias e que os principais professores e pesquisadores que iriam realizar a pesquisa, na maioria dos casos não residiam lá e vinham da capital do estado (geralmente de uma universidade), da cidade do Rio de Janeiro (geralmente garantido pelo IBGE) ou da cidade de São Paulo (geralmente garantido pela USP). Após os trabalhos de pesquisa de campo as equipes reuniam-se em espaços previamente preparados para tabular os resultados, desenhar os gráficos e mapas, escrever os relatórios e treinar as apresentações orais, sob a supervisão dos chefes de equipes, que por sua vez eram supervisionados pelo coordenador geral da pesquisa. Esse tipo de treinamento proporcionava a todos uma oportunidade de aprendizado de pesquisa, mesmo aos considerados "iniciantes", que podiam assim, equalizar seus conhecimentos com os mais capazes e aprender com eles. (ALMEIDA, 2005, p. 545.)

Essas mudanças são sentidas também nas publicações organizadas pela AGB, pois enquanto a revista "Geografia" e o primeiro "Boletim da AGB" ocupavam-se basicamente de questões afeitas à realidade paulista, conforme se pode verificar pelo levantamento dos artigos e autores publicados, os “Anais da Associação de Geógrafos Brasileiros”, publicados a partir de 1946, trazem com destaque as teses apresentadas pelos associados nas reuniões nacionais, balanceando a origem dos colaboradores e apresentando os resultados dos trabalhos de campo realizados nos locais onde ocorriam as assembleias anuais da entidade, como, por exemplo, as de Goiânia (1948), Belo Horizonte (1950), Nova Friburgo (1951), Campina Grande (1952), Cuiabá (1953), Ribeirão Preto (1954), Garunhus (1955) e Colatina (1957), que resultaram em proveitosos relatórios de campo, exemplos acabados do treinamento acadêmico que essa geração de geógrafos obtinha diretamente no terreno. Além do mais, deve ainda ser notada uma certa correspondência entre a data que marca o início da nacionalização da AGB, o final de 1945, e a data de criação do Departamento de Geografia da FFCL/USP, que é fundado como órgão separado da subseção de Geografia e História em 4 de Junho de 1946, pois essa distinção formal 
parece corroborar a leitura de que houve um relativo enfraquecimento dos laços institucionais existente desde o início entre as cadeiras de geografia da USP e a AGB, o que denota um certo amadurecimento organizacional da geografia universitária paulista e a consolidação da AGB como entidade profissional de classe, muito embora os geógrafos uspianos, como já se disse, nunca tenham deixado de influenciar a AGB, percebendo o periódico editado por sua seção local, o "Boletim Paulista de Geografia", como mera continuidade das publicações anteriores da $\mathrm{AGB}^{44}$.

No Rio de Janeiro, a criação do curso de geografia da Faculdade Nacional de Filosofia (FNFi), herdeiro daquele vinculado à Escola de Economia e Direito da antiga UDF - porquanto não só alunos e professores, mas até mesmo suas instalações físicas são encampadas pela Universidade do Brasil -, integra o debate sobre o surgimento de um modelo-padrão de organização universitária, não se desprendendo da disputa pelo controle da educação entre intelectuais católicos e liberais, como se nota na montagem do corpo docente da nova universidade, que privilegiou em sua composição intelectuais partícipes do bloco de sustentação do Estado Novo e comprometidos com os desígnios do governo central, o que permitia um trânsito fácil entre governo e universidade. Em seu primeiros seis anos de existência (1939-1945), a FNFi assistiu à criação de inúmeros laboratórios e museus, com o curso de geografia, acoplado ao de história, sendo lotado na Seção de Ciências:

A FNFi foi criada nos moldes da UDF e mantinha os mesmos objetivos: preparar trabalhadores intelectuais para o exercício das altas atividades da cultura desinteressada e técnica, preparar professores do ensino secundário ou normal e realizar pesquisas nos vários domínios da cultura. Entretanto, diferente de sua antecessora, ela nasceria diretamente sob a tutela federal e sob o estrito controle doutrinário da Igreja Católica (...) as interferências dos grupos católicos

\footnotetext{
${ }^{44}$ Sobre os eventos que tiveram influência na vida do Departamento de Geografia, criado como instrumento de coordenação do funcionamento das cátedras, completa Pasquale Petrone: "O primeiro refere-se à fundação, ainda no ano de 1934, e a partir da iniciativa do Prof. Pierre Deffontaines, da Associação dos Geógrafos Brasileiros que, e o fato é sugestivo pela praticamente coincidência de datas, em 1945 adquiriu âmbito nacional. As relações entre o Departamento de Geografia e a Associação dos Geógrafos Brasileiros foram tão estreitas que, sob certos aspectos, em determinados momentos, suas existências, e atividades, praticamente chegam a confundir-se. No momento, o que parece mais importante é considerar que determinados aspectos da vida do departamento de Geografia não podem ser compreendidos sem que se compreenda o papel da Associação dos Geógrafos Brasileiros nas atividades dos seus docentes. Tão somente à guisa de exemplo, cabe citar o fato de que, afora a participação de docentes seus na série de 'Boletins da Faculdade de Filosofia, Ciências e Letras', o Departamento de Geografia não se empenhou em editar uma publicação sua, no âmbito da Faculdade, na medida em que a solução para a divulgação da sua produção foi encontrada nas publicações da Associação dos Geógrafos Brasileiros. Dessa forma, uma parte não descurável da produção do Departamento de Geografia pode ser encontrada na revista 'Geografia', no 'Boletim da Associação dos Geógrafos Brasileiros', no 'Boletim Paulista de Geografia', nos 'Anais da Associação dos Geógrafos Brasileiros’ ou, ainda, nos ‘Avulsos’ da mesma Associação”. (PETRONE, 1982, p. 9.)
} 
e também dos grupos conservadores tanto na constituição da FNFi como nos seus anos iniciais de funcionamento foram significativas, o que pode ser percebido a partir da montagem de seu corpo docente. Para a contratação dos professores franceses foi novamente solicitada a colaboração de Georges Dumas, que apóia a extinção da UDF em carta à Capanema, posteriormente utilizada pelo próprio ministro em resposta às críticas que recebeu da intelectualidade liberal do país (...). Todos os contratos de professores, estrangeiros ou não, eram feitos diretamente pelo Ministério da Educação. Assim, outras injunções políticas, além das pressões da Igreja, interviera nas contratações, principalmente com relação aos brasileiros. Como as influências e pressões advinham de todos os lados, a montagem da FNFi acabou envolvendo diversificados acordos: conciliar os vários pretendentes às cátedras com padrinhos e indicações variadas, agregar os pleitos advindos de professores que já ocupavam as cadeiras da UDF e harmonizar candidatos nacionais com os indicados pela embaixada francesa e pelo professor Georges Dumas, vencendo as barreiras contra os professores estrangeiros. Esse quebra-cabeça foi montado com as peças existentes à época. Entretanto, segundo a literatura sobre a estruturação da FNFi, os pensadores católicos, especialmente Amoroso Lima, e os integralistas foram os eixos centrais da implantação desse projeto universitário e tiveram papel e postos fundamentais na Faculdade. (MACHADO, 2009, pp. 99-100.)

A proximidade com o centro do poder, e as interferências diretas que os educadores mais próximos do regime varguista exerciam no curso de geografia e história da Universidade do Brasil, estabeleceram uma visão de geografia que a deixava mais próxima das estratégias governamentais, valorizando diretamente a pesquisa, concepção um tanto quanto diferenciada daquela desenvolvida em São Paulo, onde a visão pedagógica da geografia, mui bem representada pela figura e obra de Aroldo de Azevedo, era definitivamente dominante. A própria estruturação do corpo docente parece mostrar essa diferenciação, pois ainda que muitos estrangeiros tenham lecionado no curso de geografia e história da Universidade do Brasil, como André Gibert (1939-1940), Francis Ruellan (1941-1956), Pierre Danserau (1946), Preston James (1949) e Carl Troll (1953 e 1956), para citarmos apenas alguns, o grupo de professores ocupados com o curso, como de resto na Universidade do Brasil como um todo, tinha um perfil diferenciado daquele arregimentado pela USP, até por conta da interferência direta do Ministério da Educação na organização do pessoal, que deixava evidente um contorno mais afeito à composição de forças que possibilitara a consolidação do Estado Novo, e alinhava o curso com os projetos do governo federal. Assim, avulta a quantidade e a maior influência de intelectuais brasileiros no comando das cátedras, normalmente nomes consagrados no ambiente científico nacional que gozavam de grande prestígio no aparelho estatal, como Victor Leuzinger (catedrático de Geografia Física entre 1940 e 1966), Hilgard O’Reilly Sternberg (catedrático de 
Geografia do Brasil de 1944 a 1964) e Josué de Castro (cadeira de Geografia Humana entre 1940 e 1955), além de Hélio Viana, Arthur Ramos e Carlos Delgado de Carvalho, mais ligados ao curso de história $^{45}$.

A centralização autoritária operada na época aponta também para a estabilização de uma geografia universitária como ação de interesse prioritário para o governo federal, pois permitiria tanto a ampliação do conhecimento sobre as potencialidades do território por meio da elaboração de um discurso descritivo e mensurável acerca das possibilidades de sua exploração, que era uma necessidade e uma meta a ser alcançada, como também a constituição, em parte e em moldes controlados, da identidade nacional, objetivos amplos que requeriam profissionais aptos a atuar em duas frentes, quais sejam, o ensino secundário e superior e os serviços de perfil mais tecnoburocrático dos novos postos públicos surgidos com a modernização institucional dos anos 1930:

$\mathrm{Na}$ realidade, o projeto do governo federal consubstanciava-se na implementação do centralismo nacional, ou seja, de um projeto centralista para a nação, do qual o Rio de Janeiro, através de suas instituições públicas, seria o mais importante pólo difusor. Em contrapartida estava o projeto paulista, sustentado no federalismo oligárquico e, portanto, no seu fortalecimento regional, estadual, e na idéia de estabelecimento de um diálogo permanente com o mundo, um projeto que parece ter sido levado à frente pela USP, que busca defender internacionalmente sua marca de excelência. (MACHADO, 2009, p. 107.)

\footnotetext{
${ }^{45}$ Embora enxergue certa semelhança no fato de ambas as universidades terem alguns de seus professores arregimentados em missões de estrangeiros, Fernanda Peixoto Massi vislumbra uma diferença: "É interessante pensarmos, a título de comparação, a situação carioca. A Faculdade Nacional de Filosofia é criada em 1939, seguindo de perto a experiência paulista. E Dumas, mais uma vez, o intermediário na contratação de professores franceses. A diferença é que no Rio de Janeiro este convite foi realizado por vias oficiais, com autorização direta de Vargas. Além disso, um requisito básico é exigido dos novos professores: que sejam ligados à Igreja". (PEIXOTO MASSI, 1991, pp. 36-37). Algumas cartas e outros documentos citados por Simon Schwartzman (2000) em seu estudo sobre a atuação de Gustavo Capanema no Ministério da Educação, durante o governo Vargas, reforça a afirmação de que a contratação dos professores para o Rio de Janeiro contrastava com a via experimentada em São Paulo, que não sofreu influências diretas do governo central. Em carta escrita a Getúlio Vargas em 10 de abril de 1939. Capanema dá explicações detalhadas acerca das necessidades de criação da Faculdade Nacional de Filosofia, escrevendo a certa altura: "Estou dando os passos necessários à abertura das aulas da Faculdade Nacional de Filosofia no dia $1^{\mathrm{O}}$ de maio. Podemos obter, no meio nacional, professores para grande número de cadeiras. Outras, porém, umas 15 talvez, só poderão ser regidas bem por professores estrangeiros". (CAPANEMA, 2000, p. 349). Numa outra carta, escrita por Capanema a Georges Dumas, em 17 de junho de 1939, após a aprovação da contratação dos professores estrangeiros por Vargas, fica claro o controle doutrinário católico exigido para a investidura nos cargos da universidade. Diz o ministro: "desejo professores habituados à pesquisa e de estudos bem orientados, mas ligados à Igreja. A faculdade vai ficar sob a direção do Sr. Alceu Amoroso Lima, católico, amigo de Jacques Maritain. Daí não encontrar eu boa acolhida para nomes que sejam conhecidos por suas tendências opostas à Igreja ou dela divergentes". (Ibidem, p. 232). Durante a negociação, as respostas dadas pela embaixada francesa no Brasil esclareciam as orientações dos professores propostos, lembrando, por exemplo, que Jacques Lambert, candidato à cadeira de sociologia no Rio de Janeiro, era um católico tão militante quanto Robert Garric e Pierre Deffontaines, os dois únicos, aliás, a terem lecionado em São Paulo e no Rio de Janeiro (SCHWARTZMAN et al., 2000).
} 
De mais a mais, a condição histórica de o Rio de Janeiro ser a capital fornecia uma proximidade com o centro do poder que, possibilitando uma ligação mais direta entre o Estado e os intelectuais, não pode ser desprezada, já que facilitava o acesso a recursos financeiros para viagens de campo e excursões de pesquisa, ambas fundamentais para o desenvolvimento de um projeto epistemológico mais afeito a um perfil técnico, o que se percebe sobretudo na atuação de Francis Ruellan, que aproxima definitivamente os estudantes de geografia da Universidade do Brasil do CNG/IBGE, criando uma espécie de espaço de reserva profissional até então inexistente para a carreira de geógrafo no Brasil ${ }^{46}$. Entretanto, não se deve esquecer que essa mesma proximidade poderia dificultar a liberdade intelectual e a proliferação de visões apartadas do consenso oficial, isto é, politicamente independentes.

Duas situações exemplificam o acima afirmado. Primeira, a atuação de professores temporários que ocupavam cargos de relevo dentro da estrutura do CNG, sendo reconhecidos por suas qualidades intelectuais no âmbito técnico e acadêmico nacional, como Christovam Leite de Castro, secretário-geral do CNG que ministrou o curso de cartografia entre 1947 e 1950, Jorge Zarur, que lecionou cursos de geografia regional e de cartografia entre 1951 e 1955, e Fábio de Macedo Soares Guimarães, que deu cursos de geografia física, em 1948, e de geografia regional americana, em 1949. Segunda, nomes como os de Hilgard O'Reilly Sternberg e Victor Leuzinger, que angariavam um grande capital de relações políticas, se destacando por sua atuação dentro da universidade, caracterizada sobretudo pelo desenvolvimento de um trabalho de consolidação do curso que é importante do ponto de vista institucional e administrativo. De fato, Sternberg e Leuzinger foram os principais atores a garantir o intercâmbio entre o curso de geografia e o CNG, o que acabou também por incentivar o estabelecimento de uma aproximação com a geografia dos Estados Unidos, destino preferencial dos geógrafos cariocas que buscavam continuar seus

\footnotetext{
${ }^{46} \mathrm{O}$ itinerário profissional de Ruellan encaixa-se no perfil requerido pelos órgãos subvencionados do governo francês para desenvolver uma política cultural que captasse a América Latina para a esfera de influência de Paris. Sua condição de adido militar, aliás, deixa ainda mais claro o cariz geopolítico de tais ações do governo francês nos campos científico e universitário, evidenciando as imbricações entre a política e a cultura: "Francis Ruellan (18941975), geógrafo francês especializado em geomorfologia, trabalhou no Rio de Janeiro entre 1940 e 1956, e esteve fortemente vinculado à Universidade do Brasil e ao IBGE. Quando veio ao Brasil, sua carreira profissional já parecia estar consolidada na Universidade de Paris, onde, sob forte influência de Emmanuel de Martonne, atou como mestre de conferências e como diretor adjunto da Escola de Geografia e do Instituto de Geografia da Universidade. Sua vinda se deu em função de participações em várias missões técnicas na Ásia e América do Norte. Em 1940 é enviado da França pra o Rio de Janeiro como adido militar, ficando encarregado das relações militares entre França, América do Sul e Caribe. Em consequência da Segunda Guerra e da invasão alemã na França, foi desmobilizado pelo Exército, em 1941, aceitando o cargo de consultor técnico do Conselho Nacional de Geografia e de professor de Geografia da Faculdade de Filosofia". (MACHADO, 2009, p. 132.)
} 
estudos em nível de pós-graduação (ADAS, 2006; ALMEIDA, 2000). Sobre o caso de Sternberg, é importante ainda citar que foi ele o artífice da organização, em 1952, do Centro de Pesquisas de Geografia do Brasil, o CPGB, órgão de pesquisa anexo à cadeira de Geografia do Brasil que contava com financiamento da Fundação Rockfeller e foi um dos primeiros centros de pesquisa geográfica organizados em âmbito universitário no Brasil:

A primeira e segunda gerações de geógrafos formados no Rio de Janeiro acabaram preenchendo a lacuna criada pela demanda no país de professores do ensino médio, aliás, um dos motivos de implantação das faculdades de Filosofia no Brasil e também de técnicos dos novos órgãos de planejamento estatal. O preenchimento do quadro de técnicos do IBGE é, nesse sentido, bastante revelador. Ao se observar a procedência dos geógrafos "ibegeanos" dos anos 1940 e 1950, é possível perceber que a maior parte deles era oriunda da UDF e da Universidade do Brasil. A contratação de professores franceses que, no caso particular do Rio de Janeiro, atuavam ao mesmo tempo como professores universitários e como principais consultores das pesquisas geográficas no IBGE veio facilitar essa mesclagem institucional e a configuração do campo científico da Geografia brasileira. (MACHADO, 2009, p. 133.)

As teias de relações pessoais e a necessidade de uma remodelação territorial do país, que acompanha a mobilização de capacidades técnicas e humanas na construção de um governo centralizado, formam o contexto que viabilizou a institucionalização universitário-acadêmica da geografia brasileira. Nesse sentido, a imbricação de interesses e as inter-relações que se estabelecem entre as novas instituições ficam claras, por exemplo, na atuação de Deffontaines e Monbeig na formação do CNG, uma vez que eles encaminham ao Ministério de Relações Exteriores, após reunião da AGB, em 19 de outubro de 1936, a sugestão da criação de um órgão nacional de geografia, aumentando o ambiente favorável para a institucionalização definitiva de um órgão federal com esses propósitos, de vez que a existência de uma instituição oficial de geografia era uma das condições impostas por Emmanuel de Martonne para a aceitação do país nos quadros da União Geográfica Internacional (UGI), que ele então presidia.

Contudo, não seria correto dimensionar superlativamente as gestões dos dois professores franceses na organização do CNG e na aceitação do país na UGI, conferindo a suas ações um lugar que de fato não ocupam, já que o primeiro contato oficial de um órgão geográfico brasileiro com a UGI remonta ao ano de 1931, quando Alberto José Sampaio, membro da SGRJ e da Academia Brasileira de Ciências ( $\mathrm{ABC}$ ), que anos antes havia integrado a Comissão Rondon, vai a Paris participar do Congresso Internacional de Geografia promovido pela entidade. Sua atuação chama a atenção de Emmanuel de Martonne, o incansável animador de redes internacionais de 
trocas intelectuais ao longo das décadas de 1920 e 1930 (DELFOSSE, 2001), que tomava suas providências, é claro, para que estas redes internacionais funcionassem sob a influência do pensamento geográfico francês (ROBIC, 1996). Com efeito, após esse contato de Sampaio, o grande geógrafo francês visitou o Brasil, em 1933, proferindo uma palestra conjunta que reuniu a SGRJ, o IHGB e a Academia Brasileira de Ciências (ABC) num evento que deu novo sopro aos debates internos que buscavam garantir as condições necessárias para o país ingressar na UGI:

A criação de um comitê instituído por essas instituições, revelou-se ao longo do ano de 1934 uma tarefa muito além da capacidade administrativa e financeira desse grupo. O memorial de 29/12/1934 apresentado pela Academia Brasileira de Ciências ao então Ministro da Agricultura Odilon Braga, indica que os serviços estatísticos e geográficos desenvolvidos no ministério (Diretoria de Estatística da Produção) encaixam-se perfeitamente nas atividades da nova ciência geográfica. Percebendo ali um excelente ponto de iniciação de um órgão governamental que poderia, no futuro, tornar-se uma instituição responsável pela Geografia brasileira. Esta percepção por parte dessas instituições estava vinculada ao entendimento de que o planejamento territorial (cartografação e normatização das divisões territoriais entre Estados e Municípios) seria uma das principais atribuições de um órgão nacional de Geografia, que necessariamente teria de pertencer ao governo central. Foi neste contexto que as anteriores articulações dos ministros Juarez Távora e Francisco Campos com Mário Augusto Teixeira de Freitas, iniciadas em 1931 e ampliadas em 1933, no sentido de organizar um instituto de estatística em escala nacional, estavam paralelamente tomando forma através do decreto 24.609 de $06 / 07 / 1934$, que definia a criação do Instituto Nacional de Estatística, processo longo e complexo que somente torna-se realidade em 29 de maio de 1936 com sua instalação solene no Palácio do Catete. Nada mais conveniente portanto, do que a agregação dos serviços geográficos/cartográficos ao novo instituto, que teria ramificações espaciais até a escala municipal. Mas, para que isto acontecesse, seria necessário formar profissionais especializados através de cursos superiores de Geografia. (ALMEIDA, 2000, pp. 77-78.)

Sendo assim, pode-se inferir que o início das relações do Brasil com a UGI é parte não negligenciável na criação do CNG. Portanto, se o fato de o país ser aceito numa associação profissional de renome internacional animou o movimento de renovação pelo qual passava a geografia, que dava passos largos em direção a sua institucionalização universitária e acadêmica, a mediação de associações culturais consagradas que há tempos estavam envolvidas com a prática e a difusão dos saberes geográficos, como a SGRJ, a ABC e o IHGB, mostra com segurança que o contorno institucional assumido após a criação das universidades veio coroar esforços mais antigos na defesa do campo disciplinar, buscando auxílio em experiências anteriores: 
A implementação de políticas públicas que buscavam articular iniciativas científicas com a conformação de uma cultura política, na qual a temática do território nacional, a exploração racional dos seus recursos naturais e sua ocupação ordenada ganhariam um espaço singular. Isto redundou naquilo que decidimos denominar de "cultura geográfica", ou seja, um conjunto de ações sistemáticas com o objetivo de utilizar o conhecimento geográfico para subsidiar ações governamentais. Na esteira das reflexões de Ângela de Castro Gomes, é possível inferir que ao lado da sua dimensão temporal, própria de uma "cultura histórica", uma sociedade também se empenha em definir o espaço físico que ocupa. Isto enseja o surgimento de uma "cultura geográfica", por assim dizer, capaz de estabelecer vínculos entre os indivíduos e o território pátrio. É evidente que para desenvolver essa "cultura geográfica" não se fez tabula rasa do passado (...). Estabeleceu-se, assim, uma espécie de via de mão dupla entre os órgãos federais que reconheciam a contribuição do tradicional reduto, recebendo em troca apoio e colaboração na implementação dos seus programas de trabalho. Não houve, portanto, inicialmente, um conflito de interesses entre a "associação de diletantes" e os organismos que seriam criados ao longo aos anos 1930, ou querelas, uma vez que o sistema geográfico instituído em 1938 integrava antigos e modernos. No desenvolvimento dessa "cultura geográfica", a experiência da Sociedade seria valorizada e seus associados desempenhariam papéis de primeira grandeza. (CARDOSO, 2009, pp. 8-9.)

De fato, a possibilidade de se filiar à UGI já aparecia nas primeiras resoluções tomadas em assembleia após o decreto que, em 1937, criou o Conselho Brasileiro de Geografia, integrando-o ao Instituto Nacional de Estatísticas (INE). Tal decreto regulamentava, entre as atividades do Conselho, a função de coordenação e de sistematização das atividades geográficas desenvolvidas no país por instituições particulares ou profissionais. Por conseguinte, as tarefas centralizadoras atribuídas ao Conselho de Geografia em sua Resolução ${ }^{\circ} 22$, de 18 de julho de 1938, vieram a instituir o sistema geográfico nacional, do qual seriam integrantes a Sociedade de Geografia do Rio de Janeiro, o Instituto Histórico e Geográfico Brasileiro, a Academia Brasileira de Ciências, o Clube de Engenharia e a Associação dos Geógrafos Brasileiros, com a adesão de representantes do Exército e da Marinha. Interpreta-se essa centralização administrativa do chamado "movimento geográfico nacional" como um desdobramento do contexto de criação do CNG, e circunstância que dá base à afirmação de que as novas instituições profissionais de geógrafos remetiam-se às experiências anteriores como forma de consolidar uma tradição para o campo disciplinar. A propósito, assim se expressava o secretário-geral Christovam Leite de Castro no relatório que descreve as principais decisões e acontecimentos da Assembleia Geral do CNG realizada entre os dias 1 e 20 de julho de 1938:

... predestinada a uma perpetuação gloriosa, esta Assembéia assistiu ao desenrolar deslumbrante da integração do Conselho Nacional de Geografia, como sistema nacional de articulação das atividades geográficas brasileiras. 
Quatro fatos importantíssimos dizem dessa integração. O primeiro fato foi o ingresso no nosso Conselho da representação militar: o Exército e a Marinha, vigilantes defensores de nossa Pátria, identificaram-se com os objetivos do Conselho; fato caríssimo a todos nós, porque pelas gloriosas tradições geográficas militares, a essas duas instituições nacionais compete um lugar de destaque em todo e qualquer movimento que, no país, se faça em proveito de seu conhecimento territorial (...). Finalmente, Senhores, o quarto fato. Um acontecimento singular na história cultural brasileira, ocorrido na me- morável tarde do dia 19 de Julho de 1938: a Assembléia Geral do Conselho Nacional de Geografia em reunião especial recebeu, solenemente, a incorporação das magnas instituições culturais do País. Repito os artigos da Resolução $\mathrm{n}^{\mathrm{O}} .22$ da Assembléia, que bem exprimem o significado da efeméride: Art. $1^{\circ}$. - Fica aprovada e enaltecida, com aplausos calorosos, a integração no sistema geográfico do Instituto Brasileiro de Geografia e Estatística do Instituto Histórico e Geográfico Brasileiro, da Sociedade de Geografia do Rio de Janeiro, da Academia Brasileira de Ciências, do Clube de Engenharia e da Associação dos Geógrafos Brasileiros. (CASTRO, 1939, pp. 121-122.)

No número inaugural da Revista Brasileira de Geografia, lançado em 1939, há um artigo sem autoria definida - supõe-se ser do mesmo Leite de Castro - que conta o histórico de criação do Conselho Nacional de Geografia. Num tom explicitamente laudatório, que enxergava a organização do órgão como resultado de uma verdadeira missão patriótica, fica claro que a criação do CNG respondeu a estímulos de duas ordens: de um lado, às iniciativas em torno da adesão do Brasil à UGI, e de outro lado, aos esforços em torno da necessidade de criação de um organismo que centralizasse a coordenação das atividades geográficas do país. No relato, não foram esquecidas as gestões efetuadas por diversos atores, como o papel mediador da $\mathrm{ABC}$, que tentou organizar um comitê que permitisse a adesão do Brasil logo após a palestra ali proferida por De Martonne, em 1933, os esforços dos professores franceses, que "reforçando os convites anteriores, insistiram sobre o assunto, sendo de destacar as solicitações formuladas em 1936 pelo eminente geógrafo P. Deffontaines e pelo professor Pierre Monbeig junto ao Ministério das Relações exteriores do Brasil” (RBG, 1939, p. 10), e o processo de centralização das informações estatísticas tentado desde o início da década de 1930, que finalmente unificou:

As duas correntes de iniciativas para a criação de um órgão oficial de Geografia, uma relacionada com as atividades internacionais, a outra preocupada com a coordenação das atividades nacionais, ao fim encontraram-se. Isto em outubro de 1936. Era Ministro das Relações Exteriores o eminente brasileiro José Carlos Macedo Soares, também presidente do Instituto Nacional de Estatística: como Chanceler, chegavam-lhe as solicitações partidas das maiores autoridades mundiais de geografia, dizendo da indispensável colaboração cultural do Brasil, país geograficamente interessantíssimo, no concerto da geografia internacional; como presidente do Instituto, avivavam-se-lhe os apelos no sentido de ser cuidada a geografa nacional, cujos problemas, tão ligados à estatística, 
precisavam ser tratados por um organismo nacional, congregador das energias geográficas brasileiras, em uma patriótica somação de esforços. (RBG, 1939, p. 14. $)^{47}$

Nessa direção, a ação de Leite de Castro exemplifica as estratégias pessoais e institucionais de criar novos lugares para a produção e difusão da geografia no Brasil. Engenheiro de formação e integrante da seção de Estatística Territorial do Ministério da Agricultura, que em 1934 teve sua base transferida para a criação do Instituto Nacional de Estatística, (ALMEIDA, 2000; PENHA, 1993; SENRA, 2008), sua presença como aluno da primeira turma do curso de geografia da UDF, em 1935, coloca-o lado a lado com outros nomes que futuramente angariariam enorme prestígio na comunidade geográfica nacional, como os já citados Jorge Zarur, Fábio de Macedo Soares Guimarães e Orlando Valverde. O último, aliás, que sempre afirmou ter sido o primeiro geógrafo profissional oficialmente contratado pelo IBGE, expresaria até o fim da vida profunda gratidão a Christovam Leite de Castro, por ter sido ele o principal responsável por sua entrada no CNG (ADAS, 2006).

No caso da USP, o corpo de alunos era completamente diferente, sendo formado tanto por filhos de uma elite oligárquica bem ou mal empobrecida, que viam na carreira acadêmica uma possibilidade de manutenção de seus status no meio social, quanto pelos descendentes da nova burguesia urbana, que acreditavam ser possível manter a nova posição através dos estudos. O fato novo no caso paulista, conforme o aventado, diz respeito não só às mulheres vindas da escola normal, mas também aos filhos dos muitos imigrantes estabelecidos na capital paulista (BLAY e LANG, 2004). Para esses, o horizonte das profissões de cariz técnico do CNG, que facultava a

\footnotetext{
${ }^{47}$ No Decreto Federal $\mathrm{n}^{\mathrm{O}} 1.527$, de 24 de março de 1937, que regulamentou as atribuições do novo Conselho de Geografia, pode-se observar o papel central a ser ocupado pelo CNG dentro do edifício institucional que então se erigia para a geografia: "Fica instituído o Conselho Brasileiro de Geografia, incorporado ao Instituto Nacional de Estatística e destinado a reunir e coordenar, com a colaboração do Ministério da Educação e Saúde, os estudos sobre a Geografia do Brasil, e a promover a articulação dos Serviços Oficiais (federais, estaduais e municipais), instituições particulares e dos profissionais que se ocupem da Geografia do Brasil, no sentido de ativar uma cooperação geral para um conhecimento melhor e sistematizado do território pátrio". (RBG, 1939, p. 16). Expressivamente, a Resolução ${ }^{\circ} 6$ da Assembleia Geral do Conselho de Geografia, de 13 de julho de 1937, que ratificou o apoio integral à modificação de nome proposta para o Instituto Nacional de Estatística, doravante Instituto Brasileiro de Geografia e Estatísticas, deixa evidente as duas missões que incidiram no processo de criação do CNG: "Considerando que a estrutura do Conselho Brasileiro de Geografia é análoga à do Conselho Nacional de Estatística, de tal forma que estes dois Conselhos constituem como que metades simétricas, em que se decompõe o Instituto Nacional de Estatística; Considerando que, presentemente, o Instituto tem que preencher duas altas missões equivalentes, uma, a coordenação das atividades estatísticas brasileiras, outra, a das geográficas, enfeixando-se ambas no sentido comum do conhecimento da terra e do homem do Brasil; Considerando que, nestas condições, a atual designação do Instituto não satisfaz, por não revelar a sua dupla finalidade; Considerando que o Conselho Brasileiro de Geografia está autorizado a aderir à União Geográfica Internacional e que para as relações internacionais e geográficas a designação 'brasileiro' melhor convém que a 'nacional'". (CNG apud SENRA, 2008, p. 94.)
} 
participação em projetos e políticas territoriais do governo federal, estava bem distante, e não representava uma opção viável de carreira, que ficaria restrita ao magistério secundário ou superior. Como quer que seja, a ação de Monbeig, que chamava para si e seu grupo a responsabilidade pela produção e difusão de um discurso geográfico construído a partir das premissas da ciência moderna, afasta-se sensivelmente da iniciativa erigida no Rio de Janeiro, donde a conveniência de uma análise comparativa dos primeiros centros superiores da geografia universitária brasileira. De fato, a meta paulista permaneceria claramente ancorada no ensino mesmo depois da volta de Monbeig à França, quando então Aroldo de Azevedo, autor de uma obra didática que se projetou por décadas como referência no ensino da disciplina, exercendo domínio absoluto no mercado escolar (VESSENTINI, 1992; VLACH, 1988), assume uma posição de destaque na FFCL/USP ${ }^{48}$.

Embalado pelo verdadeiro boom no mercado cultural que as mudanças estruturais pelas quais passava o país impulsionaram como nunca a partir da década de 1930 e 1940 (CANDIDO, 1989), a extensão dos circuitos de comercialização de livros provocou um surto editorial marcado pelo estabelecimento de várias editoras e pelas decorrentes especializações, que resultaram na criação de uma hierarquia entre gêneros literários, classificação organizada a reboque da extensão cada vez maior do contingente de leitores (MICELI, 2001). Nessa realidade, mesmo sofrendo com as seguidas reformas educacionais que constantemente redefiniam o programa oficial, os livros didáticos de autores de renome tornaram-se um nicho de mercado de certeiro sucesso. Essa espécie de direcionamento pedagógico conferido à geografia paulista por Aroldo de Azevedo fica mais clara quando se sabe que, entre 1934 e 1960, ele escreveu 20 obras que atingiram a marca

\footnotetext{
${ }^{48}$ Para José William Vessentini, a função básica da geografia escolar seria a de assegurar a consolidação da identidade nacional tal como projetada a partir do viés estatal: "Difundir uma ideologia patriótica e nacionalista: eis o escopo fundamental da geografia escolar. Inculcar a idéia de que a forma Estado-nação é natural e eterna; apagar da memória coletiva as formas anteriores de organização espacial da(s) sociedade(s), tais como as cidades-estado, os feudos, etc.; enaltecer o 'nosso' Estado-nação (ou 'país', termo mais ligado ao território e menos à história), destacando sua potencialidade, sua originalidade, o 'futuro' glorioso que o espera (...). Dessa forma, a instituição escola e a 'geografia dos professores' (aquela parte da geografia moderna adaptada ao ensino elementar e médio) foram e são interligadas desde o século XIX. O discurso geográfico desempenhou um importante papel na difusão do imaginário nacional de cada Estado-nação e, inversamente, o lugar que lhe foi reservado no sistema escolar influenciou enormemente a evolução da geografia moderna. Basta lembrar, por exemplo, o peso que exerceram Vidal de La Blache e Aroldo de Azevedo nos rumos seguidos pela geografia acadêmica na França e no Brasil. Esses dois geógrafos, em que pesem suas diferenças, tiveram algo importante em comum: ambos começaram como autores de livros didáticos para o ensino elementar e transmitiram aí uma visão da geografia como 'discurso da Pátria' que, com poucas alterações, foi o paradigma que se tornou hegemônico durante décadas" (VESSENTINI, 1992, pp. 1112.) Sobre a "doutrinação patriótica", ver o estudo de Marcelo Escolar (1996).
} 
de mais de 11 milhões de livros impressos e comercializados ${ }^{49}$. Entretanto, deve ser sempre lembrado que sua obra é prenhe de posições questionáveis a respeito da diversidade étnica e social da população brasileira, não hesitando em se utilizar abertamente de explicações racialistas e de se valer de modelos naturalistas no tratamento de fenômenos humanos, entre muitos outros pontos passíveis de questionamento. Ademais, saliente-se também que seus livros didáticos representam um evidente empobrecimento teórico quando comparados com a matriz francesa que lhe serviu de inspiração, primando em muitos casos pela descrição pura e simples e deixando de lado a decisiva etapa da interpretação dos fenômenos observados e localizados cartograficamente no terreno.

Por outro lado, caberia ainda notar as diferenças no que diz respeito ao alcance das pesquisas empreendidas em cada um dos centros, pois enquanto o grupo uspiano raramente ultrapassava os limites de São Paulo, preocupando-se com questões mais afeitas à realidade paulista, como as propostas de uma nova regionalização para o estado, a rápida urbanização da capital e as movimentações pioneiras no planalto ocidental, os geógrafos do CNG tinham estrutura, pessoal e verbas disponíveis para desenvolver seus trabalhos de campo pelas mais variadas regiões do país, a depender da necessidade ou do interesse do governo em um determinado projeto.

Um bom exemplo disso é dado pelas monografias regionais defendidas como tese de doutoramento na FFCL/USP, dentre as quais não iremos avaliar apenas a de Conceição Vicente de Carvalho (1944), sobre Santos, e a de João Dias da Silveira (1946), que trata dos contrafortes ocidentais da Mantiqueira, na região de Bragança Paulista e Amparo. Como um todo, as pesquisas elaboradas na USP abarcam praticamente todo o litoral de São Paulo, desde São Sebastião e Ilha Bela, no chamado litoral norte (FRANÇA, 1951), até Itanhaém (ARAÚJO, 1950) e a baixada do rio Ribeira do Iguape (PETRONE, 1966), ao sul. O trabalho de Nice Lecocq Müller (1951), cujo tema são os "Sítios e sitiantes do estado de São Paulo", trata de áreas interiores, mas também restritas à realidade paulista, sendo exceção o trabalho de Renato da Silveira Mendes (1950), que aprecia as modificações pelas quais passavam as paisagens culturais

\footnotetext{
${ }^{49}$ Informações da Cia. Editora Nacional conseguidas no documentário "Perfil do Educador", da TV Cultura de São Paulo, disponível em: http://univesptv.cmais.com.br/perfil-de-educador/perfil-de-educador-aroldo-de-azevedo-porjose-bueno-conti. Acesso em: 12/12/2012.
} 
da Baixada Fluminense, que anos antes havia passado por intensas obras de engenharia que visavam a regularização de sua rede de drenagem ${ }^{50}$.

Contudo, podemos visualizar mais claramente as diferenças de posicionamento existentes entre o grupo de geógrafos da USP em relação aos estudiosos centrados no CNG e na Universidade do Brasil na análise de um episódio ocorrido quando ambos estavam a discutir o mesmo assunto. Tal fato se deu quando o CNG publicou um estudo sobre a divisão regional oficial do estado de São Paulo. Tomando ciência dos resultados apresentados pelo CNG, os geógrafos paulistas empreenderam um grande esforço para produzir um relatório, aproveitandose então de uma reunião da AGB, não por acaso a que sacramentou a nacionalização da entidade, coroando os esforços que cariocas e paulistas faziam em separado, para contestar os pressupostos teóricos e a nomenclatura utilizadas pelo grupo do CNG em sua proposta de regionalização.

\section{As nuances de uma tentativa de regionalização}

Com efeito, sobre o esforço de regionalização do estado de São Paulo, objetivo presente na ata de fundação da AGB que foi perseguido pelos geógrafos uspianos desde então - como mostra a série de textos de síntese que se detiveram sobre o tema, como o primeiro escrito de Deffontaines (1936), e os esforços de caráter mais sistemático de Monbeig (1949; 1954), retomados a partir daí como ponto de partida para as discussões posteriores nos trabalhos de Ary França (1960) e Pasquale Petrone (1966) -, é interessante notar as diferenças entre a regionalização proposta pela seção paulista da $\mathrm{AGB}$ e aquela proposta pelo CNG, que no início da década de 1940 agregou esforços para formular uma nova divisão regional para o Brasil (GUIMARÃES, 1942). Segundo nos parece, o ponto mais relevante dessa disputa é a definição dos parâmetros básicos que guiariam a regionalização, feita por Monbeig logo no início de seu

\footnotetext{
${ }^{50}$ No arquivo pessoal de Pierre Monbeig lotado no IEB/USP, encontramos duas cadernetas de campo, somando mais de 300 páginas, referentes a uma excursão efetuada para o Nordeste entre 20 de janeiro e 3 de fevereiro de 1944 (Códigos de referência 27, 2 e 27,3, Caixa 27, Sala 1), que revelam bem o sentido de grupo existente no curso de geografia da FFCL/USP. Essa excursão, da qual tomaram parte Ary França, Aroldo de Azevedo, M. Conceição Vicente de Carvalho, José Ribeiro de Araújo Filho e João Dias da Silveira, contou com o apoio financeiro do CNG e do Instituto do Açúcar e do Álcool (IAA), autarquia federal criada por Getúlio Vargas, em 1933, para planejar a expansão dos canaviais, o financiamento das usinas e organizar a produção, funcionando como um mecanismo de regulação do mercado. Os resultados desse trabalho de campo compõem, ao final, um exemplo acabado da geografia praticada naquela época, contenho inúmeras fotografias, cartas, gráficos e desenhos elaborados de próprio punho por diversos autores, além de relatos fiéis do dia a dia da expedição. Para o conjunto de trabalhos executados pelos geógrafos uspianos, essa excursão não deixa de ser a exceção que confirma a regra, pois trata-se de um dos únicos trabalhos feito além dos limites administrativos de São Paulo.
} 
primeiro trabalho sobre o tema. O relatório sobre a divisão regional de São Paulo proposta pelos agebeanos paulistas, apresentado na $2^{\mathrm{a}}$ Assembleia Geral da AGB, ocorrida em Lorena, no ano de 1946, parte de alguns esclarecimentos conceituais que não haviam sido feitos pelo CNG: "as 'regiões' correspondem a vastas unidades fisiográficas, as 'sub-regiões' são delimitadas levandose em conta, essencialmente, a paisagem geográfica (...), as 'zonas' são encaradas sobretudo tendo-se em vista os fatores econômicos e, particularmente, as relações regionais que se organizam em função de um centro urbano" (MONBEIG, 1949, p. 20).

A discussão terminológica sobre o significado conferido aos termos "região", "sub-região" e "zonas", feita por conta da nomenclatura utilizada pelo CNG, pode parecer estéril caso não seja apontada a novidade que então representava a definição das "zonas" a partir dos aspectos puramente econômicos, particularmente aqueles organizados em torno de um centro urbano. No caso, deve ser lembrado o avanço que a preferência pelos fenômenos econômicos representava como critério de base para o estabelecimento de limites regionais, pois até então, os trabalhos geográficos continuavam ainda muito presos aos fenômenos físicos e naturais, que deveriam tanto quanto possível guiar as observações dos geógrafos, conforme já se pôde observar a propósito do texto de Fábio de Macedo Soares Guimarães (1942).

Para Monbeig, que retornou ao tema em 1954, num texto saído no livro que o CNG editou em homenagem ao IV centenário da cidade de São Paulo, intitulado "Aspectos Geográficos da Terra Bandeirante", o substrato físico era o ponto de partida para a divisão regional, e não o seu resultado final, assim, a região natural era concebida como uma extensão da superfície terrestre originada pela ação recíproca e inseparável de elementos físicos e biológicos que, ao interagirem, constituem uma unidade: "uma região natural, portanto, é um complexo geográfico. Sua individualidade concretiza-se na paisagem. Se paisagens vizinhas diferem, é porque há complexos geográficos diferentes no interior dos quais a combinação dos elementos físicos e biológicos se efetuou de modo diferentes" (MONBEIG, 1954, pp. 182-183). O que estaria em jogo seria exatamente os "mecanismos das ações recíprocas do meio e do homem" (Ibidem, p. 183), pois não se poderia estabelecer, a priori, uma concordância direta entre as regiões naturais e as atividades humanas: "a pesquisa regional não deve, pois, deter-se na delimitação espacial da região, nem na enumeração e simples descrição dos elementos que formam a região natural. Mais do que isso, deve prender-se à explicação estrutural, isto é, demonstrar o mecanismo que une entre si os agentes formadores desse complexo geográfico" (Loc. cit.). Portanto, a divisão 
regional em grandes unidades naturais seria um procedimento útil e suficiente apenas caso se quisesse definir, em linhas gerais, as feições apresentadas por um complexo geográfico sobre o qual a sociedade ainda não agiu decisivamente como fator de modificação, "mas não se o estudo regional tiver o objetivo de registrar e cartografar o comportamento dos homens" (Ibidem, p. 195):

Os fenômenos da geografia humana não se acham inscritos automaticamente nos grandes quadros físicos que vimos tentando definir (...). Sem paradoxo, seria possível demonstrar como as relações sociedade-região natural expostas nas páginas precedentes dão sempre uma visão deformada da realidade (...). Não se pode dar por finda a tarefa do geógrafo, uma vez reconhecidas e delimitadas as regiões naturais e estabelecidas suas relações com as atividades dos homens que nelas habitam. É grave erro de ótica procurar enquadrar os fatos sociais e econômicos nas paisagens naturais. Nada impede que surja a pergunta: - Não decorrem de tal método as dificuldades encontradas em tantas tentativas de divisão regional paulista? (MONBEIG, 1954, pp. 196-197.)

Nessa direção, um dos principais problemas das tentativas de divisão regional efetuadas no Brasil seria a vontade de replicar aqui as diretrizes de trabalho consagradas na Europa, pois em países de povoamento recente não haveria nada próximo ao "sentimento regional" que em França é intrínseco aos termos pays e paysan, que encerram em suas definições o resultado de uma longa experiência de relações recíprocas entre os homens e o meio, as quais tenderiam pois ao equilíbrio. Expressivamente, Monbeig diz que os séculos de colonização de origem europeia em solo hoje paulista deixaram traços perceptíveis nas paisagens, uma vez que o processo de ocupação do solo foi agitado pela sucessão de ciclos agrícolas, conjugando uma série de fatores históricos, políticos e econômicos, como o movimento de expansão para os planaltos de oeste, o desembarque em massa de imigrantes e a afirmação do império do café. Todavia, o processo de aprendizado da natureza presente no movimento de posse e alteração de paisagens naturais, que na época ainda não havia se completado, demandaria, para a elaboração de uma divisão regional minimamente comprometida com a realidade geográfica, a aplicação de outros critérios que não apenas o fisiográfico ou o histórico, ganhando pois destaque a estrutura econômica:

Inicialmente, consideremos a "região geográfica", isto é, a unidade regional onde se processou a síntese entre as condições físicas e os fenômenos humanos (...). Da pré-história às últimas décadas, pode-se acompanhar às apalpadelas os malogros e os êxitos dos grupos que se sucederam neste quadro e que lhe completaram a conquista, depois de se ter com tamanha intensidade e por tanto tempo, agido sobre o meio a ponto de, de certo modo, terem-no criado de novo. Quatro séculos marcam atualmente a presença dos paulistas em São Paulo. Se foi espaço de tempo suficiente para transformar a paisagem paulista, não o foi, 
entretanto, para enrijecer o sentimento regional nas zona rurais (...). Quadros históricos ou quadros naturais, uns e outros são insuficientes. Talvez o erro esteja em procurar quadros em lugar de considerar fatos. Provém ainda da aplicação demasiadamente fiel, no caso paulista, de métodos aplicados em outros casos. Se há regiões cuja história esclarece a geografia humana, a volta ao passado não tem a mesma eficácia em São Paulo. É necessário, portanto procurar alhures o traço fundamental de sua geografia humana (...). A estrutura econômica é o fator decisivo, a chave das duas características fundamentais da geografia paulista: dinamismo e instabilidade. É lógico, portanto, ir buscar nos fatos econômicos os elementos de uma divisão regional. (MONBEIG, 1954, pp. 197/199/201.)

A noção de complexo geográfico presente nos trechos compilados confere à análise geográfica das paisagens um claro direcionamento de cunho metodológico, pois compreende que cada secção do espaço pode ser explicada a partir de um arranjo de diferentes fatores físicos, biológicos e sociais (DANTAS, 2002). Por esse princípio, derivado de Vidal de La Blache e aperfeiçoado por André Cholley, que aceitou assumir a direção da tese de Monbeig em 1947 visto que desde a morte de Albert Demangeon, em 1940, Monbeig não possuía formalmente um orientador -, um complexo geográfico seria o resultado sempre dinâmico de uma combinação dos fatores que incidem diretamente na organização das paisagens de uma região ${ }^{51}$. Assim, ao analisar uma paisagem florestal, os fatores de ordem física e biológica teriam uma importância maior do que os de ordem humana para a caracterização e descrição explicativa do complexo

\footnotetext{
${ }^{51}$ O princípio de combinação subjacente à ideia de complexo geográfico, detalhado por Cholley nas décadas de 1940 e 1950, é encarado por comentadores contemporâneos como o "ancestral" das atuais abordagens sistêmicas em geografia (FRÉMONT, 2005; REIS JR., 2012). Para Cholley, que explicitou de que se tratava as combinações geográficas na obra Guide de l'étudiant en Geographie, lançada em 1942 e reeditada, com pequenas modificações, em 1951, a geografia deveria estudar a organização do espaço, não tomando em separado apenas um dos diversos componentes da superfície terrestre, isolado analiticamente tal um "fato geográfico" sem relação com os demais fenômenos ocorrentes na superfície terrestre, mas se debruçando sobre o resultado da combinação entre eles, ou seja, os geógrafos abordariam de frente a complexidade das paisagens presentes na superfície terrestre, encarando a geografia como uma disciplina de síntese, uma vez que as combinações associam esses diversos fatores numa relação dinâmica de interdependência recíproca: "La structure même des combinaisons géographiques nous interdit de considérer les faits qui les composent à l'état isolé c'est-à-dire en eux-mêmes. Ils n'existent pour nous que comme éléments de la combinaison; c'est dans les combinaisons dont ils font partie qu'il faut les placer pour les apprécier. En dehors de leur structure propre, de leur essence que nous devons connaître, c'est la combinaison où ils se rassemblent, qui leur donne leur vrai sens. Nous devons donc nous attacher à saisir les rapports qui les enchaînent aux autres éléments de la combinaison, et le rôle qui leur revient dans la marche qu'elle a prise et dans le dynamisme qui l'anime. La combinaison réalisée pour la mise en valeur de la Prairie canadienne comportait, on l'a vu, des éléments physiques, biologiques et humains que l'on retrouve généralement dans toutes les combinaisons analogues se rapportant à l'exercice de l'activité agricole, mais ce qui a fait son originalité, c'est la façon même dont ils ont été groupés, dont ils ont réagi les uns vis-à-vis des autres, dont certains même ont mené le jeu. C'est évidemment un fait politique qui a été à l'origine de la combinaison : mais il est certain qu'elle n'a pris corps que lorsqu'on a trouvé la variété de blé capable de s'adapter aux exigences du climat et qu'on a amené à pied d'œuvre les hommes nécessaires à la mise en valeur de la terre. Une fois déclenchée, la combinaison s'est déroulée, a évolué dan un certain sens jusqu'au jour où son mécanisme et sa structure se sont trouvés modifiés par la densité accrue du peuplement, par le développement des villes, par les crises qui ont pesé sur le commerce du blé: alors il a fallu réaliser autre combinaison." (CHOLLEY, 1948, p. 127.)
} 
geográfico considerado, ao passo que, numa paisagem humanizada, são os fatores econômicos, políticos ou culturais os que se combinariam com maior influência na organização do arranjo paisagístico, estabelecendo os laços de solidariedade em escala local e regional que seriam identificados pelo olhar do geógrafo. Logo, nos mecanismos de ação e interação desenvolvidos entre o meio físico-biológico e as sociedades humanas, o complexo regional natural orientaria as atividades e comportamentos dos grupos humanos, mas não os determinaria de maneira alguma, limitando-os, apenas, pois, de lugar para lugar, variam os hábitos, as técnicas e a estrutura econômica dos grupos humanos, mesmo que estes estejam alocados em meios naturais similares ou até mesmo idênticos.

Embora esse procedimento possa parecer atualmente banal, a luta contra uma geografia determinista, que via a atividade dos grupos humanos como reação mais ou menos direta das contingências impostas pela natureza, era uma pauta que continuava na ordem do dia na década de 1940. Isso não quer dizer, obviamente, que Monbeig ou Cholley enxergassem de maneira crítica as contradições inerentes às relações sociais, que eram compreendidas mais a partir dos resultados que plasmavam as alterações materiais nas paisagens. Em outras palavras, as relações sociais não eram o foco da análise, sendo naturalizadas e tomadas apenas enquanto um fator geográfico a mais dentre as outras forças consideradas como agentes de modificação da natureza. Mesmo assim, a incorporação dos fenômenos econômicos relacionados ao processo de povoamento e ocupação do território como critério para a delimitação regional do espaço não deixava de ser um avanço se comparada às regionalizações que continuavam a se guiar de modo preponderante pelas regiões naturais ${ }^{52}$.

Essa postura favorável ao uso do critério natural, presente no trabalho do CNG, já havia sido criticada no relatório de 1946, quando Monbeig faz sutil alusão à "preocupação geológica do

\footnotetext{
${ }^{52}$ Em seu texto de 1954, após indicar a possibilidade de se elaborar regionalizações a partir de informações sobre a distribuição dos diferentes grupos étnicos e sobre a concentração populacional, fenômenos cujo entendimento "depende mais da explicação sociológica do que da interpretação dos fatores naturais" (MONBEIG, 1954, p. 205), Monbeig sugere a confecção de outros estudos geográficos não convencionais para o momento, que serviriam para tornar mais complexas as divisões regionais embasadas no critério econômico: "Há um outro ramo de pesquisas que ainda reteve menos a atenção dos geógrafos, o que é de lastimar-se: a geografia dos preços. Já se tem tocado nos problemas do custo da terra e do valor dos contratos de parceria. Mas creio que não se ligou a menor importância às variações regionais dos salários e do custo de vida, nem tampouco às variações regionais das economias. Se não se esquece o que é a economia de hoje e a importância que têm os fenômenos econômicos sobre as práticas agrícolas e os tipos de produção, pensar-se-á que uma região será muito melhor caracterizada e delimitada através do estudo geográfico da renda agrícola do que pela natureza das rochas. Pesquisas orientadas nesse sentido muito provavelmente mostrariam agrupamentos regionais de fenômenos que, relacionados a outros fatos econômicos, demográficos ou técnicos, reforçariam as individualidades regionais." (Ibidem, p. 206.)
} 
CNG (que não é censurável senão quando leva a uma exclusão muito radical dos caracteres geográficos)" (MONBEIG, 1949, p. 23), crítica que aparece de forma cristalina quando o francês passa a discutir em pormenor os motivos que levaram os geógrafos paulistas da AGB a rejeitarem, na regionalização oficial do CNG, a delimitação de uma "zona industrial" que incluiria na sub-região da capital paulistana as cidades de Campinas e Jundiaí:

As atividades industriais das duas cidades têm grande autonomia em relação às da capital; a produção agrícola é, pelo menos, tão importante quanto às das fábricas. Se a divisão em zonas funda-se na existência de unidades econômicas e em fatos de relações e de circulação, ninguém pode recusar a Campinas uma função de "capital regional" (...). Devemos, pois, inclinar-nos diante da realidade $\mathrm{e}$, consequentemente, considerar à parte uma zona de "Campinas". Mas o problema torna-se cada vez mais delicado: esta zona de Campinas tem uma existência econômica própria e, tomada como tal, seus limites deveriam ser levados às cidades de Americana e Pedreira. Estamos em face de uma região econômica cujos limites sobrepõem-se aos das regiões naturais. No caso agora considerado, estabelece-se ela ao mesmo tempo na região do Planalto Atlântico e na Depressão Paleozóica; chega a abranger, mesmo, tonalidades paisagísticas mais variadas. Entretanto, salvo má compreensão de nossa parte, o método seguido na confecção da divisão regional aceita como princípio que uma "zona", ainda que fundada sobre fatos econômicos, não pode ser inscrita senão no interior de uma só e única sub-região; e que, de mais a mais, ela própria tem sua unidade fundada sobre critérios físicos. Isto estabelece como que um primeiro postulado: que a região física determina a existência da região econômica; do que resulta um segundo postulado: que uma unidade física corresponde sempre a uma unidade cultural ou econômica. (MONBEIG, 1949, pp. 26-27.)

A recusa em tomar o critério físico-natural como forma de estabelecer os limites entre as diferentes zonas, que deveriam, segundo a definição proposta pela AGB, ser definidas a partir de outros parâmetros, como as "unidades econômicas" e os "fatos de relação e circulação" polarizados em função de um centro urbano de alcance regional, transforma-se então na recusa de uma geografia que tentava fazer coincidir os limites das regiões naturais com a extensão de determinadas atividades humanas, tarefa ainda mais arriscada no Brasil, onde "a posse do solo pelo homem é ainda recente (...) [e] o trabalho dos homens não teve tempo ainda de modelar as paisagens a ponto de lhes dar uma personalidade que se imponha" (MONBEIG, 1949, p. 21). Contudo, se fica evidente no trecho em destaque o esforço em dotar a geografia humana de critérios mais adequados para a divisão regional de fenômenos sociais, isso não quer dizer que se prescindia absolutamente da contribuição da geografia física. $\mathrm{Na}$ verdade, o entendimento da geografia como a ciência que busca fazer uma síntese das relações homem-meio não se desprende facilmente da linguagem organicista herdada de seu alinhamento com as Ciências 
Naturais, propugnado por Vidal de La Blache (BERDOULAY, 1981). O status naturalista da geografia vidalina, ciência natural da sociedade (CLAVAL, 2007), ainda que contivesse a possibilidade de análise das esferas política, econômica e cultural, conferia autonomia relativa a cada um desses aspectos, enredando a vida social ao meio onde esta enraizava-se (RIBEIRO, 2010). Sendo assim, vejamos como Monbeig lança mão de um vocabulário naturalista e de aproximações entre a sociedade e a natureza no exato momento em que recrimina as interpretações deterministas que impõem uma unidade econômica e cultural decorrente de uma unidade física e natural:

Pelo contrário, os fatos correntes ensinam que uma zona, possuindo uma unidade econômica e gravitando em torno de um centro regional urbano, é quase sempre constituída pela coexistência de numerosas células, cujas produções não são as mesmas e cujos habitantes não têm os mesmos gêneros de vida. Uma zona econômica é, pois, formada de células, cuja infraestrutura física não é a mesma. Bem ao contrário, tudo se passa de modo a nos provar que a unidade econômica superpõe-se à variedade física; são a variedade física e a justaposição de recursos naturais, frequentemente complementares um dos outros, que, ao mesmo tempo, dão origem à unidade econômica. $\mathrm{O}$ método seguido pelo $\mathrm{CNG}$ leva a pensar que as divisões regionais se encaixam uma nas outras como aquelas construções com as quais brincam as crianças: paralelepípedos com bonitas figuras (as "paisagens" dos geógrafos), que entram umas nas outras. Nosso maior paralelepípedo é a unidade fisiográfica; o volume de tamanho médio é a unidade de paisagem; e o menor, que é o econômico, entra automaticamente no médio, que não pode senão encaixar-se no maior. Infelizmente, esta uniformidade não passa de uma simples concepção teórica. Pensamos que seria desejável proceder à organização de uma divisão regional fundada exclusivamente sobre dados da geografia física, isto é, na existência de regiões naturais. Paralelamente, seria desejável focalizar regiões cuja unidade seria fundada sobre fatos da geografa humana: gêneros de vida, tipos de ocupação do solo, relações econômicas. Em seguida, mas somente em seguida, poder-se-ia comparar os resultados das duas pesquisas e tirar conclusões práticas, diretrizes positivas (...). Finalmente (e esta conclusão parece-nos a mais importante), verificamos mais uma vez que as "regiões humanas" ou, se for preferível, "econômicas", ou "culturais" (o importante é saber se o que se procura e o sentido dado às palavras) não podem ser inscritas a priori nas "unidades naturais". São duas ordens de cousas distintas. Do ponto de vista científico, torna-se cair no determinismo anacrônico, quando se teima em fazer coincidir a "região natural" com a "região humana". Se se encara a aplicação para fins administrativos, econômicos ou demográficos, políticos em uma palavra, é perigoso violar-se a realidade; partindo de princípios errôneos, chegarse-á a uma divisão regional muito diferente da realidade; e daí a uma política (no verdadeiro sentido do termo), que irá de encontro ao real, senão para a calamidade. (MONBEIG, 1949, pp. 27/36.)

Numa apreciação cuidadosa, a preocupação de Monbeig com a adoção de critérios adequados para a elaboração de uma regionalização mais afeita à geografia humana abarca 
também o aspecto político da atuação científica do geógrafo. Como se pode depreender da citação acima, uma divisão regional que negasse a realidade dificultaria sua aplicação para fins administrativos, econômicos ou demográficos, afastando-se da prática da verdadeira política, compreendida como o locus das decisões administrativas, um campo decisório sem conflitos que poderia melhor direcionar suas ações de governo a partir de um embasamento científico das necessidades reais da população. Esse juízo, que será retomado por Monbeig em outras ocasiões, inclui uma clara interpretação sobre a inserção do CNG no aparelho de Estado brasileiro, uma vez que o Conselho era o órgão responsável por sistematizar as informações geográficas do país. Nessa direção, fica claro que Monbeig não desprezava a contribuição de estudos regionais pautados por critérios físicos e naturais, ao contrário, ele os incluía como estudos fundamentais para a geografia, mas indicava a necessidade de se definir com mais rigor os parâmetros utilizados para uma regionalização, evitando que uma mesma proposta contivesse regiões delimitadas a partir de critérios distintos:

Reconhecer e cartografar as regiões naturais do Brasil é uma tarefa; reconhecer e cartografar suas regiões humanas é uma outra tarefa. Todas as duas são da competência do geógrafo; todas as duas têm um caráter científico e todas as duas, em conjunto, deve servir para fins práticos. Devem elas caminhar paralelamente, para que se possa, em seguida, confrontar seus resultados e tirar as concussões. Confundi-las em suas origens e em suas realizações não pode senão criar confusões e levar à impotência. (MONBEIG, 1949, p. 36.)

Em resumo, o projeto científico-pedagógico encampado pelos cursos universitários e pelas novas instituições geográficas de ensino e pesquisa, a AGB, o CNG e as universidades, foi bem sucedido no estabelecimento de uma rede de relações e de trocas científicas e intelectuais que erigiram as condições concretas para a reprodução da geografia institucional no Brasil, valendo dizer ainda que, apesar de contundentes evidências, nítidas no caso do CNG - que, devido a seu caráter técnico-administrativo de órgão auxiliar na produção de diagnósticos de problemas e na elaboração de políticas territoriais inseridas no contexto planificador do governo central, reverbera de modo mais explícito os valores ideológicos estatais -, a análise da questão da associação direta entre projetos políticos, trajetórias institucionais e os interesses do Estado é assunto ainda em aberto para a AGB ou para o grupo de geógrafos da FFCL/USP ${ }^{53}$.

\footnotetext{
${ }^{53} \mathrm{O}$ estabelecimento de uma rede de relações institucionais e de trocas científicas entre a AGB, as Faculdades de Filosofia e o CNG era reconhecida por contemporâneos do processo de consolidação acadêmica do campo geográfico. Falando sobre a atuação de Monbeig a um público estudantil, Fábio de Macedo Soares Guimarães a ele assim se refere: "Pierre Monbeig faz parte do muito estimado grupo de professores franceses que desde 1934 vêm orientando os estudiosos brasileiros da Geografia. É bem verdade que o movimento renovador dos estudos
} 
Em relação aos uspianos, embora seja possível vislumbrar por vezes um tom utilitário, patente seja nos textos de Aziz Ab’Saber $(1954$; 1958) sobre o potencial hidrelétrico das linhas de quedas (as fall lines) identificadas na bacia hidrográfica do Tietê-Paraná, seja nos estudos de Maria de Lourdes Pereira Radesca (1956) sobre as necessidades energéticas do parque industrial paulista, ou ainda nos textos de Elina de Oliveira Santos (1956) sobre as possibilidades de urbanização trazidas pelas obras de retificação do Tietê, não é possível verificar, sem antes efetuar uma apreciação mais detida, a conexão entre o conhecimento geográfico produzido e a tomada de decisões políticas cientificamente informadas, sendo pois de difícil comprovação o enunciado que liga diretamente as obras dos geógrafos uspianos das décadas de 1940 e 1950 às eventuais modificações impetradas nas paisagens paulistas. Todavia, como veremos no próximo capítulo, o próprio Monbeig não negava à geografia a qualidade de ser uma ciência de utilidade pública, que poderia sim, quando chamada, opinar em determinados problemas de ordem política dentro de seus modestos limites.

Além do mais, comparando o contexto institucional da geografia no início do século XX com a situação vivenciada a partir da década de 1930, vemos que além das universidades, que passam a comandar a formação do professorado e do pessoal técnico especializado, a consolidação do IBGE e a crescente profissionalização dos serviços e atividades desempenhados por essa agência trouxeram aos servidores ali lotados a percepção e o reconhecimento de ser este o órgão que centralizava os trabalhos oficiais de levantamentos estatísticos, cartográficos e geográficos do país, o que acarretou a perda da importância e deferência conferida à SGRJ no início do século XX. Nessa situação, a SGRJ deixou de receber os recursos financeiros subvencionados que a sustentavam, assistindo ao seu esvaziamento material e de pessoal ao longo da década de 1940, principalmente após 1945, visto que os militares e diplomatas da ativa, que antes tinham a SGRJ como referência básica das discussões de cunho geográfico empreendidas, ao menos até a década de 1930, passam a circular cada vez mais pelo IBGE e

geográficos já se vinha esboçando, pela abnegada e persistente atividade de mestres brasileiros, dentre os quais é justo lembrar Delgado de Carvalho e Everardo Backheuser; mas lenta era ainda a repercussão desse movimento, por faltar o ambiente propício. A Faculdade de Filosofia, Ciências e Letras de São Paulo e a Universidade do Distrito Federal (hoje transformada na Faculdade Nacional de Filosofia), seriam os núcleos da renovação necessária. Pierre Deffontaines e Pierre Monbeig foram dos primeiros professores estrangeiros chamados a atuar nesses novos centros de cultura (...). Faculdades de Filosofia, Associação dos Geógrafos e o Conselho Nacional de Geografia, eis os três grupos surgidos quase simultaneamente, a transformar e dar vida nova às pesquisas geográficas em nosso país. Em todos eles atuou Pierre Monbeig com destaque. Professor da Faculdade de Filosofia de São Paulo a partir de 1935; presidente, sempre reeleito, da Associação dos Geógrafos Brasileiros desde 1936, foi ele ainda um dos que entusiasticamente se manifestaram a favor da criação do Conselho." (GUIMARÃES, 1943, pp. 7-8-9.). 
outras agências de informação a ele vinculadas direta ou indiretamente. Ao final, em 1945, sob a presidência do embaixador José Carlos de Macedo Soares, à época também presidente do IBGE, a SGRJ passa por reformas de tom mudancista, passando a se chamar Sociedade Brasileira de Geografia, o que de certo modo corrobora o progressivo esvaziamento da antiga Sociedade ante às novas instituições e formas de organização do campo geográfico (CARDOSO, 2011).

Finalizando, após a reconstrução do contexto histórico do período, que deu relevo às discussões que tinham a questão do povoamento e ocupação do território como objeto principal, pudemos observar algumas das características do processo de institucionalização da geografia no Brasil - entre outras tantas, ressalte-se a tradição existente no pensamento político-social do país, que de longa data utilizava-se de conceitos de base espacial como forma de responder a algumas questões fundamentais de sua formação nacional (OLIVEIRA, 2000; MAIA, 2008), fez com que a comunidade dos geógrafos não assumisse de pronto o monopólio das discussões sobre o espaço, sendo sensato reconhecer que o campo geográfico foi consolidado em um ambiente políticointelectual que contava com um histórico de debates no qual conceitos e categorias de base espacial ocupavam há muito um lugar de destaque, circunstância que decerto influenciou as novas formas de organização profissional do campo disciplinar a não prescindirem das experiências institucionais anteriores para se legitimarem enquanto centros reconhecidos de produção do saber geográfico. As referências que fizemos à Comissão Geográfica e Geológica de São Paulo, às Missões Civilizatórias do Instituto Oswaldo Cruz e aos trabalhos heterogêneos executados no âmbito da SGRJ são representativas desse pormenor, mostrando que a "cultura geográfica" (CARDOSO, 2009) nacional encontrava-se já amadurecida no início da década de 1930. Por fim, mas não menos importante, vimos também que o debate no interior desse campo disciplinar vai assumindo um rumo diverso com a progressiva afirmação da geografia universitária, como no caso das discussões acerca da regionalização do estado de São Paulo, que, dando cabo a um debate entre dois caminhos teóricos distintos, o natural e o econômico, ilustra bem a maneira como o tom diletante das discussões presentes nas antigas sociedades de geografia foi suplantado de vez, possibilitando que se aprimorasse um discurso coeso que fundamentará uma nova tradição no pensamento geográfico brasileiro. 


\title{
CAPÍTULO II
}

\section{A MOBILIDADE DO POVOAMENTO E A PSICOLOGIA BANDEIRANTE}

\begin{abstract}
"Da bandeira caminhando no espaço, desde o início do povoamento, saiu a sociedade que se fixou no interior do país. Da sua fronteira móvel, conduzida para norte, oeste e sul, saiu a fronteira fixa que configura, no mapa, a imagem fisica do Brasil. Da bandeira caminhando no tempo saiu o grupo nacional democrático, que vem da família, passa pelo clã, torna-se povo e chega até nós pelo sangue e pelo sentimento, como um retrato humano que se viesse reproduzindo através de ampliações sucessivas do original. A bandeira nos oferece, portanto, na sua rude, mas típica enquadratura politica, os lineamentos do Estado moderno, baseado no culto da tradição e do heroísmo: comando seguro (autoridade forte) e disciplina consciente (cooperação de todos os brasileiros, agora irmanados numa só alma, para o mesmo sacrificio e para o mesmo triunfo)."
\end{abstract}

Cassiano Ricardo

\section{Introdução}

No capítulo passado, a caracterização da conjuntura histórica da primeira metade do século $\mathrm{XX}$, feita com ênfase nos projetos do governo Vargas que incluíam de alguma forma uma discussão acerca da integração do território, serviu como pano de fundo para que discutíssemos o processo de formação do campo geográfico, comparando entre si as vias de consolidação institucional da geografia universitária no Rio de Janeiro e em São Paulo. Este caminho apresentou-se como o mais conveniente para a argumentação desenvolvida, na medida em que sublinhou a relativa oposição de metas existentes entre os sujeitos mais diretamente envolvidos em cada caso, revelando a predominância de uma visão estratégica influenciada pelos objetivos governamentais, presente na geografia fluminense, e os objetivos de cariz marcadamente pedagógicos e intelectuais que qualificam o projeto paulista ${ }^{54}$.

\footnotetext{
${ }^{54}$ Essa interpretação do processo de formação institucional do campo geográfico acompanha, grosso modo, as indicações efetuadas por Sérgio Miceli (2001a) para as Ciências Sociais. Para o sociólogo paulista: "São Paulo foi praticamente o único espaço institucional em que se constitui algo próximo ao que se poderia qualificar como uma elite propriamente intelectual. Numa perspectiva de história intelectual comparada, a elite de cientistas uspianos é o que mais se assemelha àquela fração cultivada da classe dirigente capaz de fazer valer sua presença e autoridade em função da contribuição que traz ao exercício de funções culturais irredutíveis à sua contribuição econômica. Tal fato teve consequências duradouras no tocante à posição social e institucional dos cientistas sociais e de suas obras, mormente no que diz respeito às relações que essa 'alta classe média não econômica' mantém com os detentores do poder econômico e político. (...) Na então capital federal do país e cento das lutas envolvendo as diversas facções de jovens intelectuais radicalizados no pós-1930, praticamente todas as iniciativas de 'construção institucional' que repercutiram de pronto e a longo prazo sobre as Ciências Sociais foram caudatárias dos recursos estatais e dos projetos políticos de lideranças emergentes no interior da máquina governamental. Ao que tudo leva a crer, sobretudo no período que vai de 1930 a 1945, quando cai o estado Novo, o principal patrono das reformas educacionais e culturais foram os mentores intelectuais e políticos à testa do então Ministério da Educação e Saúde
} 
Desse modo, após termos reconstruído, em linhas gerais, o contexto histórico do país nas década de 1930 e 1940, diferenciando, no processo de formação institucional da geografia, o caldo comum das ideologias geográficas e políticas territoriais que permeavam o pensamento político social brasileiro, ao menos no que concerne ao uso de categorias espaciais para explicar o país, pretende-se agora observar, através de um exemplo concreto, a maneira como um professor estrangeiro inseriu-se no ambiente intelectual brasileiro desenvolvendo, dentro de sua obra, imagens sobre a população brasileira que não se distanciavam muito daquilo que era compartilhado no Brasil pelo grosso da classe letrada, na época praticamente reduzida às elites políticas, econômicas e culturais.

Mais especificamente, a questão da psicologia bandeirante, atrelada à explanação das frentes pioneiras, ganha na obra de Monbeig uma formulação bastante próxima dos ideais difundidos pela corrente do pensamento político-social que elegia a experiência bandeirante como a principal matriz da nacionalidade brasileira. Tal corrente de pensamento se apresentava com objetivos distintos e de maneira diversa tanto no núcleo do pensamento modernista conservador da intelectualidade paulista, segundo o exemplo clássico dos intelectuais ligados ao movimento "verde e amarelo" (VELLOSO, 1990), quanto nas ideias de hegemonia daqueles que orbitavam à roda do grupo responsável pela organização da USP (CARDOSO, 1982). Por isso, apreciar mais a fundo as relações entre o registro encontrado na obra de Monbeig e a posição ideológica expressa por certos setores da sociedade paulista acaba por revelar as injunções que queremos ressaltar no caso da institucionalização da geografia em São Paulo, até por aquilo que a noção de frente pioneira representa na organização das pesquisas geográficas na USP ao longo das décadas de 1940 e 1950.

Efetivamente, Mônica Velloso $(1993 ; 2002)$ aponta para a existência de uma argumentação construída sobre o critério espacial-geográfico como eixo de uma tipologia do caráter nacional. Nela, a conquista do sertão pelos antigos e novos bandeirantes, obra de alargamento territorial genuinamente paulista, justificaria a proeminência de São Paulo na direção do destino nacional. Por isso, o posicionamento de Monbeig ao falar da psicologia bandeirante, ainda que não demonstre assunção irrestrita de qualquer dos projetos de poder então em voga, indica claramente a internalização de um debate que, quando de sua chegada ao Brasil, estava posto e era feito por

Pública, primeiro através do ministro Francisco Campos, parceiro do grupo de reformadores da educação, como por intermédio do ministro Gustavo Capanema.” (MICELI, 2001a, pp. 115-116-117.) 
pessoas com quem manteria inegável proximidade. Sendo assim, focando na figura de Pierre Monbeig, discutiremos nas próximas páginas alguns aspectos de sua obra que podem ajudar na compreensão de como poder-se-ia dar a inserção de um professor universitário estrangeiro na sociedade brasileira das décadas de 1930 e 1940.

\section{Visões 'tradicionais' da obra de Pierre Monbeig}

Segundo os pressupostos e objetivos dessa pesquisa, faz-se necessária uma nova avaliação da contribuição intelectual de Monbeig precípua e principalmente no que diz respeito à sua suposta adesão a certos parâmetros ideológicos compartilhados por parte da elite paulistana envolvida em sua vinda ao Brasil. Esta nova avaliação se justificaria, por sua vez, na medida em que há uma espécie lugar-comum na caracterização de sua obra, que acabou por ser reiteradamente repetido ao longo dos anos seguintes. De fato, num texto do início da década de 1980, época que por assim dizer marca a retomada definitiva dos estudos sobre a historiografia das ideias geográficas no Brasil, Sílvio Carlos Bray caracterizou-a nos seguintes termos: [Pierre Monbeig] "incorporou o positivismo como método, o liberalismo político como doutrina e a abordagem sistêmica-organicista como prática” (BRAY, 1983, p. 84). Essas características seriam observáveis na defesa que Monbeig faz da neutralidade das ciências e na luta que empreende pela afirmação e reconhecimento do estatuto científico da geografia, disciplina que procura estabelecer como se fosse um saber de caráter utilitário e pragmático que não mistura o domínio científico com o político. Logo, o geógrafo idealizado por ele não tomaria as decisões finais, apenas ajudaria a produzir, a partir dos inquéritos e observações de campo, uma documentação consistente que poderia oferecer sugestões a serem ou não acatadas pelos tomadores de decisão e formuladores de políticas, prestando assim um serviço técnico-científico especializado, mas não exercendo função de comando (BRAY, 1983).

A ressalva passível de ser feita aos que se inclinam a esta chave interpretativa concentrase na oportunidade e exatidão do emprego do termo "escola" para qualificar de modo idêntico o conjunto da produção intelectual de sucessivas gerações de geógrafos. Com efeito, se a existência de um "fundador" é inquestionável, neste caso - a saber: Paul Vidal de La Blache -, seria muito difícil sustentar que todos os seus discípulos, diretos ou não, professavam a exata mesma doutrina do mestre (BROC, 1993). A bem dizer, tanto trabalhos de referência, como os estudos de Vincent 
Berdoulay (1981) e Paul Claval (1993), quanto os esforços de Marie-Claire Robic (2001; 2006) para divulgar os programas de pesquisa coletiva que dirige, apresentam não só as grandes diferenças existentes em França entre as gerações de Marcel Dubois, Paul Dupuy e Lucien Gallois, mais antiga e partícipe do momento de afirmação da geografia como disciplina universitária, e a de Albert Demangeon, Jean Brunhes, Camille Vallaux, Emmanuel De Martonne, Antoine Vaucher, Raoul Blanchard, Jules Sion e Maximillien Sorre, seus herdeiros diretos e os grandes patrões da geografia universitária francesa da primeira metade do século XX, mas também apontam a existência de interesses variados mesmo entre colegas de geração, com as verdadeiras batalhas por postos dentro das universidades e as estratégias de perpetuação epistemológica dos grupos intelectuais dando origem a teses de natureza tão distinta que entre si não guardariam semelhança senão nas dedicatórias a La Blache e em esparsos pontos comuns, como a predileção pelo trabalho de campo e a inevitável produção de detalhado material cartográfico e iconográfico (WOLF, 2005).

É claro que não negamos a existência de similaridades que conseguem enredar autores díspares numa mesma chave conceitual e metodológica, sendo talvez um caso ilustrativo as acirradas disputas que alguns dos discípulos diretos de La Blache acima citados travaram pelos cargos de maior prestígio na estrutura de ensino superior francês do início do século XX, pois tais contendas, quando vistas em detalhe, ajudam-nos a diferenciar também as afinidades e as especificidades da produção intelectual de cada autor frente à homogeneidade do grupo como um todo, algo importante para o bom entendimento da trajetória francesa do processo de institucionalização da geografia, e consideração válida para compreender o certo marginalismo acadêmico experimentado por Jean Brunhes e alguns de seus interlocutores mais próximos, como Camille Valaux e Pierre Deffontaines, que pode ser creditado à militância católica e à não ortodoxia de suas doutrinas quando comparadas com os cânones estabelecidos por Lucien Gallois, Emmanuel De Martonne e Albert Demangeon.

A carreira internacional de Pierre Deffontaines (1894-1978), nome de imensa importância para a consolidação da geografia universitária no Brasil, foi analisada nos trabalhos de Claire Delfosse (1998; 2000) e Marieta Ferreira (1998), sendo um exemplo do marginalismo acadêmico acima referido. Eximindo-nos de análises mais detalhadas acerca das motivações mais profundas que desembocaram nesse isolamento de Brunhes e seus discípulos, vale lembrar as informações colocadas por Ferreira, que, trabalhando com relatos contidos na autobiografia e nos diários de 
Deffontaines, esclarece sua trajetória de inserção profissional, compreendendo a marginalidade a ele imposta como uma das motivações para esse geógrafo ter feito sua carreira de renome internacional fora da França, haja vista sua atuação fundamental como professor também em Barcelona e em Montreal. Um dos pontos mais interessantes diz respeito exatamente à sua professada militância católica: segundo se depreende de seus relatos pessoais, a formulação de uma geografia humana mais afeita às causalidades religiosas e espirituais dificultou o acesso de Deffontaines a cargos mais prestigiosos dentro da fechada estrutura universitária francesa. Mesmo tendo isso em mente, não deixa de ser surpreendente descobrirmos a bronca de Emmanuel De Martonne, o grande patrão institucional da geografia de então, por não ter sido mencionado nos agradecimentos de sua tese, pois, ao invés de nomear suas influências intelectuais universitárias, como era o costume, o fervoroso geógrafo preferiu endereçar as homenagens iniciais a ninguém menos que São Francisco de Assis, com o que foi preterido na disputa de alguns cargos, como na Universidade de Rennes. Assim, o posto que conseguiu na Universidade Católica de Lille não deixava de representar um fracasso para Deffontaines, que viu no Brasil, além de uma boa oportunidade, uma saída honrosa para seu início de carreira (FERREIRA, 1998).

Contudo, o certo é que a maioria dos autores fazia uso dos mesmos fundamentos gerais ao organizar as categorias e conceitos de análise do real, e isso desembocava em uma prática disciplinar até certo ponto monocórdica, uma vez que o arsenal teórico e metodológico era posto em articulação através dos princípios geográficos então sistematizados e aceitos: o princípio da extensão, o da analogia (ou geografia geral) e o da causalidade. A esses, Jean Brunhes acrescentaria o princípio da atividade, que buscava estabelecer de vez o caráter dinâmico da realidade geograficamente estudada, e o da conexidade, que apontava a complexidade dos fatos geográficos e as qualidades explicativas das combinações, ou seja, das múltiplas conexões entre fenômenos físicos, biológicos e humanos nas formas de organização e evolução histórica destes numa dada localidade (BRUNHES, 1925). Isso levaria realmente os autores dessa geração a entender o conjunto dos fatos considerados como atinentes à análise da geografia pelo prisma do ininterrupto inter-relacionamento levado a cabo entre os quadros naturais e os grupos humanos, vistos sob um prisma naturalista como produtores ativos das paisagens que iriam ser localizadas, observadas, cartografadas e descritas explicativamente pelos geógrafos através dos conceitos de meio, gênero de vida e região (SANGUIN, 1993). 
Em sua obra máxima, o Traité de Géographie Physique, lançado originalmente em 1909, Emmanuel De Martonne, que era genro de Paul Vidal de La Blache, apresenta e define com detalhes os três princípios básicos da geografia moderna, não escondendo a intenção de fundar uma tradição. Ao remeter os princípios que ia definindo aos seus criadores, De Martonne esboçava uma linhagem intelectual, procedimento que indica a tentativa de apresentar a geografia como um campo disciplinar autônomo, já que sugere certo aspecto de continuidade histórica linear entre a produção do início do século XX e a dos sobreditos "precursores da Geografia Moderna", principalmente Alexander von Humboldt e Karl Ritter. Ao final, De Martonne apresenta uma definição de geografia que será incansavelmente repetida nas décadas seguintes: “a geografia moderna encara a distribuição à superfície do globo dos fenômenos físicos, biológicos e humanos, as causas dessa distribuição e as relações locais desses fenômenos. Tem caráter essencialmente científico e filosófico, mas também caráter descritivo e realista. Isto é que constitui a sua originalidade" (DE MARTONNE, 1953, p. 20$)^{55}$.

De volta a Monbeig, sabemos que entre os intérpretes de sua obra há também aqueles que aproximam sua concepção sobre os pioneiros ao uso ideológico que certos setores da sociedade

\footnotetext{
55 "Na realidade, a delimitação exacta do campo das investigações geográficas é uma empresa quimérica. Esta ciência tem relações com muitas outras e - a sua história demonstra o - demasiado interesse em permanecer em contato com elas para que essa delimitação seja de desejar. O essencial é extrair os princípios de método que agora se afiguram adquiridos. O princípio de extensão foi particularmente esclarecido por Ratzel. Bastam alguns exemplos para demonstrar o seu significado: o botânico estuda os órgãos de uma planta, as suas condições de vida, a sua posição na classificação; se procura determinar a sua área de extensão, diz-se que realiza geografia botânica (...). Da importância do princípio de extensão resulta a da cartografia. Sem que se chegue ao ponto de pretender que geografia e cartografia sejam sinônimos, deve notar-se que qualquer estudo recebe o sinete geográfico quando se procura exprimir cartograficamente os seus resultados. O princípio de geografia geral foi vigorosamente expresso por Ritter e, mais recentemente, por Vidal de La Blache. Pode ser formulado assim: o estudo geográfico de um fenômeno implica a preocupação constante dos fenômenos análogos que podem apresentar-se em outros pontos do globo (...). A aplicação deste princípio implica o conhecimento da maior parte do globo terrestre; por isso não nos devemos admirar de que fosse preciso chegarmos ao século XIX para colher seus primeiros frutos (...). O terceiro princípio do método geográfico é o princípio de causalidade: nunca contentar-se com o exame de um fenômeno sem tentar remontar às causas que determinam sua extensão e procurar as suas consequências é colocar-se num terreno que não é propriamente o de qualquer das ciências físicas, naturais ou sociais com as quais a geografia está em relação. É na aplicação deste método que reside a principal originalidade dos escritos de Humboldt (...). Tais são os três princípios essenciais do método geográfico, mas é necessário compreender bem que o verdadeiro geógrafo deve tê-los, aos três, simultaneamente diante dos olhos. E isto nem sempre foi suficientemente esclarecido. Cartografia e geografia não são sinônimos, e para ser geógrafo não basta representar a extensão de um determinado fenômeno. A preocupação das leis gerais é um princípio científico; a busca das causas é uma preocupação filosófica. Mas o geógrafo é o único sábio que simultaneamente se obriga a conhecer a distribuição dos fenômenos superficiais, físicos, biológicos ou econômicos, a desfibrar as causas dessa distribuição ligando-a a leis gerais e a procurar os efeitos. É assim levado a enfrentar combinações locais de influências, cuja complexidade ultrapassa tudo aquilo que os físicos, os botânicos ou os estatísticos imaginam. A superfície da Terra é o seu laboratório, maravilhoso campo de experiências, onde se acha realizada uma espantosa variedade de tipos regionais, cuja originalidade ele tem de reconhecer e explicar. Aquilo que no método geográfico há de simultaneamente fecundo e original é o facto de evidenciar realidades terrestres." (DE MARTONNE, 1953, pp. 17-18-19.)
} 
paulista conferiam à figura do bandeirante (ROLLO GONÇALVES, 1998), antepassado glorioso dos fazendeiros que no início do século XX comandavam a expansão das lavouras de café e algodão no oeste de São Paulo e norte do Paraná. O núcleo dessas reflexões vem ao encontro de nossas preocupações, na medida em que é comum estabelecer uma ligação entre a ideologia de membros do "grupo do Estado", que viam a liderança paulista como algo natural, - porquanto embasada num "imperialismo benéfico" que o texto da Comunhão Paulista considerava intrínseco à política de São Paulo - e os escritos de Monbeig sobre as franjas pioneiras (ZUSMAN, 2001). Prenunciado na expansão territorial comandada pelos bandeirantes e continuado na política de construção de ferrovias impulsionada pelo surto do café, esse imperialismo paulista teria encontrado nos estudos do geógrafo francês uma sua variante acadêmica, dado que a maior parte dos que defendiam essa posição eram intelectuais que gozavam de uma proximidade com figuras importantes do grupo que havia participado diretamente da organização da $\mathrm{USP}^{56}$. Desse modo, em larga medida sobrepondo o tratamento que Monbeig confere ao fenômeno das franjas pioneiras aos desígnios explicitados pelas elites paulistas em seu projeto de país, o posicionamento que aproxima o trabalho intelectual do francês ao projeto de poder do "grupo do Estado" acaba considerando seus escritos como não mais que uma justificativa de cunho científico que visaria legitimar os anseios hegemônicos de classe do grupo que intermediou sua vinda ao Brasil:

Poder-se-ia inferir dessa afirmação, então, que Monbeig associa o pioneirismo ao processo de avanço e ocupação do território, de diversificação e ascensão social, processo desejável para todo o território brasileiro. A frente pioneira de Monbeig apareceria assim carregando tanto a significação de democracia social contida na visão do bandeirante de Cassiano Ricardo quanto dos valores de democracia social, política e de progresso presentes no discurso de Jackson Turner vinculado à Marcha para Oeste americano (...). Em síntese, poderíamos

\footnotetext{
${ }^{56}$ Valeria aqui um esclarecimento do significado do termo "Comunhão Paulista". Analisando alguns documentos produzidos por Júlio de Mesquita Filho ao longo da década de 1920 que defendem abertamente a criação de uma universidade em São Paulo, como o Inquérito sobre a Instrução Pública de São Paulo, organizado por Fernando de Azevedo e publicado ao longo 4 meses nas páginas do jornal O Estado de São Paulo, em 1926, o livro A Crise Nacional, saído originalmente em 15 de novembro de 1925, também n'O Estado, e o texto A Comunhão Paulista, publicado no jornal e depois na Revista do Brasil entre novembro e dezembro de 1922, Irene Cardoso sublinha a circunstância da educação aparecer, em todos eles, "como o elemento por excelência de regeneração da sociedade brasileira" (CARDOSO, 1982, p.38). Entretanto, a autora enxerga uma espécie de declaração de princípios no texto escrito em 1922, pois é ali que o imperialismo benéfico e a missão superior dos paulistas na formação da nacionalidade são claramente enunciados: "O "grupo do Estado" considera-se a Comunhão paulista (...) A Comunhão paulista não se identifica com o estado de São Paulo (estado da Federação), mas é a representação ideológica que o "o grupo do Estado" faz de si mesmo. A via de realização fundamental do projeto de regeneração política da nacionalidade proposto pela Comunhão paulista é a educação, e dentro dela o elemento de maior importância, a Universidade.” (Ibidem, p. 41.)
} 
dizer que Pierre Monbeig consolida institucional e discursivamente a Geografia enquanto disciplina tanto na USP quanto na AGB. Utiliza os métodos da Geografia Humana francesa, numa de suas vertentes, para compreender os processos que aconteciam em São Paulo. A partir da abordagem da frente pioneira ele faz da Marcha para Oeste em São Paulo seu principal assunto de pesquisa e, desta maneira, legitima o projeto político e econômico de seus protetores: a elite ilustrada paulista. (ZUSMAN, 2001, p. 27.)

Como já foi observado, a tentativa de aproximar os pioneiros americanos dos bandeirantes luso-brasileiros, reinterpretando suas ações para forjar um mito que reforça o caráter nacional da expansão territorial por eles engendrada, ganha no século XX uma versão atualizada (OLIVEIRA, 2000). Nesse registro, os fazendeiros paulistas que estavam à testa da expansão do café iniciada no XIX, considerados os herdeiros diretos do legado bandeirante, poderiam sem prejuízo ser chamados de "novos bandeirantes". Em tais interpretações, esses fazendeiros e seus prepostos, não por acaso integrantes da elite econômica e política do estado de São Paulo, eram compreendidos como agentes ativos da modernidade, uma vez que, por meio das cidades que fundavam e das fazendas que abriam, punham-se a conquistar terras "vazias" para o Estado brasileiro, levando a economia da nova civilização industrial que despontava no planalto paulista aos longínquos sertões indevassados do território nacional (RAIMUNDO, 2004).

Guardadas as devidas diferenças, as ferramentas conceituais manejadas por Pierre Monbeig em seus estudos sobre o fenômeno pioneiro no Brasil, que identifica na expansão das lavouras de café e algodão que observou pessoalmente em São Paulo e no norte do Paraná, revelam, grosso modo, sua familiaridade com esse tipo de interpretação, evidente sobretudo quando o francês está a discutir o que chama de psicologia bandeirante, traço da mentalidade coletiva brasileira fixado na memória dos que, em pleno século XX, empreendiam suas migrações:

Em todos os países novos, do norte ao sul do continente americano, observa-se a sedução das terras novas e a paixão pelo ganho rápido do dinheiro. Apelo do Grande Norte ao Canadá, marcha para oeste, ainda não há muito tempo, nos Estados Unidos, desbravamento do sertão paulista, não passam de variações de um grande tema continental. Ali o colono moderno se põe a serviço do caçador, acolá se converte em herdeiro do pionner; em São Paulo é o continuador do bandeirante. Os hábitos dos grupos sociais e étnicos, as diferenças de estrutura política e social bastam para criar apreciáveis matizes entre uns e outros. Mas, todos esses homens jovens, povoadores de terras novas, buscam ligar-se a uma tradição e a criar sua própria história. Talvez sentissem necessidade de tirar dessa história, senão uma justificativa do seu tumulto, ao menos uma fonte de energia. (MONBEIG, 1984 [1952], p. 124.)

Ainda que não seja possível ratificar um eventual consenso que confirme a plena associação entre a produção científica de Pierre Monbeig sobre as franjas pioneiras, a mitologia 
criada em torno da figura do bandeirante (RAIMUNDO, 2002; VELLOSO, 1990) e os projetos governamentais estaduais e federais que efetivamente se materializaram no território, provocando alterações na configuração espacial de São Paulo e do país - uma vez que, tanto quanto pudemos averiguar, não há muitos estudos que esclareçam detalhadamente em que medida os geógrafos localizados fora dos muros do CNG/IBGE foram convidados a opinar sobre questões políticas, territoriais e de desenvolvimento econômico e social -, pode-se realmente encontrar em suas obras inúmeras passagens nas quais ficam claras as intenções de capitanear um grupo de intelectuais comprometidos com a construção de um programa coletivo de pesquisas multidisciplinares que visava fornecer embasamento técnico e científico para determinadas ações governamentais. Resumindo esta interessante discussão, tomemos como exemplo trechos de um diálogo estabelecido entre Monbeig e Luís Flores de Moraes Rego, geólogo, professor da Escola Politécnica da USP e sócio fundador da AGB, que teve como tribuna, no ano de 1935, as páginas do jornal "O Estado de São Paulo", e como assunto básico o estabelecimento de metas comuns para um eventual relacionamento entre a Associação de Geógrafos Brasileiros e o desenvolvimento econômico de São Paulo:

A Associação de Geógrafos Brasileiros, fundada em São Paulo, tem por objetivo geral o desenvolvimento dos estudos geográficos do país, especialmente São Paulo e das regiões adjacentes. Concorrendo para o conhecimento das regiões de influência econômica de São Paulo, permitirá a sistematização dos esforços para o desenvolvimento dessas regiões. Promoverá o conhecimento dessas regiões sobre diversos pontos de vista mas com orientação essencialmente geográfica, isto é, sem perder de vista o método geográfico baseado nos princípios bem conhecidos de extensão, coordenação e da causalidade. Servirá como coordenadora e animadora dos esforços no sentido de valorizar vastos territórios brasileiros. A Associação, além de ser órgão de desenvolvimento da cultura paulista, desempenhará um papel relevante de caráter prático na evolução moderna da vida econômica do Brasil. De um lado fará a propaganda das regiões a desenvolver junto ao capital e seu comércio, tornando conhecidos seus recursos e suas possibilidades. De outro cooperará com os governos da União e estaduais para a resolução das questões ligadas ao progresso desses territórios. A influência da Associação far-se-á sentir junto às populações locais, mostrandolhes o interesse que dedicam ao melhoramento de suas condições econômicas as classes esclarecidas do Brasil. (MORAES REGO, 1935, p. 8.)

Por seu turno, dando um verniz mais acadêmico à discussão, Monbeig respondia a Moraes Rego, esclarecendo para todos, no primeiro artigo que escreveu para o "Estadão" após sua chegada ao país, os casos em que, defendendo ser a geografia uma ciência de utilidade pública, aceitaria a intervenção da disciplina nos assuntos decisórios de governo. Diz ele: 
Em que casos determinados será a investigação geográfica suscetível de ser utilizada pelos não geógrafos? Em que casos determinados terá ela interesse prático? (...) Aqui mesmo, o sr. Moraes Rego demonstrou claramente qual a relação entre a expansão econômica paulista e a Associação de Geógrafos Brasileiros (...). É evidente que antes de se lançar a novas experiências, deve um país ter perfeita consciência de suas possibilidades. É mister, pois, conhecer tudo o que o solo e o clima permitem, na complexidade de suas interações (...). Enfim, uma série de monografias das atividades humanas atuais permite que nada se ignore dos recursos econômicos do país; as origens, as condições naturais, as dificuldades econômicas e as importâncias reais dos diversos ramos da agricultura, do comércio e da indústria são estudados com cuidado e os trabalhos geográficos acabam por constituir uma verdadeira "suma", que reúne o valor científico à utilidade nacional. É o fim que se propõe a Associação dos Geógrafos Brasileiros. Para lográ-lo, entretanto, é mister que se reúnam as boas vontades e se agrupem homens de formações e profissões várias: os quais, por não considerarem os fatos sob o mesmo ângulo, têm visões diferentes e podem sugerir observações e discussões fecundas. (MONBEIG, 1940, p. 274-275-276.)

Nestas passagens, é mesmo possível notar uma correlação entre a consolidação das pesquisas geográficas feitas em moldes científicos ou modernos, que vinham combater a antiga prática disciplinar, vista como uma coleção inútil de localizações, dados numéricos e nomes de lugares (a chamada "geografia de nomenclatura"), a possibilidade de instrumentalização política do saber produzido pelos geógrafos ligados ao projeto universitário de institucionalização da disciplina e o desejo de planificação das atividades estatais envolvendo o desenvolvimento econômico regional e a racionalização do domínio e gestão sobre o território ${ }^{57}$. Porém, dada a distância entre intenção e gesto, pensamos haver ainda uma lacuna no que diz respeito aos estudos que analisam o quanto essas produções ideológicas foram eficientes, passando do plano das elaborações culturais para o das práticas políticas concretas, o que nos obriga a não aceitar

\footnotetext{
${ }^{57}$ Vejamos como Monbeig enxergava a divisão do trabalho intelectual nos inquéritos que tinham como objetivo principal o fornecimento de informações de base para a tomada de decisões políticas: "Matéria de ensino, a geografia é também um instrumento moderno que pode servir eficazmente as coletividades públicas ou grupos privados. A pesquisa geográfica é suscetível de aplicação e a opinião dos geógrafos mereceria, muitas vezes, ser ouvida. Não se veja nisso estranha novidade! Da mesma maneira que se admite dever-se consultar um geólogo antes de se construir uma barragem, o economista antes de se desenvolver um ramo de produção, e até mesmo um sociólogo antes de se legislar sobre a imigração, acabar-se-á por considerar normal a consulta ao geógrafo. Qual é o valor prático duma pesquisa geográfica? (...) A própria criação do Conselho Nacional de Geografia tem por finalidade o melhor conhecimento do país, indispensável à sua boa administração (...). Deve-se isto ao fato de que, por toda a parte surgiu e se impôs o problema da organização do território da forma mais racional possível, da melhor forma de ocupação do solo a fim de aumentar a produção e melhorar a produtividade. Ora, ninguém mais indicado que o geógrafo para fazer inquéritos onde podem surgir decisões concernentes a esses problemas. Se, precisamente, o geógrafo estuda as relações complexas dos meios naturais e dos grupos humanos em sua localização e em função de sua área espacial, é ele, por excelência, o técnico da organização do espaço. Mas não basta organizar o espaço, é preciso organizá-lo bem (...). Mas, atenção! Impõe-se prudente reserva. A participação dos geógrafos a esse tipo de inquérito não exclui a participação de outros especialistas. $O$ geógrafo não é onisciente e o que lhe cabe é apenas um lugar numa orquestra, mas não é ele toda a orquestra!" (MONBEIG, 1957, pp. 20/22-23. Grifo nosso).
} 
senão com reservas as aproximações que vinculam diretamente o pensamento de Monbeig a um específico projeto político paulista, pela importância que o geógrafo objetivamente conferia ao que intitula de "psicologia bandeirante", tomada como um dos fatores explicativos que permitiriam compreender a extrema mobilidade e a instabilidade do povoamento dos planaltos ocidentais de São Paulo e do norte do Paraná (MONBEIG, 1952; 1957).

Sobre o assunto, vale citarmos o estudo de Rollo Gonçalves (1998), que busca aproximar o modo como Monbeig trabalhava com a figura do bandeirante ao uso ideológico que alguns setores da intelectualidade paulista faziam deste capítulo da história brasileira, largamente instrumentalizado pela classe política após a generalização dos anseios estatais colonizadores e expansionistas resumidos no slogan "Marcha para o oeste". Carregando nas tintas de suas críticas, Rollo Gonçalves faz boas colocações, mesmo que, ao final, conceda à psicologia bandeirante uma proeminência que de maneira alguma tal noção possui nos escritos do geógrafo francês sobre as franjas pioneiras:

Em sua tese de doutoramento, publicada nos anos 50 - mas escrita na década anterior, Pierre Monbeig trabalhou com dois registros epistemológicos bastante distintos e de difícil (mas não impossível) conciliação. Por um lado, ele operou com os conceitos funcionalistas que estavam entrando em voga naqueles anos. Por outro, reproduziu construções históricas que, decorrentes de sua adesão acrítica ao acervo de idealizações épicas das elites intelectuais paulistas, terminaram por beirar as fronteiras dos discursos mitológicos. Neste sentido, seu estudo é deveras representativo de uma das várias formas de recriação - no contexto de uma construção técnico-científica da figura do pioneiro - daquilo que, na falta de um termo mais exato, pode-se chamar de mitema bandeirante. Não se trata, portanto, de procurar, anacronicamente, fazer correções críticas de conteúdo ao texto. Meu foco de análise concentra-se apenas no modo como o mitema foi retomado, de forma que não estou preocupado com a veracidade fáctica do que foi dito (...) sua representatividade aparece bem definida pelo modo como se apropriou da figura do bandeirante para dar fundamentos a certas considerações a respeito de possíveis traços psíquicos que sedimentariam o comportamento de amplas frações da população brasileira. Ele essencializou e reificou um ethos bandeirante, sem romper com os termos da questão tais como foram colocados, sobretudo, por Cassiano Ricardo. E seguiu este caminho para operar uma reconstrução do passado - tomando a longevidade de determinados mitemas no discurso das elites como dados adquiridos, fatos de veracidade inquestionável. Outro argumento pela representatividade é o fato de que ele expressou uma avaliação afirmativa do mitema bandeirante por acreditar que alguns de seus traços estavam incrustados nas pautas de conduta dos brasileiros. Monbeig, um francês que usufruiu da generosidade liberal-aristocrática da grande burguesia paulistana, segregou em seu texto muitos traços da cultura política das elites locais, o que permite que se afira o grau de sedução das crenças e opiniões daquele grupo sobre supostos atributos mentais dos brasileiros. Por fim, ele entendeu o bandeirante menos como um personagem de 
carne e osso do que como elemento simbólico, apesar de estar convencido de que existia um solo factual que assegurava a veracidade da conversão simbólica daquele ator social. Daí ter-se concentrado nos efeitos psíquicos que sua perenidade ocasionaria no seio das mentalidades coletivas. (ROLLO GONÇALVES, 1998, pp. 41-42.)

$\mathrm{O}$ assunto é interessante e valeria a pena ser considerado um pouco mais a fundo, visto que o próprio Monbeig relatou, no início da década de 1980, que em seu exame de tese se surpreendera com o fato de nenhum dos integrantes do júri ter dito uma palavra qualquer, seja de reprovação ou de elogio, sobre as poucas páginas que dedicou à psicologia bandeirante no seu estudo Pionniers et Planteurs de São Paulo. Contudo, esta surpresa, originada talvez por considerar que a preocupação com a mentalidade coletiva daqueles que empreendiam as migrações em São Paulo consistia então uma novidade, ao menos numa pesquisa geográfica ocupada em desvendar as mudanças na organização espacial das paisagens atingidas pelas vagas pioneiras, não pode ser considerada por si uma declaração de sua adesão intencional a algum projeto político em nível estadual ou federal, mesmo que evidencie uma aproximação do francês a certos modos de compreender o processo de povoamento e colonização que ocorriam no país que eram comuns em determinados meios políticos-intelectuais ${ }^{58}$.

A seguir, faremos uma leitura verticalizada de alguns escritos de Monbeig, tentando rastrear em sua obra as passagens mais representativas que tratam da psicologia bandeirante, bem como os trechos nos quais esse aspecto subjetivo da expansão do povoamento ocorrido no oeste de São Paulo e norte do Paraná é entendido como parte da mentalidade coletiva dos pioneiros, dito de outro modo, indicaremos nas próximas páginas de que maneira a mentalidade foi compreendida por Monbeig como um dos fatores que incidem diretamente na combinação complexa de fenômenos naturais e processos sociais que dão origem às paisagens humanas.

\footnotetext{
${ }^{58}$ Pondo em destaque o episódio acontecido em sua defesa de tese, Monbeig rememora a importância que o relacionamento de proximidade que desenvolveu no Brasil com um grupo de intelectuais de outras áreas do conhecimento (economistas, sociólogos, historiadores e etnólogos) teve para a conformação de seus interesses pessoais por temas pouco ortodoxos para os geógrafos: "Tout particulièrement au Brésil, le fait que nous soyons un groupe de cinq ou six jeunes, de disciplines différentes, a été très utile, en tout cas pour moi. Je crois que cela n'a pas été inutile pour les autres non plus (...). Tout cela serait jamais arrivé si j'avais été en France : chacun aurait été dans son propre Lycée, tandis que là, nous avions des temps morts, surtout au commencement, avant que la machine de l'Université de São Paulo ne se mette à marcher vraiment, nous avions le temps de bavarder, de discuter: nous ne nous en sommes pas privés (...). Je crois qu'il s'est passé quelque chose, j'avoue que j'ai été très surpris quand j'ai fait ma thèse, d'entendre des collègues, plus jeunes que moi, m'en dire du bien sur certains points. Par exemple, on m'a dit que j'avais innové en attachant tellement d'importance à l'évolution du prix du café, alors que cela me paraissait tellement évident: là-bas, ça crevait les yeux. Et personne, à ma soutenance de thèse, aucun des membres du jury, ne m'a dit une parole, soit de louange, soit de blâme, pour les quelques pages que j'avais consacrées à la psychologie bandeirante. J'avais l'impression que c'était une nouveauté, et que j'allais probablement me taper sur les doigts, ou bien, on m'en dirait du bien." (MONBEIG, 1991, pp. 31-32.)
} 


\section{Os fatores psicológicos e a organização das paisagens pioneiras}

Examinando alguns de seus textos que esmiúçam esse ponto, quais sejam, um dos primeiros artigos escritos sobre as migrações internas de São Paulo após sua chegada ao Brasil, publicado em sua língua materna, em 1937, e intitulado "A zona pioneira no estado de São Paulo" (MONBEIG, 1940), o capítulo terceiro da segunda parte de sua tese (MONBEIG, 1952), no qual se detém com mais vagar no relacionamento que pensava haver entre a mobilidade exacerbada do povoamento pioneiro e a herança psicológica do passado bandeirante, e o artigo "Modos de pensar na Geografia Humana" (MONBEIG, 1957), saído originalmente no Boletim Paulista de Geografia, em 1953, podemos observar o real alcance que a alusão às mentalidades coletivas tinha dentro do edifício explicativo que Monbeig construiu para compreender o espraiamento espacial do povoamento e as constantes migrações ocorridas no interior de São Paulo e no norte do Paraná.

Focalizando o texto de 1937, percebemos que as referências sobre o passado bandeirante aparecem pela primeira vez, ainda que não formalmente explicitadas, quando o autor, se encaminhando para a conclusão do artigo, passa a descrever os tipos sociais que habitavam as zonas pioneiras paulistas, que em sua estrutura populacional caracterizava-se por apresentar "um dos fenômenos habituais às regiões de desbravamento: a variedade étnica e a amálgama progressiva das raças" (MONBEIG, 1940, p. 51), condição esta que faria delas um lugar propício para a assimilação dos colonos no universo cultural nacional, funcionando tal verdadeiro "cadinho onde se caldeiam as raças" (Ibidem, p 54). Sem por ora aprofundar a crítica dessa visão asséptica e não conflituosa das relações sociais engendradas nas zonas pioneiras, que para ele seriam locais afeitos a uma convivência "pacífica e laboriosa" entre os diversos elementos étnicos ali presentes, o fato é que Monbeig, atentando para outro traço da composição populacional que diferenciava as velhas zonas de ocupação das novas zonas pioneiras em expansão - o predomínio do elemento estrangeiro nestas últimas versus o número mais equilibrado de proprietários brasileiros nas primeiras -, aventa explicar os deslocamentos frequentes rumo às novas áreas pela permanência entre todos, estrangeiros ou não, de um sentimento de aventura que seria resultante do fascínio exercido pela zona pioneira:

O maior deslocamento de população no interior do Estado vai das zonas antigas para as zonas pioneiras; é uma migração constante e maciça que escapa às estatísticas, mas o mínimo inquérito "in loco" revela sua profundidade. A zona 
pioneira povoa-se essencialmente com os antigos fazendeiros do vale do Paraíba, com os colonos que não encontram mais trabalho nas fazendas de solo esgotado, as de Campinas, por exemplo, com pequenos proprietários da Araraquarense que querem melhorar ainda mais. Ao lado dos paulistas desembarcam homens de Minas Gerais ou da Bahia, atraídos pelos salários relativamente elevados desta região onde há falta de braços para a colheita do algodão (...). Ao lado do fazendeiro clássico existe um outro tipo social paulista, direi mesmo brasileiro, porque encontrei em outros estados, o do desbravador. É uma verdadeira e bela loucura em alguns desses homens, e isso através de todas as classes sociais, a de partir para mais longe desde que chega o primeiro trem na cidade que eles fundaram ou contribuíram para fundar. Herança psicológica, poder-se-ia dizer, evocando a história; e, também uma necessidade geográfica, porque o solo tropical, empobrecido pela prática da "queimada" esgota-se depressa. (MONBEIG, 1940, pp. 53-54-55. Grifo nosso.)

O trecho em destaque, além de reforçar o fato de que o povoamento das zonas pioneiras se efetuava com um efetivo populacional oriundo das antigas zonas cafeeiras - circunstância que revela que o povoamento pioneiro se fazia às custas do despovoamento de áreas desbravadas nos momentos históricos precedentes, num movimento de evolução progressiva linear que liga o desenvolvimento de novas áreas ao retrocesso das antigas, que se tornam decadentes -, deixa claro que a "herança psicológica" que permearia a mentalidade daqueles que se dispunham sempre e de novo ao deslocamento encontrava-se, para todos os efeitos, submetida à mais crua das "necessidades geográficas": a fertilidade natural dos solos onde a atividade agrícola que dava impulso aos movimentos de população iria se desenvolver. Seria o esgotamento dos frágeis solos tropicais pelas queimadas e pela forma intensiva de exploração agrícola que comandaria, num primeiro momento, a dinâmica das migrações.

Tal arranjo explicativo, que confere pesos diferentes aos fatores de ordem psicológica e geográfica no processo de alteração das fisionomias paisagísticas, será utilizado novamente quando Monbeig retomar de forma clara a temática da psicologia bandeirante em sua obra mais conhecida (MONBEIG, 1952). A bem dizer, o capítulo referente à mentalidade dos pioneiros é o mais curto dos que compõem a segunda parte do livro primeiro de seu estudo sobre as zonas pioneiras de São Paulo, na qual se ocupa em reconstruir as condições históricas que ocasionaram os deslocamentos populacionais no oeste paulista. Descrevendo o jogo dos fatores econômicos atuantes como auxiliares ao funcionamento da atividade cafeeira na primeira metade do século $\mathrm{XX}$, a tática argumentativa de evocar a lembrança do passado bandeirante, tratando-o como uma componente do imaginário pioneiro atual, deve ser entendida dentro da explicação fornecida por Monbeig como um todo, sublinhando-se alguns aspectos. 
Em primeiro lugar, a recuperação da figura do bandeirante, que à época era celebrado por setores intelectuais tradicionalistas ligados à elite política e econômica de São Paulo como a mais perfeita encarnação das qualidades genuinamente paulistas, cumpre a função de sublinhar o fato de que a incessante ocupação de terras a que se denomina pioneirismo, expresso na conquista de solos fundamentada numa atividade agropastoril essencialmente comercial, aparecia aos olhos de Monbeig, assim como o bandeirismo aos da sobredita elite tradicionalista, como um fenômeno original da sociedade paulista: “Em sua forma atual, a 'Marcha para o oeste' é essencialmente paulista e continua a sê-lo, mesmo ao penetrar territórios de outros estados, porque não somente o impulso é dado por São Paulo, como a maior parte dos homens provêm desse estado e as relações econômicas se fazem sobretudo com São Paulo e Santos” (MONBEIG, 1984 [1952], p. 23). A sinonímia entre a "Marcha para o oeste" e o pioneirismo paulista já atestaria a aproximação de Monbeig com uma determinada maneira de enxergar o processo de expansão das áreas cultivadas com café nas décadas de 1930 e 1940, mas o geógrafo vai mais além. Diferenciando o que seria uma corrente de povoamento originada exclusivamente do dinamismo encontrado na economia e na sociedade paulista do mero estabelecimento de relações econômicas com outras áreas hegemonizadas a partir do capital e da infraestrutura de exportação presente em São Paulo, Monbeig reconhece no território brasileiro a existência de correntes de colonização cujos elementos demográficos e impulsos econômicos provêm de outras localidades. Nessa circunstância, os aspectos "psicológicos" pretensamente compartilhados pelos paulistas é um fator que o ajuda a delimitar o objeto de estudo ao qual ele irá se dedicar, que se atém "ao movimento pioneiro paulista propriamente dito. Pois que não somente ele se reveste de sua unidade própria, que repousa antes de mais nada na homogeneidade de uma população marcada pelos hábitos e pelo espírito paulista, mas também porque se desenrola num quadro em que se pode reconhecer certa unidade geográfica" (Ibidem, p. 30).

Esses registros decerto aproximam Monbeig dos desígnios expostos pelos participantes da "Comunhão Paulista", que compreendiam o "imperialismo benéfico" de São Paulo como uma forma de civilização de outras regiões brasileiras (ZUSMAN, 1996), estagnadas num estágio inferior de desenvolvimento, vistas como regiões atrasadas que dificultavam a sincronização do Brasil com a velocidade do mundo moderno. Neste caso, sua visão sobre o fenômeno pioneiro ficaria seguramente próxima da retórica territorialista amplamente divulgada pelos próceres do regime varguista ao longo dos anos do Estado Novo (1937-1945), período que, aliás, coincide 
quase que totalmente com o de sua estadia no Brasil. Outros exemplos presentes em escritos mais antigos do que o livro "Pioneiros e Fazendeiros", cuja redação findou em 1949, são ainda mais ilustrativos, até mesmo por representar uma fase inicial da carreira do geógrafo francês, quando, após chegar a um país estrangeiro, buscava ainda um maior entrosamento com membros influentes da sociedade local. Num texto escrito por volta de 1939, como resultado de uma viagem de avião feita entre São Paulo e Goiânia, que então contava apenas seis anos desde sua fundação, Monbeig diz:

Os agentes do telégrafo da nova capital já transmitiram provavelmente um bom número de telegramas oficiais; eu desejaria, porém, que a primeira mensagem enviada de Goiânia aos poderes federais tivesse sido redigida assim: "Bandeirismo não morreu!" (...). A bem dizer, a influência paulista vai além de Goiânia. Desde logo convém notar que a nova cidade só vive de São Paulo: os materiais de construção, os gêneros alimentícios, as fazendas, as ferramentas para o trabalho, tudo o que é necessário à vida quotidiana procede de São Paulo (...). Ora, os produtos paulistas não se detêm em Goiânia: vão mais longe ainda, até o Araguaia que não fica longe (e é uma possibilidade da indústria turística para a jovem cidade), e para o norte do estado de Goiás, onde encontram a concorrência das importações da Bahia e de Belém do Pará. Seria interessante fixar com precisão as zonas de contato dessas três bacias econômicas, no sentido em que se fala de bacia fluvial: a de Belém, a da Bahia e a de São Paulo. Entrementes, verificamos que os eternos traçados da geografia impõem aos transportes modernos, caminhão ou lancha a motor, as mesmas direções das bandeiras. (MONBEIG, 1940, pp. 80/82-83.)

O trecho em questão toca em diversos pontos relevantes, como o fato de a fundação de Goiânia ser evocada como uma continuação moderna do bandeirismo, o que nos leva a referendar uma aproximação entre os juízos de Monbeig em relação à integração territorial das distintas regiões brasileiras e o enquadramento geral do programa "Marcha para o oeste", conforme autoriza, aliás, a citação antes transcrita, que toma o fenômeno do pioneirismo - tido por essencialmente paulista - como a forma assumida pela "Marcha" na época em que Monbeig a observava. O lapso de dez anos entre os dois textos parece não ter esmorecido a certeza de que o pioneirismo paulista era a materialização territorial do lema da "Marcha para o oeste" do Estado Novo. Ademais, é relevante sublinhar que a fundação de Goiânia foi circundada por um ambiente de celebração, sendo explorada exaustivamente pelos ideólogos e propagandistas do regime varguista como exemplo da capacidade humana de modificação da natureza proporcionada pela técnica e pela ciência, uma vez que a criação de uma cidade moderna em pleno planalto central tornou-se a prova do sucesso certo das ações colonizadoras defendidas pelo governo, que 
conseguia enfim amansar o sertão mais longínquo do país, tirando-o da letargia e integrando-o aos fluxos da economia nacional.

Ao fim e ao cabo, essa espécie de "neobandeirismo" do Estado Novo, que promovia a retórica sobre a ocupação dos "espaços vazios" como uma missão patriótica, é uma visão de mundo que parece ser mesmo aceita em seus termos gerais por Monbeig, que confere uma dimensão de corte mais geográfico à afirmação que justifica o domínio econômico de São Paulo sobre as demais regiões do país, pois o que estaria a ocorrer seria mais exatamente um fenômeno de polarização, consequência da centralidade de São Paulo e resultado da captura econômica exercida pela capital e capitais paulistas em áreas muito afastadas. Em termos atuais, poder-se-ia dizer que São Paulo hegemonizava os fluxos econômicos de outras regiões, organizando-os e ordenando-os sob seu comando através de um sistema de circulação que ele chama de "bacia de drenagem", analogia feita com a rede fluvial que prenuncia quase ipsis litteris os termos futuramente utilizados por Bernard Kayser (1968) na análise da organização do espaço econômico dos países subdesenvolvidos ${ }^{59}$.

Num outro trecho do texto de Luís Flores de Moraes Rego que citamos há pouco, o alcance da opinião que considerava a expansão econômica paulista como uma continuação moderna do bandeirismo surge também com clareza. Visto que esse texto de Moraes Rego incitou uma réplica de Monbeig, que no geral não se afasta da argumentação nele estabelecida, pode-se mesmo inferir que um tal juízo fosse comum a outros integrantes do "grupo Estado", incluso aí Pierre Monbeig, colaborador assíduo desse diário ao longo de sua estadia no Brasil e figura próxima de Júlio de Mesquita Filho:

Os mercados consumidores para os produtos paulistas dividem-se em duas categorias: de um lado, a costa servida pela cabotagem, de outro o interior e as regiões adjacentes para as quais os produtos são transportados pelas vias terrestres. Os mercados costeiros têm sua capacidade limitada, sujeitos à concorrência direta da importação. O desenvolvimento dos mercados do estado

\footnotetext{
${ }^{59}$ Em texto escrito ao final da década de 1930, após uma excursão de campo efetuada ao longo da Estrada de Ferro Noroeste do Brasil, Monbeig reafirma a centralidade paulista no processo de expansão da economia moderna no Brasil, retomando uma vez mais suas crenças acerca dos limites do trabalho intelectual do geógrafo, que não poderia ultrapassar a função meramente consultiva: "Assim, na direção de Mato Grosso, se repetem os fatos que, no ano passado, uma viagem pelo Triângulo Mineiro e pelo sul de Goiás me permitiu constatar. Trata-se de um dos mais amplos movimentos de população e expansão que atualmente se registram em países novos: e sua amplitude se mede facilmente se se recordar o que era a economia paulista, há apenas cem anos. Evolução de zonas abertas há vinte e cinco anos, abertura à civilização de regiões até então invioláveis, laços econômicos e afetivos com territórios longínquos, hoje integrados na vida nacional, tudo isso suscita problemas administrativos, econômicos e políticos consideráveis, para os quais o geógrafo só pode contribuir com a documentação e cuja solução pertence a outros." (MONBEIG, 1940, pp. 99-100. Grifo nosso.)
} 
processa-se agora de maneira normal, que não é possível apressar. Tudo indica a necessidade cada vez maior de serem as vistas dirigidas para as regiões adjacentes de expansão comercial e da indústria de São Paulo. Essa ação natural vem-se verificando de há muito, com melhores resultados. Constitui o que poderia ser chamado de bandeirismo moderno. As "bandeiras" do passado desbravavam o Hinterland brasileiro quase em sua totalidade. Criaram em vasta região do planalto a população que sucedeu imediatamente aos silvícolas, formadas pela mestiçagem desenvolvida pelo isolamento. Para incrementar o consumo de utilidades manufaturadas cumpre apressar a nova vaga de povoamento e aumentar o poder aquisitivo das populações, promovendo seu desenvolvimento econômico. Para esses fins faz-se necessária a cooperação do capital e da energia paulista que atuando nessas regiões engendrarão não só a devida remuneração como trabalharão para o desenvolvimento de São Paulo e do Brasil. Já se vem observando essa modalidade do esforço paulista. Resta incrementá-la e sistematizá-la para que maior seja a eficácia. A primeira penetração paulista através do país teve lugar conforme os processos da época. A segunda vaga necessita para ser praticada racionalmente o conhecimento das regiões a desenvolver. (MORAES REGO, 1935, p. 8. Grifo nosso.)

Também aqui reaparecem alguns pontos básicos das políticas territoriais de Getúlio Vargas aos quais já tivemos oportunidade de nos referir, como a conjugação entre a colonização de novas terras a partir de uma atividade eminentemente agrária, o desejo de aumentar a renda dos trabalhadores e a necessidade de criação de um mercado para os produtos industrializados, numa ação de complementaridade entre o campo e a cidade que era um dos objetivos das ações deliberadas de povoamento incentivadas pelo governo. Em todo caso, convém ainda notar que as ditas "regiões adjacentes" de expansão econômica paulista, que não são nominadas, referem-se basicamente ao Triângulo Mineiro, Goiás e Mato Grosso, áreas consideradas igualmente um prolongamento do Hinterland paulista por Monbeig, que as entendia como atreladas historicamente aos fluxos econômicos que demandavam São Paulo, visto que os caminhos terrestres disponíveis mantinham, no geral, as linhas básicas das trilhas de penetração abertas pelos bandeirantes: "Entrementes, verificamos que os eternos traçados da geografia impõem aos transportes modernos, caminhão ou lancha a motor, as mesmas direções das bandeiras" (MONBEIG, 1940, p. 83) ${ }^{60}$.

\footnotetext{
${ }^{60}$ Essa assertiva de Monbeig sobre a continuidade moderna dos antigos caminhos bandeirantes receberia, depois de muitos anos, o referendo de outros estudiosos, dentre os quais destacamos Paulo Bertran (1988; 1994; 2002), que numa série de trabalhos sobre o Planalto Central brasileiro desencavou documentos que realmente dão fé à versão de que os caminhos atuais perpetuaram as principais vias de penetração bandeirante naquelas paragens. Em trabalho anterior, já havíamos notado que a direção dos fluxos econômicos e demográficos que demandavam as antigas capitanias de Goiás e Mato Grosso (ou delas provinham) seguiam, no mais, o rumo das vias fluviais, que influenciavam até mesmo na construção das estradas terrestres, localizadas nos "espigões", os divisores d'água. Nessa realidade, as comunicações feitas entre as terras da antiga região Centro-Oeste e o que viria a ser o restante do país formaram setores espacialmente compartimentados que desenvolveram nexos territoriais divididos mais ou
} 
Outro elemento que reforça a aproximação entre o pensamento de Pierre Monbeig e os desígnios ideológicos dos grandes fazendeiros paulistas é a relação de proximidade que o francês estabeleceu com alguns dos maiores produtores de café do estado, uma vez que muitos deles tornaram-se seus informantes privilegiados, fornecendo a logística necessária para suas excursões de campo na forma de abrigo, transportes e mesmo facilitação de acesso a dados estatísticos para o desenvolvimento das pesquisas. Um dos exemplos mais significativos dessa relação de intimidade de Monbeig com os fazendeiros pode ser encontrado quando o geógrafo passa a descrever, como exemplo do que de melhor se produziu no movimento pioneiro paulista, o sucesso econômico de um indivíduo ou grupo, a inovação que representava algum maquinário implantado em uma dada fazenda ou até o itinerário de avanço de algumas famílias abastadas, dentre as quais sobressaem-se os Lunardelli, os Toledo Piza, os Queirós Teles, os Alves de Lima e "o caso típico" dos Almeida Prado, que partindo da região de Limeira e Araras, abarcaram ao final do XIX propriedades imensas em não menos extensas manchas de terra roxa na região de Ribeirão Preto.

Convém então notar, ainda que de passagem, a amizade de Monbeig com Caio Prado Jr., o que decerto facilitou não só as excursões de campo do geógrafo, que muitas vezes fícava hospedado nas propriedades da família ou em lugares onde a indicação de um Prado "valia mais do que uma ordem" ou documento oficial, como ele mesmo afirmou certa vez, mas sobretudo na descoberta de fontes que, de outro modo, permaneceriam inacessíveis, como livros contábeis das fazendas ou documentos internos relativos ao trânsito de mercadorias nas estradas de ferro. Isso revela, por um lado, o demorado processo de constituição das fontes primárias com as quais Monbeig trabalha, e de outro, o quanto suas relações interpessoais influenciaram no tratamento que confere aos documentos escolhidos. Por exemplo, a menção que o francês faz à fazenda Guatapará, propriedade organizada por Martinico Prado que contava com mais de 1.767 .000 pés de café por volta de 1910, é ilustrativa, visto que Caio Prado Jr. passava longas temporadas nessa fazenda (IUMATTI, 2007), sendo de supor que Monbeig tenha aproveitado alguns momentos de descontração com algum dos herdeiros desse grande domínio para obter informações sobre os negócios da família, como ele mesmo confessa em nota de rodapé após citar tal fazenda: “Por alinhamento dos rios Guaporé, Mamoré e Madeira, que levavam a Belém, os afluentes do São Francisco, como o rio Paranã, que fazia as conexões com os sertões baianos e pernambucanos, e os tributários da bacia do Prata, como os rios Paraná, o Grande e o Tietê, o caminho bandeirante por excelência, que ligava São Paulo ao interior profundo de Goiás e Mato Grosso (NOGUEIRA, 2008). 
outro lado, o sr. Caio Prado Júnior não me regateou algumas informações complementares" (MONBEIG, 1984 [1952], p. 140) ${ }^{61}$.

A intersecção entre a assimilação de certas concepções de classe e a seleção das fontes de informação utilizadas para a redação do trabalho evidencia-se igualmente quando o francês se vale de um livro lançado em comemoração ao centenário de Martinho Prado Jr. para descrever a atuação dele e de seu irmão, o conselheiro Antônio Prado, tios de Caio Prado Jr., na organização da imigração de colonos estrangeiros vindos da Itália, ação que considera uma prova da "modernidade" desses fazendeiros, que anteviram o fim da escravidão. Desenvolvendo um estilo de texto que não saberíamos separar de uma bem feita hagiografia, tantos os elogios dissimulados em tom de ciência neutra e desinteressada, Monbeig pontua a liderança exercida pelas famílias abastadas nas movimentações pioneiras ocorridas na passagem do século XIX ao XX, identificando a proeminência desses grandes proprietários de terras na sociedade brasileira pela convergência de interesses entre os fazendeiros, loteadores de terras, banqueiros e políticos, normalmente membros da mesma família que compartilhavam um claro interesse de classe, conformando em São Paulo o que veio a ser conhecido com o sugestivo nome de "governo dos fazendeiros":

Assim, estava a família Prado bem situada nas posições chaves do movimento pioneiro - a terra, o comércio, o banco, os meios de transporte, a organização da mão-de-obra, o poder político - graças aos postos ocupados por seus membros e por suas alianças com famílias similares. De situação idêntica gozavam outras famílias. Casamentos, camaradagem entre colegas de escola, relações de negócios apertavam os laços entre elas. Podiam surgir rivalidades políticas, ásperas as vezes, porém concerniam mais à eleição deste ou daquele, que a divergências doutrinárias. Tinham todos os mesmos interesses profundos e

\footnotetext{
${ }^{61} \mathrm{O}$ acervo pessoal de Pierre Monbeig (IEB/USP) contém alguns documentos que revelam esse trajeto de construção das fontes utilizadas na redação de sua tese de doutoramento, tema de trabalho riquíssimo que permanece em aberto. Ilustra bem o acesso do geógrafo a documentos não usuais nos trabalhos científicos de então, uma série de relatórios e quadros estatísticos datados de 1946, referentes à Companhia Mogiana de Estradas de Ferro, que também tinha a participação acionária da família Prado. Nesse conjunto documental, pudemos ver dois relatórios, o primeiro, intitulado "Distribuição das propriedades rurais na região da E.F. Mogiana/SP" (Código de Referência: 19,1 - Caixa 19, Sala 01), que trata da economia e do processo de divisão das propriedades nas áreas do entorno da via férrea, e um outro, nomeado "The Mogiana zone: economic conditions" (Código de Referência 19,4 - Caixa 19, Sala 01), que caracteriza de modo geral as zonas servidas pela estrada de ferro. Vimos também um quadro que discrimina o volume das mercadorias carreadas, entre 1943 e 1945, da E.F. de Goiás para a Mogiana, que está arquivado junto com um cartão de visitas do assistente do Departamento de Estatísticas da E.F. Mogiana (Cód. Ref 19,2 - Caixa 19, Sala 01), e um outro inquérito, também redigido em inglês, que versa sobre a necessidade de se introduzir agricultores e colonizadores na região próxima da cidade de Franca/SP (Cód. Ref. 19,3 - Caixa 19, Sala 01), que na visão do autor do relatório necessitava de trabalhadores para dinamizar sua pauta produtiva, garantindo assim maiores lucros para a empresa. Ao nosso ver, esta última conclusão ajuda a revelar, para todos os efeitos, os interesses concretos da companhia de estradas de ferro na abertura de novos loteamentos rurais e na consolidação de núcleos de colonização, vale dizer, na apropriação de terras.
} 
estavam de acordo quanto às grandes linhas que a administração devia seguir. Até a década de 1930, foram os grandes fazendeiros, de algum modo, os dirigentes de São Paulo. Confundia-se o interesse coletivo com o seu interesse de classe. Esse fato sociológico liga-se à geografia do movimento pioneiro. Os problemas de mão-de-obra e, consequentemente, o povoamento, os das vias de comunicação, os dos preços foram considerados e tratados acima de tudo, em função dos interesses dos fazendeiros. A marcha pioneira foi primeiramente assunto deles. (MONBEIG, 1984 [1952], p. 141. Grifo nosso.)

Primeiramente, pode-se perceber um esforço de delimitação daquilo que devia ser o assunto de interesse precípuo da análise geográfica em confinidade com o campo da sociologia, pois a liderança exercida pelos grandes fazendeiros na vida política e econômica de São Paulo até poderia aparecer como um "fato sociológico" de interesse à geografia do movimento pioneiro, mas não se constituía de maneira alguma no objeto de interesse específico para o estudo do geógrafo, isto é, a confusão entre os interesses coletivos da sociedade paulista com os interesses privados dos fazendeiros, entendidos enquanto uma classe social, era algo que teria um evidente reflexo na organização das paisagens pioneiras na passagem do século XIX ao XX, quando a monocultura que dava suporte ao "oceano de café" dinamizado a partir da grande fazenda, forma de povoamento em torno da qual se estruturou toda a vida pioneira até a década de 1930, dominava as paisagens. Entretanto, eram os elementos formadores dos cenários paisagísticos observados, e não os interesses dos fazendeiros e suas relações pessoais, o fato especificamente geográfico que deveria ocupar o geógrafo.

Demais, é importante perceber como o vocábulo utilizado para definir o objeto cientificamente observado, um "fato", seja sociológico ou geográfico, denota a filiação de Monbeig ao positivismo do método empírico-indutivo disseminado na geografia por Ratzel e La Blache, que atrela a construção do conhecimento à observação direta dos dados da realidade sensível. Em pormenor, sua definição de "fato geográfico" ilumina novamente a influência de A. Cholley na sua obra, uma vez que a noção de complexo geográfico se mostra fundamental em sua explanação. Na concepção de geografia de Monbeig, a constatação da altitude de uma montanha, a descrição da composição química de um solo, a marcação exata da localização de uma cidade ou a referência em separado a qualquer outro dado relacionado à descrição de um meio natural ou humano não eram considerados verdadeiros "fatos geográficos", uma vez que o interesse do geógrafo não deveria voltar-se ao conhecimento de grandezas numericamente quantificáveis ou dados locacionais tomados isoladamente: o mais importante era desenvolver uma visão que abarcasse a totalidade, efetuando a síntese das relações entre os grupos humanos e os meios 
naturais e examinando os conjuntos de fatores e combinações que originavam determinadas situações observáveis e localizáveis na superfície da Terra ${ }^{62}$.

Embora utilize o termo "classe social", isso não representa nenhuma forma de adesão a teses marxistas, mesmo que denote uma sensibilidade para identificar a formação de grupos de interesse na sociedade brasileira. Na verdade, na esteira da sociologia de Durkheim, com a qual teve contato sobretudo através das obras de Maurice Halbawchs, Marcel Mauss, Lévi-Strauss e Roger Bastide (DROULERS, 2006), os dois últimos seus colegas de FFCL/USP, Monbeig falava mais de "tipos sociais", o que o levou a identificar na sociedade paulista a tessitura de grupos de interesse abarcando diferentes atores. Essa atitude pode ser encontrada, por exemplo, quando Monbeig registra a existência dos "fazendeiros médios", que mesmo sem possuir a influência e os recursos econômicos dos tradicionais, participavam com estes do mesmo mundo e do mesmo "sistema", como diz, partilhando "suas maneiras de ver, sem perceber que, em mais de um ponto, não coincidiam seus profundos interesses forçosamente com o dos outros" (MONBEIG, 1952 [1984], p. 141). Como se percebe, no argumento de Monbeig a mentalidade coletiva compartilhada pelos paulistas fazia com que o pequeno e o médio fazendeiro imitassem as atitudes dos grandes proprietários, e se esses direcionavam suas atenções para o estabelecimento de grandes domínios florestais em terras do oeste do estado, que rapidamente transformavam em cafezais, os fazendeiros menos abastados:

Formavam, também eles, pequenas associações familiares, agrupando-se parentes e amigos, para realizar capitais e possuir domínios vizinhos uns dos outros. Clamavam todos por trabalhadores para suas terras, e todos participavam do mesmo espírito senhorial. Mas não gozava o fazendeiro médio da mesma independência econômica do grande plantador; dependia muito mais dos intermediários que lhe compravam o café e o revendiam aos exportadores. Não

\footnotetext{
62 "Não é a altitude das Agulhas Negras que é um fato geográfico, mas o conjunto do maciço, constituído por certas categorias de rochas, situado em determinado conjunto orográfico, submetido a certas condições climáticas que determinam certa distribuição da vegetação, originando certos modos de ocupação do solo pelo homem e tornando possíveis certos produtos. Se se quiser um exemplo da geografia humana, podemos encontra-lo na estação D. Pedro II da Central do Brasil. A estação, em si, não é um fato geográfico; o fato geográfico é o movimento dos trens, dos viajantes, das mercadorias, sua proveniência, seu destino; fato geográfico serão também as consequências da presença dessa estação na paisagem do bairro da capital onde se encontra, a circulação urbana e seu ritmo cotidiano e estacional, uma determinada localização dos ramos de comércio ligados à estação da estrada de ferro, etc. (...). O geógrafo procurará o conjunto dos fenômenos, como acima enumeramos rapidamente, e os laços que os unem e fazem deles um todo vivo. Portanto a noção de fato geográfico tal como é correntemente admitida é errônea, e deve ser corrigida (...). A pesquisa geográfica trata dos complexos de fatos e são esses complexos que, por sua localização no globo, são verdadeiros "fatos" geográficos. Cabe ao geógrafo explicar essa localização, procurar-lhe as consequências, examinando as relações, ações e interações que unem uns aos outros os elementos constitutivos do complexo geográfico. Complexo geográfico, sim, porque se localiza e porque implica em ações recíprocas mutáveis do meio natural e do meio humano." (MONBEIG, 1957, p. 9.)
} 
tinha resistência financeira que lhe permitiria suportar as dificuldades, em caso de crise econômica. Enquanto as grandes fazendas, que representavam o investimento de considerável capital, aguentavam as depressões, devia a média lavoura ser hipotecada e vendida. Retomava então seu proprietário a marcha a diante. (MONBEIG, 1984 [ 1952], p. 142.)

Aqui, relações sociais que se realizavam de forma assimétrica, desenvolvendo-se em uma estrutura social, política e econômica hierarquizada que favorecia a continuidade da dominação e da hegemonia dos grandes proprietários em detrimento dos pequenos e médios - os simples camponeses e posseiros sequer aparecem nessa descrição, embora sejam citados conjuntamente com outros tipos sociais presentes no mundo pioneiro - , não são alvo de crítica nem sequer de reparação, surgindo efetivamente no registro de Monbeig como decorrência de uma naturalizada tradição "psicológica" já existente na sociedade brasileira, como fruto do "espírito senhorial" e de uma suposta mentalidade bandeirante, encontrada entre todos, que daria fundamento a um mito “cuja eficácia psicológica é incontestável”, convertendo a escalada do desmatamento e da formação de fazendas privadas a partir do patrimônio público de terras em um episódio moderno de um fenômeno histórico que já contava com uma tradição sedimentada no instinto de aventura e no fascínio dos grandes espaços vazios, que seduziam igualmente aos antigos e aos novos bandeirantes:

Quando se quer celebrar um fazendeiro, desbravador de matas, plantador de cidades, nenhum título melhor a deferir-lhe que o de bandeirante. Diz-se tudo de um homem quando se diz que ele é um bandeirante. Levemos em conta essa ênfase bem latina e não nos espante essa promoção indireta e póstuma do bandeirante a colonizador. No dinamismo do fazendeiro-pioneiro, a massa popular encontra a lembrança da legenda do bandeirismo: a penetração pelo sertão adentro, o engrandecimento de São Paulo e do Brasil. Nos heróis de outrora, como no grande homem do momento, admira-se a mesma temeridade, a mesma sede de aventura, a mesma paixão da riqueza. Perpetua uma tradição aquele que "abre" uma fazenda e sua ação direta suscita vocações. (MONBEIG, 1984 [1952], pp. 121-122.)

Um outro aspecto a ser relembrado acerca da incorporação da memória bandeirante como parte da explicação sobre o problema da mobilidade do povoamento pioneiro, que não criava facilmente núcleos fixos de colonização nas novas áreas desbravadas, sugere que a citação do passado bandeirante como forma de qualificar as movimentações pioneiras é passível de ser compreendida como um esforço de incorporação da história, vale dizer, de seu movimento e temporalidades sincrônicas e diacrônicas, na explicação geográfica do real. Esta é, por exemplo, a opinião de Marcel Roncayolo, que considera a tese de Monbeig sobre as frentes pioneiras um estudo-modelo que coloca o tempo como dimensão essencial de uma análise geográfica 
despreocupada em respeitar estritamente os limites colocados entre as práticas disciplinares: "Pierre Monbeig encontrava-se no Brasil diante de uma geografia que estava sendo feita, uma geografia em construção, e ele se interessava por um mundo pioneiro, com problemas mas sempre em movimento, o que lhe dava grande liberdade em relação às disciplinas" (RONCAYOLO, 2006, p. 119).

Em outras palavras, ao distinguir os tipos sociais que coexistiam nas zonas pioneiras, a geografia em movimento que ele declaradamente se propõe a examinar revela a preocupação com a simultaneidade, isto é, com o que chamaríamos hoje de distintas temporalidades experimentadas simultaneamente pelos diferentes tipos sociais que ele identifica nas zonas pioneiras - colonos, camponeses, fazendeiros, grileiros, banqueiros, especuladores, entre outros , os quais demonstram as tensões, contradições e esgotamentos da marcha pioneira no entrelaçamento de escalas temporais e espaciais (RONCAYOLO, 2006).

Sem nos demorar em demasia nas relações entre a geografia e a história, seria importante frisar a proximidade de Monbeig com o historiadores do grupo dos Annales, principalmente Marc Bloch e Lucien Fevbre, seus professores em Paris e interlocutores privilegiados dos geógrafos junto às outras ciências humanas no meio universitário francês, e Fernand Braudel, é claro, amigo para a toda vida que conheceu em São Paulo (BURKE, 1997; DOSSE, 2004). Além desses nomes, cumpre lembrar que Albert Demangeon, seu primeiro orientador, é o verdadeiro responsável pela aproximação do círculo de afinidades dos geógrafos da Sorbonne com o grupo intelectual dos Annales. Com efeito, em um artigo escrito originalmente como introdução da obra Traité de Géographie Humaine, que sua morte deixou inacabada, Demangeon propõe dar um sentido à geografia humana, cujo progresso remontaria ao próprio avanço do conhecimento sistematizado sobre o globo terrestre, definindo-a, por aproximações, como o estudo dos grupos humanos em suas relações com o meio geográfico, termo que acha mais apropriado e amplo do que o genérico "meio físico", porquanto permite considerar a história da ação contínua das sociedades humanas sobre a natureza: "Ainsi les œuvres humaines issues de tout le passé de l'humanité contribuent elles-mêmes à constituer le milieu, l'environnement, le milieu géographique qui conditionne la vie des peuples. Ainsi pouvons-nous adopter comme définition de la géographie humaine l'étude des rapports des groupements humains avec le milieu géographique" (DEMANGEON, 1942, p. 29). 
Depois de definir o objeto de estudos da geografia humana, Demangeon passa a descrever os três princípios gerais que regeriam seu método: o princípio da causalidade, que age de maneira diversa nos fenômenos sociais quando comparados com a geografia física, pois os fatores naturais não exerceriam um total condicionamento das atividades humanas; o princípio que sustenta a necessidade de a geografia produzir seu conhecimento a partir de uma base territorial, visto que nenhuma sociedade pode ser estudada fora do solo que habita e lhe serve de fundamento; e o princípio que defende as vantagens de se recorrer ao estudo do passado de um grupo social para bem explicar os fatos da geografia humana:

Pour être compréhensive et explicative, la géographie humaine ne peut pas s'en tenir à la seule considération de l'état actuel des choses. Il lui fait envisager l'évolution des faits, remonter dans le passé, c'est-à-dire recourir à l'histoire. Beaucoup de faits qui, considérés en fonction des conditions présentes, nous paraissent fortuits, s'expliquent dès qu'on les considère en fonction du passé. L'histoire ouvre de vastes horizons sur le passé qui a vu se succéder tant d'expériences humaines. San elle, la raison de ce qui existe nous échapperait souvent (...). Voilà pourquoi les travaux de géographie humaine contiennent toujours beaucoup de recherches historiques, et pourquoi les géographes se rencontrent souvent, dans les dépôts d'archives, avec les historiens. Pour expliquer les faits qu'il observe, le géographe ne doit pas se contenter de les situer rationnellement dans l'espace ; il faut aussi qu'il les projette dans le passé. Aussi doit-il savoir se servir des documents historiques et savoir aussi où il peut les trouver. (DEMANGEON, 1942, p. 33.)

Decerto, a dificuldade em enquadrar uma sociedade em movimento num estudo clássico preocupado com o gênero de vida, mais adequado para descrever as paisagens de longa duração do Velho Continente, não deve mascarar a importância da história e das temporalidades no estudo de Monbeig. Esse traço da geografia por ele praticada, que se deve em grande parte à sua formação universitária, até mesmo por conta da ascendência da geografia e da obra de Vidal de La Blache na formação da geohistória dos Annales, especialmente em Fernand Braudel (BURKE, 1990; LACOSTE, 1989; RIBEIRO, 2008), certamente pesa na valorização conferida por ele à história na estruturação das paisagens, ou melhor, na definição dos conteúdos e dinâmicos que as animam - se bem que Braudel, quando se referia ao protagonismo da geografia no fazer da história, estivesse mais preocupado com as permanências impostas pela imobilidade do tempo longo (DOSSE, 2004) ${ }^{63}$.

\footnotetext{
${ }^{63}$ Já no prefácio do livro Pioneiros e Plantadores, Monbeig deixa claro essa sua opção por um caminho não convencional para a geografia francesa da época: "Tão rápidas são as transformações que tudo que se pode escrever a respeito entra logo na história. Por isso, foi o próprio movimento que eu tentei descrever e explicar; não era possível elaborar uma monografia regional, por isso procurei compor o estudo de uma sociedade em movimento, de
} 
A propósito, vejamos como Monbeig se refere ao uso da história na explicação das paisagens em duas conferências de extensão universitária intituladas, respectivamente, "Paisagens agrícolas: o exemplo do Mediterrâneo", proferida na FFCL/USP, no ano de 1937, e “A paisagem, espelho de uma civilização", realizada na mesma instituição e local, em 1939. Na primeira delas, Monbeig diz que a paisagem adquire cidadania científica plena apenas com a geografia moderna, que a constitui desde o início do século XIX como seu campo de trabalho exclusivo, o seu domínio particular, pois enquanto outros cientistas como geólogos, botânicos e arqueólogos estudam as paisagens separando as diferentes partes que as constituem, o geógrafo deve tomar todas essas partes em conjunto, analisando-as e procurando "compreender como e por quê diferentes elementos geológicos, botânicos ou arqueológicos formam um todo" (MONBEIG, 1940, p. 250).

Após esse momento inicial, Monbeig faz um questionamento, pois ao mesmo tempo em que reconhece as transformações que a chamada civilização moderna introduziu na superfície terrestre, pergunta quais seriam as transformações que devem ser atribuídas a esta civilização na organização das paisagens milenares da Europa ocidental, que parecem as mesmas desde os tempos gloriosos dos gregos e romanos. Esse ponto de partida justifica para o palestrante a escolha do Mediterrâneo como local privilegiado de suas observações, pois além de ser o berço de uma das mais antigas civilizações do mundo, é a região que abrigava o que à época se consideravam "os povos mais adiantados do planeta":

Quem diz civilização adiantada, diz quase sempre forte densidade de população e, sequência lógica, quem diz civilização evoluída, diz plantas e culturas determinadas: o arroz acompanha a civilização chinesa tal como o milho os précolombianos. Ora, encontra-se situação idêntica às margens do Mediterrâneo, nas quais a população se mantém numerosa, onde se sucederam as civilizações, sempre brilhantes e onde, desde Homero até os inquéritos agrícolas os mais modernos, veem-se pequeno número de culturas cuja técnica nunca mudou. (MONBEIG, 1940, p. 251.)

preferencia a um estudo de gêneros de vida". (MONBEIG, 1984 [1952], p. 19). Essa opção de tentar apreender uma geografia em movimento, em tudo oposta à realidade europeia, é recolocada mais à frente, na introdução do mesmo trabalho: "Espanta-se o europeu, quando ouve chamar de 'velha' uma cidade como Ribeirão Preto, que não conta três quartos de século; custa-lhe compreender que 'outrora' significa 1910 e mesmo 1920, se o seu interlocutor é um homem moço. Tudo se passa como se este país conhecesse em setenta e cinco anos, um século no máximo, o que se levou milênios para se fazer na Europa. E certamente é isso: nascimento e formação de uma paisagem rural, fundação e crescimento das cidades, construção duma rede de comunicações, mistura de raças, elaboração de uma mentalidade regional, tal o imenso trabalho que ainda prosseguia, aos nossos olhos". (Ibidem, p. 23.) 
Avançando sobre a associação existente entre as distintas civilizações e o cultivo de certas plantas, dá como exemplo acabado o trigo, cuja técnica de cultura fossilizara-se, sendo praticada desde os tempos dos agrônomos gregos e romanos de forma associada à criação, alternando-se com um pouso rotativo bienal, técnica ainda em uso em todo o Mediterrâneo. Entretanto, a partir do século XVIII, o mundo Mediterrâneo conhece uma revolução agrícola passível de "ser estudada nas paisagens modernas das regiões mediterrâneas" (MONBEIG, 1940, p.254), pois a partir dessa época novos característicos advieram às estruturas milenares. A introdução da navegação a vapor, a colonização do norte da África e a expansão de culturas irrigadas ou arbustivas fizeram com que a agricultura mediterrânea caminhasse da policultura para a monocultura, com resultados nem sempre satisfatórios, já que esses novos empreendimentos, com seus imensos campos monocultores de vinhas, oliveiras, pêssegos ou laranjas, culturas que necessitam de grandes capitais para serem praticadas, são "verdadeiros negócios que nada têm a ver com a pequena cultura individual cantada por Hesíodo" (Ibidem, p. 257).

Ao compreender as novas formas de financiamento introduzidas na Europa no final do XIX como um fator de desequilíbrio, que transformava paisagens de agricultura milenar em áreas de modernos latifúndios monocultores, Monbeig criticava a especialização exacerbada das culturas comerciais atreladas exclusivamente aos mercados, sempre instáveis, notando os inconvenientes da monocultura, que perturbaria o equilíbrio social e requereria, no mais das vezes, intervenção do Estado ou órgãos de controle, como de fato ocorreu com as crises de superprodução da vinha na França e com o café em São Paulo. Analisando a situação conforme ela se apresentava em meados da década de 1930, ele observava na Europa indícios de um novo equilíbrio "entre a paisagem da agricultura industrial e a paisagem rural da tradição" (MONBEIG, 1940, p. 260), entrecruzamento de paisagens de idades diferentes que revela o espaço como palimpsesto, digamos (SANTOS, 1997), já que Monbeig coloca em evidência o caráter processual da evolução das paisagens reiteradamente modificadas pelos grupos humanos ao longo da história, embora o faça num enquadramento claramente evolucionista.

Nessa direção, Monbeig afirma que um dos exemplos cristalinos da evolução das paisagens devido ao avanço das técnicas de intervenção humana podia ser encontrado exatamente em São Paulo, onde, num período de duas a três décadas, as paisagens simples e monótonas das fazendas de café escravocratas, tradicionalmente monocultoras, cediam lugar a uma paisagem mais equilibrada, com laranjais, terras aradas para o algodão ou campos com hortaliças, produtos 
agrícolas que "não sustentam a exportação da fazenda, mas contribuem à melhoria sensível do nível de vida de seus próprios habitantes e da coletividade nacional. Os riscos das variedades de cultura compensam-se e a fase puramente especulativa da agricultura tende a evoluir" (MONBEIG, 1940, p. 261).

Essas considerações acerca da agricultura comercial do Mediterrâneo, sem dúvida apoiadas nos estudos regionais que Monbeig havia desenvolvido em seus tempos de estudante (SALGUEIRO, 2006), foram retomadas e desenvolvidas na conferência posterior, que cunha em seu título uma expressão que resume em termos precisos as indicações metodológicas de La Blache, quais sejam, a de se tomar a paisagem como um "espelho da civilização", isto é, como o reflexo do nível de desenvolvimento técnico de uma sociedade ou povo, consequência do domínio progressivo exercido por um grupo humano sobre uma área natural que lhe serve de espaço de vivência ao longo da história. De fato, ao notar que a geografia moderna recobra com vigor o interesse científico sobre as paisagens, documentação geográfica verdadeiramente humana, que revelam a ação das sociedades sobre o meio natural, Monbeig diz, na conferência de 1939, que "A história e o método do historiador de hoje podem levar-nos a uma explicação: para julgar-se uma obra humana é necessário recolocá-la no seu meio histórico" (MONBEIG, 1940, p. 234).

Fornecendo uma descrição ampla de diferentes paisagens culturais surgidas na Europa ao longo dos séculos, Monbeig ora sugere a existência de habitats semelhantes que se apresentam em tipos variados de terrenos e regiões naturais, ora delineia habitats muito desiguais desenvolvidos em um substrato territorial homogêneo, sutileza retórica que tem por finalidade explicitar uma crítica nada velada ao determinismo geográfico, que para ele pecaria por dar um sentido único à relação entre homem e meio natural, com cada região servindo de base territorial perfeitamente encaixada aos gêneros de vida que nela florescem ${ }^{64}$. Em um estilo de

\footnotetext{
64 “Tudo ia bem, na melhor das geografias. E todas as ações dos homens em relação ao meio se desenvolviam num quadro geográfico facilmente demarcado: a região natural. Compreendia-se assim, sem dificuldade, que os gêneros de vida montanheses se desenvolvessem e prosperassem no vale alto dos Alpes ou dos Andes; que a zona situada entre os isotermas e isoietas $x$ e $v$ encerrava a mesma atividade humana e correspondia exatamente a certo tipo de casa. A região natural constituía inexoravelmente a base territorial dos gêneros de vida. Mas esta concepção geográfica, que tem qualquer coisa de tragédia clássica pela preocupação da unidade, foi logo desmentida pelos fatos; à medida que os geógrafos amontoavam, nas prateleiras das bibliotecas, monografias preciosas e eruditas, eles eram levados a constatar que o determinismo falhava muitas vezes, que os fatos desmentiam as teorias. Ao lado das forças naturais como a chuva, o vento, o mar, o vulcão, aparece outra força natural, o homem. O homem, que, com seus utensílios, a inteligência que lhe guia as mãos, é capaz de transformar a tal ponto o meio natural que, aquilo que tomamos atualmente por uma paisagem obra da natureza, não é senão o cenário construído por ele. Tornava-se cada dia mais evidente que a ação geográfica dos homens se exercia como se exerce o talento do arquiteto urbanista, que
} 
argumentação que passa em revista um sem-número de exemplos, por certo válidos para enriquecer o conhecimento de sua plateia sobre a realidade europeia, "onde desde milênios são elevadas as densidades humanas e os homens tiveram tempo de modelar a natureza e criar paisagens de civilização" (MONBEIG, 1940, p. 244), Monbeig ilustra a escolha do título de sua conferência citando a Inglaterra, cuja paisagem de open field, nítida aos camponeses do século XVI, transformara-se no século XVIII, durante a Revolução Industrial, na paisagem dos enclosures: "Dois períodos da história do povo inglês, dois tipos de paisagens culturais" (Ibidem, p. 243).

Ao final, num exercício prático do tradicional princípio da analogia legado por La Blache e De Martonne, Monbeig indaga aos ouvintes acerca da validade científica em se estabelecer, para países novos e de povoamento rarefeito como o Brasil, “onde as civilizações conservaram-se primitivas [e] (...) nos quais a vitória dos homens sobre a natureza data de ontem, de hoje mesmo" (MONBEIG, 1940, p. 244), as mesmas relações entabuladas entre o nível de desenvolvimento das técnicas, o peso das conjunturas históricas e a formação de paisagens que embasam a descrição explicativa dos dois tipos distintos de paisagens culturais inglesas antes mencionadas.

Nesse caso, a análise das paisagens modeladas nas chamadas "regiões novas", alvo prioritário do dinamismo pioneiro, apareceriam como o caso de maior interesse para os geógrafos, que em viagens separadas por poucos anos de diferença conseguiriam surpreender empiricamente os progressos efetuados nas paisagens de antanho, pois entre o final do século XIX e as primeiras décadas do XX novos cenários e relações sociais foram criados, deixando para trás um recente passado colonial com a mesma rapidez com que se derrubavam florestas e se abandonavam antigas fazendas com solos esgotados. Ao fim e ao cabo, quando da feitura dessa conferência, em 1939, a composição de um estudo que versasse sobre uma sociedade em movimento estava ainda em gestação, e iria ainda amadurecer até as reflexões atingirem o nível entrevisto em seu doutorado - mas a senda aberta seguia um rumo seguro, embasado num caminho metodológico já há muito pavimentado:

transforma o ingrato arrabalde industrial urbano em uma sequência de parques verdejantes, como o arquiteto desenhista de jardins cria uma paisagem amável no lugar onde se erguia uma floresta frondosa. A ação dos homens sobre a paisagem natural foi então comparada à de jardineiro de tal modo familiarizado com o espetáculo que tem sob os olhos que chega a esquecer o quadro natural. Assim, os parisienses que vão da Avenida da Ópera ao Banco da França ali vizinho, não suspeitam que atravessam um meandro do Sena o qual, entretanto, subsistiu bastante tempo e os grupos de rapazes e moças que passeiam pela Avenida Paulista nem de leve pensam que seus avós poderiam caçar ai há algumas dezenas de anos.” (MONBEIG, 1940, pp. 236-237.) 
$\mathrm{Na}$ fazenda clássica tudo se agrupava à vista do dono: a sede era sempre cuidadosamente localizada em ponto elevado para abranger-se o conjunto de instalações: terreiros e máquinas de beneficiar, ao mesmo tempo que as longas e tristes filas das colônias. A plantação de café tal como nos descreve Pierre Dennis em seu "Brasil no Século XX", tal como existe ainda, é um vasto domínio diante do qual o historiador não pode deixar de pensar nos domínios feudais. Tal paisagem exprime portanto uma estrutura social caracterizada e uma economia ainda colonial em muitos de seus traços. Em 1939 a paisagem paulista sofreu transformação completa. Seria suficiente para convencer-se disto, percorrer uma destas gloriosas e vastas fazendas abertas nas intermediações de Ribeirão Preto na época heroica: o cafezal já não se estende uniformemente em todos os solos; seus detritos cobrem a terra nos lugares onde ela não lhe dá rendimentos suficientes para equilibrar o preço de produção, refugia-se na verdadeira terra roxa e o restante da propriedade passa para o algodão, à laranja, à mandioca, ao arroz e à criação. Uma paisagem fragmentada, mas mais adaptada às condições geográficas, substitui-se às extensões uniformemente plantadas dos anos 1890-1900. Não somente a paisagem se anima pelos coloridos variados das diversas culturas, como se povoa pela divisão da grande fazenda: os pequenos proprietários ou mesmo os meeiros que tomam o lugar do antigo fazendeiro, vencido pelas crises econômicas, quebram o velho molde da colônia; cada um vai viver em sua própria terra a colônia cai em ruínas e nas pequenas casas isoladas, novo tipo de "habitat", surge em cada lote. Nas zonas novas da Noroeste ou de Marília, encontram-se lado a lado a fazenda tradicional com seu cafezal e as casas isoladas dos colonos japoneses, construídas a meia-encosta, acompanhando a curva de nível. Coexistência de dois tipos de "habitat", de duas estruturas sociais que se concretizam na paisagem. Por vezes, ao contrário, o viajante descobre índices do recuo da pequena propriedade: minúsculos terreiros de chão batido invadidos por ervas daninhas, casas de pau a pique em ruínas, pomares sufocados pela capoeira e gado que pasta em cafezal abandonado. Extraordinária variedade atual das paisagens paulistas, que bem pouco corresponde o que esperava o europeu, à fé de narrativas já velhas de 25 anos, mas que é o reflexo das profundas e surdas revoluções agrárias. Duas épocas da história paulista, dois tipos de paisagens paulistas. (MONBEIG, 1940, p. 247. Grifo nosso.)

Com efeito, esse enquadramento seria retomado em sua tese de doutoramento, adicionando-se ainda a mentalidade dos fazendeiros entre os fatores geográficos que explicavam as alterações ocorridas no conteúdo das paisagens ao passar do tempo. Nesse trabalho, as progressivas modificações verificadas nas direções e no conteúdo das frentes pioneiras em momentos distintos, do final do XIX ao início do século XX, e desta época aos anos que se sucedem à crise de 1929, ilustram claramente como as mudanças substanciais pelas quais passava a sociedade brasileira tiveram um imediato reflexo no processo de organização espacial do mundo pioneiro, dando origem a dois tipos distintos de paisagem: um tipo de paisagem residual mais ligado ao antigo mundo dos senhores de escravos, que se concentrava nas chamadas "regiões velhas", e um outro tipo de paisagem moderna, o das "regiões novas" do oeste paulista, 
que mesmo mantendo ainda a grande fazenda como forma básica de ocupação do solo, já dava sinais de alterações em seu conteúdo.

Sendo assim, se na época da primeira grande crise de preços sofrida pelo café, ocorrida em 1905, a franja pioneira, alimentada pela "sede de terras novas e a paixão em aumentar as plantações" (MONBEIG, 1984 [1952], p. 177), podia ser compreendida como uma mera continuidade do movimento que se iniciou no século XIX nas terras montanhosas do Rio de Janeiro, subiu pelo vale do rio Paraíba em direção a São Paulo, passou pelos contrafortes ocidentais da Mantiqueira, na região de Bragança Paulista, e avançou pouco a pouco pelas escarpas da depressão periférica, em direção a Jundiaí, Campinas e Limeira, onde se deteve brevemente antes de finalmente dominar os planaltos a oeste, isso não era mais verdade para as décadas de 1910 e 1920, quando as frentes pioneiras já haviam ultrapassado as manchas basálticas de terras roxas de Ribeirão Preto e Araraquara, alcançando os limites administrativos de São Paulo:

Mas o quadro físico não era o mesmo e, o que é mais significativo, tendo as instituições sociais evoluído, as marcas deixadas pelo homem na paisagem haviam mudado (...). Tudo era feito com uma distribuição astuciosa do terreno: os pastos ocupavam os fundos dos vales, enquanto o café monopolizava os melhores solos e os pontos altos, menos sujeitos às geadas. Nada disto era novo ou original, mas o tipo mesmo da plantação colonial girando em torno de um só produto comercial. A grande propriedade era a regra na franja pioneira e o grande senhor, o latifundiário, continuava a ser o pioneiro do café, como já o havia sido no vale do Paraíba, nos arredores de Campinas ou no relevo montanhoso de Amparo (...). Mas não se poderá, igualmente, surpreender aí a imagem de uma sociedade aristocrática rural? $\mathrm{O}$ velho fazendeiro raramente ia à cidade e sua numerosa família habitava permanentemente essa espécie de castelo (...). O fazendeiro comandava pessoalmente a colheita, assim como o transporte dos grãos de café, sua secagem e preparação (...). A concentração das construções junto à casa do fazendeiro, se facilitava a vigilância, concretizava e consolidava os laços que se formavam (...). Mas a fazenda pioneira dos planaltos é bem diferente: é uma empresa ao mesmo tempo agrícola, industrial e comercial (...). Como homem de negócios, o fazendeiro do século $\mathrm{XX}$ deve habitar tanto a cidade como a fazenda. Sem negligenciar completamente o trato da terra, ele delega esse cuidado, cada vez mais, a um administrador, empregado de sua confiança (...). À nova estrutura e à psicologia social novas, corresponde um novo tipo de habitat (...). Existe, ao mesmo tempo, dispersão e estiramento de todas as construções. O viajante abarcava, com uma só visada, todos os elementos da velha fazenda. Agora, para visitar o núcleo da sede, ele deve circular por ruas sinuosas, alternadamente poeirentas ou lamacentas, de um verdadeiro povoado. A rigorosa segregação social que correspondeu ao esplendor da antiga unidade, baseada na escravatura, e os laços que uniam outrora todas as partes da fazenda, foram, uns e outros, dissociados. Tudo isso contribuiu para diferenciar a franja pioneira dos 
planaltos ocidentais, tal como ela se apresentava nos primeiros anos do século, das demais regiões cafeicultoras paulistas ou fluminenses. (MONBEIG, 184 [1952], pp. 177-178-179. Grifo nosso.)

No excerto supracitado, embora possamos identificar uma primeira modificação na organização do espaço pioneiro, impulsionada pelo caráter empresarial das fazendas dos planaltos ocidentais, que organizava paisagens mais heterogêneas, contrastando com a rigidez do mundo senhorial das antigas fazendas escravocratas, alguns traços se mantém sólidos, pois a grande propriedade e os fazendeiros continuavam comandando a marcha dos pioneiros no início do século XX. Contudo, algumas diferenças substanciais já podiam ser notadas na marcha dos pioneiros, como o fato de o avanço se dar também em terrenos situados para além das áreas basálticas das terras roxas, na faixas de solos férteis dos espigões, em áreas vizinhas de pastos há muito dedicados à criação de gado ${ }^{65}$. A chegada dos pioneiros a regiões produtoras de gado, coincidiu com uma conjuntura internacional propícia, pois além do crescimento populacional verificado no estado de São Paulo, que garantia novos consumidores para os gêneros alimentícios produzidos nas fronteiras em expansão, a época da I Guerra (1914-1919) havia requisitado ao Brasil, bem como aos países Platinos, o fornecimento de carne em conserva ou congelada, "houve, portanto, a feliz coincidência da abertura de um grande mercado e da chegada do movimento pioneiro até zonas propícias à criação de gado ou até as vizinhanças dos tradicionais criatórios de Mato Grosso, Goiás e do Triângulo Mineiro” (MONBEIG, 1984 [1952], p. 182), que tiveram sua produção em muito beneficiada pela construção dos frigoríferos de Barretos, no ano de 1913. Outra tendência de modificação de suma importância que esboça seus traços por essa época, é o desenvolvimento da pequena propriedade, que revelava um dos traços mais originais das zonas pioneiras nos anos imediatamente anteriores à crise de 1929, a saber, a coexistência dos sítios e pequenas propriedades dos recém-chegados imigrantes com a tradicional

\footnotetext{
${ }^{65}$ Esse trecho resume bem como sua visão da geografia como uma ciência de síntese, que visava esclarecer as influências reciprocas entre meios naturais e os grupos humanos, fornece um embasamento naturalista ao entendimento das relações sociais: "Os planaltos ocidentais foram submergidos pela marcha para oeste, desencadeada entre os anos de 1870 e 1880 , a ponto de deter-se atualmente. O lendário sertão paulista cedeu lugar às plantações de café, depois às culturas alimentícias e de algodão, ao mesmo tempo que se aprimorava a criação com as invernadas. Cidades, estradas de rodagem e de ferro ocupam o que foi o Far West de São Paulo. A unidade natural parece corresponder a um episódio da conquista do solo, conquista essa que não foi fácil. Nos espigões, a febre amarela silvestre e a leishmaniose ainda ameaçam os pioneiros, que evitam os vales maleitosos. É um último traço a assinalar, este permanente contraste entre planaltos e vales. Os homens, suas culturas e as vias de circulação concentram-se nos espigões, nas encostas e nos ressaltos que, muitas vezes, os interrompem. As margens dos rios exercem ainda menor atração, ainda quando atravessam boas manchas de terra roxa. O homem delas se afasta não apenas com medo da malária, mas também das geadas prejudiciais ao café, a principal cultura dos planaltos ocidentais". (MONBEIG, 1954, p. 195.)
} 
fazenda, fato ligado à evolução dos meios de comunicação e à ampliação dos loteamentos, rurais e urbanos ${ }^{66}$.

Como quer que seja, podemos dizer que Monbeig aconselhava aos geógrafos, sobretudo os iniciantes, que renunciassem às explicações simplistas, evitando os caminhos limitados de uma observação unilateral dos fatos: recorrendo a Max Sorre e André Cholley, seus antigos professores, lembrava ele que a complexidade dos fenômenos sociais remetia à possibilidade de se associar com maior assiduidade o estudo dos modos de pensar com a tradicional preocupação dos geógrafos com os inquéritos sobre os gêneros de vida, de vez que os "modos de sentir e modos de pensar têm seu lugar na história das civilizações” (MONBEIG, 1957, p. 26). Ao conferir importância aos fatores psicológicos e espirituais, intrínsecos ao entendimento do conceito de gênero de vida e fundamentais no desvendamento das maneiras materiais de viver, Monbeig acenava com a possibilidade de não subestimar os fatores de ordem moral, tão importantes para a compreensão do processo de formação das paisagens e de suas dinâmicas quanto os mecanismos econômicos, o quadro físico ou o comportamento da população, mas sequer cogitava a hipótese de "proclamar a primazia da mentalidade e conceder-lhe a priori uma espécie de primazia na explicação geográfica” (Ibidem, p. 30). Em resumo, o progressivo desenvolvimento das pesquisas em ciências humanas recolocava a questão das mentalidades e das formas de sentir e pensar no processo de construção da realidade:

Reabrir o debate entre o ovo e a galinha a propósito das estruturas econômicas e das superestruturas mentais não nos levaria a nenhum resultado; mas demonstrar o mecanismo que as reúne e investigar suas origens e consequências geográficas seria frutuoso (...). Torna-se necessário que o homem seja considerado outra coisa além de uma casa, de um trator ou de uma estatística. Se o homem, o homem em sociedade, constitui o centro da Geografia Humana, deve aparecer de maneira total, com seus modos de vida e com seus modos de pensar, que afinal se confundem. A limitada tarefa dos geógrafos deve consistir em explicar a parte dos fatores geográficos na formação e evolução dos modos de pensar, e das influências que eles exercem sobre os modos de vida e o peso que estes

\footnotetext{
66 “Entre loteamentos sobravam, às vezes intactas, grandes áreas de florestas (...). A devastação da mata sempre fora feita de maneira dispersa, mas jamais essa dispersão foi mais flagrante. A causa principal desse fato foi a estrada de rodagem, que ajudou a venda dos loteamentos e permitiu que se levassem as queimadas a maiores distâncias. A estrada contribuiu, assim, para exagerar um traço permanente da paisagem pioneira: a desordem, pela mistura de grandes plantações com pequenos cultivos e com trechos de floresta poupados provisoriamente. Dessa forma, a paisagem pioneira tornou-se incessantemente mais heterogênea, e o mundo pioneiro mais complexo. Etnicamente, diversificou-se com a chegada de novos imigrantes europeus, asiáticos e 'baianos' cada vez mais numerosos. Socialmente, tornou-se mais complexa, com a instalação dos sitiantes e o aparecimento de novos tipos humanos, como os caminhoneiros, os comerciantes de beira de estrada, os loteadores de terras, os criadores e tropeiros, ao lado dos tipos clássicos do fazendeiro e do colono. A cidade e o pequeno povoado rural assumiram uma importância desconhecida até então.” (MONBEIG, 1984 [1952], pp. 203-204.)
} 
representam sobre aqueles. Dar mais atenção a estas pesquisas significará enriquecer a contribuição que a Geografia Humana pode ser capaz de trazer ao conhecimento do social. (Monbeig, 1957, pp. 30-31-32. Grifo nosso.)

Como dissemos acerca dos "fatos geográficos", fica claro que Monbeig busca enredar o desenvolvimento dos "modos de pensar" aos fatores que constituem a combinação momentânea de elementos expressa por um determinado complexo geográfico, conferindo um pouco mais de profundidade ao velho tema das influências do meio nos grupos humanos, agora transmutado nas relações entre as estruturas econômicas em sua realidade terrestre (o meio geográfico já construído) e as superestruturas mentais próprias de cada gênero de vida. Ao fim, é a instabilidade do mundo pioneiro, entrevisto na ausência de arraigamento (SORRE, 1955), do apego intransigente à terra e ao pays, caracteres comuns a um observador acostumado com as imutáveis paisagens rurais francesas, que surpreende o geógrafo em suas sondagens sobre as migrações paulistas. Nesse arranjo, a psicologia bandeirante pode ser vista como parte do esforço de compreensão da extrema mobilidade que caracterizava as zonas pioneiras, ou, como diz, da atração que a convicção da fortuna a ser conquistada, aliada à existência de grandes espaços "livres", exercia na população pioneira, que não se fixava por muito tempo nas terras que desbravava.

Dito de outro modo, quando o geógrafo francês incorporava à sua explicação certos aspectos da mentalidade coletiva pioneira, tal como a enxergava no desmedido gosto do lucro, no fascínio das terras desocupadas e no espírito de aventura, epítomes modernos do imemorial mito do Eldorado e qualidades comportamentais atribuídas aos latino-americanos por outro informante estrangeiro com muita influência na geografia brasileira, o americano Preston James - que desde a década de 1930 se detivera na análise dos problemas relacionados ao povoamento e colonização do Brasil e outros países latino-americanos (JAMES, 1942) -, ele aceitava a visão acrítica de James em relação aos mecanismos sociais de dominação e expropriação presentes no processo de açambarcamento de terras por uma classe social específica, que originaram os grandes domínios do café ainda existentes no início da década de 1930, aproximando-se de fato da concepção que os grandes fazendeiros tinham da massa dos migrantes, mesmo que numa tentativa de tornar mais completa sua descrição das paisagens. Nessa direção, Ozouf-Marignier (2006) considera que o empenho de Monbeig em valorizar a psicologia como um dos fatores explicativos das movimentações pioneiras tinha o intuito de sublinhar o peso da memória coletiva e das representações mentais no processo de organização das paisagens, adicionando o fator subjetivo 
às condições naturais, geográficas e econômicas que explicariam a marcha pioneira. Inspirada nos trabalhos de Lucien Febvre, Pierre Deffontaines e Georges Hardy, a geografia psicológica de Monbeig inscreve-se num tipo de abordagem que iria se generalizar somente algumas décadas depois:

É bem verdade que os geógrafos não se acham preparados para os estudos de mentalidades. Eles sabem disso e recusam-se a experiências audaciosas (...). Um das melhores justificativas para essa prudência incomum encontra-se no temor da má literatura, terreno para onde poderia descambar uma geografia das mentalidades. Uma certa geografia psicológica ocasionou, noutros tempos, a vigorosa indignação de Demangeon, que possuía bastante bom senso para não se deixar levar num turbilhão de fatos e de idéias. Não se trata de defender uma nova Geografia, psicológica ou não, e, ainda menos, de torná-la o coroamento da Geografia Humana (...). O esforço para penetrar e compreender as maneiras de pensar do grupo estudado torna-se ainda mais necessários se elas diferem das nossas. Cholley observou que uma das dificuldades da Geografia Humana, desconhecida na Geografia Física, consiste no fato de que exige julgamentos de qualidade. Por isso mesmo, torna-se preciso ter cuidado em não julgar em relação a si mesmo. O pecado do "europeu- centrismo" tão corrente nos estudos de Geografia Física, é ainda mais temível para a Geografia Humana, que se afasta de nosso continente. Não estamos acostumados a constatar a oposição dos sábios provérbios de nossos camponeses às práticas culturais dos agricultores tropicais? E, no caso, trata-se apenas de técnica do solo (...). A percepção de um modo de pensar radicalmente diferente do nosso exige, se não uma certa convivência, pelo menos um sério esforço da parte do pesquisador. Se este o esquece, cometerá um pecado que, para ser situado no espaço, deverá ser comparado no mínimo aos pecados do anacronismo, de que fala Lucien Febvre. (MONBEIG, 1957, pp. 29-30-31.) ${ }^{67}$

Para ele, a mentalidade coletiva pioneira, que não se reduz à "psicologia bandeirante", diria então respeito às influências recíprocas que relacionavam as paisagens pioneiras aos modos de pensar e aos gêneros de vida em desenvolvimento nos planaltos paulistas, tal uma predisposição subjetiva que influiria na estruturação do complexo geográfico, visto que ao lado dos fatores econômicos, do esgotamento dos solos e da pobreza generalizada, a "psicologia" dos pioneiros poderia também dar sentido aos constantes deslocamentos espaciais dos trabalhadores e às

\footnotetext{
67 "Nesse conjunto heterogêneo de geógrafos voltados para questões de psicologia distinguem-se, entretanto, referências e práticas comuns. Não é por acaso que todos citam Siegfried, Mauss ou Friedman e fazem alusões uns aos outros. Falar em rede seria exagero, mas evidencia-se uma cadeia de relações que não exclui formas de troca e transmissão. A expatriação de longa duração fora da Europa é uma situação que parece adquirir uma significação particular: a África do Norte para Jean Brunhes, a AOF [África Ocidental Francesa] e depois a África do Norte para Hardy, o Brasil para Deffontaines e Monbeig, deram oportunidade de experimentarem a parcial inadaptação das ferramentas conceituais e metodológicas forjadas para os territórios europeus. O encontro da alteridade suscita de maneira privilegiada o recurso à explicação pela mentalidade, que não se impõe tanto na observação das situações familiares.” (OZOUF-MARIGNIER, 2006, p. 83.)
} 
mudanças efetuadas na pauta produtiva de pequenos e médios fazendeiros, que, imitando os grandes negociantes, sempre procuravam o nicho de mercado no qual pudessem obter os maiores lucros. É claro que esse tipo de análise, em muitos aspectos, pode ser sem prejuízo considerada uma forma de naturalização da dominação exercida na época pelos grandes proprietários de terras, banqueiros, especuladores e demais tipos sociais colocados pelo próprio Monbeig no alto da pirâmide da estrutura social da sociedade pioneira. Realmente, a sobredita naturalização das relações sociais hierarquizadas explicita-se mesmo quando o geógrafo francês está a descrever algumas das formas assumidas por esses mecanismos de dominação através de alusões aos "fatores psicológicos" presentes no mundo pioneiro, mas, paradoxalmente, o próprio fato de Monbeig identificar na sociedade paulista a existência de relações desse tipo relativiza até certo ponto a tese de sua assunção completa ao modo como os fazendeiros enxergariam o mundo, pois mostra sinais de sua não concordância com algumas situações identificadas na realidade tal como ela se lhe apresentava.

Expressivamente, no capítulo de sua tese dedicado às "Cidades Pioneiras", há uma seção inteira intitulada "Os fatores psicológicos e o papel dos indivíduos". Ali, depois de haver descrito as motivações locacionais (de sítio e de situação), econômicas (vantagens de financiamento pelos fazendeiros instalados), naturais (existência de solos mais férteis) e estruturais (disponibilidade de uma rede de transportes eficiente) que favoreceriam a proeminência do desenvolvimento de algumas cidades, tornadas "capitais regionais", em detrimento de outras, que passavam a orbitar na esfera de influência das primeiras, Monbeig diz que também as influências provindas "da própria pessoa do fundador" ou "da psicologia coletiva dos pioneiros" seriam responsáveis por fazer de loteamentos recém-abertos nos sertões vilas urbanas de sucesso ${ }^{68}$. Para justificar essa informação, Monbeig diferencia os objetivos das grandes empresas de colonização, que abriam loteamentos rurais com o intuito de criar uma fonte de lucros, associando-se direta e indiretamente com as indústrias da capital, os bancos, as casas de comércio de exportação e demais interessados em estabelecer uma atividade econômica com retorno financeiro garantido, das finalidades que os grandes fazendeiros vislumbravam na fundação de um loteamento urbano:

\footnotetext{
68 “As cidades que, em cada um dos espigões, vieram a ser pequenas capitais regionais, São José do Rio Preto, Araçatuba, Marília, Presidente Prudente e Londrina, não o deveram só às condições naturais mais favorecidas, porém às circunstâncias econômicas e sociais: os sucessos urbanos eram ao mesmo tempo o triunfo dos indivíduos e, em tal sentido, a geografia humana da franja pioneira é o fruto da sua estrutura social e econômica." (MONBEIG, 1984 [1952], pp. 357-358. Grifo nosso.)
} 
Não é raro que contribuam as ambições políticas para mudar um grande plantador em fundador de patrimônio. Nisso vê ele excelente ocasião para tornar-se popular, aumentar seu prestígio político e formar seu feudo eleitoral (...). Conjugam-se tais intenções com os direitos que se pode ou se pretende ter à propriedade do solo: o poder político reforça tais direitos e se adquire quando se constitui uma ampla clientela urbana. O patrimônio aberto por um chefe político aproveita-se das relações deste com o governo e com a administração pública. Serão, assim, mais facilmente e mais rapidamente atendidas as suas promoções para os trabalhos urbanísticos e a publicidade no jornal e no rádio. Podem-se medir os efeitos desse fato, ao constatar que na maior parte do tempo, as pessoas da terra associam o nome de um homem político a dos centros urbanos mais importantes (...). Depende, pois, do "manda-chuva" a sorte de um patrimônio, a favor do qual emprega todo o seu talento e toda a sua iniciativa, faz uso de uma consumada arte da publicidade e põe em jogo todas as suas relações. Não pode ser subestimada a eficácia desses atributos individuais e dessas influências pessoais, eficácia que se desenvolvia livremente, numa sociedade em que o controle administrativo e a direção política permanecem ainda nas mãos de uma minoria, que frequentemente confunde o seu enriquecimento com o da coletividade (...). Pouca gente, aliás, surpreende-se com tais métodos, nem se aventura a formular julgamento sobre essas especulações de grande envergadura ou sobre o controle da economia urbana por um só indivíduo. No fundo, são mais admirados que censurados os poderosos da terra, que a gente modesta imita, em sua humilde esfera. A especulação atrai especulação. Assim, procura comprar, vender, resgatar e revender casas e lotes urbanos, aproveitando a excelente publicidade feita em torno do patrimônio, pelo seu dinâmico fundador. (MONBEIG, 1984 [1952], pp. 354-355-356.)

É a partir do reconhecimento do caráter ao mesmo tempo mercantil e político envolto na fundação das cidades, pensadas como mercadorias, que se pode compreender a menção à eficácia da propaganda e ao poder da imprensa, que incensava deliberadamente a habilidade comercial de certos figurões com ambições políticas, lembrava as qualidades excepcionais dos solos de um loteamento recém-aberto ou sublinhava o lucro sem erro conferido pelo plantio de um novo produto, incitando outros a seguirem os exemplos das histórias celebradas ${ }^{69}$. Essa propensão à imitação, aliás, generalizando-se entre todos os partícipes da febre pioneira, brasileiros e estrangeiros, foi descrita no caso do cultivo das amoreiras para a criação do bicho-da-seda,

\footnotetext{
69 "Pode então a publicidade desdobrar todos os seus artifícios, oferecendo aos últimos hesitantes a massa de argumentos que os decidirá, por sua vez, a vir engrossar a população da cidade nova. São enviados agentes recrutadores, que percorrem às velhas zonas; podem eles anunciar os primeiros progressos da urbanização; exaltam a valorização das terras; longe de dissimular os grandes golpes da especulação, revelam-lhe todos os pormenores. Dos grandes jornais da capital, obtêm-se reportagens ou páginas especiais. E se o fundador merece a confiança do governo, então é o jornal do partido no poder que se encarrega dessa propaganda tanto mais eficaz, quanto nela se vê a chancela oficial. Nos trens, nos bares, cartazes com slogans enfáticos proclamam belezas e riquezas da nova cidade. Lança-se uma cidade, como se lançaria uma moda, com grandes golpes de propaganda. Os primeiros compradores de terrenos eram comerciantes que tinham sido atraídos. Os que os seguiram, vinham em busca de bons negócios. E por fim, exatamente como se torna popular a moda, depois de adotada por uma minoria, afluíam então para o jovem centro urbano pessoas de todas as classes sociais e de todas as regiões, novas ou velhas." (MONBEIG, 1984 [1952], p. 357.)
} 
incentivada no momento em que a II Guerra havia obstado a produção do Japão, mas que caiu em desgraça após o fim do conflito. As tentativas de lucrar com a seda, percebida com vantagens entre os colonos de origem japonesa e italiana, foi sucedida pelos investimentos a fundo perdido feitos no cultivo da menta, e até mesmo a mandioca, produção de subsistência básica do mundo rural brasileiro, contou com uma ação de contrapropaganda de clara origem estadunidense, que entre 1943 e 1944 tentava desviar as atenções dos lavradores paulistas da cultura de algodão, então em processo de franca recuperação nos campos dos EUA:

Tentativas decepcionantes como essas não teriam mais do que sabor anedótico, se não evidenciassem a permeabilidade do mundo pioneiro a toda propaganda montada para seduzir com a esperança de lucros desmesurados. O pioneiro aposta em uma cultura, da mesma forma como joga na loteria, com a mesma ingenuidade e o mesmo ardor, talvez porque não possa contar com uma melhora progressiva da sua sorte. A obstinação com que seus antepassados cultivaram oliveiras ou arrozais, ele a coloca no empenho com que persegue a fortuna, através de tentativas dirigidas para produtos diferentes; mas a essência permanece a mesma. A infatigável resignação campesina é secundada aqui pelo entusiasmo do desbravador, porque é sabido que a fortuna não vai parar às mãos do preguiçoso e que o pioneiro é um trabalhador rude. O provérbio diz: "quem vai na frente não bebe água limpa"; e tudo é uma questão de audácia e oportunidade, porque nada é estável. (MONBEIG, 1984 [1952], pp. 319-320.)

Assim, se ao lado da "infatigável resignação campesina" e do "entusiasmo do desbravador" Monbeig igualmente observa que a existência da "mentalidade de jogador" dos pioneiros é um fator que pode justificar a instabilidade e a extrema itinerância do povoamento, ele acaba por relativizar tal afirmação, mostrando que "seria, de resto, inexato levar exclusivamente à conta do gosto do lucro a facilidade do paulista em deixar seu estabelecimento para ir fundar outro, não menos efêmero que o primeiro. No fundo, a principal responsabilidade por esse nomadismo pioneiro recai sobre a estrutura econômica" (MONBEIG, 1984 [1952], pp. 122-123).

A propósito, vejamos trechos de textos distintos que mostram a permanência da opinião de Monbeig a respeito da instabilidade da ocupação pioneira, característica comum aos cinturões pioneiros de todos os continentes, que é compreendida por ele como o resultado de uma combinação complexa de fatores naturais e humanos, dentre os quais a mentalidade, que podia obviamente ser utilizada para qualificar de modo pejorativo os camponeses, não era o mais importante, colocando-se como um adorno na descrição da paisagem, um fator subjetivo a completar a realidade imposta pelos solos esgotados, por uma exploração predatória da terra e por uma estrutura econômica por demais dependente das variações do mercado: 
A terra tropical, frágil e maltratada por homens que têm pressa em enriquecer, é a primeira responsável pela instabilidade. Mas os resultados não seriam tão graves sem as próprias responsabilidades dos homens: a ignorância dos sitiantes, a incerteza muito frequente quanto aos títulos de propriedade, a pobreza, a desorganização do crédito, o controle do comércio por alguns grupos, tanto brasileiros quanto estrangeiros e a força da especulação. (MONBEIG, 1984 [1952], p. 320.)

Também o desaparecimento ou simplesmente o declínio da cafeicultura em determinadas regiões não podem ser explicados unicamente pelas condições naturais. A reconstituição de muitas fazendas paulistas que haviam sido abandonadas porque seus solos estavam esgotados vem provar o que acabamos de dizer. O rendimento de seus solos deixara de ser compensador relativamente à ambição dos plantadores; sua utilização não era mais possível tendo-se em conta as técnicas conhecidas ou praticáveis em determinadas condições econômicas (...). A progressão dos cafezais paulistas para oeste foi consequência tanto das condições econômicas e das mentalidades como do esgotamento dos solos. E este esgotamento foi muito mais uma consequência dessas mesmas condições econômicas do que uma causa das vicissitudes financeiras dos produtores brasileiros. Responsabilizar o meio tropical pelas deficiências da sua economia agrícola em geral ou, de modo mais preciso, da economia do café, é uma solução cômoda porque foge à procura das verdadeiras responsabilidades. Os homens se isentam assim dos erros cometidos, culpando de todos os pecados a natureza tropical, que tem as costas largas. (MONBEIG, 1957, p. 164.)

On a déjà dit qu'il existe une certaine communauté de mode de penser aux différentes sociétés pionnières ; l'homme qui part plus loin, dès qu'il entend le sifflet du train est aussi bien américain que brésilien et l'on songe au blédard ou au broussard, qui n'est pas seulement une création littéraire. Goût du risque assurément, mais, au moins dans toutes Amériques, l'espoir de s'enrichir vite et bien, une sorte de passion du jeu et de la spéculation (...). L'extrême mobilité des pionniers s'explique, pour beaucoup, par l'excessive rapidité avec laquelle s'épuisent les sols défriches. Elle est également imputable aux oscillations implacables des économies commercialisées, à incertitude des marchés de matières premières et à l'inorganisation du crédit agricole qui affecte surtout les petits planteurs. Si les défricheurs des prairies d'Amérique du Nord ou des forêts d'Amérique du Sud, quoique issus souvent longues générations de paysans, paraissent avoir perdu le souci de la sécurité, le sens du sédentaire et même l'amour de la terre bien traitée, de l'arbre bien soigné, il faut chercher la cause de cette nouvelle mentalité dans la fragilité du milieu naturel comme dans les incertitudes économiques. C'est l'opportunité du marché, bien plus que la sage utilisation d'un milieu (qu'il n'a pas eu le temps de connaître), qui règle pour le pionnier le choix de ses cultures. (MONBEIG, 1966, pp. 981-982.)

Ora, mesmo a pretensa existência de terras desocupadas, que realmente se põe como um ponto de partida em muito influenciado pela visão que os fazendeiros tinham dos "espaços vazios" - pois implica considerar que essas áreas estavam ali à espera de quem a ocupasse, tirando-as do atraso em que se encontravam -, será até certo ponto revista quando o geógrafo notar a coexistência de especuladores imobiliários e grileiros ao lado de proprietários e posseiros, 
opondo o caráter até certo ponto "livre" da terra nas zonas pioneiras americanas e canadenses à condição "cativa" da propriedade da terra no Brasil. Portanto, é dever asseverar que autores como Rollo Gonçalves têm certa parcela de razão quando aproximam a psicologia bandeirante de Monbeig da retórica territorialista do Estado Novo, uma vez que, para o francês, a atração das terras por ocupar sujeitaria todos os habitantes das zonas pioneiras aos mesmos mecanismos psicológicos ${ }^{70}$, instrumentalizando de maneira positiva o passado bandeirante e naturalizando como um traço da mentalidade coletiva a dominação social exercida por mecanismos políticos e econômicos:

Eis um estranho modo de subtração do real. Ali, onde forças de uma tradição de dominação e monopólio secular das terras atuavam como vetores determinantes das migrações, encontramos, na fala de Monbeig, o peso de uma tradição meramente psicológica, verdadeira camisa de força mental legada pelo passado. Lá, onde a seletividade estrutural das relações sociais implicava na fabricação de vencidos e vencedores, ele preferia apenas ver predisposições ao risco, fidelidades hereditárias e encantamentos (...). Em vários sentidos ele acatou os termos verbais do discurso colonizador estadonovista como se expressassem algo mais do que pura retórica destinada a justificar a territorialização completa do Estado e do capitalismo no Brasil. Assumiu a narrativa dos feitos bandeirantes feita pelos funcionários intelectuais do regime e pelos publicitários das empresas de colonização como se fossem consensuais. Em particular, superestimou a escolarização dos nativos e sua capacidade de fixar a epopéia bandeirante. Neste particular, tudo leva a crer que ele viu com simpatia aquela idéia de uma democracia sentimental, onde uma imagem vale cem vezes mais do que um argumento, como dizia Cassiano Ricardo. É bem verdade que ele não faz referência ao trabalho do poeta. Mas usa o ícone bandeirante num registro bastante próximo. (ROLLO GONÇALVES, 1998, pp. 56-57.)

Todavia, quando Monbeig prefere sublinhar traços do mecanismo psicológico presente nas migrações a partir da força da tradição e do exemplo, compreendidos por ele como alusivos à epopeia bandeirante, ao invés de se deter nas relações sociais que repunham o domínio dos fazendeiros sobre a vida dos que chegavam às novas terras por terem sido impelidos a migrar, a novidade representada pela valoração dos aspectos subjetivos presentes na formação de novas paisagens, do ponto de vista dos limites colocados para a geografia praticada na época, não deve ser obnubilada por sua evidente absorção de certos juízos de valor verbalizados por setores da

\footnotetext{
70 “Desejo de solidão ou vocação de luta podem ser satisfeitos, porque vastos espaços estão à disposição de todos. Uma espécie de fascínio exerce sobre os espíritos a presença de terras desocupadas. Ao mesmo tempo, essa circunstância provoca o desinteresse: se as coisas não vão bem, se a tera fatiga, se os preços descambam, simples é o remédio, pois basta partir para mais longe; os fartos rendimentos dos primeiros anos de cultura, num solo pela primeira vez arroteado, compensarão as fadigas, normalizando a situação. A sede do ganho rápido mantém-se continuamente desperta, por causa da facilidade de encontrar um solo virgem e altamente produtivo" (MONBEIG, 1984 [1952], p. 122.)
} 
elite paulista, que viam a massa de trabalhadores como elementos subalternos, meros "braços para as lavouras" empregados após o fim da escravidão, pois essa afinidade, que sem sombra de dúvida deve ser lembrada e levada em consideração para compreender algumas de suas valorações, tem importância secundária quando comparada com as muitas passagens nas quais os fatores de ordem política, econômica, natural e geográfica são alçados à condição explicativa fundamental para o entendimento do fenômeno pioneiro:

Tomado em conjunto, o estado de São Paulo caracteriza-se geograficamente pelo apossamento inacabado do solo pelos homens e, ao mesmo tempo, pela expansão contínua do povoamento nos quadros duma economia movediça. $\mathrm{O}$ povoamento e a economia da fase colonial deixaram fortes traços, facilmente localizados no plano regional, como já se tem repetido. Esses setores "históricos", mais ainda, os outros, que abrangem a maior parte do território, nada mais fazem do que exprimir, nas suas paisagens geográficas, a expansão moderna do povoamento e a organização que prevalece desde o fim do último século [o XIX]. O seu traço predominante é a instabilidade, com fases de prosperidade e períodos de dolorosas depressões. Expansão e instabilidade são as características essenciais das regiões que, deixando à retaguarda uma economia de tipo colonial ou semicolonial, caminham para uma economia de tipo mais harmônica (...) o motor da expansão paulista é a instabilidade. É ela que impele para frente o avanço pioneiro, deixando para trás terras cultivadas à pressa, abandonadas logo que o possível rendimento tende a diminuir. Idêntico mecanismo provoca mutações que marcam profundamente todas as etapas urbanas paulistas. A fase de depressão não é menos operante do que a de prosperidade. Acarretando a má proteção dos solos e das plantas, ela estimula a procura de novas culturas, favorece a policultura sempre altamente comercializada, desprovida das sólidas bases da policultura nos países de velha civilização agrária. Por sua vez, o desenvolvimento urbano, consequente dos abalos econômicos, conduz a novos processos de ocupação do solo. A fim de abastecer as grandes cidades e aproveitar os mercados mais lucrativos que elas constituem, lançam-se em culturas de frutas, de hortaliças ou novas formas de criação. Mas ao mesmo tempo os abalos econômicos, que são o verdadeiro motor da utilização destrutiva dos solos, provocam uma evolução constante da estrutura social do mundo rural. São Paulo não é exclusivamente a terra de fazendeiros ricos, mas também o é de sitiantes mais ou menos abastados e de trabalhadores rurais. Em consequência disto, cria-se uma nova paisagem que corresponde às suas necessidades $\mathrm{e}$ às suas técnicas. A economia $\mathrm{e}$ a mentalidade dos fazendeiros e dos sitiantes modernos não são as mesmas que de seus predecessores do começo do século [XX]. Não se chegou a isso por lenta e insensível evolução. Falar no dinamismo paulista é reconhecer um estado de fato que o geógrafo deve procurar registrar. (MONBEIG, 1954, pp. 199-201. Grifo nosso.)

Finalmente, nossa tentativa de problematizar a opinião que atribui sem mais aos escritos de Monbeig a pecha de esbirro pseudocientífico da ideologia de classe da elite paulista que o trouxe para São Paulo indica a possibilidade de se construírem novas interpretações sobre o tema, as 
quais, ponderando os termos básicos das críticas efetuadas ao longo dos últimos trinta anos, abrem outros caminhos para a historiografia da geografia, enriquecendo a avaliação que até aqui os próprios geógrafos têm feito da "geografia clássica"71. Além do mais, a caracterização que Monbeig faz dos bandeirantes não se distancia muito do entendimento que deles tinha a historiografia ortodoxa do bandeirismo, única fonte documental disponível na época. Essa historiografia aduzia como qualidades distintivas das bandeiras a extrema pobreza de seus participantes, a relativa independência e isolamento dos habitantes de São Paulo em relação a Portugal - o que favoreceria as movimentações rumo ao interior -, e uma abstrata "atração do sertão", termo muito comum nos documentos coloniais dos séculos XVII e XVIII, quando era empregado para traduzir a propensão dos paulistas para o movimento. Essa plasticidade incomum dos antigos povoadores paulistas, motivada em tese pelas raízes indígenas que teriam aclimatado os habitantes do planalto de Piratininga antes dos demais colonizadores aos segredos da natureza tropical (HOLANDA, 1990), teve como resultado geopolítico prático, ainda que não projetado por inteiro pela Coroa portuguesa, o alargamento das fronteiras terrestres da colônia para oeste, que, chegando às margens do rio Paraguai, ultrapassou em muito os limites impostos pelo antigo

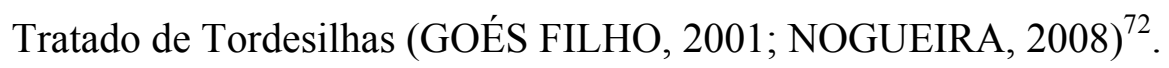

\footnotetext{
${ }^{71}$ Segundo Manuel Correia de Andrade (1987), admite-se esquematicamente, para o caso da geografia, que o período iniciado com a institucionalização universitária da disciplina na Europa, que foi seguido por uma época de consolidação e difusão do conhecimento geográfico, manteve na prática da disciplina certos denominadores comuns que permitem denominar como "clássico" os anos que abarcam desde o final do XIX até a década de 1950: "Os geógrafos clássicos, vivendo a fase de desenvolvimento do capitalismo industrial e da necessidade de um conhecimento aprofundado do espaço produtivo, fizeram estudos corológicos, procurando desenvolver uma análise de porções mais ou menos restritas da superfície do planeta. Partiram do princípio de que a análise das várias partes levaria à soma das mesmas e ao melhor conhecimento do todo. Levavam a Geografia consolidar-se como uma Ciência ideográfica e descritiva, usando o método indutivo, que parte do particular para o geral. Nesses estudos regionais, os alemães preocuparam-se com a descrição e análise da paisagem, em suas características naturais, enquanto entre os franceses a geografia da paisagem, considerada uma ciência de síntese, dava grande importância à visualização da mesma, tanto em seus aspectos físicos como nas marcas nela deixadas pelo homem. De qualquer forma, o positivismo era transformado em um funcionalismo que invadiria todas as ciências sociais. Os estudos regionais ganharam grande prestigio e muitos geógrafos admitiam ser eles os mais legítimos estudos de Geografia porque preocupavam tanto com os aspectos naturais como os sociais, sem se aperceberem que nesses estudos havia muito mais uma justaposição do físico ao humano do que a necessária integração. Isto porque na análise regional predominava, conforme a formação do geógrafo, ora a caracterização do humano, sobretudo do histórico, ora a caracterização do natural". (ANDRADE, 1987, p. 64.)

72 "Se a essa característica do movimento, a pobreza, aliarmos duas outras - sua independência e o que se poderia chamar de atração pelo sertão - teremos os três elementos básicos da visão ortodoxa do bandeirismo, isto é, aquela que fica da leitura dos principais estudiosos do movimento, que são também os que mais se apoiam nas fontes documentais publicadas neste século [o século XX].” (Góes Filho, 2001, p. 107). Neste mesmo estudo, Synesio Góes Filho pondera acerca da retomada mitológica do bandeirismo no início do século XX, e conclui: "Com o desenvolvimento atual de São Paulo, a visão ortodoxa do bandeirismo, cujos traços principais tentamos identificar acima, sofre deformação idealista. Começam a repetir, com frequência irritante, expressões heróicas sobre os bandeirantes, pinçadas aqui e ali, tais como 'raça de gigantes', uma frase traduzida de Saint-Hilaire, que serviu de
} 
De fato, a identificação da propensão ao movimento como uma característica "ancestral" dos paulistas, qualidade quiçá herdada dos bandeirantes, não era exatamente uma posição exclusiva de certa historiografia conservadora, sendo possível mesmo dizer que se tratava, na década de 1940, de um assunto prenhe de debates, pois o que estava em jogo era a discussão acerca das motivações geopolíticas, econômicas ou até mesmo religiosas dessas incursões para o interior do continente americano. Caso conhecido, a interpretação de Sérgio Buarque de Holanda, lembrando-nos da importância do mito do Eldorado nas incursões que rumavam ao interior do território colonial português na América (HOLANDA, 1942), sustenta que o tipo de colonização singular que se teria desenvolvido no Planalto do Piratininga deixara margem maior para o intercurso dos reinóis com os indígenas, ainda que a pobreza do meio natural, as necessidades de sobrevivência e a vontade de ganho econômico, comum a todos os colonizadores portugueses, fossem os fatores condicionantes da extrema mobilidade dos bandeirantes (HOLANDA, 1986; 1990). Com efeito, em sua obra Monções, lançada originalmente em 1945, Sérgio Buarque diz que a instabilidade da sociedade constituída no planalto paulista teria facultado ali a origem de uma sociedade cuja "vocação estaria no caminho, que convida ao movimento; e não na grande propriedade rural, que cria indivíduos sedentários" (HOLANDA, 1990, p.16), juízo que além de abrir um debate interessante com Gilberto Freyre, que analisou em detalhe o sedentarismo agrário dos núcleos formados no massapê gordo e úmido do litoral canavieiro do nordeste (FREYRE, 2002), explica em grande medida a força com que se exerceria nos paulistas a atração do sertão:

A mobilidade dos paulistas estava condicionada, em grande parte, a certa insuficiência do meio em que viviam; insuficiência para nutrir os mesmos ideais de vida estável, que nas terras da marinha puderam realizar-se, ao primeiro contato entre o europeu e o Novo Mundo. Distanciados dos centros de consumo, incapacitados, por isso, de importar em apreciável escala os negros africanos, eles deverão contentar-se com o braço indígena - os "negros" da terra;

título a uma obra de Ellis Junior. O bandeirante, rude caçador de índios, virou herói de epopéias infantis, ilustre ancestral de famílias 'quatrocentonas' de São Paulo, altivo personagem das pinturas e estátuas que adornam o Museu do Ipiranga, em São Paulo; sempre elegante, nobre, de chapelão, colete e botas de couro (...). As críticas, umas mais pertinentes, outras menos, são enriquecedoras: as excrescências devem ser podadas, a boa história não é escrita com fantasias e invenções. O que não se pode, entretanto, é ignorar ou apequenar o fato de que, durante dois séculos, sertanistas de São Paulo trilharam e de certo modo ocuparam várias partes do interior da América do Sul, que, por isso mesmo, ficaram brasileiras. O mito é sempre uma construção fantasiosa; mas em muitos casos, como neste, tem uma sólida base na realidade. Na realidade, acabamos de ver isso, o personagem que se tira dos autores 'clássicos' do movimento, de Alcântara Machado em especial, pois foi quem mais estudou o 'homo' bandeirante, é basicamente um pobre mameluco, um rústico escravizador que, 'descalso y pie y perna', como diz um documento de 1676 do 'Cabildo' de Assunção, percorre sem parar as trilhas do interior do continente. Dotado, no entanto, daquela vitalidade brutal que lhe permitia, na esteira de seus antepassados paternos, navegar confiante pelas tormentosas rotas do sertão sem fim.” (GOÉS FILHO, 2001, pp.125-126-127.) 
para obtê-lo é que são forçados a correr sertões inóspitos e ignorados. Em toda parte é idêntico o objetivo dos colonos portugueses. Diverge unicamente, ditado por circunstâncias locais, o compasso que, num e noutro caso, dirige a marcha para esse objetivo (...). Desenvolvendo-se com mais liberdade e abandono do que em outras capitanias, a ação colonizadora realiza-se aqui por um processo de contínua adaptação a condições específicas do ambiente americano. Por isso mesmo não enrija logo em formas inflexíveis. Retrocede, ao contrário, a padrões rudes e primitivos: espécie de tributo exigido para um melhor conhecimento e para posse final da terra. Só muito aos poucos, embora com extraordinária consistência, consegue o europeu implantar, num país estranho, algumas formas de vida, que já lhe eram familiares no Velho Mundo.

Com a consistência do couro, não a do ferro ou do bronze, ajustando-se, amoldando-se a todas as asperezas do meio. É inevitável que, nesse processo de adaptação, o indígena se torne seu principal iniciador e guia. $\mathrm{O}$ simples recurso às rudes vias de comunicação, abertas pelos naturais do país, já exige uma penosa aprendizagem, que servirá, por si só, para reagir sobre os hábitos do europeu e de seus descendentes mais próximos. A capacidade de resistir longamente á fome, à sede, ao cansaço; o senso topográfico levado a extremos; a familiaridade quase instintiva com a natureza agreste, sobretudo com seus produtos medicinais ou comestíveis, são algumas das imposições feitas aos caminhantes, nessas veredas estreitas e rudimentares. Delas aprende o sertanista a abandonar o uso de calçados, a caminhar em "fila índia", a só contar com as próprias forças, durante o trajeto. (HOLANDA, 1990, pp.16-17. Grifo nosso.)

Conforme pode ser notado nos trechos que colocamos em destaque, para Sérgio Buarque de Holanda a colonização do planalto paulista foi em muito influenciada pelas condições desfavoráveis apresentadas pelo meio natural, que exigiram, por parte dos colonizadores, uma adaptação ao novo espaço em que a apreensão das técnicas e dos ensinamentos dos naturais da terra foram imprescindíveis. A busca do caminho, que incita à experiência da fronteira, transformada depois num movimento de conquista dos sertões, marcaria então as formas de sociabilidade provisória e itinerante desenvolvidas desde o século XVII entre portugueses, negros, indígenas e a massa de descendentes mestiços (KOK, 1998; MELLO E SOUZA, 1997). Isso quer dizer que o ajustamento do colonizador à natureza americana, facilitado pelo aprendizado das técnicas indígenas, teria sido encetado em terras futuramente paulistas com mais afinco e vigor do que em outras localidades da América portuguesa, sobretudo por conta da insuficiência de recursos naturais imediatamente disponíveis na forma de solos férteis e riquezas minerais, circunstância que originou uma ação colonizadora que se distancia das sólidas casasgrandes do litoral nordestino, forma fixa e sedentária de povoamento que em tudo difere da experiência vicentina ${ }^{73}$.

\footnotetext{
73 “Geógrafos e economistas são levados a constatar que os grupos humanos, apossando-se de uma região e valorizando-a, atingem-na toda uniformemente, mesmo as terras mais ingratas. A primeira fase da conquista agrícola
} 
A releitura americana do legado ibérico efetuada por Sérgio Buarque em livros como Monções e Caminhos e Fronteiras, que se valem de uma explicação situacional que confere papel ativo à singularidade do espaço do Novo Mundo na transformação dos valores e instituições transladados da Europa pelos colonizadores, foi já notada por Robert Wegner (2000), que avalia a possibilidade de se analisar a importância da fronteira na obra do historiador paulista a partir de uma chave interpretativa de inspiração turneriana. Para Wegner, é produtivo ler os textos de Holanda que tratam do bandeirismo e da conquista do oeste a partir de certos aspectos presentes no núcleo da tese de Turner, principalmente a influência transformadora recebida pelos colonizadores no contato com os indígenas - o que explicaria a originalidade dos novos países do continente americano no processo de adaptação dos europeus aos espaços da fronteira, abrindo a possibilidade de as "terras livres" funcionarem como uma válvula de segurança apta a receber os habitantes de núcleos de povoamento demograficamente saturados -, na medida em que permite vislumbrar como Sérgio Buarque pensou a dinâmica de americanização proporcionada pela fronteira a partir da relação engendrada entre o espaço tropical, a tradição ibérica e a modernização imposta a essa tradição no processo de expansão das fronteiras continentais lusoamericanas.

Comparando o que denomina de "explicação genética" sobre as Américas, que teria como característica o entendimento do Novo Continente como uma página em branco escrita e desenhada completamente pelo conteúdo cultural e institucional ali despejado pelos europeus, a uma "explicação situacional", exemplarmente representada pela tese de Turner e seus seguidores, que conferem à dinâmica da fronteira um protagonismo até então inimaginado no processo de formação das diferenças entre europeus e americanos, Wegner identifica três momentos fundamentais atinentes aos fenômenos de fronteira: um primeiro momento "de quase absoluta adaptação do adventício às condições fornecidas pelo ambiente e aos meios nativos" (WEGNER, 2000, p. 101); um segundo momento no qual o colonizador, já adaptado, consegue "transformar o ambiente com base, pode-se supor, nos meios fornecidos por seu legado transatlântico" (Loc.

seria marcada pelo desprezo completo de suas vantagens geográficas: lembrarei em poucas palavras que os primeiros solos cultivados no estado de São Paulo no período colonial são considerados como sendo os mais medíocres. Em seguida viria a verdadeira adaptação às condições geográficas: a paisagem rural se matiza; cada vantagem do relevo, do clima, do solo é utilizada na medida do possível. Então, somente, se pode falar de domínio da natureza por parte do homem, porque a melhor maneira, talvez, de dominar, é adaptar-se. Nas terras velhas do Mediterrâneo, o fenômeno aparece claramente, mas devo dizer, e não apenas como fecho de uma conferência, que o compreendi plenamente em minhas viagens às novas campanhas do interior brasileiro.” (MONBEIG, 1940, pp. 261-262.) 
cit.); e um terceiro momento verdadeiramente fundacional das peculiaridades continentais americanas, enfim, no qual ocorreria "o produto americano, fruto do rearranjo da tradição europeia sobre um fundamento de completa adequação aos padrões indígenas" (Loc. cit.). Ou seja: no núcleo da tese de Turner ocorreria, mediado pela fronteira, uma evolução linear de um estágio primitivo, representado pela adaptação do europeu aos hábitos indígenas, condicionada pela natureza americana, a um estágio superior de civilização, progressão que, embora represente a vitória da cultura e da técnica, não reproduz na América a velha Europa, dando origem a uma nova sociedade.

Com essas considerações na algibeira, Robert Wegner efetua uma possível esquematização dos estudos de Sérgio Buarque dedicados ao processo de conquista do oeste, na qual observa que a cada século analisado pelo historiador corresponderia a proeminência de algumas figuras emblemáticas da experiência da fronteira. Assim, se no século XVII a personagem-chave seria o bandeirante, passa a ser o monçoneiro no XVIII, chegando, no século XIX, às figuras do tropeiro e do fazendeiro, ao mesmo tempo continuadores e herdeiros da longeva tradição sertanista dos paulistas. A linha de continuidade histórica entre essas personagens, que teriam em comum uma propensão ao movimento impulsionada por uma "força expansiva", torna-se clara nos argumentos de Holanda, mas o que Wegner quer ressaltar é a possibilidade de essa transição do bandeirante ao tropeiro comportar uma leitura do processo de construção, no Brasil, de uma nova mentalidade de cariz capitalista, que se teria formado por aqui exatamente a partir da conquista da fronteira oeste:

O disciplinamento do sertanista modifica os "hábitos de vida patriarcais" - é bom lembrar mais uma vez, os mesmos hábitos encontrados em Raízes do Brasil. Portanto, nas monções e, mais ainda, entre os tropeiros, começamos a encontrar o cálculo, o planejamento e até mesmo "certa dose de previdência, virtude eminentemente burguesa" (...). Dessa forma, qualidades adequadas à moral capitalista, como o cálculo e a previdência, surgem sem solapar de todo características de um mundo patriarcal, não excluindo, inclusive, certo grau de personalismo nas transações comerciais e uma "dignidade sobranceira e senhorial". Se agora começamos a vislumbrar um mundo que valoriza o negócio antes que o ócio, este e as características que o acompanham não estão ausentes de forma absoluta (...). Em suma, podemos dizer então que por meio da dinâmica de conquista do oeste forma-se uma mentalidade compatível com o moderno capitalismo, sem, contudo, um completo rompimento com valores e costumes associados normalmente a um mundo pré-burguês. Detecta-se uma mentalidade capitalista sem ascetismo racionalizante - o qual "parece inseparável do ideal burguês, ao menos em suas origens" -, e que, por isso mesmo, possibilita a vazão dos sentimentos e prazeres. (WEGNER, 2000, pp. 183-184-185.) 
Como pudemos acompanhar, a valorização da temporalidade e a preocupação com as mentalidades coletivas dos grupos sociais envolvidos numa dinâmica migratória são os elementos por meio dos quais Monbeig maneja os fatores psicológicos integrados à explicação sobre as franjas pioneiras em sua obra. Ao final, ainda que reconheçamos a proximidade que o francês manteve com amplos setores da elite política e econômica de São Paulo, a ideia das combinações entre diferentes aspectos do real que acompanha o conceito de complexo geográfico com o qual trabalha, coloca os fatores psicológicos por ele identificados em um aposição subalterna ante aos elementos econômicos, sociais e naturais que explicariam de maneira mais completa a mobilidade do povoamento dos planaltos ocidentais. Nas próximas páginas, veremos o papel que a colonização das terras interiores do Brasil ocupa no arranjo explicativo de Monbeig, analisando também a maneira como os elementos psicológicos aparecem nos escritos de alguns de seus discípulos.

\section{A expansão da colonização e os vetores de modernização do território}

Na seção passada, a breve alusão ao trabalho de Sérgio Buarque surgiu como um exemplo das maneiras pelas quais o espaço podia ser trabalhado nos textos de autores que formularam explicações clássicas sobre o Brasil, pois os três momentos descritos como atinentes aos fenômenos de fronteira, que estão presentes na explicação situacional, podem muito bem ser remetidos às diferentes etapas de valorização do espaço que integram todo e qualquer processo de colonização, constituindo-se em variante específica e historicamente localizável do processo de produção do espaço (MORAES, 2000) ${ }^{74}$. Além disso, a transformação do antigo sertanista

\footnotetext{
${ }^{74}$ Esse equacionamento teórico considera a importância da dimensão geográfica na interpretação da história humana, concebendo o próprio movimento histórico como um processo contínuo de apropriação e transformação da superfície terrestre, tal uma reiterada antropomorfização do espaço (MORAES, 2002). Nesse caso, as etapas comuns da colonização, que se inicia com a descoberta, exploração e conquista de um lugar de interesse, seguida da instalação e da consolidação do colonizador, e desembocando na expansão e complexificação do espaço conquistado, se apresentam mais como um padrão básico do processo geral do que uma cronologia específica: "Apropriação, transformação, perenização, construção: características caras à perspectiva de geografia que se assume. Captar o movimento interno da valorização do espaço - entendendo a lógica que presidiu a execução das construções e dos arranjos locais - seria seu objetivo primeiro. O outro seria apreender os condicionamentos do resultado de tal processo em diferentes momentos, isto é, as influências da estruturação do espaço transformado e produzido com que se defronta uma sociedade numa dada conjuntura histórica (...). Em outras palavras a forma criada só se revela pelo uso social a cada momento, sendo este que lhe atribui um conteúdo ao qualificá-la como um 'valor de uso'. Novamente, se reafirma a idéia de que são os processos sociais que qualificam os lugares (e não o inverso), inclusive qualificando as características naturais nele contidas, tornando-as recursos naturais; um qualificativo histórico, dependente de determinações da tecnologia disponível (...). Enfim, a espacialidade se afirma como um elemento
} 
explorador de terras e caçador de índios na figura tropeiro e fazendeiro, que acompanha com avanços e recuos o movimento de expansão territorial da sociedade brasileira, pode ser entendida a partir de uma escala temporal de análise que valoriza a longa duração dos fenômenos históricos, ajudando na compreensão de que nas décadas de 1940 e 1950, o estabelecimento de um elo de ligação entre as antigas movimentações bandeirantes e a expansão pioneira dos fazendeiros de café, não era um procedimento esposado única e tão somente por intelectuais que gozavam de uma proximidade ideológica e afetiva com a oligarquia rural de São Paulo.

De todo modo, a caracterização da expansão pioneira como um movimento de conquista que busca integrar os sertões indevassados do território brasileiro, vistos como o repositório de um mundo primitivo, na esfera de influência política e econômica do Estado - o verdadeiro representante da moderna civilização técnico-industrial -, não era de modo algum estranha a Monbeig, que em distintas passagens de seus trabalhos não hesitava em aplicar esse termo a áreas cujas paisagens ainda não haviam sido completamente humanizadas, sendo dominadas por elementos naturais. Seguindo de perto os primeiros textos do geógrafo francês sobre o Brasil, escritos em francês, ao longo da década de 1930, e publicados no vernáculo, em 1940, com o título de Ensaios de Geografa Humana Brasileira, podemos avaliar o significado atribuído ao termo "sertão" na associação por ele empreendida entre o povoamento, a expansão das lavouras e a construção das vias de comunicação, considerados sem dúvida os principais vetores da modernização no território. Fixemos a atenção, primeiramente, no já citado texto surgido após uma viagem de avião feita entre São Paulo e Goiânia, que foi originalmente publicado, em 1939, no Bulletin de l'Association des Géographes Français (BAGF). Após descrever o itinerário percorrido em aproximadamente seis horas de voo, Monbeig nota a ocorrência de uma mudança nos aspectos paisagísticos depois de o avião ter deixado para trás a cidade de Franca, que marcava uma rápida diminuição dos cafezais na direção do rio Grande, na divisa de São Paulo com Minas Gerais, no Triângulo Mineiro. Já nas proximidades de Uberaba, "a primeira cidade mineira mais intimamente ligada a São Paulo" (MONBEIG, 1940, p. 77), o geógrafo percebe a

particularizador, uma mediação que quando aplicada sobre o próprio processo universal de valorização do espaço, ajuda a qualifica-lo como processo singular de formação de um território (...). O valor fixado pelo trabalho vai se tornando uma qualidade dos lugares, fazendo da constituição de um território um processo sincrônico e cumulativo. As construções e destruições realizadas passam a fazer parte daquela parcela do espaço, qualificando-a para as apropriações e usos futuros. Nesse sentido, o território aparece para a sociedade, a cada momento, como um resultado e uma possibilidade, como condição e meio de reprodução da vida social. Assim, pode-se dizer que o processo de formação territorial é a manifestação empírica da valorização do espaço, da mesma maneira que a formação econ6omico-social expressa o modo de reprodução numa situação singular.” (MORAES, 2010, pp. 25-2627.) 
oposição entre as margens paulista e mineira do rio Grande: “a bela fábrica, as massas de casas, a intensa valorização da terra, eis a margem paulista, ao passo que, defronte, as culturas se tornam raras, predominam a criação de gado e os vastos espaços nus e as habitações empobrecem" (Loc. cit.). Como se pode reparar, a exploração produtiva do espaço por um uso intensivo do solo - sua valorização, portanto (COSTA E MORAES, 1984) - é o que daria origem às paisagens fortemente humanizadas que são perceptíveis do lado paulista, opondo-se às paisagens culturais rarefeitas observadas do lado mineiro do rio Grande, com seus vastos campos cerrados entrecortados de pastos reservados à criação do gado solto:

A conquista do homem sobre a natureza é cada vez menos importante: raras fazendas, ranchos cobertos de folhas de palmeiras, arame, estradas incansavelmente retas, tudo são indícios de uma valorização balbuciante e de uma exploração extensiva. Já não voamos sobre essa parte do Brasil que, pela densidade de população e pelo ritmo de vida, é comparável a uma região europeia ou norte-americana, e, entretanto, ainda não é o sertão bruto; pode-se dizer que as paragens e a cidade de Uberlândia representam o fim de um mundo, o do Brasil moderno, e o começo do sertão. Desde os famosos mapas, que, ainda no começo do século, indicavam no interior das fronteiras paulistas "um sertão habitado pelos índios", o avanço dos desbravadores e dos colonizadores, em sua prodigiosa amplidão, fez recuar para bem longe o verdadeiro sertão; exceção feita da estreita zona situada entre a fronteira do Paraná e a Alta Sorocabana, creio que empregar a palavra "sertão" no estado de São Paulo constitui uma impropriedade e que só assaz longe, fora dos limites deste estado, é que convém localizar o limite das terras desbravadas (ou em vias de ser) e de natureza ainda inexplorada. (Monbeig, 1940, p. 78. Grifo nosso.)

No trecho citado, afora a referência aos mapas do início do século XX que indicavam os "sertões habitados por índios" no interior paulista, que indubitavelmente dizem respeito aos mapas produzidos no âmbito das expedições que a Comissão Geográfica e Geológica de São Paulo efetuou entre o final do século XIX e o início do seguinte (FIGUEIRÔA, 1987; 1997), avulta a caracterização explícita do sertão como um espaço ainda não conquistado, como o domínio das paisagens naturais intocadas, o espaço que marca os limites entre a civilização moderna, sincronizada com um ritmo de vida "comparável a uma região europeia ou norteamericana", e as terras e homens inscritos num tempo lento, vagaroso, subserviente às distâncias e ao isolamento por ainda não terem sido alcançadas e valorizadas por desbravadores, agricultores e homens de negócio que prenunciam o progresso e seus signos, a urbanização, os aviões e as estrada de ferro - exceção seja feita à Goiânia, dirá ele pouco depois, cidade moderna 
que se desenvolve tal uma planta teimosa que insiste em crescer mesmo em um meio hostil, segundo as recorrentes metáforas organicistas que marcam seu estilo de escrita.

Em outro artigo que trata das vias de comunicação do estado de São Paulo, publicado primeiramente em 1937, também no $B A G F$, Monbeig evidencia os laços entre a formação de paisagens humanas, o crescimento demográfico e o aumento da superfície plantada com o café e a inauguração das vias férreas que demandavam o interior, vivificando a ligação entre o planalto, a capital e o litoral, ou melhor, entre as zonas pioneiras, o centro urbano de comando das atividades econômicas e seu porto de exportação. Dentre os inúmeros detalhes que se podem salientar desse texto, como, por exemplo, o vínculo entre a configuração do relevo, a disposição da hidrografia e a construção de estradas, que deveriam aproveitar as "vantagens geográficas" oferecidas pelas vias naturais, interessa-nos mais exatamente a ligação que Monbeig estabelece entre a antiga penetração fluvial dos bandeirantes e a moderna construção dos trilhos, entendendo a recente propagação territorial do povoamento, que resultava na organização de paisagens culturais, a partir de uma relação que reservava ao sertão o significado de área ainda não apropriada e humanizada, a periferia do povoamento, ponto de encontro entre civilizações:

A antiga penetração fez-se acompanhando o fundo dos vales, o povoamento moderno, pelo contrário, localiza-se de preferência nos planaltos; estradas e trilhos alongam-se paralelamente às linhas de distribuição de águas, os "espigões" (...). Toda gente sabe que a valorização e o povoamento dos imensos horizontes do interior do estado de São Paulo estão intimamente ligados à extensão da cultura do café e ao progresso das vias férreas, fenômeno comum a quase todos os países novos (...). Assim também, comparando-se os mapas da rede ferroviária e a densidade de população dos recenseamentos do fim do século passado [o XIX], nota-se uma evidente concordância entre as regiões onde terminam os trilhos e a periferia do povoamento. Para além era o sertão desconhecido, ocupado pelos índios. (MONBEIG, 1940, pp. 134-135.)

A continuidade do juízo que opunha as paisagens humanizadas às zonas de sertão pode ser entrevista na representativa passagem constante no terceiro capítulo que fecha o livro segundo de sua tese, cuja feitura, lembremos, findou-se em 1949. Efetivamente, ao iniciar suas análises acerca das direções tomadas pela franja pioneira ao longo das décadas de 1930 e 1940, Monbeig retoma um dos primeiros trabalhos a que Pierre Deffontaines (1936) se dedicara assim que chegou ao Brasil, em 1934, e que era um esboço de divisão regional para o estado de São Paulo ${ }^{75}$.

\footnotetext{
${ }^{75}$ Trata-se do trabalho Pays et paysages de l'État de Saint-Paul. Première esquisse de division régionale, publicado no ano de 1936, em duas partes, nos Annales de Géographie. Uma primeira versão desse trabalho havia saído em português, em 1935, no segundo número da revista "Geografia", publicação brasileira idealizada pela AGB que foi o primeiro esforço editorial voltado exclusivamente para assuntos geográficos. Posteriormente, a versão francesa foi
} 
Comentando o fato de Deffontaines ter delimitado, no tocante às regiões paulistas, uma "zona pioneira" e uma "zona do sertão" - esta localizada no extremo oeste do estado e definida como uma área anecúmena ainda não explorada -, Monbeig surpreende o esquematismo de tais conclusões, quanto mais por essas áreas já terem sido atravessadas por estradas de ferro na época em que Deffontaines as analisava, mas reconhece que "em 1934 poder-se-ia distinguir zona pioneira e sertão" (MONBEIG, 1984 [1952], p. 205). Todavia, continua dizendo que, em 1949, a marcha de conquista sobre terras virgens estava chegando ao fim, pelo menos dentro dos limites administrativos do estado de São Paulo: “quinze anos depois, não é mais exato falar de um sertão paulista, pois tudo o que permanecia intacto até a grande depressão econômica foi invadido pelos derrubadores de mato e hoje faz parte da zona pioneira (...). Tem-se perfeita consciência desse fato, e é por essa razão que a penetração no norte do Paraná vem recebendo impulso novo" (Ibidem, pp. 205-206-207). ${ }^{76}$

Um outro ponto interessante é o uso do termo "boca do sertão" para designar as cidades que funcionam como pontos terminais dos trilhos. Em detalhe, as cidades "bocas do sertão" podiam ser definidas como postos avançados de povoamento que mobilizavam em suas áreas de influência as chamadas "zonas de derrubadas" localizadas mais adiante, que eram onde se construíam os núcleos fixos de povoamento efetivamente alcunhados de pioneiros. Essa relação entre a fundação de um centro urbano e a apropriação de terras fundamentada em uma atividade agrária revela os aspectos mais representativos que tentamos aqui estabelecer, quais sejam, a semelhança existente no Brasil entre o sentido centrífugo das correntes colonizadoras abarcadas no termo frontier (KRISTOF, 1959) e o processo de conquista dos sertões impulsionado pela

traduzida para o português, por Orlando Valverde, em 1945, quando foi publicada sem os mapas, fotos e com alguns trechos suprimidos em dois números do Boletim Geográfico, do CNG. Utilizamos aqui, pois, a versão completa em francês, visto que é a ela que Monbeig faz referência direta.

${ }^{76}$ Vale reproduzir o trecho no qual fica claro que também para Pierre Deffontaines o sertão era compreendido como um lugar ainda por explorar, espaço habitado por povos indígenas, caboclos e foras-da-lei que estavam à margem do mundo civilizado e moderno encarnado nas frentes pioneiras, meros instrumentos dos grileiros e açambarcadores de terras, uma vez que esse parágrafo foi inexplicavelmente suprimido da versão em português constante no Boletim Geográfico: “En avant de la zone pionnière s'étend le sertão, c'est-à-dire la zone encore anœkoumène, non exploitée. Elle n'est cependant pas absolument vide d'hommes. En plus des quelques tribus indiennes qui reculent devant la civilisation en se décimant, il y a une sorte de prépeuplement surtout composé de hors-la-loi, de fueros et cabocles qui ne savent s'habituer à la vie civilisée, gens qui ont eu des démêlés avec la police et qui vivent, en marge de la société, d'étonnantes et scabreuses vies d'aventure et d'isolement. Autrefois même, quand les prisions des villes étaient pleines, on conduisait les prisonniers dans le sertão et on les lâchait. Ce prépeuplement rendait de vrais services à la colonisation: c'est par lui que s'opèrent les premières reconnaissances, relevé de point d'eau, de cours de rivières, de gués, de coins de terre plus favorable. Peut-être rappellent-ils ces "hôtes" du moyen âge qui ont constitué souvent 1'avant-garde des défricheurs en nôtre Europe. C'est avec eux que s'entendent les premiers accapareurs de terrains pour constituer leur faux titre de possession; parce que qu'ils sont des hors-la-loi, ils aident à la première appropriation nécessairement illégale.” (DEFFONTAINES, 1936, pp. 173-174.) 
movimentação das fronteiras, que cria uma nova configuração territorial pela apropriação e valorização de áreas ainda não exploradas produtivamente. Dando um significado um pouco diferente a uma expressão consagrada nos documentos coloniais da história paulista, nos quais a expressão "bocas de sertão" era abundantemente utilizada como referência aos pousos fortificados ou arraiais isolados fundados pelos bandeirantes à beira dos caminhos de penetração para o interior, Monbeig concede um protagonismo ao avanço pioneiro no interior do processo de formação territorial brasileiro, uma vez que a multiplicação de cidades, lavouras e pastagens iam paulatinamente transformando paisagens naturais que se encontravam até aquele momento pouco alteradas por uma coordenada ação humana de modificação do espaço.

Enfim, em sua análise do processo de formação territorial do Brasil, percebe-se que Monbeig fazia uso de uma visão unilinear do processo histórico, enxergando a expansão pioneira como um movimento de conquista de terras que modificava as áreas habitadas por povos primitivos a partir da instalação de grupos humanos que estariam num estágio mais avançado de civilização, donde a importância da fundação de centros urbanos, da especulação imobiliária e da propriedade privada da terra em sua definição do fenômeno do pioneirismo. Por outro lado, convém igualmente afirmar que o recurso aos aspectos subjetivos dos grupos humanos como forma de tornar mais completa a descrição do processo de formação das paisagens não ficou restrito, na geografia, à obra de Monbeig, aparecendo em enunciados formulados por seus discípulos a partir dos dois registros básicos que vimos aqui rastreando, quais sejam, o que considera o pioneirismo um fenômeno essencialmente paulista, que mais não é do que uma manifestação singular da "Marcha para o oeste" - arranjo explicativo que fica próximo da concepção territorialista do Estado Novo -, e o que compreende a necessidade de se apreciar os modos de sentir e pensar como um fator geográfico inserido no complexo geográfico, posição que, no mais, deixa transparecer uma visão naturalizada das relações sociais.

No início de seu livro A marcha do café e as frentes pioneiras, elaborado como livro-guia de uma das excursões de campo feitas durante o Congresso Internacional de Geografia da UGI, ocorrido no Rio de Janeiro, em 1956, Ary França (1960) também identificava a posição de comando assumida pelos proprietários de grandes plantações de café que, no século XIX, depois dos séculos de dominação dos senhores de engenho e dos abastados mineradores, formaram "o escol social brasileiro": “A chamada I República (1889-1930) apoiar-se-ia nos fazendeiros de café e os estados cafeicultores exerceriam na política federal o comando indiscutível. Seria a 
partir, principalmente, das fortunas feitas com o café que se iniciaria o grande surto industrial moderno brasileiro, com São Paulo na posição de líder" (FRANÇA, 1960, p.12-13). Na opinião de Ary França, a marcha do café, que influenciara decisivamente a formação de paisagens humanas modernas e a consolidação da liderança de São Paulo nas esferas política e econômica do Brasil, ficaria marcada, nos campos e nas cidades, pela instabilidade da população e do habitat, situação que era consequência da falta do arraigamento dos colonos ao solo, expressão da ausência de laços mais profundos entre o homem e a terra a que nos referíramos anteriormente:

Em todo Brasil tropical do sudeste, as influências da maior cultura praticada no país vêm-se manifestando. Não só nas zonas rurais onde se o cultiva, ou onde existiram culturas de café no passado foram afetadas (...). As cidades, por vezes, cresceram desmesuradamente. Como as áreas rurais, depressa evoluíram; diferenciaram-se ao amadurecerem, a maioria industrializou-se e incorporou novas conquistas da civilização. $\mathrm{Na}$ sua generalidade têm como modelos os grandes centros regionais de Ribeirão Preto, Marília e Londrina e a própria cidade de São Paulo, cujo progresso repercute em toda sua imensa área de influência. A capital paulista é, por outro lado, o reflexo do alargamento e das transformações operadas nas regiões agrícolas da hinterlândia, sobretudo nas "frentes" cada vez mais distantes, que a excursão irá alcançar no planalto ocidental do Paraná. Assim, não só nos campos mas também nas cidades há movimento, ambição, muito arrojo e certa instabilidade, traços esses que podem ser reconhecidos na atividade e na psicologia paulista, como a observação de muitos estudiosos dos problemas brasileiros já salientou. (FRANÇA, 1960, p. 18.)

Afora a ligação estabelecida entre a expansão das lavouras de café e o crescimento das cidades, numa conjugação entre o rural e o urbano que é uma das marcas do fenômeno pioneiro, ao menos tal como ele é descrito nas obras dos geógrafos uspianos, podemos observar no texto de Ary França que a ambição e o arrojo, qualidades intrínsecas à "psicologia paulista", são tidos como fatores subjetivos que, conjuntamente com a estrutura econômica e social forjada nas frentes pioneiras, ajudam a compreender a instabilidade da organização espacial surgida dos processos de povoamento e colonização impulsionados a partir do café. A novidade desse escrito datado do primeiro lustro da década de 1950, que em mais de um aspecto completa a descrição de certas tendências já esboçadas por Monbeig, está na percepção de que a provisoriedade, característica dominante do mundo rural paulista, não resultaria, como antes, somente da propalada falta de apego ao solo, propensão psicológica entrevista na busca de terras mais distantes que dinamizava a abertura de novas "frentes", pois agora, além da possibilidade de maiores ganhos nas áreas novas da fronteira, os trabalhadores rurais também seriam atraídos para os centros urbanos, afirmação que revela o surgimento da questão do êxodo rural para as grandes 
cidades no horizonte da realidade brasileira, conjugando a formação de um a rede de cidades com a abertura de novas plantações, pois a concentração populacional observada nos centros urbanos ocorria ao mesmo tempo em que o aproveitamento econômico do solo retomava sua marcha expansiva $^{77}$.

Falando exatamente sobre a questão da provisoriedade, mas focalizando nos assentamentos rurais criados pelos sitiantes e pequenos proprietários de terras, Nice Lecocq Müller também se vale dos aspectos subjetivos presentes na formação das paisagens ao indagar em que medida as paisagens organizadas a partir das pequenas explorações rurais, que desenvolviam uma forma de ocupação do solo "como resultado de uma dupla ação, a do meio físico e a da evolução econômica e social" (MÜLLER, 1951, p. 195), representavam um modo de estabilização do povoamento, ou seja, em que medida o sitiante podia ser tomado como um verdadeiro elemento de equilíbrio na análise do processo de conquista e colonização de novas terras:

Como parceiro ou arrendatário, tudo que faz tem caráter provisório; como pequeno proprietário, suas finanças são precárias e, mesmo quando habita zonas de povoamento antigo, nem sempre resiste aos apelos da publicidade e dos altos rendimentos, que o colocam na posição de quem espera constantemente encontrar, mais adiante, o El-Dorado. Ele passa de uma cultura a outra segundo os preços da moda; vemo-lo mesmo orientar-se para a criação, à imitação do fazendeiro. Em tudo isso sitiante se enquadra na orientação geral, característica da economia e da psicologia de um país jovem. (MÜLLER, 1951, p. 196.)

Por fim, Pasquale Petrone nos fornece um exemplo historicamente mais atualizado de como as formas de sentir e pensar poderiam aparecer enquanto fatores geográficos importantes na explicação da dinâmica de evolução das paisagens. Em sua tese de doutoramento, escrita ao longo dos anos de 1950, após delimitar a região que será alvo de sua análise e descrever as características gerais do meio físico, Petrone (1966) trata do histórico do povoamento e da evolução das paisagens na Baixada do Ribeira. Para tornar mais palpáveis os dados dos Censos

\footnotetext{
77 “Com surpreendente facilidade o trabalhador rural muda de emprego, geralmente atraído pelos salários mais altos das plantações novas ou das cidades. Os próprios fazendeiros e, o que é mais significativo, os sitiantes em áreas onde a colonização se fez à base de pequenas propriedades, revelam falta de apego ao meio rural. Quanto aos primeiros, é comum habitarem cidades ou passar a habitá-las, inclusive os grandes centros como São Paulo e Rio, depois de haverem atingido boa situação financeira. Outros, mais ligados às atividades agrícolas, não hesitam em se deslocarem "mais para a frente" quando novas perspectivas de êxito são abertas com deslocamentos mais recentes do movimento pioneiro. Quanto aos sitiantes, que predominam em algumas áreas como nos loteamentos da Companhia de Terras do Norte do Paraná, também não resistem aos atrativos das cidades. A grande maioria dos que formaram sítios ou dos que os exploraram nos primeiros anos (por exemplo, há dez ou quinze anos atrás), não é mais possuidora dos lotes, nem os explora. Deslocaram-se, como tantos outros, para novas 'frentes', quando não foram atingidos pelo êxito; para as cidades, onde se estabeleceram com o capital acumulado em períodos de bons negócios, como aconteceu, por exemplo, nos anos que se seguiram à última guerra.” (FRANÇA, 1960, pp. 13-14.)
} 
de 1940 e 1950 que tratam da distribuição e da composição da população regional, o autor comenta a questão populacional à luz do nível de instrução e da preferência religiosa dos habitantes da região, temas ainda incomuns aos geógrafos em 1960, ano em que apresentou seu trabalho à cadeira de Geografia Humana da FFCL/USP.

Diferentemente do que ocorria então no país, que contava com mais de $90 \%$ de católicos, Petrone observa na Baixada do Ribeira um percentual de $75 \%$, pois em algumas cidades da região crescia em importância o espiritismo, o protestantismo (cuja origem e expansão era difícil de rastrear, dado o número pouco representativo de imigrantes estrangeiros que professavam essa religião na região), e principalmente o budismo, ali presente em número muito superior ao resto do país por conta da concentração de colonos japoneses nas lavouras dedicadas à cultura do chá. Portanto, a distribuição da população segundo as religiões serviria para melhor caracterizar os diferentes núcleos urbanos, como Juquiá, que contava com mais de $20 \%$ de protestantes em sua população, Jacupiranga, que concentrava 18\% de espíritas no total de seus habitantes, e Registro, que apresentava 6,5\% de budistas em sua população municipal: "Percebe-se, em consequência, que as áreas onde o catolicismo ainda conserva quase intactas suas posições anteriores são litorâneas, nas quais Iguape, aliás, é grande centro de romarias” (PETRONE, 1966, p. 65). Já acerca do nível de instrução dos habitantes da Baixada do Ribeira, o autor usa aspectos subjetivos como fatores explicativos quando descreve a perceptível diferença existente no acesso à educação de homens e mulheres, sendo contudo o isolamento da população, as distâncias entre as cidades e a falta de bons caminhos que conseguissem integrar as distintas localidades os motivos básicos que dificultariam a criação de uma rede escolar que atendesse a população como um todo:

O caráter eminentemente rural da população, e a presença de número relativamente pequeno de povoados, com uma predominância, conforme veremos, de habitat disperso, torna difícil localizar escolas que sirvam a uma população em idade escolar numericamente satisfatória. Acresce que, como sempre acontece nas áreas rurais, especialmente naquelas onde é mais comum o cultivador direto, a escola pode significar a subtração de braços para a lavoura, não sendo, por isso, sempre bem acolhida. O próprio modo de ver de uma parte da população tem sua influência. Assim é que a maior taxa de analfabetismo entre as mulheres deve ser atribuída ao fato de muitos julgarem desnecessário a mulher frequentar escola (...). Os aspectos relativos aos quadros demográficos regionais, que poderão ser melhor compreendidos por intermédio dos fatos concernentes à dinâmica de povoamento, objeto das considerações que virão a seguir, constituem importantíssimos elementos condicionadores dos fatos referentes à organização do espaço da Ribeira. (PETRONE, 1966, pp. 66-67.) 
A permanência do juízo que toma o pioneirismo, um fenômeno essencialmente paulista, como a forma mais acabada do programa "Marcha para o oeste" aparece com clareza em outro escrito de Pasquale Petrone que ultrapassa os limites temporais desta pesquisa, mas que, por representativo, vale ser analisado em pormenor. No texto intitulado "Povoamento e colonização", que foi incluído no segundo volume da coletânea Brasil - A Terra e o Homem, organizado por Aroldo de Azevedo (1970), Petrone reconstrói século a século o processo de apropriação de terras que fundamenta a organização espacial do território brasileiro, fazendo referência direta aos principais "ciclos" econômicos que deram vida às mais dinâmicas correntes de povoamento ocorridas nas diferentes regiões brasileiras. Ao chegar no século XX, Petrone destaca o papel das frentes pioneiras, dizendo que:

A primeira metade do século XX conheceu, em várias partes do Brasil, com diferentes intensidades, um processo de desbravamento e povoamento de áreas novas, normalmente rotulado por pioneirismo. As áreas objeto do pioneirismo recente constituíram as denominadas frentes pioneiras, sendo que a evolução do fenômeno no espaço deu margem à marcha das frentes pioneiras. Fenômeno interessantíssimo, permitiu uma série de estudos que relacionamos no fim, dentre todos destacando-se, pelo seu aspecto de síntese das mais completas, a obra de Pierre Monbeig, Pionniers et planteurs de São Paulo. Embora aparecendo, conforme dissemos, em várias partes do Brasil, o fenômeno do pioneirismo recente tem características marcadamente paulistas, tendo se iniciado em São Paulo com os traços que lhe são particulares, estendendo-se por áreas contíguas a esse estado e aparecendo em outros trechos em seguida. Portanto, é em função do estado de São Paulo que devemos considerálo. (PETRONE, 1970, p. 149. Grifo nosso.)

Após enumerar os fatores que em conjunto permitiram a formação da marcha pioneira em São Paulo, como o caráter extensivo da atividade agrícola praticada, que aliou a necessidade de os fazendeiros conseguirem sempre novas terras, rapidamente esgotadas e deixadas para trás por conta do uso intensivo do solo, com a existência de uma imensa área despovoada no oeste do estado, a expansão da rede ferroviária que acompanhava de perto o avanço dos desbravamentos de florestas, ou o rápido crescimento demográfico ocorrido em São Paulo - o que fornecia braços para as lavouras e um mercado consumidor para os produtos de abastecimento produzidos nas fronteiras em expansão -, Pasquale Petrone afirma que, ao longo do século XX, o pioneirismo assumiu a condição de fenômeno de amplitude nacional, espraiando-se por diferentes pontos do território brasileiro com características semelhantes às experimentadas em São Paulo, como o ocorrido na década de 1950 no sudoeste de Goiás, no vale do rio Doce, no Espírito Santo e no sul do estado do Mato Grosso. 
O interessante dessa afirmação é que Petrone estabelece pontos em comum entre o trabalho de Monbeig e os escritos de outros geógrafos que estudaram a questão do pioneirismo nas áreas acima referidas, como Speridião Faissol (1952), Walter Egler (1954), Nilo Bernardes (1953), Lysia Bernardes (1953) e Leo Waibel (1955), pois, para ele, "a busca de áreas novas se efetuou, ou ainda se verifica, em função do empobrecimento das áreas de povoamento mais antigo e, de qualquer forma, com grandes contingentes humanos fornecidos por essas áreas velhas" (PETRONE, 1970, p. 151). Afora o fato de todos esses geógrafos serem ligados diretamente ao CNG ou à Universidade do Brasil, o que sem dúvida ajuda a compreender o alcance das pesquisas produzidas no Rio de Janeiro, que não se restringiam aos aspectos geográficos de apenas um estado brasileiro, como era o comum no caso das pesquisas desenvolvidas na USP, cumpre assinalar a divisão entre as "zonas novas" receptoras de elementos demográficos e as "zonas velhas" que por diversos motivos eram abandonadas, apresentando muitas vezes um decréscimo populacional e uma decadência econômica, parâmetro qualificativo que também havia sido utilizado por Monbeig para caracterizar o movimento pioneiro paulista.

Na última seção do capítulo, Petrone definitivamente aproxima sua interpretação sobre as frentes pioneiras ao sentido conferido por Cassiano Ricardo à "Marcha para o oeste". Notando que a questão dos chamados vazios demográficos nas terras interiores do Planalto Central brasileiro restava ainda não resolvida na década de 1970, o geógrafo estabelece uma relação entre o lema da "Marcha para o oeste", que a partir da década de 1930 "marcou a orientação do governo federal no sentido de utilizar os "desertos" ocidentais do Brasil” (PETRONE, 1970, p. 152), e a construção de Brasília, que de certa forma havia completado o processo de ocupação das terras interiores do Brasil iniciado por Getúlio Vargas, que no seu governo forçara "o aparecimento de novos núcleos de povoamento, quase sempre muitos distantes e isolados, enriquecendo-se o 'arquipélago' demográfico e econômico brasileiro de mais algumas ilhas, contribuindo, paralelamente, para o avultamento dos já numerosos problemas do país” (Ibidem, p. 153).

Apesar de reconhecer o caráter especulativo da colonização do Planalto Central, feita preponderantemente a partir de operações de compra e venda de terras orientadas ou mesmo dirigidas por companhias particulares, que atuavam não raro com amplos incentivos fiscais, num esforço conjunto de colonização com os órgãos oficiais que claramente abriram imensas áreas do país à apropriação privada, Pasquale Petrone acompanha a interpretação de Cassiano Ricardo 
sobre o avanço das fronteiras, pois, segundo ele, as políticas territoriais de interiorização da colonização desenvolvidas pelo Estado brasileiro, a despeito das críticas que se poderiam elaborar e dos problemas que efetivamente trouxeram para o país, foram bem-sucedidas em alterar os quadros demográficos e a organização do território do Brasil, valorizando grandes extensões de terras "desertas" e originando novas paisagens humanas ${ }^{78}$.

Na realidade, o livro Marcha para oeste: a influência da bandeira na formação social e política do Brasil, de Cassiano Ricardo, conta com diversas edições, sendo produtivo citar rapidamente as alterações efetuadas pelo autor em cada uma delas. Na primeira, de 1940, Ricardo faz no prefácio um explícita defesa do Estado Novo, considerando a bandeira e sua estrutura social hierarquizada como portadora dos gérmens do Estado nacional autoritário, única forma política capaz de preservar a verdadeira identidade nacional já esboçada pelos bandeirantes. $\mathrm{Na}$ segunda edição, de 1942, o autor alterou o prefácio e o posfácio, mantendo as passagens que apoiavam o regime varguista no corpo do texto. Na terceira edição, de 1959, o poeta de Martim Cererê escreve um novo prefácio, no qual faz coro às metas desenvolvimentistas de Juscelino Kubitschek, enxergando a nova capital federal como uma etapa subsequente dos anseios de integração territorial já expressos por Vargas. Em 1970, durante o governo do general Médici, quando o projeto da Rodovia Transamazônica ganhava ampla divulgação, o livro saiu em sua quarta e última edição, na qual o bandeirismo moderno encarnado pelo Estado Novo ganhava um novo rebento nas ações dos militares envolvendo a região amazônica.

A convergência entre as conjunturas políticas ditatoriais vivenciadas em 1940 e em 1970 reforça o interesse em notar as adaptações de objetivos operadas no texto de Cassiano Ricardo, à medida que em ambos os períodos os governos de exceção então no poder se utilizavam de uma retórica (e de uma prática) autoritária, recorrendo a discursos nos quais a conquista de terras, a

\footnotetext{
${ }^{78}$ O mecanismo da movimentação pioneira, que nas décadas de 1930 e 1940 ainda respondia, em parte, a um estímulo bem ou mal espontâneo, alimentado em grande parte pelo crescimento demográfico que coagia uma parte da população a migrar pela falta de terras para a prática da atividade agrícola, principalmente nas famílias numerosas já instaladas em propriedades pequenas, que passavam por problemas de sucessão dos herdeiros, os quais necessitavam de novas terras sob o risco de inutilizar o pequeno domínio agrícola de seus pais, havia se modificado completamente nas décadas de 1960 e 1970, quando os grandes projetos de colonização dos governos militares repuseram a marcha de apropriação territorial num diapasão mais ajustado às necessidades do capital: "Certos aspecto do pioneirismo recente já podem ser considerados fatos do passado. Atualmente, grande parte da abertura de frentes pioneiras se faz sob a orientação - mais propriamente, direção - dos interesses especulativos de companhias particulares, quando não sob a direta supervisão de órgãos oficiais. O processo de pioneirismo confunde-se, algumas vezes, com iniciativas tendentes à criação de novos núcleos de colonização de nacionais e estrangeiros. Sob o signo da especulação, a febre de lotear continua abrindo novas fronteiras que, muitas vezes, ficam apenas nas aparentemente tentadoras ofertas das seções imobiliárias dos jornais domingueiros das grandes capitais". (PETRONE, 1970, pp. 151-152.)
} 
integração do território e o desenvolvimento econômico se apresentavam como metas inquestionáveis do governo federal, legitimando em última instância o autoritarismo e funcionando como mote de grande apelo popular para o desenvolvimento de ações de propaganda que ajudariam a sustentar ideologicamente as políticas implantadas:

Vimos, nas partes que se seguiram, que a existência do enorme vazio no CentroOeste brasileiro resultou de uma seleção decorrente dos fatores que presidiram a marcha do povoamento, desde os primórdios da colonização (...). O contraste entre esse enorme vazio e a fachada litorânea relativamente bem povoada, contraste frequentemente visado como um dos responsáveis por muitos dos problemas brasileiros, particularmente os de natureza econômica, tornou-se, a partir da década de 1930, fonte de preocupações oficiais, justificando a interferência do governo federal no incentivo à ocupação do Oeste brasileiro (...). Especialmente a partir da década de 1940, o processo adquiriu contornos como de redescoberta das áreas mais interioranas do país. Vastíssimas parcelas do Centro-Oeste passaram a ser valorizadas, dando margem a uma desenfreada especulação. Gigantescas áreas de Mato Grosso e de Goiás passaram a ser vendidas, quando não cedidas em lotes. Particulares, frequentemente favorecidos pela legislação federal ou estadual, iniciaram um verdadeiro retalhamento dos dois estados (...). O processo como que foi completado com a construção da cidade de Brasília e a transferência da sede do governo federal para a nova cidade, em pleno Planalto Central. A nova capital federal constituiu-se desde logo um extraordinário polo de convergência de interesses. As áreas dentro de um raio de dezenas de quilômetros da cidade sofreram uma rápida valorização; a presença do novo núcleo justificou formas novas de organização econômica do espaço vizinho, ao mesmo tempo que intensificou as relações com Belo Horizonte, Rio de Janeiro e São Paulo. As novas rodovias, a exemplo da Brasília-Acre, Brasília-Fortaleza e, especialmente, a Belém-Brasília, abertas sob indiscutível onda de críticas, tornaram-se eixos de cristalização de novos nódulos de povoamento, contribuindo para transformar radicalmente os quadros demográficos do espaço brasileiro. (PETRONE, 1970, pp. 152-153.)

Como se percebe, Petrone acompanha integralmente o juízo expresso por Cassiano Ricardo no que diz respeito ao alcance das políticas territoriais do governo federal voltadas para a integração dos diferentes núcleos de povoamento existentes no território brasileiro, inclusive quando nosso "Turner autoritário" vislumbra nas obras dos governos militares os objetivos já expressos na época de Getúlio. A alcunha dada a Ricardo por Velho adequa-se bem ao momento histórico vivido entre 1940 e 1970, pois as expansões pioneiras vinculadas ao café, ao algodão e à produção pecuária, ao invés de representarem uma possibilidade de abertura da fronteira pela via do acesso às "terras livres" do sertão, conforme constava no ideal de democracia utopicamente descrito por Turner, foram feitas num quadro fechado de ditadura e repressão (MARTINS, 1995). Ao fim e ao cabo, a permanência dessa ideologia bandeirante que celebra as correntes de colonização dirigidas pelo Estado aos "vazios territoriais" presentes no país, transformando-as 
em justificativas de projetos de poder, não parece ter escapado aos geógrafos, que, mesmo professando sua convicção mediante a neutralidade da ciência, não deixavam de emitir opiniões que guardavam proximidade com determinadas vertentes do pensamento político autoritário.

Em resumo, o fenômeno descrito pelas frentes pioneiras parece indicar, em certo sentido, uma forma de compreensão da maneira como o capitalismo se desenvolveu no Brasil que se fundamenta em uma chave interpretativa que congrega simultaneamente o espraiamento espacial da ocupação do território e a integração dos distintos focos de povoamento do "arquipélago brasileiro", conjugando a expansão dos fluxos internos representada pela circulação de mercadorias, pessoas, ordens e ideias com a organização de uma infraestrutura de comunicações compatível com as necessidades de deslocamento experimentadas pelo país a cada momento, de modo que se chega mesmo a vislumbrar, ao menos nos geógrafos que se detiveram nesse tema, uma preocupação mais ou menos explícita com o papel do Estado como veículo de difusão dos sistemas de engenharia (SANTOS, 1994) que garantiriam a fluidez interna e a consequente modernização do território:

Visto em perspectiva histórica ampla, o Brasil parece um arquipélago. As suas diversidades sociais, econômicas, políticas e culturais, com frequência expressas em termos locais, estaduais, raciais e outros, fazem com que o país dê a impressão de um arquipélago que se forma e transforma ao longo do tempo. Daí a impressão de que periodicamente busca novos arranjos, encontra outras dispersões. Os movimentos no sentido da integração parecem atravessados pelos movimentos no sentido da dispersão. Tem-se a impressão de que as mesmas forças germinam tendências contraditórias, não só divergentes, mas frequentemente opostas. Essa é uma história antiga. O tema da integração e dispersão atravessa a realidade e o pensamento brasileiros. Em dadas ocasiões, ele se põe de novo, umas vezes em termos bem diversos dos anteriores, outras com ingredientes antigos (...). Por isso o Brasil dá a impressão de um país em busca de uma fisionomia. (IANNI, 1992, pp. 159-160.)

A imagem do Brasil como um país em permanente transformação, arquipélago dilacerado por forças contraditórias, permite que imaginemos, do ponto de vista do território, que a busca por uma fisionomia sugerida por Otávio Ianni seja compreendida como uma corruptela do imperativo da conquista que marca o processo da formação brasileira desde o berço, já que a própria colonização portuguesa da América pode ser vista como resultado de um contínuo movimento de apropriação de terras, cuja gênese repousaria no expansionismo lusitano (MORAES, 2000; NOVAIS, 1979). A propósito, a preocupação com o tema da integração e dispersão, que marca o pensamento e a realidade brasileira, inspirou os trabalhos de muitos dos geógrafos que se dispuseram a fornecer sua contribuição para o entendimento do país, 
aparecendo no horizonte das obras daqueles que mais detidamente analisaram o tema das franjas pioneiras sob a forma de análises acerca da infraestrutura de transportes que facilitaria a chegada (ou a manutenção) da população e o escoamento das mercadorias produzidas nas novas áreas produtivas incorporadas ao espaço econômico do país. Todavia, é importante notar que nesses trabalhos o problema da integração do território não é explicitado claramente, ou melhor, no tratamento do fenômeno do pioneirismo, a integração territorial normalmente aparece associada à questão da circulação, traduzida na atenção dispensada às dificuldades interpostas pela condição de isolamento dos núcleos de povoamento enfocados nas monografias regionais, e, pois surgindo como um ponto subsidiário da descrição de um processo de colonização que abarcaria um conjunto de outros aspectos, quais sejam, o aumento demográfico, a mobilidade da população e a conquista de novas áreas para as atividades agropecuárias que dinamizariam as correntes colonizadoras, fixando a ocupação e catalisando a modernização ${ }^{79}$.

Acompanhando a interpretação de Otávio Guilherme Velho (1979), as fronteiras em movimento, ao integrar espaços considerados vazios às áreas economicamente ativas do território brasileiro, deram continuidade ao desenvolvimento de tipo autoritário bem particular à via brasileira de formação do capitalismo, numa ação de controle da mão-de-obra que insuflou as migrações internas do "campesinato marginal" pela interdição do acesso às terras na fronteira. Essa situação de "fronteira aberta, porém controlada" (VELHO, 1979, p. 87) pode ser compreendida como uma ação de repressão que facilitou o crescimento da população excedente nas cidades, dando origem a um exército industrial de reserva aproveitado nos momentos de crescimento da indústria. A expansão territorial do capital no campo, que continuou a se utilizar da força de trabalho expulsa de suas terras no desmatamento de florestas para a produção das

\footnotetext{
${ }^{79}$ A ideia de que o processo histórico de ocupação do território brasileiro resultou em uma configuração espacial semelhante a um arquipélago, ou seja, o entendimento de que a formação territorial do país teria sido presidida pela consolidação de núcleos mais ou menos isolados de povoamento, que guardariam características próprias de desenvolvimento demográfico, econômico e cultural, é tema recorrente em autores das mais diferentes áreas do conhecimento, conforme se pode observar principalmente ao longo da primeira metade do século XX, quando era comum referir-se às singularidades históricas e geográficas de cada um desses núcleos como forma de explicar a gênese e desenvolvimento das qualidades e disparidades existentes entre as distintas regiões do Brasil. No mais, a busca de uma integração entre essas regiões-ilha pode também ser vista como um objetivo citado a todo instante como meta a ser alcançada pelo país, catalisando, nesse pormenor, políticas territoriais por parte dos órgãos de Estado, que viam nessa questão uma forma de justificar a implementação de projetos de desenvolvimento econômico e social fundamentados em determinadas estratégias de apropriação territorial. Para citarmos apenas alguns dos estudiosos que produziram páginas sobre tal tema: Gilberto Freyre (1942); Viana Moog (1942); Caio Prado Jr. (1945); Celso Furtado (1959) e Manuel Diegues Jr. (1960).
} 
fazendas (MARTINS, 1979) ${ }^{80}$, criou condições para o desenrolar de um processo de acumulação primitiva, comum nos momentos de transição de um padrão de acumulação agrário-exportador para uma padrão mais ligado à atividade industrial, como o que então experimentava o país (CANO, 1978; 1985; MELLO, 1982).

É com esse pano de fundo que Cassiano Ricardo foi considerado um “Turner autoritário", pois ao elaborar um mito de origem da identidade brasileira a partir da experiência nacional da fronteira, mimetizada na saga bandeirante, o modernista verde-amarelo constrói uma leitura do processo de formação do país que legitima o autoritarismo estatal, pois, para Ricardo, “a experiência da fronteira leva ao desenvolvimento do autoritarismo brasileiro" (VELHO, 1979, p. 136):

A analogia entre a bandeira e o Estado Novo é clara. São ambos autenticamente brasileiros ou "americanos" e não importados (embora, significativamente, Ricardo os aproxime diversas vezes de experiências "romanas"). Através da "democracia hierárquica" ambos têm que enfrentar e submeter o "feudalismo" (no caso do Estado Novo o coronelismo) e o comunismo (o comunismo "selvagem" para a bandeira e o comunismo "russo" para o Estado Novo). E ambos têm um território a conquistar ou ocupar. Assim, ideologicamente a Marcha para Oeste do Estado Novo foi da maior importância no estabelecimento de uma ponte com o movimento bandeirante e uma reencenação dele através do cultivo de um "espírito bandeirante". Agora o território tinha que ser definitivamente ocupado. Não era mais apenas uma questão de marcha para oeste, mas também de marcha para $o$ oeste. E a ênfase de C. Ricardo sobre a pequena propriedade como sendo característica do bandeirante estabelecido (um traço que para dizer o mínimo parece ser historicamente de pouca importância), em contraste com a grande propriedade "feudal", também determina o tipo de ocupação que tinha em mente e que completaria o quadro. Na quarta edição de seu livro C. Ricardo acentuaria no capítulo final o prosseguimento do "espírito

\footnotetext{
${ }^{80} \mathrm{~A}$ articulação existente entre a apropriação de terras nas áreas de movimentação de fronteira e o processo de produção do capital na forma de fazendas é o que permite asseverarmos aqui que a interpretação geográfica das frentes pioneiras comporta um entendimento acerca do processo de consolidação do capitalismo no país. Em texto de 1995, José de Souza Martins, referindo-se às origens estruturais da situação de escravidão de peões por ele observadas nas frentes de expansão que retalharam a Amazônia brasileira em imensas fazendas de gado, destaca o mecanismo de inserção marginal da ocupação da fronteira no processo de reprodução ampliada do capital, afirmando que na expansão territorial do capital ocorrida no Brasil: "Essa modalidade de exploração do trabalho se traduz em acumulação primitiva porque é, em parte, produção de capital no interior do processo de reprodução ampliada do capital. Isso fica claro se entendermos que, historicamente, pode-se falar em reprodução capitalista de capital, reprodução de capital com base em relações formalmente capitalistas de produção. Mas não se pode falar em produção capitalista de capital, pois a produção de capital envolve mecanismos e procedimentos próprios da acumulação primitiva (...). Essencialmente, o que define o processo não é o resultado, mas o modo como foi obtido, isto é, o modo de produção do excedente econômico: o resultado é capital, capitalista, mas o modo de obtê-lo não o é. O que a peonagem tem promovido na frente pioneira desde pelo menos a expansão dos cafeeiros brasileiros para o oeste de São Paulo, no século XIX, é a produção de fazendas e não, fundamentalmente, a produção de mercadorias, nas fazendas, para o mercado de consumo; isto é, a peonagem tem produzido, sobretudo nos casos recentes, os meios de produção a serem utilizados pelo capitalista na produção de mercadorias. E não principalmente nem diretamente as próprias mercadorias." (MARTINS, 1995, p. 9.)
} 
bandeirante" estatal para além do Estado Novo, enfatizando sobretudo como marcos a construção de Brasília, a Rodovia Belém-Brasília, o Projeto Rondon e a Rodovia Transamazônica. O ideólogo sensível percebia, ainda utilizando a fronteira como matéria-prima para as suas elaborações, o fio condutor que dava unidade ao nosso modo de desenvolvimento capitalista, mesmo numa época em que a maioria preferia acentuar as descontinuidades. (VELHO, 1979, p. 137.)

Enfim, esse encaminhamento da questão ajuda a revelar uma face da dinâmica espacial no Brasil do século XX, sobretudo se tivermos em conta o exame das ações de incentivo à economia propostas tanto na época de Getúlio Vargas quanto nos governos ditatoriais encampados pelos militares. Com efeito, o avanço da modernização do Brasil entre 1930 e 1960 acentua a formação de paisagens heterogêneas, criadas pela associação existente entre a expansão de produtos agrícolas de exportação, como o café e o algodão, a diversificação do parque industrial do país e o avanço da urbanização. Seguindo aqui as pistas deixadas por Antônio Carlos Robert Moraes, que em livro recente esquadrinha o tratamento do conceito de território na obra de Milton Santos, podemos dizer que, conciliando-se com as modificações de cunho epistemológico pela qual passava a geografia, o tema da modernização do território, associado à questão da integração territorial, adquire contornos nítidos nos trabalhos do intelectual baiano elaborados entre o final da década de 1960 e início de 1970, quando sua adesão aos pressupostos da geografia regional francesa eram ainda muito claros, mesmo nos textos de acentuado caráter crítico que tratam do processo de urbanização do mundo subdesenvolvido (MORAES, 2013). Por exemplo, no livro $A$ urbanização desigual, lançado originalmente em francês, em 1971, Milton Santos compara a evolução urbana dos países industrializados com o caso dos países subdesenvolvidos, apontando que a fluidez experimentada pelos fluxos de bens e capitais, que caracterizaria os espaços urbanos nos primeiros, torna-se, quando ausente, uma qualidade distintiva dos espaços subdesenvolvidos, vale dizer, um fator explicativo da macrocefalia urbana dos países periféricos, "o reflexo da não fluidez do espaço e de sua desarticulação" (SANTOS, 2010, p. 128). Os países subdesenvolvidos teriam então, como ponto em comum, que avaliar a necessidade de construção de uma infraestrutura de equipamentos específicos, como estradas, portos e aeroportos, que garantissem a circulação interna dentro de seus territórios e respondessem às condições de modernização da economia:

Nos países desenvolvidos, a modernização, consequência direta da industrialização, desempenhou um papel estimulante em face da quase totalidade dos outros setores da atividade econômica. Já nos países subdesenvolvidos, onde a modernização não é uma consequência direta da industrialização local, mas de fatores externos, os resultados não foram os mesmos (...). Enquanto a cidade dos 
países industrializados é parte integrante de um território que mais ou menos a gerou e com o qual viveu, em constantes inter-relações, a mesma aventura histórica e econômica, a cidade dos países subdesenvolvidos aparece muitas vezes como um corpo estranho, alógeno, inserido em um meio com o qual estabelece relações descontínuas no espaço e no tempo. A não integração do território, impedindo a livre circulação dos elementos da economia (homens, bens, capitais), freia, por si só, o desenvolvimento. É por isso que se pode dizer que a cidade dos países subdesenvolvidos se lança à conquista do espaço a partir de duas verdadeiras alienações: a cidade mesma nasce para servir a interesses distantes e, por outro lado, sua zona de influência é, muitas vezes, um desses "espaços derivados", cuja vida depende, em grande parte, de fatores externos (...). Dessa forma, a ausência de ligações fáceis entre as diferentes partes do país constitui fator de atraso, como se pode ver nas dificuldades encontradas pelo Brasil por ocasião de seu desenvolvimento industrial. O país teve de fazer face aos problemas de transportes e serviços de base, anteriormente organizados em função dos interesses da economia de exportação e, por isso, não adaptados para servir um mercado interno. (SANTOS, 2010, pp. 107/109110. Grifo nosso.)

Tendo em vista a conjuntura da expansão mundial do capitalismo e do capital no início do século XX (HARVEY, 2011; ARRIGHI, 1996), dentro da qual o incremento do avanço pioneiro paulista é uma manifestação contextualmente adequada, pode-se perceber, com Milton Santos (1988; 2002), que a ideia do desenvolvimento geograficamente desigual, prefigurada nas diferentes paisagens surgidas do contraste entre as áreas agrícolas dinamizadas pelos pioneiros, os centros urbanos que se dinamizavam e o incremento demográfico e industrial da capital paulista, ganha um novo alcance com a crescente mundialização da economia, visto que a propagação dos modernos processos de produção, que a partir de então vão se espalhando diferencialmente por todo o globo, fixando-se de forma concentrada em variados pontos da superfície terrestre, precipita uma intensa especialização dos lugares ${ }^{81}$.

Uma tal especialização do processo de produção do espaço, percebida na coexistência de paisagens pretéritas que respondiam a um arranjo surgido numa conjuntura histórica de um passado mais ou menos recente com paisagens modernas dinamizadas pelos processos urbanoindustriais mais atualizados do momento, é uma chave interpretativa frutífera para compreender

\footnotetext{
81 "O desenvolvimento desigual e combinado caracteriza toda a formação social brasileira, ao longo da Colônia, Império e República. A sucessão dos "ciclos" econômicos, em combinação com os surtos de povoamento, expansões das frentes pioneiras, organização do extrativismo, pecuária e agricultura, urbanização e industrialização, tudo isso resultará numa sucessão e combinação de formas as mais diversas e contraditórias de organização da vida e trabalho (...). O resultado, periodicamente alcançado e recriado, é uma vasta e surpreendente "desarticulação". O presente, em cada época, parece um mapa histórico, ou melhor, arqueológico, no qual se combinam vários pretéritos (...). Aí está uma peculiaridade básica da formação social brasileira, conforme ela se revela no século XX. O presente capitalista, industrializado, urbanizado convive com vários momentos pretéritos. Formas de vida e trabalho díspares aglutinamse em um todo insólito. A circulação simples, a circulação mercantil e a capitalista articulam-se em um todo no qual comanda a reprodução ampliada do capital, em escala internacional.” (IANNI, 1989, pp. 71-72.)
} 
as contradições estruturais que opunham as "zonas velhas" da expansão cafeeira, organizadas ainda no XIX sob o regime escravista, às "zonas novas" das frentes pioneiras de meados do XX, financiadas como um negócio de base capitalista, abrindo a possibilidade para que esse processo possa ser interpretado a partir da concepção que toma o espaço como resultado de uma “acumulação desigual de tempos” (SANTOS, 1997) ${ }^{82}$.

Ora, no primeiro parágrafo da introdução de seu livro sobre o mundo pioneiro paulista, o francês já alertara para o entrelaçamento de temporalidades diversas engendradas pela expansão do povoamento, uma vez que o movimento, por incessante, integrava constantemente zonas "novas" ao espaço econômico brasileiro, com o que teríamos, como consequência, polarizações entre estas áreas recém-conquistadas e as zonas "velhas" deixadas sem desenvolvimento na retaguarda das correntes em expansão ou por elas abandonadas após um período de fausto a que se seguia um não menos acachapante declínio:

A atividade econômica do estado de São Paulo, centro vital da economia brasileira, recebe, da existência das zonas novas, seu impulso mais forte. $\mathrm{O}$ cultivo de terras há pouco recobertas de matas, a avançada constante dos pioneiros, a abertura de novas fazendas são fatores que agem com raro vigor sobre o conjunto da vida paulista. Toda ela se ressente do contínuo deslocamento de importante massa da população cuja instabilidade, quatro séculos após o desembarque dos primeiros portugueses, persiste como um dos seus traços fundamentais. Por outro lado, o crescimento dos bairros da capital reflete os impulsos do povoamento em tal ou qual direção; dependem as indústrias das matérias-primas fornecidas pelas regiões pioneiras, assim, como da absorção dos seus produtos nos espaços recém-povoados; seus operários provêm das terras cuja decadência, em grande parte, não é senão a consequência

\footnotetext{
${ }^{82}$ Embora o objetivo explícito de Milton Santos seja desenvolver um arcabouço teórico-conceitual apropriado para a análise de uma geografia do presente, em sua obra podemos encontrar diversas passagens que podem enriquecer a análise dos geógrafos preocupados com questões históricas. Em uma das mais significativas, Milton defende que o enfoque geográfico deve obrigatoriamente levar em consideração a noção de tempo (ou de processo) no estudo da divisão do trabalho, uma vez que, num mesmo momento histórico, pode-se reconhecer nos lugares a incidência de uma sobreposição das divisões do trabalho passadas: "Cada lugar, cada subespaço, assiste, como testemunha e como ator, ao desenrolar simultâneo de várias divisões do trabalho. Comentemos duas situações. Lembremo-nos, em primeiro lugar, de que a cada novo momento histórico, muda a divisão do trabalho. É uma lei geral. Em cada lugar, cada subespaço, novas divisões do trabalho chegam e se implantam, mas sem exclusão da presença dos restos de divisões do trabalho anteriores. Isso, aliás, distingue cada lugar dos demais, essa combinação específica de temporalidades, diversas. Em outra situação, consideremos, apenas, para fins analíticos, que, dentro do todo, em uma dada situação, cada agente promove sua própria divisão do trabalho. Num dado lugar, o trabalho é a somatória e a síntese desses trabalhos individuais a serem identificados de modo singular em cada momento histórico. É nesse último sentido que podemos dizer que cada divisão do trabalho cria um tempo seu próprio, diferente do tempo anterior. Isso, também, é muito geral, pois esse ‘tempo' acaba por ser abstrato, apenas ganhando concretude com sua interpretação, na vida ativa, pelos diversos agentes sociais. É assim que, a partir de cada agente, de cada classe ou grupo social, se estabelecem as temporalidades (interpretações, isto é, formas particulares de utilização daquele tempo geral, 'temporalizações práticas' no dizer de J. P. Sartre) que são a matriz das espacialidades vividas em cada lugar." (SANTOS, 2002, p. 136.)
} 
da proximidade de vastas áreas intactas. Saindo-se da metrópole paulista e percorrendo-se os territórios demais longa data conquistados e povoados, neles também se revela a influência das zonas novas, ainda que longínquas (...). Por toda parte, na cidade como no campo, sente-se que nada se estabiliza, nada é definitivo, e que a economia e o povoamento se solidarizam com a marcha pioneira, que inexoravelmente arranca rumo ao oeste, a centenas de quilômetros (MONBEIG, 1984 [1952], p. 21).

De mais a mais, do ponto de vista da geografia, as frentes pioneiras podem ser compreendidas como um movimento contínuo de apropriação e povoamento de novas terras impulsionado desde sua origem por um atividade agrária de fins comerciais, representada pelas lavouras de café, de algodão e o gado, e por uma selvagem especulação imobiliária, percebida nos loteamentos de terras que originaram de forma legal e ilegal grandes domínios fundiários. O nexo comercial dessa corrente colonizadora é reposto e ampliado pela transformação da terra em mercadoria, que estimulava a especulação, feita de preferência nas proximidades de um centro urbano ou nas adjacências das estradas. Contudo, conforme se pode depreender dos textos analisados, o importante na análise geográfica das frentes pioneiras, que sugere uma interpretação do processo de desenvolvimento do capitalismo no Brasil, não são as relações sociais engendradas nas áreas de movimentação das fronteiras, nem sequer as motivações econômicas e políticas daqueles que comandam a expansão da fronteira, embasando a dinâmica migratória, mas sobretudo o aspecto visível das transformações que tais fenômenos impõem à configuração territorial do país, isto é, na análise geográfica do pioneirismo enfoca-se apenas o resultado material que as relações sociais fixam na organização das paisagens.

Por fim, se nossa análise não comportasse um aprofundamento de certos tópicos da geografia urbana - assunto tratado em sua integralidade, entre outros, por Maurício Abreu (1994; 2006) e Marie-Claire Robic (1998) -, a referência a alguns dos textos de Milton Santos dedicados ao tema pareceria um ponto fora da curva na estruturação dos nossos argumentos. Sem embargo, vem em nosso auxílio uma arguta observação de Heliana Angotti Salgueiro, estudiosa da obra de Monbeig que muito oportunamente notou a relação fundamental estabelecida pelo geógrafo francês entre as movimentações pioneiras, a construção de uma rede de transportes, a industrialização e a fundação de centros urbanos:

Para entender a fundação e a evolução das cidades das franjas pioneiras deve-se ter em mente, sobretudo, que as redes de transporte funcionaram como meios de organização do território: os traçados dos lotes e as fundações urbanas dependiam das linhas da estrada de ferro. Cidades e circulação se associavam nas terras de São Paulo (...). Sua leitura sobre as cidades inscreve-se num jogo 
de escalas em que se associam: rural/urbano e cidade/circulação. A cidade é fato de deslocamento de população e capitais (...). A tendência à mobilidade é um dos níveis da associação do fenômeno urbano ao rural. (SALGUEIRO, 2006, pp. 98-99.)

Expressivamente, na obra Pioneiros e fazendeiros de São Paulo, Monbeig dedica os dois últimos capítulos aos fatos urbanos que se relacionavam com a expansão das fronteiras agrícolas para o oeste de São Paulo e norte do Paraná, asseverando, logo no início, que "confunde-se a geografia das cidades com a das comunicações, sendo esta última uma função do relevo" (Monbeig, 1984 [1952], p. 338). Assim, se o francês atrelava o traçado das vias de comunicação às facilidades ou dificuldades impostas pelo relevo, numa operação que traduz a indisfarçável verve naturalista presente nos estudos geográficos das cidades embasados na metodologia de Vidal de La Blache (ABREU, 2006), ele igualmente afirmava, numa amostra de sua luta contra as explicações de cariz determinista, que conferiam peso demasiado aos quadros da natureza no entendimento das decisões tomadas pelos homens, que as condições naturais e o modelado do relevo não eram os maiores responsáveis pelo sucesso momentâneo ou eventual fracasso dos núcleos urbanos, sendo na verdade os grupos humanos “os únicos responsáveis pelos destinos desiguais de suas obras urbanas" (MONBEIG, 1984 [1952], p. 346) ${ }^{83}$.

As relações de solidariedade entre os processos correlacionados da industrialização, da urbanização e do avanço pioneiro das fronteiras agrícolas brasileiras, que Monbeig observa tendo os olhos no caso paulista, evidenciam-se no livro intitulado La croissance de la ville de São Paulo, que foi concluído em 1949 como tese complementar ao seu trabalho principal, dedicado aos pioneiros e fazendeiros de São Paulo (MONBEIG, 1953). Logo na abertura, após declarar que o fenômeno urbano experimentado por São Paulo desde o final do século XIX pode ser compreendido como um reflexo das técnicas modernas e das possibilidades de modificação dos meios naturais que elas facultam à sociedade, afirma que a distância crescente que se interpôs entre a capital paulista e as zonas pioneiras, levadas cada vez mais para oeste, não apagou os laços que as uniam: “Quoique São Paulo soit maintenant fort distant des zones pionnières, il est

\footnotetext{
${ }^{83}$ Tampouco vem ao caso fazer uma incursão aprofundada acerca da influência do trabalho de Monbeig no desenvolvimento dos estudos de geografia urbana no Brasil. Entretanto, é válido assinalar o texto "O estudo geográfico das cidades", escrito em 1941, que orientou a feitura de inúmeros trabalhos nos anos seguintes, definindo a "monografia urbana" como o resultado da aplicação do método regional francês para a análise de uma cidade. Entre os pontos avaliados pela monografia urbana, não poderia ficar de fora a discussão acerca do sítio, da posição, da evolução histórica, das funções urbanas e do raio de ação das cidades: "Assim delineada, o que se poderia esperar de uma monografia urbana? Nada menos do que uma síntese urbana. E como fazer essa síntese? Da mesma forma como vinham sendo feitas as 'sínteses regionais', ou seja, através da integração analítica de dados físicos e humanos, objetivando com isso demonstrar a individualidade deste 'fato geográfico' que era a cidade.” (ABREU, 1994, p. 27.)
} 
toujours solidaire: sa croissance, l'évolution de ses fonctions sont complémentaires des transformations de la frange pionnière. Marche pionnière et croissance de la Capitale sont les deux panneaux d'un dyptique" (MONBEIG, 1953, p. 5). A definição é feita em termos sedutores: a urbanização da capital e a marcha pioneira são como os painéis de um díptico, duas obras de um mesmo e único gênero, ou processo, que se completam.

Pelo que foi dito, nota-se que na análise do que chama de urbanização pioneira, Monbeig estabeleceu uma relação de dependência entre o surto urbano dinamizado nas franjas pioneiras, a industrialização generalizada que o animava e a clientela cativa de pequenos proprietários rurais que provocavam o crescimento das funções comercial e industrial nos núcleos pioneiros, e isso tanto nas maiores cidades interioranas já desenvolvidas, qualificadas de "capitais regionais", quanto nos pequenos e fervilhantes núcleos recém-fundados, ambos viabilizados apenas e tãosomente "na medida em que a rede de comunicações assegure o pleno desenvolvimento de suas funções. Aqui está o dado essencial. O trilho e a estrada de rodagem criam os sítios favoráveis às fundações urbanas" (MONBEIG, 1984 [1952], p. 347). Infere-se portanto que a construção de uma rede eficiente de comunicações é encarada como a garantia do desenvolvimento da vida urbana, pressuposto que pode ser visto de maneira clara se atentarmos para as etapas do que Monbeig chamava de "evolução funcional e morfológica" das cidades. Acompanhando a trajetória de transformação de antigos patrimônios em cidades, Monbeig faz uso de metáforas que naturalizam as relações sociais, exprimindo-se num vocabulário evolucionista muito em voga nos estudos geográficos inspirados pela figura de Vidal de La Blache (BERDOULAY, 1982). Essas características revelavam-se mormente quando ele descrevia os estágios de desenvolvimento de uma cidade, considerada como um organismo criado por meio de um "ato de posse do solo por um grupo humano" (MONBEIG, 1943, p. 8). Contudo, ele evitava se utilizar livremente do esquema que generaliza para todas as cidades as etapas formativas de um núcleo urbano - que, como no esquema que William Morris Davis desenvolveu para a Geografia Física, passaria pelos estágios de "infância", "juventude”, "maturidade" e "decadência” -, notando ser possível rastrear, nas franjas pioneiras, uma certa similitude entre a evolução funcional e a modificação das paisagens urbanas dos diferentes centros. Estabelecidos esses parâmetros, concluía então que o início da urbanização dos antigos patrimônios rurais podia ser avaliado a partir das transformações permanentes que a industrialização introduzia nas paisagens: 
Mede-se a progressão da cidade por transformações menos ruidosas, porém, duráveis. Grande passo é dado com a instalação de estabelecimentos industriais. Os primeiros a instalar-se são as serrarias, rapidamente seguidas pelas máquinas de despolpar café, descascar arroz e descaroçar algodão. Ligam-se todas essas indústrias à produção rural e a presença delas robustece tanto mais a solidariedade da cidade com o campo, quanto os donos das máquinas são ao mesmo tempo os banqueiros dos pequenos plantadores (...). Sob outro aspecto, contribuem as primeiras indústrias para a criação de uma paisagem urbana, favorecendo uma primeira tendência à formação de bairros. Colocam-se nos lugares mais favoráveis, nas entradas das cidades, para quem vem das zonas de desbravamento, e sobretudo perto da estação, ao longo da estrada de ferro. (MONBEIG, 1984 [1952], pp. 359-360.)

Apoiado em um texto de Pierre Deffontaines (1944) escrito originalmente no ano de 1938 que aprecia a formação da rede de cidades brasileiras, Monbeig considerava que o processo de fundação de cidades nas áreas de movimentações pioneiras não havia se modificado muito desde os tempos coloniais, pois o "sistema de patrimônios" nas zonas pioneiras atrelava a fundação de uma cidade aos interesses diretos de uma grande fazenda ${ }^{84}$. Com efeito, a existência de uma aglomeração urbana era assunto de interesse dos fazendeiros, que buscavam centralizar, de um só golpe, a disponibilidade de armazéns para comprar mantimentos ou ferramentas e as facilidades de arregimentar mão-de-obra. Para tanto, o proprietário resolvia então dispor de um pedaço de sua fazenda para um loteamento urbano, que também proporcionaria lucros com a venda de terras no entorno do terreno destinado à cidade: “este terreno traz o nome de 'patrimônio' com um qualificativo qualquer (o mais das vezes o próprio nome do agricultor)" (MONBEIG, 1940, p. 44).

Outro aspecto importante é a sutil diferenciação feita pelo francês entre o núcleo de povoamento qualificado como "boca do sertão" e aquele adjetivado como "cidade pioneira". Considerados como estágios de desenvolvimento ou evolução de um núcleo urbano, a cidade

\footnotetext{
${ }^{84}$ Esse texto foi republicado em 1944, em tradução de Orlando Valverde, no Boletim Geográfico do CNG. Nele, Deffontaines confere destaque ao sistema de fundação de cidades praticado no Brasil desde o início da colonização portuguesa, diferenciando os patrimônios religiosos dos patrimônio leigos. Os primeiros, mais tradicionais na história brasileira, pois que Deffontaines cita documentos do século XVII que comprovariam a permanência desse hábito, teriam sua origem ligada à doação de um terreno feita por um ou vários fazendeiros, que constituíam um patrimônio oferecido à igreja, ou, o que era mais comum, a um santo, o verdadeiro patrono sob cujo nome se erigia uma capela e um cemitério, dinamizando outras construções e arruamentos que se aproveitavam das vantagens desse agrupamento inicial, que levava o nome da figura católica homenageada. Mais recentemente, isto é, desde o início do século XX, Deffontaines identificava a dispensa da intermediação da Igreja: "Nesses casos o fazendeiro torna-se povoador, isto é, criador de povoamento ou ainda plantador de cidades e não é mais a igreja que assume o patronato das fundações urbanas. A nova nomenclatura da cidades novas se ressente dessa laicização". (DEFFONTAINES, 1944, p. 302). De todo modo, a questão da "abertura de patrimônios" está intimamente relacionada com a história da apropriação da terra e da constituição da propriedade privada no Brasil, constituindo-se num dos mais poderosos instrumentos de legitimação da posse da terra desde a época colonial. Sobre a questão, vide Silva (1996) e Smith (1990).
} 
julgada pioneira seria mais exatamente a ponta de lança do movimento de conquista de terras, localizando-se em meio às áreas de derrubadas e ladeada de florestas em vias de desaparecimento, a uma certa distância dos núcleos ditos "bocas do sertão", normalmente associados a uma estação ferroviária ou a uma estrada, ou seja, a retaguarda imediata do povoamento. Quando a ferrovia se deslocava buscando novas terras, o antigo núcleo pioneiro tornava-se o ponto terminal dos trilhos, deslocando-se também para adiante as franjas do povoamento pioneiro. Na verdade, num dos primeiros textos que escreveu sobre o fenômeno do pioneirismo paulista, publicado pela primeira vez em 1937, em francês, na futuramente prestigiosa revista Annales d'Histoire Économique et Sociale, Pierre Monbeig define os termos que vimos até agora destacando, ressaltando o duplo caráter rural e urbano do processo de colonização que se efetuava no oeste de São Paulo e no norte do Paraná. Tendo como exemplo os casos de Marília (fundada em 1928) e de Londrina (fundada em 1934), ambas então no auge de seu desenvolvimento pioneiro, conclui:

Nascidas de um plano estudado ou construídas ao acaso, estas cidades pioneiras têm atividades idênticas; uma parte da população tem vida rural, quer no ano inteiro, quer nos períodos de urgência nos trabalhos das plantações (...). Ao lado deste elemento rural ou semi-rural da população urbana coloca-se o grupo dos funcionários e das profissões liberais: serviços administrativos, sanitários policiais, empregados de bancos, de seguros, advogados, médicos e professores, cuja presença é indispensável numa cidade pioneira, que representa muito mais o papel de capital regional do que a maioria das cidades do interior paulista, apesar de mais povoadas. Possui as instalações industriais complementares das culturas tropicais, mas a principal função de Marília, de Londrina e de outras é o comércio (...). Em Marília, mais do que em Londrina, tem-se a impressão de um perpétuo mercado. A cidade pioneira, centro industrial, é um nó de comunicações; é o ponto terminal das raras estradas que servem a zona, é o fim da linha férrea, ou, em todo caso, a estação melhor equipada (...). Para o paulista a cidade pioneira é a porta do "bled", a "boca do sertão"; sua febre, sua atividade foram conhecidas de quase todas as cidades do estado: Ribeirão Preto, Bauru, Botucatu, Jaú, Barretos, Rio Claro ou Franca. Dura dez, quinze, vinte anos no máximo, e passa quando os trilhos são levados para mais longe e nasce uma nova cidade pioneira. Os mapas do fim do século XIX e do princípio do século XX mostram-nos muito bem essas cidades-terminus e, a certa distância, como perdidas no sertão, aquelas que as destronarão. Elas definham então pouco a pouco; sua economia transforma-se também, ao que parece, menos ligada à vida rural e com indústria própria; em uma região de população estável e relativamente densa são focos de instrução com um bairro de escolas oficiais ou particulares. Há um ciclo urbano, com diferentes estágios, até mesmo o rejuvenescimento. (MONBEIG, 1940, pp. 48-49-50. Grifo nosso.)

O caráter integrador da frontier, termo que é compreendido praticamente como sinônimo do avanço das frentes pioneiras em áreas tidas como sertões, é indicado principalmente pelo uso 
da palavra francesa bled, termo de origem militar que designava as terras interiores da África do Norte francófona em vias de incorporação pelo desbravamento comandado pelas políticas colonialistas francesas. No geral, a convicção de Monbeig sobre o papel estratégico das vias de comunicação na apropriação de novas terras expunha a questão da integração territorial associando-a diretamente aos problemas colocados à circulação pela falta de estradas, podendo ser assim resumida:

Ora, em todo o imenso continente brasileiro, uma das necessidades mais imperiosas é sem dúvida a de assegurar relações constantes entre todos os elementos da população. É preciso conseguir resolver - no sentido que dão à palavra os médicos ao referir-se a um abcesso - os agrupamentos que vivem nessas ilhas raramente atingidas pelos vapores, fora do mundo atual, num estádio de economia arcaica e cuja contribuição para a vida nacional se torna, em consequência, extremamente fraca. É preciso conseguir que a nação brasileira, toda ela, viva num mesmo ritmo e numa mesma época. Para tal, entretanto, é necessário suscitar o desenvolvimento das trocas entre todos os seus elementos e, antes de mais nada, criar os meios de efetuá-las: as estradas. (MONBEIG, 1940, pp. 141-142.)

A integração territorial surge, aqui, como um pressuposto para a modernização do país, sobressaindo-se, ainda, a visão padrão do Brasil como um arquipélago, formado no mais por ilhas isoladas que apresentam níveis muito distintos de desenvolvimento, partes de um todo funcionando em ritmos desconexos, revelando a convivência de um "mundo arcaico", domínio do tempo lento, contraposto às ilhas de modernidade, numa concepção dualista da realidade brasileira que não era incomum ao pensamento político-social do momento.

Enfim, conforme pode-se esboçar do que foi acima exposto, a análise das fronteiras colocadas em movimento pelo fenômeno do pioneirismo, tal como feita nos estudos geográficos sobre o tema, aqui avaliados a partir da obra de Pierre Monbeig, permite observar a maneira pela qual a modernização - ajuste sincrônico dos espaços periféricos à temporalidade do mundo capitalista - aparece como um componente da integração territorial, desdobrada em termos dos ganhos de mobilidade e fluidez do território que adviria da construção de uma infraestrutura de comunicações e transportes. A existência de um movimento expansivo de colonização lastreado em uma atividade econômica de origem agrária, que incide decisivamente na organização do território, alterando paisagens rurais e urbanas, coloca a consolidação das cidades como um pressuposto das movimentações pioneiras nos campos: "Cidades e campanhas pioneiras são, pois, tão estreitamente unidas espiritualmente, quanto materialmente. Depende o destino das organizações urbanas do surto e estabilização da agricultura. Não se concebe como suas 
indústrias e seus comércios possam achar outros recursos que não os do solo" (MONBEIG, 1984 [1952], p. 374).

Essa relação de comando exercido pelos centros urbanos nas áreas rurais, que se vê replicada em variadas escalas, convergindo para a capital paulista, era dinamizada pelo aumento das atividades bancárias nas franjas pioneiras, um "prolongamento direto da função mercantil e o complemento da atividade industrial" (Ibidem, p. 366), sendo ainda reforçada pelo estabelecimento de um parque industrial voltado para a transformação e beneficiamento das mercadorias produzidas em escala regional, que ao circular teceriam circuitos espaciais de cooperação e auxiliariam na formação de uma hierarquia urbana entre as capitais regionais e suas cidades-satélite, e destas com a metrópole paulista, conquanto cada capital regional da franja pioneira organize internamente paisagens especializadas no exercício de diversas funções (financeiras, comerciais, culturais, religiosas, administrativas, entre outras), assenhorando-se de uma rede de estradas que as fazem verdadeiros "nós de comunicação" dentro de um sistema mais amplo, condição que lhes permite estender seu raio de ação e influência para além de seus limites administrativos, consolidando um domínio sobre uma região mais ou menos extensa, que se torna assim uma sua tributária:

Nas capitais regionais, evoluiu a função comercial, no mesmo sentido que a função industrial. Drenando a produção de uma zona mais vasta, mais povoada e na qual sobretudo a produção cafeeira tivera tempo de crescer, é a grande cidade pioneira um mercado regional para a exportação dos produtos do solo: cereais, expedidos para os centros muito grandes de consumo do estado de São Paulo e mesmo do Distrito Federal, café e algodão para São Paulo e Santos. Atividades idênticas reconheceria todas as outras aglomerações dos planaltos, mas nestas, à falta de instalações adequadas, embarcam-se as colheitas à medida que chegam à estação. Nas capitais regionais, as firmas exportadoras dispõem de galpões que lhes permitem estocar, escoar progressivamente os produtos, não somente conforme as demandas do mercado, mas principalmente segundo as possibilidades de transporte, muitas vezes limitadas nas redes brasileiras. $\mathrm{O}$ comércio de exportação é, ao mesmo tempo, um comércio de entreposto (...). A capital regional pioneira não é somente um pequeno centro industrial e um mercado, mas exerce outras funções que se aproveitam daquelas, ao mesmo tempo que fortalecem e multiplicam, para os roceiros, ocasiões de ir à cidade. (MONBEIG, 1984 [1952], pp. 366-367.)

A questão do "raio de ação" dos centros urbanos, que diz respeito à formação de áreas de influência econômica de limites imprecisos e cambiantes nas quais os campos encontram-se subordinados aos negócios e decisões que tinham lugar nas cidades, decorreria da intensidade tomada pela função comercial da rede de cidades paulistas, fundamento básico para a 
consolidação das regiões urbanas, que estabelecem uma hierarquia de relações que tem como ponto culminante a capital do estado, cuja preponderância está em relação direta à sua estrutura econômica complexa, "aparentada à de todos os países onde a economia continua a ser mais comercial do que industrial, mais voltada para o exterior do que para o interior" (MONBEIG, 1954, p. 204) $)^{85}$.

Em resumo, o fenômeno do pioneirismo, tal como aqui se desvela, comporta não apenas a expansão do espaço econômico pela via da colonização de novas áreas, mas encampa também a tessitura de um relacionamento entre a industrialização do país, a fundação de cidades e a formação de um circuito de trocas entre as localidades estruturadas a partir da movimentação das fronteiras, o que sem dúvida agia para fortalecer os nexos territoriais entre as novas áreas incorporadas aos fluxos econômicos nacionais e os centros urbanos de comando das atividades, base dos laços de solidariedade estabelecidos entre distintos pontos do território. A propósito, Manuel Correia de Andrade foi um dos primeiros geógrafos a alertar para essa característica presente na obra de Pierre Monbeig:

Compreendendo os grandes problemas da produção do espaço e da expansão do povoamento no Brasil que vivia uma fase de modernização, ele formou discípulos que estudaram em teses, ensaios e artigos problemas ligados a modernização agrícola, a expansão das frentes pioneiras, o crescimento urbano e a sucessão das paisagens humanizadas (...). Ao mesmo tempo escrevendo uma tese sobre paisagens rurais e outra sobre o crescimento urbano, Monbeig demonstrava que não costumava criar barreiras entre o rural e o urbano, demonstrando que dentro do processo de desenvolvimento capitalista, o capital comanda a apropriação de recursos e a organização da circulação de capital e de mercadorias na cidade e no campo. Em lugar de oposição campo-cidade sente-se o comando da economia e da vida rural pelos agentes urbanos. (ANDRADE, 1991, p. 54.)

A preocupação dos geógrafos com o adensamento da ocupação do território, que para acarretar modernização deveria ser efetuada de uma maneira economicamente produtiva, traz em sua esteira o reconhecimento de que a questão do povoamento e colonização de novas terras por meio da expansão da ocupação produtiva do solo, naquilo que se convencionou denominar de avanço das fronteiras, seria um problema a ser resolvido pela construção de vias de comunicação que conseguissem integrar as diferentes partes do território, ou, em outras palavras, a construção

\footnotetext{
85 “Tal estrutura acarreta a concentração, num centro urbano, dos elementos que mantêm em suas mãos as alavancas de comando e controlam a economia do país. A hipertrofia torna-se logo ameaçadora. Mas o fenômeno, gritante na escala nacional, é encontrado, guardadas as devidas proporções, na escala regional. É sempre notável a desproporção entre a cidade, seja ela grande capital política ou modesta capital regional, e o resto do país, desproporção em todos os domínios, em qualquer dos aspectos econômico e social da vida.” (MONBEIG, 1954, p. 204.)
} 
de um sistema de transportes eficiente, que subordinava a formação de centros urbanos e de novas zonas de produção agropecuária, era condição fundamental para que o país efetivamente atingisse a modernidade.

Como pudemos acompanhar neste capítulo, ao tratar desses temas, Monbeig muitas vezes replicou, de forma mais ou menos irreflexa, a visão que os grandes fazendeiros tinham do processo de expansão das lavouras e do povoamento, mesmo que, nessa empreitada, os objetivos declarados do geógrafo fossem os de compreender mais a fundo a realidade, incutindo em sua descrição explicativa remissões à mentalidade do grupo humano em movimento que ele então estudava. Ao final, o entrelaçamento entre o crescimento urbano, a industrialização do país e a expansão da economia rural, que na obra de Monbeig aparece na análise da diferença de desenvolvimento percebida na apreciação das "zonas velhas" e das "zonas novas", parece indicar a possibilidade de afirmar, a despeito de não ser esta a sua preocupação, que o geógrafo francês estava a observar e descrever in loco o movimento de desenvolvimento geograficamente desigual que marca a expansão territorial do capitalismo no Brasil. 


\title{
CAPÍTULO III
}

\section{A GEOGRAFIA DAS FRENTES PIONEIRAS: ANTECENDENTES E DEFINIÇÕES}

\begin{abstract}
"A todos é possivel 'ver' a paisagem, observar-lhe a composição, apreender-lhe a beleza e mesmo compará-la a outras paisagens; uma só pessoa, porém, o geógrafo, a "explica", the compreende o sentido e a realidade naquilo que apresenta de mais vivo e concreto. Para tal necessário se faz estabelecer relações complexas. Se a geografia é a ciência da realidade, ela o é, conseqüentemente, do "complexo". Cabe-lhe estudar fatos mui diversos e não raro penetrar muito longe no passado. Para explicar tal ou qual característico da paisagem é preciso fazer intervir toda uma série de fatores."
\end{abstract}

Pierre Monbeig

\section{A crise de 1929 e os novos temas de pesquisa da geografia acadêmica}

Nesta parte trataremos do estado da arte da geografia mundial na primeira metade do século XX, com destaque ao período em que Monbeig recebe sua formação acadêmica na França, na década de 1920, no intuito de compreender em que medida a influência de certos autores, somada às limitações da prática da geografia no momento, direcionaram suas escolhas ao equacionar o tema das frentes pioneiras. O objetivo básico, portanto, é acompanhar o caminho intelectual que Monbeig percorreu até eleger as fronteiras em movimento como objeto de sua tese de doutoramento, verificando em que medida seu trabalho deu origem a uma abordagem original que marcou definitivamente o modo de praticar geografia no Brasil.

Em resumo, interessa-nos rastrear a importância de seu trabalho no que diz respeito ao estabelecimento de um estilo modelar de escrita científica para a geografia (ORAIN, 2003) que foi bastante bem sucedido na tarefa de pautar a produção subsequente por ele coordenada, uma vez que o ponto de vista assumido entende que este tipo de texto, que poderíamos denominar de uma descrição geográfica explicativa, logrou assumir no Brasil a forma de um modelo paradigmático de trabalho científico, cujos resultados, tomando a forma de uma monografia regional não muito afastada dos cânones franceses, eram fruto de observações aprofundadas efetuadas diretamente em campo não raro traduzidas em cartas, mapas e representativas fotos.

Isso posto, torna-se interessante localizarmos o estágio de desenvolvimento do fazer geográfico nos momentos antecedentes e subsequentes à chamada "crise de 1929", uma vez que a geografia passava, nesse período entreguerras, por uma mudança de seus interesses que aponta para o surgimento de novas tendências de pesquisa. Tais tendências podem ser esquematicamente 
caracterizadas a) pela necessidade de melhor organizar as pesquisas universitárias, donde se destaca o real impulso a programas coletivos, tanto em escala nacional como na escala internacional; b) por uma preocupação com os então chamados "problemas contemporâneos", tais como o superpovoamento, a industrialização à escala do mundo, as migrações em massa e o inchaço cada vez mais nítido das aglomerações urbanas, fenômenos que abriam novas perspectivas de afirmação para a disciplina em relação aos desafios de um mundo em transformação; e c) pela questão, relacionada às anteriores, da aplicabilidade do saber do geógrafo, que nessa época buscava aproveitar o prestígio recém-adquirido de que gozava a planificação da economia e o Regional Planning para legitimar a geografia frente às novas práticas discursivas das chamadas disciplinas de ação (ROBIC, 2006).

Com efeito, avulta a percepção das décadas de 1920 e 1930 como um momento de notável efervescência para a geografia, que participa então de uma conjuntura científica muito mais controversa do que a historiografia da disciplina comumente apresenta (ARRAULT, 2007). Isto se mostra de maneira particularmente clara no processo de autonomização acadêmica do campo disciplinar, destacando-se, entre outros, o lançamento de programas coletivos de pesquisa incentivados no âmbito da União Geográfica Internacional (UGI) ${ }^{86}$. Fundada em 1922, em Bruxelas, a UGI aparece no cenário internacional em um momento da prática disciplinar que responde à conjuntura do final da I Guerra, quando o Conselho Internacional de Pesquisas (CIR, na sigla em francês) colocava em evidência a clivagem entre os países da Entente e as Potências Centrais, pano de fundo de uma diplomacia europeia ainda em conflito, impondo uma ótica nacional às ações estatais e barrando o movimento de internacionalização das ciências que vinha

\footnotetext{
86 "Sem constituir, portanto, um fator desencadeante, a Crise manifestamente acirrou as tensões entre a tendência à organização autocentrada da pesquisa e a tendência a uma orientação pragmática, fosse ela espontânea ou pouco orientada (como na França, por exemplo) ou, ao contrário, coordenada centralmente pelo Estado, como no caso da Alemanha, onde, a partir de 1933, a pesquisa logo foi controlada pelas organizações nazistas e, no que toca a geografia, foi posta a serviço de diversos imperativos, entre os quais a organização do espaço (...). Qualquer que tenha sido sua amplitude, essas políticas foram acompanhadas, para aqueles que dela participavam, de certa confiança na racionalidade estatal, na racionalidade de uma ação ancorada na pesquisa científica e, em suma, de uma adesão a idéia de legitimidade da especialização posta a serviço da organização do espaço. A centralização de muitas pesquisas no nível nacional revela a amplitude da crispação nacional. Crispação no sentido de que a escolha dos perímetros de observação (o território nacional) e o destaque dado a muitos estudos econômicos sobre as disparidades internas revelam, com outros indícios, uma consciência mais ou menos clara de que esse nível constituía o quadro pertinente de estudo e de resolução das tensões, dos problemas de toda ordem que os geógrafos deviam abordar (...). Do mesmo modo, as tensões cidade-campo e o crescimento das metrópoles urbanas deviam ser analisados como formas novas de uma estruturação em curso, problemática para o futuro nacional. A primazia desse nível territorial não excluía, entretanto, a presença de uma outra escala estruturante: o nível mundial. Nele é que residia um dos nós dos problemas identificados como novos, com a consciência que havia se formado ao longo do século, sendo a crise mundial uma de suas manifestações mais extremadas.” (ROBIC, 2006, pp. 46-47.)
} 
ocorrendo desde o final do XIX. Visto que o CIR incentivava a criação de uniões internacionais disciplinares desde 1919, não surpreende ter a UGI tomado forma exatamente nas assembleias gerais desse Conselho, sendo o boicote à geografia germanófila, dominante nos congressos internacionais organizados pelas Sociedades de Geografia antes da I Guerra, uma de suas principais marcas de nascença ${ }^{87}$.

Como expressão dos projetos de pesquisa coletivos que colocariam à testa as preocupações com o que era então definido como "geograficidade", a UGI, reconhecida por seus pares como um organismo internacional de representação profissional permanente, visava articular relações mais aprofundadas entre os pesquisadores por meio dos órgãos ou instituições oficiais de geografia de cada país, que participavam da entidade como representantes oficiais de cada Estado-nação. Por isso, tendo a França como nódulo central e modelo, a UGI se tornaria veículo de uma renovada integração entre distintos centros de produção do saber geográfico, que passam a sustentar uma rede de contatos acadêmicos, institucionais e pessoais internamente à comunidade geográfica:

Tal auto-organização da comunidade geográfica tem por corolário a definição de conceitos específicos, o aprofundamento de técnicas e de problemáticas próprias, a realização de grandes projetos comuns (Geographie Universelle, lançada em 1908, Atlas de France, iniciado pouco depois da guerra pela escola francesa de geografia; trabalhos da Comissão de estudo das variações climáticas, pesquisas da Comissão do habitat rural, por exemplo, no âmbito da União Geográfica Internacional). Mas, ao mesmo tempo, a geografia manifesta uma tendência cada vez mais nítida rumo à abertura para o mundo, à participação nos desafios políticos, sociais ou econômicos contemporâneos. Assim, os geógrafos devem manifestar sua legitimidade, menos em relação a disciplinas concorrentes, a antigos lobbies, destituídos, do que em relação a novas práticas discursivas, a novos saberes aplicados tendo-se em vista a atualidade e o futuro. Locais de elaboração de uma prática erudita (universitária), as novas associações nacionais de geógrafos (como a Association de Géographes Français, nascida em 1920) e a Union Géographique Internacionale são perpassadas por essas

\footnotetext{
87 “C'est lors de l'assemblée générale de Bruxelles, du 25 au 29 de juillet 1922, qu'a été décidée cette création (...). La formation de l'Union et l'adoption des statuts ont été présentés à la session finale de l'assemblée générale du CIR. Leur statuts ont été ensuite soumis pour confirmation aux comités nationaux et les différents pays ont été invités à adhérer à l'Union (...). La création du CIR et des Unions disciplinaires qui lui sont affiliées permet en somme la revanche des Académies des sciences et des universitaires face aux sociétés savantes qui ont contribué, à la fin du XIXe siècle, au développement de plusieurs nouveaux champs scientifiques (...). Alors l'UGI est donc acceptée par les milieux dirigeants de la géographie comme cet organisme international permanent dont la nécessité était reconnue avant-guerre. Selon l'état de a recherche en géographie, selon les formes nationales prises par le développement scientifique à la fin du XIXe siècle, la composition des comités nationaux mis en place au début des années vingt et la nature des professions et des organismes qui y dominent sont variables. Leur orientation doit refléter les rapports de force qui prévalent en cet immédiat après-guerre. De plus, l'exclusion forcée ou volontaire de certains États instaurée au moment de sa naissance hypothèque sa représentativité dans le domaine de la science et son universalisme." (ROBIC, 1996, pp. 36/39.)
} 
tendências. Tribuna de expressão, por isso freqüentemente conflituosa, a UGI é também um lugar de negociação entre comunidades e uma vitrine coletiva voltada para os não-geógrafos. (ROBIC, 2006, p. 39-40.)

A propósito dessa tomada de consciência da comunidade dos geógrafos a respeito da mundialização econômica que se consolidava durante a primeira metade do século XX momento que exprime, afinal, o próprio processo de construção de um meio técnico no qual se esboça uma nova divisão territorial do trabalho mundial, que passa a conectar cada vez mais profundamente diferentes países e lugares numa mesma lógica, tecendo relações de cooperação recíproca que Milton Santos bem definiu como nexos de solidariedade territorial ${ }^{88}-$, Arrault (2007a) sustenta que o discurso geográfico dos anos 1930, informado pela crise econômica mundial de 1929, põe em evidência o processo de mundialização que tornava solidário distintos pontos do planeta, colocando a escala mundial como um dos fatores explicativos fundamentais para a compreensão das súbitas alterações observadas em escala regional, a despeito do recuo das trocas comerciais encetadas internacionalmente nos decênios que se seguiram ao término da I Guerra (1914-1918):

Au cours des années 1920, les géographes se seraient donc accoutumés à penser le monde sous le signe de la crise. Mais la crise elle-même, elle leur apparaît le plus souvent comme un révélateur d'interdépendance (et donc d'une certaine mondialisation) (...). On constate presque systématiquement que le milieu mondial ne détermine pas véritablement les milieux nationaux ou régionaux, mais y interfère néanmoins. Et ce maintien d'une pluralité de facteurs explicatifs

\footnotetext{
${ }^{88}$ A sobreposição territorial de lógicas locais, regionais e mundiais, que incidem de maneira distinta sobre as heranças espaciais legadas pelo processo social através das formas presentes nos ambientes construídos (portos, estradas, ferrovias, mas também a distribuição da população), tornadas condições para o desenrolar da história, é a circunstância que preside à formação sempre momentânea dos nexos de solidariedade territorial, já que a cada momento há uma redistribuição dos fatores envolvidos no processo social que não é indiferente às condições preexistentes: "Um estudo da divisão do trabalho sob o enfoque do tempo, comporta, pelo menos, duas entradas, duas acepções. Uma delas analisaria as divisões do trabalho sucessivas, ao longo do tempo histórico uma cadeia das transformações ocorridas, suas causas e suas conseqüências, os períodos assim estabelecidos e suas duração, os lugares de suas incidência. A outra entrada levaria a reconhecer as divisões do trabalho sobrepostas, num mesmo momento histórico. Este último enfoque é mais propriamente geográfico, obrigando ao casamento objetivo de noções freqüentemente tão vagas como as de espaço e tempo (...). Todos os lugares existem em relação com um tempo do mundo, tempo do modo de produção dominante, embora nem todos os lugares sejam, obrigatoriamente, atingidos por ele. Ao contrário, os lugares se diferenciam, seja qual for o período histórico, pelo fato de que são diversamente alcançados, seja quantitativamente, seja qualitativamente, por esses tempos do mundo. O tempo do mundo seria o tempo mais externo, abrangente de todos os espaços, independentemente de escala. Haveria, nessa hierarquia e nessa ordem, tempos do Estado-Nação e tempos dos lugares (...). O que é fundamental, aqui, não é propriamente o manejo de instrumentos de medida, mas o reconhecimento de que a cada lugar é teatro de tempos 'externos' múltiplos. Na verdade, a partir do tempo mundial, que é o tempo extenso absoluto, os outros tempos comparecem como tempos internos. O tempo do Estado-Nação é interno em relação ao tempo mundial e externo em relação ao tempo das regiões e ao tempo dos lugares. E a partir do mais mínimo tempo interno - o lugar ou o ponto - todos os demais lhe são externos." (SANTOS, 2002, pp. 135-136/138-139.)
} 
est sans doute à mettre au crédit de la géographie, alors qu'il aurait été évidemment facile de rapporter tous les maux des économies nationales et régionales à la crise mondiale (pour justifier par exemple le protectionnisme). (ARRAULT, 2007a, pp. 501/505.)

Polemizando com os autores que defendem ter havido justamente nessa época um ajuste de foco da comunidade geográfica francesa, que com a crise econômica e a guerra passou a privilegiar em suas análises o cenário nacional, descrito em suas partes constituintes a partir da imposição do método regional - como, entre outros, André-Louis Sanguin (1993), o qual afirma peremptoriamente que uma espécie de imobilismo científico impediu o surgimento de inovações não enquadradas na ortodoxia epistemológica do período, segundo ele, clássico da geografia francesa $(1918-1968)^{89}$-, Arrault vai na contramão da opinião corrente na historiografia da disciplina, sustentando que, embora a guerra tenha imposto uma ótica nacional à interpretação de eventos mundiais, como se percebe na participação dos geógrafos nas negociações de paz em Versalhes, a percepção de que havia um movimento de construção de um espaço globalizado, mantido mesmo ante a estagnação da integração econômica internacional, mostra o período entreguerras como um momento de abertura sem precedentes da geografia a novos temas e preocupações, de vez que a crise de 1929 pode ser interpretada, quando menos, como clara manifestação da existência de um alto nível de interdependência entre os Estados-nação:

Car l'entre-deux-guerres semble être au contraire un moment d'adaptation de l'analyse géographique et de ses schémas explicatifs, et d'abord parce que le contexte des années 1920 et 1930 propose aux géographes un certain nombre de nouvelles thématiques, comme le surpeuplement ou le développement industriel et urbain, à des échelles souvent internationales ou mondiales. Mais aussi parce qu'il va devenir en quelque manière nécessaire de s'intéresser au niveau mondial pour comprendre ce qui se joue au niveau national, régional, local (...). L'évolution du contexte historique pousserait à complexifier les procédures explicatives de la géographie avec l'introduction d'un «facteur mondial», pour reprendre une expression employée par A. Weiler en 1932 au sujet du tourisme international. La question n'est pas de savoir au fond si le repli national de l'entre deux-guerres a incité les géographes à se replier eux-mêmes sur le cadre

\footnotetext{
89 "Les travaux et les jours de l'époque classique de la géographie française furent structurés par quatre concepts fondateurs directement issus de l'héritage vidalien: région, milieu, genre de vie, paysage. Entre 1918 et 1968 , l'école française développa donc un paradigme orthodoxe où l'innovation scientifique ne devait pas dépasser les limites fixées par l'establishment. Cette orthodoxie assez pesante marginalisa certains esprits novateurs (...). Durant cette époque, la géographie française est une géographie unilingue. Elle vit sur ses propres acquis et ignore les publications étrangères. Les étudiants ne lisent pas la production géographique extérieure à la France, parce que leurs professeurs ne les y invitent pas. Conséquemment, ils ne savent rien des autres pratiques de la géographie (...). Néanmoins, malgré son cadre assez strict, l'époque classique de la géographie française fut un âge d'or par son unanimisme, la qualité et la quantité de sa production et par sa réputation internationale.” (SANGUIN, 1993, pp. 618-619.)
} 
national, mais de se demander en quoi travailler dans ce cadre empêcherait de se préoccuper de ce qui se passe ailleurs dans le monde, et au niveau même du monde ; les géographes adapteraient de la sorte l'étude régionale à un contexte marqué par une forte mondialité. Accepter cette hypothèse, c'est accepter aussi que l'entre-deux-guerres ne soit plus un «temps mort» dans l'histoire de la géographie. (ARRAULT, 2007a, pp. 498-499.)

Há algumas ponderações a fazer sobre essa discussão. De fato, quando se fala do processo de institucionalização da geografia francesa no início do século XX, é frequente observar as conexões que se teriam estabelecido entre o rápido desenvolvimento desta após 1870 e o contexto econômico, político e intelectual da expansão colonial europeia, ou seja, haveria um certo paralelismo entre a expansão do imperialismo no final do XIX e o acervo de conhecimentos produzido sobre o mundo colonial por aqueles ocupados com essa disciplina, seja nas universidades, com os recém-implantados cursos de geografia, seja nas antigas sociedades de geografia e demais órgãos incentivadores das viagens de exploração, donde inadvertidamente se conclui pela identificação da geografia europeia, e mais ainda a francesa, com a causa imperialista (SOUBEYRAN, 1997). A bem dizer, a possibilidade de se reconstruir a trajetória de autonomização temática e metodológica da geografia através das pistas deixadas pelo uso de uma argumentação fundamentada em categorias espaciais como justificativa da existência natural do Estado, da nação e do território, caso feita por meio de um levantamento das instituições vinculadas diretamente à produção dos saberes geográficos, passa por certo pela problematização da atuação das Sociedades Geográficas, dado que os discursos tidos como científicos utilizados como legitimação de projetos estatais ou nacionais são concebidos geralmente em instituições especializadas, públicas ou privadas, vinculadas diretamente à difusão da doutrina ou política cultural oficial (PEREIRA, 2002; ZUSMAN, 1996) ${ }^{90}$.

A remissão da chamada "geografia acadêmica" ao contexto das sociedades de geografia cumpre aqui o objetivo de iluminar o relacionamento entre os saberes geográficos e o

\footnotetext{
${ }^{90}$ As Sociedades Geográficas se apresentam historicamente como dois tipos distintos de instituição: ao longo do século XIX, quando são criadas as primeiras sociedades desse tipo, como a Societé de Geographie, fundada em Paris, em 1821, e a Royal Geographic Society, organizada em Londres, em 1830, elas não passam de centros culturais, verdadeiras "sociedades de sábios" que agregam em seu grêmio um grupo de interessados de perfil heterogêneo, colocando lado a lado industriais, comerciantes, profissionais liberais, exploradores, políticos e diplomatas, todos interessados de uma ou outra forma naquilo que então se considerava geografia. Já no século XX, com a difusão da geografia nos sistemas públicos de ensino, sua padronização como disciplina universitárioacadêmica e a maturação das chamadas "escolas nacionais" - donde se destaca o papel fundamental das escolas alemã e francesa, consideradas os modelos práticos de organização do temário que visavam conferir um renovado estatuto de cientificidade à disciplina -, tais Sociedades têm suas atividades voltadas quase que exclusivamente para o treinamento, formação e aperfeiçoamento profissional de professores primários, secundários e universitários (CAPEL, 1977; 1981).
} 
imperialismo no processo de institucionalização da disciplina, uma vez que este elo não se resolve apontando-se o deslocamento de uma geografia colonial "protocientífica" em direção à uma geografia regional neutra e verdadeiramente "científica" 91 . Em outras palavras, é preciso sanar a relativa amnésia que envolve a origem comum da geografia humana francesa com o movimento colonialista, isto é, há um passado compartilhado entre ambos que não pode ser esquecido, sendo importante recordar que a tradição geográfica francesa guarda profundas raízes nas discussões sobre o desenvolvimento ultramarino do país, que envolviam questões sobre a administração, exploração e organização espacial do mundo colonial, pois para além do incentivo de expedições que efetuassem o reconhecimento empírico dos territórios coloniais, era do interesse da chamada "geografia colonial", subcampo de reconhecida importância acadêmica ao final do XIX, que fossem efetuados estudos mais detidos sobre as condições técnicas (topografia, recursos naturais, rotas, condições para a drenagem das riquezas) e sociais (classificação dos grupos étnicos locais, propensão para se montar grandes projetos) das colônias consolidadas ou por se constituir (SOUBEYRAN, 1994; 1997).

Aliás, há que reconhecer a existência de um ponto de vista comum, na historiografia da geografia, que data o início de sua trajetória científica fazendo referências à virada do século XIX ao XX, quando sob a liderança de Vidal de La Blache, ter-se-ia organizado uma "escola vidalina" que se opunha ferozmente tanto à geografia mnemônica, mera reprodução de nomes e localizações, quanto à geografia de caráter mais utilitário que sempre se associou ao colonialismo. Porém, para outros comentadores, a identificação direta da institucionalização universitária da geografia com a formação da "escola vidalina" faria na verdade parte do registro daqueles que foram bem-sucedidos nas disputas epistemológicas travadas, constituindo um “discurso dos vencedores” (BERDOULAY, 1981; SOUBEYRAN, 1997). Neste viés, entre os elementos que corroborariam a identificação da ruptura do grupo de Vidal com o passado, teríamos: a) a criação do Annales de Geographie, em 1891, quando o mestre já possuía uma doutrina identificável; b) a vulgarização experimentada pela metodologia regional, da qual é exemplo evidente o Tableau Geographique de la France, publicado por La Blache em 1903; e c) o aparecimento, divulgação e amplo reconhecimento científico e pedagógico das primeiras teses e

\footnotetext{
${ }^{91} \mathrm{O}$ caso da geografia portuguesa é exemplar para mostrar o sentido de continuidade no envolvimento da geografia acadêmica com os negócios imperiais, haja vista a atuação de geógrafos como Silva Telles e Orlando Ribeiro nos órgão oficiais do governo português, como a Junta de Investigações Coloniais, que visava reorganizar a exploração das colônias e defender o luso-tropicalismo como forma de justificar a continuidade da dominação colonial portuguesa após a II Guerra. Sobre a vida e a obra de Orlando Ribeiro, vide Amaral (1973; 1979) e Garcia (1984).
} 
dissertações de geografia regional orientadas por Vidal, notadamente as de Albert Demangeon (1905) e Raoul Blanchard (1906), fundamentais para o estabelecimento de um modelo ou guia metodológico para a escrita científica em geografia:

It was therefore assumed that an evolution in geographical thought separated pre-Vidal (that is to say, "pre-scientific") and post-Vidal (or "scientific") thought. Further, according to this view, it was in the pre-Vidal era that all the geography associated with the colonial movement was concentrated. In this historical reconstruction, colonial geography was initially amalgamated with the history of geographic exploration, and then confused with the history of the building of the colonial empire, which, after 1870, really took off. Colonial geography, then, was seen as culminating in nothing more than the simple production of practical facts, and was consequently deemed incapable of the disinterested stature which was considered the sine qua non of a "science". (SOUBEYRAN, 1994, p.245.)

Indubitavelmente, a afirmação universitária da geografia acompanha o crescimento das sociedades geográficas existentes no mundo, pois, entre 1878 e 1935, triplicou o número de instituições desse tipo, passando de cinquenta sociedades congregando cerca de vinte mil sócios para cento e trinta e seis sociedades com um efetivo de mais de cem mil sócios. Ao longo desse período, o perfil dos associados (e o das próprias sociedades geográficas) também experimentou alterações profundas, pois se no final do XIX as sociedades de geografia eram grêmios heterogêneos predominantemente formadas por militares, naturalistas, comerciantes, políticos e diplomatas, o avanço do processo de institucionalização universitário-acadêmica da disciplina na Europa favoreceu em muito, no início do século XX, o surgimento do geógrafo profissional e do professor de geografia, que passam a monopolizar as sociedades, transformadas em verdadeiras associações profissionais-corporativas (CAPEL, 1977) ${ }^{92}$.

A multiplicação dessas instituições pelo velho continente aponta, de um lado, para o fato de que qualquer conquista imperialista envolve invariavelmente a expansão territorial de uma sociedade, com a conquista de terras e homens sendo a forma mais simples de medir e demonstrar o poder e a riqueza dos impérios, e, de outro lado, para a negligenciada importância dos conhecimentos geográficos e da história da geografia no que diz respeito ao empreendimento fundamentalmente europeu de dominação intelectual do espaço, fenômeno que revela a

\footnotetext{
${ }^{92}$ No primeiro capítulo, já tivemos oportunidade de discutir o caso do Brasil, onde o domínio dos geógrafos profissionais e professores de geografia no âmbito de instituições similares ocorreu um pouco mais tarde, sendo mais preciso dizer que apenas após a década de 1940 esse processo passou a ser perceptível, principalmente com os novos congressos de profissionais organizados pela AGB e pelo IBGE, que se afastou dos Congressos Geográficos realizados no âmbito da SGRJ, que a partir de então passou a ser alcunhada de "veneranda" (PEREIRA, 2002).
} 
maturação de uma decisiva dimensão da consciência humana moderna, a saber, a "consciência planetária eurocentrada" (PRATT, 1999), pano de fundo da efetiva tomada de posse da Terra. Em verdade, a imagem que temos hoje de uma civilização ocidental está intimamente ligada ao lento processo de construção interior desse imaginário, iniciado com a formação de um circuito comercial mundial que articulou o Atlântico com a economia-mundo Mediterrânea. Nesse registro, a América não se incorporaria a uma economia capitalista já existente, mas seria o ponto nodal para a sua constituição enquanto um sistema, uma vez que o circuito de trocas criado no Atlântico teve a particularidade de estabelecer uma maior complementaridade e integração entre os lugares, criando novos nexos territoriais entre a Ásia, a África e a Europa (MIGNOLO, 2005; WALLERSTEIN, 2004). Assim, a análise dos mecanismos de exercício do poder desenvolvidos para sustentar a relação de dominação estabelecida entre a Europa e a América autoriza a afirmação de que essa dominação colonial pode ser entendida como constitutiva da modernidade, e não como sua mera derivação (QUIJANO, 2005) $)^{93}$.

Nesse detalhe, a história da cartografia é reveladora da própria história da geografia, uma vez que o desenvolvimento técnico da cartografia em diversas direções, que acompanha o processo de institucionalização acadêmica da disciplina no final do XIX, quando se vulgarizam os mapas, as plantas cadastrais, a cartografia urbana e outros signos cartográficos do poder, permite que observemos as maneiras pelas quais as imagens cartográficas poderiam ser utilizadas como mais do que apenas símbolos do império, funcionando como auxiliares na manutenção ou no questionamento de determinados status quo territoriais. Ao final, as ferramentas cartográficas exerceriam o papel de fundamento imagético da própria consolidação interna dos Estados-nação, uma vez que os mapas, expressando a vontade de controle de um espaço por sua apropriação intelectual, são representações culturais informadas por mensagens políticas (HARLEY, 2001; $2009)^{94}$.

\footnotetext{
${ }^{93}$ No chamado ocidentalismo, a ideia de hemisfério ocidental, que como figura geopolítica urdiu a trama do imaginário do sistema-mundo moderno-colonial, nos mostra que as "Índias Ocidentais", a América Latina, nunca foi um outro em relação à Europa, mas sua diferença em meio ao processo de constituição da modernidade. Dessa maneira, ela se torna um anexo ou extensão da Europa que se expandia, não sua alteridade: "Isto é, no Ocidente a imagem 'interior' construída por letrados e letradas, viajantes, estadistas de todo tipo, funcionários eclesiásticos e pensadores cristãos, esteve sempre acompanhada de um 'exterior interno', ou seja, de uma 'exterioridade', mas não de um 'fora' (...). A partir do século XVI, com o triplo fato da derrota dos mouros, da expulsão dos judeus e da expansão atlântica, mouros, judeus e ameríndios (e com o tempo também os escravos africanos), todos eles passaram a configurar, no imaginário ocidental cristão, a diferença (exterioridade) no interior do imaginário". (MIGNOLO, 2005, p. 72.)

${ }^{94}$ Compreender em que medida as ações desenvolvidas por instituições dedicadas à produção de saberes geográficos foram bem-sucedidas na elaboração e difusão de certas representações acerca do território pode ser um caminho
} 
Como quer que seja, partindo do pressuposto de que na passagem do XIX ao XX o imperialismo francês assumiu inúmeras formas discursivas que influenciaram e foram influenciadas pelos debates internos ao campo disciplinar em pauta, Michael Hefernan (1994) identifica, dentre as correntes intelectuais que se posicionavam sobre o imperialismo dentro do contexto da comunidade geográfica francesa, que a de maior influência era a tendência nacionalista que se organizava em prol de um imperialismo cultural ${ }^{95}$. Numa visão de conjunto sobre o período acima referido, entende-se que, embora a maioria dos geógrafos estivesse comprometida de alguma maneira com a defesa do imperialismo francês, não havia, dentro da comunidade dos geógrafos, uma adesão total a uma versão única do que quer que fosse o imperialismo e a política colonialista. No geral, as diferenças eram mais de tom ou ênfase, e todos os grupos e correntes podiam trabalhar unidos em prol de questões coletivas fundamentais, como ocorreu na época da I Guerra Mundial, quando o governo francês, ansioso para que o império estivesse no centro das futuras negociações de paz, organizou uma série de comissões secretas de especialistas para tecerem considerações acerca dos possíveis pontos de interesse para a França.

Essas comissões, abrigadas nos tempos de guerra na Sociedade de Geografia de Paris, dona da maior coleção de mapas da França, contavam com significativa presença de geógrafos, pois nada menos do que quarenta e cinco membros-sênior da SGP foram cooptados para os trabalhos,

interessante de estudar as maneiras pelas quais as sociedades geográficas auxiliaram a consecução de projetos estatais-nacionais de poder. Evitando os prejulgamentos, é possível dizer que as sociedades geográficas atuavam em duas frentes principais: de um lado, fornecendo um norte teórico (e empírico) com vistas a orientar as políticas territoriais destinadas a consolidar um âmbito geográfico de dominação política, seja elaborando mapas e reconhecendo áreas ignotas, seja estabelecendo eixos estratégicos de apropriação territorial, e de outro, assumindo a função de agências formuladoras de discursos que, ao serem socializados pelos sistemas de ensino, viriam a contribuir com a incorporação de uma dada componente da identidade coletiva que eventualmente se quisesse ressaltar. Em ambos os casos, mesmo reconhecendo as sociedades de geografia como lugares centrais para a produção e o desenvolvimento dos saberes geográficos (LIVINGSTONE, 2003), questiona-se a atuação de seus membros na produção e difusão de argumentos científicos de algum modo relacionados com a legitimação de projetos de poder (ZUSMAN, 1996).

${ }_{95}$ Congregando nomes como Pierre Foncin (um dos fundadores da Aliança Francesa), Vidal de La Blache e Marcel Dubois, professor da cadeira de Geografia Colonial da Sorbonne desde o início da década de 1890 e protagonista de uma disputa epistemológica travada com Lucien Gallois e o círculo de afinidades intelectuais mais identificado com a geografia regional de La Blache pelo controle editorial dos Annales de Geographie, essa tendência interpretava o imperialismo francês enxergando na difusão mundial da língua e civilização francesas pela via de uma colonização enérgica as respostas para certos problemas do país, como a estagnação da economia e a questão da pressão demográfica, pois tal colonização em tese compensaria, na arena exterior, as perdas econômicas e territoriais do país na recém terminada Guerra Franco-Prussiana: "Geographers associated with this position saw their educational and imperial roles as inextricably interwoven. While the carefully directed study of France's rich and varied regional geography was to be a central educational component in fostering the spirit of patriotism and devotion to the Republic, the expansion of France overseas was interpreted as crucial to the nation's future survival as a vibrant culture and civilization.” (HEFERNAN, 1994, pp. 102.) 
com destaque para Emmanuel De Martonne e Lucien Gallois, o que demonstra claramente o prestígio e relevância do movimento geográfico francês dentro do governo. Como se desfizessem as comissões de cientistas organizadas durante o período da conflagração, o final da guerra e o início das negociações de paz obrigou muitos dos membros de tais comissões secretas a voltarem seus esforços aos estudos estratégicos realizados no chamado Comité d'Etudes, cuja principal preocupação dizia respeito às questões geopolíticas que certamente surgiriam na nova ordem europeia do pós-guerra. Presidido por Ernest Lavisse e secretariado por ninguém menos que Paul Vidal de La Blache, que conseguiu trazer os encontros regulares do grupo para o Instituto de Geografia da Sorbonne, o Comité, ainda que não fosse dominado por geógrafos, revela a confiança que o governo francês depositava nesses profissionais durante a I Guerra, confirmando a importância que a projeção dos interesses nacionais em escala mundial tinha para a formação do campo disciplinar na França, e reforçando a posição pró-imperialista de grande parte dos principais nomes da comunidade geográfica francesa ${ }^{96}$.

Nesses trabalhos, além de já ser possível identificar um incipiente entrelaçamento entre as escalas nacional e mundial no encaminhamento de respostas aos problemas enfrentados pela França, uma vez que os eventos de escala mundial eram filtrados por uma ótica nacionalista, vemos que a posição em prol do imperialismo cultural sustentaria um juízo no qual se esboça certa noção de reciprocidade da "missão civilizadora" da França, como se a dominação colonialista envolvesse uma via de mão dupla, já que, para os seus defensores, a civilização francesa seria enriquecida pela interação com as colônias de além-mar ao mesmo tempo em que estas desfrutariam da expansão benéfica da cultura e língua francesas entre seus habitantes: “Many of the central aspects of French colonial policy after the 1890's - the ideas of misssion

\footnotetext{
${ }^{96}$ Foram quatro as comissões estabelecidas durante a guerra: duas concernentes às questões europeias (a ocupada com a localização da linha fronteiriça entre a França e a Alemanha, em particular a questão da Alsácia-Lorena, e a que iria discutir as futuras fronteiras políticas da Europa do Leste e Central), e duas ligadas diretamente às ambições imperialistas francesas (a que discutiria os possíveis ganhos territoriais na África, especialmente nas colônias germânicas, e a voltada para a construção de uma esfera de influência na Ásia e no Oriente Médio, dado o esperado fim do Império Otomano). Dentre as obras produzidas dentro do escopo de trabalhos incentivados ou projetados no Comité, ou ao menos condicionadas em maior ou menor grau pelo conflito de 1914, sem dúvida alguma merecem destaque o trabalho La France de l'Est (Lorraine-Alsace), publicado por Vidal de La Blache em 1917, e o livro La Géographie de l'Histoire - Géographie de la Paix et de la Guerre sur Terre et sur Mer, lançado por Jean Brunhes e Camille Vallaux em 1921. A preocupação mais geral em ambas refere-se ao desenvolvimento de argumentos históricos, geográficos e etnográficos a serem utilizados nas disputas diplomáticas travadas ao final do conflito armado, pois que se almejava a construção teórica de posições vantajosas para a França frente à Alemanha, claro, mas também junto aos aliados de ocasião, como a Inglaterra e a Itália. Para uma leitura que localiza as discussões empreendidas neste livro dentro da obra de La Blache, vide Ribeiro (2010). Para informações sobre a influência de Vallaux na Geografia Política, vide Escolar (1998).
} 
civilisatrice and of assimilation - were couched explicity in these cultural terms" (HEFERNAN, 1994, p. 104).

De todo modo, devemos sublinhar que uma discussão aprofundada sobre o imperialismo e suas múltiplas facetas (econômicas, políticas, ideológicas e culturais) é uma empresa que supera em muito os limites deste trabalho. Mesmo assim, temos claro que o que chamamos de imperialismo, numa perspectiva mais próxima da Economia Política, se refere a uma fase do desenvolvimento histórico do capitalismo, grosso modo iniciada a partir de 1870, que pode ser qualificada por certas características gerais, como a formação de uma verdadeira economiamundo capitalista, que congregou num sistema planetário de relações o conjunto das mutuamente intervenientes relações políticas, econômicas e culturais entre Estados, indivíduos e grupos sociais (WALLERSTEIN, 1979) ${ }^{97}$; a existência das rivalidades entre as diferentes potências industriais europeias, que levaram à expansão econômica ultramarina e à divisão política do globo em uma miríade territórios coloniais e áreas de influência por essas mesmas potências (HOBSBAWM, 2002); e a progressiva consolidação, ao longo do século XX, de um "novo ciclo sistêmico de acumulação" apoiado na proeminência do capital financeiro, que foi tornando mais e mais diferenciada a lógica de poder territorialista, que identifica "o poder com a extensão e a densidade populacional de seus domínios, concebendo a riqueza/o capital como um meio ou um subproduto da busca de expansão territorial” (ARRIGHI, 1996, p. 33), do modo de governo capitalista, que identifica "o poder com a extensão de seu controle sobre os recursos escassos e consideram as aquisições territoriais um meio e um subproduto da acumulação do capital" (Loc. cit. $)^{98}$.

97 "What we mean by a world-economy (Braudel's economie-monde) is a large geographic zone within which there is a division of labor and hence significant internal exchange of basic or essential goods as well as flows of capital and labor. A defining feature of a world-economy is that it is not bounded by a unitary political structure. Rather, there are many political units inside the world-economy, loosely tied together in our modern world- system in an interstate system. And a world-economy contains many cultures and groups-practicing many religions, speaking many languages, differing in their everyday patterns. This does not mean that they do not evolve some common cultural patterns, what we shall be calling a geoculture. It does mean that neither political nor cultural homogeneity is to be expected or found in a world-economy. What unifies the structure most is the division of labor which is constituted within it (...). Since world- economies lack the unifying cement of an overall political structure or a homogeneous culture, what holds them together is the efficacy of the division of labor. And this efficacy is a function of the constantly expanding wealth that a capitalist system provides (...). A capitalist world-economy is a collection of many institutions, the combination of which accounts for its processes, and all of which are inter- twined with each other. The basic institutions are the market, or rather the markets; the firms that compete in the markets; the multiple states, within an interstate system; the households; the classes; and the status-groups (to use Weber's term, which some people in recent years have renamed the 'identities')." (WALLERSTEIN, 2004, pp. 23-24.)

${ }^{98}$ Compreendida em perspectiva geográfica, a história do capitalismo marca a expansão de determinadas relações sociais por todo o planeta, inaugurando a escala global de análise dos fenômenos sociais: "Pode-se dizer que o 
Dito isso, aclara-se então a condição nada fortuita de o aspecto cultural e os objetivos nacionalistas da política imperial francesa caminharem juntos, sendo, pois, justamente apontados como os caracteres distintivos do imperialismo francês no início do século XX, cuja retórica invariavelmente repunha a questão colonial nesses termos, como se pode inferir, aliás, das ações desenvolvidas na América Latina pelo Groupement e outros organismos públicos e privados fundados especificamente para "tecer redes de aliados políticos a partir de uma influência cultural e política, tanto como meio de penetração econômica, como para ter o apoio desses aliados nos enfrentamentos das grandes potências" (PETITJEAN, 1996, p. 91).

Tendo sido criado no início do século XX como um órgão de cooperação científica e universitária, o Goupement afina seu lado político e diplomático ao longo da década de 1920, quando se aproxima institucionalmente do Service des Euvres Françaises à l'Étranger (SOFE) por meio de Jean Marx, diretor desse órgão após a I Guerra. Com efeito, entre 1920 e 1938, Georges Dumas realizará nada menos do que dezessete "missões" na América Latina, criando, entre outras instituições, o Instituto de la Universidad de Paris, em Buenos Aires, o Institut de Haute Culture, no Rio de Janeiro e, dentro da Societé des Lycées franco-brésilien, o principal deles: o Liceu São Paulo, que contava com uma mescla de professores brasileiros seguindo uma metodologia francesa, reservando-se o ensino das humanidades e línguas greco-latinas aos agregés franceses, que o faziam sempre em sua língua pátria, expandindo e consolidando a francofilia, que poderia resultar, assim se pensava, em ganhos diplomáticos, financeiros e mesmo simbólicos para a França.

Um aspecto a sublinhar numa análise desses órgãos de cultura é o crescimento da ingerência do Estado francês nas ações desenvolvidas nos diferentes países onde atuavam, pois que a organização de conferências e palestras com nomes conhecidos da intelectualidade francesa, que ficavam a cargo dos Liceus, tinha como objetivo a "expansão intelectual" da

capitalismo gerou uma economia-mundo de fato, mundializando as relações humanas e criando uma circulação mundial regular antes inexistente (...). Antes do sistema capitalista convivia-se em espaços mais restritos, que abrigavam histórias 'particulares' no sentido geográfico do termo, isto é, que se desenrolavam em porções espacialmente circunscritas da superfície terrestre. O capitalismo introduz contínuos fluxos internacionais, objetivando um espaço de relações que acabou por envolver todo o planeta (...). Por tanto, o primeiro aspecto relevante de se reter diz respeito à própria história geográfica da constituição da economia-mundo capitalista, processo plurissecular no qual a lógica e os interesses desse modo de produção vão se instalando nas diversas partes da Terra, submetendo e subordinando as formas de produção prevalecentes e criando novos fluxos e novos sistemas produtivos. Nesse movimento - complexo, contínuo, e múltiplo - a espacialidade própria do capitalismo vai se conformando na apropriação dos lugares, no ordenamento dos territórios, nos usos dos recursos naturais. Enfim, vai se explicitando uma nova lógica de relacionamento das sociedades com seus espaços, a qual particulariza os processos sociais mencionados de interesse direto na investigação da geografia.” (MORAES, 2011, pp. 15-16.) 
ciência à francesa para arregimentar aliados em potencial contra outros contendedores no plano internacional, notadamente a Alemanha. Sendo assim, tendo à frente Miguel Ozório de Almeida, quarenta e um universitários franceses de renome deram cursos no instituto do Rio de Janeiro entre 1922 e 1939, incluindo aí nomes como Paul Rivet, Henri Piéron, Henri Wallon e o futuro sogro de Monbeig, Pierre Janet, o que permitiu o estabelecimento de intercâmbios científicos e de vínculos diretos entre franceses e brasileiros, estreitando os laços que seriam ainda mais estreitados após a criação da Academia Brasileira de Ciência, nos anos 1920. Em São Paulo, desde a criação da Union franco-pauliste, braço local do Groupement organizado pelo próprio Dumas, em 1909, a presença francesa só faz se expandir, tendo culminado, em 1925, na organização do Instituto Técnico Franco-Paulista (ITFP), criado pelo secretário de estado José Lobo, Geraldo de Paula e Souza, do Instituto de Higiene, Ramos de Azevedo, diretor da Escola Politécnica e Pedro Dias da Silva, diretor da Faculdade de Medicina, que nesse pormenor empreenderam um esquema organizacional bem próximo ao que seria encontrado anos depois na USP.

$\mathrm{Na}$ mesma toada, tampouco se pode esquecer o papel estratégico que as políticas culturais francesas tiveram na organização das universidades públicas no Rio de Janeiro e em São Paulo. Valendo-se da atuação dos professores envolvidos com as missões universitárias enviadas para o estrangeiro, que implementavam localmente as diretrizes definidas pelos órgãos de diplomacia, agindo em cada país como verdadeiros "embaixadores culturais", a estruturação institucional dos cursos universitários no Brasil, efetuados sob clara inspiração francesa, representa um aspecto importante dentro da política imperialista francófona, com a aproximação intelectual da França com a América Latina bem servindo para iluminar a convergência entre os interesses geopolíticos mais amplos do governo francês, os ganhos econômicos mais imediatos que este poderia obter em novas áreas e países e as gestões extraclasse feitas pelos professores aqui chegados ${ }^{99}$.

\footnotetext{
99 "Essa evolução do Goupement o desloca progressivamente da universidade para o Ministério das Relações estrangeiras da França. Ela se traduz pela marginalização das universidades em suas relações científicas com a América Latina (...). Essa marginalização das universidades faz igualmente eco a um problema equivalente: aquele da organização da ciência colonial francesa, objeto de disputa em um conflito de competência administrativa e poder entre os ministérios franceses da Educação Nacional e das Colônias, que se acompanha de um debate sobre as escolhas das pesquisas a desenvolver (aplicadas ou fundamentais?) e do atraso na criação de universidades nas colônias francesas (...). Nos anos 1930, ele era, ao mesmo tempo, uma ajuda e um obstáculo, em razão de sua perda de autonomia diante do Ministério de Relações Estrangeiras da França. Desenvolvendo as relações científicas, tratava-se não de fazer a ciência por ela mesma, mas de procurar ganhos no plano político, depois econômico. Sem dúvida, nem então, nem agora, em nenhum país, as relações científicas são desinteressadas, mas, no caso do Groupement, tratava-se progressivamente de uma instrumentalização direta e de pequeno alcance, em detrimento de uma dimensão política real.” (PETITJEAN, 1996, pp. 115/119.)
} 
Até mesmo o funcionamento das universidades brasileiras em suas primeiras décadas de existência, notadamente em São Paulo, e a construção de uma hierarquia acadêmica, que deu origem a uma via de acesso a cargos e posições baseado fundamentalmente na excelência do trabalho intelectual desenvolvido, são em muito tributários da herança trazida pelos "docentes estrangeiros treinados nas regras e costumes da competição acadêmica europeia (e francesa, em particular)" (MICELI, 2001a, p. 101), sendo mesmo possível afirmar, com Paulo Arantes, que o contato dos professores franceses com seus alunos brasileiros introduziu no país uma nova postura intelectual, que valorizava o olhar dos alunos sobre sua própria cultura sem esquecer-se das teorias e métodos modernos trazidos da Europa, circunstância que fez com que a Faculdade de Filosofia, Ciências e Letras da USP funcionasse, no limite, como um "departamento francês de ultramar" (ARANTES, 1994).

Por outro lado, analisando a ação de Dumas na estratégia política que objetivava aumentar a influência cultural francesa no Brasil, Hugo Suppo (2000) afasta-se sensivelmente das conclusões de Patrick Petitjean, pois ao contrário deste, Suppo não vê uma mudança de perspectiva entre os professores universitários que trabalhavam na USP e os agentes de cariz político-diplomático mais entranhados na doutrina oficial do rayonament cultural, visto que o Ministério de Relações Exteriores da França teve um papel central na montagem da política cultural praticada no Brasil, condição que the confere uma dinâmica própria que permite inclusive visualizar uma certa continuidade entre as ações empreendidas de 1908 até 1940:

A simbiose entre a propaganda e a política cultural é perfeita. A palavra "propaganda" aparece freqüentemente nos documentos diplomáticos da época analisada. Na realidade, esta palavra possui duas dimensões; uma ligada à propaganda política (basicamente na imprensa) e outra à propaganda cultural, também denominada "propaganda intelectual". A segunda é de longe a prioritária; ao produzir a francofilia, ela desenvolve e cria o espaço para a primeira, não se alterando seja em função das mudanças periódicas de governo nos países alvos, seja daquelas verificadas na própria França. A primeira só adquire importância crucial em momentos determinados, como por exemplo, depois da assinatura dos acordos de Munique, em 1938, ou durante a guerra. A política cultural é pensada em termos quase exclusivamente de propaganda, em termos de "influência cultural", a qual deve fomentar a admiração pela cultura francesa e incentivar o consumo dos produtos culturais franceses (livros, teatros, óperas, perfumes, turismo, vinhos, idéias etc.) (...). Nos anos vinte, a questão da propaganda não é discutida apenas no nível oficial, mas também pelas associações ditas privadas. Gabriel Louis Jaray, diretor do Comité FranceAmérique, por exemplo, apresenta suas propostas para uma melhor condução do problema da propaganda, que, no seu entender, padece de falta de direção e de um método global. Sete ministérios estão implicados e, nos diferentes países, os 
adidos militares, comerciais, os correspondentes universitários, etc. encontramse subordinados a autoridades distintas. Jaray propõe que o Ministério das Relações Exteriores francês atue como ministério coordenador e que as associações privadas sejam melhor integradas e coordenadas. Em 1932, a questão da propaganda se transforma numa obsessão, uma nota enviada aos diplomatas franceses lotados no exterior afirma que "todo Francês residente no estrangeiro, deve considerar-se como uma espécie de embaixador de seu país", destacando em particular os professores, os comerciantes e os industriais. Uma segunda nota estabelece que, em caso de guerra, os professores franceses que trabalhassem em estabelecimentos franceses de ensino em países não inimigos deveriam permanecer nos seus postos, já que "seriam provavelmente utilizados pelo Serviço Geral de Informação, em razão do conhecimento particular que eles têm dos países". O Ministério da Educação concorda com as diretivas do Ministério das Relações Exteriores francês e as autoriza. (SUPPO, 2000, pp. 313-314.)

Em verdade, pode-se dizer que a influência cultural francesa no Brasil é um fato que remonta ao início do XIX, pondo-se como modelo direto de organização da vida cultural desde ao menos a passagem da conhecida "missão francesa", em 1816, e da tentativa de organização de um liceu de Artes e Ofícios no Rio de Janeiro anos depois (SCHWARCZ, 1995). Realmente, Lilia Schwarcz já chamara a atenção para a importância que a vulgarização do positivismo, do conceito de raça e de teorias evolucionistas apoiadas em modelos deterministas, como aquelas legadas por autores como Taine e Gobineau, assumiu para os museus etnográficos criados entre 1870 e 1930, que normalmente abrigavam os cientistas estrangeiros de passagem pelo país, atualizando a influência destes na elaboração da vida cultural brasileira ${ }^{100}$. Aliás, a presença francesa no país desde o XIX continuou a merecer destaque nos estudos recentes da autora (SCHWARCZ, 2008), nos quais se sustenta que a tal "missão" não foi contratada oficialmente nem sequer convidada por qualquer autoridade lusitana para acompanhar a Corte no tempo de D. João VI em terras fluminenses, pelo contrário, a iniciativa de organizar um grupo de artistas foi do diplomata francês de formação iluminista Joaquim Lebreton, partindo então dos próprios

\footnotetext{
100 "Herdeiros de uma forma específica de classificação, os museus etnográficos aplicaram as máximas do evolucionismo social, que pressupunha uma estrita analogia biológica, substituindo organismos vivos por grupos sociais. Fiéis às máximas dos evolucionistas sociais, cujo foco de interesse centrava-se no desenvolvimento cultural da humanidade como um todo e não de uma sociedade em específico, os antropólogos dos museus pareceram entender o pais como um grande "arquivo" de documentos originais e fundamentais para a verificação e estudo das "etapas atrasadas da humanidade". Seu papel principal era tomar parte de um debate que se realizava em outros estabelecimentos científicos do exterior, os quais almejavam captar o ritmo de crescimento humano e por meio da comparação formular esquemas de ampla aplicabilidade." (SCHWARCZ, 1995, p. 92.)
} 
artistas toda a iniciativa para a realização do projeto, que só recebeu apoio e guarida oficial do governo português quando o grupo já tinha aportado no Rio de Janeiro ${ }^{101}$.

De volta à apreciação da UGI, que em parte também pode ser vista como um órgão cultural afinado com as políticas culturais francesas desenvolvidas em além-mar, a ação de Emmanuel De Martonne na criação de redes internacionais de relações entre órgãos e institutos oficiais de geografia, que sob a guarida institucional da UGI ficariam sob a inconteste influência da escola francesa, funciona bem como exemplo da amplitude geopolítica dessas ações de propaganda com fins culturais, que buscavam entrelaçar a esfera da política stricto sensu com os âmbitos aparentemente neutros da ciência e da pesquisa universitária (DELFOSSE, 2001). Suas viagens ao estrangeiro como representante da União Geográfica Internacional, com destaque aos dois períodos em que esteve no Brasil, em 1933 e em 1937, tinham como objetivo principal organizar as condições necessárias para a adesão dos países à UGI, entretanto, o reforço das ações culturais e suas ligações com a política exterior da França no período entreguerras conferem um indisfarçável caráter diplomático-militar à rede de relações por ele tecida:

Ainsi De Martonne s'est fortement impliqué dans différents types d'associations et de sociétés savantes, il a de la sorte constitué une série de réseaux entrecroisés qui assoient sont propre pouvoir, mais qui contribuent à promouvoir celui de la géographie au sein de l'université et auprès du grand public, et à accroître le rayonnement de l'école de géographie française au niveau international. Les actions de De Martonne sont souvent marquées par la rivalité franco-allemande. Cette rivalité $n^{\prime} e s t$ pas uniquement scientifique, elle est le fait du géographe " engagé », comme l'ont été la plupart des géographes durant la Première Guerre mondiale et l'après-guerre. Cet engagement ainsi que sa conception d'une géographie appliquée, qu'il exerce au sein du service géographique de l'armée et du Comité d'études du Quai d'Orsay, mettent en relief les liens entre la diffusion des savoir géographiques et la diplomatie française. (DELFOSSE, 2001, pp. 198-199.)

\footnotetext{
101 "Hora de juntar as cartas: artistas desempregados ou em vias de ser; uma moda francesa nas artes; uma monarquia européia estacionada nas Américas; uma colônia até então fechada aos estrangeiros - sobretudo franceses - e com imensas possibilidades de comércio, mercado e artes, e um príncipe carente de representação oficial. É preciso, pois, combinar isso tudo e ainda adicionar mais dois elementos: o papel do Brasil no imaginário francês e o fato de nossos viajantes saberem que a língua culta da realeza e de uma parte da elite da corte era justamente o francês. Com todos esses argumentos reunidos, talvez o mais correto seja pensar que, juntando a fome com a vontade de comer, os viajantes decidiram partir: alguns financiados, outros não. Por seu lado, a Coroa só daria seu apoio com o fato consumado. Aí sim pagaria pela estada dos artistas em território americano. Convidados ou não, o fato é que a partir dessa troca de correspondências pode-se atestar que existiram relações entre a oficialidade da diplomacia portuguesa e os artistas franceses e que os mesmos chegaram protegidos. Pode-se perceber mais: como o Brasil continuava fazendo parte dos mapas imaginosos dos franceses Quando a 'colônia Lebreton' aportou no Brasil a corte já estava resolvida a levar em frente a idéia de contratar esses artistas vacantes no mercado. Não se pode esquecer também que nessa época a França parecia simbolizar a civilização e a cultura, e os pintores vindos daquela nação valiam, sem dúvida, mais no mercado das artes." (SCHWARCZ, 2008, p. 68.)
} 
Seja como for, ainda que aceitemos em parte o juízo de Jean-Baptiste Arrault e MarieClaire Robic acerca da emergência de novas temáticas na geografia acadêmica do entreguerras, como mostra o desenvolvimento, no seio da UGI, de comissões de estudo específicas, como a preocupada com a confecção da carta do mundo ao milionésimo, a que desenvolveu um programa de pesquisas sobre o habitat rural - liderada por Albert Demangeon, que inclusive desenvolveu um questionário para orientar e padronizar as pesquisas levadas a cabo em outros países -, ou os esforços em torno da definição de um dicionário que normalizasse um vocabulário internacional comum para a geografia, ações que com maior ou menor ênfase aparecem desde 1925, no primeiro Congresso Internacional organizado pela UGI, na Cidade do Cairo, e que foram adensadas nos Congressos posteriores, como o de 1928, em Cambridge, e o de 1931, ocorrido em Paris, que prefiguram sem sombra de dúvidas novos horizontes profissionais para os geógrafos, com a afirmação de novos campos de pesquisa em geografia humana, o que se pode sem receios apontar na análise das ações iniciais da UGI é a existência de contornos geopolíticos que revelam o esforço dos geógrafos centrados em Paris para que houvesse um deslocamento do centro de gravidade da geografia mundial, que passaria da esfera alemã para a esfera francesa (ROBIC, 1996; 2006).

A bem dizer, a comissão de estudos sobre o superpovoamento, criada no Congresso de Paris, em 1931, foi encampada, em 1934, no Congresso de Varsóvia, pela comissão de estudos sobre o habitat rural, passando, em 1938, no Congresso de Amsterdã, à seção dedicada à geografia colonial, a mais concorrida no certame havido esse ano, quando se discutiu abertamente as novas formas de intervenção europeia em terras tropicais: “À côté de la question des nouvelles terres colonisables, ailleurs formulée en termes de fronts pionniers, on y traite des relations entre les densités humaines et l'utilisation du sol" (ROBIC, 1996, p. 217). Assim, quando Arrault fala do entrelaçamento das preocupações nacionais com a escala do mundo, que teria ocorrido no período entreguerras, abrindo a geografia para outras temáticas e proporcionando novas possibilidades de atuação para os geógrafos, não se pode perder de vista que isso foi feito tendo como pano de fundo a continuidade dos estudos geográficos sobre os espaços coloniais, campo tradicional de pesquisas que avança até já bem passadas as primeiras décadas do século XX.

Compreendida a questão deste ângulo, pode-se perceber, a partir da Exposição Colonial de Paris, realizada em 1931, não coincidentemente mesmo ano e local do XVIII Congresso Internacional de Geografia, o terceiro patrocinado pela UGI, um movimento de retomada da 
questão colonial que indica certa continuidade de temas e problemas entre as antigas sociedades geográficas e as novas formas de organização profissional de geógrafos. Aliás, é interessante observar que os certames internacionais organizados pela UGI, a despeito da novidade representada pela roupagem mais científica conferida pelos geógrafos profissionais, mantinha a sequência numérica dos eventos e a divisão interna de seções e assuntos herdadas dos antigos congressos realizados sob a égide das sociedades de geografia, numa relação bastante próxima ao que ocorreu depois no Brasil, principalmente nos Congressos Brasileiros de Geografia de 1940 e 1944, organizados pela AGB e pelo CNG a partir das experiências já encampadas nos eventos da SGRJ.

Em meio a esse debate, Sanguin não deixa de ter razão quando aponta que a geografia francesa, menos suscetível de se abrir às influências estrangeiras, teria vivido um período de relativo fechamento teórico em si mesma até a década de 1960, bastando para sustentar esse juízo lembramos o domínio quase absoluto da profissão exercido pelos "patrões" da pequena comunidade geográfica francesa durante o período, em regra pouco afeitos à inovações. Controlando em maior ou menor grau o ingresso de alunos nos programas de pós-graduação, e mesmo o acesso dos pós-graduados aos principais cargos disponíveis na estrutura de educação superior - em 1920, o número de geógrafos ocupando cargos universitários não superava os 40, número que chegou a 336 em 1968 -, esses verdadeiros "mandarins" da geografia francesa, grupo heterogêneo formado com o caldo comum da herança vidalina, expressavam seu domínio na restrição que imprimiam às escolhas temáticas e metodológicas de seus alunos, que se traduziu na ortodoxia e exiguidade da maior parte dos eixos de pesquisa e programas de ensino, que orbitavam ao redor de quatro grandes áreas de concentração: a geomorfologia, a geografia rural, a geografia regional e a geografia tropical (SANGUIN, 1993), denominação renovada que a antiga geografia colonial recebeu após o início do processo de descolonização no período após a II Guerra Mundial (BRUNEAU, 2006; CLAVAL, 2005; VENNETIER, 1991) ${ }^{102}$.

\footnotetext{
102 "II faut bien reconnaître que, pendant plusieurs décennies, la géographie des régions tropicales fut pour l'essentiel un travail de découverte des pays et des sociétés, dans l'empire colonial dont la France s'était dotée au XIXe siècle. On peut aisément juger de cette orientation par la répartition des articles et notes publiés par les Annales de Géographie dans les quarante premiers volumes de la revue (1891-1931); les plus nombreux, de très loin, concernent le Maghreb, qui était alors la possession la plus ancienne : 35,3\% d'entre eux lui sont consacrés. Viennent loin derrière l'Afrique noire (19,2\%), l'Asie du Sud-Est $(9,5 \%)$ où l'Indochine prend une place prépondérante, l'Amérique du Sud (9\%), les îles de l'océan Indien (7,2\%) et l'Asie du Sud (7,2\%). Mais bien d'autres publications participaient à cette diffusion de la connaissance: Bulletins du Comité de l'Afrique française, du Comité de l'Asie française, Tour du Monde, la Géographie, la Revue Coloniale, les C.R.de l'Académie des Sciences, etc., auxquels il conviendrait d'ajouter des revues plus spécialisées telles que le Bulletin de la Sté de Géographie d'Afrique
} 
O campo da geografia tropical, cujo principal nome, como veremos, é Pierre Gourou, pode ser compreendido, conforme o ponto de vista de Arnold (1996, 2000), na mesma chave interpretativa que Edward Said (1978) aplica ao Orientalismo, a saber, como um discurso que cria a realidade mesma que pretende descrever (SAID, 1978), ou seja, os trópicos são, a um só tempo, um espaço físico com características singulares e uma realidade conceitual intelectualmente criada, pois denominar uma parte do mundo (e seus habitantes) de "tropical" é uma maneira de identificar, separar e controlar um espaço ambientalmente diferente, o "outro" em relação ao ocidente temperado (BOWD e CLAYTON, 2006) ${ }^{103}$.

A propósito, num texto já antigo que faz um balanço dos principais temas de pesquisa da geografia francesa sobre os países tropicais, Guy Lassere e Pierre Vennetier (1968) apontavam certa predominância, nos autores da geografia humana, dos estudos sobre a estrutura agrária e a colonização de terras consideradas "novas". Na mesma direção, Jean-Pierre Raison (1973), em texto apresentado na reunião do Comitê de Estudos sobre os Trópicos Úmidos do Congresso da UGI de 1972, efetuou um levantamento detalhado da bibliografia geográfica francesa sobre a colonização das "terras novas intertropicais", diferenciando as distintas interpretações sobre a expansão do povoamento na África, na Ásia e na América e conferindo ao trabalho de Pierre Monbeig o título de obra seminal que inaugura uma nova forma de abordar o assunto ${ }^{104}$. Mesmo

occidentale, les Annales de la Sté de Géographie Commerciale, le Bulletin de la Sté d'Histoire et de Géographie de la Martinique, le Bulletin économique de l'Indochine, les Cahiers de la Sté de Géographie de Hanoï, etc. On constate un foisonnement extraordinaire de textes, parfois simples récits de voyages, mais souvent aussi riches d'un grand nombre d'observations dans tous les domaines, et qui fournissent d'ailleurs aujourd'hui des éléments irremplaçables de comparaison." (VENNETIER, 1991, p. 647.)

103 "Tropicality can thus be conceived as a discourse - or complex of Western ideas, attitudes, knowledges and experiences - that, since the fifteenth century, has both created and been shaped by distinctions between temperate and tropical lands, with the temperate world routinely exalted over its tropical counterpart, and tropicality becoming central to the definition of the West as a temperate (moderate and hard-working rather than extreme and indo- lent) human as well as physical environment. Tropicality has been a deeply ambivalent discourse, with positive and negative strains captured, respectively, in the image of tropical island edens (such as Tahiti) and the spectre of the jungle (such as the Belgian Congo) as "the white man's grave'. Such ambivalence has become the focus of a fastgrowing interdisciplinary literature, as has the way tropicality can be traced through a range of disciplinary ventures (such as botany, tropical medicine and tropical geography), and discourses (most notably climatic racism and other species of environmental determinism). Yet whether viewed as the exotic site of a noble innocence and simplicity that the West has lost, or as a fertile yet primitive estate awaiting the civilising and modernising intervention of the West, the tropics have been affixed to Western frameworks of meaning, desire and knowledgeable manipulation - a framework in which tropical peoples have been deemed to be unable to represent themselves and the Westerner observer/scholar decides on what counts as right, normal and true (and what does not)." (BOWD e CLAYTON, 2006, p. 209.)

104 "Le mouvement de colonisation des terres neuves semble donc, selon des modalités diverses, devoir combiner deux faits: le mouvement d'individus ou de groupes vers des terres moins densément peuplées que celles qu'ils quittent, et l'apparition de nouveaux types de travail, de nouvelles formes d'organisation sociale, ou de fissures très 
assim, com o desenrolar da década de 1960, um grupo de autores preocupados com problemas mais afeitos à geografia urbana, como Étienne Juillard e Michel Rochefort, ambos de forte influência na formação de Milton Santos, vai paulatinamente desenvolver uma abordagem regional voltada para explicar as singularidades do fenômeno da urbanização no mundo tropical, abrindo uma senda para o tratamento da questão do subdesenvolvimento. Nessa linha, é conhecido o seminário internacional do CNRS acontecido entre 20 e 22 de novembro de 1968 no Centre d'Études de Géographie Tropicale da Universidade de Bordeaux, que contou, entre outros, com a participação de nomes como Rochefort, Juillard, Jean Gallais, Guy Lasserre, Pierre Vennetier, Bernard Kayser, Orlando Ribeiro e Pierre George, os ex-professores uspianos Pierre Deffontaines, Pierre Monbeig, Pierre Gourou e Louis Papy, e os brasileiros Celso Furtado, Manuel Correia de Andrade, Lysia Bernardes, Pedro Geiger e Milton Santos, que então exercia o cargo de professor nessa mesma universidade durante seu exílio (CNRS, 1971).

A despeito das diferenças internas de cada autor, o seminário dividiu-se em três partes, discutindo no primeiro dia os fatores de regionalização do espaço brasileiro, com destaque para as condições históricas, as influências do meio natural e o papel da criação e das plantations tropicais na organização das paisagens; na sequência, debateu-se a possibilidade de se estabelecer uma tipologia das regiões brasileiras; o que resultou, ao final do seminário, em reflexão sobre o modo como o estudo do processo de estruturação de uma rede de cidades, que incidia diretamente na organização da vida econômica do Brasil, seria o caminho mais adequado para se proceder a uma regionalização do espaço brasileiro, pois que esse estudo de síntese envolveria considerar, simultaneamente, a influência do meio tropical e da história de ocupação do espaço no estabelecimento dos diferentes tipos das regiões brasileiras.

A emergência do mundo tropical como um tema relevante para a geografia aparece então como um ponto que merece uma explanação mais detalhada. Na França, a preocupação com o estudo das áreas intertropicais "quentes e úmidas", ou melhor, da adaptação da "raça branca ao trópicos", para ficarmos com uma expressão consagrada à época, vem desde o final do século XIX, pois dos dezenove volumes de sua Geografia Universal, publicados entre 1875 e 1891, Elisée Reclus dedica nada menos do nove aos países tropicais. Em contrapartida, nos quinze rupture qui, bien souvent, ne se consomme que progressivement. Cette rupture est plus importante que les mouvements de population en eux-mêmes qui, dans maintes régions tropicales, ne sont pas des faits nouveaux." (RAISON, 1973, p. 376.) 
tomos da homônima Geografia Universal de Vidal de La Blache e Lucien Gallois, obra projetada pelo primeiro e publicada por segundo como homenagem póstuma ao patrono da moderna geografia francesa, entre 1928 e 1948, seis tratam exclusivamente dessas mesmas regiões localizadas nos trópicos (GALLAIS, 1981) ${ }^{105}$.

Como quer que seja, os primeiros nomes de peso a elegerem como terrain de seus inquéritos científicos áreas localizadas nos trópicos, ainda que hajam escolhido a Indochina - o extremo oriente da arena imperial francófona da Ásia do sudeste -, são Charles Robequain, com o seu trabalho Le Thanh Hoá: étude géographique d'une province annamite, de 1929, e o clássico estudo de Pierre Gourou Les Paysans du Delta Tonkinois: étude de géographie humaine, tese de doutoramento apresentada pelo autor em 1939 (BRÉELLE, 2002). Portanto, a escolha de uma área tropical como área-objeto de estudos aprofundados não constitui, por si só, uma novidade passível de ser atribuída a Monbeig, sendo imprescindível reconhecer que, neste peculiar, ele acompanha tendências já solidificadas de pesquisa.

Todavia, tal afirmação não se aplica de todo, é bom que se diga, ao tratamento dado ao tema escolhido, pois que o de Monbeig é em certa medida inovador dentro do que então se produzia no mundo universitário francês. De fato, autores como Aldo Dantas (2002), estudioso recente da obra de Monbeig, asseveram sem pestanejar que "desde sua chegada ao Brasil, Monbeig se dá conta de que o instrumental da geografia regional francesa não dará conta de explicar nosso país, e esta compreensão vai se consolidando ao longo da década de 1940" (DANTAS, 2009, p. 13), motivo pelo qual esse autor defende que, em seus estudos sobre as zonas pioneiras brasileiras, Monbeig abandonou algumas noções caras à análise regional francesa, como por exemplo o conceito de gênero de vida, que era utilizado por ele sempre com ressalvas.

\footnotetext{
${ }^{105}$ Destas, além da parte dedicada ao Brasil no tomo sobre a América do Sul, escrito por Pierre Denis, em 1927, ganham destaque a contribuição de Jules Sion sobre a Ásia das Monções, publicada em 1928, e a de Augustin Berque sobre a África Setentrional e Ocidental, lançada em 1939, que não diferem muito em conteúdo dos trabalhos apresentados na seção de "geografia colonial" do já comentado Congresso Internacional de Amsterdã, patrocinado pela UGI, em 1938. Em todos eles, encontramos questionamentos acerca das consequências geográficas eventualmente trazidas aos países "novos" pela moderna colonização europeia, então animada por grandes movimentos migratórios, além de impressões e prognósticos acerca do eventual impacto causado pela instalação europeia nas regiões conquistadas: abririam essas novas regiões possibilidades para o desenvolvimento econômico europeu? Esse o ponto básico. Expressivamente, das setenta e uma comunicações apresentadas na seção de geografia colonial do Congresso de 1938, quarenta e duas colocam a questão das "possibilidades de colonização das raças brancas nos trópicos" em termos claros (GALLAIS, 1981).
} 
Sem chegar ao extremo de atribuir ao trabalho desenvolvido por Monbeig no Brasil uma originalidade que ele não possuía, uma vez que sua interpretação dos fenômenos que aqui observou deve em muito aos métodos de trabalho consagrados pela escola francesa de geografia, que ele tão bem representa, não há como desconsiderar a afirmação de Fernanda Áreas Peixoto, que entende que o período brasileiro de Monbeig, assim como para Roger Bastide, Claude LéviStrauss e Fernand Braudel, representou um momento de consolidação de sua carreira intelectual e, pois, uma fase que marca indelevelmente sua produção acadêmica posterior (PEIXOTO, 2008). De mais a mais, o que se pode dizer sem sombra de dúvidas é que Monbeig inaugura, em nosso país, uma tradição de pesquisas metódicas que frutificou, como se quer aqui demonstrar, nos trabalhos de toda uma geração de pesquisadores.

Em vista do que vimos discutindo, não seria demasiado afirmar que há uma relação de proximidade entre a geografia colonial, entendida no contexto de então como um saber aplicado, uma ferramenta utilitária produzindo informações territoriais de base para o estabelecimento das diretrizes de exploração dos espaços colonizados na expansão imperialista, e a geografia tropical, cujo exemplo mais significativo é a obra de Pierre Gourou, que busca compreender os motivos do fraco progresso material dos povos que habitam as áreas quentes e úmidas do planeta, atraso atribuído, ao fim e ao cabo, ao baixo nível de desenvolvimento técnico das sociedades tropicais (BRÉELLE, 2009) ${ }^{106}$. Com efeito, a afirmação que qualifica o movimento pioneiro como "um aspecto da exploração do planeta pelos brancos", a todo momento lembrada por aqueles que se ocupam do assunto, não pode ser deixada de lado, pois assume a força de um categórico eurocentrismo, sendo interessante ainda perceber que quando Monbeig lança mão deste qualificativo, ele está se questionando também sobre a ação dos elementos climáticos sobre a

\footnotetext{
${ }^{106}$ Nota Paul Claval, na passagem da geografia colonial para a geografia tropical, uma mudança de foco que indicaria uma ruptura, pois não se trataria mais de um saber comprometido com o avanço imperial, mas apenas da aplicação no além-mar dos métodos científicos (e neutros) da geografia regional. Contudo, no trecho abaixo fica claro que a geografia tropical continuava a se interessar pelas possibilidades que os países "novos" abririam aos europeus que buscavam expandir sua "aventura ocidental":"La géographie tropicale cesse d'interpréter les mondes dont l'altérité est profonde comme s'il s'agissait de pays neufs où la seule question qui méritât d'être posée est: quel champ offrent-ils à l'aventure occidentale? On les analyse dans leur logique propre. La géographie avait été conçue en Europe occidentale comme une étude des rapports que les groupes humains entretiennent avec les environnements où ils sont installés et d'où ils tirent leur subsistance. C'est ce paradigme qui est transposé sous d'autres cieux (...). La géographie tropicale applique à un milieu différent les recettes que les maîtres de la discipline avaient inventées à la fin du XIX siècle dans des sociétés européennes où les campagnes portaient encore la marque profonde des limitations naturelles. La rupture est totale avec le parti-pris économiste et commercial de la géographie coloniale. Mais le retour de balancier va trop loin: on enferme les sociétés dont on cherche à comprendre l'altérité dans les milieux où elles ont longtemps évolué au moment où la modernisation les aspirent dans le grand chamboulement de la globalisation”. (CLAVAL, 2008, pp. 16-17.)
} 
fisiologia humana, repondo em termos renovados, bem à moda da Geografia Médica então em voga, "o famoso problema do povoamento das regiões tropicais, a questão da aclimação do homem branco aos climas quentes" (MONBEIG, 1947, p. 124).

Esse assunto é tratado por Monbeig numa série de artigos publicados no Boletim Geográfico, do CNG/IBGE, entre 1946 e 1948, quando ele havia acabado de retornar à França. O público europeu para o qual escreve originalmente tais artigos, portanto, faz toda a diferença no encadeamento de seus argumentos. Nesses textos, intitulados "O Clima e o Organismo Humano" (1946), “O Homem Branco e o Meio Tropical” (1947) e "Geografia Humana dos Países Tropicais" (1948), no qual ele comenta o recém-lançado livro de Pierre Gourou (1948), fica evidente que, dialogando fundamentalmente com Max Sorre (1943), que havia lançado anos antes o primeiro tomo de sua obra máxima, Les Fondaments de la Geographie Humaine, dedicado aos fundamentos biológicos das atividades geográficas do homem, Monbeig está preocupado em entender em que medida o meio biológico pode funcionar como obstáculo à conquista da superfície terrestre pelos grupos humanos, ou melhor, poderíamos mesmo dizer que sua preocupação era avaliar em que medida o meio poderia funcionar como uma barreira à ocupação capitalista do espaço, uma vez que o processo de seleção organizada dos elementos naturais que cercam os homens, formando diversas combinações que ampliam os limites do ecúmeno, revelam as associações de simbiose que podem existir entre a implantação de um grupo humano num espaço novo e os diversos tipos de clima, solos e domínios de vegetação que dão suporte à sua instalação: "no momento em que se recomeça a prever a chegada de nova vaga de imigrantes e a pensar-se nos vastos territórios à espera do povoamento e da agricultura, importa mais do que nunca fazer-se o balanço do que é possível e, principalmente, de saber como e a que preço será possível” (MONBEIG, 1946, p. 5).

Ao relacionarmos os argumentos presentes nos artigos, extremamente dependentes do contexto histórico subsequente à II Guerra, fica claro que o objetivo da discussão é sublinhar a vitória da população branca e de sua civilização de base técnica e científica ante os adversários biológicos que concorreram para dificultar a expansão europeia pelo mundo: neste caso, a definição dos índices ótimos de temperatura dentro da média térmica anual de $16^{\circ} \mathrm{C}$ a $23^{\circ} \mathrm{C}$, fora da qual, segundo Sorre (1943), as funções fisiológicas estariam comprometidas, indica não apenas a dificuldade do arraigamento das populações europeias acostumadas com o clima temperado nas zonas polares e tropicais, que para serem habitadas deveriam passar por um 
processo de reorganização dirigida, tal uma verdadeira evolução mediada pela técnica, mas também a existência de certos limites ecológicos para o desenvolvimento de culturas agrícolas com um bom nível de rendimento. Desse modo:

Pergunta-se então se seria possível aproveitar outros métodos de cultura, que permitissem tirar dos solos tropicais jovens o máximo de rendimento, sem esgotá-los, susceptíveis, assim, de alimentar populações muito densas. O problema de melhorias eventuais da agricultura tropical é de uma realidade particularmente aguda. Primeiramente, interessa aos povos indígenas permanentemente sujeito às ameaças da fome. Depois, num mundo em que cada dia se toma maior consciência da estreita solidariedade dos Estados e dos continentes, nas boas e nas más coisas, o aproveitamento das terras tropicais constitui poderoso elemento de reconstrução e de paz. (MONBEIG, 1948, p. 1462.)

A referência às novas levas de migrantes que seriam direcionados para as terras passíveis de ocupação, por um lado, e à tomada de consciência da estreita solidariedade dos Estados e dos continentes, que sem dúvida reverberam as negociações de paz do pós II Guerra, quando começam a tomar forma os organismos internacionais que irão redesenhar o mapa do mundo, consolidando uma nova ordem geopolítica mundial, colocam a questão da melhoria da agricultura tropical como um fator de harmonização das relações entre os continentes e países, visto que, numa Europa destroçada, a produção de alimentos deveria ser feita, inicialmente, em outros lugares, engendrando, como não poderia deixar de ser, uma nova divisão territorial do trabalho que continuava a enxergar o "mundo tropical" como um elemento auxiliar periférico posto a reboque das necessidades e vontades do centro.

Contudo, embora Monbeig realmente concorde com Pierre Gourou quando este aponta o problema da insalubridade das terras tropicais, fato que, aliado à baixa fertilidade do solo, mais exposto aos processos de laterização causados pelas constantes alterações de estações secas e úmidas, tornaria o clima tropical hostil ao homens e abrasivo aos solos, situação que somente seria resolvida com a aplicação metódica de soluções embasadas em inquéritos científicos, ele não referendava inteiramente as conclusões do colega acerca do povoamento e do aproveitamento dos solos tropicais, censurando-lhe o "ter pensado como europeu que jamais se livra de certa saudade de seu doce país, saudade que o faz realmente esquecer seus problemas naturais" (MONBEIG, 1948, p. 1461):

Região quente e úmida - eis o que logo sugere, e sobretudo para um leitor europeu, o problema da salubridade e da adaptação psíquica e física do branco. O Sr. Gourou, que tem uma longa e dura experiência pessoal na Ásia tropical, 
não hesita em afirmar que a natureza tropical é hostil ao branco. Não é que desconheça os mil aspectos do problema. Mesmo tomando largamente em conta a contradição dos fatos observados, não deixa de opor os países da Europa central e ocidental, ou os temperados da América do Norte, ou o da Nova Gales do Sul, aos países tropicais, que conservam um ambiente hostil (...). Quantos milhares de anos levou a raça branca para reajustar a natureza da Europa? Também ela não teve de triunfar das "doenças temperadas"? (...) Os historiadores, caso se voltassem para esse aspecto pouco estudado do passado, não nos apresentariam fatos novos, capazes de nos reconduzir à modéstia? A domesticação da natureza tropical pela raça branca apenas começou. Seria absurdo negar a necessidade de considerável esforço para tornar mais salubre e mais sã a vida nos trópicos embora não estejamos senão na fase inicial desse esforço cuja precisão apenas começa a ser percebida, porque até então o colono branco cogitou sobretudo de ganhar dinheiro a fim de voltar o mais depressa possível à Europa e porque a saúde do indígena foi sempre seu menor cuidado. Mas com a ajuda do tempo, a salubridade poderá ser adquirida. (MONBEIG, 1948, pp. 1460-1461.)

Deixando de fora comentários mais aprofundados sobre o eurocentrismo criticado (embora também praticado) por Monbeig, que chega até a aventar "o desastre da intervenção branca nos trópicos" expresso na destruição de suas riquezas florestais, esse tipo de visão do problema da colonização, que enxerga uma colaboração estreita da ciência em geral, e da geografia em particular, com a expansão do ecúmeno, executada pela via da conquista de novas áreas, mormente a feita nas terras quentes e úmidas dos trópicos, não era raro nos trabalhos de geografia dos anos 1930 e 1940, sendo importante frisar, dentro desse conjunto de textos, a mudança geral de foco em relação aos trópicos, pois se na passagem do século XIX ao XX as regiões "quentes e úmidas" do globo eram não raro consideradas áreas anecúmenas, o avanço da ciência e da técnica, associado ao sucesso da instalação europeia em diversos pontos do mundo tropical, colocavam os trópicos como os principais alvos dos inquéritos técnicos destinados a informar cientificamente a elaboração de políticas que dariam base à expansão do ocidente pelo $\operatorname{mundo}^{107}$.

\footnotetext{
${ }^{107}$ Livros de referência, como o mundialmente divulgado White Settlers in the Tropics, de Geenfell Price, lançado com notas explicativas de Robert Stone, em 1939, sob os auspícios da American Geographical Society, que foi alvo de comentários por parte de Caio Prado Júnior (1939) e de Pierre Monbeig (1941), as obras dos geógrafos norteamericanos Ellen Semple e Ellsssworth Huntington, fortemente inspiradas pela geografia de Ratzel, e, como vimos, igualmente o livro Les Pays Tropicaux, de Pierre Gourou (1948), afirmavam de maneira contínua a questão das dificuldades que o mundo tropical, leia-se a sua natureza, impunha à aclimatação do homem branco: "Sou levado a perguntar-me se o Sr. Gourou, que tão escrupulosamente traçou os grandes característicos da ação constantemente nefasta dos europeus nos países quentes e chuvosos, não permaneceu, em suma, sob o golpe da impressão pessimista que recebeu e se não se excedeu ao atribuir à natureza erros que não eram senão dos europeus? (...) Seja como for, os desastres da intervenção branca me parecem que, talvez, levam os europeus mais lúcidos a não mais considerar o meio tropical senão em função desses desastres, tidos por inevitáveis. É assaz surpreendente que não se indague se a causa dos malogros não está tanto, senão mais, na intervenção européia que nas características geográficas dos países
} 
No tocante à emergência de um novo campo de intervenções para a geografia, por sua vez, ligado à temática da planificação territorial comandada pelos Estados ou órgãos associados de planejamento regional, o Congresso de Varsóvia, em 1934, é o precursor, pois nesse encontro e no posterior, acontecido em Amsterdã, em 1938, aparece com clareza nos anais da UGI a contribuição de diversos grupos de geógrafos engajados diretamente no reordenamento territorial, normalmente evocando as vantagens das ações políticas embasadas em informações adquiridas a partir de levantamentos geográficos realizados diretamente no campo:

À partir des années trente, la plupart des démocraties secouées par la Dépression ont elles aussi adopté des politiques de planification territoriale, qu'elle soit à base de Survey à la manière britannique ou de planification complexe à la manière du New Deal américain. On pourrait enfin rappeler deux autres tensions vers 1'application : celle que produit la politique coloniale, premier grand terrain de planification pour des pays comme la France, et la vogue des sciences sociales appliquées qui, diffusée à partir des Etats-Unis, se déploie dans l'Europe des années trente sous l'égide de fondations internationales comme la Fondation Rockfeller ou la Fondation Carnegie. Dès 1934, I. Bowman trace cette nouvelle frontière de la pratique géographique à Varsovie, en évoquant concrètement les «land-use studies », les «hazard» ou les «risk-maps», des recherches orientées par le point de vue de la planification e de l'économie nationale envisagée par le président Roosevelt (...). Ces nouveaux champs de recherche et d'intervention ne son pas inconnu des géographes fréquentant l'UGI, car au moins à l'occasion de la guerre et des politiques d'après-guerre, tous ont participé de près ou de loin à des projets de reconstruction qui dépassaient la dimension de l'urbanisme. Le congrès de Varsovie est le lieu où, pour la première fois peut-être, des géographes-praticiens pouvant ouvertement partager des expériences diverses se rencontrent. Mais, avec la généralisation de la planification, c'est le congrès d'Amsterdam qui permet le mieux de faire état d'expériences en vraie grandeur, de seulement les évoquer ou de les prendre de front. (ROBIC, 1996, pp. 220-221-223.)

De todo modo, vale lembrar que a colonização dirigida de terras com baixa densidade demográfica, que deveriam ter sua organização espacial planejada para atingir um nível aceitável de desenvolvimento ou "civilização", para ficarmos com um vocábulo comum da época, era um dos caminhos que a geografia dos anos 1930 indicava como modo de resolver os problemas globais, cujos efeitos eram localmente identificados em suas particularidades por meio dos exaustivos inquéritos de campo e diagnósticos territoriais projetados e executados. Os trabalhos de Albert Demangeon desenvolvidos no âmbito da comissão de estudos sobre o habitat rural,

quentes e chuvosos. A intervenção européia tomou em toda parte a forma de uma exploração devastadora, porque era feita sob o signo do enriquecimento e do comércio fácil. Essa intervenção não conheceu as longas hesitações e a paciente adaptação que foram a história das centenas de anos em que se deu a conquista do solo europeu." (MONBEIG, 1948, p. 1466.) 
bem como as obras coletivas dirigidas por Isaiah Bowman nos Estados Unidos, são talvez os exemplos mais acabados de como a geografia estava tratando dos novos problemas colocados pelas mudanças encetadas no período entreguerras.

Ponto por demais relevante, o sentido conferido por Albert Demangeon ao termo "colonização", que é fundamental no modo como Pierre Monbeig vai tratar a questão da expansão pioneira nos planaltos ocidentais de São Paulo e norte do Paraná, encontra-se intimamente imbricado ao sentido conferido por Isaiah Bowman ao termo pioneirismo. Sendo assim, discutiremos na próxima seção alguns textos de Demangeon e Bowman que abordam a questão da colonização e uso da terra, avaliando sua importância dentro do arranjo explicativo enunciado na geografia de Monbeig.

\section{Albert Demangeon, Isaiah Bowman e a geografia do pioneirismo}

Comecemos partindo da definição do verbete "colonisation" constante no Dicionário Manual-Ilustrado escrito por Demangeon em colaboração com Joseph Blayac, Jules Sion e Antoine Vacher, em 1907. Obra de vulgarização que teve um grande alcance editorial e acadêmico, já que se trata de um dos primeiros esforços editoriais visando o grande público efetuado por discípulos diretos de La Blache, os verbetes inclusos neste dicionário revelam o conjunto de temas e definições gerais que faziam parte das preocupações dos geógrafos no início do século XX, sendo interessante acompanhar o número elevado de nomes de portos importantes do mundo colonial, a referência exaustiva a acidentes geográficos, antigos exploradores e curiosidades sobre países distantes que se encontram lado a lado com definições conceituais ainda em processo construtivo.

Em uma primeira acepção, o termo "colonização" se define ali como a ocupação e a valorização de uma área ou país "novo" por um grupo que se encontra num estágio de civilização mais avançado, ou seja, nesse primeiro sentido, a colonização é um fenômeno de conquista e apropriação de terras que pode ocorrer internamente à área de jurisdição de um Estado-nação, mas que sempre é comandado por um grupo humano que se encontra em um estágio superior de desenvolvimento civilizacional (DEMANGEON, 1907). Esse tipo de visão evolucionista do desenvolvimento humano, que liga o processo de apropriação e transformação da natureza pelos grupos humanos ao nível de desenvolvimento técnico apresentado pelas diferentes sociedades, 
que ficariam assim dispostas numa taxonomia que vai das sociedades primitivas, as que mais sofrem a influência do meio natural, até as sociedades civilizadas ou modernas, aquelas que dominam a natureza, será repetido exaustivamente pelos geógrafos que analisaram a expansão do povoamento por meio das frentes pioneiras, uma vez que o próprio pioneirismo, apoiado no espraiamento espacial de lavouras e na fundação de cidades, era entendido na época como um sinal do progresso, o vetor de modernização pelo qual a sociedade urbano-industrial civilizada dominava a natureza ainda intocada de territórios tropicais indevassados.

Após fazer um breve histórico dos diferentes casos aos quais se aplicaria a definição proposta inicialmente, Demangeon confere ao termo um significado que prolonga os pressupostos contidos na primeira acepção, referindo-se às colônias como uma possessão territorial ou administração direta de uma nação civilizada em "país de bárbaros", das quais seriam exemplos as colônias de exploração dos Impérios Espanhol e Português, sustentadas no trabalho escravo. Após uma descrição breve desses dois casos, chega ele à época sua contemporânea, que assistia a um novo esforço de colonização definido sobretudo pela organização interna dos territórios colocados sob a proteção ou controle direto de uma metrópole. Esses territórios coloniais teriam como função básica satisfazer a contento as necessidades de matérias-primas para as indústrias modernas dos países europeus (DEMANGEON, 1907), definição que por si só atrela o conhecimento geográfico então produzido ao contexto do imperialismo europeu, então vivendo no auge de sua fase expansionista em busca de novos territórios que fossem capazes de fornecer matérias-primas industriais e produtos tropicais, ao mesmo tempo em que funcionassem como uma reserva de mercado para a comercialização não apenas dos produtos industrializados metropolitanos, os bens de consumo, mas também para a exportação de bens de capitais, sobretudo na forma de investimentos em infraestrutura de transportes, como portos e ferrovias, estas últimas voltadas fundamentalmente para agilizar a produção especializada das arenas coloniais de acordo com as demandas dos países centrais.

$\mathrm{O}$ entrelaçamento de escalas contido nessa definição de colonização, que encampa o processo de ocupação e valorização de uma área vazia ou considerada vazia dentro de um mesmo território, por um lado, e a organização territorial de um espaço externo de dominação voltado para atender as necessidades metropolitanas satisfeitas a partir do desenvolvimento de uma economia agrícola complementar, por outro, fica ainda mais claro em outros escritos de Albert Demangeon. No texto Economie agricole et peuplement rural, escrito em 1934 e publicado como 
parte da obra póstuma Problèmes de Geographie Humaine (1947), organizada por seu cunhado, Emmanuel De Martonne, Demangeon nos fornece um exemplo de seu entendimento acerca da colonização (branca e europeia) do mundo, concebendo-a como um aspecto do fenômeno mais geral da ocupação do solo pelos grupos humanos. Considerando que tal fenômeno era passível de ser observado à escala do mundo, Demangeon se propõe a tratar de dois conjuntos de problemas correlacionados: a questão das relações existentes entre o meio geográfico e o povoamento rural, que implica meditar sobre a adaptação dos europeus aos diferentes meios naturais, e a questão da exploração da terra em busca de maiores rendimentos, que se colocava conjuntamente com a expansão do povoamento rural.

Sobre o primeiro conjunto de problemas, do qual não falaremos mais a fundo, Demangeon fornece exemplos regionais embasados em estudos de caso, donde é surpreendente o uso abundante de uma bibliografia de língua alemã, inclusive um dos mais importantes livros de Leo Waibel, o Probleme der Landwirtschaftsgeografphie (Problemas de Geografia Agrária), lançado em 1933, quando Waibel era um dos integrantes mais destacados do grupo de geógrafos ocupados com os estudos sobre o habitat rural na UGI (ETGES, 2000). Descrevendo as variadas formas de adaptação dos europeus ao redor do mundo, que conduziram à organização de estabelecimentos rurais cujas diferenças respondiam mais às diversas formas de exploração do solo empregadas pelos homens do que a assimetrias existentes nos meios naturais, principalmente do relevo, do clima ou da vegetação, é interessante acompanhar o exemplo que opõe as antigas áreas de colonização espanhola, como a Argentina e o México, às áreas de colonização anglosaxã, como os Estados Unidos e a Austrália, entendidas como exemplos materializados nas paisagens das diferenças existentes entre o nível de civilização dos grupos humanos e os meios geográficos onde estes se fixavam (DEMANGEON, 1947) ${ }^{108}$.

\footnotetext{
108 "D’immenses régions de la Terre se sont ouvertes à la colonisation européenne. Plusieurs types de société, d'économie et d'habitat ont été transportés du vieux monde dans les pays neufs. Comment leur nouveau milieu géographique les a-t-il accueillis, adoptés, transformés? Comment chaque civilisation, espagnole ou anglo-saxonne, a-t-elle pris possession de son domaine exotique? En ce qui concerne la colonisation espagnole, on peut prendre deux exemples, l'un en Argentine, l'autre au Mexique; l'un qui montre en action un pur peuplement de Blancs, l'autre, un peuplement mixte d'Européens et d'Indiens (...). Dans les pays de colonisation anglo-saxonne, ce sont au contraire des exploitations agricoles de type moderne, parvenues à la spécialisation et même parfois à la monoculture qu'on rencontre. Ils présentement aussi un mode de peuplement rural par habitats isolés qui exclut les communautés villageoises. Les plus souvent, aux États-Unis et en Australie, sont les bourgs, qui groupent les boutiques, les services et les fonctionnaires dont les cultivateurs ont besoin (...). On voit quelle richesse de formes nous offre le peuplement rural, quelle variété de relations existe entre ce peuplement et l'économie agricole, mais aussi combine il est parfois difficile de discerner, dans ces faits sociaux et économiques, l'influence respective des conditions géographiques et du degré de civilisation.” (DEMANGEON, 1947, pp. 214-215/218/220.)
} 
Já sobre o conjunto de problemas derivado da exploração produtiva da terra, Demangeon inicia suas reflexões perguntando se a tarefa da conquista dos meios naturais pelos grupos humanos poderia ser considerada, no início do século XX, uma obra já terminada, ou, em outras palavras, num mundo onde praticamente todos os quadrantes do globo já eram conhecidos, mais ou menos ocupados e divididos territorialmente entre as potências coloniais, haveria ainda possibilidades de expansão e conquista de novas terras para a exploração econômica do solo pela "raça branca"? ${ }^{109}$ Respondendo positivamente à sua indagação, Demangeon separa as direções tomadas por essas correntes de contínua exploração produtiva do espaço em intensivas e extensivas, dizendo que o primeiro tipo de exploração do solo caracterizar-se-ia pela busca de uma maior produtividade das culturas instaladas em terras já ocupadas, enquanto o segundo tipo diria respeito a um processo expansivo que incorpora cada vez mais terras ao circuito espacial de produção agrária: "L’époque actuelle nous montre deux domaines où chacun de ces efforts s'applique plus ou moins méthodiquement: les pays tropicaux où penetre chaque jour plus profondément la culture de plantations; les pays de la lisière des zones tempérées et subtropicales où se poursuit une véritable lutte pour la conquête et l'occupation du sol" (DEMANGEON, 1947, p. 220). No caso dos países tropicais, as formas de exploração agrícola se dividiriam basicamente em duas, a plantation de origem ou comando europeu, que se desenvolvia em grandes áreas de monocultura, com técnicas avançadas de base científica e com a disponibilidade de estradas e ferrovias, e a cultura de enxada presente nos gêneros de vida tradicionais de cada país tropical considerado, o que exprimia não só o contraste entre duas formas de exploração e uso do solo, mas sobretudo "l'opposition de deux civilisations" (Loc. cit.).

Entre as características da plantation europeia implantada em países tropicais, que segundo Karl Ritter, citado por Demangeon, estariam associadas à cultura da cana-de-açúcar, muito familiar ao Brasil, não se pode olvidar seu aspecto de grande exploração agrícola de caráter industrial que se desenvolve apoiada num uso intensivo de mão-de-obra (antigamente escrava) e de solos, produzindo gêneros agrícolas de grande valor no mercado internacional. Para serem implementados, esses empreendimentos necessitavam de grandes somas de capital, além de se

\footnotetext{
109 "Le second problème consiste à se demander si la mise en exploitation de la terre, qui marché de front avec le peuplement rural, peut être considérée comme un conquête terminée, ou si, au contraire, il n'existe pas de possibilités d'extension pour ce domaine humain. En réalité, ce domaine ne cesse ni de s'enrichir, ni de s'élargir, comme le montrent les progrès de la mise en valeur des pays tropicaux et les poussées locales de colonisation qu'on voit s'effectuer un peu partout sur les lisières des civilisations conquérantes." (DEMANGEON, 1947, p. 206.)
} 
utilizar de técnicas científicas normalmente voltadas para minimizar o esgotamento rápido dos solos e aumentar a produtividade das lavouras:

Certains traits et certaines tendances composent la physionomie économique des plantations: l'industrialisation, car beaucoup de leurs produits être lavés, séchés, fermentés ou transformes avant de partir pour les marches de consommation; la monoculture et, par suite, l'épuisement rapide des sols et l'emploi de quantités énormes d'engrais artificiels (...) une certaine instabilité et des crises de prospérités fréquentes (...) là nécessite de puissants capitaux (...) l'emploi d'une main-d-ouvre très nombreuse, ce qui explique jadis le commerce des esclaves noirs et aujourd'hui le recrutement de certaines milliers de travailleurs indiens et chinois; la présence d'un personnel de direction, formé à l'européenne, bien préparé techniquement et scientifiquement; enfin la perspective constante du marché universel qui exige la connaissance des débouchés, le sens des concurrences possibles et la présence de bons moyens de transport. (DEMANGEON, 1947, p. 221.)

Ficam claras nesse trecho algumas similaridades com a maneira como Monbeig encarava a expansão das lavouras de café e algodão que embasavam as movimentações pioneiras no Brasil, principalmente a instabilidade a que ficava exposta a atividade econômica que dependia unicamente dos humores do mercado externo, bem como a aproximação existente entre uma tal exploração agrícola de feição exógena, o montante de capital investido e a consequente industrialização resultante do desenvolvimento da economia agrícola baseada nas plantations. Se bem que Monbeig use pouco o termo plantation ao longo de suas obras, reservando-o basicamente para os momentos em que descreve os primórdios da vaga pioneira, que, como vimos, se iniciou no século XIX lastreado pelos grandes fazendeiros e pelo "oceano verde do café", as características básicas aqui descritas por Demangeon são fielmente reproduzidas por Monbeig na caracterização das atividades agrícolas que fundamentam o povoamento pioneiro, principalmente a ligação destas atividades com o mercado externo, o rápido esgotamento do solo pelo seu uso intensivo e a necessidade de bons meios de transporte que garantiriam a integração e a fluidez do território.

Além do mais, a separação levada a cabo por Demangeon entre as duas formas de exploração agrícola presentes no mundo tropical, a plantation comercial moderna, símbolo da ciência e do domínio europeu que coroa o comando das civilizações avançadas sobre os trópicos, e a cultura tradicional de enxada, epítome do atraso e incapacidade técnica dos países e populações tropicais, é também seguida por Monbeig, que, mesmo tentando mitigar o eurocentrismo explícito de Demangeon, caracteriza cada etapa da marcha pioneira exatamente a partir do nível de desenvolvimento das técnicas de exploração do solo utilizadas pelos grupos 
humanos no domínio da natureza ao longo da história, considerando a ocupação centenária de posseiros e caboclos como uma forma arcaica de exploração agrícola que será inexoravelmente sepultada com o avanço pioneiro.

Após detalhar as formas intensivas da conquista europeia dos solos tropicais expressas pelas plantations, Demangeon detém-se brevemente na segunda das direções ou formas tomadas pela corrente de exploração agrária das terras, a que progride menos em intensidade do que em superfície, incorporando terras novas ao domínio humano: "Sur la lisière de plusieurs pays tempérés et subtropicaux, nous voyons s'étendre tout un front de colonisation, une Pioneer fringe, selon l'expression de M. Is. Bowman, où s'avancent encore les pionniers de l'humanité, apportant avec eux les types de peuplement et les méthodes agricoles de leurs pays d'origine" (DEMANGEON, 1947, p. 225). Embora Albert Demangeon diga nesse artigo, escrito originalmente em 1934, nos Annales de Géographie, que as franjas pioneiras, ao contrário das plantations, se espraiavam em meios naturais que são temperados ou subtropicais, o que equivale dizer que as correntes de povoamento, ao contrário das correntes de exploração comercial, ganhavam força em quadros naturais similares ou mesmo iguais aos da Europa, valorizando e povoando terras novas ainda não ocupadas produtivamente por uma economia de base agrícola, isso não representa de todo sua opinião sobre as frentes pioneiras. De fato, dois anos antes de publicar esse texto - em 1932, portanto -, Demangeon havia resenhado o então recém-lançado livro de Isaiah Bowman ao qual ele faz referência no artigo saído em 1934. Nesse escrito de 1932, a definição proposta pelo francês não apresenta esse reducionismo quanto à base natural dos meios onde se dinamizavam as franjas pioneiras:

Il existe à la surface de la Terre des régions que l'occupation sédentaire des hommes n'a pas encore conquises, régions de lisière, zones-frontière où ils avancent en tâtonnât, luttant pied à pied contre les rigueurs d'un climat trop chaud, trop froid ou surtout trop sec, terres d'essais et d'expériences, où ils tentent leurs chance, où souvent après de dures épreuves ils parviennent à fonder un foyer. Ce sont les conditions de ce combat opiniâtre, ce sont les territoires où progressent lentement les pionniers de l'humanité que nous décrit Mr. Isaiah Bowman, dans un livre plein d'ingénieuses observations et copieusement illustré (...). Toutes ces zones de combat ont un trait commun: elles imposent la nécessité d'une lutte contre les rigueurs de la nature, de longues épreuves pour réaliser l'adaptation au milieu, la recherche de moyens propres à garantir l'emprise du colon sur la conquête. Les régions tropicales posent le grave problème du peuplement blanc, qui n'a guère dépassé le stade du laboratoire : l'homme blanc ne peut y supporter l'obligation du travail manuel, ni accepter le bas niveau de vie du simple pionnier. Dans les régions froides, il faut résoudre le problème de l'acclimatation des plantes cultivées et de la création de variétés 
susceptibles de résister aux gelées ou d'accomplir en peu temps leur cycle de végétation (...). Mais ce sont les régions arides qui constituent actuellement le principal domaine du pionnier. Dans les hautes plaines des Etats-Unis, le long du pied oriental des Montagnes Rocheuses (...). Malheureusement, même avec les secours de la science, le progrès des pionniers ne s'effectue, pas plus aujourd'hui que jadis, selon un rythme régulier; dans certaines régions, le front de marche s'est arrête avant d'atteindre les limites possibles de l'occupation; ailleurs, les ayant dépasses, il se trouve exposé à des grands risques. (DEMANGEON, 1932, 631-632-633.)

As referências de Demangeon a Isaiah Bowman, que serão notadas também para o caso de Monbeig $^{110}$, abrem a oportunidade de discutirmos um pouco os trabalhos do geógrafo norteamericano. Expressivamente, quando se fala do fenômeno das frentes pioneiras, é inescapável fazer menção ao nome de Bowman, sem o qual a caracterização geral que estamos a fazer acerca da análise geográfica do pioneirismo ficaria incompleta. Para Neil Smith (2003), que estudou pormenorizadamente a vida e a obra de Isaiah Bowman (1878-1950), o interesse do geógrafo na colonização pioneira, somado à sua atuação nos conflitos mundiais do século XX, como um dos principais conselheiros do presidente Woodrow Wilson nas conferências de paz de Paris, ao final da I Guerra, e como defensor das estratégias propostas pelo Council of Foreig Relations (CFR), que ele ajudou a fundar, durante a II Guerra, prefiguram exemplarmente a geografia política do chamado "Império Americano", refletindo o expansionismo que é inerente à mudança de foco da política externa dos EUA, que desde o "fechamento da fronteira americana" anunciado por Turner, em 1893, passaram a atrelar a resolução de problemáticas afeitas à realidade interna do país a uma ambição cada vez maior de uma expansão global em arenas exteriores (SMITH, 2003).

Tendo em vista o contexto de rápida urbanização pela qual os EUA passavam nas primeiras décadas do século XX, não deixa de ser surpreendente a atenção dispensada por Bowman aos cinturões pioneiros do mundo, sendo pertinente, pois, fazermos referência ao envolvimento pessoal do geógrafo estadunidense com o tema, que remete à sua infância de trabalhos na fazenda do pais, em Brown City, e aos trabalhos de campo efetuados no Kansas e Oklahoma, em 1905, e no Chile, em 1913, quando pela primeira vez a questão da relação entre a colonização de novas

\footnotetext{
110 "Les études d'esprit géographique ont apporté plus de précision dans la connaissance du fait pionnier et plus de souplesse dans sa compréhension. Dans les années qui précédèrent et suivirent la crise économique de 1929-1930, I. Bowman entreprit et inspira des nombreuses enquêtes sur les fronts pionniers à travers les continents. L'élan gagna d'autres disciplines et d'autres pays. A l'optimisme des ilimetd possibilities de l'espace et de la nature succédait le souci de l'observation prudente des réalités physiques; on commençait de s'interroger sur les perspectives. Les temps changeaient, l'épopée pionnière ne semblait plus possible et il paraissait évident que l'époque était venue d'un pioneering moder style." (MONBEIG, 1966, pp. 980-981.)
} 
terras e as condições extremas de meios naturais considerados hostis à instalação humana aparece nos registros do autor. Em verdade, os esforços de pesquisa de Bowman, que fazem parte do processo de afirmação institucional-acadêmica da geografia no início do século XX, respondendo, pois, a estímulos de ordem interna aos EUA, não se descolam do despertar do imperialismo americano para além de suas fronteiras continentais, expressando, por isso, a imbricação entre as escalas nacionais e internacionais que vimos sublinhando desde o início deste capítulo:

However vaguely, Bowman was anticipating that as the political geography of global affairs would be reworked at the behest of a rising American globalism, the "geography of internal affairs" would experience a commensurate reworking. The implied contrast between experience metropolitan centers and still-developing frontiers anticipates a concern with uneven geographical development, a concern that did not gain the attention of the social sciences until four or five decades later but that has everything to do with the closure of the frontiers. Bowman's frontier-pioneer research does little more than a gesture in that direction. Needless to say, a worked-out theory of the geography of capitalist expansion and crisis across different scales was the furthest thing from his mind; nor did offer a vista of the dense connections across these international and subnational scales. Still, in casting his frontier and pioneer research in this way, he did tie the geography of internal affairs to U.S foreign policy. To be sure, he saw this connection in terms personally familiar to him - pioneering and frontier settlement rather than industrial regionalism - but in the context of 1920's geography the identification of even this narrow cross-scale was rare. (SMITH, 2003, 214.)

No geral, seus trabalhos, que não foram analisados de modo aprofundado nesta pesquisa, redundaram em programas internacionais de estudos sobre as franjas pioneiras apresentados em obras coletivas como The Pioneer Fringe (1931), composta de sete monografias resultantes da cooperação pluridisciplinar na investigação de áreas consideradas pioneiras em diferentes continentes, e o livro Limits of Land Setlement: A Report on Present-day Possibilities (1937), coletânea publicada pelo $C F R$ que apresenta, entre diversos textos oriundos de levantamentos efetuados diretamente no campo, uma contribuição de Carl Sauer sobre a necessidade de repensar a distribuição da população pelo planeta e um capítulo do editor averiguando as possibilidades de colonização na América do Sul, sua conhecida desde as longas viagens de campo que empreendera aos Andes, na década de 1910, e ao Atacama, nos anos 1920.

Este capítulo sobre a América do Sul, que conta com consistentes páginas sobre o Brasil, é ancorado numa surpreendentemente atual bibliografia, não hesitando em citar trabalhos de publicação recente naquele momento, como os estudos fundamentais de Preston James (1932; 
1937), os primeiros trabalhos de Pierre Deffontaines $(1936$; 1937) sobre o país e mesmo um único texto de Pierre Monbeig (1935), então neófito em terras brasileiras. Curiosamente, embora faça referência a inúmeros outros autores, o material utilizado tem em comum o fato de terem sido todos publicados na Geographical Review, nos Annales de Geographie ou no periódico de vida breve da AGB, a revista Geografia.

Em detalhe, Bowman apontava a falta de um plano adequado de uso do solo no Brasil, notando o quase inexistente apoio técnico para os colonos desenvolverem suas culturas, exceção feita aos estados do Rio Grande do Sul, Santa Catarina, e, em menor escala, São Paulo e Paraná, que teriam compreendido antes dos demais a importância de se buscar um equilíbrio na densidade demográfica das áreas colonizadas, construindo núcleos mais integrados às bordas do povoamento - o ecúmeno - e não isolando os pioneiros uns dos outros, o que inviabilizaria o desenvolvimento de uma vida econômica de nível razoável. Lembrando que, do ponto de vista dos imigrantes, os cinturões pioneiros incluiriam não só as condições naturais, mas também a população já instalada nas terras consideradas novas, com suas ideias e desejos, Bowman aponta como um dos aspectos renovados do pioneirismo moderno o fato de o movimento de população que o sustenta trazer consigo um "choque de culturas": "Therefore, in dealing with South American possibilities of setlement it will be necessary by way of preface to speak of peoples and systems of society and government, and the history of past undertakings, as well as the physical character and capacity of underpopulated lands". (BOWMAN, 1937, pp. 294-295.)

$\mathrm{O}$ questionamento subjacente a todos os inquéritos científicos sobre as áreas de interesse para o povoamento e colonização, colocado em termos claros por Isaiah Bowman, - ou, como preferia o então diretor da AGS e da $\mathrm{UGI}^{111}$, subjacente ao tema das possibilidades econômicas oferecidas pela "land settlement" feita em bases científicas - traz a simplicidade pragmática que o momento de crise mundial então vivenciado requeria. Em inglês castiço, perguntava-se sobre as ações colonizadoras desenvolvidas nos trópicos: "Does it pay?"

$\mathrm{O}$ que estaria em jogo nesses estudos de caso seria a produção de um diagnóstico de viabilidade econômica referente à expansão do "povoamento moderno" em novas áreas ainda não

\footnotetext{
${ }^{111}$ No início da década de 1930, Bowman ascende a uma posição de destaque dentro do edifício institucional da geografia estadunidense, congregando um cargo de diretor (1915-1935) da mais antiga sociedade geográfica dos Estados Unidos, a American Geographical Society (AGS), fundada em 1851, com o posto de presidente da UGI, para o qual foi eleito após o Congresso de Paris, em 1931, ocupando o cargo até o Congresso de Varsóvia, em 1934. Por fim, lembremos que a AGS não deve ser confundida com a Association of American Geographers (AAG), associação profissional fundada em 1904 que Bowman presidiu na passagem dos anos de 1920 para os anos 1930 (LOWENTHAL, 2005; WRIGHT e CARTER 1959).
} 
totalmente aproveitadas pelos grupos humanos, ou, dito de outro modo, os trabalhos coordenados por Bowman procuravam estabelecer parâmetros aceitáveis para a dominação das civilizações urbano-industriais da Europa e dos EUA em terras consideradas "disponíveis" para a instalação de colônias. No caso, para que as possibilidades de povoamento pudessem se realizar por completo, a colonização deveria ser referendada (ou não) pela ciência, que teria a incumbência de avaliar o potencial de exploração de cada área. Atendo-nos aos termos dos textos analisados, vemos que também para Bowman a ciência e a técnica são vistas como bases cada vez mais fundamentais para a manutenção e o desenvolvimento das zonas pioneiras:

The dry border of the pioneer lands of every continent offers science an especially wide field of inquiry and experiment. The engineer sees the physical job - the dam to be built, the canals for water distribution, the installation that will provide electric current - the harnessing of power, in short. If he is more than a technician he will look at the economic return also, and, if not, he will be brought back to realities by the economist or the hard facts of existence quickly realized by the farmers who use his beautifully organized but possibly uneconomical plant. (BOWMAN, 1931, p. 76.)

Como um todo, sua visão de pioneirismo moderno trazia em seu bojo uma concepção internacionalista de desenvolvimento econômico atrelada à colonização de novas áreas, circunstância que expressa a ascensão do novo tipo de imperialismo americano por meio da diminuição de importância da lógica territorialista de poder do colonialismo europeu, para ficarmos nos termos de Arrighi (1996), dado que os investimentos capitalistas com vistas a incentivar uma colonização moderna fundamentada em inquéritos científicos, além de cavar um espaço de atuação acadêmica para a geografia, podem ser vistos como uma forma de exploração mais próxima da lógica de poder capitalista, que visa a acumulação do capital sem a necessidade de haver o controle direto de territórios estrangeiros, que apareciam, pois, apenas como o meio pelo qual o investimento feito poderia retornar de forma ampliada dentro de uma economia globalmente unificada.

Nessa direção, os esforços coletivos por ele dirigidos nos Estados Unidos, que se iniciaram ainda na década de 1920, quando um primeiro esboço do projeto de estudos sobre o pioneirismo apareceu, com financiamento da Fundação Rockefeller, no âmbito do National Research Council, são dos exemplos mais significativos de como os geógrafos poderiam trabalhar os novos temas postos na pauta da UGI, uma vez que Bowman foi talvez o primeiro geógrafo a projetar um programa de pesquisas de alcance mundial que se detinha nas possibilidades e vantagens oferecidas pela colonização programada de áreas identificadas como pioneiras em todo o globo: 
The significance of the frontier-pioneer studies project also had to do with the trajectory of geography as a discipline. As he declared to his AAG [Association of American Geographers] colleagues in his presidential address, if geography was going to "influence political and social policies", it would have to "deal with ideas that seem to be of critical importance to government and society", and Bowman was cocksure that frontier-pioneer research represented one of these ideas. American geography in the 1920's was changing dramatically (...). "The great epic of America is the conquest of the land", Bowman held, and he felt no reason to think that would end. Quite against the ethos of the 1920's, when rural issues were fading from the national agenda, he argued that intensive plowing and cultivation of western grasslands coupled with unprecedented urban demand for food would amplify the issue of frontier zones and pioneering on more marginal lands. His fervor for frontier and pioneering studies in advance of the disastrous dust bowl proves prescient. The study of pioneer settlement should not be a backwater academic field but a frontier of directly usable knowledge. His primary goal was to systematize the knowledge of frontier zones first in North America then globally in preparation for new waves of colonization that would inevitably come as population growth mushroomed (...). If geography was the study of "man in relation to his environment", then the discipline was uniquely positioned to undertake the study of pioneer belts. Mankind was "biologically crowding the planet", he explained, and pioneer belts provided an obvious safety valve. He proposed to map the world's pioneer belts, identify their distinctive characteristics and conditions, document the different modes of advance into marginal lands, and calculate the limits of feasible settlement. A "scientific" index might be devised to measure the natural, cultural, economic, and technological conditions of a particular frontier zone, thus allowing easy quantitative comparisons of settlement potential. (SMITH, 2003, pp. 214/216217.)

Como se pode deduzir da introdução de Bowman aos livros que organizou, os cinturões pioneiros do mundo eram encarados como verdadeiras "regiões laboratório" já descoladas da tradição americana das fronteiras à la Turner, sendo pois esperável que fosse desenvolvida uma "ciência da colonização" que fornecesse uma descrição explicativa do substrato territorial por onde se exerceria a movimentação dos pioneiros. Esta descrição deveria ser completa o suficiente para comandar a exploração produtiva dos locais, indicando quais os sítios mais indicados para a localização das colônias, bem como os melhores produtos a serem cultivados a partir de uma dupla finalidade, a produção de gêneros alimentícios para os novos habitantes das zonas pioneiras, que manteriam a estabilidade do povoamento, e o comércio de produtos com abertura no mercado mundial, que garantiria a rentabilidade dos capitais investidos por empresas, governos e particulares:

Relieving the population pressure in overcrowded lands is now a broad social, economic, and political question with unique twentieth century aspects that require fresh study and appraisal (...). Today the limitations of a new environment interest both the settler and the country to which he comes. Most of 
the pioneer lands that remain are "marginal" in climate, fertility, and transport (...). In most of the pioneer fringes of the world, experts are now required to plan out measures in advance if colonization is to be rational. An appraisal or inventory of the resources must be made. Population capacity and the well-being of settlers cannot be guessed at or left to an office of propaganda. It may be determined in part by the degree of applicability of new technical accomplishments, and special techniques of cultivation. These, as well as the land itself, give the farmer new opportunities and an altered prospect for his family. Changes in transport facilities also play their revolutionary part, political and economic aims often coinciding in this field (...). What these experiments and experiences forecast is that the population capacity of the land depends not on its degree of vacancy, but on the total available resources that land, people, science, technology, and market demand, plus transport facilities, make possible in combinations that are largely unique from region from region and from country to country. Basic material can be provided, including maps and map notations, for the study of the general problem as well as the details of the several regions; but it is not out of such materials that policies are made. These grow chiefly out to political, social and economic conditions and situations. Once a policy has been determined upon, however, its form will be guided largely by the data presented in studies of this type. (BOWMAN, 1937, pp. 1-23-4-5.)

No entendimento de Bowman, a colonização dinamizada pelo pioneirismo moderno seria uma forma de desenvolvimento econômico, podendo funcionar como uma válvula de escape para certos problemas surgidos em momentos de crise. Assim, ao contrário de Turner, que argumentava ser a dinâmica da fronteira um repositório espiritual da renovação da identidade nacional norte-americana, Bowman se utilizava do vocabulário que opunha os "selvagens" à "civilização" numa chave mais afastada das teses que consideravam as condições naturais do meio como o fator preponderante do sucesso ou fracasso da colonização, pois o que seria determinante para caracterizar os cinturões pioneiros, até como uma forma de incentivar os estudos geográficos pensados como fundamento a indicar as reais possibilidades de negócios que poderiam surgir, seria a estrutura econômica, social e política dos países e regiões onde estes estariam localizados. Logo, em vez de cristalizar gêneros de vida singulares originados pela instalação humana em regiões fisiográficas muito diferentes, as zonas pioneiras expressavam a organização de novas formas de regionalização decisivamente influenciadas por fatores econômicos.

Avultam então as diferenças entre as concepções de pioneirismo de ambos os intelectuais estadunidenses: em primeiro lugar, a visão de pioneirismo de Bowman, tributária das modificações pelas quais passava o mundo no início do século $\mathrm{XX}$, preocupava-se integralmente com a qualidade de vida dos colonizadores, ou seja, a imagem heroica do pioneiro isolado 
lutando contra selvagens povos indígenas e a natureza hostil devia ficar para trás, dando lugar à busca intencional de condições que possibilitassem a formação de uma comunidade que contaria necessariamente com certas facilidades no acesso a escolas, médicos, estradas e financiamento que só poderiam ser alcançados com a mediação do governo. Em uma palavra, o pioneirismo moderno era uma política estratégica do interesse dos governos, e não apenas uma ação isolada fruto de vontades individuais (BOWMAN, 1931; 1937) ${ }^{112}$.

Por outro lado, como já notamos linhas acima, o novo pioneirismo seria dependente de inquéritos científicos, isto é, não cabia de modo algum às famílias ou indivíduos em constante deslocamento decidir livremente, a partir de sua capacidade de trabalho, onde seriam instalados os novos núcleos pioneiros, como se poderia depreender no arranjo utópico de Turner em relação à free land do Meio Oeste americano. Ao contrário, um levantamento minucioso das condições naturais, climáticas e sociais dos novos lugares considerados como passíveis de serem apropriados e transformados pela civilização seria imprescindível para o sucesso do empreendimento moderno de colonização. Essa postura, que conferia importância prática e acadêmica à geografia, vista como a "ciência da colonização" por excelência, engrandecia a atenção devotada ao pioneirismo, justificando-a exatamente por este possibilitar a resolução de questões fundamentais postas pela crise econômica, tais como o abastecimento de gêneros alimentícios para a população que crescia em razão geométrica nas grandes cidades, a absorção do capital excedente provindo das crises de superacumulação ou o fornecimento de matériasprimas industriais a baixo preço para as indústrias ${ }^{113}$. Por fim, mas não menos importante, uma

\footnotetext{
112 "As Bowman saw it, governments across the world had no choice but to engage with pioneering: how to encourage or discourage it as appropriate, what kind of pioneer settlement and where, and what kinds of policies to implement. A science of settlement would address these issues and provide a fundamental knowledge available to pioneers and governments alike. Such a science called for an "exact study of the advances and retreats of population" in different parts of the world, aiding rational settlement practices. Yet this appeal to science of settlement was never well detailed, remaining almost as diaphanous in his latter work as it had been in the original 1925 proposal. He made much of the apparent parallel between science and pioneering. Pioneering belts are "regions of experiment" in much the same way as science is necessarily experimental. Both yield only provisional truths, truths that had to be revised periodically in the light of new conditions and technologies." (SMITH, 2003, pp. 225-226.)

${ }^{113}$ Ponderando sobre as dificuldades para a consolidação dos novos ramos de pesquisa abertos à geografia ao longo da década de 1930, diz Marie-Claire Robic: "A atenção dada nos congressos internacionais às transformações recentes dos territórios nacionais, à planificação que se aplica a eles, revela bem, por meio de sinalizadores tais como as questões propostas no congresso e as intenções, a acuidade da questão nacional. As análises da crise econômica sublinham que os fatos geográficos modernos dependem de um mundo em transformação, tanto na escala do planeta como na dos países industrializados: trata-se de uma mudança irreversível cujas lógicas os geógrafos pensam ser capazes de depreender. Muitas vezes, portanto, abrem-se debates sobre considerações pragmáticas relativas à maneira como a geografia, em nome de seu saber específico, pode contribuir para uma ação voluntária sobre os acontecimentos: seja sozinha, graças sua capacidade para compreender situações complexas, como conselheira das políticas, seja em companhia de outras disciplinas, em situações de expertise em vias de definição. Mas tudo se passa
} 
última diferenciação entre ambas as concepções de pioneirismo refere-se ao foco explicitamente internacionalista de Bowman, que negava o fechamento da fronteira e o fim da experiência americana do pioneirismo ampliando-o à escala do mundo, contrapondo-se à visão internalista enraizada fortemente na experiência dos EUA defendida por Turner e seus seguidores:

Bowman's emphasis on "modern pioneering", his insistence on a science of settlement, an international scale of analysis and a focus on land hunger, all point to a concern with what we might now think of as development through settlement. Through the 1920's and most of the 1930's, he believed that pioneer belts represented practical alternative regions of development that could absorb widespread population increases and capital surpluses. If the equation of settlement with development represented a continuance of the pre-twentiethcentury connection between economic and geopolitical expansion - a significant step backward from the heightened insights about international economics and territory that emerged from the Open Door policy and from Paris 1919 - it also marked a evolution. Bowman was clear that the "old colonial idea" connecting land control and economic progress was obsolete, but especially following the economic depression that had begun in the late 1920's, he also stressed the imperative of economic expansion through settlement (...). In global perspective, Bowman's vision of modern pioneering came at a time when the European colonial model of economic expansionism was in crisis but before the language and paradigm of economic development was fully un place. That would not occur until after World War II. Accordingly, for all his insistence on an international perspective and his recognition of the priority of economic progress, Bowman struggled but was never fully able to translate the frontierpioneering rubric into liberal developmental internationalism championed by the Council of Foreign Relations. He was not yet able to resolve what he called the "anomaly in human behavior", such that intense "land hunger" and frontier settlement coincided with the "human flood" of urbanization. (SMITH, 2003, pp. 228-229.)

$\mathrm{O}$ viés internacionalista de Bowman, que liga a expansão do imperialismo americano à colonização produtiva de novas terras, pode ser melhor percebido em seus trabalhos da década de 1940, quando os problemas relacionados com as migrações de refugiados, principalmente de judeus, após o término da II Guerra, já aventados pelas autoridades americanas desde o final da década de 1930, ganham corpo com o secreto "Projeto M" (M de "migração"), pensado como um dos esteios da reconstrução global do pós-guerra. De fato, questão do assentamento dos milhões de refugiados, que certamente se poria como imperiosa ao final das hostilidades bélicas, era, dentre os muitos outros assuntos e aspectos geopolíticos das discussões que pautavam o

como se as experiências fossem distintas demais de um país para outro, como se os conflitos geopolíticos fossem fortes demais também para que uma formulação clara e unânime dos desafios se mostrasse possível. Para isso, seria preciso esperar o pós-Segunda Guerra Mundial ” (ROBIC, 2006, p.50). 
Departamento de Estado americano, essencial para a consolidação e exercício das futuras relações de poder mundial projetada pelo governo dos Estados Unidos (SMITH, 2003) ${ }^{114}$.

O envolvimento de Bowman com o levantamento e diagnósticos territoriais de áreas próprias para o estabelecimento de refugiados sensibilizou o governo americano acerca das necessidades de investir em estudos de caráter sistemático sobre as possibilidades de colonização em diferentes áreas no globo. Assim, com verbas garantidas, Bowman contratou, em 1938, o alemão Karl Pelzer, especialista que havia feito estudos sobre o potencial de colonização em diversas áreas da costa do Pacífico, para efetuar estudos sobre o continente africano. Como curiosidade, vale dizer que é aqui que vemos ganhar corpo o elo de afinidade que liga a trajetória intelectual de Bowman com a de Leo Waibel, que veio ao Brasil depois de uma estadia forçada nos Estados Unidos, uma vez que foi o próprio Isaiah Bowman, então nome de relevo no meio universitário estadunidense, quem viabilizou a ida de Waibel aos Estados Unidos, onde o geógrafo alemão conheceria seus futuros discípulos brasileiros, construindo a partir daí um itinerário que o atrela ao $\mathrm{CNG}$.

Refazendo rapidamente a trajetória intelectual de Waibel, percebe-se que após seus primeiros estudos em geografia, feitos na década de 1910 sob a influência de Jäger e Hettner, seu

\footnotetext{
${ }^{114}$ Influenciada talvez pelo erro que consta no curriculum vitae inserido na segunda edição dos "Capítulos de Geografia Tropical e do Brasil" (1979), escrito pelo próprio Leo Waibel, Virgínia Etges (2000) chama o Projeto M de Projeto N, o que pode causar confusões no entendimento de seus objetivos. Todavia, em seu estudo sobre Isaiah Bowman, Neil Smith mostra como os estudos sobre as zonas pioneiras comandados por Bowman ajudam a revelar, caso sejam analisados sob o prisma dos objetivos estratégicos dos EUA durante a II Guerra, o nível de comprometimento com o Estado que uma ciência praticada como auxiliar de decisões políticas podia atingir quando integrada aos anseios geopolíticos do nascente imperialismo americano: "The top secret M Project was initiated on 1 November 1942 under Bowman's leadership with the express purpose of surveying the possibilities of large-scale refuge resettlement. The M Project was conceived by Bowman as an updated and more focused Inquiry. The Inquiry, as we have seen, was Woodrow Wilson's think tank for the Paris Conference, and when Bowman looked ulat Europe in 1942, he saw an exaggerated version of Europe in 1919. Intensified displacement and brutality kept unresolved territorial questions on the agenda, but questions of population and migration, settlement and development, were now more vital then before. Like Roosevelt, Bowman was increasingly convinced that resettlement had to be conceived in terms of broader questions of population growth. In addition to questions of land and sovereignty, boundaries and trade, security and the territorial separation of antagonistic ethnic groups, the settlement after World War II would have to "go a step further and consider populations themselves; their structure and growth, their standards of living, their freedom (or the lack $f$ it) to expand territoriality, the possibility of increasing the development of undeveloped lands" [BOWMAN, 1942]. Eugenic arguments looked increasingly attractive to Bowman, and he connected population growth to questions of national security as well as development. "Every argument for security in the future les to the exercise of wider influence and power on the part of the United States", he believed, and the undervalued study of populations would be central to an informed and appropriate exercise of that power. This put the question of colonial settlement more squarely on the U.S. agenda than it had been in 1919. Then it was simply a question of how colonies ought territories to be settled, developed, and brought into commercial intercourse with the United States." (SMITH, 2003, p. 301.)
} 
grande mestre ${ }^{115}$, ele empreendeu inúmeros trabalhos de campo, cabendo destacar sua primeira experiência como observador do mundo tropical, ocorrida em 1911, quando foi convidado a participar de uma expedição africana patrocinada pela Sociedade Colonial Alemã. Em 1913, doutorou-se em Heidelberg, com a tese Formas de vida e hábitos dos animais na África Tropical. Após o início da I Guerra Mundial, em 1914, Waibel, que se encontrava novamente na África, se alista como reservista, tendo sido posteriormente preso por tropas inglesas. Ele permaneceu na condição de prisioneiro até 1919, embora desde 1916 os ingleses tivessem autorizado a continuidade de suas pesquisas, mais voltadas, nessa época, para questões de morfologia, hidrologia, e estudos daquilo que então se denominava como zoogeografia (ETGES, 2000).

Na década de 1920, Waibel trabalha por um tempo em Colônia, exercendo o cargo de professor-assistente junto a Thorbecke, mesma função que exercerá depois em Berlim, quando auxiliou o eminente geógrafo Albert Penck, pioneiro nos estudos de climatologia dinâmica. Nessa época, produziu textos importantes que revelam a predileção pelos conceitos de paisagem e de formação econômica, como o intitulado "As regiões pastoris do Hemisfério Sul”, que seria vertido para o português e publicado em livro, em 1958, no Brasil (ETGES, 2000). Posteriormente, por volta de 1923, assume a direção do Instituto de Geografia, em Kiel, de onde saiu, em 1929, para tomar posse do mesmo cargo na Universidade de Bonn, onde ficou até ser aposentado compulsoriamente, em 1937.

Nos anos 1930, Waibel promoveu intensas mudanças em sua prática científica, agora mais voltada para as discussões da aplicabilidade da obra de Von Thünen e para problemas relativos à geografia agrária e econômica. Com efeito, seu livro Problemas da Geografia Agrária, lançado em 1933, considerado por Orlando Valverde uma contribuição magnífica como método de exposição geográfica, pode ser tomado como um marco dos estudos desenvolvidos pelo alemão nesse período, sendo relevante notar, ainda, que são desse volume os originais da maior parte dos textos traduzidos para o português no livro Capitulos de Geografia Tropical e do Brasil (1979 [1958]). Por essa época, ele supera o nacionalismo extremo que permeou suas atividades ao

\footnotetext{
${ }^{115}$ As informações de caráter biográfico sobre Waibel foram retiradas principalmente do livro de Virgínia Etges (2000), que fez um estudo completo da vida e obra do geógrafo alemão. Outros fatos e datas importantes foram também compilados na apresentação que antecede o livro Capitulos de Geografia Tropical e do Brasil (1979), lançado originalmente em 1958 e cuja segunda edição recebeu anotações importantes de seu mais conhecido discípulo brasileiro, Orlando Valverde. Digno de nota é pequena notícia escrita por outro de seus alunos brasileiros, Nilo Bernardes, em 1952, na seção "Vultos da Geografia do Brasil" da Revista Brasileira de Geografia (RBG), além do texto de Valverde (1968) que versa sobre a contribuição de Waibel à geografia brasileira, aparecido também na RBG.
} 
longo das décadas de 1910 e 1920, quando inclusive esposou algumas das ideias do nacionalsocialismo, deixando de ser um pesquisador engajado no projeto imperialista alemão. Como consequência, Waibel abandona suas antigas preocupações com a redivisão do território africano, buscando compreender as particularidades que envolviam a exploração econômica dos espaços tropicais, pois "não se tratava mais da aquisição de colônias e sim de questões sobre a troca de mercadorias na divisão internacional do trabalho" (ETGES, 2000, p. 31).

As dificuldades impostas pelo regime nazista à sua atividade de pesquisa, que culminaram na perda do cargo que ocupava na Universidade de Bonn, fez com que a causa mais divulgada para a sua destituição fosse a ascendência judia (ou o não arianismo) de sua esposa, entretanto, as mudanças operadas em suas preocupações científicas, com destaque para a questão da colonização de terras tropicais por elementos europeus, que passa a ser seu principal foco de interesse, têm um papel não desprezível em sua demissão, de vez que é justamente então que ele abandona o antigo hábito de condicionar questões demográficas, culturais e políticas aos desígnios naturais, o que supervalorizava a influência do meio natural na compreensão de problemas sociais e econômicos. Nesse sentido, tornam-se relevantes os comentário feitos por Orlando Valverde (1991) em entrevista concedida à revista Geosul. Diz o geógrafo carioca:

Durante o governo de Hitler, Waibel tinha dois motivos grandes de incompatibilização com o regime: primeiro, porque casou com uma mulher de origem judia, que não praticava a religião, mas não era ariana; segundo, porque ele publicara em 1933, em Breslau, um pequeno livro, intitulado Probleme der Landwirtschaftsgeographie (Problemas de Geografia Agrária), em que, num dos capítulos, mostrou que os "boers", embora descendentes de holandeses, portanto arianos, devido ao isolamento econômico e cultural tinham baixado seus padrões até o nível de pastores nômades. Na conclusão, ele afirmou então que a teoria de "Blut und Boden" (sangue e solo), a teoria racista, não era verdadeira. Isto em 1933, justamente quando Hitler subiu ao poder! O livro foi queimado. (VALVERDE, 1991, p. 176.)

Para Valverde, o fato de Waibel atribuir a regressão por ele observada no modo de vida de descendentes de europeus ao isolamento econômico e cultural, e não a uma possível inadaptação dos pastores bôeres arianos aos rigores do clima tropical, estaria na raiz das desventuras pelas quais o alemão passaria na década de 1930, mas também, paradoxalmente, é o motivo maior do encontro de Waibel com o Brasil, de vez que seu exílio nos Estados Unidos, caminho que tomou para escapar das restrições a ele impostas na Alemanha, marca profundamente as escolhas futuras que irá realizar, pautando inclusive o cruzamento de sua trajetória pessoal e científica com um 
grupo de geógrafos brasileiros recém-saídos dos bancos universitários. A história é boa, e vale maiores comentários ${ }^{116}$.

No início da década de 1940, inicia-se, via IBGE, um progressivo aumento do intercâmbio científico do Brasil com os Estados Unidos, estreitamento de relações que pode sem sombra de dúvidas ser remetido ao contexto mais amplo da política do presidente Roosevelt para a América Latina na época da II Guerra, que defendia a integração e cooperação em escala continental, com destaque para as chamadas "relações culturais" (TOTA, 2000). No caso em questão, como as relações oficiais com a geografia francesa encontravam-se suspensas, até por conta da ocupação alemã, o intercâmbio de técnicos do CNG com os EUA se deu principalmente através de órgãos e universidades envolvidos diretamente com questões relativas ao planejamento regional, que contava já com a experiência anterior das mudanças empreendidas pelo governo americano no Vale do Tennessee como parte da política do New Deal (ALMEIDA, 2000).

Postas as linhas gerais do início do relacionamento da geografia brasileira com o mundo universitário e acadêmico norte-americano, sabe-se que o primeiro geógrafo brasileiro a viajar para os EUA foi Jorge Zarur, que em 1942 foi para a Universidade de Wisconsin, onde cumpriu as etapas necessárias para o obtenção de seu mestrado. Nesse mesmo período, frequenta também a Universidade de Chicago, onde se aproximou de nomes como Clarence Jones e Cotton Mather, geógrafos especializados no planejamento regional que já haviam prestado inúmeros serviços ao governo dos Estados Unidos:

Agências de Inteligência americanas como o Office of Strategic Service (OSS), e o Army Map Service (AMS) empregaram muitos geógrafos durante a Segunda Guerra, como Cotton Mather, Clarence F. Jones, Preston James e Richard Hartshorne Foi através desses geógrafos que Jorge Zarur (funcionário do IBGE), convidado pelo governo americano a se especializar nos Estados Unidos, tomou contato com a escola americana de Geografia voltada para o planejamento

\footnotetext{
${ }^{116}$ Completando suas lembranças dos antecedentes que marcam os primeiros contatos estabelecidos com Waibel, Valverde assim responde, quando perguntado se seu antigo orientador teve que fugir da Alemanha: "Não, propriamente. Primeiro, ele foi intimado pelo partido nazista, pressionando o Reitor da Universidade, para que fizesse, antes de iniciar as aulas, a saudação "Heil Hitler". Ele se recusou. Então, o partido nazista mandou como emissário um "chefão" lá; um militar que, perante o Reitor e a congregação foi intimá-lo a fazer o "Heil Hitler". Quando o "chefão" the estendeu a mão, ele pôs as suas mãos para trás e virou-Ihe as costas. Não sei como não foi parar num campo de concentração! Ele foi, em seguida, aposentado compulsoriamente. Mas os alunos gostavam tanto dele que iam visitá-lo em casa, para ter aulas. O Serviço Secreto soube, e aí o proibiu de lecionar em toda Alemanha. Estava ele em tratamento de nervos, quando o geógrafo americano Richard Hartshorne, voltando de uma excursão à URSS, sendo um grande admirador das obras de Waibel, o visitou e se interessou em levá-lo para os Estados Unidos. De volta ao seu país, obteve de Isaiah Bowman, presidente da John Hopkins University, que enviasse a Waibel uma carta de chamada. Ele pôde, assim, vir para os EUA, mas trazendo apenas duas malas e 28 dólares no bolso, nada". (VALVERDE, 1991, p. 176.)
} 
espacial do New Deal de Franklin Roosevelt, da qual o planejamento do Vale do Tennessee foi um dos principais projetos. Jorge Zarur, que em 1942 vai para o mestrado em Winsconsin e depois para uma especialização em técnicas de trabalho de campo em Chicago, torna-se amigo de Cotton Mather e Clarence F. Jones. Seu retorno ao Brasil faz surtir um efeito quase imediato, ao trazer um convite do Governo americano para que mais cinco geógrafos do IBGE fossem, em 1945, estudar em universidades americanas. Fábio de Macedo Soares, Orlando Valverde, José Veríssimo, Lúcio de Castro e Lindalvo Bezerra foram os indicados para Winsconsin, Northwestern e Chicago, universidades especializadas em estudos regionais voltados para o processo de ocupação do território. (ALMEIDA, 2000, p. 113.)

Após a volta de Zarur para Brasil, em 1943, uma nova leva de geógrafos ligados ao CNG parte para os Estados Unidos. Na entrevista já referida, Valverde lembra que Fábio de Macedo Soares Guimarães e ele ficaram em Wisconsin, Lúcio de Castro e Lindalvo Bezerra partiram para Chicago e José Veríssimo da Costa Pereira foi para a Universidade Northwestern (VALVERDE, 1991). É nesse curso de Wisconsin que Valverde conhece Waibel, cuja ida aos EUA havia sido intermediada, como já referido, por Richard Hartshorne, Bowman e por um seu ex-aluno, o também alemão Karl Pelzer, que já se encontrava em terras americanas. Após concluir seu doutorado na UCLA, em 1938, Pelzer, envolvido com alguns projetos do governo dos EUA, serviu como intermediário do convite feito a Waibel pelo Consulado Americano em Berlim. Por isso, os estudos desenvolvidos por Waibel no início de sua carreira americana, principalmente os levantamentos das possibilidades de colonização da América Central, devem ser bem contextualizados, pois podem nos ajudar a compreender melhor o surgimento de certas posturas que influenciaram o direcionamento de suas reflexões quando de sua chegada ao Brasil.

Como já se pode inferir, foi Pelzer quem indicou a Bowman a contratação de Waibel, seu ex-professor, para participar das novas geographical surveys a serem realizadas na América Latina. Com efeito, Waibel participou dos estudos que foram feitos na Costa Rica e se desdobraram na indicação da compra de uma grande área no país, o que acabou não se concretizando. Resultou ainda dessa participação a publicação, no ano de 1939, na Geographical Review, de um estudo intitulado White settlement in Costa Rica. Todavia, as ligações desse estudo com as diretrizes estratégicas que seriam futuramente estabelecidas pelo Projeto $\mathrm{M}$ foram até certo ponto mascaradas pelo amparo institucional fornecido pela Universidade John Hopkins aos especialistas que dele participaram, entre 1938 e 1942.

Os resultados práticos desse esforço de reconhecimento de áreas propícias à ocupação planejada anterior ao Projeto M, patrocinado por uma entidade controlada por judeus, a Refugee 
Economic Corporation (REC), e alocado na universidade John Hopkins, podem ser ilustrados por uma série de noventa e três relatórios, todos destinados aos conselhos e comitês presidenciais que discutiam as alternativas para o assentamento de refugiados. Além disso, esse esforço embrionário do projeto secreto compilou uma soma considerável de material descritivo sobre muitos lugares em todos os continentes, à exceção da Europa, informação de primeira mão que de forma alguma poderia ser descartada em tempos de guerra ${ }^{117}$. Ao fim e ao cabo, o Projeto M, insuflado no início da década de 1940 pela divulgação das atrocidades cometidas contra os judeus na Europa, funcionou, entre 1942 e 1945, em três salas de estudo adjacentes à Livraria do Congresso. Porém, embora tenha conseguido agregar mais de seiscentos e cinquenta documentos, sendo cento e cinquenta e dois relatórios inéditos, trezentos e vinte e oito pequenos memorandos, cento e três traduções de materiais de interesse não publicados originalmente em inglês, quarenta e sete palestras e dezessete documentos administrativos, não conseguiu resultados mais efetivos do ponto de vista da instalação de refugiados nas áreas pesquisadas (SMITH, 2003).

Para o que nos interessa mais diretamente, a participação de Waibel como especialista nas pesquisas financiadas por essa iniciativa de cunho estratégico para os EUA, que inclusive resultou, como vimos, em pesquisas feitas em diversos países da América Latina, pode ajudar a melhor compreender a gestação de algumas de suas preocupações básicas na análise do tema da colonização e povoamento do território brasileiro, bem como iluminar aspectos relevantes de seus hábitos de pesquisa, percebidos quando da feitura das muitas excursões que efetuou em nosso país entre 1946 e 1950. Na verdade, poder-se-ia pensar até em desenvolver uma análise comparativa que estabelecesse um paralelo entre a geografia produzida pelos alunos brasileiros influenciados por Leo Waibel no CNG/IBGE e o acervo de conhecimentos produzido pelo grupo

\footnotetext{
117 "The goal, in Bowman's eyes, was not so much the solution of immediate refugee problems as an attempt to establish the scientific basis that would guide later solutions. He was as much excited by the scientific opportunity as by any practical humanitarian implications; resettlement under these conditions represented a unique scientific 'experiment', he told his sponsor. He worked hard to depoliticize the work and to deflate any public optimism about large-scale resettlement." (SMITH, 2003, p. 298). Todavia, os objetivos do Projeto M eram um pouco mais explícitos: "The 1938-1942 refugee resettlement project at Hopkins was haphazard in its geographical coverage, but the M Project was to be systematic and comprehensive. Roosevelt wanted to know: Who will be in need of resettlement at war's end? Where are they? Where could be settled? And what would it take to resettle them permanently and successfully? The mass of work was divided geographically - Far East, Russia, the Near East, Central America, South America, Africa, and Europe - and it provided extensive reportage on everything from climatic and hydrological conditions to estimates of 'surplus population', national immigration legislation, previous and existing resettlement projects, population 'absorption capacities', and so on. Never as gigantic as the State Department feared it might be, the M Project comprised eight to ten permanent staff at any one time and a further twenty to thirty research associates and consultants (...). Among the consultants were Owen Lattimore, Karl Pelzer, and Robert Bowman, who had all worked on the earlier project along with Leo Waibel on the staff." (SMITH, 2003, pp. 301-302.)
} 
de geógrafos mais diretamente influenciado por Monbeig na Universidade de São Paulo. De todo modo, sua contratação como assistente-técnico do CNG, que certamente foi referendada por sua atuação e experiência como pesquisador, aponta para a permanência da colonização dirigida e dos estudos sobre uso do solo como assuntos de importância estratégica para as agências governamentais ocupadas com a geografia no Brasil, bem como para a abrangência do tema do pioneirismo dentro do campo geográfico.

Em conjunto, a caracterização do momento vivido pela geografia em âmbito internacional oferece um bom ponto de partida para avaliar a maneira como Monbeig interpretava o fenômeno do pioneirismo. Primeiramente, a referência a Demangeon, seu orientador no início de carreira, e a Bowman, um dos únicos autores citados textualmente por Monbeig ao longo das mais de 400 páginas de sua tese de doutoramento, são fundamentais para que possamos acompanhar a filiação teórica de suas posições, bem como as modificações que Monbeig empreendeu nas concepções teóricas colhidas por ele no trabalho de outros autores. Colocando frente a frente as passagens de Bowman com as definições encampadas por Demangeon, emergem de súbito alguns pontos comuns na caracterização das zonas pioneiras do mundo. Inicialmente, destaque-se a situação "marginal" das terras consideradas como pioneiras, que seriam no mais as terras ainda não colonizadas a partir de uma ocupação produtiva do solo, situação que revelaria as limitações impostas a elas pelos rigores do clima, pela pobreza do solo (ou pelo desconhecimento de suas propriedades) e pela falta de vias de comunicação adequadas para escoar a produção ali organizada. Neste ponto, as estradas não eram pensadas unicamente como vias de escoamento da produção, mas também como o móvel necessário para que fosse possível instalar, nos novos núcleos, as facilidades da vida urbana moderna com as quais os pioneiros estariam em tese acostumados em seus países ou lugares de origem, como escolas, igrejas e condições sanitárias compatíveis com aquilo que encontravam em sua terra natal antes de empreender a migração.

Somada a esta condição marginal das terras, destaca-se também, dentre as características comuns das zonas pioneiras, o caráter de luta dos homens com o meio natural, o que, por consequência, ajuda a tornar mais robusto o perfil de laboratório experimentado pelas áreas qualificadas como pioneiras, já que seria somente a partir das técnicas de intervenção criadas modernamente e amparadas por um conhecimento científico que a conquista das áreas poder-seia realizar plenamente, dando origem a novas oportunidades para os imigrantes desenvolverem um lar junto às novas terras que vêm habitar. É nessa chave que devemos compreender a frase de 
Monbeig, de clara inspiração em Bowman: “A zona pioneira do estado de São Paulo é por mais de um título um laboratório" (MONBEIG, 1940, p. 55).

Os traços essenciais do posicionamento que concebe a colonização moderna como uma forma de desenvolvimento econômico secundada por inquéritos científicos aparecem, por exemplo, num texto do francês devotado à análise da paisagem do núcleo colonial Barão de Antonina, entendido à época como a mais acabada expressão de uma tentativa moderna de colonização efetuada em terras brasileiras. Após se deter momentaneamente nos problemas colocados pela assimilação dos colonos estrangeiros, questionando-se acerca das vantagens potencialmente advindas da completa fusão dos colonos estrangeiros no caldo da população brasileira, que evitaria a formação dos polêmicos "quistos étnicos" tão debatidos pela intelectualidade brasileira dos anos 1930 e 1940, Monbeig põe a questão da colonização moderna em termos muito próximos à concepção de Bowman, que pensava a conquista pioneira de terras pelo prisma da criação de indivíduos aptos a participar de uma economia de mercado: "ao nosso ver, o problema não reside apenas em facilitar a disseminação, sobre uma dada extensão territorial, de algumas centenas de brasileiros natos ou futuros brasileiros pequenos proprietários, mas agir de maneira a que esses colonos se transformem em elementos ativos da comunidade nacional e possam finalmente comprar e vender" (MONBEIG, 1940, pp. 124-125). Mais à frente, tomando o desenvolvimento econômico conseguido pela colonização pioneira como uma política estratégica de interesse dos governos, ele evidencia a conotação política tomada pela imigração num momento de guerra, diferenciando o translado internacional de pessoas ocorrido nos séculos anteriores dos movimentos modernos de povoamento e colonização, cujos objetivos devem pautar-se em inquéritos científicos:

Se se consideram as recentes publicações americanas ou os estudos efetuados pelo "Bureau" Internacional do Trabalho, de Genebra, o povoamento e a valorização das zonas novas, em nossa época, tornaram-se cada vez mais atribuições do Estado e não assuntos de especulações individuais. As severas regulamentações da imigração e da emigração, inspiradas quase sempre por motivos políticos, terminaram com a idade do ouro das grandes migrações transoceânicas do último século (...). É evidente que uma tal política, a qual, pense-se o que quiser, é um fato, não se coadunava com uma liberdade absoluta de colonização interior nem tão pouco com uma colonização que não se baseie em observações científicas. Dizemos observações científicas sim, isto é, conhecimento exato do meio físico e biológico onde os imigrantes devem aclimatar-se, uma noção perfeita dos costumes, da psicologia desses indivíduos, provenientes de todos os cantos do mundo, finalmente uma documentação econômica, a mais completa possível, afim de orientar as culturas agrícolas 
segundo as particularidades e necessidades dos mercados regionais e mundiais. Em suma, pondo-se de lado o que há de esquemático e deformante na fórmula, o que é preciso é povoar, não com um tipo heroico, bandeirante, mas com um tipo científico "pioneering modern style", como dizem os geógrafos norteamericanos. Nada, portanto de liberdade absoluta de colonização. (MONBEIG, 1940, pp. 125-126.)

Além disso, um outro ponto que aproxima o enquadramento de Monbeig ao de Bowman é o fato de Monbeig não falar nunca em "frente", mas em "franja" pioneira, e isso não apenas como modo de evitar a metáfora militar, algo perigoso nesses anos de tensão bélica e falha indesculpável para um legítimo representante da geografia francesa, que defendia a neutralidade da ciência, mas principalmente para não sugerir a existência de uma linha contínua e estática fruto de uma ação intencional dos pioneiros na apropriação de terras. Tratava-se, então, de precisar a singularidade da situação estabelecida na relação entre um grupo social em constante movimento e o seu confronto com novos espaços, uma vez que, ao transformar e reorganizar esses espaços, os grupos sociais estariam sofrendo, ao mesmo tempo, uma influência transformadora do meio, sendo pois imprescindível para o analista se deter no processo pelo qual os homens atuariam na formação do novo complexo geográfico, alterando-o decisivamente.

Expressivamente, Monbeig discute a terminologia a ser utilizada em seus trabalhos no início da segunda parte do livro segundo de sua tese. Ali, reconhece as vantagens da expressão clássica "frente de colonização" (front de colonisation), que acentua o caráter de luta do avanço pioneiro ante as dificuldades impostas por um meio natural no mais desconhecido dos imigrantes que formavam o grosso da massa populacional, apontando até mesmo a tentação de se ampliar as metáforas militares que levariam observadores mais apressados a realmente considerar, ao lado dos problemas de abastecimento, das agruras trazidas pelas derrubadas e da circunstância de o dinheiro ser o motor central da expansão, a existência de estratégias e estrategistas providos de informações cartográficas exatas para estabelecer as posições de seus “exércitos". As diferenças entre uma frente e uma franja pioneira, portanto, diriam respeito mais exatamente ao fato de o segundo termo poder revelar as inconstâncias do movimento, seus avanços e recuos, as contingências de toda a sorte a que a expansão do povoamento e exploração estava sujeita, atenuando um pouco a imagem de um avanço inquebrantável da civilização ante meios naturais desconhecidos habitados por bárbaros, embora acentuando a situação de confronto de uma sociedade confrontada com um espaço novo (THÉRY, 2007). Entretanto, a generalização do termo "frente pioneira" entre os estudiosos do assunto, mesmo os mais críticos, caso não venha 
acompanhada das limitações e imprecisões aqui descritas, não atrapalha de modo algum o entendimento da noção, sendo mesmo uma boa possibilidade de avançar no detalhamento da complexidade de situações sociais e naturais a que se refere o fenômeno que esta quer descrever e explicar:

O avanço do povoamento está longe de ter o aspecto de um front contínuo que se pudesse balizar cuidadosa e regularmente. Trata-se mais de incursões de grupos numerosos difíceis de localizar. É, portanto, melhor falar, como Isaiah Bowman, em "franja pioneira", expressão um tanto vaga, mas que convém melhor a esta região instável e incerta, onde manchas de floresta subsistem às vezes por muito tempo, envolvidas por culturas e pastagens, mesmo quando já bem mais distante o solo abriga os primeiros cultivos. É uma fronteira que progride irregularmente e em direções confusas. Cabe ao geógrafo assinalar as etapas desse avanço e procurar até onde são explicáveis pela influência dos elementos naturais ou, ao contrário, até que ponto correspondem a mecanismos econômicos. (MONBEIG, 1984 [1952], p. 165.)

L'initiative conquérante de l'homme est ici particulièrement spectaculaire. C'est devenu un thème classique que de parler de champ de bataille pour évoquer le spectacle de la forêt tropicale brûlée dont le subsistent que des troncs calcinés, que de parler de l'armée des défricheurs, qu'ils soient agriculteurs ou éleveurs, et d'un front pionnier pour designer cette sorte de frontière séparant les régions humanisées des contées qui vont l'être. L'inconvénient de cette terminologie est de suggérer de la part des pionniers une action concertée et dirigée, ce qui n'a pas le cas dans le passé et demeure encore l'exception. C'est aussi de faire croire à une rigueur qui n'existe pas dans les faits. Plutôt que de "front", il vaut mieux parler de "frange pionnière", car c'est rarement par une coupure brutale, mais plutôt par une progression plus ou mois rapide que l'on passe des espaces organisés à ceux qui le deviennent (...). Tout région pionnière est essentiellement marginale, incertaine et fugitive. Cela rend sans doute difficile sa cartographie exacte mais la valeur de son étude réside précisément dans la connaissance d'une société en mouvement. (MONBEIG, 1966, pp. 974/975.)

De mais a mais, nos trechos de Bowman e Demangeon supracitados, fica sugerido o que se poderia denominar de "duplo caráter" das zonas pioneiras, pois ao mesmo tempo em que ficamos sabendo que as zonas pioneiras guardam entre si um aspecto comum que permite que as identifiquemos em diferentes pontos do planeta, notam-se igualmente as singularidades regionais originadas da combinação única de certos fatores em um lugar específico. Ora, no primeiro capítulo de sua obra póstuma Princípios de Geografia Humana, Paul Vidal de La Blache diz ser o princípio da unidade terrestre (ou o da conexidade, nos termos sempre claros de Jean Brunhes) "a ideia que domina todo o progresso da Geografia", querendo com isso sublinhar o papel absolutamente fundamental que "a concepção da Terra como um todo, cujas partes estão coordenadas e no qual os fenômenos se encadeiam e obedecem às leis gerais de que derivam os 
casos particulares" (LA BLACHE, 1954, p. 30) cumpriu na formação da moderna tradição científico-discursiva identificada com esse campo do conhecimento.

Desdobrando o raciocínio de La Blache, de inegável cariz positivista - visto que busca estabelecer as "leis gerais" que presidiriam ao desenvolvimento das paisagens em todo mundo -, ter-se-ia como corolário o juízo que, considerando o organismo terrestre uma totalidade, afirma a impossibilidade de qualquer fração do globo ser estudada isoladamente, isto é, de ser observada, descrita e explicada por si mesma, sem referência a outras localidades em situação geográfica similar, donde teríamos que "o estudo de um fenômeno em certo ponto localizado comporta necessariamente a comparação com os mesmos aspectos do fenômeno em toda a superfície do globo" (MONBEIG, 1940, p. 12).

Como se pode já desconfiar a essa altura, a clássica divisão da geografia em dois ramos distintos, a "geografia geral" e a "geografia regional", deve em muito à postura positivista de trabalho esboçada a partir deste princípio, que serviria de embasamento para o ponto de vista especial do geógrafo, um especialista em considerar os conjuntos e que tenta fixar, a partir de diferentes escalas, conclusões válidas para todo o globo, o que vincula o arranjo singular de certos elementos naturais e humanos na origem e transformação das paisagens terrestres às "leis gerais" que presidiriam às relações de recíproca influência e íntima solidariedade entre seres e coisas, ou, em outras palavras, entre os grupos humanos e os meios que habitam:

Les contrastes ne manquent donc pas qui s'expliquent moins par les conditions propres aux milieux naturels que par les circonstances historiques et les traits inhérents aux différentes sociétés pionnières (...). D'un bout à l'autre de la planète l'ouverture des fronts pionniers a mis en branle des mouvements de population aussi surprenants par leur importance numérique que par l'ampleur des déplacements. Aux tropiques antillais ou brésiliens, l'élimination de la majorité des Indiens a entraîné l'immigration forcée des esclaves noirs qui, pour les cultures caféières du Brésil, furent relayés par le flot de l'immigration blanche (...). Les poussées pionnières modernes ne furent pas simplement une étape entre les autres de l'expansion de l'espace œkouménique mais elles ont marqué l'intégration de toutes les parties du monde dans un seul espace économique dont l'unité de direction appartenait à l'Europe. Où qu'elles fussent situées, les avances pionnières recevaient leur impulsion de l'Europe, et surtout de l'Europe occidentale. Les défricheurs, lorsqu'il n'étaient pas eux-mêmes des Européens or leur descendance immédiate, étaient dirigés, rétribués, commandés par eux. Grâce aux machines fournier par l'Europe ou qu'elle venait d'inventer, les productions des terres défrichées étaient aussitôt commercialisées pour les besoins de la consommation européenne et le moteur financier était d'origine européenne (...). Triomphe de l'Europe, plus encore triomphe de la race blanche, agrandissement mais unité du monde libre-échangiste, ce sont des 
évidences pour nous qui venons après et regardons avec plus de détachement que nos devanciers. (MONBEIG, 1966, pp. 978-979-980.)

O nítido enfoque eurocêntrico dessa passagem, que vê com naturalidade o aumento do desbravamento de novas terras e a eliminação dos indígenas que nelas habitavam pelos europeus, repõe a dominação colonialista em novos termos, pois considera que a expansão do ecúmeno, que fica implícita nos movimentos de população, encontrava-se mediada pela consolidação de um espaço econômico mundial unificado sob o comando e o incentivo dos capitais europeus. A definição de quais seriam as culturas praticadas e comercializadas, bem como o financiamento e o fornecimento de máquinas, deixava os desejos e necessidades da Europa e de seus mercados como o motor dos deslocamentos populacionais, que representam, ao fim e ao cabo, o "triunfo da raça branca e o engrandecimento da unidade do mundo livre cambista", diz o geógrafo francês num rompante de liberalismo ocidentalista alinhado aos Estados Unidos em plena ordem mundial da Guerra Fria.

Por outro lado, a crescente vontade de aproximação da geografia com as esferas decisórias governamentais, que Robic identifica já no início dos anos de 1930, sendo mui bem representada pela trajetória intelectual de Isaiah Bowman, foi uma posição igualmente encampada por Pierre Monbeig, que iria defender, no início da década de 1950, o aspecto utilitário da geografia em inúmeras passagens, como por exemplo no texto de sua aula inaugural no Conservatoire des Arts et Métiers, realizada em 1952 (THÉRY e DROULERS, 1991), ou então no artigo "Papel e valor do ensino da geografia e sua pesquisa”, originalmente publicado em 1954, no Boletim Carioca de Geografia, no qual ele afirma que:

Não compete aos geógrafos nem tão pouco aos demais técnicos, tomar a decisão final. Esta cabe à Política, e dou à palavra o seu sentido original: o que administra a cidade. À administração e ao poder púbico incumbe a decisão suprema, tal como é tomada pelo Diretor numa empresa particular. A colaboração dos cientistas é informativa, mas não é uma função de comando. A pesquisa geográfica leva à elaboração de inquéritos que constituem uma documentação; ela pode ir até apresentar sugestões, mas a Política, que tem horizonte mais vasto ainda, deve assumir sua própria responsabilidade e fazer a escolha. As competências e domínios de uns e outros avizinham-se, sem se confundir. Faz-se mister lembrar isso, pois bem conhecemos a forte tendência atual para dirigir a pesquisa científica tal como a grande tendência de se entregar aos técnicos regência da vida das nações A pesquisa geográfica deve ser livre, para ser frutífera. Qual seria o valor de um inquérito sobre as possibilidades de organização da Amazônia, se ele fosse realizado por agentes que tivessem recebido diretrizes políticas favoráveis a uma conclusão orientada? Todo organismo de pesquisa científica tem interesse em trabalhar dentro da independência científica tradicional nas universidades. Somente sob esta 
condição a pesquisa poderá ser útil à coletividade. Tal como o conhecimento geográfico é indispensável á formação do homem moderno, a pesquisa geográfica é indispensável a boa gestão de um grande empreendimento, a boa administração dum Estado moderno. E tal a multiplicidade dos problemas que surgem no quadro do meio atual, que a contribuição de cada técnico arrisca-se a cair numa especialização estreita, às vezes esterilizante. Pela largueza de seus pontos de vista, o geógrafo completa os técnicos. Os problemas que ele pode ajudar a resolver mais se evidenciam num país como o Brasil, onde ha tantas áreas para organizar, onde tantas possibilidades restam a explorar, onde tanto dinamismo se gasta em tantas direções contraditórias. (MONBEIG, 1957, pp. 24-25.)

Novamente, vemos afirmar-se a concepção básica de Monbeig acerca do trabalho científico do geógrafo, que deveria apenas informar, oferecendo indicações técnicas aos governantes, mas não tomando a decisão final, que caberia apenas à "Política", vista à feição das funções exercidas numa empresa particular pelo "Diretor". Essa visão neutra da ciência e da política, que nega o conflito praticamente incontornável quando se trata de relações sociais, separava completamente o trabalho do cientista, preso à esfera neutra da produção do conhecimento, dos círculos de poder nos quais os interesses pessoais e de classe punham-se como fatores-chave no direcionamento e implementação de políticas territoriais que visavam modificar a organização espacial das paisagens nas mais diferentes escalas de intervenção.

Entretanto, interessa-nos mais exatamente reter a assimilação, por parte de Monbeig, do tipo de explicação que ressalta a sobreposição de circunstâncias políticas e econômicas mundiais, regionais e locais num complexo e intrincado jogo de escalas. No caso, combinadas em proporções cambiantes, tais circunstâncias expressar-se-iam espacialmente em formas muito distintas de organização territorial, influenciando diretamente os movimentos de conquista e ocupação de terras. Vejamos alguns exemplos de como esse entendimento ajudaria na explicação da vaga pioneira em terras paulistas, iniciada no último quartel do século XIX e ainda ativa no momento em que Monbeig redigia essas linhas, em meados da década de 1940:

Por mais bem dotada que seja, por mais rica que se apresente, uma zona ainda inatingida pelo povoamento moderno é em si mesma desprovida de virtude capaz de desencadear o avanço do desbravador e de assegurar o seu próprio aproveitamento econômico. Ficariam elas adormecidas, como estiveram durante longos séculos de ocupação indígena, se o movimento colonizador não tivesse sido acionado por circunstâncias fortuitas. Assim, os planaltos ocidentais de São Paulo e os do norte do Paraná esperaram até o último quartel do século XIX para se tornarem zonas pioneiras (...). Essas causas não são apenas paulistas, nem somente brasileiras. A marcha ininterrupta da frente de povoamento não passa de um aspecto da exploração do planeta pelos brancos. Tanto em suas origens, como em sua continuidade, ela se prende, por sobre os oceanos, às condições 
técnicas, econômicas e políticas do mundo (MONBEIG, 1984 [1952], pp. 9394.)

É evidente que os elevados rendimentos obtidos nas plantações em terra roxa são um fator essencial para a compreensão dos grandes centros produtores que apareceram outrora em São Paulo e que se estão desenvolvendo atualmente no norte do Paraná e no sul do Mato Grosso. Entretanto, as condições físicas favoráveis não são as únicas que têm importância: assim como as jazidas de ferro de Minas Gerais ficaram inexploradas embora fossem perfeitamente conhecidas, aguardando circunstâncias econômicas e políticas mais favoráveis, também o melhor solo, no melhor clima, permanecerá coberto pela floresta virgem enquanto as circunstâncias não incitarem os homens a desbastá-lo e cultivá-lo. Ocorre a pergunta: quais as circunstâncias humanas que favorecem ou retardam a formação de uma cafeicultura em regiões onde ela ecologicamente possível? (MONBEIG, 1957, pp. 163-164.)

Já acentuamos a importância que as crises econômicas exerceram sobre os deslocamentos para oeste. Elas não correspondem a datas precisas, como um dia de batalha, mas a uma época em que se esboça a nova situação, e em seguida desenvolve-se e resolve-se. As crises de superprodução correspondem à invasão do mercado exportador por enormes quantidades do produto lançado pelas plantações recém-abertas. Abalando toda a vida econômica, a crise reduz as exigências de mão-de-obra, pois só as regiões verdadeiramente prósperas são capazes de atrair o imigrante. Se é verdade que, a qualquer momento, não importa que zona pioneira deve ser estudada sob o triplo aspecto da produção, da mão-de-obra e dos transportes, em tempo de crise esses problemas são singularmente mais graves. A crise também marca, como já vimos, uma desaceleração do avanço pioneiro e, ao mesmo tempo, traz os germes de nova fase (...). Procurando localizar, ao mesmo tempo, as culturas, os focos de atração de imigrantes e as vias de circulação em cada período de crise, ter-se-á uma imagem correta da franja pioneira em determinado momento. Essa imagem precisa ser comparada constantemente com o mapa dos solos e deve ser analisada levando em conta a evolução dos rendimentos agrícolas. Em um só golpe de vista será possível, então, apreender os pormenores do mecanismo que liga a crise econômica à marcha do povoamento. (Ibidem, p. 166.)

Como já tivemos oportunidade de comentar, manifesta-se nesses trechos uma concepção de geografia fortemente embasada na noção de "complexo geográfico", que visava ultrapassar a mera descrição da paisagem para incluir a explicação da realidade analisada (DANTAS, 2009). Além disso, o enquadramento de Monbeig no primeiro trecho, que revela sua interpretação do processo de conquista e apropriação do espaço do mundo pela "raça branca", acompanha o direcionamento já conferido por Demangeon em sua definição de colonização, uma vez que as zonas ainda despovoadas, por mais bem dotadas que fossem do ponto de vista dos recursos naturais, só deixariam para trás a letargia e o atraso próprios aos meios geográficos dominados pela natureza bruta e por povos primitivos após a implantação da ocupação produtiva do solo, que é a marca distintiva do povoamento moderno. Em outras palavras, até a chegada da 
"civilização" e seus vetores de modernização, os espaços dominados pelos indígenas encontrarse-iam num estágio inferior de desenvolvimento, ficando então as terras "adormecidas" até serem tocadas pela marcha ininterrupta da exploração do planeta pela civilização capitalista e industrial dos brancos e europeus.

As combinações dos diversos componentes paisagísticos dentro de um complexo geográfico indicam que a descrição explicativa da complexa inter-relação de fatores essenciais à compreensão de uma paisagem constitui-se para Monbeig em um explícito procedimento metodológico, uma vez que o complexo geográfico não diria exatamente respeito a uma extensão variável da superfície terrestre delimitada de antemão, isto é, a um substrato territorial de limites fixos dados pela natureza e identificados em campo pelo pesquisador, mas à prática de associação e combinação dos elementos paisagísticos considerados a partir do aspecto específico que o observador pretende ressaltar:

Pôr em evidência os complexos que têm caráter regional e analisar-lhe o funcionamento constitui a contribuição original da geografia às ciências humanas. Efetivamente, o geógrafo é capaz de relacionar os fatos sociais ao meio físico-biológico. A última etapa do estudo das divisões regionais é a da comparação entre as regiões humanas e as unidades naturais, comparação que, também ela, fará aparecer os problemas das concordâncias e discordâncias. $\mathrm{O}$ problema da divisão regional de São Paulo não se apresenta nos termos tradicionais. O substratum territorial não é o único ponto de partida de uma divisão regional. Seu valor reside na utilização que dele fazem os grupos humanos; ele é, para usar a fórmula do professor André Cholley, antes um resultado que um ponto de partida. As grandes unidades naturais, que começam a ser identificadas e em cujo interior há uma espantosa variedade de nuanças locais, tornam-se plenamente significativas só quando comparadas às regiões estabelecidas com os critérios humanos. Este comportamento científico contribuirá mais para o conhecimento das relações entre os homens e os meios naturais do que a aceitação a priori de uma concordância dos tipos de região. O princípio que orienta o geógrafo é, nessas condições, o que preside a todas as ciências: observar os fatos para depois interpretá-los. (MONBEIG, 1954, pp. 206-207. Grifo nosso.)

A questão da escala regional de análise dos fenômenos aparece de forma gritante nesse excerto, opondo as grandes unidades naturais identificadas a partir do estudo do embasamento geológico, das características do modelado do relevo, da definição dos tipos de clima e do aspecto geral da vegetação às regiões geográficas propriamente ditas, definidas sobretudo a partir do uso produtivo, leia-se econômico, dado ao meio natural pelos grupos humanos, que é o motor das modificações dos meios naturais em meios geográficos. Isso significa que dentro de uma mesma unidade natural, que pode apresentar mais ou menos nuanças locais, a apropriação do 
espaço pelos grupos humanos, mediado pelas técnicas de exploração do solo, tende a originar distintas regiões, que ganham forma e extensão apenas a partir da ação intencional desses mesmos grupos. Logo, se o objetivo do geógrafo é explicar a contento uma paisagem após sua observação e descrição minuciosa, ele deve ter a sensibilidade de indicar, dentre os múltiplos fatores em jogo, quais seriam os mais adequados para dar conta do problema específico que coloca a si mesmo, por exemplo, para a análise da formação de uma paisagem industrial, os fatores mobilizados não são os mesmos que se elegem para descrever e explicar a área de incidência de um tipo específico de clima ou de um domínio de vegetação. Disso, concluímos que o complexo geográfico:

se exprime antes de tudo na paisagem, a qual, formada una e indissoluvelmente pelos elementos naturais e pelos trabalhos dos homens, é a representação concreta do complexo geográfico. Por esta razão, o estudo da paisagem constitui a essência da pesquisa geográfica. Mas é absolutamente indispensável que o geógrafo não se limite à análise do cenário, à apreensão do concreto. A paisagem não exterioriza todos os elementos constituintes do complexo. Nem sempre nela se encontrarão expressos com clareza os modos de pensar, as estruturas financeiras que são, entretanto, parcelas apreciáveis do complexo geográfico. Outro perigo - a limitação do campo de estudo geográfico à paisagem ameaça levar o pesquisador ao recurso exclusivo da descrição. Este olha, observa minuciosamente e com perfeito espírito científico, mas tende a esquecer o essencial: a explicação. Satisfaz-se com ser excelente máquina fotográfica e, nesse jogo atraente, prende-se menos à análise dos processos do que à sua descrição. Passa ao lado dos problemas, pois, submerso pela massa dos fatos observados, já não pode distingui-los com clareza. A paisagem é um ponto de partida, mas não um fim. Resulta do complexo geográfico, sem confundir-se com ele. Espero ter explicado suficientemente até que ponto nossa geografia se preocupa mais com os laços que dão origem ao complexo geográfico, do que com os fatos isolados que o compõem. Fatos de origens diversas, umas físicas, outras biológicas ou históricas, econômicas ou psicológicas, associam-se em determinados setores do planeta. A associação deles é, às vezes, produto do meio regional, mas caracteriza uma região que pode ser cartografada e cuja extensão é a mesma do complexo geográfico. Estamos longe da simplicidade, de aparência enganadora, do pretenso fato geográfico isolado e conhecemos agora o que constitui o tema fundamental da pesquisa geográfica moderna. (MONBEIG, 1957, p. 11-12. Grifo nosso.)

Os trechos em destaque explicitam de uma só vez tanto a definição daquilo que Monbeig entendia como o objeto de estudo da geografia, quanto a distinção passível de se estabelecer entre as noções de paisagem, região e complexo geográfico. Produto da combinação singular de elementos físicos, biológicos e humanos, as paisagens humanas, o reino por excelência da observação, são resultantes da ação histórica das sociedades humanas sobre a natureza, organizando-se regionalmente em padrões complexos que cabe ao geógrafo observar, descrever, 
compreender e explicar. Por vezes, essas paisagens serão condicionadas pelo meio regional, ou seja, serão elas a expressão momentânea da força com que nelas atuam os elementos e fatores regionalmente considerados (clima, distribuição da população, vegetação, relevo, nível de desenvolvimento local das técnicas, etc.), noutras situações, porém, estarão as paisagens mais ligadas às condições do mundo, respondendo pois a lógicas e processos que são exteriores ao quadro regional. Utilizando um vocabulário geográfico mais atual, poder-se-ia dizer que, nesse segundo registro, as paisagens, o aspecto visível do complexo geográfico, podem ser influenciadas por fatores externos ao quadro regional, sendo hegemonizadas por processos e decisões que lhes são exógenos, porquanto prescindem de relações de contiguidade espacial. Em ambos os casos, o complexo geográfico, sempre dinâmico e em vias de organização, diz mais respeito aos laços de equilíbrio estabelecidos entre os fatores que lhe dão origem do que a apenas um dos fatores isolados que o compõem.

A crítica explícita de Monbeig, que acompanha nisso o posicionamento de Bowman e Demangeon, refere-se mais precisamente ao equívoco em considerar os quadros naturais - o substratum territorial - como ponto de partida único e suficiente para se proceder a uma divisão regional. Isso acarreta algumas implicações, pois para o geógrafo francês, a extensão de uma paisagem até poderia coincidir com um determinado aspecto do quadro físico e natural, porém, como a paisagem é vista como o reflexo do nível de desenvolvimento do grupo humano que lhe deu forma e extensão, quanto maior o desenvolvimento técnico do grupo humano, maior o controle que este exerce sobre a natureza e maior também o "nível de civilização" do grupo humano considerado. Por conseguinte, tem-se que as paisagens não são um produto direto das condições naturais locais ou regionais, mas um reflexo da história e da técnica. Nesse caso, um mosaico de regiões naturais distintas pode vir a ser base da formação de paisagens idênticas, e o mesmo tipo de habitat pode ocorrer em diferentes formações climáticas e rochosas:

os geógrafos confessaram "mea culpa": reconheceram que o sentido único do determinismo geográfico era infinitamente mais complexo do que haviam pensado. E o quadro da região natural pareceu muito estreito: por certo, muitas vezes a extensão de uma determinada paisagem corresponde com precisão à extensão de uma curva térmica ou pluviométrica, ou ainda para exatamente num contato geológico. Entretanto, o mais das vezes, a paisagem se superpõe a duas ou mais regiões naturais e convém fazer uma classificação dos tipos e subtipos de paisagem depois de compará-las à classificação que nos dão os morfologistas, os climatologistas e os botânicos. Trata-se, de todo modo, de uma paisagem cultural, substituída pelos homens à paisagem natural; o grupo humano apoderase sempre do meio, quer vindo a dominá-lo, quer preferindo adaptar-se a ele, o 
que constitui ainda uma maneira de vencê-lo. Mas, como a cultura de um grupo evolui, sua paisagem também evolui: o mesmo suporte natural viu sucederem-se paisagens diferentes, sendo cada uma um reflexo da civilização do grupo em dado momento de sua história. Assim, a paisagem não é mais considerada como produto da geologia e do clima, mas como o reflexo da técnica agrícola ou industrial, da estrutura econômica ou social, e mesmo, se se pensa no Partenon, nas catedrais e nos estádios modernos, da psicologia do grupo humano. Normalmente a geografia de Vidal de La Blache e de seus alunos encontrava prolongamento na história, reveladora das transformações da paisagem, mergulhando suas raízes mais profundas na pré-história tão rica de ensinamentos. (MONBEIG, 1940, pp. 237-238.)

$\mathrm{O}$ arranjo explicativo sugerido acima adquire ainda maior significação quando percebemos que, na análise que faz da expansão pioneira para o oeste de São Paulo e norte do Paraná, Pierre Monbeig estava a par da influência das crises mundiais do capitalismo no ritmo da apropriação de terras catalisada pela itinerância da economia cafeeira. Em seus escritos, o geógrafo não circunscrevia o entendimento da realidade paulista e brasileira apenas a fatores de ordem interna, relacionando as modificações das paisagens rurais com a urbanização, a industrialização, o crescimento da atividade bancária e a organização de novas formas de financiamento para a economia cafeeira, em uma palavra, apontando para a alteração da divisão social e territorial do trabalho, objetivada em um novo arranjo geográfico projetado para dar suporte às modernas atividades econômicas que se instalavam no Brasil:

As velhas práticas do crédito, baseadas em relações diretas e afetivas, eram assim substituídas por uma organização sem dúvida mais eficaz, mas que acentuava a penetração dos interesses estrangeiros cujos lucros escapavam à economia nacional (...). Assim, ao bafejo da crise, assentara-se solidamente a finança estrangeira na economia cafeeira do Brasil. Não se limitou ela às funções comerciais pura e simplesmente. Forneceu fundos aos fazendeiros em dificuldades e se tornou finalmente proprietária de terras (...). Nessas condições, a crise do início do século XX, oriunda da superprodução das fazendas novas, vinha pejada de consequências para toda economia brasileira (...). O movimento pioneiro paulista era cada vez mais um negócio mundial (MONBEIG, 1984 [1952], pp. 111-112.)

A Segunda Guerra Mundial nada acarretou que pudesse frear a marcha dos pioneiros. Ao contrário, favoreceu ela a industrialização de São Paulo. Cresceu consideravelmente a população urbana. Para nutri-la, eram necessários arroz, café, trigo, feijão, batatas, culturas fáceis para o desbravador, que deles retirava lucro imediato. Alemanha e Japão tinham desparecido de cena, substituídos pelos Estados Unidos. Este país comprava tudo e sua propaganda exercia-se por toda a parte, incitando os pioneiros a tentar culturas variadas: o rícino a menta, o tungue; e demandava ainda algodão e gado (Ibidem, pp. 117-118).

Nascido no momento em que se instalava a economia capitalista, o movimento de conquista dos planaltos ocidentais não cessou, pois, de progredir, a despeito das crises inerentes ao sistema e até mesmo por causa dessas crises. As 
depressões econômicas, que balizam esses três quartos de século, procederam das zonas pioneiras. Mas cada uma delas suscitou oportunidades novas que, a cada vez, reajustaram o mecanismo. Assim, se confunde o dinamismo da frente de povoamento paulista com o da economia mundial. Num velho país rural, os abalos da economia raramente acarretam um abandono brutal das culturas do solo; está o camponês por demais ancorado, para que a borrasca o arraste; participa ele de uma economia regional ou nacional, que amortece o choque dos acontecimentos internacionais. Nas zonas novas, não existem amortecedores, pois a produção se limita a alguns produtos destinados à exportação e diretamente submetidos às vicissitudes do mercado mundial. A franja pioneira é o ponto de encontro dos apetites e ambições tanto nacionais como estrangeiros. $\mathrm{O}$ que a expõe a ser duramente atingida pelas crises, mas ao mesmo tempo the permite recuperar muito depressa sua vitalidade (Ibidem, pp. 118-119.)

Nos recortes compilados, Monbeig comenta o jogo dos fatores econômicos na estruturação do complexo geográfico decorrente do fenômeno pioneiro paulista, mostrando as influências das diversas crises mundiais vividas pelo capitalismo na velocidade da expansão do povoamento e da colonização ocorridos em terras brasileiras. Essas crises, observadas ora em escala global, com destaque para o crack da economia norte-americana em 1929 e para as duas conflagrações mundiais, ora em escala localizada, como fruto das mudanças políticas internas e das oscilações da própria produção cafeeira, umbilicalmente dependente dos humores dos mercados externos, mostra também uma mudança no eixo do comércio exterior do Brasil, que ao longo do século XX se vai afastando dos mercados europeus para atrelar-se definitivamente na esfera de influência dos Estados Unidos.

Chega-se pois à conclusão de que o avanço pioneiro não foi detido pela derrocada da economia mundial, ao contrário, a organização de novas fazendas, a construção de ferrovias e a fundação de cidades, com o aumento da população urbana e a aparição de um incipiente parque industrial, continuou aceleradamente nas quatro primeiras décadas do século XX, muito embora as crises tenham modificado permanentemente a estrutura da sociedade paulista. Isto se deu pois o abandono das áreas de exploração mais antigas, que com os solos esgotados ficavam na retaguarda dos avanços pioneiros, eventualmente valorizando as reservas de matas deixadas desocupadas pelos proprietários em meio às áreas de derrubada, incentivava a venda de terras e a especulação imobiliária, o que influiu no fim das fazendas de tipo tradicional e contribuiu para o aumento numérico da pequena propriedade:

A frente pioneira se constitui e evolui, assim, na articulação de tempos locais e de tempos do comércio internacional - articulação entre as escalas deste fato. Numa linguagem mais científica, poderíamos dizer que a colonização de terras e a expansão do café constituem um sistema aberto, em transformação contínua, 
sustentada ao mesmo tempo por suas próprias características, de origem endógena (conquista do solo, povoamento e deslocamento de populações, atração exercida pelos lucros obtidos da fertilidade de novas terras), e pelos mercados, de dimensão mundial, fator exógeno. O sistema, assim, jamais chega a um estado de equilíbrio (...). A crise - suas razões e as mudanças que se anunciam ou que desencadeiam rupturas nas estruturas econômicas e políticas alimenta a literatura, o arquivo, as contagens. Por um aparente paradoxo, o quadro geográfico se constrói, para cada período, sobre a radiografia de cada um desses grandes acidentes econômicos, radiografia, aliás discutível, mais ou menos vaga, na realidade inspirada nos interesses, nas ideologias, nas empresas envolvidas - mas também no Estado federal ou nos estados federados. (RONCAYOLO, 2006, pp. 120-121-122.)

Nessa passagem de um tipo a outro de paisagem pioneira, resultado das alterações conjunturais pelas quais passava a economia e a sociedade brasileiras no período, a expansividade intrínseca ao funcionamento do capitalismo, seu apetite territorial, resultaria em uma "homogeneização diferenciadora" dos lugares (MORAES, 2011), vale dizer, em uma espacialidade desigual que é fruto exatamente dessa tensão entre as contraditórias tendências à concentração e à expansão geográficas, manifestação do capitalismo na diferenciação dos lugares (HARVEY, 2005). Além disso, deve-se ter em conta a complexificação das operações financeiras executadas pelos bancos e casas de crédito nacionais e estrangeiras, que passam a custear as atividades agropecuárias desenvolvidas nas frentes pioneiras, cada vez mais afastadas das antigas relações pessoais e afetivas que permeavam o relacionamento entre fazendeiros e colonos nas fazendas do final do XIX, bem como o papel absolutamente imprescindível que, na expansão pioneira paulista, foi desempenhado pelos loteadores e açambarcadores de terras, que investiam no retalhamento de áreas florestais e fazendas arruinadas incentivados pela valorização crescente das terras.

Utilizando-se muitas vezes de documentos forjados (os "grilos"), esses tipos sociais transformavam as áreas de movimentações fronteiriças em um palco onde a especulação imobiliária e a venda de terras era dos negócios mais lucrativos e procurados, ainda que executado em prejuízo dos direitos de propriedade da população de posseiros e pequenos agricultores que não possuíam títulos legais ou não conseguiam comprovar a posse da terra. Ademais, a atuação de empresas colonizadoras particulares na abertura de novos loteamentos e núcleos colonizadores, normalmente apresentando forte aporte de capital estrangeiro (principalmente de origem inglesa) e interessadas apenas nos ganhos especulativos que poderiam obter, apontam para a diversificação da atuação do capital no processo de apropriação de terras nas zonas pioneiras, que passa a submeter o processo de produção do espaço, culminando na 
construção de paisagens geográficas eivadas de contradições, arranjos espaciais em perpétuo movimento que, como tendência, estão sempre dispostas a romper o equilíbrio momentaneamente conquistado.

Isso quer dizer que os arranjos e acordos estabelecidos socialmente em uma dada época, que resultam em uma organização espacial específica passível de ser observada nas diversas formas construídas nesse momento localizado, tendem a se modificar em uma situação posterior, o que demanda então outras soluções para a fluidez do capital no território, com a organização de novas formas espaciais e consequentes alterações na configuração territorial do espaço considerado. Por exemplo, a paisagem típica das antigas fazendas do café do final do XIX, reflexo de uma dada estrutura econômica, política e social vivida por São Paulo e pelo país, altera-se progressivamente ao longo do século XX, principalmente após a crise de 1929, dando origem às paisagens pioneiras descritas por Monbeig na década de 1940. Esse mecanismo que atrela a produção das paisagens humanas às atividades engendradas socialmente numa dada época e lugar foi identificado pelo francês inúmeras vezes para o caso paulista, conferindo um feixe de particularizações históricas e territoriais ao enunciado que enxerga a expansão geográfica do capital e a reorganização espacial dos lugares como opções estruturalmente válidas para resolver momentaneamente a tendência capitalista à formação de crises de desvalorização ou excedente (HARVEY, 2006) ${ }^{118}$.

\section{0 pioneirismo segundo Pierre Monbeig}

Postas as linhas gerais do posicionamento do autor frente ao fenômeno do pioneirismo, iremos aprofundar agora os comentários sobre seus textos que tratam das frentes pioneiras, devendo-se recordar, primeiramente, que os livros que publicou sobre a realidade brasileira abarcam, grosso modo, os mais representativos artigos escritos durante sua longa estadia em

\footnotetext{
118 “A capacidade tanto do capital como da força de trabalho de se moverem, rapidamente e a baixo custo, de lugar para lugar, depende da criação de infraestruturas físicas e sociais fixas, seguras e, em grande medida inalteráveis. A capacidade de dominar o espaço implica na produção de espaço (...) O desenvolvimento capitalista deve buscar uma solução de continuidade entre a preservação dos valores dos compromissos passados (assumidos em um espaço e tempo específicos) ou a sua desvalorização, para abrir espaço novo para a acumulação. Continuamente, portanto, o capitalismo se esforça para criar uma paisagem social e física da sua própria imagem, e requisito para suas próprias necessidades em um instante específico do tempo, apenas para solapar, despedaçar e inclusive destruir essa paisagem no instante posterior do tempo. As contradições internas do capitalismo se expressam mediante a formação e a reformação incessantes das paisagens geográficas. Essa é a música pela qual a geografia histórica do capitalismo deve dançar sem cessar." (HARVEY, 2005, pp. 149-150.)
} 
nosso país (1935-1946). Isso facilitou a realização da leitura tal qual a projetamos, uma vez que os livros fornecem uma periodização que, por evidente, é bem ou mal aceita. Além do mais, essa divisão cronológica das leituras, conquanto limite o material avaliado, serve também como um guia, uma vez que cada texto fica assim mais preso ao contexto da época em que foi redigido, o que nos ajuda a levar em consideração o processo de amadurecimento do autor em relação a certos temas, bem como sua proximidade com influências que, àquele momento específico, se faziam mais presentes em sua obra.

A primeira obra de Monbeig editada no Brasil, intitulada Ensaios de Geografia Humana Brasileira, foi publicada em 1940, e congrega o conjunto dos primeiros artigos escritos pelo autor ao chegar ao país. Constituído no mais de traduções de artigos elaborados originalmente para serem publicados em periódicos franceses de renome, como o Bulletin de l'Association de Géographes Français (BAGF), o Annales de Géographie (AG), ou a revista Annales d'Histoire Économique et Sociale (AHES), esse livro permite que acompanhemos a primeira fase dos estudos de Pierre Monbeig, quando o jovem professor apenas se iniciava no estudo da realidade brasileira, sublinhando a sensação de estranhamento de um jovem europeu diante da monumentalidade da natureza tropical e da grandeza continental que os fenômenos adquiriam quando comparados com aqueles antes observados na Europa.

Em conjunto, os textos reunidos nos Ensaios permitem que observemos a maneira pela qual o recém-chegado professor aborda a realidade que irá estudar. Problemáticas então em voga na geografia, como os movimentos migratórios vinculados ao superpovoamento e a questão do surgimento do pioneirismo à escala do mundo, que relacionam a mobilidade de um excedente demográfico com a conquista e a valorização de terras consideradas "vazias", são exemplarmente observadas em território paulista. Na verdade, Monbeig surpreende tais fenômenos no exato momento em que eles se desenvolvem, tomando a realidade paulista como "laboratório", elegendo-a como seu terrain: "Talvez tenham os meus leitores, aqui nascidos e aqui vivendo, menos consciência que um estrangeiro, cuja profissão é justamente pesquisar os fenômenos das relações entre as sociedades humanas e o meio natural, do que representa meio século dessa conquista do solo paulista: estudo que desde logo provoca forçosamente admiração" (MONBEIG, 1940, p. 113).

O segundo livro que trata mais detidamente do fenômeno do pioneirismo é sua tese de doutoramento, redigida ao longo da década de 1940 e originalmente apresentada, em 1950, na 
Universidade de Paris, sob o título Marche de peuplement et pionniers de São Paulo. Publicada em livro no ano de 1952, pela Fondation Nationale de Sciences Politiques, que lhe havia conferido o prêmio de melhor tese, com o título Pionniers et Planteurs de São Paulo, ela foi traduzida para o português por dois de seus ex-alunos, Ary França e Raul de Andrada e Silva, somente em 1984, demora que não deixa de ser intrigante, haja vista a penetração e influência do autor na geografia brasileira. De todo modo, a obra Pioneiros e Plantadores é um registro fiel da maturação do trabalho de pesquisa didático e científico desenvolvido pelo professor durante sua estadia em São Paulo. Em verdade, este livro tem até mesmo uma faceta de trabalho coletivo, uma vez que a presença de estudantes e outros professores que gravitavam próximos à cadeira de Geografia Humana da USP era constante nas viagens de campo empreendidas.

No prefácio da tese, Monbeig homenageia de início Albert Demangeon e Henri Hauser, professor de História Econômica na Sorbonne e amigo da família que lhe sugeriu o tema das movimentações pioneiras paulistas. Além desses nomes, ele faz referência, ao final desse mesmo prefácio, aos companheiros de viagens Nice Lecocq Müller, Maria Conceição Vicente de Carvalho, João Dias da Silveira e Ary França, seus antigos alunos, bem como aos colegas Aroldo de Azevedo, Félix Rawitscher e José Setzer. Sobre a participação direta dos alunos da FFCL/USP na feitura dos trabalhos de campo, Ary França confirmou, em uma de suas últimas entrevistas, que durante sua época de assistente de ensino, ele havia participado diretamente na coleta de dados para a tese de seu antigo professor:

$\mathrm{Eu}$, neste momento [c.1939], era o terceiro assistente, o segundo assistente era o Renato da Silveira Mendes. Passei a segundo assistente e logo em seguida a primeiro assistente. O Renato ficou para trás, não gostou muito, mesmo porque ele era bem mais velho do que eu (...). Eu passei à frente dele justamente porque estava fazendo carreira, fazendo trabalhos e dando assistência ao Monbeig. Passei a ser o companheiro do Monbeig de excursões, de trabalhos. Na tese do Monbeig, eu fui o colaborador principal. Ele foi embora depois da guerra. Foi uma das primeiras viagens depois da guerra. Seis meses depois de terminar a guerra nós viajamos juntos, mas o Monbeig ficou na França durante algum tempo (...). Ele se inscreveu no doutoramento e ficou aproximadamente dois anos - ou até mais - acabando a tese. $\mathrm{O}$ que ele levou daqui foi considerado insuficiente (...). Quando cheguei aqui no Brasil, trouxe várias incumbências dele com relação à tese. Eu tive que fazer pesquisas, recolher dados gerais - eu tinha uma longa lista de problemas que ele deu. Durante um ano ou dois mandei dados para o Monbeig completar sua tese. (FRANÇA, 2004, pp. 48-49.)

Nessa obra, a expansão do povoamento catalisada pelo avanço do café e do algodão nas zonas pioneiras dos planaltos ocidentais paulistas e do norte paranaense - estes vistos como mera continuação do movimento animado por aquelas - recebe um tratamento detalhado que descreve 
as fases da vaga pioneira em sua infatigável marcha a partir de dois prismas: as cidades, que se sucedem ao longo das vias férreas como "contas de um rosário", testemunhando os ritmos diversos de um avanço progressivo que as circunstâncias políticas e econômicas mundiais concorrem para acelerar ou retardar, mas não impedir; e as paisagens, que em sua fisionomia e dinâmica expressavam, tal como elas então se apresentavam, as marcas e as lembranças de conjunturas históricas que não desaparecem de todo com a progressão do povoamento e o seu arraigamento.

Por fim, o livro Novos Estudos de Geografia Humana Brasileira, publicado em 1957, é em muitos aspectos parecido com aquele publicado em 1940, congregando textos esparsos já saídos no Brasil e incluindo traduções de artigos publicados originalmente em periódicos estrangeiros. De maneira um pouco distinta da coletânea anterior, contudo, este guarda o mérito de reunir em um só volume textos de uma fase intelectualmente mais madura do autor, que, de volta à França, procede, em textos como "As estruturas agrárias da faixa pioneira paulista", "As tendências atuais da agricultura em São Paulo" e "Evolução dos gêneros de vida rural tradicionais no sudoeste do Brasil", a uma sorte de reavaliação de seus estudos precedentes sobre o pioneirismo, indicando novos ângulos de observação do fenômeno ou mesmo alterando sem pestanejar juízos e posições defendidos anteriormente.

Exemplificando a filiação metodológica de Monbeig aos cânones da geografia regional francesa, os textos a respeito do pioneirismo saídos nos Ensaios e nos Novos Estudos seguem no geral um padrão de exposição que não se distancia sobremaneira dos modelos fornecidos pelas teses de Raoul Blanchard (1906) sobre Flandres, ou, e principalmente, do trabalho de Albert Demangeon (1905) sobre a Picardia, tido, numa visão retrospectiva, como um dos trabalhos mais influentes nos anos subsequentes, pois estabeleceu um modelo de apresentação dos assuntos no qual o tratamento do objeto é dividido em duas partes distintas: uma preocupada com os aspectos físicos, com destaque para os solos, relevo, rede hidrográfica e vegetação, e outra parte dedicada aos aspectos humanos, embora esta possa ser subdividida em duas grandes áreas de interesse, uma mais ligada à economia regional, que trata da agricultura, das indústrias e das vias de comunicação que servem o comércio regional, e outra mais afeita ao histórico de ocupação, que se detém nas etapas do povoamento, no surgimento das cidades, na repartição da população, na descrição dos habitat e nas divisões territoriais das propriedades rurais (WOLF, 2005). 
A preocupação de Monbeig com uma série de temas considerados de tratamento incontornável em qualquer inquérito de campo digno desse nome, como a colonização, as vias de comunicação, o povoamento, as migrações, os tipos de habitação, o habitat e as transmutações das paisagens urbanas e rurais, isso para não falar dos aspectos naturais mais ligados à geografia física, que serviam de base para o entendimento dos aspectos humanos, sendo descritos conjuntamente com os fenômenos sociais - já que se trata de uma geografia física voltada para a exploração humana, pois a valorização positiva ou não de uma dada condição natural seria feita sempre a partir das possibilidades de seu aproveitamento pelos grupos humanos -, segue em geral as indicações pedagógicas de Albert Demangeon, que havia escrito um questionário-guia na época em que estava à testa das famosas excursões interuniversitárias que perscrutaram o território da França ao longo da década de 1910 e 1920.

Pensado inicialmente como instrumento didático para a padronização dos relatos dos informantes locais em suas próprias viagens de campo, esse questionário, publicado originalmente nos Annales de Geographie, em 1909, inspirou inúmeras monografias regionais, sendo inclusive adaptado para orientar o olhar de pesquisadores iniciantes no campo e largamente utilizado nas recém-mencionadas excursões interuniversitárias, que alçaram o trabalho de campo à condição de atividade sine qua non para o produção do conhecimento geográfico em França (WOLF, 2005). Vale dizer, afinal, que também para Monbeig a preocupação pedagógica com a normalização dos procedimentos de pesquisa e dos inquéritos de campo era absolutamente fundamental, sobretudo no Brasil, país que no início do século XX contava com uma escassa documentação cartográfica e estatística para servir de base para estudos sobre o território $(\text { SALGUEIRO, 2006) })^{119}$.

Feito isso, vejamos mais detidamente dois textos, quais sejam, "A zona pioneira do Norte Paraná", escrito em 1935, e “As zonas pioneiras do Estado de São Paulo”, publicado originalmente em 1937. Explicitadas as influências básicas de Monbeig, não é de estranhar que os capítulos dos Ensaios que tratam do fenômeno do pioneirismo sigam basicamente o mesmo

\footnotetext{
${ }^{119}$ Não seria desperdício comentar que o próprio Monbeig publicou aqui no Brasil, em 1945, dois textos de destacado valor pedagógico que saíram no apêndice intitulado "A Excursão Geográfica - Guia do Professor", primeira publicação da Biblioteca Geográfica Brasileira, do Conselho Nacional de Geografia (CNG). Seus artigos, "Guia para o estudo monográfico de uma fazenda" e "Questionário para estudo de uma cidade", completavam o texto principal, "A excursão Geográfica", redigido por Carlos Delgado de Carvalho alguns anos antes, em 1941, para a Revista Brasileira de Geografia (MENEZES, 2011). Seguindo o mesmo caminho didático-pedagógico postos nestes manuais, Aroldo de Azevedo havia já redigido, em 1943, o opúsculo Monografias Regionais, também voltado para auxiliar alunos iniciantes nos trabalhos de pesquisa de campo.
} 
caminho já trilhado por Demangeon: primeiramente, alguns parágrafos apresentando o assunto de que irá tratar, bem como algumas referências a autores que já produziram estudos na temática geral a ser desenvolvida, tratando de problemas similares na mesma região-objeto ou em outras áreas. Depois, como não poderia deixar de ser, passa-se a uma localização geral da região, ao que se segue uma rápida caracterização de seu quadro físico, com especial atenção à estrutura geológica, aos solos, à rede hidrográfica, ao modelado do relevo e à vegetação: nesse momento, normalmente é apresentada a documentação geográfica e os dados estatísticos porventura existentes.

Terminada essa introdução-padrão, a exposição segue normalmente na busca de uma recomposição histórica da região, tentando localizá-la dentro do quadro mais amplo da qual ela faz parte, em outras palavras, após descrever o sítio, tenta compreender a situação da região analisada, compondo um quadro que abrange uma escala um pouco mais ampla. Posteriormente, o autor passa a descrever a localização das estradas de ferro e de rodagem, assim como a relação destas com a origem das aglomerações humanas, que nos planaltos ocidentais paulistas normalmente alongam-se acompanhando os espigões e divisores d'água "à moda das vias romanas da Gália" (MONBEIG, 1940, p. 24), como diz a certa altura, num rompante de observador europeu desconcertado tentando se apegar a uma referência sua conhecida. $\mathrm{O}$ próximo passo, invariavelmente, é a descrição histórica de como vieram a se formar as propriedades rurais e os patrimônio urbanos, ou seja, para o caso da zona pioneira centrada em São Paulo, importa a questão do desbravamento das áreas florestais, vale dizer, da derrubada da mata e da formação das fazendas, uma vez que "Através de toda a zona pioneira, a colonização encontra sua origem na especulação da venda de terras, especulação que toma formas diversas e, por isso mesmo, imprime variantes sensíveis a esta colonização" (MONBEIG, 1940, p. 25).

Embora não toque diretamente no tema da concentração de terras, visto que ele não discute a questão da formação da propriedade privada nas zonas pioneiras, Monbeig reconhece em diversas passagens a ação de especuladores e grileiros no açambarcamento de terras que deu origem aos grandes domínios agrários observados por ele no inicio do século XX. Sendo assim, de forma indireta, a questão da terra assume em seus escritos um registro intimamente imbricado com a questão da mão-de-obra e com os projetos oficiais de colonização, articulando a expansão do povoamento à questão da fixação do trabalhador na terra. Todavia, ao apreciar as tentativas de se elaborar planos de colonização pelo governo federal e estadual, o geógrafo diferencia o caso 
brasileiro do canadense ou americano, dizendo que os planos de colonização elaborados por órgão oficiais esbarrava no fato de que, no Brasil, não haveria terras disponíveis para implantar os projetos:

Convém sublinhar que a colonização oficial no Brasil tornou-se particularmente difícil, porque toda a terra pertencia a um proprietário particular. Os domínios da União ou dos estados eram muito limitados e as terras devolutas eram sempre as mais afastadas, de acesso difícil e condenadas por muito tempo ao isolamento. Para organizar focos de colonização, com pequenas propriedades, escolas, oficinas, direção agronômica, rodovias e ferrovias, via-se o governo na continência de comprar as terras ou contratar uma empresa privada. A situação jurídica das terras, nesse país provindo da colonização régia portuguesa, foi assim grande obstáculo à execução de um plano de colonização efetiva, cuja concepção não era estranha aos espíritos lúcidos. (MONBEIG, 1984, [1952], p. 160.)

No estado de São Paulo todas as terras são de propriedade particular, tanto as de florestas como as de campos. Isso se deve à legislação fundiária, ao povoamento da fase inicial e à perseverança dos grileiros. A noção de terra pertencente ao estado é tão estranha à mentalidade paulista, que foi impossível manter uma reserva florestal na serra do Diabo. No Paraná a situação é diferente e o governo do estado possui ainda grandes extensões florestais. Se, às vezes, ele mesmo criou centros de colonização, no norte do estado preferiu vender glebas a empresas de grande porte. Dessa forma, para onde quer que se dirija, o avanço paulista encontra sempre propriedades privadas. $\mathrm{O}$ pioneiro não pode, portanto, como nos países de free land, instalar-se ao seu bel-prazer e criar amplos patrimônios, limitados apenas pelas suas possibilidades de trabalho, sem despesa e sem o risco de ser barrado pela propriedade de um vizinho. Aqui, ele deve instalar-se em um quadro preestabelecido, com limites traçados pelo proprietário da terra que ele comprou. (Ibidem, p. 211.)

Para Monbeig, a questão da colonização, ao invés de se pautar pela questão da formação de núcleos fixos de colonização voltados para a manutenção dos pequenos produtores em sua própria terra, esteve sempre vinculada aos interesses imediatos dos quadros dirigentes (banqueiros, fazendeiros e vendedores de terras), sendo tratada, desde o final do XIX, como uma questão a ser resolvida a partir das necessidades de mão-de-obra dos grandes fazendeiros. Estabelecendo um claro diálogo com a posição expressa por Caio Prado Júnior (1953), que em duas conferências, pronunciadas em 1946, havia tratado das políticas de povoamento e da formação da pequena propriedade rural exatamente a partir da instabilidade do homem rural brasileiro e das exigências de braços para as lavouras nas grandes propriedades exportadoras, vinculando o surgimento dos pequenos domínios ao sucesso ou fracasso econômico das grandes explorações, Monbeig diferencia a mera exploração agrícola das terras, feita de maneira extensiva, sem preocupações com a preservação dos recursos naturais e com grandes prejuízos 
para o povoamento do país, da verdadeira colonização, que diria respeito à formação de uma classe de pequenos ou médios proprietários sedentarizados à feição dos camponeses europeus ${ }^{120}$. Assim, só haveria uma colonização digna desse nome com a fixação do trabalhador rural à terra, caso contrário, o que haveria seria apenas uma conquista de terras tributária da mera especulação, fato cada vez mais generalizado com a valorização que conferia aos especuladores lucros inversamente proporcionais à disponibilidade de terras, pois se o espaço rareia e aumenta a procura por solos naturalmente férteis, os preços disparam e a venda de terras torna-se um negócio cada vez mais procurado: "Já tivemos ocasião de ver como outrora florestas foram vendidas e depois revendidas, antes de serem abatidas, os vendedores auferindo lucros substanciais (...). Nos últimos 15 anos, a especulação generalizou-se, a terra virgem produz lucros antes de produzir colheitas e os preços não cessam de aumentar" (MONBEIG, 1984 [1952], p. 212).

É exatamente no que diz respeito à colonização e efetivo povoamento de novas áreas que encontramos uma diferenciação que irá acompanhar boa parte dos desdobramentos posteriores dos textos de Pierre Monbeig dedicados ao pioneirismo, a saber, aquela que dá relevo ao contraste entre os métodos de colonização praticados no norte do Paraná pela inglesa Companhia de Terras, de cariz indiscutivelmente capitalista e moderno, que trabalha com previdência e planos pré-traçados, procurando sistematizar cientificamente aquilo que antes era feito de modo empírico, e os métodos empregados em São Paulo, que o geógrafo alcunha de "velho sistema paulista", iniciado na maior parte das vezes com a posse de grandes extensões de terras por um indivíduo ou pequeno grupo familial que só irá "abrir fazendas", desfazendo-se de suas matas

\footnotetext{
${ }^{120}$ Os textos a que se faz referência são "Problemas de povoamento e a divisão da propriedade rural" e "A imigração brasileira no passado e no futuro", publicados por Caio Prado Jr. (1953) em seu livro A evolução política do Brasil e outros estudos. Nesses artigos, o historiador paulista estabelece um rico diálogo com Monbeig, formulando uma crítica à política oficial de colonização do governo federal e argumentando favoravelmente ao estabelecimento das pequenas propriedades rurais, uma vez que os pequenos sitiantes proprietários eram considerados por ele como elementos demograficamente mais estáveis do que os demais trabalhadores rurais. Sem se aprofundar na questão, basta dizer que, na época, marcada pela redemocratização do governo Dutra, a questão agrária e a discussão acerca do papel da agricultura no futuro do país ganhou forte relevo e os debates acerca da estrutura fundiária, apontando-se as vantagens da pequena propriedade ante o latifúndio, tornou-se uma opinião comum tanto para intelectuais de esquerda quanto para certos políticos e intelectuais bem ou mal alinhados com as políticas territoriais do Estado Novo que tiveram continuidade no governo Dutra. Para uma discussão aprofundada do assunto, que contextualiza as discussões ocorridas ao longo da década de 1940 a partir das modificações ocorridas no fazer geográfico de Orlando Valverde, vide Adas (2006).
} 
intocadas e retalhando-as, quando o proprietário vir a "civilização" se aproximar, ou melhor, quando as áreas de derrubadas chegarem a uma distância de 200 ou $300 \mathrm{~km}$ de seu domínio ${ }^{121}$.

Tendo em vista o que já foi discutido em capítulos anteriores, poderíamos ver nessa diferenciação entre um tipo "moderno" de colonização e o modelo do grande fazendeiro paulista, herdeiro direto do antigo período colonial, uma discussão acerca das vias de desenvolvimento do capitalismo (MORAES, 2011), pois a interpretação de Monbeig sugere que o passado colonial, ao criar estruturas econômicas, políticas e sociais expressas na organização espacial das paisagens das grandes fazendas monoculturas, mantiveram-se ativas mesmo em uma situação posterior, sendo, então, a realidade a ser superada pelas mudanças ocorridas com a expansão das relações capitalistas. Os resquícios desse passado colonial, que continuava a influenciar as direções tomadas pelas correntes de povoamento pioneiras, seriam visíveis nas plantações de café abandonadas e nas grandes extensões de solos desgastados, aspectos decadentes da paisagem observados por toda a parte e que deram origem a uma expressão largamente utilizada para qualificar o abandono, as "capoeiras", que se referiam exatamente às paisagens humanizadas de outrora que se encontravam em vias de serem retomadas pela natureza. E mesmo nos modos de pensar dos fazendeiros, que tinham dificuldade em encarar a imigração fora da perspectiva de suas necessidades básicas de mão-de-obra, pode-se perceber a força com que o passado colonial se fazia presente nos novos arranjos que iam surgindo, compondo uma nova estrutura econômica e social $^{122}$.

121 “A zona pioneira é essencialmente o domínio da pequena propriedade e da valorização direta, o que já não constitui exceção no estado de São Paulo, mas que revela, no entanto, uma verdadeira revolução agrária que se faz sem barulho. Andar-se-ia, contudo, longe da verdade, julgando-se que não existe a grande fazenda clássica na zona pioneira (...). Apesar de tudo a característica da zona pioneira atual é, indiscutivelmente, a pequena propriedade, enquanto que na zona pioneira de 1880 ou 1912 a grande fazenda parecia a única forma de exploração possível." (MONBEIG, 1940, pp. 28-29.)

122 "O declínio do café e da grande plantação são, portanto, incontestáveis e não são os fazendeiros das velhas zonas os únicos a se queixarem. Na imprensa de São Paulo faz-se eco quase diariamente das lamentações dos fazendeiros, através de reportagens, entrevistas, estatísticas e também de estudos seriamente documentados. $\mathrm{O}$ brado 'braços para a lavoura' ressoa, como no momento da Abolição. Queixas sobre os salários muito elevados e sobre a rotatividade dos colonos, alternam-se com as lastimações sobre a decrepitude dos cafeeiros, o empobrecimento dos solos, a broca, ou com as indignações diante das taxas recolhidas pelo governo e os golpes de especulação dos intermediários e exportadores. Chega-se à exaltação patriótica quando são abordadas a questão da concorrência de outros países produtores, ou a do domínio que a bolsa de Nova Iorque exerce sobre o comércio mundial do café. A conclusão é sempre a mesma: o fazendeiro de café está arruinado e, consequentemente, a prosperidade de São Paulo está em perigo... Entretanto, a grande propriedade agrícola não desapareceu e o fazendeiro continua sendo um tipo social atual. O industrial, o banqueiro e o criador lhe disputam a riqueza e o poder, mas ainda precisam contar com ele. E isso porque, com um senso agudo da realidade, o fazendeiro compreendeu que não mais poderia tirar tudo do café e passou a ser, ao mesmo tempo, plantador de algodão ou de cana-de-açúcar, ou criador de gado. A economia agrícola diversificou-se, ao mesmo tempo em que o aproveitamento do solo tornou-se mais complexo. A franja pioneira paulista atual não é mais a de uma região de estrutura econômico-social simples.” (MONBEIG, 1984 [1952], p. 279.) 
Além do mais, os elogios explícitos feitos por ele à colonização efetuada pela Companhia de Terras, tomada como superior ao clássico modelo paulista exatamente por criar uma massa de pequenos e médios proprietários e não se pautar unicamente pelos interesses das classes dirigentes, tradicionalmente favoráveis à manutenção dos grandes domínios, aponta para o fato de que a generalização das relações capitalistas no campo, que perturbava os antigos acordos socialmente estabelecidos, era vista como um caminho seguro para a superação do passado colonial brasileiro, em outras palavras, para a superação do atraso do país, que seria conseguida somente com a introdução de novas técnicas agrárias que dão auxílio a novas formas de relacionamento entre o homem e o meio. $\mathrm{Na}$ entrevista antes referida, a propósito, Ary França chega mesmo a sugerir que Monbeig teria relações mais estreitas do que as usuais com a Companhia de Terras do Norte do Paraná, que até sua nacionalização, em 1944, encontrava-se sob o controle de capitais ingleses. Segundo o geógrafo paulista: "O Monbeig teve relacionamento internacional com eles, acho que desde a França, desde que ele chegou. A tese do Monbeig, inclusive, foi patrocinada pelas empresas, ele ganhava uma ajuda" (FRANÇA, 2004, p. 54).

De volta à caracterização geral dos escritos de Monbeig, após a descrição das culturas mais praticadas, sempre o café ou o algodão como produto principal ou único - embora nas áreas de domínio da pequena propriedade, especialmente preponderante no norte do Paraná, o produto principal venha normalmente associado com culturas de cereais, legumes, árvores frutíferas, gado e pequenos animais-, parte-se para a descrição dos tipos de habitação, o que serve de mote para que o autor teça comentários acerca da disposição e traçado dos lotes, com ênfase no debate sobre a localização das culturas em cada um deles segundo o passar do tempo e a perenização da ocupação, de vez que cada época vê o pioneiro se dedicar a culturas que necessitam e exigem diferentes condições de temperatura, precipitação e solo, fatores extremamente variáveis caso se esteja falando de uma meia encosta, um fundo de vale ou topo de morro com ou sem presença de derramamentos basálticos ${ }^{123}$.

\footnotetext{
123 "Quando se fala de zona 'pioneira', deve ter-se em vista que a zona é de policultura: traço distintivo da colonização atual da do último século ou dos princípios do século XX (...). É ainda necessário não esquecer que se trata de uma organização nova da colonização com um financiamento do tipo novo: o grande empreendimento capitalista; e sendo assim, não se acha ele levado pela sua estrutura, pelas suas múltiplas ligações, pela soma de seus interesses a favorecer o retalhamento do solo entre um grande número de possuidores? (...) Assim, pois, a pequena propriedade 'pioneira' não dependeria ela da forma moderna de colonização tanto quanto da constituição biológica do terreno?” (MONBEIG, 1940, pp. 62/64.)
} 
De fato, utilizando novamente um vocabulário inspirado nos já citados estudos de Albert Demangeon sobre "A geografia do habitat rural", escritos ao longo da década de 1920 e 1930, Monbeig está preocupado em identificar o processo de formação da estrutura agrária da faixa pioneira, e, por isso, passa a diferenciar o sistema de partilha de lotes encontrado em São Paulo, que dependeria ainda da divisão de glebas imensas, daquele praticado no norte do Paraná, que suscita uma estrutura com tendência maior à fixação da pequena propriedade ${ }^{124}$. Nesse pormenor, percebe que o desenho e traçado dos lotes eram os mesmos, seja em Marília, capital da zona pioneira desenvolvida em torno dos trilhos da Companhia Paulista de Estradas de Ferro - a região da "Alta Paulista", no vocabulário cotidiano da época -, seja na zona pioneira da "Alta Sorocabana", centrada em Presidente Prudente, seja ainda na zona hegemonizada por Londrina, cujas terras, servidas pela Estrada de Ferro São Paulo-Paraná, "administrativamente pertencem ao estado do Paraná, mas cujo povoamento e valorização estão intimamente ligados à economia paulista" (MONBEIG, 1940, p. 23).

Pois bem, essa homogeneidade, observada por toda a parte devido ao fato de o sistema de demarcação das parcelas ser similar na quase totalidade da zona pioneira, não se manifestaria claramente nas paisagens rurais, dificultando a identificação de uma estrutura agrária e demandando o desenvolvimento de parâmetros avaliativos mais adequados para a análise de em um mundo tropical em acelerada marcha de transformação. Vejamos como esses pontos são colocados em trechos em que o autor diferencia as zonas de plantação recente das mais antigas, valendo notar que, nesse texto, quando usa o qualificativo de "zonas velhas", Monbeig está se referindo às áreas de Campinas/Jundiaí, pioneiras no final do XIX, e, portanto, "antigas" se comparadas a vaga pioneira dinamizada após 1929:

E, mesmo quando não restam de pé nem uma árvore, como nas zonas velhas, as parcelas são grandes demais para que se possa ver-lhe o traçado: tudo se

\footnotetext{
${ }^{124}$ Demangeon procede uma classificação dos habitat em disperso ou em concentrado. Levando em consideração uma grande variedade de fatores, desenvolve uma gradação que origina uma tipologia das aglomerações rurais observadas em cada caso, perscrutando os motivos que levaram ao estabelecimento de uma dada situação: "Por carências de mapas exatos, enquanto a zona não está ainda inteiramente povoada, não é nada fácil aplicar ao 'habitat' da zona pioneira alguns dos qualificativos a que estamos habituados; quando muito pode-se falar de dispersão primária nas regiões de pequena propriedade, sem nos arriscarmos, porém, precisar o grau dessa dispersão (...). Mas, por mais representativa que seja dos modos de culturas, dos regimes agrários, da mistura de raças e também do meio físico, a pobre casa do colono não é o que mais impressiona na paisagem rural. A vista sente maior atração pelas ruínas da vegetação espontânea eriçando o solo onde se insinuam plantas cultivadas. E o maior espanto provém, talvez, por estarmos habituados a certa visão de terra cultivada, que não encontramos aqui; em lugar da nitidez e da uniformidade das alturas e cores, o olhar apenas distingue confusão e contrastes de tons e todos os andares da vegetação". (MONBEIG, 1940, pp. 39-40.)
} 
confunde na massa dos cafeeiros. Seria necessário subir num avião para decifrar esta paisagem nascente, da mesma maneira como somente o avião permitiu, em regiões antigas, descobrir paisagens mortas. A estrutura agrária, portanto, não faz parte da paisagem geográfica da zona pioneira e os elementos desta se distinguem muito mais nos processos de desbravamento, nos tipos originais de habitação e na maior ou menor variedade de culturas (...). Destruindo a floresta, o homem criou a paisagem, mas o próprio progresso da derrubada é deixado ao acaso: ele é determinado pelas necessidades puramente agrícolas. (MONBEIG, 1940, pp. 36-37.)

Da parte de Monbeig, surpreende a arguta percepção, por parte de um estrangeiro, do entrelaçamento íntimo, no Brasil, entre o desenvolvimento urbano então em marcha decisiva, pois que catalisado pela industrialização, e a existência de terras consideradas "livres" ou "vazias", o que trazia consigo a marca de uma constante instabilidade: é sob o signo da marcha pioneira em direção ao oeste que se engendram renovados nexos de solidariedade entre pessoas e lugares, é da conquista progressiva de novas terras e gentes, colocadas, ambas, sob a decisiva órbita de influência do capital, que o novo e o velho se produzem mutuamente, na medida em que a esperança da riqueza inexplorada e os dissabores da decadência se interpenetram, expressandose objetivamente na organização das paisagens das cidades, bem como na dos campos. Voltemos agora a atenção ao modo como Pierre Monbeig equaciona o fenômeno do pioneirismo oferecendo uma definição ampla que em nenhum momento esconde sua filiação ao que se convencionou chamar de escola francesa de geografia:

A paisagem do Estado de São Paulo que talvez mais desconserta o recémchegado ao Brasil não é tanto a planície de bananeiras e mangues de Santos, nem a floresta de vertentes da Serra do Mar, nem tão pouco as vastas extensões plantadas de café, mas sim a paisagem que ele descobre ao acordar, depois de uma noite de trem, entrando nas regiões de derrubada (...). Ali, uma cidade velha tem vinte, trinta anos no máximo. Deixa-se São Paulo com seus arranha-céus, sua atividade febril, atravessam-se pacatas cidades provincianas que caminham em marcha-lenta apesar de não contarem três quartos de século, e encontra-se outra animação, outra atividade nas cidades de madeira que a estrada de ferro atingiu há cinco anos, às vezes há alguns meses. É a zona pioneira, da qual Isaiah Bowman e os geógrafos americanos fizeram excelentes descrições no Canadá, Austrália, Manchúria ou extremo sul da Argentina, zona que conserva em toda parte um certo ar de família, mas revela-se também grandemente variada para quem procura mais do que uma simples impressão de viajante. (MONBEIG, 1940, pp. 21-22.)

Fica evidente, nesse trecho, as particularidades que a zona pioneira paulista, manifestação regional de um fenômeno mundial, apresentaria quando confrontada à áreas que, se bem que localizadas em outros países e contando com climas, solos, relevo e vegetação diversas, manteriam com o caso brasileiro "um certo ar de família", vale dizer, características comuns que 
autorizariam um observador atento a enxergá-las ambas como variações ou combinações locais de um tema ou fenômeno global. Não é por outro motivo também que Monbeig, no primeiro texto que escreveu após sua chegada em São Paulo, em 1935, dedicado ao exame d' "A Zona Pioneira do Norte-Paraná", fundamenta o tratamento conjunto que irá conferir a essa área na análise dos movimentos migratórios perceptíveis em território paulista, pois esta seria para ele, como dissemos há pouco, referindo-nos a Londrina, "uma região que - se bem que pertença administrativamente ao estado do Paraná - não deixa de ser de fato uma região de economia paulista" (MONBEIG, 1940, p. 56) ${ }^{125}$.

A apreciação conjunta das zonas pioneiras de São Paulo e do Paraná, a despeito das diferenças existentes entre elas, pode ser percebida em um artigo que trata das vias de comunicação do estado de São Paulo, no qual ele descreve as etapas evolutivas de um centro pioneiro originado pelo desenvolvimento de uma estrada de ferro, chamando a atenção para o incremento da especulação imobiliária e para a mudança de status dos núcleos fixos de ocupação desenvolvidos no entorno das estações, centros urbanos que em menos de dez anos deixavam de ser febris "cidades pioneiras" ou "bocas do sertão", onde o afluxo de pessoas era incessante e tudo tinha um aspecto provisório, e passavam a viver no ritmo cadenciado das demais pequenas cidades interioranas do Brasil. Para Monbeig, os trilhos eram "criadores de paisagens", e, por isso, era para ele impossível separar a análise do povoamento do histórico de construção das vias de comunicação. Contudo, uma característica própria do caso paulista era o fato de que "nunca as companhias de estradas de ferro foram ao mesmo tempo sociedades de colonização (ao menos até os últimos anos próximos passados)" (MONBEIG, 1940, p. 136). Dito de outro modo, não haveria uma atenção das companhias de estradas de ferro na efetiva colonização, nem um planejamento prévio do percurso das estradas, logo, embora estas seguissem de perto o avanço dos desbravadores e agricultores, os trilhos jamais os precediam, visto que:

A via férrea progride aos saltos, tendo por ponto terminal durante 3 ou 4 anos um centro urbano importante, uma "boca do sertão"; durante esse período forma-se mais para diante um novo foco de densidade, nasce e se desenvolve uma pequena cidade pioneira. E, é somente quando a companhia de estrada de ferro está segura de encontrar frete e viajantes, que ela se decide a levar os trilhos até a cidade pioneira, que de chofre recebe como que uma chicotada: os

\footnotetext{
${ }^{125}$ Sobressai já na primeira página deste texto outra referência direta aos trabalhos de Bowman, colocada nos seguintes termos: "Depois dos estudos da American Geographical Society sobre as zonas pioneiras australiana, canadense, manchuriana e outras, resta estudar a faixa pioneira brasileira. É pois um início de estudo neste sentido que se vai tentar aqui". (MONBEIG, 1940, pp. 56-57.)
} 
terrenos valorizam-se, desenvolve-se o comércio e todos os dias chegam novos desbravadores. A antiga ponta dos trilhos, pelo contrário, perde sua atividade: torna-se centro administrativo e escolar, aparecem algumas fábricas, a estação desdobra-se em oficinas de consertos; tudo sossega e toma um aspecto provinciano. A "boca do sertão" está mais adiante. Foi assim que evoluíram cidades como Ribeirão Preto, Jaú, Botucatu, Ourinhos e muitas outras. E a via férrea desempenha então um papel geográfico importante: o povoamento estende-se de um e de outro lado dos trilhos como às duas margens de um rio, mas não vai além de um certo limite, o que tolera o abastecimento e sobretudo a exportação fácil e rápida dos produtos do solo (...). Os trilhos são pois criadores de paisagens; razão a mais para pensar que a consciência popular paulista não se engana quando considera que as verdadeiras regiões do estado são as regiões ferroviárias. (MONBEIG, 1940, pp. 136-137.)

Os termos utilizados por Monbeig são suficientemente claros, estabelecendo uma relação direta entre a construção das vias de comunicação, o crescimento demográfico, a conquista de novas terras agricultáveis e a alteração nas paisagens operada pelo incremento das atividades econômicas. Aliás, é forçoso reconhecer que o abastecimento de gêneros alimentícios e as possibilidades de exportação atuavam como fatores limitadores do povoamento, restringindo o raio de alcance e o poder de captura das ferrovias, que somente se expandiam quando as companhias de estradas de ferro se certificavam, para além de qualquer dúvida, do retorno financeiro e da rentabilidade do investimento, o que torna a integração e a modernização do território até certo ponto efeitos colaterais do caráter capitalista do empreendimento, entrevisto na busca por áreas produtoras de mercadorias cujos fretes poderiam pagar a construção da infraestrutura ferroviária, objetivo maior que não lograva se esconder atrás do véu do neutro progresso por muito tempo. Tirante esses pontos, seria importante guardarmos, por ora, a ressalva que Monbeig faz acerca das companhias de estradas de ferro atuantes em São Paulo, que em sua opinião não teriam interesses maiores na apropriação de terra nem atuariam como empresas colonizadoras até o momento em que redigia esse texto, originalmente lançado em 1937.

A preocupação de Monbeig com a construção das vias de comunicação, que serviriam como suporte para o avanço pioneiro, reflete um traço que não era uma novidade, ao menos se tivermos em conta o trabalho de Isaiah Bowman. A propósito, por essa época Bowman já havia inclusive escrito em sua obra clássica, The Pioneer Fringe, lançada em 1931, um capítulo inteiro dedicado ao relacionamento engendrado entre as ferrovias e os movimentos pioneiros, significativamente nomeado Railways as Pioneers. É desse capítulo que Monbeig tirou algumas de suas conclusões sobre a limitação do raio de influência das estações ferroviárias na indução do povoamento, na especulação de terras e na fundação de centros urbanos. De fato, o geógrafo 
estadunidense lembrava-nos que a partir de uma certa distância, variável para cada caso e país, as ferrovias e estradas poderiam agir como barreiras à produção e comercialização de determinados produtos, já que por conta dos elevados custos de transporte inclusos nos fretes, algumas mercadorias tornar-se-iam inviáveis de serem produzidas com o lucro esperado nas zonas pioneiras (BOWMAN, 1931) ${ }^{126}$.

Tais características eram mais facilmente percebidas no caso da zona pioneira do Paraná, que revelava traços característicos de uma ocupação planejada que a diferenciam sensivelmente do processo de conquista de terras genuinamente paulista. Ali, um detalhe faz toda a diferença, pois enquanto na faixa pioneira localizada em São Paulo os trilhos ajudaram a desenvolver o povoamento, mas nunca o organizaram com antecedência, na faixa localizada no estado do Paraná é-se obrigado a reconhecer que a via férrea abria trincheiras que iam bem além dos últimos pontos habitados, o que, se não dá origem aos célebres povoados tidos por "bocas do sertão", fruto do desenvolvimento dos trilhos aos saltos, estruturou uma rede de estradas da qual derivavam os sítios urbanos, podendo-se observar um povoamento em gestação vinculado a três elementos inseparáveis, a saber, os centros urbanos, as habitações dispersas dos colonos e o caráter capitalista da empreita:

Mas limitar a ação da estrada de ferro à esfera econômica, situá-la - por assim dizer - como posterior ao povoamento, faria negligenciar um dos aspectos clássicos do trilho como agente do povoamento. "Railways as Pionners", escreveu Isaiah Bowman no seu belo livro sobre a faixa "pioneira"; e ele indicou sucintamente a importância do raio de ação da via férrea. É um outro exemplo desta importância que é despertado pelo estudo da localização das cidades criadas pela Companhia "Terras do Norte do Paraná". De fato, para cada uma destas cidades artificiais, a escolha da situação exata pôde - por certo - ser determinada por condições exclusivamente locais e intimamente ligadas ao meio natural (...). Mas o mapa ensina - e o inquérito confirma - alguma cousa a mais. Qualquer que seja a cidade, esta se acha à margem da estrada de rodagem e da estrada de ferro (...). Mas muitas outras localizações reúnem as mesmas vantagens de situação; porque, então esta regularidade das distâncias entre as

\footnotetext{
${ }^{126}$ Vale citar uma passagem do capítulo do livro de Bowman acima mencionado: "The efficiency and success of modern farming depend in large part on good transport. This is not obvious at once. It is only as we see the working of the whole economic machine that we realize how closely related are good roads and motor cars to the prices paid at the local market (...). The pioneer of today comes out of a motor community. Before he occupies new land he knows the market price of the products he can expect to sell and the sort of economy that he must follow if he is to realize the advantages of cheap land with all its virgin fertility unimpaired (...). This means that the front of the wave will get the most desirable land and show the widest margin between original cost and later value, except where chance and man-made opportunity may conspire o place a town on the railway. Close settlement comes later and always means good system of roads and a railway nearby. We shall now see what experience and expert opinion have shown to be the effective economic distance to a railway in a normal community". (BOWMAN, 1931, pp. 67/69-70.)
} 
estações e por conseguinte entre as cidades? (...) O isolamento econômico e a solidão são, deste modo, muito atenuados. Em muitos lugares da Europa, tratarse-ia de suprimir estações tão vizinhas. O raio de ação destas estações determinou a localização dos centros de povoamento urbano (...). O papel representado pela estrada no delineamento dos lotes nos quais residem os colonos, a estação o exerceu para a localização das aglomerações. Deste modo notamos a mesma vontade de organização na criação da pequena propriedade. Não há que admirar na colonização do norte do Paraná uma concepção nova dos colonizadores. Estes não utilizaram senão o que uma experiência secular ensinou aos paulistas. E por isso mesmo, não se deve ficar surpreendido de achar de novo em Londrina o que se pode observar em outros pontos da faixa paulista. Muito empirismo aplicado em grande escala e aplicado racionalmente, eis o que caracteriza a colonização do norte do Paraná e a torna interessante: é uma colonização "planificada" para usar-se um termo em voga. É também uma colonização - não mais de francos atiradores ou de associação familiar - mas do tipo de economia capitalista moderna. (MONBEIG, 1940, p. 70-71-72.)

Em sua tese de doutorado, embora o problema da integração continue a receber destaque, a análise do papel das ferrovias no comando do rumo tomado pelas frentes pioneiras não constitui um capítulo separado, sendo discutido aos poucos, uma vez que Monbeig divide as etapas do movimento pioneiro por períodos. Assim, ao falar das comunicações, ele trata primeiramente do papel das estradas de ferro nas primeiras décadas do século $\mathrm{XX}$, que assistiram a um grande crescimento das ferrovias, tornando a se deter no assunto mais adiante, quando irá falar das franjas pioneiras ao desfraldar da crise de 1929. Em ambos os capítulos, o autor volta a acentuar a relação já referida entre o povoamento, a expansão dos cafezais e a construção das vias de comunicação.

Na primeira das etapas comentadas, notando o número bastante alto de imigrantes chegados aos municípios do interior que contavam com solos férteis, inscrevendo-se nas áreas de derrames basálticos que embasam as "terras roxas", percebe que o aporte de colonos era diretamente proporcional à importância dos respectivos centros produtores, isto é, nos locais onde havia declínio da produção, seguia-se uma estabilização das relações, com a saturação de migrantes nacionais e estrangeiros - leia-se mão-de-obra, ou, no vocábulo da época, "braços para a lavoura" - e a partida destes para outros centros, buscando as novas "bocas do sertão" e os novíssimos núcleos pioneiros plotados em meio às áreas de florestas. Nessa realidade, diz Monbeig que as estradas de ferro não iam além dos cafezais plantados na terra roxa, desenvolvendo-se sem um plano sistemático mais amplo que fosse voltado para os benefícios da coletividade brasileira, mas sim em benefício particular dos sujeitos sociais mais envolvidos com os negócios do café, 
normalmente membros de uma mesma família que controlavam o financiamento, a produção, o comércio e a circulação da rubiácea:

Não preocupava ao imigrante o fato de partir para regiões que só eram acessíveis depois de longo percurso em caminhos, e isso depois de viajar de trem. As estradas de ferro não iam além dos cafezais da terra roxa. Nos 30 anos seguintes, depois de construída a linha básica Santos a Jundiaí [1870], a rede ferroviária paulista havia feito grandes progressos. Vistas sobre a carta, as novas linhas pareciam penetrar notadamente em direção às terras virgens. Não se pode resistir à tentação de comparar tais empreendimentos com os dos Estados Unidos e Canadá. $\mathrm{Na}$ realidade, a maior parte só foi construída depois de as derrubadas já haverem avançado suficientemente, de o povoamento já ser numeroso e de as culturas estenderem-se o bastante para assegurar fretes (...). O desenvolvimento das estradas de ferro não obedecia, portanto, a um plano sistemático, antes foi conduzido pelos interesses dos administradores, dos produtores e dos comerciantes de café. (MONBEIG, 1984 [1952], pp. 174-175. Grifo nosso.)

Até onde podemos compreender, não há aqui nada que desdiga o que antes foi colocado a respeito, pois Monbeig continua entendendo a expansão ferroviária como uma consequência da busca de centros produtores de mercadorias para serem carreadas até o porto de Santos, ou seja, a ferrovia chega apenas onde as derrubadas e as plantações já haviam executado os primeiros trabalhos de valorização dos sertões, acompanhando de perto os desbravadores e agricultores, como já se disse, mas nunca precedendo-os. Como curiosidade, vale a pena também efetuar um comentário rápido sobre a nota de rodapé que acompanha o parágrafo transcrito, pois nessa nota Monbeig dialoga com o geógrafo anarquista Élisée Reclus, que, na parte dedicada ao Brasil de sua obra Géographie Universelle, reconhecia também a função de drenagem regional exercida pelas vias férreas e seus ramais, verdadeiras "sugadeiras" mais preocupadas em servir as zonas de produção das fazendas do que em promover a integração das áreas já povoadas, mas afirmava exatamente o contrário do que concluiu Monbeig num outro aspecto: para Reclus, similarmente ao que ocorria nos Estados Unidos e Canadá, as vias férreas também antecederiam o povoamento $^{127}$.

\footnotetext{
${ }^{127}$ O livro Café e ferrovias: a evolução ferroviária de São Paulo e o desenvolvimento da cultura cafeeira, de Odilon Nogueira de Mattos (1974), antigo aluno de Monbeig no curso de geografia e história da USP, coroa a expressão "ferrovia cata-café" como modo de qualificar os caminhos seguidos pelos trilhos, permanecendo como referência obrigatória para quem quer que queira se aprofundar no tema. Mais recentemente, Marcelo Werner da Silva (2008) efetuou uma análise geo-histórica da formação dos territórios ferroviários no oeste paulista, dando relevo sobretudo às rivalidades e disputas encetadas pelas diferentes companhias, que projetavam os trajetos a serem seguidos tendo como objetivo sempre as áreas onde as plantações estavam no auge, o que vem embasar o reconhecimento de que as ferrovias, no que tange à integração territorial, eram pensadas basicamente em termos de facilidade para a circulação de mercadorias.
} 
Contudo, ao falar da evolução das vias de comunicação na década de 1920, quando os trilhos já dividiam as atenções com as estradas de rodagem, mais versáteis e que garantiam o transporte de mercadorias mesmo em lugares muito afastados das estações terminais, Monbeig retifica em parte uma sua opinião emitida anteriormente, pois embora continuasse afirmando o paralelismo entre a localização dos cafeeiros, a expansão da malha ferroviária e o destino das mais importantes levas de imigrantes, passa a enxergar novos fatores que, combinados, perturbam essa realidade. De fato, como a progressão das lavouras por sobre a terra roxa tinha transformado em raridade as áreas naturalmente férteis, o esgotamento dos solos passou a incidir na lucratividade das operações de compra e venda de terras, incentivando a prática da especulação imobiliária, novo nicho de atuação dos homens de negócios que fez surgir na frente pioneira um tipo social diferente, o loteador de terras, que agregado ou não a um outro, o "grileiro" falsificador de títulos de propriedade, permitiu aos trilhos que precedessem em alguns casos as derrubadas e o povoamento.

Nesse sentido, nos momentos imediatamente anteriores à deflagração da crise de 1929, a configuração espacial dos cafezais, que então cada vez mais dividiam as atenções com os pastos e com as pequenas propriedades produtoras de gêneros alimentícios, resultado do reaproveitamento de antigas propriedades arruinadas na primeira crise experimentada pelas quedas no preço do café, em 1905, parece ser mera continuação das correntes dinamizadas no momento anterior, pois a "localização dos imigrantes e distribuição dos cafeeiros são dois fatos que coincidem, portanto, nos anos que precedem ao desmoronamento econômico e também coincidiam em 1900. A cartografia do segundo período é um prolongamento do primeiro e a marcha pioneira desenvolvese normalmente" (MONBEIG, 1984 [1952], pp. 194-195).

A inauguração da Noroeste do Brasil e o prolongamento dos trilhos da Sorocabana, que foram as principais novidades entre as ferrovias construídas depois de 1905, quando após anos de projetos frustrados, finalmente as vias férreas atingiram os limites administrativos de São Paulo, nas barrancas dos rios Paraná e Paranapanema, expressam assim um feito não desprezível, pois pela primeira vez na história paulista, "os trilhos penetravam em um sertão, uma região quase desabitada" (MONBEIG, 1984 [1952], p. 196). Em outras palavras, de maneira inédita no processo de formação territorial do estado de São Paulo, os trilhos e loteamentos precediam o avanço das plantações, deixando para trás grandes áreas florestais ainda indevassadas, fundos 
territoriais (MORAES, 2002) à espera de uma ocupação futura que, momentaneamente, permaneciam intactos:

Uma multidão variada de fazendeiros, de loteadores de terras e de aventureiros acompanhou os progressos da construção da ferrovia, em um verdadeiro rush, digno da tradição americana. Tanto nos lugares já habitados como nos acampamentos dos empregados da construção abriam-se casas de comércio e nasciam pequenas aglomerações (...). Essa pressa e a confusão facilitaram todos os tipos de negocio imagináveis sobre as terras e os títulos de propriedade. Ao lado do fazendeiro que comprava para plantar, os grileiros, buscando ganhar mais do que podiam, atraíam habitantes das velhas zonas e lhes vendiam glebas mais ou menos contestáveis. A partir de Bauru e até Araçatuba viram-se pela primeira vez coexistirem grandes domínios e pequenas propriedades (...). Antes mesmo de serem atingidas pela estrada de ferro, já em 1916 e 1917, futuras aglomerações como Presidente Prudente e Santo Anastácio viram afluírem os primeiros pioneiros. O povoamento desencadear-se-ia com a circulação dos primeiros trens, coincidindo as datas, com poucos meses de diferença. Enquanto na Noroeste os trilhos haviam precedido o pioneiro, o que em outras áreas não havia acontecido, na Alta Sorocabana, além de Assis, o que houve foi sincronismo entre a marcha do povoamento e o avanço da estrada de ferro. Continuou a haver paralelismo entre a distribuição geográfica da cultura cafeeira, a localização dos imigrantes e a expansão da rede ferroviária. (MONBEIG, 1984 [1952], pp. 196-197. Grifo nosso.)

Os juízos divergentes de Monbeig acerca do papel das ferrovias como catalisadores das frentes pioneiras, que dizem respeito aos fenômenos que ocorriam em São Paulo, decorrem mais especificamente de uma diversificação ocorrida na estrutura política, econômica e social dentro da qual estas se dinamizaram. Assim, se entre o final do século XIX e início do século XX a estrutura mais hierarquizada da sociedade brasileira, aliada à maior disponibilidade de solos férteis passíveis de serem apropriados, permitia que os fazendeiros e plantadores se movessem com maior liberdade em busca dos melhores terras para o café, a partir da década de 1930 a crise mundial, as guerras, o crescimento das indústrias, a urbanização do Brasil e o esgotamento das terras impunham novas condições para a expansão pioneira, das quais o aumento das pastagens, o desenvolvimento da pequena propriedade e a crescente lucratividade da policultura eram alguns dos resultados mais evidentes nas paisagens.

Já no norte do Paraná, onde o sistema rodoviário havia sido projetado para facilitar as ligações entre o campo, as cidades, as casas de comércio e as estações ferroviárias, a colonização efetuada pela Companhia de Terras coordenava-se perfeitamente com a criação de cidades e a expansão da estrada de ferro, que seguia de perto os centros urbanos, sendo imperativo dizer que o sucesso de um loteamento rural dependia diretamente do desenvolvimento desses núcleos 
urbanos, havendo portanto um planejamento da localização das futuras aglomerações junto à rede de caminhos que constava na planta dos loteamentos antes mesmo de as primeiras derrubadas serem iniciadas, uma vez que as grandes empresas de loteamentos "compreenderam perfeitamente que a instalação dos caminhos era inseparável das funções urbanas, uns e outras igualmente indispensáveis ao sitiante produtor de artigos comerciais (...). Assim, a fundação de núcleos urbanos precede de pouco à colocação à venda dos lotes rurais" (MONBEIG, 1984 [1952], p. 235).

Outro ponto que merece destaque, e que não pode ser desvinculado da relação existente entre as ferrovias e a colonização, é a mudança de postura do francês acerca dos interesses das companhias de estradas de ferro na apropriação de terras no estado de São Paulo. Expressivamente, se nos textos inclusos nos Ensaios Monbeig alertava para a total separação de interesses entre os loteamentos voltados para a colonização e a construção das estradas de ferro, e isso a despeito de serem os mesmos os nomes presentes nos cargos de chefia tanto nas companhias colonizadoras quanto nas empresas de transportes, pois "se são os mesmos homens que figuram nos conselhos de administração, as razões sociais diferem" (MONBEIG, 1940, p. 136), no livro Pioneiros e Plantadores essa posição é em muito alterada. No capítulo II do livro segundo dessa obra, há uma seção inteira dedicada aos líderes da marcha pioneira, cafeicultores que entre 1880 e 1910 inundaram as terras do oeste paulista com suas plantações, atraindo um contingente cada vez maior de pessoas. Esse momento é, para Monbeig, muito distinto do que havia até então ocorrido, pois se os chamados precursores do avanço pioneiro, que abriram os caminhos e plotaram nos sertões os primeiros núcleos de povoamento fixos, ainda no início do XIX, eram formados por caboclos isolados e grupos de lavradores e criadores mais homogêneos do ponto de vista da origem e classe social, na passagem para o século XX o movimento foi encampado pelos grandes proprietários de terras, que formavam a classe dirigente e a elite econômica de São Paulo: "uma classe de grandes fazendeiros, que ao mesmo tempo dirigia importantes sociedades bancárias e ferroviárias, bem como detinha postos na administração pública (...). Sua obra consolidou, por muito tempo, a grande burguesia paulista” (MONBEIG, 1984 [1952], p. 139).

Como foi observado, Monbeig divide a marcha dos pioneiros em três grandes momentos. $\mathrm{O}$ primeiro deles, que marca o início da expansão do café em terras paulistas, vai desde a segunda metade do século XIX até os anos de 1904 e 1905, época da primeira grande crise de 
superprodução do café; o segundo, mais curto, estende-se desta primeira crise até o ano de 1929, quando ao crack financeiro iniciado em Nova Iorque junta-se novamente a problemática da superprodução das novas plantações, que a partir do início da recuperação do preço do café, por volta de 1910, tinham tomado novamente o lugar antes ocupado por reservas florestais em São Paulo e no Paraná, chegando ao auge de sua produção exatamente no final dos anos de 1920; por fim, Monbeig descreve as direções então atuais das franjas pioneiras tais como foram por ele ser observadas diretamente no terreno entre os anos de 1930 e a década de 1940. Entre a primeira e a terceira etapa, o Brasil passou por alterações na estrutura econômica, social e política que na opinião de Monbeig imprimiram suas marcas nos tipos de paisagem organizadas a partir da expansão das lavouras. Assim, interpunham-se consideráveis diferenças entre os personagens aristocráticos comuns à fazenda escravocrata clássica, que até o final do XIX comandavam sem rivais as franjas pioneiras inscritas num mundo rural de indisfarçável cariz senhorial, e a empresa capitalista moderna que dinamizava as frentes pioneiras associadas à urbanização e à industrialização, que em meados do século XX lucrava com loteamentos urbanos e demais negócios ligados aos pioneiros:

Pouco a pouco, destacaram-se do movimento pioneiro grandes famílias que o haviam lançado. Seus descendentes tornaram-se negociantes, business-men, para os quais era secundária a importância da terra. Não se formou, pois, uma aristocracia de proprietários. A mesma evolução experimentou a massa dos fazendeiros, embora em menor escala. Trocava-se o campo pela cidade; os filhos eram advogados, médicos, engenheiros. Renunciava a gerir suas propriedades rurais, confiando-as a um administrador, responsável pela fazenda. Acabam muitos desses novos citadinos por desinteressar-se completamente da vida rural. A maioria deles, porém, mantinha contato com a fazenda. Fiéis a um hábito herdado dos seus antepassados, gostavam de possuir cem ou duzentos alqueires de mata virgem, correspondentes a um capital fácil de realizar e cuja valorização era certa. Enquanto se urbanizavam os fazendeiros paulistas, outros novos apareciam: colonos penosamente enriquecidos, pequenos comerciantes estrangeiros que compravam plantações postas à venda ou que corajosamente se lançavam no desbravamento de terras virgens. O grupo de plantadores perdeu sua homogeneidade. Enfraqueceu-se econômica e socialmente, ao diversificarse. Mas a fazenda continuava a ser uma das formas predominantes do povoamento, na zona pioneira. Longe estava o fazendeiro de ter perdido seu antigo prestígio. Se já não era o único a dirigir a marcha pioneira, prosseguia sendo um de seus elementos mais ativos. (MONBEIG, 1984 [1952], p. 142.)

Se do ponto de vista da estrutura social Monbeig notava uma diversificação, com a perda de importância dos grandes fazendeiros e o surgimento de novos elementos, o que de certo modo aponta para o fato de a mobilidade experimentada nas áreas pioneiras ser simultaneamente uma 
mobilidade espacial e social, do ponto de vista das paisagens observadas a característica mais saliente era o estado transitório de um processo de conquista da natureza pelos homens, pois a completa humanização das paisagens, que se iniciava com a queimada das matas que abriam caminho aos fazendeiros e agricultores, continuava na instalação dos núcleos fixos de povoamento e atingia sua plenitude na passagem do estágio de conquista pioneira para a estabilização de formas consolidadas de ocupação, que indicariam uma tendência a um equilíbrio (sempre momentâneo) da relação do homem com o meio, pode ser entendida como uma contingência da conjuntura histórica vivenciada, que influenciava o processo de organização do espaço na medida em que as correntes colonizadoras originavam formas de ocupação perenes somente na aparência, visto que até mesmo a solidez das grandes fazendas, que reinaram sozinhas no antigo mundo patriarcal, poderia esfacelar-se num momento subsequente de crise, como de fato veio a ocorrer nas "cidades mortas" do vale do rio Paraíba, cujo patrimônio arquitetônico era considerado na década de 1930 monumento de uma época já fugidia de riqueza proporcionada pela vaga do café ${ }^{128}$.

A rápida construção de estradas de rodagem por particulares ou empresas de colonização, que generalizou o uso de caminhões a tal ponto que se poderia afirmar que "os Ford desses tempos heroicos revolucionaram a circulação" (MONBEIG, 1984 [1952], p. 198), expressa uma vez mais a importância da construção dos meios de circulação para a integração territorial, de vez que os novos caminhos motorizados buscavam atender as lavouras mais distantes das estações ferroviárias, menores e localizadas em terras de pouco valor. Nessa situação, as empresas colonizadoras, reunidas junto aos administradores das companhias de estradas de ferro, procuravam incorporar as zonas produtivas mais promissoras na esfera de influência ou captação do eixo de circulação que controlavam, em outras palavras, a associação entre as matrizes rodoviária e ferroviária de transporte aguçou a rivalidade entre os grupos de empresários mais destacados que atuavam na política municipal de cada um dos diferentes núcleos urbanos. Cada um desses grupos político-empresariais de base local intentava capturar a produção das outras localidades em sua rede de caminhos, drenando para o seu círculo ou órbita de influência direta a

\footnotetext{
128 “Com a expansão, o dono da fazenda deve tomar consciência mais diretamente de sua dependência em relação ao mercado, das diferentes escalas das quais seu sucesso depende. Ele deve não apenas plantar, mas vender e reagrupar a mão-de-obra indispensável em relações de produção de outra natureza. (...) De uma economia dominial, passa-se a um sistema de cultura "industrializado" ou quase, praticando a monocultura, seguindo o ritmo dos mercados, de classes dirigentes seduzidas pela urbanização, de trabalhadores tornando-se assalariados. Essa ruptura não é brutal, e uma certa combinação do rural, do mercantil e do capitalismo fortalece os grandes fazendeiros que subsistem." (RONCAYOLO, 2006, pp. 123-124.)
} 
riqueza produzida em lugares cada vez mais distantes da circunscrição municipal administrativa que dominavam:

Homens de negócio, que agora são fazendeiros e loteadores de terras, compreenderam rapidamente que a estrada era o prolongamento do trilho. Graças à estrada e ao caminhão, tornava-se possível impulsionar as novas lavouras (as estradas de ferro haviam atingido pontos extremos), de cada lado dos trilhos, alargando o raio de ação das ferrovias e aumentando, com a estrada e o caminhão, as possibilidades de colonização (...). A estrada e o caminhão, completando a ferrovia, permitiram que os pioneiros se afastassem ainda mais, pois tinham a certeza de poder transportar sua produção. As terras valorizavamse e a revolução dos meios de circulação iria juntar-se ao conjunto de fatores desfavoráveis ao desenvolvimento da pequena propriedade (...). Comerciantes fixavam-se nas margens das estradas, proporcionando aos modestos pioneiros contatos constantes com o resto do mundo. A estrada era uma garantia contra $o$ isolamento e um oportunidade a mais para a pequena propriedade, o sítio. (MONBEIG, 1984 [1952], pp. 199/201.)

Essa situação gerou um paradoxo observado por Monbeig no trecho acima, pois se por um lado a generalização do transporte feito por caminhões beneficiava os pequenos sitiantes, que deixavam sua antiga condição de isolamento e passavam a conviver lado a lado com os grandes proprietários, por outro, a melhoria das condições de circulação, aumentando as possibilidades de ganhos com plantações em terras novas, valorizavam exponencialmente áreas cada vez mais distantes dos trilhos e centros urbanos, que restavam inacessíveis para a apropriação e uso produtivo nas condições anteriores, aumentando o interesse dos grupos de empresários e favorecendo a formação de grandes domínios, que forçavam a migração e o deslocamento dos sitiantes e posseiros mais para adiante.

Fechando o sistema, os sitiantes e pequenos proprietários saídos de suas antigas terras punham-se de novo em movimento, ocupando uma vez mais velhas áreas de floresta, desbravando terras menos valorizadas e dando continuidade à engrenagem capitalista da marcha pioneira em seu incessante apetite territorial. Nessa realidade, é importante também dizer que as terras servidas pelos trilhos da E. F. Sorocabana, principalmente na região conhecida como Alta Sorocabana, cuja capital regional é Presidente Prudente, nas cercanias dos rios Paranapanema e Paraná, não contavam com boa fama entre os agricultores, uma vez que "ninguém ignorava que os títulos de propriedade eram mais duvidosos ali do que em qualquer outra região. Era pouco tentador ao agricultor arriscar-se em uma região que parecia mais fértil em produzir demandas do 
que cafeeiros (...). Ela interessou mais aos loteadores do que aos fazendeiros" (MONBEIG, 1984 [1952], p. 203) $)^{129}$.

A crítica velada endereçada aos grileiros e especuladores, que manejavam terras com títulos pouco confiáveis, serve para diferenciar as terras que interessavam aos colonizadores por seus solos de maior fertilidade ou situação geográfica privilegiada, ou bem graças a uma cidade melhor equipada com máquinas de beneficiamento, estocagem, ou bem graças a uma rede de transportes mais eficiente, daquelas que por seu isolamento ou falta de registros legais de propriedade eram alvos de falsificadores e oportunistas, mas se torna ainda mais intrigante quando lembramos o fato de que a E. F. Sorocabana era de propriedade do governo do estado de São Paulo. Não por acaso, essa região da Alta Sorocabana, dentro da qual se insere a área hoje conhecida como Pontal do Paranapanema, continua a ser uma das que mais produzem litígios que questionam a validade dos títulos de propriedade dos grandes empresários do setor agropecuário (SILVA, 1999), o que faz dela um lugar histórico para os movimentos sociais que atualmente lutam pelo acesso à terra.

Embora se distancie um pouco do tema aqui tratado, devemos fazer um breve comentário acerca da legislação relativa à propriedade da terra no Brasil. Realmente, um dos pontos mais importantes a ser notado é que desde ao menos a Lei de Terras de 1850, que objetivava discriminar as terras públicas dos patrimônios privados, a posse pura e simples, com a presença de uma cultura efetiva e uma morada fixa e habitual, passou a ser o principal meio de apropriação

\footnotetext{
${ }^{129}$ Utilizando-se de fontes cartoriais de primeira mão, Christian Brannstrom $(2000 ; 2001 ; 2006 ; 2010)$ escreveu diversos artigos analisando as relações de trabalho no processo de desmatamento da floresta impulsionado pela expansão das lavouras de algodão e café na região de Assis, em São Paulo. Uma das novidades que este estudioso de geografia histórica apresenta diz respeito ao levantamento dos contratos de trabalho lavrados entre fazendeiros e sitiantes para a abertura das fazendas, que demostraram o domínio dos prepostos, da parceria e do arrendamento como formas principais de contratação de famílias de camponeses na expansão da fronteira. Com efeito, Brannstrom nota que o estabelecimento desses contratos de trabalho para a abertura de fazendas em terras consideradas "virgens" pode ser compreendido como uma das estratégias utilizadas pelos fazendeiros para criar evidências da posse e obter o acesso legal à terras muitas vezes griladas, uma vez que o cultivo direto de uma propriedade poderia ser mobilizado como argumento judicialmente válido para a legalização do domínio: "The importance of possession in establishing land access conflicted with the imperative to secure large tracts of land. Limited or costly capital, technologies and geographical information meant that no single person could occupy effectively forested areas much larger than 50 hectares. Land claimants adopted familiar institutions, usufruct-based labour relations, to carry out this necessary task. Preposto and share-tenant relations did not lower legal costs directly, but they increased substantially the legal basis of possession, introduced few new costs and possibly generated a rent stream (...). Thus by enforcing preposto or share-tenant contracts, land claimants took advantage of the incentive system inherent to usufruct labour schemes and exploited labour for enforcement of land claims. If sharecroppers or tenant farmers planted cotton, then a substantial rent stream could have resulted for the benefit of the land claimant, possibly offsetting the cost of enforcing contracts. Without preposto and share-tenant relations, land claimants would have had to pay and feed workers to enforce their land claims, while probably losing the possibility to create a visible imprint on the landscape." (BRANNSTROM, 2001, pp. 871-872.)
} 
territorial, transformando-se na forma mais comum de aquisição de domínio, o que servia aos pequenos lavradores, é claro, mas se prestava sobretudo para que os grandes latifundiários aumentassem suas posses (SILVA, 1996). Em outras palavras, a regularização da posse como fundamento do direito à propriedade plena das terras ocupadas favoreceu o processo de constituição dos grandes domínios privados, feitos normalmente à custa do patrimônio público (ANDRADE, 2002), para o que sem dúvida contribuíram muito as indefinições acerca da figura jurídica das terras devolutas, base para a máxima "terras públicas, ocupação privada". Com a proclamação da República, em 1889, essa situação se agravou, na medida em que as terras devolutas passaram para o domínio dos estados, que legislavam sobre o assunto a partir de seus interesses imediatos, o que teve óbvios reflexos em São Paulo, estado onde "o governo dos fazendeiros" encontrava seu ambiente ideal, como evidencia a análise das leis estaduais elaboradas em 1898 e 1921 (esta conhecida como "jubileu do grileiro"), que acompanharam as duas primeiras fases de expansão da frente pioneira há pouco descritas e tornaram legais todas as posses efetuadas, estimulando a continuidade da grilagem pela garantia de que os títulos seriam reconhecidos (SILVA, 1997):

Surgiu o problema da propriedade em todos os países pioneiros. Não foi muito difícil resolvê-lo, onde a topografia plana e a vegetação de pradarias facilitava a aplicação de uma legislação rigorosa, apoiada numa magistratura e numa polícia soberanas. Outras dificuldades apresentava esse problema, numa região coberta de matas de penetração difícil e na qual nem os costumes políticos, nem a moral individual, sempre se inspiravam em considerações desinteressadas. Lembremos o que acima foi indicado: a colonização era uma questão de segundo plano, vindo antes o desejo de especular (...). Era efeito das circunstâncias a preocupação demonstrada, em 1900, pelo governo paulista em regular a questão territorial: os progressos do povoamento, o afluxo de imigrantes, a avidez geral de adquirir terras, obrigavam as autoridades a buscar uma solução. Tal solução, porém, só concorreria para que o problema se complicasse, e ia suscitar mais de um processo espinhoso. As medidas legais de 1895 e 1900, exigindo a apresentação de documentos antigos, sugeriam a possibilidade de os forjar. Os falsários deram prova de imaginação e habilidade diabólicas (...). Era preciso também premunir-se contra os adversários, pois muitas vezes dois ou três indivíduos moviam demandas em relação ao mesmo território, com algumas variantes na delimitação. Nesse caso, era indispensável cair nas boas graças do juiz de direito e dos agrimensores. E, por fim, era o assassinato uma solução levada em conta. Toda a zona pioneira, em São Paulo como no Paraná, conheceu os grileiros e a prática dos grilos. Ainda hoje tornaram-se litigiosas muitas glebas, e as mais poderosas companhias colonizadoras, que haviam comprado 
seus domínios ao governo provincial, tiveram de arrostar os grilos. (MONBEIG, 1984 [1952], pp. 144-145.)

Vemos então que, do ponto de vista da estrutura agrária, haveria duas maneiras distintas de descrever o processo de criação das propriedades rurais no mundo pioneiro: de um lado, haveria a fragmentação de antigas fazendas de café, que encontrando-se arruinadas pelo uso intenso de seus solos não ofereciam mais uma boa rentabilidade na atividade comercial principal, sendo mais interessante seu retalhamento em pequenos lotes e venda para os pioneiros. Nesse caso, os loteadores não se preocupavam com a organização de uma infraestrutura de estradas ou com a fundação de centros urbanos nas proximidades dos loteamentos. Por outro lado, haveria igualmente a divisão de grandes áreas de floresta em loteamentos, operação comercial feita por particulares ou companhias especializadas de colonização que representavam, na opinião de Monbeig, uma experiência mais acabada de colonização, pois era executada metodicamente e com previsão, vindo acompanhada da fundação de cidades e da construção de estradas. $\mathrm{Na}$ verdade, o caráter comercial dos loteamentos e a feroz competição entre as diversas companhias colonizadoras que atuavam em São Paulo e no norte do Paraná faziam com que os vendedores de terras se preocupassem em oferecer vantagens aos potenciais compradores. Essa circunstância, por sua vez, obrigando os loteadores a elaborar e aplicar, no terreno, um plano de colonização mais completo que garantisse, tanto quanto possível, a fixação das famílias nas terras, tornava a experiência das zonas pioneiras paulistas "muito longe do individualismo do pioneiro na free

130 "Durante a Primeira República, o processo de passagem das terras devolutas para o domínio privado não somente não foi estancado (apesar de continuar em vigor a Lei de 1850), como conheceu um momento de grande intensidade. Em razão da aceleração do processo de ocupação territorial, a transferência das terras devolutas para o domínio privado ocorreu numa escala sem precedentes. Apesar de todas as facilidades oferecidas pela legislação republicana para a regularização de sua situação, havia uma resistência generalizada por parte dos posseiros em cumprirem a Lei. As razões para esta atitude era a prática de uma agricultura predatória, que esgotava rapidamente o solo e impelia os fazendeiros a incorporarem incessantemente novas terras ao cultivo. Enquanto fosse possível incorporar terras devolutas, não havia necessidade de alterar o padrão de cultura. Essa legislação liberal em relação ao apossamento não democratizou o acesso à terra. Muito pelo contrário, contribuiu decisivamente para a recriação do latifúndio, e, nesse particular, o caso de São Paulo é mais uma vez exemplar. É unânime na bibliografia especializada a idéia de que o latifúndio foi introduzido em São Paulo pelo café (...). Por outro lado, a exclusão de parcelas significativas da população brasileira da propriedade da terra não deve obscurecer o fato de que a continuidade do apossamento, defendida pelos fazendeiros, tornou menos rígida a situação social no campo (em comparação com outros países, e permitiu a ocupação da terra pelo pequeno posseiro, mesmo que de maneira instável e secundária. Neste sentido seria possível, talvez, falar-se no exercício de uma hegemonia por parte dos grandes fazendeiros, organizada em torno do continuado acesso às terras devolutas, e integrando de modo subordinado os pequenos posseiros." (SILVA, 2002, p. 169). 
land. Convém ajuntar que essa experiência de colonização, que se impõe ao vendedor de terras, é uma novidade na terra dos fazendeiros" (MONBEIG, 1984 [1952], p. 222) ${ }^{131}$.

O que se pode observar, portanto, é que a proliferação das pequenas propriedades expressava uma modificação na estrutura social das zonas pioneiras, que se afastavam cada vez mais da simples divisão entre fazendeiros, escravos e colonos, dominante no final do século XIX, para se tornar mais diversificada e complexa ${ }^{132}$. A propósito, uma primeira diferenciação operada por Monbeig na descrição da estrutura social das áreas de movimentação de fronteiras opõe o fazendeiro ao simples colono. De fato, enquanto o primeiro era descrito como um homem rico, cujo tipo ideal seria o antigo fazendeiro de Ribeirão Preto, o simples pioneiro seria, "ao contrário, um homem pobre. Ele acompanhava o movimento provocado pelo esgotamento dos solos das antigas zonas, movimento que se parece mais com uma fuga do que com uma conquista" (MONBEIG, 1984 [1952], p. 223).

Após essa primeira diferenciação, Monbeig notava também a existência de certas especificidades entre os próprios colonos, sendo exatamente a propriedade da terra o fator determinante para descrever em detalhes as condições de vida de colonos e sitiantes, esses normalmente qualificados como caboclos que se encontravam numa posição inferiorizada exatamente pela situação precária de suas finanças. Aqui, pode-se perceber com clareza uma crítica de Monbeig aos mecanismos de endividamento presentes na frente pioneira, pois ele

\footnotetext{
${ }^{131}$ Em texto escrito originalmente em 1951, para a revista Les Cahiers d'Outre Mér, quando Monbeig ocupava o cargo de professor de Geografia Colonial em Estrasburgo, alguns dos juízos sobre o processo de formação da propriedade da terra na franja pioneira paulista são retomados, sublinhando-se a oposição entre o velho sistema paulista e o moderno processo de divisão da terras em loteamentos por empresas especializadas: "Desde o momento e que a gleba é dividida e cultivada, observa-se o nascimento e a evolução de uma estrutura agrária. Aí se distinguem dois tipos de loteamentos, como duas maneiras diversas de evolução: uma antiga, clássica, que consiste na fragmentação progressiva e que, começando pela instalação das grandes fazendas, termina na formação de pequenas propriedades; outra, recente, que consiste em dividir a gleba imediatamente em pequenos lotes. A distinção entre esses dois processos evolutivos não é sempre muito violenta, muitas glebas foram divididas em plantações de tamanho respeitável que não foram depois subdivididas; neste caso, as fazendas originadas do parcelamento inicial continuam a existir sob sua forma primitiva. Às vezes, a passagem da grande plantação para a pequena propriedade se efetua sem transição. A oposição entre os dois tipos de evolução só tem a vantagem de tornar mais clara a exposição". (MONBEIG, 1957, p. 112.)

132 "Sem dúvida, poder-se-á agora concluir, indagando: não parece reinar certo equilíbrio no mundo pioneiro? Aparentemente, a base da economia pioneira foi consolidada com o abandono da monocultura do cafeeira. O desenvolvimento da pequena exploração agrícola levou a uma utilização do solo mais completa e, ao mesmo tempo, a melhor distribuição da riqueza. Quanto ao futuro, ele não 'mais incerto para a franja pioneira do que para as regiões de antigo povoamento. A partir de fatos como esses, só é possível chegar a uma conclusão otimista (...). A queda do café acelerou o acesso à propriedade a pessoas com poucos recursos e provocou a eclosão da policultura. A paisagem perdeu em monotonia o que as atividades humanas e a estrutura social ganhariam em diversidade. A franja pioneira não mais conhece a homogeneidade que, durante os três quartos de século em que o café fora o rei incontestável, havia sido a garantia de uma estabilidade hoje desvanecida.” (MONBEIG, 1984 [1952], pp. 316/321.)
} 
afirmava que "desde a instalação, o sitiante pioneiro é obrigado a contrair empréstimos. Desencadeia-se, dessa forma, o mecanismo de uma armadilha de que os desafortunados não sairão jamais e que, de qualquer forma, amarrará por muito tempo o pioneiro, por mais corajoso e empreendedor que ele seja" (MONBEIG, 1984 [1952], p. 224). Fazendo empréstimos duas vezes ao ano, no período da semeadura e no da colheita, os sitiantes colocavam a sua produção à disposição daqueles que financiavam suas lavouras, normalmente agentes locais enriquecidos, sejam gerentes de máquinas de beneficiamento, sejam os intermediários negociantes de café e algodão, que os sitiantes mais pobres preferiam aos grandes bancos oficiais, dada a dificuldade em se conseguir crédito rural ${ }^{133}$. Desse modo, a desorganização do crédito agrícola, em conjunto com o endividamento crescente dos sitiantes, que empenhavam os resultados futuros de seu trabalho nos juros que deviam pagar aos intermediários, são dois fatores novos que incidiam diretamente na instabilidade do povoamento:

Eis porque, da mesma forma como o colono deixa facilmente uma fazenda por outra onde o salário é ligeiramente superior, o sitiante abandona sem dificuldade sua terra por uma outra. Alguém irá seduzi-lo, apregoando as qualidades de determinado solo, as facilidades de pagamento ou de crédito e ele espera escapar, pela fuga, às reivindicações dos credores. Essa instabilidade é, em parte, determinada pelo sistema de crédito; mas, em contragolpe, volta-se contra ele, acentuando os seus defeitos. Os bancos hesitam em emprestar a um homem cuja atividade é dificilmente controlável e de que perderão a pista se ele partir para nova "frente". Os negociantes e "maquinistas", como têm mais contatos diretos, estão mais ao par dos fatos e das intenções de seus clientes e possuem, através de sua clientela e seus colegas, uma rede de informações de que não dispõem os grandes bancos (...) é fora de dúvida que as dificuldades financeiras e a inorganicidade do crédito rural incitam os pequenos sitiantes à instabilidade. A fluidez da população explica o mau funcionamento do crédito que, por sua vez, a reforça. (MONBEIG, 1984 [1952], pp. 226-227.)

Para Monbeig, a distinção entre os diversos tipos sociais existentes nas frentes pioneiras, como fazendeiros, banqueiros, especuladores, colonos, sitiantes e caboclos, para citarmos apenas alguns, mostra que o verdadeiro pioneiro, entendido como o tipo social que realmente realiza uma obra de colonização, com a estabilização do povoamento e a harmonização das relações com

\footnotetext{
133 "Essa preferência corresponde, sem dúvida, a certa desconfiança com relação aos bancos oficiais, para eles instituições distantes e um tanto misteriosas, talvez demasiado associadas, no espírito da gente simples, a tudo que diz respeito a administração e governo. É mais fácil falar diretamente com um conhecido que nada ignora da vida rural, do que a um funcionário que fica atrás de um guichê, ou a um diretor à retaguarda de sua escrivaninha, funcionário e diretor vindos ontem de outra terra e que amanhã partirão. É um reflexo típico de camponês. O comerciante vizinho ou o "maquinista" não pedirão títulos das propriedades nem estimativas de safras. É mais simples e econômico tratar com eles que, concluído o negócio, tirarão letras de câmbio do bolso, sem maiores complicações." (MONBEIG, 1984 [1952], p. 225.)
} 
o meio natural, é aquele que compra sua propriedade, ou, na melhor das hipóteses, o colono que, através das muitas formas de trabalho descritas pelo francês (o arrendatário, meeiro, foreiro, empreiteiro de café, algodão ou pastos, etc.), todas devidamente inscritas numa relação de trabalho que poderia ou não conter uma remuneração em dinheiro, fixa-se na terra (FALEIROS, $2007)^{134}$. Nesse caso, os posseiros, descritos no mais como os portadores das piores condições técnicas, os representantes do mundo arcaico que se quer superar, participam do movimento pioneiro como lenhadores e abridores de fazendas, antecedendo a chegada dos colonos ou se estabelecendo em terras doutrem com seu nível de vida beirando a autossuficiência, mas não são considerados em seu real papel, vale dizer, como os artífices da produção não-capitalista do capital na forma das unidades de produção agropecuárias, as fazendas (MARTINS, 1979). Expressivamente, referindo-se à segunda etapa da expansão pioneira, que abrange os anos de 1905 até a crise de 1929, quando ainda dominavam nas paisagens pioneiras as grandes propriedades rurais que iriam ser retalhadas na etapa subsequente, Monbeig nota a presença do caboclo exatamente no registro que vimos descrevendo:

As glebas mais antigas abrangiam superfícies enormes (...). Evidentemente, os proprietários não moravam nas suas terras: eram, na maioria, fazendeiros nas velhas zonas cafeeiras, e só permaneciam nas fazendas quando era necessário fiscalizar o trabalho, passando longas temporadas na cidade. Para tais

\footnotetext{
${ }^{134}$ Em sua tese de doutorado, Rogério Faleiros (2007) efetuou um levantamento documental de mais de duas mil escrituras de contratos de formação e trato de cafezais em municípios como Campinas, Rio Claro, Araraquara, Botucatu, Catanduva, Lins, São José do Rio Preto e Ribeirão Preto, entre outros, que forneceram uma base para a análise tanto das zonas antigas quanto das zonas novas em expansão. O estabelecimento de relações de trabalho marcadas pela desigualdade de obrigações entre fazendeiros e sitiantes é uma nota comum nas escrituras, bem como o interesse dos primeiros em obter o registro legal do controle que exerciam na venda dos excedentes comercializáveis pelos colonos. No geral, o autor identificou que a possibilidade de controlar a produção de gêneros alimentícios que os colonos cultivavam nos espaços existentes entre as fileiras da rubiácea, costume generalizado na agricultura praticada na franja pioneira paulista desde meados do XIX, constituiu-se em objeto de disputa entre colonos e fazendeiros com o aumento dos preços dos produtos de abastecimento, funcionando mesmo como uma forma de atração de trabalhadores, que preferiam estabelecer contratos de empreitada ou parceria com os fazendeiros que garantiam uma liberdade relativa para este tipo de cultivo. Ao final, Faleiros mostra que as culturas intercalares eram mais rentáveis nas grandes propriedades de solos virgens das zonas novas de expansão da fronteira, circunstância que influía, pois, na mobilidade do povoamento, uma vez que se apresentava como uma possibilidade a mais de ganho para fazendeiros e sitiantes: "Há que se notar que o sistema de trabalho estabelecido no interior paulista compelia todos os agentes da vida rural à fronteira. Aos fazendeiros era de suma importância adquirir novas terras para compensar a decadência das lavouras estabelecidas nas zonas antigas. Eles também precisavam reconstituir a sua condição de agenciar um maior número de trabalhadores, vale dizer, adquirir terras para contratar trabalhadores em regime de empreitada e parceria reduzindo-se assim os custos de formação de novas lavouras ou o custo do trato das lavouras já formadas (...). Aos trabalhadores, imigrantes ou não, abria-se na fronteira um maior número de possibilidades de, mesmo que temporariamente, ter acesso a terra e a uma parcela da produção cafeeira, o que parece ter sido uma condição melhor do que a verificada pelos assalariados rurais das regiões antigas. Os trabalhadores volantes também eram dependentes do movimento da fronteira, pois lá se estabelecia a maioria das empreitadas de derrubada. $\mathrm{O}$ fato é que as relações de trabalho estabelecidas na cafeicultura paulista pressupunham a existência da fronteira, caso contrário todo o sistema se tornaria inviável.” (FALEIROS, 2007, pp. 338-339.)
} 
proprietários era fácil tolerar a presença de famílias de caboclos; em troca dessa tolerância, deviam eles instalar-se, de preferência, nos limites das glebas, das quais eram uma espécie de guardiães. A estes caboclos, desbravadores itinerantes, muito modestos, juntavam-se, não raro, pescadores, caçadores e aventureiros. Devemos considera-los os verdadeiros pioneiros? Sua ação sobre a paisagem, como a dos mineiros [criadores de gado da primeira etapa da marcha pioneira], foi praticamente nula; uns e outros, apenas derrubaram a mata. Economicamente, nada os prende ao grande movimento de expansão agrícola e comercial paulista; quando a onda de povoamento os alcança ou envolve, partem para mais longe, incapazes de se adaptar às novas condições. Estes caboclos das glebas são os últimos representantes da velha economia rural e do antigo povoamento do sertão, e não as sentinelas avançadas da marcha para o oeste, como se poderia pensar. Sua presença não implica numa valorização da floresta, no quadro econômico atual. Além do mais, os proprietários não visavam à exploração das glebas, que são para eles um emprego de capital, que renderá no futuro, isto é, quando as vias de comunicação aí chegarem, quando aumentar a densidade da população, quando os preços dos produtos agrícolas aumentarem, o que ocasionará grande procura de terras. Será então ocasião de liquidar esse capital inerte, pela divisão das terras (...). Esse fato tem importância, porque significa que a terra não desbravada, passando por diversas mãos, valoriza-se antes de ser cultivada, e esta valorização pesará na economia do pioneiro, porque é ele que por último fará as despesas de uma série de felizes especulações. (MONBEIG, 1957, pp. 112-113.)

A invisibilidade desse personagem nas análises de Monbeig, conforme já apontado por José de Souza Martins, decorre, afinal, da não consideração do processo de formação das grandes propriedades nas áreas de fronteira, pois embora o geógrafo francês realmente aponte em seu justo papel a ação de grileiros e especuladores, sua interpretação supõe o caráter privado e mercantil do processo de constituição das propriedades desde o princípio das movimentações pioneiras. Dito de outro modo, a não consideração do posseiro como um tipo social ativo do mundo pioneiro corresponde, nos escritos de Monbeig, à invisibilidade do patrimônio público de terras e à não observância da existência da frente de expansão como realidade objetiva (MARTINS, 1975; 2009), já que ao tomar como premissa que todas as terras de São Paulo tinham dono antes do início da expansão da fronteira, não se leva em consideração a extensão das terras devolutas sobre as quais foram constituídos os grandes patrimônios fundiários pelos agentes privados.

Nos artigos em que trata da caracterização sociológica da fronteira, Martins associa a interpretação geográfica sobre as frentes pioneiras, tal como esta apareceria nos trabalhos de Monbeig e Waibel, à visão que os geógrafos teriam do processo de expansão da fronteira econômica, ou seja, o que estaria em jogo, através da fundação de cidades e ferrovias, seria a modernização das novas áreas incorporadas à economia de mercado: “quando os geógrafos 
falavam de frente pioneira estavam falando de uma das faces da reprodução ampliada do capital: a sua reprodução extensiva e territorial, essencialmente mediante a conversão da terra em mercadoria e, portanto, renda capitalizada" (MARTINS, 2009, p. 137). Entretanto, como assevera o sociólogo paulista, as relações sociais que tornam singular o sistema social da zona pioneira "não constituem resultado do aparecimento da zona pioneira, mas são as relações sociais necessárias à sua implantação" (MARTINS, 1975, p. 44), isto é, embora a concepção geográfica de frente pioneira pressuponha concebê-la como um espaço de efetivação da cultura urbanoindustrial, onde novas concepções de vida são elaboradas e implantadas, a permanência de certas relações sociais não estruturadas a partir de relações com o mercado, como no caso dos posseiros, cujo horizonte da existência não é o lucro, mas a sobrevivência da família, implica considerar a fronteira como um lugar onde há a convivência de temporalidades históricas conflitantes, o que demanda a referência à existência das frentes de expansão, cujas características marcantes são a ausência da propriedade formal da terra e a formação de uma rede de trocas comerciais em que o dinheiro está quase sempre ausente: “A sobreposição da frente pioneira e da frente de expansão produz uma situação de contemporaneidade dessas relações de tempos distintos (...) as relações sociais (e de produção) na frente de expansão são predominantemente relações não capitalistas de produção mediadoras da reprodução capitalista do capital" (MARTINS, 2009, pp. 155$156)^{135}$.

\footnotetext{
135 "Se a frente pioneira se define essencialmente pela presença do capital na produção, o mesmo não ocorre, portanto, na frente de expansão, que não se constitui pela precedência do que nós definimos como econômico na constituição de seus modos de vida e da mentalidade de seus agentes. Embora sua dinâmica resulte da ação e dos interesses do capital, combinados com as concepções próprias do camponês e mesmo do índio integrado. A frente de expansão tornou-se, no fundo, o mundo residual da expansão capitalista, o que está além do território cujas terras podem ser apropriadas lucrativamente pelo capital. Explico-me: tanto Monbeig quanto Waibel mostraram claramente que na frente pioneira o capital se torna proprietário de terra, recria no terreno os mecanismos de sua reprodução ampliada. Expande-se sobre o território, de que se apossa como seu território. Essa expansão territorial traz para a própria fronteira a infraestrutura da reprodução capitalista do capital: o mercado de produtos e de força de trabalho e com ele as instituições que regulam o princípio da contratualidade das relações sociais, que é o que caracteriza a sociedade moderna. $\mathrm{O}$ mercado se constitui na mediação essencial que dá sentido ao processo de ocupação do território. A frente de expansão também é expansão de relações mercantis. Mas numa concepção inversa à da expansão da produção propriamente capitalista. As relações que na história da fronteira no Brasil têm precedido o avanço da frente pioneira propriamente dita não se caracterizam pela ação do empreendedor que expande a reprodução capitalista do capital no território novo. Antes, sua ação é no sentido de estender as relações mercantis além dos limites do território propriamente incorporado na reprodução capitalista do capital. Há um limite além do qual não é possível extrair renda capitalista da terra. Provavelmente por isso, os territórios sobre os quais se move a frente de expansão são claramente marcados pela ausência da propriedade fundiária moderna, predominando a posse efetiva ou o aforamento. A teoria da fronteira é, no meu modo de ver, basicamente um desdobramento da teoria da expansão territorial do capital." (MARTINS, 2009, pp. 156-157. Itálico do autor.)
} 
Seja como for, ainda que concordemos com esse aspecto da crítica elaborada por José de Souza Martins, principalmente no que diz respeito à caracterização da frente pioneira como uma dimensão espacial da reprodução capitalista do capital pela transformação da terra em mercadoria, processo que ocorre a partir da atuação de posseiros e derrubadores de floresta, que preparam as fazendas e permitem aos fazendeiros e especuladores auferirem lucros antes mesmo do plantio de qualquer produto, a imputação de que não haveria, nesse registro, uma preocupação latente com os conflitos que ocorriam na franja pioneira, nem sequer a identificação da diversidade de relações sociais marcadas por tempos históricos distintos que coexistem contemporaneamente, é uma redução do alcance explicativo da descrição efetuada pelos geógrafos (DANTAS, 2005), porquanto é uma constante, na obra de Monbeig, a menção a disputas entre os diferentes tipos sociais do mundo pioneiro, bem como críticas aos diversos mecanismos de coerção políticos, econômicos e culturais utilizados por aqueles que se encontravam no topo da pirâmide social.

Ademais, a permanência do latifúndio como realidade econômica e social nas regiões de expansão de fronteira mostrava que a aparente fragmentação das propriedades poderia na verdade esconder as alterações nos mecanismos através dos quais a propriedade da terra continuava a concentrar-se nas mão de poucos, pois que agora as grandes propriedades não se encontrariam necessariamente atreladas a um grande família de tradicionais fazendeiros, como antes, mas nas mãos de empresas de loteamento, sociedades anônimas que contavam com grandes somas de capital para efetuar investimentos, buscando ampliar suas possibilidades de ganho com investimentos em outros produtos, como o algodão, a cana-de-açúcar, o gado e mesmo cereais voltados para o abastecimento das cidades:

As cifras demonstram que a fragmentação extrema da propriedade cafeicultora esconde um pouco a realidade social. Não bastou o aumento do número de cafeicultores, nem a diminuição da superfície média dos cafezais para tornar democrática a estrutura social. Os números não indicam que o mesmo agricultor pode possuir muitas propriedades, pois estas podem aparecer no papel como uma fazenda qualquer, entre tantas outras. Mas, se levarmos em consideração que 3 ou 4 plantações acham-se em mãos de uma só pessoa, vê-se que, se o latifúndio não existe mais nas estatísticas, ele permanece como uma realidade econômico-social Às vezes as diferentes propriedades de um só estão situadas a grande distância umas das outras, uma na retaguarda da franja pioneira, outra mais na frente do avanço, outra em uma zona diferente. Mais frequentemente, um proprietário detém várias explorações na mesma região, às vezes em um mesmo município. Em outro local, os membros de uma família receberam parte de antiga gleba, que foi partilhada ou que lhes coube por herança e eles 
administram fazendas vizinhas. Certa dose de racionalização da cultura e da preparação industrial do café torna tudo mais fácil. Mas, se as propriedades são muito extensas, o café deixa de ser o único recurso e é completado por plantações de cana, pastagens e culturas de algodão e essa nova infraestrutura agrícola acaba transformando-se em uma organização industrial. (MONBEIG, 1984 [1952], pp. 262-263-264.)

No fim das contas, a realidade descrita por Monbeig na passagem do século XIX para o XX será muito diferente daquela observada após a crise de 1929, pois as estruturas políticas, sociais e econômicas já se haviam transformado, servindo de base para novas formas de relacionamento entre o homem e o meio e dando origem a paisagens distintas. A partir de 1930, vai se consolidando no país uma nova divisão territorial do trabalho, tal como posta pela separação entre a cidade e o campo, que se vai acentuando a reboque da industrialização. Assim, o desenvolvimento geográfico desigual produzido pela progressão da atividade capitalista passa a se exprimir nas múltiplas formas de organização do espaço pioneiro, agora não mais hegemonizado apenas pelo café, nem restrito exatamente pelos limites políticos paulistas, mas impulsionado pelas correntes de povoamento encadeadas pelas lavouras de algodão, matériaprima básica das indústrias têxteis da capital paulistana, pelos pastos que colocavam imensas áreas de Minas Gerais, Goiás e Mato Grosso na órbita da economia paulista e principalmente pela fixação das pequenas e médias propriedades policultoras, que cresciam ao arrefecer da atividade cafeeira, retalhando antigas fazendas e dando uma dinâmica renovada à franja pioneira, visto que "diferentemente dos estados americanos do sul, a franja pioneira paulista não só não precisa importar uma parte de sua alimentação, como alimenta São Paulo e vende alimentos a outros estados, além de exportar algodão e café” (MONBEIG, 1984 [1952], p. 297):

A impetuosa corrente que há três quartos de séculos conduz tanto os paulistas como os imigrantes através dos planaltos ocidentais não foi, portanto, perturbada pelos obstáculos econômicos nem pelos abalos políticos dos últimos vinte anos. Assumiu tal amplitude, que hoje se aproxima de paragens em que não tem condições de penetrar sem que perca o que lhe resta das características originais. Estas, na realidade, estão enfraquecendo. Diferentemente do que aconteceu na crise do começo do século, a catástrofe econômica de 1929 arruinou tão profundamente a economia e a sociedade paulistas, que o avanço pioneiro não pôde permanecer fiel ao café, nem o fazendeiro pôde continuar como o senhor do mundo pioneiro; não que os dois tenham sido completamente abolidos, mas tudo que havia começado a desenvolver-se em 1929 tomaria novos contornos. Homens e paisagens diversificaram-se. Talvez estejamos em face da elaboração de uma nova marcha que, rejeitando definitivamente tudo o que data da idade áurea do café, será capaz de penetrar mais longe, na direção do Brasil Meridional e, mais em frente, até o Brasil Central. Criadores de gado e pequenos 
proprietários serão, talvez, os continuadores dos grandes fazendeiros do café. (MONBEIG, 1984 [1952], pp. 207-208.)

Somos tentados a escrever que houve ruptura entre a agricultura e as finanças. A primeira é, cada vez mais, atividade de gente modesta, e, em menor escala, de grandes fazendeiros. A potencialidade financeira, se não escapou completamente dos ricos fazendeiros-comerciantes, tornou-se cada vez mais anônima. Pertence a esse tipo de organizações que controlam tudo e não produzem nada. É mais lucrativo para as grandes empresas transportar, comerciar e financiar, do que plantar. Deixou-se a agricultura com suas incertezas aos fazendeiros obstinados e aos sitiantes. Elas conservaram, agrupados, todos os meios de controle. As relações sociais encontram-se modificadas (...). O fazendeiro clássico tinha sua clientela, que levava nas suas migrações nem tudo desapareceu nas relações pessoais entre eles e seus colonos. Mas entre o sitiante e o gerente de um loteamento, o caráter das relações não pode ser o mesmo. O paternalismo do "patrão" para com seu "cliente" passou a ser substituído pelas relações d negócios do modesto sitiante com o comerciante e o industrial. Pode-se ver nessas transformações uma emancipação dos menos afortunados. Não é certo, entretanto, que eles tenham ganho muito com a troca da dependência em que estavam com relação ao fazendeiro e o controle de um credor ou o anonimato diante de uma empresa poderosa. Vender terras tornou-se, assim, fonte de recursos menos incerta e mais rendosa. Para que o negócio seja lucrativo, é preciso organizar o espaço; e as empresas de colonização estão melhor equipadas para o fazer. Trabalhos preparatórios para o povoamento, comércio da terra virgem e presença de grandes grupos capitalistas são os traços que conferem à franja pioneira paulista sua originalidade atual e marcam a ruptura com os tempos dos fazendeiros. (Ibidem, pp. 240-241).

Em resumo, vemos que o desenvolvimento geograficamente desigual engendrado nas franjas pioneiras envolve, por um lado, a existência de um surto agrícola lastreado por um produto comercial de grande penetração no mercado, e por outro lado, o desenvolvimento de centros urbanos pensados como lugares de atração da produção agrícola, uma vez que os fazendeiros-empresários, como normalmente acontecia, eram também loteadores urbanos. Para alavancar seus negócios e atrair os seus clientes (pequenos, médios ou grandes lavradores, comerciantes, profissionais liberais e demais partícipes da febre pioneira), esses empresários rurais investiam nas instalações industriais aptas a receber, em cada uma das cidades pioneiras, a produção agrícola, atraindo para sua esfera de influência a pauta produtiva semelhante que se estende por todas as zonas produtivas. Logo, o desenvolvimento rural supõe o estabelecimento urbano, pois a realização da produção agrícola é mediada pelas cidades, que exercem o papel de centros de beneficiamento e carreamento de mercadorias, polarizam as áreas rurais e colocam o fruto de sua produção no circuito de reprodução ampliada do capital. Essa complementaridade entre o desenvolvimento industrial das cidades e a ampliação dos desbravamentos rurais existente nos planaltos ocidentais, alia um desenvolvimento capitalista que contava com financiamento 
estrangeiro com o estreitamento dos laços de dependência entre as zonas pioneiras e os centros urbanos de comando das atividades econômicas, desenvolvendo nexos de solidariedade territorial que revelam a possibilidade de haver uma transferência geográfica de valor (SOJA, 1989):

O algodão das zonas novas assegura a movimentação das indústrias da capital. A rede de máquinas de descaroçar foi progressivamente estendida até os patrimônios mais recentes. Praticamente, os maquinistas estão sob dependência de grandes empresas nacionais ou estrangeiras, porque ou são simples gerentes de estabelecimentos pertencentes a essas firmas, ou são seus devedores. Como são eles os grandes distribuidores de créditos aos sitiantes, afinal de contas toda a produção algodoeira cai sob o controle de algumas empresas possantes que, por outro lado, são detentoras de uma boa parte das indústrias conexas e são donas do comércio de exportação (...). A superestrutura capitalista está melhor organizada quando se trata da jovem cultura algodoeira, do que quando se relaciona com a tradicional cultura cafeeira. Instalou-se solidamente, para que o algodão possa contar, daí para frente, com a mesma proteção existente para o café. (MONBEIG, 1984 [1952], pp. 300-301.)

Até há pouco tempo, as companhias estrangeiras eram as únicas donas dos matadouros que alimentam São Paulo, o que significa que sua atividade não se limitava só à indústria da carne e que elas faziam considerável movimento comercial interno. Como, praticamente, são os únicos grandes compradores, exercem uma ação determinante sobre os preços e podem restringir ou aumentar as compras junto aos criadores independentes, em função do estado das suas próprias pastagens. Tal controle estrangeiro, ao que parece, têm tido maior repercussão do que as queixas dos sitiantes de algodão diante da ação das empresas norte-americanas. O sindicato dos invernistas é uma força política poderosa, mas igualmente poderosos são os frigoríficos estrangeiros. Esta estrutura capitalista, que também é causa da renovação da criação na franja pioneira, não tem muito em comum com a velha sociedade patriarcal dos criadores antigos. Ela facilitou as coisas, mas difícil é reconhecer nos invernistas atuais o mesmo valor dos que os precederam, Os de hoje, na retaguarda dos desbravamentos, ocupam o lugar de sitiantes que partiram para terras mais novas. (Ibidem, p. 314.)

Em ambos os trechos citados, que descrevem a disposição organizacional do cultivo do algodão e da produção pecuária, diretamente comandados por empresas estrangeiras que se utilizavam de seus prepostos em território nacional para exercer sua hegemonia, conferindo um caráter industrial a ambos os setores de produção, pode-se perceber de que maneira os mecanismos de transferência geográfica de valor, que dizem respeito à mobilidade ou circulação de uma quantidade de valor produzido que não se fixa localmente (MORAES, 2011), estão na base de um conjunto de processos que se articulam também aos fenômenos atinentes à fixação geográfica do valor (MORAES, 1994), embasando assim a formação de regiões heterogêneas na franja pioneira. Na realidade, os mecanismos de transferência geográfica de valor, que se formam a partir de um sistema de trocas desiguais, estruturam-se a partir de redes comerciais formadas 
por meio dos círculos de cooperação estabelecidos entre grupos localizados em diferentes pontos do território nacional, agindo de forma preponderante na organização das paisagens pioneiras entre as décadas de 1940 e 1950. De fato, como o início do processo de unificação do mercado nacional, catalisado após 1930 a partir do aumento da complementaridade inter-regional, apresenta uma estreita relação com o padrão de ocupação econômica do território e a consolidação do parque industrial paulista, este processo acaba por influenciar na constituição de uma hierarquia entre diferentes pedaços do território que se expressa em relações do tipo centroperiferia, detalhe sobremaneira importante na análise do processo de formação das regiões qualificadas como de expansão de fronteira ${ }^{136}$. Por isso, a análise integrada dos conjuntos de processos de fixação e transferência geográfica de valor é de fundamental importância para a compreensão de como os nexos de solidariedade espacial fortalecidos em circuitos de produção, circulação, distribuição e consumo são originados numa relação complementar entre fixos e fluxos (SANTOS, 1988).

No caso, a expansão do povoamento e da colonização na franja pioneira paulista, responsável pela formação de campos de cultivo, pastos, uma rede de cidades e de uma infraestrutura de caminhos, manifestações territorializadas da fixação geográfica de valor, engendrou um sistema de trocas que punha áreas mais ou menos amplas polarizadas por cada uma das capitais regionais em relação com a metrópole paulistana e seu porto de escoamento, circunstância que, pela ação dos bancos e casas de crédito que atuavam em São Paulo e em Santos, acabava por mediar os contatos de subordinação das zonas pioneiras do Brasil com o mundo. A dinâmica própria das trocas comerciais encetadas nos planaltos ocidentais e no norte do Paraná, que envolviam gêneros de abastecimento e produtos industrializados voltados para o mercado interno, e produtos tropicais de exportação que demandavam o mercado internacional,

\footnotetext{
136 "De um ponto de vista geoeconômico uma região periférica caracteriza-se por seu território produzir para o exterior do qual depende em termos de mercado polarizador: a região central. Em vista dessa dependência, região periférica e região central são contrapartidas de uma mesma condição geoeconômica. O que acentua o caráter periférico da região é a não-existência de um forte espaço de produção próprio e autônomo, sendo cronicamente deficiente a acumulação de capital que é continuamente drenado para fora. O processo de geração desta situação está relacionado ao tipo de divisão territorial de trabalho que se estabelece a partir da região central. O desenvolvimento ou crescimento produzidos nessas circunstâncias promovem modificações estruturais nos espaços de produção, circulação e consumo, privilegiando os dois últimos em detrimento do primeiro. Como a região possui inerentemente características de organização, dadas geoeconomicamente, a condição periférica representa uma situação repetitiva de distorções (...). Nesse caso, a região desenvolve-se ou cresce de tal modo que o espaço homogêneo ou o espaço polarizado - que se organiza através de funções e serviços vindos de fora - não coincidem senão eventualmente. Além disso, o espaço urbano, onde se localizam os poderes de decisão, possui sua própria região geoeconômica, mas subordinada à região geoeconômica comandada pela região central.” (SILVA, 1978, p. 118.)
} 
estabeleceu uma divisão territorial do trabalho - expressão da existência de uma hierarquia entre os lugares - que parece mesmo fundamentar o esboço de um processo de circulação de riquezas bem próximo de uma transferência geográfica de valor entre as capitais regionais, as localidades por ela influenciadas e a capital paulista.

Sendo assim, é necessário reconhecer que o objeto específico do estudo de Monbeig não é exatamente a frente pioneira, mas as paisagens humanas surgidas com o avanço das correntes de povoamento que acompanhavam a expansão da cultura do café e algodão, uma vez que a apropriação e a exploração de terras com fins meramente especulativos, quando não eram bem sucedidas em fixar os colonos nas terras desbravadas, não criaria paisagens duradouras: é o arraigamento dos grupos humanos nos novos espaço que fornece, ao final, as bases para a construção da nova organização espacial do mundo pioneiro, uma vez que o estabelecimento de núcleos fixos de povoamento implica também a fixação de parte do valor socialmente produzido na forma de próteses territoriais. Por conseguinte, pode-se dizer que Monbeig está preocupado em observar de que modo a fixidez e a fluidez (ou o movimento) se combinam na franja pioneira, dando origem a paisagens humanas que expressam novos conteúdos a cada momento. $\mathrm{O}$ complexo geográfico da franja pioneira, resultado da ação de uma sociedade em movimento, define-se então pela mobilidade, mas realiza-se plenamente pelo intermédio das formas espaciais imobilizadas na paisagem em tempos distintos. Por isso dizemos que Monbeig percebia esse processo em seus aspectos sincrônicos e diacrônicos, pois ele sublinhava o movimento contínuo de expansão demográfica e econômica que se retroalimentava da construção de cidades, estradas e campos de cultivo, as marcas legadas pelos grupos humanos nas paisagens.

Ademais, ao descrever o processo de formação de regiões ligadas à uma rede de cidades e caminhos, mostrando de que maneira as distintas localidades da franja pioneira paulista reproduzem um relacionamento do tipo centro-periferia em variadas escalas, Monbeig parece exemplificar o padrão espacial de desenvolvimento atrelado à via colonial de expansão do capitalismo em nosso país. Realmente, Antônio Carlos Robert Moraes (2011) já havia notado que os chamados ciclos econômicos expressam bem o mecanismo de estruturação dos espaços periféricos, visto que a expansão do cultivo do café ou do algodão, por exemplo, compõe como que um mosaico de assentamentos produtivos que parece migrar dentro do território, manifestando uma espacialidade própria associada a sistemas de engenharia que tornam determinadas localizações privilegiadas para a circulação, que se orienta para fora, como uma 
verdadeira bacia de drenagem. Sendo assim, as etapas de evolução dos centros pioneiros instáveis e transitórios, que normalmente vivenciavam períodos de fausto e riqueza seguidos de longos anos de decadência e involução das relações econômicas, parecem demonstrar, em certos aspectos, o acerto do enquadramento da situação periférica sugerido por Armando Corrêa da Silva (1978) num texto hoje esquecido dos geógrafos: "desde sua origem e evolução uma região periférica tende necessariamente a passar pelas condições de isolamento, marginalização e complementaridade." (SILVA, 1978, p. 119). Dessa maneira, cada centro pioneiro saía de sua condição de isolamento ao se desenvolver e colocar outras áreas sob sua esfera de influência, passando, pois, à funcionar como uma região marginal ou complementar a depender das necessidades e ritmos da economia dos lugares centrais, que condicionaria em grande medida o nível de desenvolvimento dos espaços incorporados ${ }^{137}$.

De todo modo, podemos verificar, no conjunto de textos que reúne seus estudos sobre o tema, a recusa de Monbeig em utilizar o conceito de "região" para se referir à área por onde passaram, desde o século XIX, as movimentações pioneiras. Mesmo reconhecendo as dificuldades de delimitação da superfície terrestre onde ocorria a expansão das fronteiras, em seu doutoramento, talvez por imposição dos rituais de exposição de uma tese, diz que a franja pioneira paulista se estendia do reverso das cuestas da depressão periférica, a leste, até as bordas do rio Paraná, na fronteira com o Mato Grosso (hoje do Sul), a oeste, e do rio Grande mineiro, ao norte, ao conjunto de serras e planaltos paranaenses além do rio Paranapanema, ao sul. Partindo dessa grande unidade natural, que guardava bem ou mal uma certa homogeneidade climática, de vegetação e relevo, sendo uma área de transição entre o Brasil tropical e a faixa subtropical do Brasil meridional, preferia utilizar-se então da noção de “zona", presa ao uso econômico dado a um grupo humano para uma dada área, ou mesmo o termo mais amplo de "faixa", que servia para

\footnotetext{
137 “Em relação ao polo a região isolada não tem importância econômica. Daí a existência de fluxos exteriores à região e que não a alcançam. O crescimento populacional é vegetativo. As comunicações para fora são intermitentes e tendem a auto-anular-se. Os contatos externos são difíceis e esporádicos. A marginalização é uma condição transitória e instável. Ela pode ocorrer se a região isolada encontra possibilidades próprias de expansão - o que é sempre dificultado pela existência da região central - ou se, o que é mais comum, a região central, em sua expansão, alcança a região isolada. É decisiva, nesse caso, a abertura prévia de comunicações intra-regionais ligando o centro à periferia. Com as comunicações surge o enclave, o que determina a natureza dos fluxos e os tipos de carga em trânsito (...). A região marginal define-se como complementar quando a região central alcança a periferia de modo decisivo. $\mathrm{O}$ enclave deixa de ser uma unidade econômica para tornar-se um sistema econômico (...). No limite a região complementar torna-se uma unidade da região central sem perder, contudo, a condição periférica.” (SILVA, 1978, pp. 121-122/124.)
} 
qualificar tanto as áreas já devastadas e apropriadas pelos grupos humanos, quanto as áreas florestais deixadas intocadas na retaguarda do avanço pioneiro para uma ocupação futura.

De fato, como se pode depreender da leitura de seus textos, haveria no estado de São Paulo diferentes regiões em processo de formação dentro dos limites da zona pioneira como um todo. Pondo em relação os termos utilizados, teríamos o uso das noções de "zona" ou "faixa" pioneira para designar o conjunto de lugares onde o fenômeno pioneiro se realiza, isto é, para qualificar as áreas onde os desbravamentos e a exploração produtiva do solo se desenrolam. Nesse caso, uma colonização stricto sensu só ocorreria, como já dissemos, se houvesse a fixação dos trabalhadores na terra. Caso contrário, teríamos apenas o aumento da exploração especulativa do solo, visto que a "zona pioneira" seria unificada exatamente pelo impulso da colonização que qualifica decisivamente suas "paisagens" pela provisoriedade dos "desbravamentos". Internamente a este conjunto maior, encontraríamos distintas "regiões", cada qual em um estágio inicial de formação e integrada à sua "capital regional", normalmente o centro urbano de animação principal das atividades econômicas, como Araçatuba, Rio Preto, Marília, Presidente Prudente ou Londrina, entre muitos outros.

Uma outra consequência desse modo de qualificar a expansão do povoamento da sociedade pioneira paulista, que tenta acompanhar o processo de formação de uma região a partir da observação de momentos diversos da conquista de novas áreas por uma sociedade em movimento, é a possibilidade de uma cidade ou localidade perder seus status de pioneira, como Ribeirão Preto, por exemplo, principal núcleo urbano a polarizar a conquista do oeste paulista no final do XIX, mas que no momento em que Monbeig escrevia seu doutorado, na década de 1940, não poderia mais ser tida como uma cidade pioneira. Conclui-se disso que a condição de estar pioneira refere-se, pois, a algo transitório, parecendo mesmo ligar-se mais à perenidade dos núcleos de povoamento em formação: surpreender o histórico da ocupação produtiva e definitiva de parcelas do solo, tomada da natureza pelos grupos humanos, equivale então a identificar o processo de formação de uma paisagem humanizada pelo uso de metáforas organicistas, pois o que se discute é exatamente a maturidade do povoamento de determinadas regiões contrapostas à juventude ou à senilidade de outras. A condição pioneira é pois efêmera, assim como a sociedade que lhe dá origem.

As frentes pioneiras se põem, portanto, como um momento do processo de ocupação e conquista da natureza, uma etapa de instabilidade a ser superada pela consolidação das relações 
sociais entabuladas e pela fixação dos grupos humanos na terra, que expressaria, afinal, a consecução de um equilíbrio na relação homem-meio. Sendo, pois, moldada no processo de apropriação e conquista da natureza pelos grupos humanos, a homogeneidade regional das diversas zonas pioneiras, que é o que autorizaria, em última instância, a possibilidade de se indicar a existência de regiões internamente ao conjunto da franja pioneira paulista, expressaria a combinação complexa de uma miríade de fatores, sendo possível, a partir do destaque conferido a um fator específico, como a história, a rede de cidades e caminhos ou a economia, identificar a existência de regiões humanas em formação.

Ao fim e ao cabo, como já tivemos oportunidade de afirmar no capítulo anterior, a concepção de região desenvolvida por Pierre Monbeig em suas análises do fenômeno pioneiro coloca em primeiro plano a preponderância dos fatores econômicos na definição dos distintos setores territorialmente separados. Sendo assim, a fundação das cidades e a construção das vias de comunicação, influindo no funcionamento da economia, adquirem papel fundamental na apreciação das regiões humanas em processo de formação que observa no Brasil, mesmo que não expressem a contento a formação de uma região exatamente conforme constava nos manuais da geografia francesa, nos quais o sentimento de pertencimento regional próprio aos termos pays e paysage davam suporte à existência de gêneros de vida típicos, resultantes de um longo processo de conquista da natureza pelos grupos humanos.

Com efeito, desde seus primeiros escritos sobre o tema, Monbeig afirmava que, para os paulistas, os únicos nomes de região popularmente utilizados e conhecidos eram os das estradas de ferro: "Assim a 'Noroeste' designa, em linguagem comum, tanto a Estrada de Ferro Noroeste que liga São Paulo a Mato Grosso como o conjunto dos municípios servidos pela estrada" (MONBEIG, 1940, p. 23). Desse modo, após ter estudado diretamente no terreno um dos mais céleres processos de conquista de terras pelos grupos humanos ocorridos no Brasil, Monbeig questiona, no último capítulo do livro Pioneiros e Plantadores, não por acaso intitulado "Regiões ou redes de comunicação", se a ação humana que modificou as paisagens nos planaltos ocidentais do oeste paulista e do norte paranaense conseguiu formar unidades regionais reconhecíveis e observáveis no terreno. Já se teria estabelecido ali, nos lugares onde o desbravamento arrefecera e o povoamento estabilizara, um sentido de pertencimento comparável ao das regiões francesas?

Analisando um a um o fatores que em hipótese poderiam ensejar a criação de uma região bem ou mal homogênea, tais como a origem étnica dos muitos imigrantes que habitavam as 
diferentes zonas pioneiras, que facilitaria a formação de uma unidade cultural entre grupos mais ou menos numerosos, ou então a habitação dos pioneiros, "expressão do meio e do gênero de vida" (MONBEIG, 1984 [1952], p. 380), o autor volta a apontar a grande confusão e similaridades existentes entre as realidades da Alta Sorocabana, da Alta Paulista ou da zona de Londrina, por exemplo, concluindo que, para além de qualquer dúvida, os centros vitais de cada uma das "regiões" cujos nomes provêm diretamente das companhias de estradas de ferro constituem-se em uma referência mais próxima para os habitantes de cada uma dessas cidades, visto que estes se mostram mais ligados à suas realidades municipais efetivas, ou, no máximo, ao espigão rodoferroviário que os une a outras localidades num dado planalto, do que às regiões tais como entendidas no mundo europeu:

Terra sem passado, não viu ainda a franja pioneira desabrocharem regiões, mas está dividida em redes de comunicação e essa divisão, que se apoia na topografia, será talvez o germe das regiões vindouras. Criam os trilhos a unidade, porque asseguram o escoamento da produção e porque o sucesso individual, tanto quanto o das empresas colonizadoras, depende da expedição fácil, contínua e regular dessa produção (...). Até hoje é mais exato falar em regiões ferroviárias, que em regiões geográficas ou econômicas da franja pioneira. Fixar os limites dessas regiões é praticamente impossível. Ilude o paralelismo entre as grandes linhas do relevo e o traçado das ferrovias (...). As ferrovias teriam, pois, transformado cada planalto numa espécie de bacia da qual são elas as artérias mestras, ao passo que as estradas de rodagem, lateralmente construídas, são como afluentes que asseguram a drenagem. Desenham a rede de trilhos e os caminhos, que as completam, uma rede hidrográfica invertida. (MONBEIG, 1984 [1952], p. 385.)

Como é facilmente perceptível, a questão da integração territorial, viabilizada pelos caminhos, estruturou uma rede de relações hierarquizadas na qual a produção e a circulação, demandando inicialmente as capitais regionais, centros locais de atração, direcionavam-se invariavelmente para a capital, cujos tentáculos faziam-se sentir até em áreas muito distantes, concentrando em sua esfera de controle e influência tanto o comércio interno, seja de gêneros alimentícios ou de matérias-primas de origem agrária produzidos na fronteira, que buscavam o crescente parque industrial ou o mercado de sua população sempre em vias de aumentar, quanto o comércio de exportação, que São Paulo monopolizava por sua atuação conjunta com o porto de Santos. Essa situação, por sua vez, dificultava o surgimento de quadros regionais fixos dentro da área de atuação de cada uma das ferrovias, visto que as disputas entre as diferentes companhias deixava a extensão da área de influência de cada uma das empresas de estradas de ferro como uma função de uma série de fatores, como a distância de seus terminais em relação à capital e 
Santos, a capacidade de transporte dos trens e a organização técnica dos armazéns e postos de estocagem, que influíam mais do que a topografia ou mesmo a legislação no sucesso pela conquista do privilégio de exploração de uma determinada área:

As constantes modificações nessas margens rodoviárias não favorecem o desenvolvimento de sentimentos regionais na massa da população pioneira. Os frequentes deslocamentos dos indivíduos retardam a eclosão desses sentimentos, que são mais prejudicados ainda pela ausência dos quadros regionais. Agora, o sentimento de pertencer a uma região, o desejo de fixar-se nela, de enraizar nela a família, a emulação que o espírito regional pode desencadear, não passam de noções confusas. O pequeno pioneiro passa da tentação dos grandes espaços ao orgulho municipal. Só para os fazendeiros e os comerciantes, cujos interesses materiais os tornam solidários com a ferrovia, são providos de sentidos os nomes de regiões. Estão eles em relações constantes com a estrada de ferro: pedem-lhe melhores tarifas, vagões mais numerosos, horários mais cômodos; seguem com atenção os progressos dela, que são também os deles. Deve-se reconhecer que tudo isso era muito distante para o sitiante. Fica-se inclinado a ver no sentimento regional, tal como se manifesta atualmente a expressão de interesses comuns de classe. Nada há que incita o sitiante à solidariedade regional, pois a sua fixação é temporária e os interesses, como as dívidas, são de curto prazo. (MONBEIG, 1984 [1952], p. 387.)

Nesse excerto, a identificação do único sentimento regional intuído nas zonas pioneiras com um sentimento de classe comum apenas entre fazendeiros e comerciantes é bem representativa do caráter mercantil da expansão pioneira a que fizemos alusão linhas atrás. Compreendida como uma modalidade da expansão territorial do capital, a frente pioneira, conforme o indicado aqui por Monbeig, realmente tornaria solidários os principais agentes dessa expansão: os fazendeiros, grandes comerciantes e negociantes de terras, que veriam na fundação das cidades, na construção de ferrovias e rodovias e na exploração dos solos a formação de um traço comum a unificar todas as zonas, a saber, o desejo do enriquecimento rápido e do lucro imediato. A diferenciação entre os interesses de fazendeiros e comerciantes com a realidade dos pequenos pioneiros e sitiantes, contudo, mostra novamente a fixação dos grupos humanos nos terrenos como a questão básica a ser resolvida para a estabilização do povoamento do mundo pioneiro.

As ideias conjuntas de harmonia e adaptação aos meios naturais, intrínsecas ao entendimento do gênero de vida nos escritos de Vidal de La Blache, colocam-se aqui num arranjo explicativo sugestivo, indicando que numa sociedade em movimento, em que tudo é itinerante e provisório, a dificuldade em se forjar uma identidade regional próxima daquela já descrita nas campanhas francesas acompanha as dificuldades encontradas pelos grupos sociais para se 
manterem enraizados num dado espaço. Contudo, o "orgulho municipal" a que Monbeig alude, ainda que não possa ser tomado como a base para a formação de regiões, demonstra as possibilidades colocadas pelas formas mais estáveis de ocupação do solo. 


\title{
CAPÍTULO IV
}

\section{A GEOGRAFIA FRANCESA FAZ ESCOLA}

\begin{abstract}
"Incursionando em um campo comum às Ciências Naturais e do Homem, a posição original do geógrafo consiste em colocar nas suas relações espaciais os problemas do complexo físico, biológico e humano. Dentro da unidade do conhecimento, as investigações geográficas, descrevendo e explicando as múltiplas combinações da realidade terrestre, voltam-se para as associações de elementos que caracterizam os meios geográficos. Nesse sentido é que se destaca uma Geografia do Homem, habitante da superfície do planeta, que a está submetendo com sua prodigiosa disseminação e com capacidade ilimitada de criar. Não se trata de sobrepor os homens e as suas atividades, materiais e espirituais, a uma Geografia Física, atuante ou passiva, nem de reconhecer nos grupos humanos condições de ação ou virtualidades no meio natural. Mas, inegavelmente, aos fatos humanos associam-se complexos fatores terrestres, que merecem ser interpretados por uma ciência geográfica que não separe o natural do humano".
\end{abstract}

Ary França

\section{Introdução}

Tendo como pano de fundo o tema da formação do território brasileiro, acompanhamos ao longo deste trabalho a trajetória de construção da noção de frente pioneira nos escritos de Pierre Monbeig. De fato, reconhecendo que o uso de conceitos e imagens espaciais era comum no ambiente intelectual brasileiro das décadas de 1930 e 1940, tentamos identificar o processo de construção de um discurso coeso internamente ao campo geográfico, ou seja, por meio de uma análise direta da obra do geógrafo francês, buscou-se rastrear a estruturação de uma explicação especificamente geográfica para questões fundamentais que então se colocavam para o país, como o debate sobre o desenvolvimento econômico, o problema do povoamento e colonização de áreas até então pouco ou nada ocupadas e a necessidade estratégica de integração das afastadas regiões que compunham o território brasileiro. Por meio de seus trabalhos, Monbeig oferece descrições explicativas para muitos desses temas, revelando de maneira consistente o modo como a geografia acadêmica poderia participar das discussões então colocadas pelo pensamento político-social $^{138}$.

\footnotetext{
${ }^{138}$ Em um texto escrito no início da década de 1990, Marcelo Escolar (1996) faz uma resenha exaustiva das interpretações e alternativas historiográficas existentes para se contar a história da geografia, localizando e qualificando a distinção existente entre os enfoques "internalista" e "externalista" do campo disciplinar no quadro mais amplo do debate que trata da história das ciências em geral. Comentando as interpretações e principais trabalhos até então produzidos, o geógrafo argentino oferece também um possível caminho a ser seguido, propondo uma história social da geografia, modalidade analítica que visa privilegiar a gênese do contexto de justificação epistemológica do discurso geográfico sem partir de uma evidência institucional prévia. Para uma discussão recente
} 
No presente capítulo, que servirá igualmente como uma conclusão, iremos localizar os aspectos mais representativos do enquadramento proposto por Monbeig nas obras de seus discípulos brasileiros, conferindo uma atenção especial para a) a valorização da história e das temporalidades na construção da interpretação geográfica do real; b) a importância das técnicas e do nível de civilização dos grupos humanos na estruturação e organização das paisagens; c) a necessidade de se efetuar uma pesquisa de campo, validando as hipóteses elaboradas em gabinete com observações efetuadas no terreno; e d) o papel das vias de comunicação e da integração territorial para a consecução de um desenvolvimento econômico capaz de impulsionar alterações substanciais na configuração espacial das áreas analisadas.

Especificamente, ao mapear as semelhanças e diferenças existentes entre os autores, mostrando os círculos de afinidade e filiações intelectuais (BERDOULAY, 1981) que permitem diferenciar a contribuição de cada um frente ao grupo como um todo, buscamos avaliar de que maneira os pressupostos contidos na noção de franja pioneira direcionaram o olhar da primeira geração de geógrafos universitários formada em São Paulo na feitura de seus trabalhos de doutoramento. A bem dizer, considera-se que a concepção do pioneirismo, entendida como um dos principais vetores da modernidade no território brasileiro, forneceu um parâmetro avaliativo para o processo de formação territorial de São Paulo, originando a produção de obras que apresentam certos denominadores comuns, identificáveis, por exemplo, nas escolhas temáticas, nos procedimentos de pesquisa, no vocabulário teórico semelhante e no arcabouço metodológico de sotaque francês, características que acabam por conferir aos trabalhos de Ary França, Nice Lecocq Müller, Renato da Silveira Mendes, José Ribeiro de Araújo Filho e Pasquale Petrone um indiscutível "ar de família”, perceptível, ademais, pela circunstância de a maior parte deles preocupar-se com questões atinentes ao mundo rural.

A propósito, tendo em conta que a atividade econômica era considerada o principal móvel do processo de apropriação e consequente transformação dos meios naturais em paisagens culturais modernas, pretende-se demonstrar tanto quanto possível a influência do modo de fazer geografia legado por Monbeig na prática científica daqueles que frequentaram seus cursos e participaram das excursões de campo por ele comandadas, compartilhando dos termos gerais presentes em sua concepção de geografia mesmo após terem assumido posições institucionais de

dos caminhos historiográficos trilhados pelos que se aventuram a contar a história da geografia, vide o excelente artigo de Nilson Crocia de Barros (2006). 
relevo na Universidade de São Paulo. Na verdade, desenvolve-se aqui a hipótese de que ao tomar o fenômeno do pioneirismo como um parâmetro de regionalização para o estado de São Paulo, os geógrafos paulistas construíram um indicador palpável para avaliar o nível de desenvolvimento dos lugares, visto que era então comum examinar o atraso ou o avanço das paisagens paulistas tendo-se como referencial a herança exercida pela ação ou pela ausência dos fatores que acompanhavam o crescimento da atividade cafeeira. Nesse caso, a caracterização de uma região como dinâmica ou decadente, termos que diziam respeito à prosperidade das atividades econômicas desenvolvidas em cada área, ou mesmo a sempre lembrada oposição que se fazia entre as "zonas novas" e as "zonas velhas", qualificação utilizada para se referir às correntes de povoamento, são critérios de diferenciação de áreas que somente ganham sentido se se leva em conta o início da colonização engendrada em São Paulo pela expansão das lavouras de café e algodão, pois uma área seria considerada dinâmica ou decadente sempre em relação às zonas pioneiras que apresentavam maiores níveis de produtividade, assim como o povoamento só poderia ser visto como recente ou antigo tendo-se no horizonte o início do afluxo das levas de migrantes estrangeiros e nacionais ocupados com a abertura das frentes pioneiras.

Isso quer dizer que uma região como a do vale do rio Paraíba, imemorial área de passagem entre São Paulo, Rio de Janeiro e Minas Gerais, que havia sido a primeira e assistir à marcha dos cafezais no início do século XIX, podia sem problemas ser considerada uma região de povoamento antigo que apresentava sinais de decadência após o esgotamento dos solos causado por uma cultura de uso intensivo de recursos naturais, com a involução das atividades econômicas e a fuga dos habitantes para outras áreas. Nesse registro, as paisagens organizadas quando da época áurea do ciclo cafeeiro, com seus casarões, fazendas, benfeitorias e antigos campos de cultivo, apareceriam num momento seguinte como paisagens residuais, que ostentavam um claro aspecto de abandono e regressão das atividades. Não obstante, a partir da década de 1950, com o desenvolvimento da indústria, a urbanização das capitais paulista e fluminense e a construção da nova estrada de rodagem, houve uma recuperação econômica e demográfica de muitas das cidades que já haviam sido alcunhadas de "mortas" no início do século XX, o que deu início a um processo de reaproveitamento dessas antigas paisagens, que foram refuncionalizadas a partir das novas demandas colocadas por uma estrutura social, política e econômica diferentes e puderam "rejuvenescer", modificando as relações estabelecidas entre o meio geográfico e os grupos humanos. Como se pode perceber, esse tipo de arranjo explicativo, 
fundamentado nos tradicionais inquéritos de campo, consegue integrar numa mesma chave os elementos antes descritos como os mais representativos do enquadramento proposto por Monbeig, tais como a valorização das temporalidades e das técnicas na organização das paisagens humanas, a importância das técnicas e o protagonismo das vias de comunicação para a integração do território. Expressivamente, logo no primeiro texto que Monbeig escreveu sobre a zona pioneira de São Paulo, em 1937, o geógrafo francês dá uma contundente mostra da sensibilidade historiográfica que permeava a sua geografia, indicando como seu o entendimento do fenômeno do pioneirismo podia ser aplicado como um parâmetro de avaliação para se compreender as modificações que ocorriam em outras localidades:

Com efeito, se a zona fronteiriça onde, pela primeira vez, o homem tenta implantar suas culturas é nitidamente definida no norte do Paraná, ao longo da Sorocabana, a partir de Presidente e em redor, como para além de Marília, o termo zona pioneira poderia ser usado por muitas outras regiões paulistas: acompanhando o litoral, que foi o centro de povoamento na época colonial, mas que tinha adormecido, aparentemente para sempre, assiste-se hoje a uma retomada de posse do solo, ou, como seria mais certo escrever, uma tomada de posse do solo, porque a floresta cobriu inteiramente os antigos cafezais e plantações de cana; na costa norte, perto de São Sebastião, uma imensa plantação de frutas foi feita às expensas dos mangues, assim como no sul do estado; na costa meridional, a colonização japonesa faz reviver um dos antigos focos de colonização portuguesa. O vale do Paraíba, que foi a primeira grande zona cafeeira do estado, que se despovoou durante meio século, está de novo valorizado, quer pela criação, quer pelos arrozais, quer pelas plantações de laranjas, e suas cidades mortas ressuscitam. (MONBEIG, 1940, pp. 51-51.)

Seja como for, de maneira idêntica ao que ocorria na maior parte dos trabalhos inspirados no modelo regional cunhado por Albert Demangeon e Raoul Blanchard, também nas teses de doutoramento dos geógrafos brasileiros a ordem de exposição dos assuntos seguia a sequência básica quadro natural, história, homens e atividades, generalizada para praticamente toda a produção geográfica brasileira acerca do mundo agrário nas décadas de 1940 e 1950, período definido por Darlene Ferreira como os "anos dourados" da geografia agrária brasileira (FERREIRA, 2002). Iniciando-se pela descrição do sítio, com atenção à caracterização do meio natural em suas principais linhas, ou seja, pelas formas de relevo, pelo tipo da vegetação e pelo clima predominante, fatores que ajudariam a delimitar o espaço-objeto do qual se vai falar mais a fundo, seguiam-se observações sobre o histórico do povoamento, o que era feito por meio dos relatos de viajantes estrangeiros ou nacionais que visitaram o país ao longo do século XIX e com o recurso dos raros documentos estatísticos e cartográficos existentes. Neste capítulo sobre o povoamento antigo, era comum incluir referências sobre as rotas de desbravamento e os primevos 
núcleos fixos de população, tidos como os responsáveis pela abertura da região incorporada ao domínio dos grupos humanos. Após a reconstrução do processo de conquista dos meios naturais pelos grupos humanos, que podia também comportar indicações acerca dos ciclos econômicos mais importantes desenvolvidos na área analisada, desembocava-se na análise da evolução das paisagens, o que era feito sobretudo através da apreciação do estágio atual da economia regional, avaliando-se a situação da localidade escolhida em relação à circulação, pois isso influenciaria sobremaneira o nível da produção e o alcance da comercialização dos principais gêneros agrícolas ou industriais regionalmente considerados. Por fim, ao tratar dos aspectos mais próximos da geografia humana, era inescapável também fazer indicações sobre a estrutura agrária e o habitat, o que incluía avaliações sobre os tipos de habitação e indicações acerca da relação estabelecida entre as moradias e os gêneros de vida locais.

Nesse detalhe, urge notar que a identificação dos chamados "tipos tradicionais" que cada autor observa em sua área de estudos com as formas singulares de gênero de vida que se teriam desenvolvido ao longo dos séculos de colonização pelos quais passaram os trópicos brasileiros, não é um procedimento utilizado abertamente por Monbeig, que notava os perigos de se transplantar procedimentos de pesquisa consagrados na Europa para a análise das situações observadas em países de colonização recente. Expressivamente, embora Monbeig se utilizasse da expressão "caboclo" como modo de qualificar os descendentes dos antigos colonizadores lusitanos que apresentavam um grau de mestiçagem variável, isto é, para identificar a população encontrada no país antes das levas de imigrantes estrangeiros terem tomado conta dos planaltos ocidentais paulistas e norte-paranaenses, ele estava longe de estabelecer uma relação direta entre os tipos tradicionais, os gêneros de vida e os meios naturais por eles ocupados tal como esta podia ser encontrada nos escritos de seus discípulos, que sem dúvida herdaram esse modo de apreensão da realidade brasileira de outro francês: Pierre Deffontaines. Haja vista esse pormenor, valeria a pena nos determos na discussão desse tema, esboçando em linhas gerais o que então se entendia como gênero de vida.

\section{Os gêneros de vida e os tipos tradicionais}

A Revista Brasileira de Geografia (RBG), publicada desde 1938 pelo Conselho Nacional de Geografia (CNG) com o objetivo de produzir e divulgar estudos originais sobre a realidade 
brasileira, enfatizando a relação dos grupos humanos com os meios naturais, foi fundada num momento em que o processo de construção da identidade nacional comandado pelo Estado ancorava-se sobretudo nas particularidades de cada região, ação que revela o intuito de esvaziar a articulação política das antigas oligarquias estaduais por meio do fortalecimento de um regionalismo cultural que concebia a identidade brasileira como a soma das identidades regionais (MORAES, 2011). De fato, a partir de seu quarto número, saído em 1939, a RBG, num esforço de representar os matizes geográficos mais característicos do país, passou a publicar a seção "Tipos e aspectos do Brasil", constituída por imagens de paisagens naturais ou pelos chamados "tipos tradicionais" da população desenhados pelo artista Percy Lau, que se faziam acompanhar de pequenos textos redigidos por técnicos e especialistas do próprio CNG, como José Veríssimo da Costa Pereira, Nelson Werneck Sodré, Elza Coelho de Souza Keller, Dora Amarante Romariz, Lindalvo Bezerra dos Santos e Virgílio Corrêa Filho. Uma vez que a iniciativa teve uma boa acolhida do público em geral, a partir de 1940 os textos e desenhos da seção "Tipos e aspectos" são organizados em uma coletânea, dando origem a um livro que foi sendo progressivamente aumentado com o passar dos anos, dada a continuidade da seção na $\mathrm{RBG}^{139}$. Entretanto, mesmo ponderando sobre a preocupação dos ideólogos do Estado Novo com o direcionamento dos esforços editoriais que de algum modo relacionavam-se com as ações pedagógicas de difusão da identidade nacional oficialmente chancelada, Heliana Salgueiro abre novas possibilidades de análise do tema quando afirma que: "melhor do que tomar a série 'Tipos e aspectos do Brasil' como puro 'reflexo' ideológico do Estado Novo, seria mais fecundo vê-la como um sistema de ideias, de cultura, cujo sentido está tanto no olhar dos que representam os tipos - desenhistas e fotógrafos - quanto neles mesmos" (SALGUEIRO, 2005, p. 26).

\footnotetext{
${ }^{139}$ Em 1956, no Rio de Janeiro, durante o XVIII Congresso Internacional da UGI, o livro Tipos e aspectos do Brasil, então composto por mais de 400 páginas, ganhou versões em francês, inglês e espanhol, o que reforça a impressão de que ao compilar imagens e textos antes publicados de forma esparsa, os responsáveis pelo livro tinham o objetivo de consolidar imageticamente certos aspectos culturais da população brasileira: "Em 1940, há uma tiragem reduzida, pequena brochura contendo oito tipos, por ocasião da XIII Feira Internacional de Amostras; em 1942, contam-se 20 tipos numa edição da revista 'consagrada ao batismo' da nova capital de Goiás, Goiânia; em 1943, editam-se 26 tipos nas comemorações do primeiro centenário do IHG do Uruguai; em 1944, 36 tipos circulam na tiragem da Segunda Reunião Pan-Americana sobre Geografia e Cartografia, no Rio de Janeiro. Note-se que são todas edições circunstanciais visando a difusão de uma imagem do país, fixada nos seus tipos e aspectos, predominantemente rurais (...). As reedições ou edições ampliadas acontecem, então, quase todas em reuniões internacionais e reforçam minha hipótese, a do inventário e difusão de cenas do país, de seus homens e aspectos, objetivo da revista e das instituições de vocação geográfica. Estas querem afirmar e exportar a cultura e as imagens do Brasil - não se trata então unicamente da construção de imagens para circulação interna e afirmação da unidade nacional - formulações da mesma ordem, repito, estão ocorrendo numa dimensão internacional.” (SALGUEIRO, 2005, pp. 27-28.)
} 
Ora, em seu livro Geografia Humana do Brasil, lançado originalmente em 1940 e também originado de um conjunto de artigos publicados na RBG, Pierre Deffontaines dedica todo um capítulo à análise do "efetivo humano" do Brasil. Ali, destaca-se desde logo a parte intitulada "Os personagens-tipo", claramente inspirada na seção do periódico do CNG acima referida, conforme é possível observar mesmo numa rápida análise dos assuntos tratados pelo geógrafo. Com efeito, Deffontaines afirma que uma região humana definir-se-ia fundamentalmente:

...não tanto pela repartição da população ou por distribuições étnicas, mas, sobretudo, pelo conhecimento dos gêneros de vida, cuja associação íntima assegura a exploração do solo. Esses gêneros de vida encontram sua expressão em personagens-tipo cuja enumeração ocupa o primeiro lugar na caracterização de cada região. Existem muitas vezes um personagem dominante que determina na região toda a série de ocupações e o regime de trabalho, e cujos hábitos e necessidades se inscrevem na própria paisagem; os outros personagens gravitam-lhe em torno, alguns mesmo vivem como parasitas. As transformações econômicas fazem surgir, às vezes, novos tipos que se podem libertar da influência do personagem dominante e modificar, assim, a hierarquia social anteriormente construída. Os personagens de uma região não aparecem todos ao mesmo tempo; há alguns muito antigos e outros mais recentes; pertencem a ciclos econômicos distintos e é necessário pesquisar-lhes a idade. (DEFFONTAINES, 1952, p. 113. Grifo nosso.)

Como fica claro no trecho citado, o uso do termo "personagem-tipo" não se aplicava unicamente para qualificar a população que chamaríamos hoje de "tradicional", à época compreendida como se fosse composta por aqueles que representavam a "verdadeira" identidade brasileira, sendo na verdade uma forma de classificação de todos os elementos demográficos existentes no Brasil, rurais e urbanos, visto que diria respeito igualmente àqueles que se encontravam em uma posição privilegiada na estrutura social, bem como aos personagens introduzidos em uma dada região pelo desenvolvimento da urbanização ou da indústria. Ou seja: entendido o efetivo humano como um dos fatores que compõem a organização das paisagem numa determinada época, a cada ciclo econômico ou período histórico corresponderia o surgimento de certos personagens, que apresentariam idade e duração diversa passíveis de se apreender na observação efetuada no terreno, tal uma forma do relevo ou um arranjo de vegetação. Dentre os principais personagens descritos por Deffontaines, como fazendeiros, colonos, mascates e trabalhadores das fábricas, cumpre aqui sublinhar a definição por ele dada ao caboclo e ao caiçara, elementos que guardariam muitas semelhanças entre si:

Fazendeiro, colono e mascate constituem o que se poderá chamar de população do interior organizado. Há outros elementos, porém, que vivem à margem, além das regiões de desbravamento, no sertão; chamam-nos 'caboclos' ou 'caipiras'; 
são em geral mestiços em que os sangues branco, índio e negro se misturam em proporções variadas. $\mathrm{O}$ caboclo recua ante o avanço da linha de desbravamento (a "frente pioneira"). Muitos, no entanto, permaneceram no interior da zona civilizada, nos pontos que não são ocupados ou naqueles que a exploração europeia abandonou, após a depreciação do solo e a decadência das fazendas. Isto equivale a dizer que são numerosos na zona do litoral, a que foi colonizada primeiro e que hoje está sendo abandonada (...). O caboclo leva vida livre, quase sem necessidades, mas sem capacidade aquisitiva e até sem moeda, praticando uma agricultura primitiva, quase florestal, onde o campo e a floresta se entremeiam (...). Bastam-lhe algumas horas de trabalho por semana para assegurar sua subsistência. O caboclo vive fora da atividade econômica. Sua simplicidade não significa miséria. (DEFFONTAINES, 1952, pp. 128-129.)

Ao longo da costa atlântica, o caboclo torna-se pescador, ligado, porém, à floresta. Vive do mar e da floresta virgem, com que está em contato direto: frutas bananas, mandioca, peixes, constituem sua alimentação. Não mora mais em casas isoladas e perdidas na mata como o caboclo, mas se agrupa em pequenas aldeias, alinhadas ao longo das praias (...). A costa é tão piscosa que lhes bastam algumas pescas por ano para terem sua provisão de peixes, que eles secam ao sol para conservar. Por isso, mais do que o caboclo do interior, pode o caiçara viver folgado, com um trabalho muito pouco pesado. (Ibidem, pp. 130131.)

Nas passagens compiladas, é indisfarçável a visão depreciativa que Deffontaines faz dos caboclos e caiçaras, entendendo-os basicamente como sujeitos que tiravam da natureza tropical todo seu sustento sem suor no rosto, juízo que replica em grande parte certa opinião sobre os habitantes brasileiros muito em voga no início do século XX, pois que a mestiçagem e o meio hostil teriam transformado a população que vivia afastada dos grandes centros em homens e mulheres indolentes e preguiçosos, no limite indiferentes ante sua situação marginal, que somente era atenuada pela opulência garantida de antemão pela natureza. Expressivamente, nos trabalhos dos geógrafos uspianos podemos observar que os personagens-tipo surgem num registro bem próximo ao encontrado nos escritos deste discípulo de Jean Brunhes. Contudo, é bom que se diga que acompanhando uma alteração ocorrida no pensamento político-social brasileiro, principalmente a que foi catalisada no início do século XX pelos escritos de Roquette-Pinto e Monteiro Lobato, sendo depois continuada por Gilberto Freyre e Josué de Castro, os geógrafos que escreveram seus trabalhos ao longo das décadas de 1940 e 1950 não consideravam que tais elementos demográficos fossem preguiçosos, tampouco concordando acerca da disponibilidade ilimitada de recursos naturais tropicais que manteriam a suficiência de seus hábitos alimentares. De fato, salientava-se a situação de miséria e a extrema pobreza em que vivia a maior parte desses habitantes, que tinham o aspecto físico de doentes subnutridos. Assim, o planejamento e a introdução de novas técnicas agrárias eram os caminhos apontados como os ideais para 
solucionar o atraso das paisagens e das populações tradicionais. Nesse caso, seria importante verificarmos a mudança ocorrida no entendimento da população e espaços sertanejos nesse período, pois se durante o primeiro governo de Getúlio Vargas a extrema diversidade das regiões brasileiras pôde ser tomada como pura positividade, com os sertões sendo encarados como o repositório da verdadeira identidade nacional, visto que as populações sertanejas ainda não atingidas pelo cosmopolitismo internacionalista do litoral se resguardavam intocadas de exotismos exógenos, a partir da década de 1950 as singularidades culturais de cada região, exemplarmente expostas pelos gêneros de vida dos tipos tradicionais da população, passam a ser consideradas como indicadores de subdesenvolvimento e atraso, entendidos então como o epítome das características nacionais que a expansão da economia, da industrialização e da urbanização iriam remediar:

O segundo governo Vargas (findo com o suicídio do presidente em 1954) e, com maior nitidez, o governo seguinte de Juscelino, reafirmam o binômio modernização do território e construção nacional, porém já mais atentos ao componente popular no equacionamento desse processo. No que tange à articulação entre a formulação de ideologias geográficas e a prática de políticas territoriais, o governo JK inovou ao inverter o sinal de duas posições-chave da atuação varguista: a diversidade regional e a oposição litoral-interior. A variedade das regiões passou a ser avaliada como um problema para a construção nacional, sendo esta agora identificada agora como a formação de um sólido e bem integrado 'mercado interno'. As 'disparidades regionais'(para usar um termo da época) passavam a ser entendidas como uma negatividade, um sintoma de 'subdesenvolvimento' que o progresso destruiria ao promover a igualdade social (que tornaria os lugares mais homogêneos ao instalar modernas condições de vida e de reprodução social). Segundo essa visão o Brasil moderno, com o estímulo do Estado, deveria exportar seu dinamismo para as regiões do interior alterando sua 'estruturas arcaicas' (para alguns autores 'feudais'). Nesse equacionamento o Brasil positivo era o litorâneo, cosmopolita e articulado com os fluxos internacionais. Uma ideia bastante difundida neste contexto foi a da coexistência de dois países, a qual retrabalhava (em novos termos) as velhas oposições entre colonização e fundos territoriais, entre civilização e barbárie, ou entre modernidade e sertão. $\mathrm{O}$ apelo geográfico do projeto desenvolvimentista ficava bem manifesto nas ações elencadas no Plano de Metas de JK que previa uma forte interferência na materialidade do espaço nacional, com a instalação de grandes próteses territoriais e amplos sistemas de engenharia. A transferência da nova capital, a construção de grandes usinas hidroelétricas, um ambicioso plano rodoviário, constituem exemplos das políticas territoriais do período (...). $\mathrm{O}$ modo de vida moderno, de uma aspiração dos projetos nacionais, passava a se uma vivência dos setores mais envolvidos com o surto modernizador do final da década de 1950. O elogio da novidade dominou o imaginário da inteligência nacional e uma nova sociabilidade começava a se praticar no país. O Brasil moderno parecia triunfar sobre o arcaísmo secular. (MORAES, 2011, pp. 9192.) 
No caso de Pierre Monbeig, o uso do termo "caboclo" não era incomum, mas ele o concebia numa chave mais próxima do entendimento que fazia da questão Caio Prado Jr. ${ }^{140}$, e, em todo caso, é imperativo assinalar que este termo raramente aparecia diretamente relacionado a um específico gênero de vida. No livro Pioneiros e Plantadores, no capítulo que fala dos precursores da marcha pioneira, Monbeig alude aos criadores provindos de Minas Gerais que a partir das primeiras décadas do século XIX entraram em conflito com os povos indígenas que ainda eram encontrados nos planaltos ocidentais, sobretudo nas margens do rio Paraná e Paranapanema, na divisa entre São Paulo, Mato Grosso (do Sul) e Paraná. Dos índios aniquilados no contato com os colonizadores, somente a técnica da queimada teria sido assimilada, visto que a ação dos indígenas não teria deixado, na opinião de Monbeig, marcas fixas nas paisagens que pudessem ser reaproveitadas pelos pioneiros: "A técnica da agricultura de queimada que o pioneiro praticou, na fase do primeiro estabelecimento, foi a dos índios, que os caboclos brasileiros lhes transmitiram" (MONBEIG, 1984 [1952], p. 132). De fato, como observamos no capítulo passado, ao diferenciar os tipos sociais presentes no mundo pioneiro Monbeig estabelecia uma classificação bem ou mal mediada pela propriedade da terra e pelo nível das técnicas empregadas na exploração do solo, isto é, os verdadeiros pioneiros que buscavam praticar um pioneer modern style eram aqueles que miravam a aquisição de um terreno, recusando o isolamento total e instalando-se preferencialmente nas proximidades de algum centro urbano ou estação ferroviária que lhes facultasse o acesso a médicos, escolas, igrejas e a uma rede de circulação comercial. Os caboclos, ao contrário, localizando-se à margem do povoamento, assemelhavam-se mais aos indígenas, porquanto não eram responsáveis por alterações substanciais dos quadros naturais. Essa diferenciação entre o pioneiro e o caboclo, que em última instância é dada pela inserção ou não da produção familiar no circuito comercial, fica clara quando Monbeig está a comentar a produtividade das lavouras de subsistência praticadas na franja pioneira paulista, que ao contrário do que sustentava Pierre Gourou (1948), superavam as de outras regiões tropicais quentes e úmidas, aproximando-se das taxas de produtividade obtidas em regiões temperadas:

\footnotetext{
${ }^{140}$ Em sua obra Formação do Brasil Contemporâneo, no capítulo que trata do povoamento, Caio Prado Jr. escreve uma seção intitulada "Raças", explicando a importância do aproveitamento do indígena como colono dentro da estratégia lusitana de ocupação do território que foi implantada no século XVIII pelo Marquês de Pombal. Posteriormente, ao falar do século XIX, o historiador paulista analisará o surgimento da população brasileira ao final do período colonial, detalhando o cruzamento étnico havido entre colonos lusitanos, indígenas e negros, que repunha a dominação (inclusive sexual) exercida pelos brancos: "É este aliás o caráter mais saliente da formação étnica do Brasil: a mestiçagem profunda das três raças que entram em sua composição.” (PRADO JR., 2002, p. 1212).
} 
Pela simplicidade das técnicas, pela variedade da produção e pelo papel primordial que desempenham na alimentação familiar, essas primeiras culturas de subsistência enquadram-se bem no quadro de toda agricultura indígena de países quentes e úmidos (...). Compreende-se então que, uma vez que dispõe de uma produção significativa, bem superior à de outras zonas tropicais sem irrigação, o pioneiro paulista esteja em condições de reservar uma parte da sua colheita para a venda. Ele é verdadeiramente um pioneiro um homem que prepara o caminho para o vasto movimento de que ele e parte integrante, ao contrário do caboclo, desbravador que permanece à margem do mundo. (MONBEIG, 1984 [1952], pp. 253-254.)

Noutro texto, intitulado "Evolução dos gêneros de vida tradicional no sudeste do Brasil", publicado em 1949, nos Annnales de Geographie, e saído no livro Novos Estudos de Geografia Humana Brasileira com um pequeno erro no título (faz-se então alusão ao sudoeste do Brasil), percebe-se de forma mais consistente como a noção de gênero de vida era utilizada com parcimônia em suas análises sobre o Brasil. A bem dizer, logo no início deste texto, acompanhando o que fora escrito anteriormente por Deffontaines, Monbeig faz uma diferenciação dentro da sociedade rural brasileira, dizendo que esta se subdividiria em dois grandes tipos: o fazendeiro, grande proprietário de terras que pratica a agricultura de caráter comercial introduzida nas regiões tropicais pelos europeus, e o caboclo, termo "que possui sobretudo um caráter antropológico, pois designa, antes de mais nada, o mestiço de branco e índio, em oposição ao cafuzo, mestiço de negro e índio" (MONBEIG, 1957, p. 192).

Notando que a palavra teve seu significado ampliado durante o século $\mathrm{XX}$, pois que servia para designar todos os mestiços e seus descendentes, que formavam a grande maioria dos agricultores brasileiros, e não apenas para qualificar os elementos da população brasileira que ficavam isolados na floresta praticando sua agricultura itinerante com o auxílio da queimada e de técnicas rudimentares de trato do solo, Monbeig alertava para o fato de que nem todos os caboclos tinham o mesmo gênero de vida. A partir dessas considerações, identifica um terceiro tipo de agricultor, também mestiço, que poderia ou não ser proprietário de suas terras, mas que se caracterizava principalmente por ter permanecido fora das grandes correntes da imigração pioneira, formando um conjunto de relativa homogeneidade: eram os caipiras, estudados por João Dias da Silveira (1946) nos contrafortes ocidentais da Mantiqueira e por Emílio Willems (1947) na região de Cunha, manifestação identificável de um dos tipos de gênero de vida assumidos pelos caboclos no estado de São Paulo.

Sem aprofundar aqui as diferenças que Monbeig aponta entre os estudos de antropologia cultural e as monografias geográficas que tratam dos gêneros de vida, dizendo que os primeiros 
restringem os gêneros de vida ao conjunto de técnicas materiais adotadas por uma comunidade, ao passo que os geógrafos os encaram sempre em sua totalidade, na síntese das relações materiais e espirituais entabuladas entre os grupos humanos e os meios naturais, é interessante notar como o geógrafo valoriza as vias de comunicação como um fator que induz mudanças em sociedades isoladas, pois que foram as novas estradas construídas no início do século XX que reativaram as relações comerciais de Cunha, desarticulando sua antiga sociedade rural: "os tipos de produção e a estrutura econômica se transformam e, ao mesmo tempo, as relações sociais e os modos de pensar evoluem" (MONBEIG, 1957, p. 201).

Ao final, o que importa para Monbeig não são exatamente as mudanças ocorridas nos hábitos tradicionais de um determinado grupo social quando este entra em contato com uma economia e técnica novas, mas as alterações sofridas pelas paisagens engendradas pela antiga comunidade rural com a perturbação de seu equilíbrio, haja vista que, com a imposição de uma técnica diferente, também as paisagens se reorganizam. Em outras palavras, ao notar a existência do caipira e de seus hábitos seculares, que deixaram impressa nas paisagens de Cunha ou da região de Bragança Paulista uma fisionomia cuja manutenção dependia da harmonia estabelecida entre os grupos humanos e o meio natural, Monbeig indica que as modificações experimentadas pela economia, ao abalar uma estrutura social desde há muito estabelecida, funcionam como o estopim de um processo de reorganização do complexo geográfico.

Após passar em revista os pontos de vista dos mestres franceses que mais influenciaram a geografia brasileira, restaria ainda apontar uma definição ampla para a noção de gênero de vida, passo importante caso se queira compreender de que maneira ela se definia no arranjo explicativo dos trabalhos dos geógrafos uspianos. Sem dúvidas os nomes mais citados, além de Monbeig e Deffontaines, são os dos geógrafos Maurice Le Lannou e Maximilien Sorre. Partindo da concepção de La Blache, o gênero de vida era tomado por esses autores como a maneira pela qual a sociedade respondia às condições do meio, adaptando-se mediante o desenvolvimento de técnicas e hábitos que permitiriam a existência material do grupo: tratava-se pois de uma ação contínua e metódica que os grupos humanos exerceriam sobre a natureza ao longo da história. Como já se notou em outras partes deste trabalho, o nível de desenvolvimento de cada grupo, ao franquear um domínio maior ou menor sobre a natureza, expressaria os diferentes graus de civilização das sociedades ao redor do mundo, circunstância que permitiria aos geógrafos 
estabelecer uma hierarquia entre os grupos humanos definida exatamente por aquilo que se denominava como o controle da natureza.

Para Le Lannou, que afirmava ser a geografia a ciência do homem-habitante, a noção de gênero de vida, conforme empregue pelos seus criadores, apresentava um aspecto claramente naturalista, pois mesmo assumindo em sua definição que se tratava da capacidade social de agenciamento e organização dos recursos naturais postos à disposição pela natureza, as diferenças entre os meios naturais da superfície terrestre implicavam uma espécie de comando da natureza na combinação entre os grupos humanos e os meios naturais. Era por isso então que existia a possibilidade de catalogar os gêneros de vida a partir, por exemplo, dos tipos de clima, de vegetação ou de relevo. No caso, Vidal de La Blache teve o mérito de ter libertado a noção de gênero de vida das meras causalidades naturais, pondo em evidência o papel das sociedades e da ação humana na organização das combinações e definindo o gênero de vida como um complexo de hábitos, tradições e rotinas profundamente arraigados na paisagem. Em resumo, bem à feição do enquadramento positivista propugnado por La Blache, o gênero de vida era para Le Lannou mais uma causa do que um efeito geográfico (LE LANNOU, 1949). Já em Max Sorre, que através dos três tomos de sua obra magna, Les fondaments de la Géographie Humaine, efetuou uma tentativa de atualização dos ensinamentos de La Blache, esforçando-se por manter unida a ciência geográfica, cada vez mais cindida pela especialização avançada de seus ramos físico e humano, os gêneros de vida eram considerados como conjuntos de técnicas que imprimiam na paisagem a sua marca:

O modo do habitat, a estrutura agrária - distribuição e forma dos campos -, o tipo de propriedade e da exploração inscrevem no solo, sob a forma de traços materiais, o funcionamento de gênero de vida (...). Conjunto de técnicas, os gêneros de vida são formas ativas de adaptação do grupo humano ao meio geográfico. Da especialização deste, de sua estabilidade, dependem, em grande parte, a especialização e a estabilidade dos gêneros de vida, suas possibilidades de duração. Suas mudanças locais traduzem-se como variantes (...). Para ter interesse geográfico, este complexo de hábitos deve apresentar um mínimo de duração, de estabilidade, sem o que não se pode destacá-lo. Mas duração e estabilidade não significam imobilidade. O gênero de vida nasce, transforma-se, expande-se - e é, então, quando ele chega a este grau de maturidade, que nós o caracterizamos. Daí a necessidade de evocar um aspecto complementar, não contraditório: o da evolução. E será ocasião de avançar em termos de conhecimento dos gêneros de vida. (SORRE, 1984, pp. 102-104/105.)

Partindo pois da definição de gênero de vida como conjunto de técnicas, veremos a seguir de que maneira a expansão da colonização e do povoamento impulsionada pelas frentes 
pioneiras, que catalisou intensas modificações nas antigas relações de acomodação existentes entre os gêneros de vida desenvolvidos nos trópicos brasileiros e os meios naturais que lhes serviam de suporte, foi apreciada nos trabalhos de doutoramento dos geógrafos paulistas. No geral, todos os trabalhos analisados empreendiam uma tentativa de examinar as mudanças ocorridas em gêneros de vida historicamente arraigados a partir de uma série de procedimentos similares: primeiramente, faziam a reconstrução temporal das relações sociais e das paisagens, como um verdadeiro exercício de geografia histórica clássica, uma vez que descreviam em minúcias a configuração territorial de seu espaço-objeto numa dada secção temporal, que ficava restrita aos períodos cobertos pelas raras fontes primárias que continham dados estatísticos. Após terem estabelecido em suas linhas gerais a dinâmica que teria resultado em uma determinada configuração espacial em épocas anteriores, num exercício de reconstrução das geografias passadas não muito afastado das propostas de cunho metodológico do inglês H.C. Darby (1953), os geógrafos passavam então a analisar de que maneira o desenvolvimento (ou não) de uma nova atividade econômica influenciava a evolução dos gêneros de vida e a organização das paisagens do presente, verificando se tais elementos geográficos haviam se modernizado pela consolidação de uma nova estrutura econômica e social ou, ao contrário, se os fatores humanos que garantiam a dinâmica paisagística haviam regredido e entrado em decadência. Nesse registro, percebe-se que do ponto de vista do arranjo explicativo projetado, o interesse estava no presente, mas era a história que punha as paisagens em movimento, permitindo avaliar o nascimento e a formação de unidades regionais. Ao final, nas conclusões, apontava-se então possíveis soluções para cada caso, num belo exemplo do papel utilitário da geografia antes previsto por Monbeig.

\section{A importância das técnicas: o café como fator de regionalização}

Pela similaridade com o tratamento conferido ao tema por Monbeig, iniciemos comentando o trabalho de Nice Lecocq Müller, cujo título é Sítios e sitiantes no estado de São Paulo. Apresentado em 1946 à cadeira de Geografia Humana, o trabalho foi publicado sem modificações somente em 1951. Filiando-se ao ramo de estudos da geografia humana, "que tem por escopo o estudo das inter-relações entre as sociedades humanas e os fatores do meio natural" (MÜLLER, 1951, p. 11), o estudo de Nice Lecocq preocupava-se especificamente com o meio rural, concebido como "aquele cuja população vive diretamente da exploração do solo sob as 
formas da agricultura, pastoreio ou coleta" (Ibidem, p. 12). Mais especificamente, questionava-se sobre o surgimento de um elemento demográfico novo no tradicional mundo rural paulista: o sitiante, pequeno produtor rural que praticava a policultura.

Aqui, pode-se perceber a influência do fenômeno do pioneirismo na definição de seu objeto de estudo, uma vez que esse novo elemento demográfico acompanhava, de certo modo, as alterações causadas pela vaga pioneira no mundo rural paulista. Assim, se no início do século XX o café atraía todas as atenções, generalizando a grande fazenda e a paisagem do "mar verde" do café por todos os cantos, o que imprimia no mundo rural uma estrutura social em que o fazendeiro, tipo social dominante, polarizava-se com os colonos, meros substitutos da mão-deobra escrava, essa simplicidade monótona deixara de existir por volta da década de 1940, quando o fracionamento das propriedades e a queda dos preços internacionais do café sugeriam novas soluções para a continuidade da colonização e do povoamento em São Paulo:

À monocultura vai sucedendo a policultura, criando novas paisagens, mais variadas, novos gêneros de vida, também mais variados. Por outro lado, zonas que não foram atingidas pelo 'rush' do café, como o litoral, têm encontrado algumas oportunidades, ainda que modestas, de reerguimento, reintegrando-se na vida do estado; e, nessas zonas, que tinham ficado isoladas, também aparecem novas paisagens e novos gêneros de vida, algumas vezes rejuvenescidos pela influência da colonização estrangeira. O 'pivot' dessa transformação foi o fracionamento da propriedade e o desenvolvimento da policultura. Para estudá-la seria preciso, segundo cremos, partir do novo tipo de homem rural que agora toma pé e conquista seu lugar ao sol: o pequeno produtor policultor, ou seja, o sitiante. Eis, finalmente, o nosso assunto. Evidentemente, não pretendemos estudar o sitiante à luz de sua evolução histórica, econômica ou social: seria outra tese e de assunto que não é, diretamente, o nosso. O que nos propomos a fazer é estudar quem é esse sitiante do ponto de vista geográfico, ou seja, como se distribui, de que forma ocupa a terra, qual o seu gênero de vida, quais as paisagens por ele criadas. Em resumo, iríamos, dentro do ambiente rural, estudar o sitiante em duas regiões - a de povoamento antigo e a de povoamento recente, levando sempre em consideração o fator café e as diferenças do meio natural. (MÜLLER, 1951, p. 13.)

Definido o tema, percebe-se que o esforço de delimitar a contento o que seria o viés geográfico não prescindiria dos empréstimos que necessariamente se fariam às chamadas ciências afins, como a economia, a sociologia ou a antropologia social, o que a leva a tentar uma primeira definição de sitiante que de maneira surpreendente não se afasta muito dos termos até hoje utilizados nos trabalhos de geografia agrária para designar o chamado camponês: "é o pequeno produtor baseado numa organização familiar de exploração do solo que visa, direta ou indiretamente, a prover à sua própria subsistência" (MÜLLER, 1951, p. 14). Avançando nessa 
definição, a geógrafa tenta refazer o trajeto de utilização do termo sitiante, localizando em que época da história brasileira a palavra passou a designar o pequeno produtor policultor preocupado com a subsistência de seu grupo familiar, em oposição ao grande produtor ocupado com a monocultura comercial da cana ou do café.

Tendo como fonte primária os relatos do viajante naturalista Auguste de Saint-Hilaire, que visitou o Brasil no início do XIX, e se utilizando livremente dos escritos de Oliveira Viana (Populações meridionais do Brasil) e de Caio Prado Jr. (Formação do Brasil contemporâneo), Nice Lecocq tenta rastrear nos documentos antigos o termo que mais se aproxima da noção de sitiante tal como ela se lhe colocava na década de 1940, pois somente ao final do século XIX a palavra surgira fazendo referência ao pequeno produtor rural que não era dependente da grande fazenda, como o agregado, por exemplo. Referindo-se às suas fontes primárias, a autora dá mostras do trabalho verdadeiramente historiográfico que desenvolve: "A palavra 'sitiante' parece ter sido reservada desde os primeiros tempos de seu emprego, entre nós, para designar exclusivamente os pequenos lavradores independentes, pois que, nos mesmos textos, encontramos também referências ao agregado" (MÜLLER, 1951, p. 26). Por fim, após enumerar os fatores que agiram favoravelmente no desenvolvimento do sitiante, como a fragmentação das grandes propriedades cafeeiras tanto nas zonas velhas de solos esgotados quanto nas novas zonas recém-conquistadas à natureza, a fuga dos proprietários para as cidades, que catalisou o desenvolvimento do arrendamento como forma de exploração indireta do solo, a formação dos núcleos coloniais de imigrantes e até mesmo a urbanização e a industrialização, que conferiram valor comercial aos produtos de abastecimento produzidos pelos sitiantes ao organizar um mercado interno, diz que o melhor critério para se definir o conceito de sitiante é "o de considerar a opinião do próprio homem do campo a respeito" (MÜLLER, 1951, p. 27). Desse modo, fundamentada nas pesquisas que efetuou diretamente no terreno, a geógrafa desenvolve um viés comparativo analisando os sitiantes encontrados em dois tipos de municípios: aqueles localizados nas zonas de povoamento antigo e os que habitavam o meio rural das zonas de povoamento recente $e^{141}$.

\footnotetext{
141 "Em resumo, iríamos, dentro do ambiente rural, estudar o sitiante em duas regiões - a de povoamento antigo e a de povoamento recente, levando sempre em consideração o fator café e as diferenças do meio natural. Pretendíamos assim obter, dentro desse domínio em que inter-relações geográficas são mais diretas - o meio rural - uma análise comparativa de como elas se processam em relação ao sitiante, quer onde são antigas quer onde são recentes, sofrendo, ou não, a influência de um passado ou de um futuro cafeicultor.” (MÜLLER, 1951, pp. 16/19.)
} 
Para tanto, a autora dá-nos sua definição definitiva de sitiante: é todo e qualquer pequeno produtor rural que trabalha diretamente o solo com a ajuda da família e, muito ocasionalmente, com o recurso de uma mão-de-obra assalariada. Dito de outro modo, a definição de Nice Lecocq Müller, que leva em consideração o que chama de "fator café", tomado como o principal parâmetro do nível de desenvolvimento econômico e demográfico por trás da divisão entre as zonas "velhas" e as zonas "novas", pois que novas paisagens e novos gêneros de vida se desenvolveram a partir desta atividade, supõe que a principal condição do conceito de sitiante seja a exploração direta do solo e o volume da produção, ficando o regime desta exploração (mão-de-obra familiar, assalariamento ou as diversas formas de parceria e arrendamento) e mesmo a questão da propriedade da terra num segundo plano. Logo, o mais relevante na definição de sitiante é o tipo de exploração do solo desenvolvido por aqueles que trabalham na terra, e, por isso, as distinções passíveis de se fazer entre os sitiantes proprietários e os não proprietários da terra em que trabalham, como os posseiros, moradores, arrendatários ou parceiros, é de menor importância, já que o interesse geográfico por esses elementos demográficos são as consequências resultantes do trabalho executado na criação dos quadros paisagísticos ${ }^{142}$. Por fim, Nice Lecocq discute brevemente a formação étnica do sitiante, tentando assim verificar as alterações porventura incutidas pela chegada dos imigrantes. Fundamentandose em passagem do livro História econômica do Brasil, de Caio Prado Jr., que trata a mestiçagem como o signo sob o qual se forma a população brasileira, a geógrafa afirma a sinonímia entre o caboclo formado no período colonial - o embrião dos futuros homens livres pobres que se espremiam entre senhores e escravos - e o sitiante atual, etnicamente o resultado da miscigenação entre negros, índios e brancos:

Mesmo sem falar na falta de uniformidade étnica que se pode encontrar nesses três grupos - o branco colonizador, o preto introduzido pelo comércio escravagista e o índio - o sitiante, pela sua combinação desses três elementos, apresenta-se, já no início de sua história, com formação étnica bastante

\footnotetext{
142 "Por trabalhar direta e pessoalmente na terra, e por fazê-lo com a ajuda da família ou de alguns empregados assalariados, o sitiante distingue-se, de um lado, do pequeno proprietário absenteísta e, de outro, do fazendeiro. No primeiro caso, se o pequeno proprietário não tem ligações diretas com a terra, não é, pelo homem do campo, considerado com sitiante. Lembro-me de ter perguntado se uma pessoa nessas condições cabia dentro do conceito e a resposta foi: "Não, ele é o dono do sítio, mas não é sitiante; ele mora na cidade." Estava implícito que, no caso, quem era assim considerado era o parceiro que estava trabalhando na propriedade (...). Essas diferenças, porém, apesar de seu inegável interesse, não são capazes de, por si só, criar classes geográficas e sitiantes. O critério [da propriedade da terra] não tem base em fenômenos geográficos, isto é, nas inter-relações diretas entre o homem e o meio. Assim sendo, o sitiante ainda é para nós uma unidade, os diferentes tipos jurídico-econômicos que abrange só reaparecendo à medida que possam contribuir para explicar os problemas geográficos a eles ligados.” (MÜLER, 1951, pp. 28/32.)
} 
complexa. A fixação da imagem do caboclo no tipo resultante dos cruzamentos entre esses três grupos iniciais deu-se, principalmente, em contraposição aos novos elementos introduzidos por imigração recente (...). Esses novos elementos vêm, uma vez libertados de sua posição assalariada nas fazendas de café e obtidas algumas economias, juntar-se à classe do sitiante, aumentando-lhe a complexidade da formação étnica ou criando um outro tipo de sitiante, o do colono estrangeiro em contraste com o caboclo brasileiro (...) Tal como para os tipos econômicos, os diferentes tipos étnicos que encontramos entre os sitiantes têm grande importância no estudo dos gêneros de vida e na interpretação da paisagem. Trazendo novos patrimônios culturais, os imigrantes não reagem sempre da mesma maneira. Algumas vezes adaptam-se ao novo meio ambiente, aceitando muito do que encontram em matéria de técnicas; outras vezes mantém suas técnicas originais. Das novas técnicas, dos diferentes tipos de ocupação do solo e da introdução de culturas importadas e estilos arquitetônicos exóticos nas casas rurais, resultam muitas vezes gêneros de vida e paisagens inteiramente diferentes da tradicional. (MÜLLER, pp. 33-34.)

A referência à oposição entre o colono estrangeiro e o caboclo brasileiro é fundamental para se compreender a importância da expansão da cultura da rubiácea na diferenciação entre tipos sociais que compartilhavam do mesmo status de "sitiante" no arranjo explicativo construído pela autora, pois os milhares de imigrantes que afluíram para a franja pioneira, ao introduzir novos elementos étnicos e culturais no mundo rural paulista, forneceram também uma variável comum para a construção da análise comparativa buscada, pois a partir de então, um observador atento poderia comparar as paisagens engendradas pelos caboclos brasileiros com aquelas organizadas pelos recém-chegados, que manifestavam sua singularidade no cultivo de plantas incomuns aos nacionais ou em aspectos da habitação.

Já no capítulo sobre a vida econômica, Lecocq Müller nota que a sucessão de ciclos econômicos em São Paulo originou estruturas econômicas que não guardavam abertura para a integração do pequeno produtor, o que deixou os sitiantes à margem do mercado. Esse tipo clássico de sitiante praticando sua agricultura de subsistência, "o resultado da ausência das vias de comunicação" (MÜLLER, 1951, p. 109), tinha sua vida econômica "presa a um mercado estritamente local" (Loc. cit.), visto que o mais comum era o sitiante trocar algum excedente em espécie por sal ou instrumentos de trabalho nas vendas, casas de comércio de alcance local que servem de centro para a formação de um habitat cuja característica é a dispersão, seja a linear ou a coagular. Concluindo, as paisagens criadas pelos sitiantes, que ainda estavam longe de atingir a estabilização, corresponderiam aos vários tipos de exploração, ocupação e técnicas praticadas pelos diferentes grupos, havendo muitos matizes entre os dois extremos representados pelas paisagens dos grandes domínios monocultores e a organização espacial fragmentada da 
policultura. Afinal, as paisagens das zonas novas, marcadas pela variedade derivada da própria conquista do solo, têm uma fisionomia paisagística distinta daquelas das áreas localizadas na retaguarda das frentes pioneiras, que apresentam as marcas da ocupação do solo escalonadamente em diferentes estágios de humanização da paisagem, cada degrau representando uma época da conquista:

Rústica ou humanizada, monótona ou variada, a paisagem criada pelo sitiante está longe de ter atingido a cristalização: assim como ainda conta com elementos que testemunham o passado, ela só representa um elo no dinamismo do meio geográfico. Especialmente nas zonas novas, as paisagens do sitiante estão ainda em plena elaboração, às vezes não passam de mera transição para um quadro mais estável que se instalará logo depois: lembramos os sitiantes que só cultivam o terreno para prepara-lo para os pastos (...). As paisagens dos sitiantes nos dão uma síntese de todos os aspectos que nele nos interessam: da ocupação e exploração do solo, dos elementos geográfico de sua vida econômica, de sua distribuição, de seu habitat, de sua técnica de trabalho. Mas não é só isso, porque delas podemos tirar ensinamentos de caráter mais amplo: a compreensão clara da posição da pequena exploração rural e do homem que a desenvolve no conjunto da economia paulista. (MÜLLER, 1951, pp. 186/196.)

A feição de relatório de campo que o trabalho deixa transparecer em inúmeras passagens é de certo modo confirmada quando percebemos que diversos pontos indicados por Nice Lecocq foram posteriormente retomados e aprofundados por Monbeig no livro Pioneiros e Plantadores. Em seu conjunto, os temas tratados por Nice Lecocq Müller guardam grande similaridade com o trabalho do francês, e isso até por seu objeto de estudo, qual seja, os traços paisagísticos introduzidos no mundo rural paulista pela fragmentação das grandes propriedades, o que dava base para o surgimento dos sitiantes, um elemento demográfico que, se não era totalmente desconhecido no estado de São Paulo, começava a ser notado em suas necessidades, bem como a fazer parte da vida econômica mais complexa introduzida com a urbanização e a industrialização, fatores novos que incentivavam especializações produtivas, sustentando uma divisão territorial do trabalho ao criar um mercado fixo para a policultura secularmente praticada pelos grupos familiares que trabalhavam diretamente a terra.

Embora elabore um estudo de geografa regional de uma área litorânea, a Baixada do rio Itanhaém, José Ribeiro do Araújo Filho retoma muitos dos temas postos por Monbeig e Nice Lecocq Müller. Caracterizando a sua área de estudo como um "sertão bruto", o que pode parecer estranho à primeira vista, caso tenhamos em conta a oposição generalizada no pensamento político-social brasileiro do período entre o litoral e o sertão (SOUZA, 1997) - conquanto isso não seja estranho à definição de sertão proposta neste trabalho, que o concebe mais como um 
espaço a ser conquistado, um qualificativo de áreas sujeitas a implantação de estratégias de dominação (MORAES, 2003) - Araújo segue Pierre Gourou ao dizer que as florestas fechadas e o clima quente e úmido que definem essa paisagem como tipicamente tropical tornavam insalubre a baixada itanhaense, descrevendo um cenário natural que desafiava a penetração humana. Como outras tantas baixadas tropicais despovoadas ao redor do planeta, a região de Itanhaém permanecia, pois, "sufocada" pelos fatores naturais, caracterizando-se, do ponto de vista da ocupação, por sua economia primitiva e por sua pouca civilização. Estabelecendo então uma comparação desta área com os planaltos ocidentais, que se abriam à valorização e ao progresso pioneiro do café, adequando-se à temporalidade do mundo desenvolvido, o autor demonstra claramente o peso que o pioneirismo tinha no equacionamento de seu estudo:

A baixada do Itanhaém é um dos muitos exemplos de baixadas tropicais, que o litoral brasileiro oferece, com toda a série de problemas que o quadro natura, ainda não vencido pelo homem, deixa perceber. Justamente num momento em que se fala da penetração do interior, simbolizada na tão explorada frase "a marcha para o oeste", é interessante mostrar que temos ainda muitas terras para explorar na retaguarda, em zonas que, embora palmilhadas desde a colônia, ficaram à margem da valorização, mercê de uma série de circunstâncias. $O$ curioso é que a maioria dessas zonas marginais se situa à beira-mar, particularmente no litoral paulista, porta de entrada da mais rica região brasileira (...). Questões de ordem puramente física (clima tropical super-úmido, florestas densas e emaranhadas, manguezais, zonas arenosas, solos difíceis de serem trabalhados), impediram o homem de ali criar riquezas compensadoras, de acordo com os métodos então usados. (ARAÚJO FILHO, 1950, p. 8.)

Seguindo a lógica expositiva consagrada nos cânones franceses, após ter descrito o quadro natural opressivo que a baixada litorânea sul-paulista representava para o estabelecimento dos grupos humanos, Araújo Filho dedica algumas páginas ao povoamento antigo e à população atual que davam vida aos núcleos de Peruíbe, Itanhaém e Praia Grande, destacando o primitivismo generalizado que ainda vigorava nas paisagens e nos gêneros de vida ali encontrados, o que lhe permite concluir que o tipo característico de habitante da região, “o caiçara, que chegou até nossos dias tal qual fora há 100 ou 200 anos, em nada procurou diferenciar-se de seus antepassados (...) este tipo de praiano não admite modificação no que ele herdou de seus avoengos: um gênero de vida primitivo e de acordo com o meio hostil que o rodeia" (ARAÚJO FILHO, 1950, p. 30). Expressivamente, ao considerar o caiçara paulista como um resquício de um passado que se quer superar, Araújo o qualifica como um elemento demográfico que se encontra em uma situação inferior tanto em relação a outros caiçaras, como os do Nordeste, 
quanto ao caboclo planaltino, que mesmo sem escolas ia se educando aos poucos "através do contato com certos fatores do progresso, como estradas de ferro ou de rodagem" (Loc. cit $)^{143}$ :

Ao lado das paisagens naturais que o litoral paulista oferece à argúcia dos estudiosos, um tipo humano bem característico, completamente influenciado pelo meio e sem recursos para dele fugir, aparece, como que reproduzindo à beira-mar o tipo tão conhecido do "jeca" do planalto. De fato, o caiçara nada mais é do que uma variedade de caboclo, com algumas diferenças apenas do caipira de serra acima; diferenças essas que, mercê do meio em que vive, o obrigam a uma vida à primeira vista mais folgada, mas que na realidade é mais dura que a do seu irmão planaltino. Se o caiçara dispõe a seu favor de uma natureza relativamente pródiga, como mar e a floresta a lhe oferecerem alimentos, para aproveitá-los, contudo, tem de desenvolver um trabalho que, devido à técnica primitiva, não lhe traz quase resultado (ARAÚJO, 1950, pp. 3132.)

Para Araújo, o clima hostil, aliado aos solos pobres e à técnica deficiente dos caiçaras, são os fatores que, combinados, tornaram-se obstáculos consideráveis para a verdadeira instalação humana. Com efeito, a antiga ocupação que teria dado origem aos caiçaras não era considerada uma colonização digna desse nome, mas apenas um povoamento primário que deveria ser superado, o que implicava considerar que essa faixa do litoral sul-paulista continuava à espera dos fluxos modernizantes que iriam libertá-la do domínio da natureza. Assim sendo, o geógrafo nota que o elemento que poderia ter atenuado essa situação de atraso e abandono não era a expansão cafeeira, que nunca se instalou nas terras do litoral de São Paulo, mas a introdução dos bananais no início do século XX, que estruturou aquilo que o geógrafo chama expressivamente de uma "zona pioneira litorânea". Desse modo, embora a população sazonal que periodicamente afluía para os bananais tivesse contribuído para melhorar consideravelmente a situação econômica da região, o semi-nomadismo dos trabalhadores não levou à baixada itanhaense uma colonização fixa, com o que o pioneirismo dinamizado nas zonas litorâneas não ocasionou uma alteração brusca dos quadros naturais e uma modificação dos gêneros de vida, que teimavam em permanecer os mesmos. Em resumo, o homem não teria ainda conseguido dominar o meio tropical hostil à sua fixação, uma vez que a cultura da banana, por ser "baseada em métodos que absolutamente não condizem com os modernos princípios de racionalização do trabalho"

\footnotetext{
143 "Ora, isso não acontece no litoral. O caiçara, tipo que até hoje está à margem da civilização, mesmo quando teve ocasião de entrar em contato com o progresso, nada aproveitou. É que sobre ele pesam mais de dois séculos de vida rudimentar e de abandono. Há mais de um século que se abrem zonas pioneiras ininterruptamente nas terras do planalto; que se colonizam com contingentes novos, nacionais ou estrangeiros, áreas enormes de São Paulo; que se fundam cidades, abrem-se estradas, criam-se, enfim, riquezas cada vez maiores. Nada disto, porém, foi conhecido do caiçara, que, na sua limitada zona, só entrou em contato com a natureza hostil.” (ARAÚJO, FILHO, 1950, p. 30.)
} 
(ARAÚJO, 1950, p. 10), falhou em transformar os quadros naturais da baixada do Itanhaém em paisagens humanas modernas.

Tendo se desenvolvido com rapidez sobretudo a partir da década de 1920, quando os bananais deixaram a região de Santos e São Vicente, a zona pioneira itanhaense não proporcionou riqueza e desenvolvimento à sede municipal, porquanto sua zona agrícola, através da Estrada de Ferro Santos-Juquiá, ligava-se diretamente a Santos, numa operação típica de transferência geográfica de valor ${ }^{144}$. Após o esgotamento dos solos de Santos e São Vicente, onde primeiro se instalou com sucesso, os empresários da banana, dentre os quais o próprio pai de Araújo ocupava posição de destaque, tomariam decisão idêntica à dos cafeicultores do planalto, partindo em busca de novas áreas de solos férteis, ação que ao fim e ao cabo conferiu territorialidade própria a verdadeiras zonas pioneiras ao norte e ao sul de Santos. Na verdade, a expansão das lavouras da banana é o fator ao qual se deveria imputar a consolidação da ocupação de extensos trechos do litoral paulista, uma vez que seu cultivo contribuiu para a criação de um novo tipo de riqueza que incentivou o desbravamento de muitas áreas litorâneas que se conservavam até então em um estágio de letargia, como então se dizia. Por outro lado, o enquadramento dessa questão ficaria incompleto caso não se notasse o surto de construções feitas nas áreas de mangue, que após 1940 cederam espaço para a edificação das casas de veraneio dos turistas do planalto, nicho de negócios que cresceu assustadoramente principalmente depois de 1950, quando foi terminada a rodovia Anhanguera. Realmente, ao se referir às modificações ocorridas no núcleo antigo de Itanhaém, Araújo novamente exemplificava de que maneira o fenômeno do pioneirismo planaltino poderia ser tomado como parâmetro desejável para a evolução e desenvolvimento, e isso tanto para os meios rurais como para os urbanos:

Aqueles aspectos tão próprios das cidades novas paulistas, verdadeiros milagres urbanos saídos do espírito empreendedor dos pioneiros planaltinos, onde, ao lado das residências, muitas vezes de madeira, já se encontram armazéns, lojas, confeitarias, cinema, etc., tudo no mesmo ritmo de desenvolvimento e de vida, fazem contraste com o evoluir vagaroso da Itanhaém de hoje (...). Conquanto existam grandes diferenças entre as zonas pioneiras litorâneas e as do planalto,

\footnotetext{
${ }^{144}$ Falando sobre o marasmo que tomava conta do núcleo urbano de Itanhaém mesmo com o desenvolvimento da cultura da banana, afirmava Araújo: "Nem a estrada de ferro que a liga a Santos desde 1915, nem os bananais que se formaram em seu reduzido Hinteland, deram-lhe forças para reagir. Embora Itanhaém possuísse nos últimos vinte anos as zonas pioneiras mais importantes do litoral, coma criação em seus arredores de uma riqueza representada por mais de 4 milhões de touceiras de bananeiras, nem assim, à sede municipal se poderia dar, sob o ponto de vista comercial, o título de capital regional. É que aquela imensa riqueza agrícola se solara na baixada interior, estabelecendo relações diretamente com Santos, apenas transitando pela cidadezinha em viagem para o grande porto exportador, sem nada lhe deixar." (ARAÚJO FILHO, 1950, pp. 48-49.)
} 
quer no que diz respeito aos métodos, quer nas suas consequências, nelas se encontram alguns aspectos comuns. Por exemplo, no litoral as terras são "griladas" como as do planalto; também são elas ocupadas pela lavoura extensiva para fins comerciais, de maneira que glebas devassadas há dez ou quinze anos são logo deixadas para trás como pouco produtivas, à medida que se vai avançando num desbravamento sem limites. Belo exemplo desse pioneirismo destruidor, iniciado em pleno século XX em vários trechos de nossa costa, nos é dado pela Baixada do Itanhaém, onde, há justamente vinte anos, o homem vem desenvolvendo uma das maiores áreas bananeiras do país. (ARAÚJO FILHO, 1950, pp. 51/59.)

Por fim, o geógrafo pontua que embora a região por ele estudada possuísse um dos povoamentos mais antigos de todo o Brasil, uma vez que o núcleo original de Itanhaém foi o segundo núcleo fixo de povoamento fundado por Martim Afonso na capitania de São Vicente, no ano de 1549, ela está ainda à espera de uma reação do homem ante ao meio hostil, pois a zona litorânea paulista, que não acompanhava o progresso do planalto, necessitava da adoção de novos métodos de trabalho para que suas paisagens fossem completamente humanizadas. Da mesma maneira que Monbeig, Araújo também parece considerar que o processo de organização espacial era mediado pelo trabalho, isto é, que a humanização das paisagens estava atrelada à valorização do espaço. Por isso, a circunstância de a maior parte da população instalada nessa área ser constituída pelos caiçaras, tornava-se, pois, uma das provas de que o domínio exercido pela natureza caracterizaria as paisagens regionais, que consequentemente eram consideradas atrasadas quando comparadas com o restante do estado de São Paulo:

Mas a geografia moderna nos ensina que, mesmo nas regiões mais ingratas ao estabelecimento do homem, pode este, através da ciência e da técnica, e de um trabalho constante e bem dirigido, fazer verdadeiros milagres na sua reação contra os elementos naturais (...). Entre nós, porém, continuam as baixadas litorâneas no esquecimento, em resultado da famosa "marcha para o oeste". Já é tempo, pois, de fazermos qualquer coisa em prol de zonas que, mesmo difíceis de serem trabalhadas, estão em situação privilegiada quando comparadas com as longínquas terras do Centro-Oeste ou da Amazônia. Devemos, antes de mais nada, explorar, dentro dos métodos racionais de trabalho, os vazios que se encontram ainda na retaguarda dos nossos grandes centros, colonizando-os, o mais breve possível. Povoando nossas baixadas litorâneas, estaremos não só criando novas riquezas, como, particularmente, provado que nas zonas tropicais também o homem branco pode criar civilizações. (ARAÚJO FILHO, 1950, p.9.)

O trecho supracitado é revelador. Nele, pode-se observar que o trabalho científico do geógrafo, partindo de informações coletadas diretamente no terreno, tal como Monbeig ${ }^{145}$

\footnotetext{
145 “A estrutura social do mundo pioneiro está impressa na paisagem: muito cheia de contrastes, é mais bem compreendida no terreno, o que não se dá nos campos muito alongados do nosso país (...). A paisagem da faixa pioneira é um documento geográfico admirável pelos aspectos que saltam logo aos olhos, ou os que estão mais
} 
concebia e ensinava, poderia ser uma ferramenta útil para a análise de situações problemáticas do ponto de vista do desenvolvimento, valorizando a ciência e a técnica como forma racional de se obter sucesso na colonização e povoamento de áreas consideradas naturalmente "hostis" à instalação dos grupos sociais. Esse traço da geografia, a "ciência da colonização" por excelência, como a considerava Isaiah Bowman, influenciou o juízo dos geógrafos uspianos em suas avaliações sobre a faixa tropical paulista, que contrastava com o desenvolvimento alcançado na franja pioneira planaltina. Para Araújo, que novamente acompanhava o veredicto de Pierre Gourou sobre as áreas tropicais, uma ocupação produtiva do espaço seria a solução ideal para transpor a barreira interposta à evolução pela hostilidade do meio natural, uma vez que ao lado dos fatores de ordem física, como o solo e o clima, também os fatores de ordem humana, expressos nos métodos utilizados pelos trabalhadores, contribuem para conferir um aspecto de abandono e decadência encontrado mesmo nas áreas dominadas pela cultura da banana, que não contava com mais de trinta anos em Itanhaém.

Na mesma direção de José Ribeiro de Araújo Filho, as modificações intencionais que se poderiam implantar em um dado espaço caso se recorresse à técnica e à ciência também foram os principais esteios do arranjo explicativo arquitetado por Renato da Silveira Mendes em suas análises das paisagens culturais da Baixada Fluminense. Essa tese, que foi inicialmente orientada por Monbeig, tendo sido defendida quando Pierre Gourou ocupava o cargo de catedrático na USP, em 1948, foi publicada em 1950, destacando-se de início por ter como tema uma área localizada fora dos limites administrativos de São Paulo, fato que destoa da norma comum seguida por quase todos os trabalhos produzidos por geógrafos uspianos até bem passada a década de 1950. Apresentando mais de cem fotografias e cerca de vinte mapas e cartogramas elaborados manualmente pelo autor, esse trabalho aparece como um modelo bastante fiel das antigas monografias regionais francesas, expondo um traquejo historiográfico hoje incomum no tratamento de fontes documentais e na consulta de arquivos.

encobertos. Por mais sugestiva que seja, a observação não bastaria para indicar como se organiza, como vive um grupo de homens que vai tomar posse do solo. A análise das paisagens apresenta problemas e não os resolve todos. Seu complemento é o exame dos planos que apresentam as minúcias da estrutura agrária, mas os documentos cartográficos, por sua vez, mostram-se insuficientes; exprimem projetos que nem sempre se realizam e, neste país em desenvolvimento, as mudanças são por demais frequentes para que possamos confiar em dados tão precários. Somente o clássico inquérito, indispensável na pesquisa geográfica, permitirá compreender as necessidades, possibilidades, desejos e mentalidade que guiam os pioneiros na formação da paisagem. Pode-se então medir até que ponto todo esse trabalho não é apenas uma mudança de cenário: suas etapas fazem parte da elaboração de um complexo geográfico." (MONBEIG, 1957, p. 124.) 
$\mathrm{Na}$ verdade, Mendes interessou-se por estudar a evolução das paisagens da Baixada Fluminense, uma vez que as obras de saneamento e regularização da rede hidrográfica empreendidas pelo governo federal nas décadas de 1930 e 1940 para "recuperar" um dos trechos mais povoados do território brasileiro, que sofria anualmente com as chuvas, enchentes e epidemias de malária e febre amarela, haviam trazido novos elementos de modificação em uma área ocupada produtivamente com engenhos de cana e currais de criação desde o século XVI. Em seu entendimento, portanto, as ações humanas teriam elaborado diferentes paisagens ao longo dos tempo, e como a Baixada Fluminense havia assistido a várias fases de ocupação do solo desde o início da colonização lusitana em terras americanas, o objetivo do geógrafo seria a reconstrução das distintas estruturas paisagísticas a que corresponderiam cada um dos períodos históricos precedentes:

Um importante aspecto a ser encarado no estudo da paisagem cultural, aspecto esse acentuado pelos geógrafos que mais se dedicaram à conceituação da ciência geográfica, consiste na evolução da paisagem. Tanto Brunhes, ao tratar do "princípio da atividade", como Sauer, abordando a morfologia da paisagem, são unânimes em reconhecer que assim como o quadro não pode ser considerado fixo, também a paisagem humanizada modifica-se com o decorrer do tempo, em função das diferentes civilizações que ocupam uma determinada região. (MENDES, 1950, p. 18.)

Replicando as indicações feitas por Monbeig quando da discussão acerca dos critérios de regionalização utilizados pelo CNG para o estado de São Paulo, Renato da Silveira Mendes considerava que a delimitação da Baixada Fluminense em zonas fisiográficas, que se apoiava em critérios unicamente naturais, parecia "muitas vezes restrita, acadêmica, artificial, fugindo à própria realidade. Devendo considerar-se nos estudos geográficos os dois elementos - meio e homem - não seria preferível partir do elemento humano e não do quadro físico para se efetuar a classificação em regiões?” (MENDES, 1950, p. 38). De fato, o autor notava que a noção de região existiria "na mente" dos habitantes de toda e qualquer área a despeito do conhecimento científico que a população instalada nessas localidades teria a respeito dessa mesma região, e justificava a sua opinião fornecendo o exemplo dos caboclos brasileiros que distinguem e denominam perfeitamente as diversas regiões que habitam, como no caso da Zona da Mata de Minas Gerais, que teve tal denominação perpetuada nas tradições orais dos caboclos independentemente do fato de a floresta ter há muito desaparecido. Por isso, era para ele "preferível para os estudos regionais efetuar-se a classificação e subdivisão em zonas de acordo 
como conceito local, isto é, com a noção de região ou 'país' dos próprios habitantes e não tentar enquadrar essas zonas considerando-se apenas os aspectos físicos” (Loc. cit.).

Definindo então os pressupostos nos quais se embasa, Silveira Mendes vai procurar localizar nas fontes históricas disponíveis, assim como anteriormente fizera Nice Lecocq Müller, qual era a denominação utilizada e quais os limites das regiões internamente identificadas pelos habitantes da Baixada Fluminense nos tempos da colônia. Uma vez que as fontes disponíveis para o autor eram sem dúvida mais abundantes, visto que sua área de interesse foi ocupada de maneira produtiva desde meados do século XVI, ele percebe que nos registros históricos havia referências a pelo menos três sub-regiões ou "países", como então aparecia nas fontes: o Recôncavo do Rio de Janeiro, Cabo-Frio e os Campos dos Goitacazes. Para ele, portanto, haveria uma "consciência" ou ao menos uma ideia vaga de unidade destas três áreas que aproximava o antigo sentido conferido ao termo "país"146 ao conceito geográfico que então se tinha de região:

Uma região geográfica ou "país", ao nosso ver, deve considerar não somente os elementos naturais que lhe são peculiares mas principalmente o elemento humano que, utilizando-se dos recursos locais e dando a áreas fisicamente diferentes uma certa unidade pelo povoamento, ocupação do solo, vias de comunicação, é quem na realidade "cria" a região. Cada "país" pode conter mais de uma zona natural, pois justamente o aproveitamento de recursos de zonas diferentes é que determina a interpenetração e a unidade regional (...). Com o progresso da humanidade e o desenvolvimento da técnica, mais unidas se tornam as regiões naturais em virtude da construção e do aperfeiçoamento das vias de comunicação e dos meios de transporte. Não é de se estranhar, portanto, que no estado de São Paulo a noção popular de zonas esteja associada às estradas de ferro que atravessam e unem regiões fisicamente diversas. (MENDES, 1950, pp. 39-40.)

A referência que faz ao caso paulista, que segundo Monbeig somente conheceria regiões associadas às estradas de ferro, é fundamental para compreendermos como os geógrafos dessa geração relacionavam as atividades econômicas, o tipo de ocupação humana desenvolvida e o processo de organização das paisagens, pois, sendo o elemento humano o fator que conferia às distintas unidades naturais um aspecto de homogeneidade, temos que o estudo das paisagens humanizadas associava-se necessariamente à análise regional, uma vez que as várias formas de

\footnotetext{
${ }^{146}$ Num texto que integra uma coletânea organizada pelo historiador István Jancsó, François Xavier-Guerra (2003) aponta as modificações impostas ao sentido político de palavras como "pátria", "nação" e "país" na passagem do século XVIII ao XIX, mostrando como tais termos poderiam identificar realidades locais e mais fluidas, e não, como nos acostumamos a pensar, Estados-nação com fronteiras fixas e imutáveis. Focando na América espanhola, o autor lembra as adaptações sofridas no léxico de tais palavras, que foram muito utilizada, por exemplo, para definir "nações" indígenas ou "países" de bárbaros nos mapas que representavam os pretendidos territórios de dominação colonial. Especificamente sobre as mudanças ocorridas no conceito de nação o contexto americano, vide o texto de José Carlos Chiaramonte (2003) presente a mesma coletânea.
} 
apropriação e exploração do solo produzidas e reproduzidas pelos grupos humanos ao longo da história, dando sustentação a determinadas atividades econômicas, organizavam paisagens de conteúdos diversos que, ao entranhar contatos com outras localidades, consolidavam progressivamente certas diferenciações. Novamente aqui, como em Monbeig, a fixidez e a mobilidade se combinam, repondo os inter-relacionamentos entre fixos e fluxos, pois era a circulação garantida pelas próteses territoriais fixadas na paisagem o que garantiria a homogeneização diferenciadora dos espaço.

Na sequência dos capítulos, embora a questão do fator café seja atenuada, até por se tratar de um área que ficou de fora da marcha dos cafezais em terras brasileiras, a importância dos ciclos econômicos passados e presentes na estruturação das paisagens fica bem evidente já nos títulos da segunda e terceira parte da tese, respectivamente "As paisagens antigas" e "As paisagens modernas". Falando do início da colonização portuguesa, Renato Mendes lembrava que a Baixada Fluminense foi um dos primeiros centros de exploração comercial instalados na América portuguesa, formando "uma espécie de ilha de civilização, pois que a colonização portuguesa se caracterizou pela descontinuidade" (MENDES,1950, p. 46). Interessante aqui notar o mapa de uso e ocupação do solo que o geógrafo apresenta, pois com as informações levantadas em arquivo ele conseguiu descrever as modificações ocorridas na região pelo desenvolvimento assumido pela agricultura da cana-de-açúcar e pela pecuária entre o final do século XVII e inicio do XVIII, período em que a região assistiu a um surto expansivo da atividade canavieira. Ao final, o caráter comercial e especulativo da exploração agrícola, que persistiria com avanços e recuos até o momento da sua análise, na década de 1940, quando os antigos engenhos foram finalmente substituídos pela usinas, tornavam as paisagens rurais da Baixada Fluminense um "perfeito reflexo dessa atividade econômica" (Ibidem, p. 54) $)^{147}$.

\footnotetext{
${ }^{147}$ Pouco depois, o autor irá notar a revolução ocorrida na estrutura econômica regional da Baixada Fluminense com a decadência dos antigos engenhos e a implantação das máquinas a vapor ao longo do século XIX, quando então foram construídos os casarões e sobrados concentrados principalmente na chamada planície campista, elementos materiais típicos da unidade social-econômica do ciclo do açúcar, que foi renovado a partir do XIX: "As paisagens culturais da Baixada Fluminense, refletindo não só as relações entre o homem e as condições naturais como também a estrutura da economia açucareira, acompanharam durante o século passado [o XIX] a evolução da técnica do fabrico do açúcar e as alterações sofridas pela organização social na passagem do engenho colonial para o engenho a vapor. Parecia que tal estrutura social e econ6omica era bastante sólida e vigoraria por largo prazo, como se cristalizando. Os solares, a formação de uma 'nobreza' rural, davam essa impressão. Entretanto tal não se deu. Novas condições econômicas e sociais surgiram nos fins do século XIX ocasionando modificações na organização agroindustrial da Baixada. Como consequência alteram-se também as relações entre o homem e o meio físico e novas paisagens surgem na região.” (MENDES, 1950, p. 72.)
} 
Realmente, ao tratar das "paisagens modernas" organizadas no início do século XX, Silveira Mendes dizia ser possível verificar as alterações sofridas pelas paisagens desde o início da colonização europeia por meio das cartas organizadas na tese, que tinham como base os documentos e fontes históricas levantados que, por existirem desde o século XVI, possibilitavam a comparação de dados entre diferentes períodos. A diferença em relação à mais recente cartasíntese que organizou, dedicada à ocupação e uso do solo em meados do século XX, é que "as fontes em que nos baseamos para a elaboração dessa carta consistiram, principalmente, em observações pessoais feitas in loco no decorrer de diversas viagens que empreendemos pela região" (MENDES, 1950, p. 86). Assim, dois novos tipos de povoamento imprimiriam marcas nas paisagens: as aglomerações suburbanas, que formavam uma verdadeira conturbação com o Rio de Janeiro ao longo da estrada de ferro, e o povoamento rural impulsionado com a citricultura, que dava nova vida para a agricultura da região, que encontrava na cidade do Rio de Janeiro um grande mercado. Contudo, embora novos fatores de valorização tenham modificado a combinação dos elementos do complexo geográfico, as paisagens culturais continuavam a apresentar resquícios da antiga paisagem da economia açucareira, principalmente na degradação das florestas, substituídas por uma vegetação de campos e capoeiras que cresciam em solos empobrecidos, e nos testemunhos dos engenhos e casarões, vestígios de uma outra época que sobreviveram como testemunhos à estruturas econômicas e sociais há muito desaparecidas, diríamos mesmo como rugosidades que duram mais do que a estrutura social que lhes deu origem (SANTOS, 2002a).

Enfim, tratando das obras implantadas pelo Departamento Nacional de Obras de Saneamento (DNOS), como as regularizações permanentes dos cursos d'água, a construção de diques marginais, os aterramentos e a abertura de canais, intervenções completadas com a profilaxia da malária e a construção de vias de comunicação, o que possibilitou a instalação de fábricas e de torres de transmissão de energia elétrica, diz que essas ações planejadas pelo governo federal foram responsáveis por uma imensa modificação na organização das paisagens da baixada, pois "ao lado dessa obras de engenharia hidráulica, outras construções modernas também imprimem à paisagem a marca característica da civilização contemporânea (...) elementos materiais de uma paisagem muito mais cultural do que natural” (MENDES, 1950, p. 114). Sinônimo de domínio das condições adversas até então apresentadas pelo meio natural, os trabalhos de saneamento seriam completados pela implementação de um programa oficial de 
colonização das áreas reconquistadas aos pântanos, com a criação de "um sistema econômico que vise a fixação do homem à gleba e a formação de uma verdadeira classe de camponeses" (Ibidem, p. 118), que através da prática de uma agricultura racional, para a qual contribuiria em muito a instalação da Escola Nacional de Agronomia, iria valorizar as terras localizadas ao redor da metrópole carioca, com o desenvolvimento da pequena propriedade e a expansão da policultura voltada para o abastecimento do Rio de Janeiro.

Como foi visto, embora não se utilize do pioneirismo como critério objetivo para proceder à avaliação do desenvolvimento pelo qual passou a Baixada Fluminense, Renato da Silveira Mendes emprega o enquadramento bem ou mal proposto por Monbeig, que valoriza as atividades econômicas como o fator preponderante para a apreciação do processo de organização espacial e toma a história e as mudanças das técnicas de exploração do solo como protagonistas da estruturação das paisagens. Ademais, tendo escolhido uma região ocupada com a cultura da cana desde o século XVI e que fazia parte da periferia imediata da cidade que foi a sede do poder político desde o XVIII, a circunstância única da disponibilidade de fontes históricas, quadros estatísticos e mesmo documentos cartográficos mais atuais permitiu-lhe elaborar um arranjo explicativo que sublinha o caráter processual da evolução das paisagens culturais, concebidas ao fim e ao cabo como as feições materiais de uma época impressas nas paisagens, os reflexos espaciais da estrutura econômica e social.

Finalizando, faltariam alguns comentários acerca dos trabalhos de Ary França e Pasquale Petrone. Em sua tese de concurso apresentada à cadeira de Geografia Humana da FFCL/USP em 1951, que versa sobre a Ilha Bela e o litoral de São Sebastião, Ary França incorpora as indicações teóricas e metodológicas de Max Sorre, com quem havia trabalhado anos antes, quando de seu período de estudos na França. Com isso, diga-se de passagem, o primeiro brasileiro a assumir a cátedra de Geografia Humana da Universidade de São Paulo torna-se um dos únicos geógrafos a utilizar-se abertamente, no Brasil, da obra do grande geógrafo francês, defendendo que os pressupostos contidos na Ecologia Humana de Max Sorre garantiriam a unidade do saber geográfico, que seria conferida, em última instância, pelo significado humano da superfície do globo terrestre, o domínio do "homem-habitante" que transformava a geografia física no estudo dos complexos geográficos naturais onde se exercem as atividades dos grupos humanos:

Na Geografia, onde a expressão meio geográfico abrange o complexo ambiente inerte e vivo onde se desenvolve a vida de relações da espécie humana, deve ele ser considerado em função dos característicos e da atividade do ser que aí reage: 
o homem (...). A explicação geográfica da Terra, no seu todo ou nas suas combinações locais, deve basear-se nos grupos humanos e nos ambientes, naturais ou transformados em ecúmeno, a que se vincula o principal ocupante da superfície terrestre $\mathrm{Na}$ Geografia Humana encontra-se, assim, o princípio da unidade vital para a discutida ciência geográfica, e que só pode ser assegurada com a renúncia ao exagero em que incorrem certos autores, ao darem desenvolvimento demasiado a assuntos à margem do campo geográfico. É nas acomodações aos ambientes que se encontram os mais sugestivos exemplos e as aplicações práticas melhor definidas dos estudos geográficos. Nestes, a Geografia Humana não deve aparecer como um 'post-scriptum' ou com o papel de segundo tomo. Antes, o homem, ou mais precisamente, o habitante da superfície do globo terrestre, que é fator de unidade e participa, consciente ou inconscientemente, de todos os quadros geográficos, precisa ser colocado na posição ímpar que a sua ação geográfica lhe confere. Deve, assim, ser eliminada toda a discussão teórica, geralmente estéril, das 'influências', ultrapassada na moderna Geografia pelo estudo da realidade terrestre, nas inúmeras, complexas e, por vezes, imperfeitas formas do ajustamento humano. (FRANÇA, 1951, pp. 4-5.)

As várias modalidades de ajustamento dos grupos humanos aos meios naturais ou modificados, que traduzem os contatos recíprocos entre a sociedade e a natureza expressos nos hábitos, rotinas e tradições observados nas pesquisas de geógrafos e sociólogos, a quem caberia a última palavra no estudo dos gêneros de vida, serviriam para estabelecer um tratamento geográfico do homem em bases ecológicas, uma vez que a Ecologia Humana teria fornecido um critério mais adequado para se avaliar o velho tema das influências do ambiente nas ações humanas, recolocando o significado geográfico das adaptações e da utilização dos recursos do meio através da análise do conjunto de técnicas sociais que caracterizam a intervenção de um gênero de vida na humanização das paisagens:

Os grupos humanos desenvolvem formas superiores de atividade nos meios sociais que os caracterizam e a noção de meio aparece, assim, enriquecida pelos fatores que agem sobre as coletividades. Inversamente, estas encontram-se aparelhadas e na posse de técnicas de ação sobre o meio (...). Assim, as técnicas humanas de modificação do meio são, antes de mais nada, técnicas da vida em grupos, e abrangem o exercício de atividades materiais e espirituais, consolidadas pela tradição. O seu mecanismo resulta na acomodação das sociedades humanas aos quadros naturais (...). Esse vasto capítulo da Ecologia Humana, o das técnicas de exploração do planeta, envolvendo noção essencialmente funcional, aplica-se, em particular, às pequenas unidades geográficas que, dentro dos grandes conjuntos regionais, estão sendo transformadas pelas civilizações. Um determinado sistema de exploração, que abrange as técnicas postas em práticas pelos grupos humanos na transformação das paisagens, pode explicar a quantidade de homens de uma região ou o seu coeficiente demográfico; e, a partir desses dados primordiais, toda a vida de relações humanas com o meio. (FRANÇA, 1951, pp. 7-8.) 
Colocadas as indicações de caráter teórico que o guiavam, Ary França delimita como seu interesse a análise dos aspectos do uso e utilização da terra, que em sua área de estudos assumiam as formas de uma exploração deficiente e antieconômica por conta das técnicas primitivas e não conservadoras dos recursos naturais utilizadas pelos caiçaras de Ilha Bela. Numa eloquente mostra de sua definição de geografia, Ary França diz que a descrição completa do cenário atual da vida de uma região permite que se possa revelar a influência da história e dos fatores ambientais, heranças do passado das relações engendradas entre o grupos humanos e os meios naturais, perpetuadas na combinação presente dos elementos geográficos na composição das paisagens. Aqui, a importância do pioneirismo como critério de avaliação de desenvolvimento explicita-se naquilo que autor chama de "reconquista em novas bases" dos espaços já transformados pelos grupos humanos, pois "assim como a conquista dos sertões novos interessa ao geógrafo por implicar no estabelecimento de novas relações do homem com o meio" (FRANÇA, 1951, p. 10), a introdução de novas técnicas de exploração em áreas de povoamento antigo representaria igualmente a formação de outras associações e arranjos capazes de modificar o conteúdo das paisagens, adequando-as ao nível de desenvolvimento e civilização então desejáveis para todo o país.

Além disso, em face da existência de imensos "espaços vazios" ainda não efetivamente ocupados - aquilo que chamamos de fundo territorial (MORAES, 2002) - Ary França notava que de maneira equivocada se havia generalizado no país a ideia de que a colonização era praticamente sinônimo de interiorização do povoamento, de exploração das áreas interiores do território. De fato, "o pioneirismo faz parte da mentalidade comum em nosso meio e volta-se para as novas áreas do interior num movimento que está longe de paralização" (FRANÇA, 1951, p. 11), e isso fez com que a maior parte dos comentadores e estudiosos do tema da colonização se interessasse sobre as áreas interiores do país, deixando de lado as áreas litorâneas, primeiras a serem atingidas pelo movimento colonizador português, mas que na década de 1950 encontravam-se estagnadas economicamente e demograficamente, o que permite ao geógrafo criticar, apoiado em dois influentes textos de Leo Waibel $(1949 ; 1950)$ que se voltavam contra às bases do programa "Marcha para o oeste", aqueles que defendiam tenazmente a transferência de populações para núcleos de colonização com o intuito de se "criar fontes novas de riquezas no distante sertão" (Loc. cit.), pois seria mais produtivo lançar esforços no sentido de recuperar as faixas litorâneas de São Paulo, que estavam mais próximas das áreas mais desenvolvidas do país, 
do que implantar centros de colonização isolados nos sertões, que dificilmente conseguiriam alavancar a conquista de novos espaços em bases aceitáveis.

Relacionando o conjunto das técnicas com o uso socialmente dado a elas no relacionamento entabulado entre os grupos humanos e os meios tropicais, Ary França criticava a grande lacuna de análises aprofundadas de países localizados nos trópicos existente na bibliografia geográfica internacional, situação que levava a juízos apressados que somente seriam corrigidos pelo esforço dos geógrafos brasileiros em oferecer estudos monográficos detalhados ${ }^{148}$. Em resumo, Ary França considerava as técnicas de exploração dos recursos naturais utilizadas pelos caiçaras como resquícios do passado, atribuindo exatamente à permanência de tais técnicas tanto a subsistência de traços de arcaísmo nos sistemas de paisagens existentes na década de 1950, como a degradação e o empobrecimento dos recursos naturais como um todo. $\mathrm{O}$ enquadramento por ele concebido, por sua vez, utilizava-se da análise de fotos aéreas - facilidade que lhe foi facultada pela circunstância única de seu irmão, Mário França, ser tenente-aviador da Força Aérea Brasileira -, o que lhe possibilitou empreender uma apreciação até certo ponto "quantitativa" do processo de ocupação da ilha. Assim, o autor comparava o avanço do desmatamento efetuado no início do século XIX, durante dois efêmeros ciclos econômicos da cana e do café associados a um período de fartura do porto de São Sebastião, o mais importante de São Paulo até a modernização da estrutura portuária de Santos impulsionada pelos interesses cafeeiros de planalto acima, a partir das diferenças apresentadas pelo estágio de recomposição das florestas ${ }^{149}$. O mosaico de matacões de cores diferentes, cada qual indicando

\footnotetext{
148 "Não cremos que as deficiências de informações sobre a nossa geografia possam ser corrigidas, nos grandes centros geográficos do mundo, se um sério esforço não for realizado para o estudo de exemplos sugestivos de nossas paisagens humanizadas, por parte de geógrafos brasileiros. O período de explorações ligeiras e de reportagens, à guisa de geografia, deve ser considerado definitivamente encerrado entre nós. Também as generalizações sobre as grandes unidades, não encontram lugar na geografia de um país que aos poucos, está se conhecendo e revela-se muito mais complexo do que à primeira vista pode aparentar." (FRANÇA, 1951 p. 14.)

149 "Para interpretar a humanização, o desgaste da natureza e o atraso que caracterizam as paisagens da orla costeira na acidentada Ilha de São Sebastião, não são suficientes os fatos atuais da ocupação humana; em a vida econômica pouco evoluída dos agricultores e pescadores caiçaras pode explicar-se com base no estudo dos agrupamentos atuais e do meio em que desenvolvem as principais atividades (...). A história local, contando já com três séculos e meio de ocupação da Ilha e regiões vizinhas por parte de colonizadores de origem europeia, apresenta-se, entretanto, mal documentada. Não se conhece o grau de povoamento, em períodos anteriores ao século passado [XIX]; das fases da vida econômica regional ficou o registro inseguro, que se refere ao conjunto da costa de São Sebastião abrangendo continente e ilhas (...). Nenhum documento sobre as atividades do século XIX é mais valioso do que os vestígios deixados pelas lavouras de café e pelos engenhos de açúcar e aguardente. Os cafezais, pelos restos conservados na mata reconstituída, em alguns pontos chegavam a ultrapassar os níveis dos morros, por exemplo nos arredores do colo existente entre os maciços de São Sebastião e Serraria. Nessa área hoje se encontram as ruínas, completamente invadidas pela mata, da sede de uma das fazendas de café do maior latifundiário local da primeira metade do século XIX.” (FRANÇA, 1951, pp. 131/136.)
} 
estágios distintos de reconstituição da vegetação original, permitia então avaliar as modificações impostas à natureza pelos grupos humanos ao longo da história, substituindo o uso de documentos e dados estatísticos inexistentes pelo tradicional inquérito de campo. Por conseguinte, a roça itinerante dos caiçaras, ao deixar antigas áreas de cultivo em descanso por alguns anos, dava ainda mais ênfase a esse processo, pois as áreas abandonadas em épocas distantes recuperavam sua fisionomia de "floresta virgem" com mais vigor do que as áreas utilizadas com mais frequência, que atingidas anualmente pelos incêndios que o caiçara ateava até mesmo "por prazer", como chega a dizer sem disfarçar o tom depreciativo, nunca perdiam o aspecto degradado de capoeiras.

Para embasar seu juízo, o autor apresenta alguns cálculos efetuados a partir das fotos aéreas que foram confirmados em suas linhas gerais no terreno. Como um todo, o litoral de São Sebastião e Ubatuba, que compreende os municípios de Ubatuba, São Sebastião, Caraguatatuba e Ilha Bela, têm uma área de $1.950 \mathrm{~km}^{2}$, dos quais não devem entrar no cálculo de densidade e aproveitamento dos solos os costões, falésias e morros recobertos de florestas, que corresponderiam a aproximadamente $60 \%$ do total. Assim, o que seria realmente relevante para a análise seriam as 159 pequenas e médias planícies costeiras e fluviais densamente ocupadas, que perfariam somente $84 \mathrm{~km}^{2}$ do total, uma vez que, levando em conta a totalidade das terras exploradas e já devassadas no passado e no presente, que raramente ultrapassavam a cota de 500 ou 600 metros, teríamos um total de $380 \mathrm{~km}^{2}$, ou seja, apenas $20 \%$ de toda a região já havia sido modificada pelos grupos humanos ${ }^{150}$.

Ao final, Ary França também considerava que as paisagens humanizadas eram como reflexos das mudanças ocorridas nas bases econômicas e sociais ao longo da história. Os ciclos

\footnotetext{
150 "Não podemos, hoje, reconstituir o passado, para o conjunto do litoral em estudo, a ponto de precisar, em qualquer dos seus momentos, qual o estado de devastação da floresta - em outras palavras, onde passava o limite entre a paisagem transformada pelo homem e a indevassada. Por toda a parte, evidenciam-se, porém, as marcas de atividade mais importantes outrora, o que é confirmado pelas raras estatísticas do século XIX e pelos recenseamentos de 1900 e 1920 (...). A miserável situação que perdura, parece ser o reflexo das técnicas rotineiras e da falta de incentivo - que não poderá partir senão de fora - à renovação das técnicas da vida econ6omica, principalmente as agrícolas. O agricultor do litoral de São Sebastiao e Ubatuba, nos dias atuais, limita-se a utilizar uma parcela dos solos cultivados pelos seus antepassados, deslocando as roças temporárias, de uma para outra posição dentro das matas secundárias, que são impedidas de se reconstituírem, a menos que se tenha dado completo abandono da agricultura (...). Um dos problemas mais interessantes da pesquisa geográfica nesta região é, portanto, verificar em que anos ou épocas atingiram-se os limites da devastação da mata, em altitude (...). Não resta dúvidas que foram os agricultores do passado, nas vertentes do Canal de São Sebastião pelo menos, os que atingiram as cotas mais elevadas das roças e plantações localizadas nos morros, fazendo a floresta recuar até o seu domínio atual, o das mais íngremes escarpas." (FRANÇA, 1951, p. 56/59-60.)
} 
econômicos por ele identificados, como o do café, o da cana, o da pesca, e, mais recentemente, o do turismo, não conseguiram estabelecer de modo permanente uma atividade que sustentasse a população em níveis de vida razoáveis, com o que o desgaste da natureza, a decadência das paisagens e o despovoamento aparecem como os aspectos mas comuns da história do litoral de São Sebastião. A referência à Ecologia Humana de Ary França indica mesmo uma prática científica que toma a geografia como a ciência natural da sociedade. A naturalização do elemento humano, entrevisto aqui no vocabulário utilizado pelos geógrafos uspianos, que bem ou mal tentamos reproduzir não apenas neste capítulo, mas ao longo de todo o trabalho, pois que nos preocupamos sempre em repor os termos utilizados nos textos avaliados, fica evidente quando se percebe que a situação de pobreza e o nível de vida dos caiçaras, que se mantinham baixos mesmo com a introdução da atividade pesqueira e com o turismo, são avaliados a partir da ótica que julga o papel dos fatores humanos na devastação dos recursos naturais, e não a partir de críticas às relações de dependência e inferioridade estabelecidas entre aqueles que, em cada uma das épocas, controlaram as atividades econômicas principais e se utilizaram dos caiçaras como mão-de-obra barata.

Finalizando com alguns comentários sobre o trabalho de Pasquale Petrone, cujas pesquisas de campo foram efetuadas ao longo da década de 1950 sob orientação de Ary França, mas que foi apresentado à cadeira de Geografia Humana em 1961, sendo publicado apenas em 1966, vemos a permanência de um modo específico de analisar geograficamente a realidade logo na explicação inicial: assim como os cinturões pioneiros ao redor do mundo, concebidos como áreas em vias de incorporação ao ecúmeno, também a região do Ribeira por ele estudada era qualificada como um espaço que ficou historicamente "à margem do espaço econômico paulista, isolado em relação à maioria dos processos de valorização interessando territórios do estado de São Paulo" (PETRONE, 1966, p. 5), ou seja, antes de sequer iniciar a descrever o seu terrain, Petrone notava o paradoxo da situação da orla litorânea de São Paulo, que como bem havia escrito Louis Papy (1952), ficou à margem do império do café, contrastando com suas reservas florestais despovoadas e seus pequenos núcleos economicamente subdesenvolvidos os processos de expansão econômica e demográfica vivenciados nas áreas planaltinas: "Impressionou-nos, mais do que qualquer outro, o fato de no sul do estado de São Paulo, junto à costa, à distância relativamente pequena da capital, existir um verdadeiro 'sertão do litoral'." (Loc. cit.). 
Invertendo os polos da antiga proposição que opunha as áreas litorâneas desenvolvidas ao sertão isolado e atrasado, pois que, nesse pormenor, era a orla litorânea que ficava de fora dos fluxo modernizantes que tomavam conta dos planaltos interiores de São Paulo, notamos novamente a relação do tema a ser desenvolvido com o fenômeno do pioneirismo, já que uma vez mais o desenvolvimento econômico alavancado pelo café é tomado como o modelo de desenvolvimento padrão para se analisar o processo de povoamento e ocupação da Baixada do Ribeira. Em outras palavras, o atraso relativo do litoral ante ao dinamismo do planalto aparecia para Petrone como um fato que deveria ser geograficamente analisado, porquanto permanecia sem resposta os motivos que explicavam as razões para, "dentro de uma unidade político administrativa em que, através de processos de pioneirismo, a posse e a valorização das terras se verificava em direção oeste, transbordando de seus limites e atingindo o norte do Paraná e sul de Mato Grosso" (PETRONE, 1966, p. 6), a faixa litorânea permanecer ainda desocupada, o que dava origem a uma região isolada, verdadeiro "sertão no litoral". Nesse caso, pergunta o geógrafo, seria a tropicalidade mais prenunciada das faixa litorânea paulista, em hipótese, a motivação básica das diferenças de desenvolvimento?

Para responder a essa questão, Pasquale Petrone considerava fundamental lembrar que a Baixada do Ribeira havia sido alvo de diversas iniciativas que objetivavam a criação de núcleos coloniais com estrangeiros, isto é, na Baixada do Ribeira, em meados do século XIX, foram implantadas colônias com alemães e italianos praticamente ao mesmo tempo em que foram formados os núcleos coloniais nos estados de Santa Catarina e Rio Grande do Sul. Sendo assim, tal uma verdadeira região-laboratório, como diria Isaiah Bowman, o estudo dos insucessos das experiências de colonização da Baixada do Ribeira poderia fornecer algumas respostas aos problemas do povoamento produtivo dos trópicos, tanto mais por possibilitar a comparação com o relativo sucesso obtido nas colônias do sul do país, localizadas em áreas de clima subtropical, e não em áreas de florestas quentes e úmidas como no litoral paulista. Assim, para o geógrafo, verificar as razões do fracasso das experiências colonizadoras do Ribeira seria "tão importante ou mais que as razões do sucesso no vale do Itajaí ou em outras partes" (PETRONE, 1966, p. 7).

Após as ressalvas iniciais, Petrone começa seu trabalho com uma discussão sobre os problemas encontrados no significado do conceito de região, dizendo que este não se define apenas levando em conta as condições naturais, mas sobretudo pelas paisagens culturais e pelos aspectos econômicos que tornam possível a apreensão da totalidade e a comparação das unidades 
identificadas regionalmente com os espaços contíguos. Retomando a discussão das divisões regionais do estado de São Paulo, o geógrafo ítalo-paulista assume o ponto de vista da seção paulista da AGB e inclui o litoral de São Paulo no que se convencionou chamar de velhas regiões de povoamento. Na verdade, assim como Renato da Silveira Mendes, Pasquale Petrone considera as regiões geográficas criações humanas, pois são as atividades socialmente desenvolvidas que unificam ou diferenciam os quadros naturais que lhe servem de base: "a presença do homem, entretanto, criando formas de organização da ocupação do espaço econômico que, muitas vezes, não se ajustam inteiramente a este ou aquele quadro natural, expressa-se em paisagens culturais que contribuem para atenuar as diferenças dos referidos quadros, ou para mais nitidamente diferenciá-los" (PETRONE, 1966, p. 39).

Descrevendo os gêneros de vida tradicionais baseados na pesca e nas roças itinerantes que dominavam a região desde as primeiras penetrações ocorridas no final século XVI, o geógrafo percebe, como nos outros trabalhos analisados, que a introdução de novos produtos comerciais, com a renovação ou a substituição das antigas técnicas e sistemas de exploração do solo, induz à uma reorganização do espaço, com um rearranjo do habitat rural e o desenvolvimento da função urbana. Desse modo, como o processo de instalação humana conferia mais singularidade às paisagens da Baixada do Ribeira do que as diferenças do meio físico, o autor passa a reconstruir a marcha do povoamento regional, avaliando as modificações impressas nas paisagens em cada período histórico e concluindo, ao final, que o tímido desenvolvimento dos núcleos de povoamento instalados no período colonial, como Cananéia e Iguape, que já eram pontos cristalizados de ocupação no século XVII, foi responsável por transformar a Baixada num improvável sertão litorâneo, verdadeira "zona ilhada" como diz Petrone acompanhando Nelson Werneck Sodré, praticamente isolada em relação ao planalto e totalmente voltada para o $\operatorname{mar}^{151}$.

Aprofundando seus esforços de reconstrução do processo de ocupação, Petrone lembra que a mineração de ouro das terras mais interiorizadas da Baixada em meados do século XVII incentivou o devassamento da retro-terra e a valorização das áreas drenadas pelo rio Ribeira, dado que por meio da exploração da rica rede de drenagem da região, moradores de Iguape

\footnotetext{
151 "Os primeiros tempos de vida do incipiente povoamento caracterizam-se pelo isolamento, especialmente em relação ao interior. A presença de ameríndios relativamente pacíficos, em contraste do que se verificou no litoral norte de Santos favoreceu a fixação de moradores que, em pontos isolados, viviam provavelmente de alguma pesca e lavouras de subsistência, eventualmente também atividades de coleta. A distância relativamente grande que separa a 'zona ilhada' do planalto fez com que, diferentemente do exemplo de São Vicente, a vida de relações com o referido planalto não se manifestasse nos primeiros tempos senão esporadicamente.” (PETRONE, 1966, p. 71.)
} 
chegaram até Apiaí, permanecendo nas proximidades do rio Xiririca. Assim, se ao longo dos dois primeiros séculos de povoamento as atividades agrícolas limitavam-se às lavouras de subsistência explorada no tradicional sistema de roças itinerantes, a partir do final do século XVIII há um incremento das atividades agrícolas, com a expansão da cultura da mandioca para a produção de farinha e o cultivo do arroz, que fomentou a construção de engenhos que se utilizavam da força dos rios, ambos os produtos sendo exportados pelo porto de Cananéia.

No século XIX, a continuidade da expansão na reto-terra do Ribeira prosseguia vagarosamente com as mesmas características, a saber, o aproveitamento das vias naturais de penetração representada pelos rios e "o deslocamento de posseiros na base da agricultura itinerante predatória" (PETRONE, 1961, p. 83), que dispunham o povoamento em linhas de dispersão orientadas ao longo do curso dos principais rios. Por essa época, entretanto, a mineração já havia praticamente cessado suas atividades, e os principais recursos econômicos eram a cana-de-açúcar, a mandioca e o arroz, principal cultura da Baixada do Ribeira, que por meio do mar entranhava relações com Santos, Paranaguá e Rio de Janeiro: "No conjunto a região voltava-se mais para o exterior, permanecendo ainda muito isolada do planalto. Para este, as comunicações continuavam insatisfatórias" (PETRONE, 1966, p. 870).

Foi então na segunda metade do XIX que dois fatos modificaram os quadros locais. De um lado, o governo Imperial criou as colônias de Pariquéra-Açu e de Cananéia, influindo diretamente na dinâmica paisagística da região, e de outro, alguns imigrantes norte-americanos confederados instalaram-se nas vizinhanças de Cananéia, o que renovou o processo de ocupação, embora o ritmo da evolução e as técnicas empregadas na exploração do solo tenham continuado os mesmos do período anterior, haja vista a precariedade dos caminhos e da navegação, que não permitiam que a pauta produtiva local alterasse muito seu perfil, pois continuava o plantio de arroz, mandioca, milho, fumo, cana e um pouco de café. Nessa época houve um inegável aumento da população, principalmente por conta das duas colônias oficiais, que fizeram com que pela primeira vez o povoamento se afastasse consideravelmente seja do litoral seja do eixo do rio Ribeira, inclusive com o desabrochar de um viés especulativo na apropriação de terras, com a indefectível ação dos falsificadores ${ }^{152}$. No geral, ao se iniciar o século XX, a região do Ribeira,

\footnotetext{
152 “Aqueles que começavam a ocupar terras em grade escala, com objetivos especulativos, foram os principais responsáveis pelos problemas que, no século atual, iriam caracterizar os aspectos relativos à legalidade da propriedade das terras. O 'grilo' tornou-se de fato comum em toda a Baixada e, como em outras partes do estado, o
} 
concebida por Pasquale Petrone como palco de uma dinâmica de povoamento, permanecia isolada do restante do estado de São Paulo, com grandes extensões de florestas densas servindo de barreira para o acesso aos núcleos de povoamento por caminhos terrestres: o quadro letárgico esboçado pelo geógrafo teria que aguardar "durante toda a primeira metade do século atual [XX] a oportunidade de fornecer os primeiros frutos de valorização da Baixada (...) permanecendo por algumas décadas como o paradoxal 'sertão litoral'” (PETRONE, 1966, pp. 95-96).

Na verdade, a explicação de Petrone para o insucesso da colonização da Baixada do Ribeira está relacionada, em primeiro lugar, com o problema da colonização do estado de São Paulo como um todo, pois embora essa unidade da federação seja a que recebeu o maior contingente de imigrantes do país, não se criou em terras bandeirantes núcleos de colonização fundamentados em pequenas propriedades familiares da mesma maneira do que ocorreu em Santa Catarina e no Rio Grande do Sul, uma vez que a maior parte dos estrangeiros introduzidos em São Paulo voltava-se exclusivamente para o trabalho nos cafezais, isto é, em São Paulo o problema da colonização não era uma questão de povoamento, mas uma questão de mão-de-obra. Assim, o termo "colônia" assumiu ali um significado diverso, designando, no mais, o conjunto de habitações precárias dos trabalhadores assalariados que se localizava nas proximidades ou mesmo dentro das fazendas, e não projetos de povoamento que contavam com planejamento e objetivava a fixação do colono à terra em pequenas propriedades:

Ao governo, portanto, não interessava desviar para o Ribeira, ou outra área qualquer, mão-de-obra que seria necessária nos cafezais. Por outro lado, a riqueza criada por essa lavoura transformava as áreas e que se desenvolvia em zonas de sucção, do ponto de vista geoeconômico, atraindo os colonos que nelas viam a possibilidade de enriquecer mais rapidamente do que enfrentando todos os problemas implícitos na criação da própria propriedade, praticamente somente com os próprios recursos e partindo do nada. Criar uma paisagem humanizada em zonas ainda dominadas por meios naturais devia parecer-lhes mais difícil que acomodar-se a um quadro econômico, social e administrativo já definido. É significativo que na região as colônias mais importantes só foram criadas mais recentemente, quando o café já não usufruía exatamente a posição anterior, e que tenham sido criadas por japoneses, os quais só excepcionalmente adaptaram-se ao trabalho de assalariados nas fazendas de café. (PETRONE, 1966, p. 109.)

Mas a atração das terras do planalto não pode ser tomada como a maior responsável pelo insucesso das ações colonizadoras desenvolvidas desde o século XIX no Ribeira, pois à essa

'grileiro' é que muitas vezes acabou por determinar o destino de áreas imensas, frequentemente em desfavor do povoador anônimo, desbravador e morador de zonas distantes." (PERONE, 1966, p. 93-94.) 
polarização dos centros pioneiros do interior paulista veio se somar outros fatores peculiares que funcionaram como elementos de repulsão, dentre os quais ganha destaque as condições físicas marcadas pela tropicalidade extrema, que estabeleceu por parte dos colonos estrangeiros uma relação de hostilidade, a desilusão dos imigrantes ante à dura realidade encontrada, que era muito diferente do quadro idílico e miraculoso pintado nas propagandas sobre a nova terra, as técnicas primitivas dos caboclos, que os colonos assumiram como suas para prover a subsistência do grupo, mas que pelo desconhecimento das particularidades naturais da região foi depois perpetuada como a única forma de exploração do solo, uma vez que os projetos de colonização não foram precedidos de levantamentos cientificamente orientados, e, principalmente, a questão da circulação e do acesso aos mercados, que tornavam qualquer colônia instalada, mesmo as fundadas no século XX, isoladas em relação aos fluxos econômicos paulistas e brasileiros:

Conversando com velhos colonos de Pariquéra-Açu ou de Santa Maria, tivemos oportunidade de sentir como deve ter sido grande o desencanto dessa gente logo ao chegar ao que, para muitos, devis se constituir em nova Canaã. Problema, portanto, segundo acreditamos, de natureza psicológica, mas com profundas repercussões no complexo e difícil processo de enquadramento a uma região nova, não impossível de aproveitar, mas não fácil de enfrentar (...). De qualquer forma, o aspecto fundamental sobre o qual insistiremos outras vezes, foi, segundo nos parece, o da circulação e mercados. Todas as colônias da Baixada, mesmo as mais recentes, foram criadas em áreas marginais, isoladas, quase sempre de difícil acesso (...). Em vista dessas condições, os produtos comerciais que as colônias pudessem obter atingiriam os mercados de consumo com muita dificuldade. Considerando que os próprios mercados da Baixada não eram satisfatórios, a produção deveria chegar a Iguape e Cananéia para buscar SantosSão Paulo ou Paranaguá-Curitiba. (PETRONE, 1966, pp. 111-112-113.)

De fato, no século XX houve outras tentativas particulares de colonização da Baixada do Ribeira, dentre as quais ganha destaque as ocorridas ao longo da década de 1910, quando começam a ser criadas como um empreendimento oficial da "Companhia Imperial Japonesa de Imigração" as colônias nipônicas instaladas no município de Registro, e as levadas a termo em 1925, quando por iniciativa da brasileira "Empresa de Terras e Colonização Santa Maria", que possuía sede em São Paulo mas passou posteriormente para o controle de capitais ingleses, organizou-se com colonos alemães e austríacos a colônia de Santa Maria, em Cananéia. O fracasso dessa última pode ser creditada, como os esforços de colonização do período anterior, tanto à falta de vias de comunicação, que transformou a economia de Santa Maria em um sistema fechado visando a autossuficiência já em meados da década de 1930, quanto ao desconhecimento do meio tropical. 
Já as colônias japonesas são as iniciativas que contaram com os resultados mais satisfatórios dentre todas as já empreendidas na região, sendo ainda uma característica própria da colonização japonesa o forte direcionamento imposto pela companhia oficial que iniciou os trabalhos, cujas decisões, frutos de um verdadeiro planejamento, apoiavam-se nas indicações dos agrônomos e técnicos que ajudavam na escolha do produto, no desenvolvimento das lavouras e no financiamento da atividade agrícola. Porém, os japoneses inicialmente se adequaram aos quadros locais, imitando os caboclos e assumindo suas técnicas e sistemas de exploração do solo ao menos para a produção dos gêneros voltados para o seu abastecimento. Ademais, a construção de uma rede de caminhos vicinais demandando Juquiá, que estava ligada a Santos por estrada de ferro, e a ajuda financeira dada pela Companhia Japonesa para que o governo estadual edificasse uma rodovia ligando as colônias de Registro ao planalto pelos municípios paulistas de Ibiúna e Piedade, abriu possibilidades de acesso antes insondáveis aos mercados consumidores, principalmente para a produção do chá, produto comercial ali introduzido pelos japoneses que animou outras tentativas de cultivos experimentais, como as efetuadas com o cacau e as seringueiras. Ao final, o fenômeno da colonização da Baixada do Ribeira esteve sempre atrelado às possibilidades de circulação oferecidas pela rede hidrográfica, que praticamente comandou a direção do povoamento desde a instalação dos primeiros núcleos, ainda no século XVII. Desse modo, o isolamento da região desempenhou papel ativo na constrição das relações econômicas, situação modificada parcialmente somente na terceira década do século XX, quando a melhoria do sistema viário regional permite a instalação de novas culturas comerciais, o crescimento relativo dos núcleos urbanos já existentes e a valorização das terras, que atraem a atenção de especuladores e passam a ser consideradas “como mercadorias em si” (PETRONE, 1966, p. 343):

A introdução de novas plantas cultivadas, a exemplo da seringueira e do cacaueiro, a expansão de culturas como a do chá e da banana, as tentativas de retomada da lavoura cafeeira, em bases técnicas novas, fenômenos que nos casos mais expressivos estão ligados à aplicação de capitais a que já nos referimos, a par de contribuir para a diversificação e maior aprimoramento técnico das culturas, e de marcar as paisagens regionais com novos elementos, constitui, de resto, embora como decorrência de alguns dos fatos citados anteriormente, mais um fator de valorização. A melhor prova é que não seriam empatados capitais em iniciativas dessa natureza, cujos frutos surgirão, em alguns casos, somente depois de vários anos, se não existissem possibilidades desses capitais serem pelo menos reembolsados (...). Acreditamos que a diversificação regional da Baixada do Ribeira, já fruto de quadros naturais particulares, mas principalmente decorrência da diversificação das atividades do homem, pode propiciar a criação de quadros novos de organização econômica, escudados em técnicas 
apropriadas, justificando a integração da região dentro do conjunto geoeconômico do estado de São Paulo não mais como uma área subdesenvolvida mas sim como uma sua parcela economicamente atante e positiva. (PETRONE, 1966, pp. 346/351.)

Como um todo, cada um dos autores que vimos comentando neste capítulo conclusivo apresenta características singulares que permitem identificar as diferenças de tom e de posicionamento em relação a determinados assuntos e temas. Entretanto, conforme tentamos evidenciar, os traços comuns existentes entre os trabalhos são por demais ilustrativos, com o que ficamos inclinados a referendar que houve mesmo em São Paulo a constituição de um grupo de trabalho afinado com os ensinamentos geográficos obtidos na década de 1940, período que marca a atuação de Pierre Monbeig na Universidade de São Paulo. Nessa direção, o fenômeno do pioneirismo e a expansão da colonização e do povoamento impulsionado pelo café, que praticamente monopolizava as atenções de políticos e intelectuais na primeira metade do século XX, pôde cumprir o papel de tema unificador, conferindo aos geógrafos uspianos, por vezes de maneira indireta, um horizonte ideal de análise para seus trabalhos de doutoramento. Por outro lado, a importância dos fatores econômicos no processo de organização das paisagens, mesmo que utilizado a partir de um viés que carrega uma indisfarçável linearidade, como se pode inferir do recurso aos ciclos econômicos para qualificar a estrutura social existente em outras épocas, alça a questão da circulação e da integração entre as distintas regiões a um primeiro plano, abrindo novas possibilidades para a compreensão de como o processo de formação territorial aparecia nas descrições explicativas dos geógrafos dessa geração. Ao fim e ao cabo, em suas análises descritivas de distintas regiões, os geógrafos mostravam uma preocupação ímpar em desvendar as alterações que a consolidação de uma nova estrutura social e econômica impunham às paisagens populações tradicionais, revelando de que maneira desenvolvimento geograficamente desigual do capitalismo no Brasil podia ser analisado pela geografia acadêmica. 


\section{CONSIDERAÇõES FINAIS}

Ao longo desse trabalho alguns temas nortearam o encadeamento dos argumentos, guiando bem ou mal o caminho seguido e as conclusões a que chegamos em cada um dos capítulos. Desde o primeiro capítulo, que apresentava um claro perfil historiográfico, o tema da formação territorial apareceu como proeminente, pois buscamos apontar por meio do painel de discussões ali apresentadas as diferentes maneiras como o território era concebido em diferentes círculos, com ênfase para os projetos políticos do governo e para as questões que envolviam a identidade nacional, então dominantes no pensamento político-social brasileiro. No caso, da mesma forma que a questão identitária e o estudo sobre os "intérpretes do Brasil" foi capaz de dar consistência a diferentes "estilos" dentro do pensamento político-social ${ }^{153}$, a geografia acadêmica, influenciada pelo trabalho de Pierre Monbeig e por sua noção de pioneirismo, construiu igualmente uma linhagem acadêmica fundamentada em obras que apresentam denominadores teóricos e metodológicos comuns.

De fato, como tentamos ilustrar em abundantes passagens no capítulo anterior, o enquadramento conferido por Monbeig ao fenômeno do pioneirismo tronou-se mesmo um padrão para a avaliação do nível de desenvolvimento dos lugares, funcionando como o esteio que escora a unidade da geografia praticada pelo grupo de geógrafos paulista no período. Por esse motivo, é surpreendente que a tradução do principal livro que Monbeig escreveu sobre o país tenha sido feita apenas em 1984. Realmente, fazendo um breve exercício especulativo, cremos ter levantado elementos suficientes para afirmar que um dos motivos que sem dúvida contribuiu para esse hiato é a existência do livro A Marcha do Café e as Frentes Pioneiras, de Ary França.

$\mathrm{Na}$ verdade, esse livro, escrito ao longo do primeiro quinquênio de 1950 e lançado em 1960, retoma e atualiza com dados de Censo de 1950 praticamente todas as conclusões a que Monbeig havia chegado em sua tese de doutoramento. Escrito originalmente como o livro-guia da excursão de número três do Congresso Internacional da UGI ocorrido no Rio de Janeiro em 1956, o livro de Ary França é o único do certame havido esse ano que não contou com a

\footnotetext{
153 “o estudo do pensamento político-social foi capaz de formular ou discriminar na evolução política e ideológica brasileira a existência de "estilos" determinados, formas de pensar extraordinariamente persistentes no tempo, modos intelectuais de se relacionar com a realidade que subsumem até mesmo os mais lídimos produtos da ciência institucionalizada, estabelecendo problemáticas e continuidades que permitem situar e pôr sob nova luz muita proposta política e muita análise científica atual.” (BRANDÃO, 2010, p. 29).
} 
participação de algum geógrafo ligado ao CNG, visto que o outro livro escrito por um geógrafo de São Paulo, Aziz Ab'Saber, foi elaborado em parceria com Nilo Bernardes.

Até mesmo em sua composição o livro traz uma herança legada por Monbeig, pois assume mesmo o perfil de uma obra coletiva construída no campo, visto a contribuição de Aroldo de Azevedo, Nice Lecocq Müller e Pasquale Petrone. Nessa obra, com dissemos, as tendência da evolução do mundo pioneiro são novamente afirmadas: a fragmentação da propriedade, com o aumento dos sitiantes, a expansão da policultura e o surgimento de uma classe média rural, a industrialização, que ultrapassava os limites da capital e se afirmava em determinadas cidades interioranas, com Campinas, Jundiaí, as cidades do ABC e as do vale do Paraíba, como Taubaté e São José dos Campos, que retomavam seu desenvolvimento em novas bases econômicas.

No geral, o fenômeno descrito por Ary França como de avanço pioneiro, que se refere à expansão de lavouras ocupadas com um grande produto comercial que garante a relação com o mercado, por um lado, e pela consolidação dos principais centros urbanos fundados nesse movimento expansivo, por outro lado, na verdade comprovam o acerto do arranjo explicativo construído por Monbeig, pois conclui que a instabilidade da sociedade em movimento que o francês observara na década de 1930 e 1940, se não havia chegado ao fim, havia organizado novas paisagens dinamizadas agora a partir de uma nova estrutura econômica e social.

O fim do tempo dos fazendeiros vislumbrado por Monbeig estava cada vez mais próximo, e era dos exemplos mais contundentes as modificações experimentadas por Ribeirão Preto, cujas indústrias de transformação e os centros de estocagem conferiam uma gama de novas as funções urbanas que em nada deviam ao café. De fato, em algumas regiões que já não assistiam mais à vaga do café, o recuo da atividade tradicional dos paulistas não havia trazido decadência, mas deixado heranças que passavam a ser retrabalhadas em novas bases pela população ali fixada: a urbanização e a industrialização agora não era circunscrita à metrópole paulista, mas em São Paulo aumentava ainda mais o magnetismo da capital, que drenava para si a maior parte dos fluxo econômicos. Como um todo, na maior parte das regiões do planalto não houve regressão após o fim das movimentações pioneiras, mas uma mudança definitiva dos padrões de organização das paisagens, cada vez mais hegemonizado pelo capital. 


\section{ANEXO FOTOGRÁFICO154}

1.

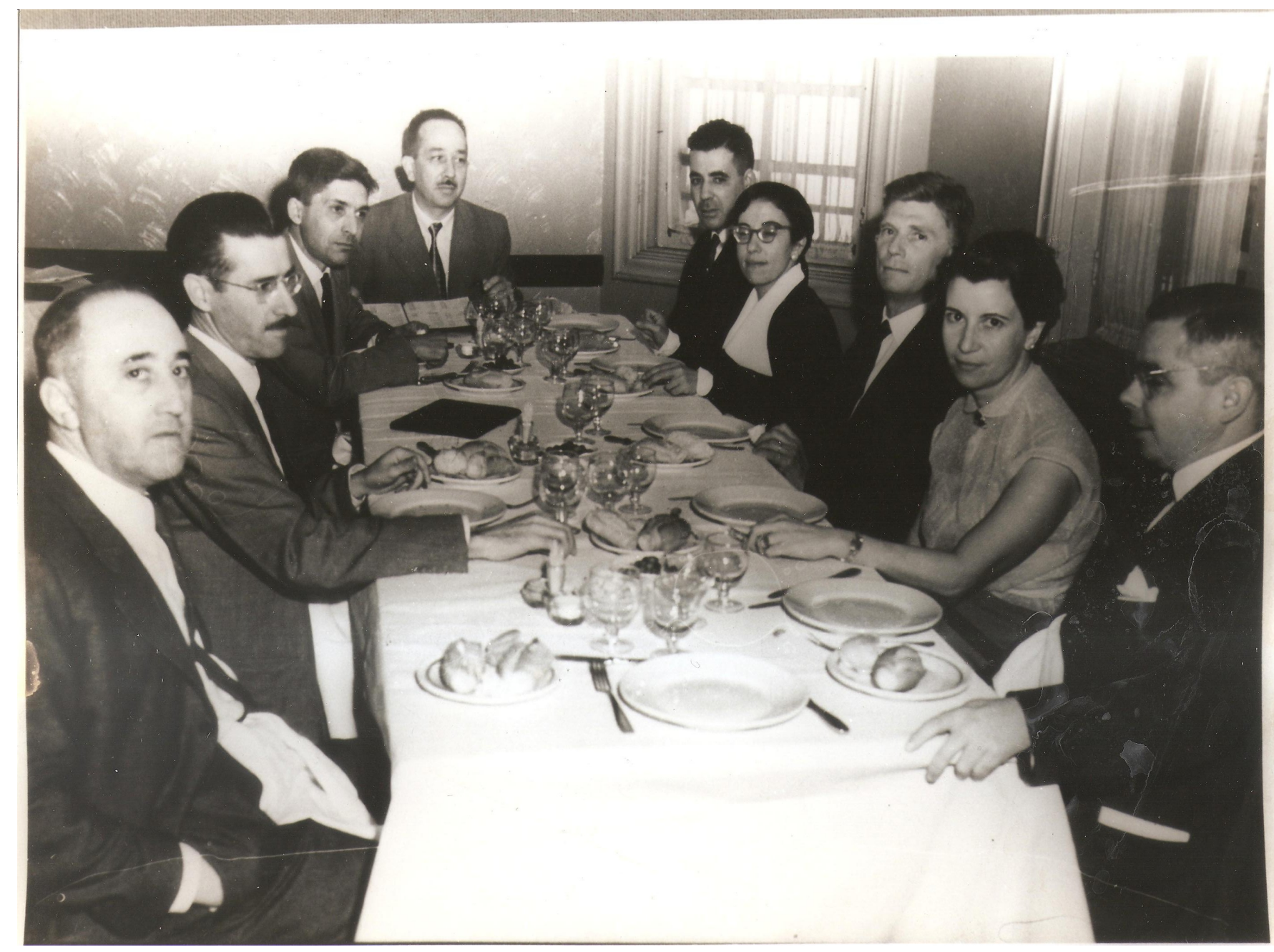

Almoço com o professor Pierre Monbeig, em 1958, da esquerda para a direita: Raul de Andrada e Silva, Dirceu Lino de Mattos, José Ribeiro de Araújo Filho, Brás Berlanga Martinez, Ary França, Alice Piffer Canabrava, Pierre Monbeig, Elina de Oliveira Santos e Odilon Nogueira de Mattos.

${ }^{154}$ Todas as fotos foram conseguidas no Centro de Apoio à Pesquisa em História "Sérgio Buarque de Holanda", no prédio do Departamento de Geografia e História da Faculdade de Filosofia, Ciências e Letras da USP.

Foto 1: BIM 0028. Foto 2: BIM 0027. Foto 3: BIM 0032. Foto 4: BIM 0026. Foto 5: BIM 0036. Foto 6: BIM 0030. CAPH/USP. Caixa 09. 
2.

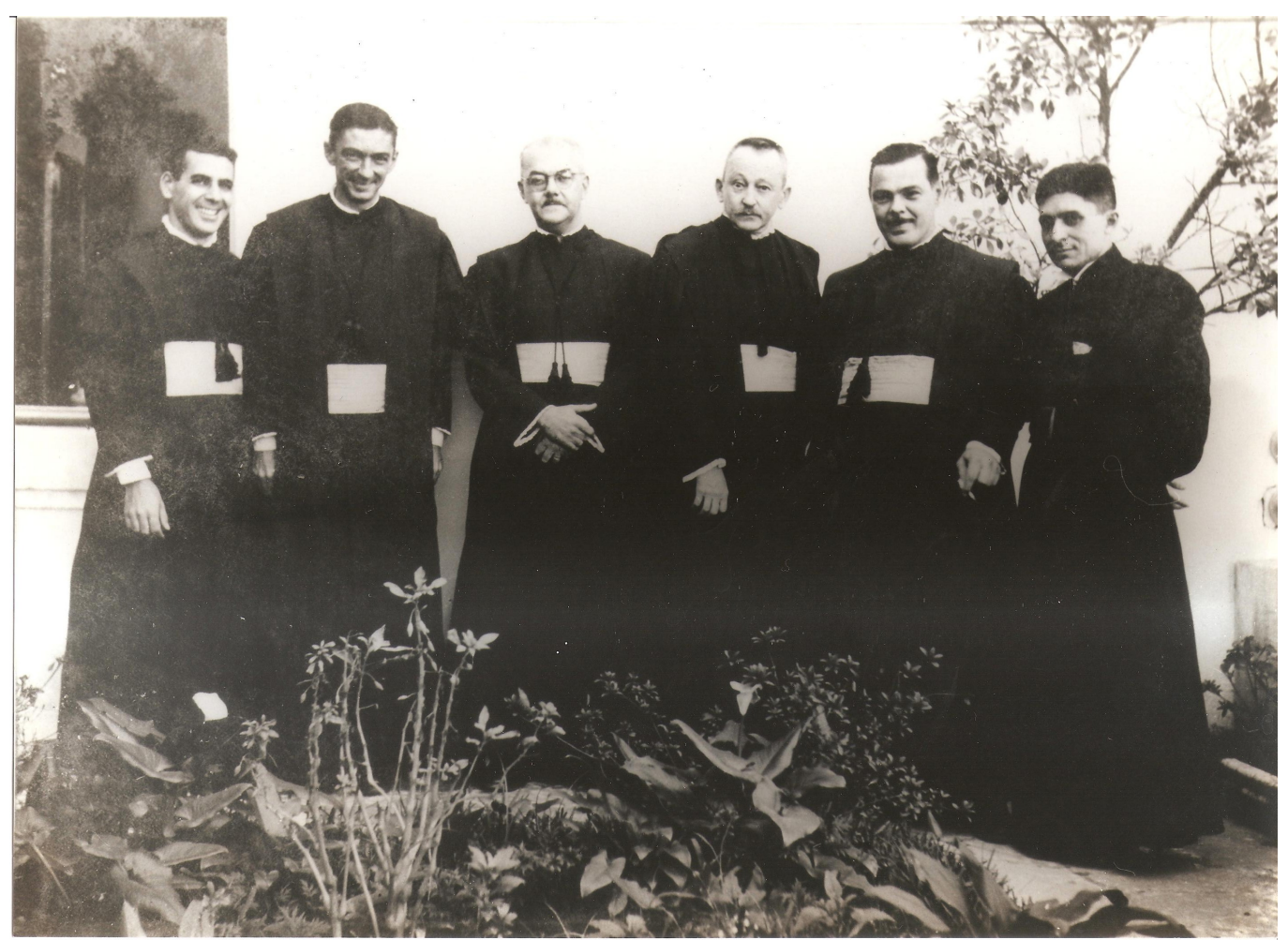

Defesa de doutorado de José Ribeiro de Araújo Filho, 1950. Centro Universitário Maria Antônia, São Paulo. Da esquerda para a direita: Ary França, José Veríssimo da Costa Pereira, Aroldo de Azevedo, Alfredo Ellis Jr., João Dias da Silveira e José Ribeiro de Araújo Filho.

3.

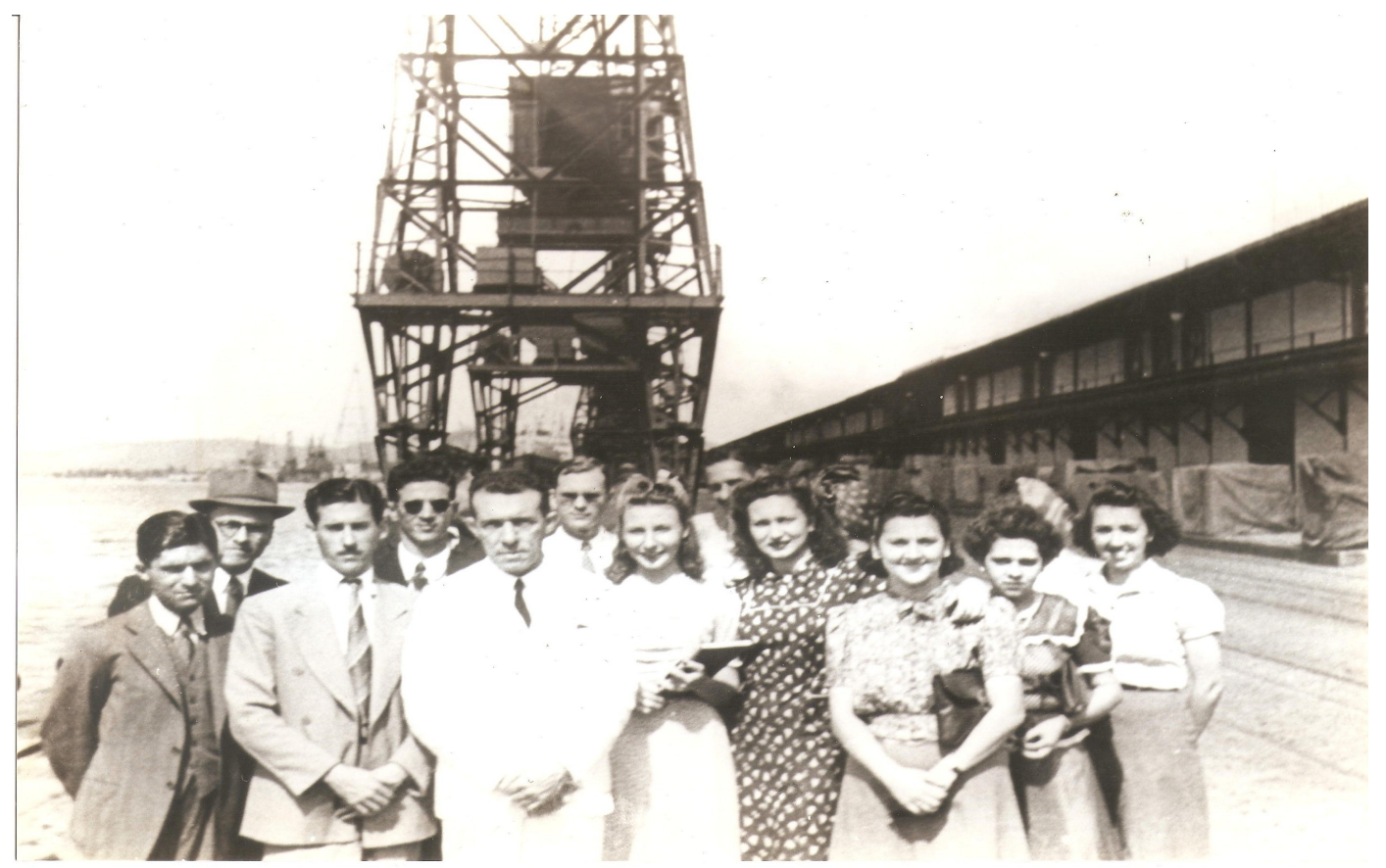

Excursão dos alunos de Geografia a Santos/SP, 1949. Os dois primeiros da esquerda para à direita são os professores José Ribeiro de Araújo Filho e Dirceu Lino de Mattos. 
4.

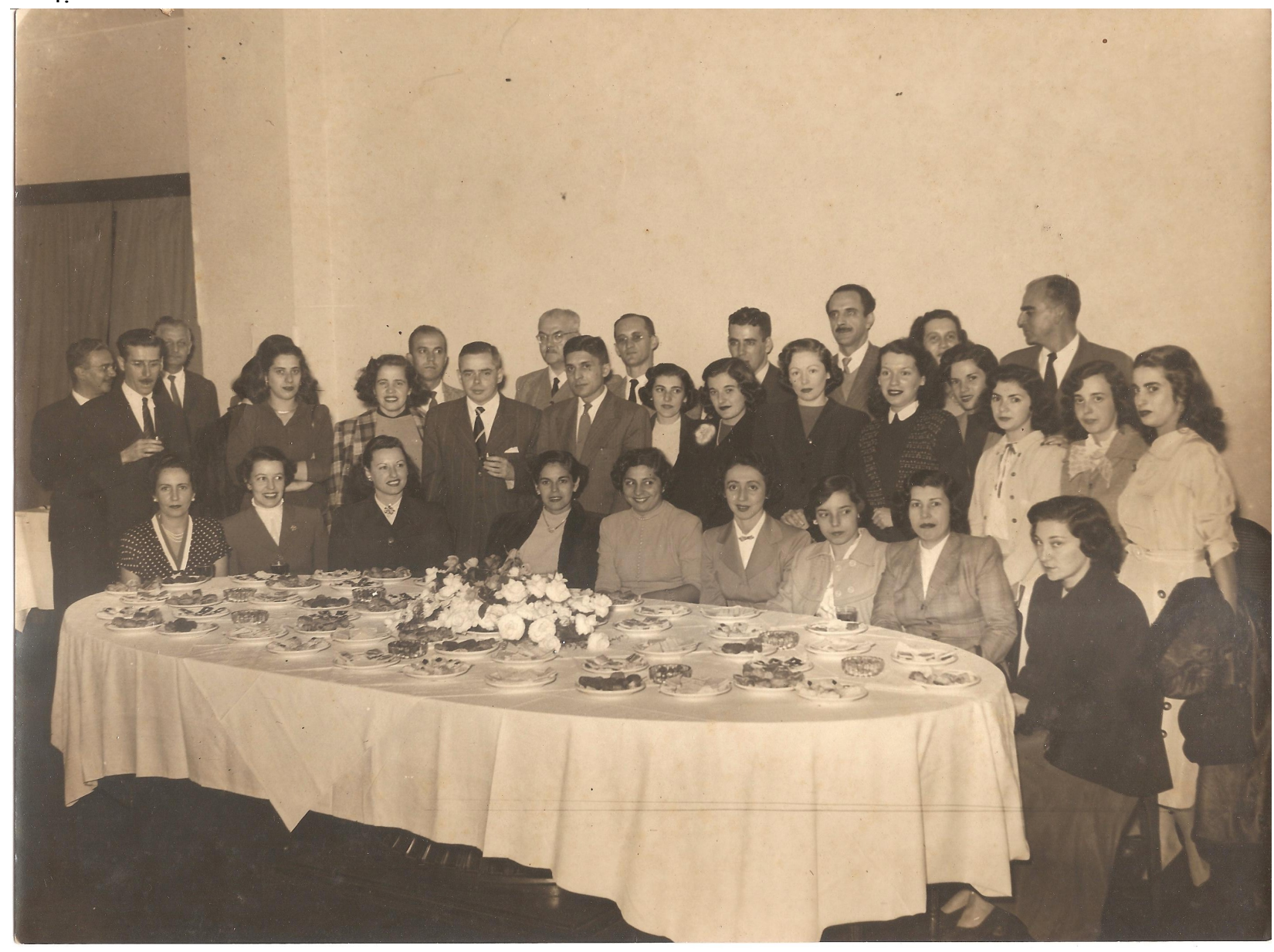

Coquetel oferecido no Mappin, na loja localizada em frente ao Teatro Municipal, em São Paulo, em homenagem ao doutoramento de José Ribeiro de Araújo Filho, em 1950. Na foto podemos ver: Renato da Silveira Mendes, Dirceu Lino de Mattos, Odilon Nogueira de Mattos, José Ribeiro do Araújo Filho, Aroldo de Azevedo, Louis Papy Ary França, Antônio Rocha Penteado, Eduardo d'Oliveira França, Nice Lecocq Müller, Maria de Lourdes Radesca e Elina de Oliveira Santos, entre outros presentes.

5.

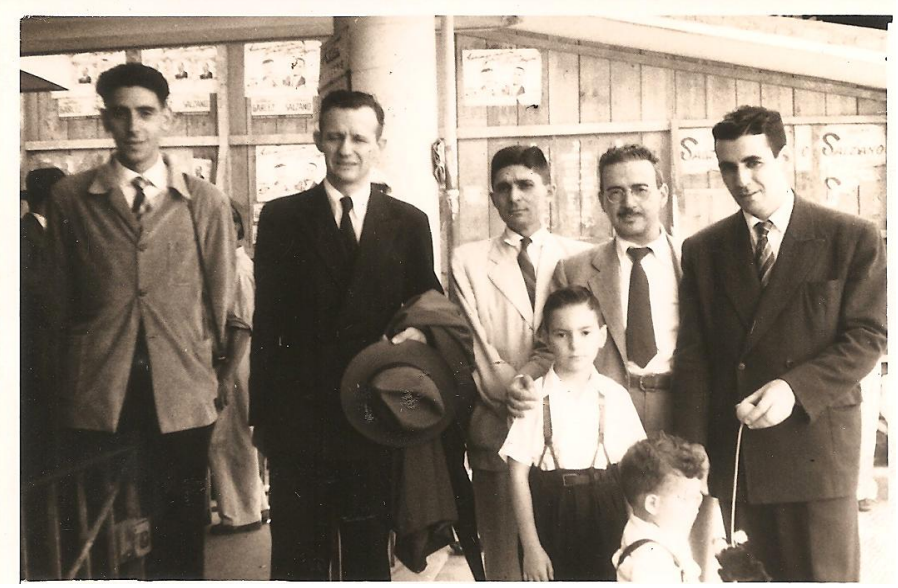

Embarque de Louis Papy de volta à França, 1950. Da esquerda para a direita: Aziz Ab'Saber, Louis Papy, José Ribeiro de Araújo Filho, Renato da Silveira Mendes e Ary França. 
6.

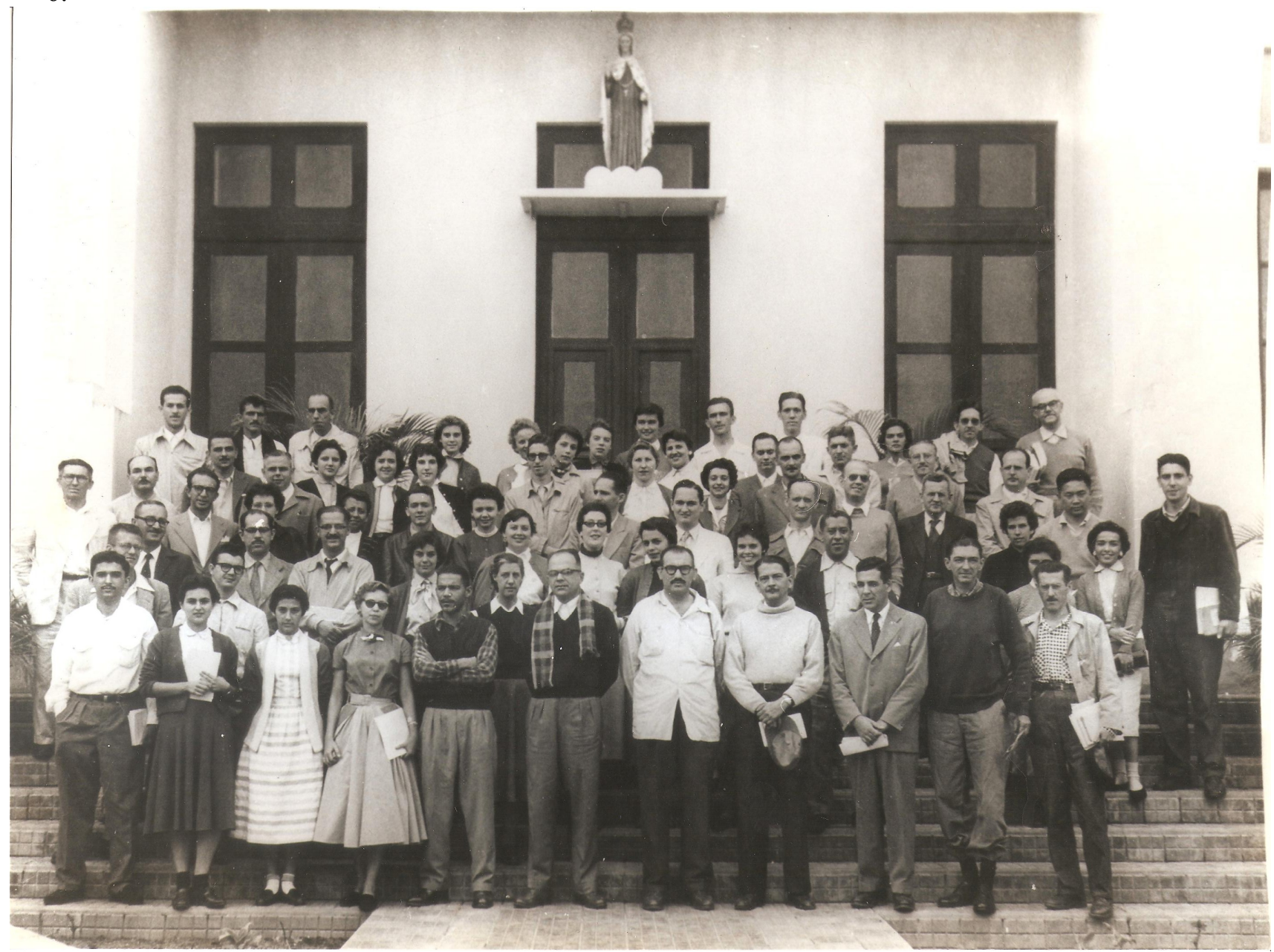

Assembleia da Associação dos Geógrafos Brasileiros (AGB) em Garunhuns/PE, 1955. Entre os presentes podemos ver, na primeira fila: Manuel Correia de Andrade, Ary França, José Veríssimo da Costa Pereira. À direita: Aziz Ab'Saber. Ao fundo: Aroldo de Azevedo. 


\section{BIBLIOGRAFIA}

ADAS, Sergio, 2006, O Campo do Geógrafo: Colonização e Agricultura na Obra de Orlando Valverde (1917-1964), São Paulo: Tese de Doutorado, DG/FFLCH/USP.

ALMEIDA, Roberto Schmidt de. A Geografia e os Geógrafos do IBGE no Período de 1938- 1998. Rio de Janeiro, Instituto de Geociências da UFRJ: Tese de Doutorado, 2000.

ALMEIDA, Ângela (org.) De sertões, desertos e espaços incivilizados. Rio de Janeiro:MAuad/FAPERJ, 2001.

ANDERSON, Benedict. Imagined Communities: : Reflections on the Origin and Spread of Nationalism. New York: Verso, 1991.

ANDRADE, Manuel Correia de. O Pensamento Geográfico e a Realidade Brasileira. In: Boletim Paulista de Geografia. $n$ 54. São Paulo: AGB, 1977.

. A Questão do Território no Brasil, São Paulo: Hucitec, 2004.

AGgiO, Alberto; BARBOSA, Agnaldo \& COELHO, Hercídia. Política e Sociedade no Brasil (1930-1964), São Paulo: Annablume, 202.

ANSELMO, Rita de Cássia M. de S. Oliveira Vianna e a Unidade - Identidade do Espaço Brasileiro. Rio Claro: Dissertação de Mestrado, UNESP, 1995.

-------------- . Geografia e Geopolítica na Formação Nacional Brasileira - Everardo Adolpho Backheuser. Rio Claro: Tese de Doutoramento, UNESP, 2000.

. Geopolítica e Formação Territorial no Brasil. In: VITTE, A. C. (org.) Contribuições á História e à Epistemologia da Geografia, Rio de Janeiro: Bertrand Brasil, 2007.

ANSELMO, Rita de Cássia M. de S. E BRAY, Sílvio Carlos. Geografia e Geopolítica na formação Nacional Brasileira. In: GERARDI, Lúcia Helena e MENDES, Iandara Alves. Do Natural, do Social e de suas Interações: visões geográficas. Rio Claro: Unesp/AGETEO, 2002

ARANTES, Paulo Eduardo, 1997, Providências de um crítico literário na periferia do capitalismo. In: ARANTES, Otilia Fiori \& Paulo Eduardo. O Sentido da Formação - Três Estudos sobre Antônio Cândido, Gilda de Mello e Souza e Lúcio Costa. Rio de Janeiro: Paz e Terra.

ARAÚJO FILHO, José Ribeiro de. A Baixada do rio Itanhaém - Estudo de Geografia Regional. Boletim da Faculdade de Filosofia, Ciências e Letras da Universidade de São Paulo n. 116, Geografia n. 5. São Paulo, 1950.

------------ . O café, riqueza paulista. In: Boletim Paulista de Geografia, n 23, São Paulo, AGB/SP, 1956.

ARÓSTEGUI, Júlio, 2006, A pesquisa Histórica - Teoria e Método, Bauru: Edusc. 
ARRUDA, Maria Arminda. Pensamento brasileiro e sociologia da cultura: questões de interpretação. In: Tempo Social, Revista de Sociologia da USP, São Paulo, v. 16, n. 1, p. 107-118, 2004.

BASSIN, Mark. Solov'ev, and the "Frontier Hypothesis": The Nationalist Signification of Open Spaces. The Journal of Modern History, Vol. 65, No. 3 (Sep., 1993), pp. 473-511.

BERNARDES, Nilo. A colonização europeia no Sul do Brasil. Boletim Geográfico. Rio de Janeiro, IBGE, n. 109, julho/agosto 1952 .

. Expansão do povoamento no estado do Paraná. Revista Brasileira de Geografia , Separata. Rio de Janeiro, IBGE, n. 4 ano XIV, outubro/dezembro, 1952.

. Vultos da Geografia do Brasil: Leo Waibel. Revista Brasileira de Geografia, v. 14 n. 2. Rio de Janeiro, IBGE, abril-junho, 1952.

O pensamento geográfico tradicional. Revista Brasileira de Geografia, v. 44 n. 3. Rio de Janeiro, IBGE, julho/setembro, 1982a.

A influência estrangeira no desenvolvimento da Geografia do Brasil. Revista Brasileira de Geografia, v. 44 n. 3. Rio de Janeiro, IBGE, julho/setembro, $1982 \mathrm{~b}$.

BESSA, Vagner de Carvalho Bessa. Território e Desenvolvimento: as Ideologias Geográficas no Governo J.K. (19561960), São Paulo: Dissertação de Mestrado, DG/FFLCH/USP, 1994.

BIELSCHOWSKY, Ricardo. Pensamento econômico brasileiro: o ciclo ideológico do desenvolvimentismo. Rio de Janeiro: Contraponto, 2000.

BOMFIM, Paulo R. de Albuquerque. Território e Movimento Integralista:Uma Contribuição ao Estudo Das Ideologias Geográficas no Pensamento Autoritário Brasileiro das Décadas de 1920-1930. São Paulo, Dissertação de Mestrado, DG/FFLCH/USP, 2001.

período pós-64. São Paulo: Tese de Doutorado, DG/FFLCH/USP, 2007.

BRAY, Sílvio Carlos. O pensamento e o método na obra de Pierre Monbeig: análise dos trabalhos produzidos no Brasil nas décadas de 1930 e 1940. Revista Geografia, n 2. São Paulo: DG/FFLCH/USP, 1983.

BRUNHES, Jean. La Géographie Humaine: essai de classification positive. Paris: Alcan, 1927

CÂNDIDO, Antônio. A Educação pela Noite - e outros Ensaios. São Paulo: Ática, 1987.

A formação da literatura brasileira - momentos decisivos. Belo Horizonte/Rio de Janeiro: Itatiaia: 1997.

CANO, Wilson. Raízes da concentração Industrial em São Paulo. São Paulo: Difel, 1978.

. Desequilíbrios Regionais e Concentração Industrial no Brasil: 1930-1970. São Paulo: Global, Campinas: Ed. Unicamp, 1985. 
----------- . Base e Superestrutura em São Paulo (1886-1929). In: COSTA, Wilma Peres da \& DE LORENZO, Helena Carvalho (org.). A década de 1920 e as origens do Brasil moderno. São Paulo: Editora UNESP/FAPESP, 1997.

CAPEL, Horacio. 'Institucionalización de la geografía y estrategias de la comunidad científica de los geógrafos'. In: Geocrítica ${ }^{\circ}$ 8, Barcelona: Universidad de Barcelona, 1977.

Filosofía y ciencia en la geografía contemporánea. Barcelona, Barcanova, 1981. 508 p.

CARONE, Edgard. A Terceira República. Rio de Janeiro: Difel, 1976

BERNARDES, Nilo, 1982, 'A Influência Estrangeira no Desenvolvimento da Geografia no Brasil’ in: Revista Brasileira de Geografia, Rio de Janeiro, v. 44, n. 3, p. 519-527. jul/set.

BOWMAN, Isaiah. The Pionner Fringe. American Geographical Society, 1931

Limits of Land Settlement: a report on present-day possibilities, Books for Libraries Press (1937)

BOURDIEU, Pierre, 1989, O Poder Simbólico, Rio de Janeiro: Bertrand Brasil.

CARVALHO, Antônio Alfredo Teles de, 2001, Josué de Castro na Perspectiva da Geografia Brasileira - 1934/1956: Uma Contribuição a Historiografia do Pensamento Geográfico Nacional. Recife, Dissertação de Mestrado: Centro de Filosofia e Ciências Humanas/UFPE.

CARVALHO, José Murilo de, 1996, A Construção da Ordem/Teatro de Sombras, Rio de Janeiro: Relume Dumara.

CARVALHO, Carlos Delgado de, 1998, História Diplomática do Brasil, Brasília: Senado Federal.

CHARTIER, Roger. A história cultural: entre práticas e representações, Rio de Janeiro: Bertrand Brasil, 1990.

COSTA, Wanderley Messias, 1992, Geografia Política e Geopolítica - Discursos sobre Território e Poder, São Paulo: EDUSP: Hucitec.

COSTA, Wanderley Messias \& MORAES, Antônio Carlos R., 1999, Geografia Crítica: A Valorização do Espaço, São Paulo: Hucitec.

COSTA, Wilma Peres da \& DE LORENZO, Helena Carvalho (org.), 1997, A década de 1920 e as origens do Brasil moderno. São Paulo: Editora UNESP/FAPESP.

CORRÊA, Roberto Lobato, 1986, Região e Organização Espacial, São Paulo: Ática

CORTESÃO, Jaime, s.d., Alexandre de Gusmão e o Tratado de Madri. Parte I, t. I (1695-1735), Rio de Janeiro: Instituto Rio Branco.

D’ARAUJO, Maria Celina (Org), 1999, As Instituições brasileiras da Era Vargas, Rio de Janeiro: Fundação Getúlio Vargas. DECCA, Edgar Salvadori de, 1930 O Silêncio dos Vencidos - Memória, história e revolução, São Paulo:Brasiliense.

DEFFONTAINES, Pierre. “Geografia humana do Brasil”, Revista Brasileira de Geografia, v. 1, n. 1 (19-67), jan.-mar.; n. 2 (20-56), abr.-jun.; n. 3 (16-59), jul./set., Rio de Janeiro, IBGE, 1939 
-------- “Como se constituiu no Brasil a rede de cidades”, Boletim Geográfico, ano II, n. 14 (141-148), Rio de Janeiro, IBGE, maio 1944.

DELFOSSE, Claire, 1998, "Le rôle des institutions culturelles dans la diffusion des idées géographiques : l'exemple de Pierre Deffontaines (1894-1978)", in : Finisterra - Revista Portuguesa de Geografia v 33, n 65, Lisboa.

DELSON, Roberta Marx, 1997, Novas vilas para o Brasil-colônia: planejamento espacial e social no século XVIII, Brasília: Alva-Ciord.

DEMANGEON, Albert Pionniers et fronts de colonisation, Annales de géographie, vol. 41, A. Colin, Paris, p.631-636, 1932

Problèmes de géographie humaine. Paris: Armand Colin, 1942.

DIAS, Maria Odila Silva, 1986, “A interiorização da Metrópole” in: Carlos Guilherme Mota (org.) - 1822: Dimensões, São Paulo: Perspectiva.

DINIZ FILHO, Luiz Lopes Diniz, 1994, Território Nacional: Ideologias Geográficas e Políticas Territoriais no Estado Novo (1937-1945), São Paulo: Dissertação de Mestrado, DG/FFLCH/USP.

DOSSE, François, 2004, História e Ciências Sociais, Bauru: Edusc.

DROULERS, Martine \& THÉRY, Hervé, 1991, Pierre Monbeig - Un Géographe Pionnier, Paris: CREDAL.

ESCAMILLA, Francisco. El significado del término frontera Biblio $3 \mathrm{~W}$. No 140, 2 de marzo de 1999.

ESCOLAR, Marcelo, 1996, Crítica do Discurso Geográfico, São Paulo: Hucitec.

ESTERCI, Neide. O mito da democracia no país das bandeiras (análise simbólica dos discursos sobre migração e colonização do Estado Novo). Rio de Janeiro, Departamento de Antropologia do Museu Nacional, UFRJ, 1972. Dissertação de mestrado.

ETGES, Virgínia Elisabeta. Geografia Agrária: A Contribuição de Leo Waibel, São Paulo, Tese de Doutorado, DG/FFLCH/USP, 1997.

---------. Geografia Agrária: a contribuição de Leo Waibel. Santa Cruz do Sul, Edunisc, 2000. 226 p.

FAISSOL, Speridião. O Mato Grosso de Goiás. Rio de Janeiro, IBGE/CNG, 1952

“'O Núcleo Colonial Barão de Antonina (SP)”, Boletim Geográfico, n. 109, IBGE, jul-ago. 1952. 2 p.

----------. “O que é colonização?”, Revista Brasileira de Geografia, n. 3, IBGE, jul.-set. 1952. 5 p.

-----------. “Alguns aspectos do problema da colonização no Brasil”, Boletim Geográfico, n. 111, IBGE, nov.-dez. 1952. 22 pp.

FAUSTO, Boris, 2001, História do Brasil, São Paulo: Edusp/FDE.

FERNANDES, Florestan, 1976, Circuito Fechado: 4 ensaios sobre o "poder institucional”, São Paulo: Hucitec. 
----------- , 2002, A Revolução Burguesa no Brasil - Ensaio de Interpretação Sociológica, in: Silviano Santiago (coord.) Intérpretes do Brasil v.3, Rio de Janeiro: Nova Aguilar.

FERRAZ, Cláudio Benito de O.,1994, O Discurso Geográfico: a obra de Delgado de Carvalho no contexto da Geografia Brasileira (1913-1942), Dissertação de Mestrado, DG/FFLCH/USP.

FERREIRA, Darlene Aparecida de Oliveira. O mundo rural sob o ponto de vista geográfico: a trajetória da Geografia Agrária brasileira da década de 30 à de 90. Rio Claro, IGCE-Unesp, 1998. 389 p. Tese de doutorado.

. Mundo rural e Geografia. Geografia Agrária no Brasil: 1930-1990. São Paulo, Editora da Unesp, 2002. 262 p.

FERREIRA, Marieta de Moraes. "Diário pessoal, autobiografia e fontes orais: a trajetória de Pierre Deffontaines", International Oral History Conference (10:1998: Rio de Janeiro, RJ). Oral history challenges for the 21st century: proceedings [of the] X International Oral History Conference /Eds. Ilana Strozemberg [et al]. Rio de Janeiro: CPDOC/FGV/Casa Oswaldo Cruz, 1998. v.1, p.379-386.

FOUCHER, Michel, 1986, “L' Invention des Frontiéres: Un Modéle Géopolitique Français" in: Hérodote: revue de géographie et de géopolitique, Géopolitiques de la France, n 40, Paris.

----------, 1991, Fronts et Frontiéres - Un tour du monde Géopolitique, Paris: Fayard.

FOWERAKER, 1981

FREYRE, Gilberto, 2002, Introdução à História da Sociedade Patriarcal no Brasil: Casa Grande \& Senzala/ Sobrados \& Mucambos/ Ordem \& Progresso, in: Silviano Santiago (coord.) - Intérpretes do Brasil v. 2 e 3, Rio de Janeiro: Nova Aguilar.

------- , 2004, Nordeste - Aspectos e Influência da Cana sobre a Vida e a Paisagem do Nordeste do Brasil, São Paulo: Global Editora.

FURTADO, Celso, 2000, Formação Econômica do Brasil, São Paulo: Cia. Editora Nacional/PubliFolha.

GARCIA, João Carlos, 2002, (coord.). A mais dilatada vista do mundo: Inventário da Colecção Cartográfica da Casa de Ínsua, Lisboa: CNCDP.

GOMES, Angela de Castro. História e historiadores: a política cultural do Estado Novo. Rio de Janeiro, FGV, 1996.

GÓES FILHO, Synesio Sampaio, 2001, Navegantes, Bandeirantes e Diplomatas - Um ensaio sobre a formação das fronteiras do Brasil, São Paulo: Martins Fontes.

GERARD, 1959

GUIMARÃES, Fábio de Macedo Soares. "O planalto central e o problema da mudança da capital do Brasil", Revista Brasileira de Geografia, Rio de Janeiro, v. 11, n. 4 (471-542), Rio de Janeiro, IBGE, out.-dez. 1949.

HARTSHORNE, Richard, 1933, "Geographic and Political Boundaries in Upper Silesia" in: Annals of the Association of American Geographers n 23: 195-228. 
1936, 'Suggestions on the Terminology of Political Boundaries', Annals of the Association of American Geographers n 26(1): 56-7.

HARVEY, David, 1982, The Limits to Capital, Oxford: Blackwell Publishing.

---------, 2001, A Produção Capitalista do Espaço, São Paulo: Annablume

2004, Justice, Nature and the Geography of Difference, Oxford: Blackwell Publishing.

, 2006, Spaces of Global Capitalism - Towards a theory of uneven geographical development, New York/

London: Verso.

HENDERSON, George, 1998, "Nature and Fictitious Capital: The Historical Geography of an Agrarian Question" in: Antipode v.30 n 2, Malden/ Oxford: Blackwell Publishers.

HESPANHA, Antonio Manuel, 1986, "Centro e Periferia nas Estruturas Administrativas do Antigo Regime" in: Ler História - v. $8 \mathrm{n}^{\circ} 6$, Lisboa.

HEVILLA, María Cristina. El estudio de la frontera una aproximación bibliográfica. Biblio $3 W$ No 125, 24 de noviembre de 1998

San Juan (Argentina): el papel cambiante de una frontera. Scripta Nova, I Congreso Internacional de Geocrítica, 1999.

HOBSBAWM, Eric J., 1983, 'La crisis del siglo XVII’ in: Trevor Aston (ed.) Crisis en Europa, 1560-1660, Madri: Alianza Universidad.

---------, 1990, Nações e Nacionalismos desde 1780: Programa, Mito e Realidade, Rio de Janeiro: Paz e Terra.

---------, 1996, A Era das Revoluções (1789-1848), Rio de Janeiro: Paz e Terra.

HOLANDA, Sérgio Buarque de, 1979, "Um Mito Geopolítico: A Ilha-Brasil” in: Tentativas de Mitologia, São Paulo: Perspectiva.

,- 1986, O Extremo Oeste, São Paulo: Brasiliense: Secretaria de Estado da Cultura.

--------- , 1990, Monções, São Paulo: Brasiliense.

--------- , 1994, Caminhos e Fronteiras, São Paulo: Companhia as letras.

--------- , 2000, Visão do Paraíso - Os motivos edênicos no descobrimento e colonização do Brasil, São Paulo: Brasiliense/PubliFolha.

IANNI, Otávio, 1992, A Idéia de Brasil Moderno, São Paulo: Brasiliense.

IUMATTI, Paulo Teixeira, 2007, Caio Prado Jr. - Uma trajetória Intelectual, SãoPaulo: Brasiliense.

IUMATTI, Paulo; SEABRA, Manoel \& HEIDEMANN, Heinz Dieter (org.), 2008, Caio Prado Jr. e a Associação dos Geógrafos Brasileiros, São Paulo: AGB:IEB:Edusp. 
JONES, Stephen, 1959, "Boundary Concepts in Setting Time and Space", Annals of the Association of American Geographers n 49: 241-55.

KANTOR, Íris, 2007, “Usos Diplomáticos da Ilha-Brasil - Polêmicas Cartográficas e Historiográficas” in: Vária História, vol 23, n⿳⺈ 37, Janeiro/Junho, Belo Horizonte.

KATZAMN, Martin T. The Brazilian Frontier in Comparative Perspective. In: Comparative Studies in Society and History, Vol. 17, No. 3 (Jul., 1975), pp. 266-285

KOK, Maria da Glória Porto, 1998, O Sertão Itinirante: Expedições da capitania de São Paulo no século XVIII, São Paulo: Tese de Doutorado, DH/FFLCH/USP.

KRISTOF, Ladis D., 1959, "The Nature of Frontiers and Boundaries", in: Annals of the Association of American Geographers v 49 n 3 (part 1): 269-282.

LAHUERTA, Milton, 1997, 'Os intelectuais e os anos 1920: Moderno, Modernista, Modernização', in: COSTA, Wilma Peres da \& DE LORENZO, Helena Carvalho (org.), A década de 1920 e as origens do Brasil moderno. São Paulo: Editora UNESP/FAPESP.

LAPA, José Roberto do Amaral, 1973, Economia Colonial, São Paulo: Ed. Perspectiva.

----------, 2002, “O interior da Estrutura” in: Tamás Szmrecsányi (org.) - História Econômica do Período Colonial, São Paulo: Hucitec/EDUSP.

LENCIONI, Sandra. Região e Geografia. São Paulo, Edusp, 1999.

LENHARO, Alcir. Crise e Mudança na Frente Oeste de Colonização, Cuiabá: UFMT, 1982.

Colonização e Trabalho no Brasil: Amazônia, Nordeste e Centro-Oeste. Campinas: Unicamp, 1986.

Sacralização da Política. 2a ed. São Paulo: Papirus, 1986a.

LINHARES, M ${ }^{\text {a }}$ Yedda \& SILVA, Francisco Carlos T. História da Agricultura Brasileira, São Paulo: Brasiliense, 1981

LIMA, Nísia Trindade. Um Sertão chamado Brasil - Intelectuais e representação geográfica da identidade nacional, Rio de Janeiro: Revan, 1999.

LOMBARDI, Mary. The Frontier in Brazilian History: An Historiographical Essay. Pacific Historical Review, Vol. 44, No. 4 (Nov., 1975), pp. 437-457

MAIA, João Marcelo Ehlert, A Terra como Invenção - O espaço no pensamento social brasileiro, Rio de Janeiro: Jorge Zahar, 2008.

Os Sentidos do Oeste: Espaço, Imaginação Social e Construção do Estado. Trabalho apresentado no XIV Congresso Brasileiro de Sociologia. Rio de Janeiro, UFRJ, 28-31 de julho, 2009

-------. As Ideias que Fazem o Estado Andar: Imaginação Espacial, Pensamento Brasileiro e Território no Brasil Central. In: DADOS._Revista de Ciências Sociais, v 53 n 3, Rio de Janeiro, 2010 
MACHADO, Lia Osório. Mitos e Realidades da Amazônia Brasileira no Contexto Geopolítico Internacional (1540-1912), Barcelona: Tese de Doutorado, Departamento de Geografia, Universidade de Barcelona, 1989.

-. 'Origens do pensamento geográfico no Brasil: meio tropical, espaços vazios e a idéia de ordem (18701930)', in: CASTRO, I. et al (orgs.) Geografia Conceitos e Temas, Rio de Janeiro: Bertrand Brasil, 1995.

MACHADO, Mônica S., A Geografia Universitária Carioca e o Campo Científico - Disciplinar da Geografia Brasileira, São Paulo: Tese de Doutorado, DG/FFLCH/USP, 2002.

MACHADO, Monica Sampaio. A construção da Geografia Universitária no Rio de Janeiro. Rio de Janeiro: Apicuri, 2009.

MAGNOLI, Demétrio, 1997, O Corpo da Pátria - Imaginação Geográfica e Política Externa no Brasil (1808-1912), São Paulo: EdUNESP/Moderna.

MARTIN, André Roberto, 1992, Fronteiras e Nações, São Paulo: Contexto.

------- , 1993, As Fronteiras Internas e a Questão Regional do Brasil, São Paulo: Tese de Doutorado, DG/FFLCH/USP.

MARTINS, José de Souza, 1975, "Frente Pioneira: Contribuição para uma caracterização sociológica" in: Capitalismo e Tradicionalismo: Estudos sobre as Contradições da Sociedade Agrária no Brasil, São Paulo: Pioneira.

A reprodução do capital na frente pioneira e o renascimento da escravidão no Brasil. In: Tempo Social. Revista de Sociologia da USP, v 6, n 1-2, 1995

O cativeiro da terra. São Paulo: Contexto, 1979.

"A vida privada nas áreas de expansão da sociedade brasileira", in: Fernando Novais (dir.) \& Lília Moritz Schwarcz (org), História da Vida Privada no Brasil vol 4 - Contrastes da Intimidade Contemporânea, São Paulo: Cia das Letras, 1998

. Fronteira: A Degradação do Outro nos Confins do Humano, São Paulo: Hucitec, 2009

MATTOS, Ilmar Rohloff de. "Construtores e Herdeiros - A Trama de Interesses na Construção da Unidade Política" in: István Jancsó (org.) - Independência: História e Historiografia, São Paulo: Hucitec: FAPESP. 2005.

MEGALE, Januário Francisco, 1984 (org.), Maximilien Sorre: Geografia - Série Grandes Cientistas Sociais 46, São Paulo: Ática.

MELLO E SOUZA, Laura de. Formas provisórias de existência: a vida cotidiana nos caminhos, nas fronteiras e nas fortificações. In: NOVAIS, Fernando (dir.) e MELLO e SOUZA, Laura de (org). História da Vida Privada no Brasil vol 1. São Paulo: Cia das Letras, 1997.

----------- . O Sol e a Sombra - Política e administração na América Portuguesa do Século XVIII. São Paulo: Companhia das Letras, 2006.

MIGNOLO, Walter D. Historias Locales/Diseños Locales - Colonialidad, conocimientos subalternos y pensamiento fronterizo. Madrid: Ediciones Akal, 2003. 
- A colonialidade de cabo a rabo: o hemisfério ocidental no horizonte conceitual da modernidade. In: LANDER, Edgardo (og.) - A Colonialidade do Saber - Eurocentrismo e ciências sociais / Perspectivas Latino-Americanas. Buenos Aires: CLACSO, 2005.

MIKESSEL, Marvin W. Comparative Studies in Frontier History," Annals of the Association of American Geographers, vol. 50, no. 1 (March 1960), pp. 62-74

MINGHI, Julian. Boundary Studies in Political Geography. In: Annals of the Association of American Geographers n 53: 407-28, 1963.

MONBEIG, Pierre. Ensaios de geografia humana brasileira, São Paulo, Livraria Martins, 1940,294 p., 14 fotos (1 de Abousse Bastide; 1 de Lévi-Strauss; 3 de G. Bondar).

"Problemas morfológicos do Brasil tropical Atlântico", "White Settlers in the tropics", "Escarpas do Rio de Janeiro". In: Revista Brasileira de Geografia, ("Atividades geográficas"- reuniões da AGB), ano III, no 1, jan.-março 1941, pp.184-188.

. "O estudo geográfico das cidades". In: Revista do Arquivo Municipal, ano VII, v. LXXIII, janeiro 1941, pp. 5-38, 4 mapas e 1 gráfico.

La crise des sciences de l'homme, Rio de Janeiro, Casa do Estudante do Brasil, 1943

------. "Observação sobre o estado atual dos estudos geográficos no Brasil", Rumo, ano I, 4o trim., 1943.

"Estudos Geográficos", Boletim Geográfico, ano I, no 11, fevereiro 1944, pp. 7-11.

. "Notas relativas à evolução das paisagens rurais no Estado de São Paulo", Boletim Geográfico, ano II, no 16, julho 1944, pp. 428-430.

----------. "Seis anos de ensino de Geografia na Universidade de São Paulo", (co-autor João Dias da Silveira), Anais IX Congresso Brasileiro de Geografia, v. V, Rio de Janeiro, Conselho Nacional de Geografia, 1944.

-. "Guia para o estudo monográfico de uma fazenda". "Questionário para o estudo de uma cidade". A Excursão Geográfica, (Apêndice) - Guia do Professor. Biblioteca Geográfica Brasileira, Publicação n 1 da série C "Manuais". Rio de Janeiro, Conselho Nacional de Geografia, 1945, 84p.

. "O clima e o organismo humano", In: Boletim Geográfico, ano IV, no 37, Rio de Janeiro, abr. 1946, pp. 5-8

-. "O homem branco e o meio tropical Boletim Geográfico, ano V, n 50, maio 1947, pp.123-125).

-----------. "Geografia Humana dos países tropicais", Boletim Geográfico, (Resenhas e Opiniões), ano VI, no 60, março 1948, pp. 1459-1467.

"Évolution des genres de vie ruraux traditionnels dans le sud-est du Brésil", Annales de Géographie, t. LVIII, no 309, 1949, pp. 35-43, 6 photos (4 de J. Dias da Silveira et 2 de P. Monbeig e 1 carte).

----------. "Geografia", MORAES, Rubens B. \& BERRIEN, William, Manual Bibliográfico de Estudos Brasileiros, Rio de Janeiro, Gráfica Editora Souza, 1949. 
Pionniers et planteurs de l'État de São Paulo, Paris, Librarie Armand Colin, 1952, 376 p. (6 graphiques, 38 cartes, 46 photos, dont 9 IBGE, 1 de Ary França, 1 de S. Almeida, 1 de Mlle. Fava).

------------. La croissance de la ville de São Paulo, Revue de Géographie Alpine, Institute de Géographie Alpine, Grenoble, 1953, 94 p., 3 graphiques, 11 cartes, 12 photos (6 de M. Le Lannou).

"O problema de divisão regional de São Paulo", Aspectos Geográficos da Terra Bandeirante, Rio de Janeiro, Serviço gráfico do I.B.G.E, 1954, 295 p., 5 fotos (4 de Aziz Ab’Sáber, 1 sem autoria - 1 mapa).

Novos Estudos de Geografia Humana Brasileira, São Paulo, Difusão Européia do Livro, 1957, 248 p., 5 fotos sem autoria.

. "Une défense de la géographie appliquée", Annales. Économies, Sociétés, Civilisations, XVI année, no 6, nov.décembre 1961, pp. 1225-1229.

--. "Les franjes pionnières", Géographie générale, Encyclopédie de la Pléiade, Paris, Gallimard, 1966, pp. 9741005,3 cartes.

"Les capitaux et la géographie", Géographie générale, Encyclopédie de la Pléiade, Paris, Gallimard, 1966a, pp. 1515-1529, 1 carte.

. "Points de vue géographiques sur le sous-développement en Amérique latine", Annales de Géographie, LXXVI année, no 418, nov.-décembre 1967, pp. 704-713.

MONTEIRO, Carlos Augusto de Figueiredo. A Geografia no Brasil (1934-1977): avaliação e tendências. São Paulo: Instituto de Geografia/ FFLCH/USP, 1980.

----------------- . Geografia no Brasil ao Longo do Século XX: Um Panorama. In: O Borrador, n. 04. São Paulo: AGB, 2002.

MORAES, Antônio Carlos R. Ideologias geográficas -Espaço, Cultura e Política no Brasil. São Paulo: Hucitec, 1988.

. Foucault e a Geografia. In: Boletim Paulista de Geografia n ${ }^{\circ}$ 66, $1^{\circ}$ semestre. São Paulo: AGB, 1988a.

------------, 1991, “Notas sobre Identidade nacional e a Institucionalização da Geografia no Brasil”, in: $\underline{\text { Revista de Estudos }}$ Históricos, v 8, Rio de Janeiro.

, 2000, Geografia, capitalismo e meio ambiente, São Paulo: Tese de Livre-Docência, DG/FFLCH/USP.

--------- , 2000a, Bases da Formação Territorial do Brasil. O território colonial brasileiro no 'longo’século XVI, São

Paulo: Hucitec.

------------, 2002, Território e História no Brasil, São Paulo: Hucitec.

----------, 2003, “O Sertão: Um ‘Outro' Geográfico” in: Terra Brasilis - ano III-IV, nº4-5 - Território, Rio de Janeiro: GTHPG.

---------- , 2005, “Território, Poder e Justiça: comentários a partir da experiência brasileira” in: Raquel Kritsch \& Bernardo Ricupero (org) - Força e Legitimidade: Novas Perspectivas?, SãoPaulo: Humanitas. 
---------- , 2006, “Território, Região e Formação Colonial - Apontamentos em torno da Geografia Histórica da Independência Brasileira" in: Ciência e Ambiente ${ }^{\circ} 33$ julho/dezembro 2006, São Paulo.

----------- , 2009, Geografia Histórica do Brasil - Cinco Ensaios, Uma Proposta e Uma Crítica, São Paulo: Annablume.

MOREIRA, Ruy, 2001, “As Categorias Espaciais da Construção Geográfica das Sociedades” in: GEOgraphia - ano III, $\mathrm{n}^{\circ}$ 5, Niterói:UFF.

MOTA, Carlos Guilherme. Ideologia da cultura brasileira (1933-1974). São Paulo, Ática, 1978. 303 p.

NASH, Roy, 1926

NOVAIS, Fernando A., 1969, “Considerações sobre o sentido da Colonização” in: Revista do IEB/USP nº 6, São Paulo.

-------- 1986, “As dimensões da Independência” in: Carlos Guilherme Mota (org.) - 1822: Dimensões, São Paulo:

Perspectiva.

------ 2001, Portugal e Brasil na crise do Antigo Sistema Colonial (1777-1808), São Paulo: Hucitec.

NEIVA, Arthur Hehl. “Aspectos geográficos da imigração e colonização do Brasil”, Separata da Revista Brasileira de Geografia, n. 2, ano IX, jul. 1946, 21 p.

NEWMAN, David, 2002, "Boundaries" in: John Agnew, Katharyne Mitchell and Gerard Toal (eds) A Companion to Political Geography, Oxford: Blackwell.

----------, 2003, “On Borders and Power: A Theoretical Framework” in: Journal of Borderland Studies 18(1): 13-24.

----------, 2006, “Borders and Bordering: Towards an Interdisciplinary Dialogue”, in: European Journal of Social Theory 9

(2): 171-186.

NEWMAN, David and PAASI, Ansi, 1998, "Fences and Neighbours in the Post-Modern World: Boundary Narratives in Political Geography", in: Progress in Human Geography 22(2): 186-207.I

OLIVEIRA, Ariovaldo Umbelino de. Contribuição para o estudo da geografia agrária: crítica ao "Estado isolado" de von Thünen. São Paulo, Departamento de Geografia da FFLCH-USP, 1978. vols. 1 e 2. Tese de doutorado. . A agricultura camponesa no Brasil. São Paulo, Contexto, 1996.

OLIVEIRA, Lúcia Lippi, Velloso, Mônica Pimenta; GOMES, Ângela Maria Castro. Estado Novo: ideologia e poder. Rio de Janeiro, Zahar Editores, 1982.

OLIVEIRA, Lucia Lippi, 1990, A Questão Nacional na Primeira República,_São Paulo: Brasiliense.

-----------. Americanos: representações da identidade nacional no Brasil e nos EUA. Belo Horizonte: UFMG, 2000

---------. Natureza e identidade: o caso brasileiro. In: Desigualdade \& Diversidade - Revista de Ciências Sociais da PUCRio, no 9 ago/dez, 2011, pp. 123-134

ORTIZ, Renato, 1991, A Moderna Tradição Brasileira,São Paulo: Brasiliense.

-----------, 1994, Cultura Brasileira e Identidade Nacional, São Paulo: Brasiliense. 
------------, 2002, “As Ciência Sociais e a Cultura”, in: Tempo Social - Revista de Sociologia da USP v 14, n 1, São Paulo.

PAASI, Ansi, 2003, "Territory" in: John Agnew, Katharyne Mitchell and Gerard Toal (eds) A Companion to Political Geography, Oxford: Blackwell.

PEIXOTO MASSI, Fernanda Áreas. Estrangeiros no Brasil : a missão francesa na Universidade de São Paulo. Campinas, Dissertação de Mestrado, IFCH/Antropologia/Unicamp, 1991.

PENHA, Eli Alves Penha, 1993, A Criação do IBGE no Contexto de Centralização Política do Estado Novo, Rio de Janeiro: Fundação Instituto Brasileiro de Geografia e Estatística (FIBGE).

PETITJEAN, Patrick (dir.), Ciência nas Relações Brasil - França 1850-1950. São Paulo: Edusp, 1996

PEREIRA, José Veríssimo da Costa. A Geografia no Brasil. In: AZEVEDO, Fernando de (Org.). As Ciências no Brasil. V. I. 2 , Rio de Janeiro: Ed. UFRJ, 1994. p. 349-461.

PEREIRA, Diamantino Alves C.. Origens e Consolidação da Tradição Didática na Geografia Escolar Brasileira. São Paulo: Dissertação de Mestrado, DG/FFLCH/USP, 1990.

PEREIRA, Sérgio Luiz Nunes. Geografias - Caminhos e Lugares da Produção do Saber Geográfico no Brasil (1838-1922), São Paulo, Dissertação de Mestrado, DG/FFLCH/USP, 1997.

----------- Sociedade de Geografia do Rio de Janeiro: Origens, Obsessões e Conflitos (1883-1944), São Paulo: Tese de Doutorado, DG/FFLCH/USP, 2003.

PETRONE, Pasquale. Aspectos Geográficos da Área de Colonização Antiga do estado Espírito Santo. In: Anais da Associação dos Geógrafos Brasileiros, Avulso n. 3. São Paulo, 1962.

--------------- . A Baixada do Ribeira - Estudo de Geografia Humana. Boletim da Faculdade de Filosofia, Ciências e Letras da Universidade de São Paulo, n. 283, Geografia n. 14. São Paulo, 1966.

. Geografia Humana. In: FERRI, M. G. e MOTOYAMA, S. (org.). História das Ciências no Brasil. v. I São Paulo, EPU/Edusp, 1979

POUNDS, N.J.G, 1951, "The origins of the idea of national frontier in France", in: Annals of the Association of American Geographers n 41

---------, 1954, "France and 'les limites naturelles' from the seventeenth to the twentieth centuries" in: Annals of the Association of American Geographers n 44.

PÓVOA NETO, Helion, 1998, No Caminho das Pedras: Itinerários na Formação da Mobilidade Garimpeira em Goiás, São Paulo: Tese de Doutorado, DG/FFLCH/USP.

PRADO Jr., Caio. Problemas de povoamento e divisão da propriedade rural (1946). In: Evolução política do Brasil e outros estudos. 10. ed. São Paulo, Brasiliense, 1977.

. História econômica do Brasil. 37. ed. São Paulo, Brasiliense, s/d. 
--------- . Formação do Brasil Contemporâneo. In: Silviano Santiago (coord.) - Intérpretes do Brasil v. 2 e 3, Rio de Janeiro: Nova Aguilar, 2002.

PRATT, Mary-Louise. Os olhos do império : relatos de viagem e transculturação. Bauru: EDUSC, 1999.

PRESCOTT, J. R. V.The Geography of Frontiers and Boundaries, London: Hutchinson University Library. 1965.

Political Frontiers and Boundaries. Chicago: Aldine, 1987.

QUAINI, Massimo. A Construção da Geografia Humana, Rio de Janeiro: Paz e Terra, 1983.

QUIJANO, Aníbal. Colonialidade do poder, eurocentrismo e América Latina. In: Edgardo Lander (og.) A Colonialidade do

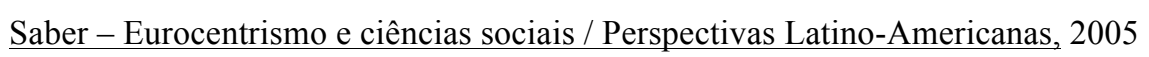

RAFFESTIN, Claude. Pour une Geographie du Pouvoir, Paris: Librairies Techniques, 1980.

RAIMUNDO, Sílvia Lopes. A Invenção do Mito Bandeirante. Tradição e Pensamento Regionalista na Historiografia Paulista das Décadas de 1920-1930, São Paulo: Dissertação de Mestrado, DG/FFLCH/USP, 2001.

RANKIN, K. J.\& SHOEFIELD, R., The Troubled Historiography of Classical Boundary Studies. In: Mapping Frontiers, Plotting Pathways Ancillary Paper No. 2, Dublin/ Belfast, 2004.

REIS FILHO, Nestor Goulart. Contribuição ao estudo da evolução urbana no Brasil (1500-1720). São Paulo: Pioneira/EDUSP, 1968.

RUMLEY, Denis, and MINGHI, Julian. The border landscape concept. In: The Geography of Border Landscapes, Dennis Rumley and Julian Minghi (org.) London: Routledge, 1991.

ROCHA, Genylton Odilon Rêgo da. A Trajetória da Disciplina Geografia no Currículo Escolar Brasileiro (1837-1942), São Paulo: Dissertação de Mestrado, Faculdade de Educação, PUC-SP, 1996.

RUDZIT,Gunther. Processo de Formação do Oficial do Exército Brasileiro e a Geografia (1850-1930), São Paulo, DG/FFLCH/USP, 1997.

SACK, Robert David. Human Territoriality - Its theory and history, Londres: Cambridge University Press, 1986.

SALGUEIRO, Heliana Angotti (org.) Pierre Monbeig e a Geografia Humana Brasileira - A dinâmica da transformação, Bauru: Edusc, 2006.

SANTIAGO, João Phelipe Santiago. A Questão Nacional na Geografia Ratzeliana e sua Assimilação no Pensamento Social Brasileiro na República Velha, São Paulo: Tese de Doutorado, DG/FFLCH/USP, 2005.

SANTOS, Milton. Sociedade e Espaço: A Formação Social como Teoria e como Método, In: Boletim Paulista de Geografia n. ${ }^{\circ} 54$ junho/77. São Paulo:AGB, 1977.

. Espaço e Sociedade (Ensaios), Petrópolis: Vozes, 1979.

Espaço e Método, São Paulo: Nobel, 1985.

. 'O Espaço como Categoria Filosófica' in: Revista Terra Livre 5 - Espaço em Questão. São Paulo: AGB, 1988. 
------------ . Pensando o Espaço do Homem, São Paulo: Hucitec, 1997.

. A Natureza do Espaço. Técnica. Tempo. Razão e Emoção, São Paulo: EDUSP, 2002.

---------- . Por uma Geografia Nova. Da Crítica da Geografia à Geogeafia Crítica, São Paulo: Hucitec/Edusp, 2002a.

SANTOS, Milton \& SILVEIRA, María Laura. O Brasil: Território e Sociedade no início do século XXI, Rio de Janeiro: Record, 2001.

SARETTA, Fausto. O Governo Dutra na transição capitalista no Brasil. Inn: SZMRECSÁNYI, Tamás e SUZIGAN, Wilson (orgs.). História econômica do Brasil contemporâneo. 2. ed. rev. São Paulo, Hucitec/Associação Brasileira de Pesquisadores em História Econômica/Editora da Universidade de São Paulo/Imprensa Oficial, 2002. p. 99-117.

SCARIM, Paulo César. Coetâneos da Crítica. Uma Contribuição ao Estudo do Movimento de Renovação da Geografia Brasileira, São Paulo: Dissertação de Mestrado, DG/FFLCH/USP, 2001

SCHWARTZMAN, Simon; BOMENY, Helena Maria Bousquet; COSTA, Vanda Maria Ribeiro. Tempos de Capanema. São Paulo, Paz e Terra/FGV, 2000. 405 p.

Estado novo: um auto-retrato. Brasília: UNB, Arquivo Gustavo Capanema, 1983.

SECRETO, Maria Verônica. A ocupação dos "espaços vazios" no governo Vargas: do "Discurso do rio Amazonas" à saga dos soldados da borracha. In: Revista Estudos Históricos. Rio de Janeiro: CPDCOC/FGV

SPOSITO, Eliseu Savério, 2000, Contribuição à Metodologia de Ensino do Pensamento Geográfico, Tese de Livre Docência: Presidente Prudente/UNESP.

SILVA, Aldo Aloísio Dantas da, 2002, Conexidade, Complexo Geográfico de La Blache e de Pierre Monbeig, São Paulo: Tese de Doutorado, DG/FFLCH/USP.

SILVA, Armando Correa da, 1978, O Espaço Fora do Lugar, São Paulo: Hucitec.

,1986, De Quem é o Pedaço? Espaço e Cultura, São Paulo: Hucitec.

,1986a, “As Categorias como Fundamentos do Conhecimento Geográfico” in: Milton Santos e Maria Adélia A. Souza (org.) - O Espaço Interdisciplinar, São Paulo: Nobel.

, 1991, Geografia e Lugar Social, São Paulo: Contexto.

SILVA, Jorge Luiz Barcellos da, 1996, Notas Introdutórias de um Itinerário Interpretativo sobre a Formação do Pensamento Geográfico Brasileiro, São Paulo: Dissertação de Mestrado, DG/FFLCH/USP.

SILVA, Lígia Ma Osório, 1996, Terras Devolutas e Latifúndio. Efeitos da lei de 1850, Campinas/ São Paulo: Ed. Unicamp. , 2001, A Fronteira e outros Mitos, Campinas: Tese apresentada para o concurso de Docente Depto. de Política e História Econômica, IE/Unicamp.

SILVA, Francisco Carlos Teixeira da, 2002, "Pecuária, Agricultura de Alimentos e Recursos Naturais no Brasil-Colônia" in: Tamás Szmrecsányi (org.) - História Econômica do Período Colonial, São Paulo: Hucitec/EDUSP. 
SMITH, Neil, 2008, Uneven Development - Nature, Capital, and the production of Space, Athens/ London: The University of Georgia Press.

SOJA, Edward, Geografias Pós-Modernas - A Reafirmação do espaço na Teoria Social Crítica, Rio de Janeiro: Jorge Zahar. SORRE, Maximilien, 1955, Les Migrations des Peuples, Paris: Flammarion.

SOUSA NETO, Manoel Fernandes de, 1997, Senador Pompeu: Um Geógrafo do Poder No Império Do Brasil, São Paulo, DG/FFLCH/USP.

------------ , 2004, Planos para o Império: Os Planos de Viação do Segundo Reinado (1869- 1889), São Paulo: Tese Doutorado, DG/FFLCH/USP.

SOUZA, Candice Vidal e, 1997, A Pátria Geográfica: Sertão e Litoral no pnesamento Social Brasileiro, Goiânia:UFG.

------------ , 1998, "Fronteira no Pensamento Social Brasileiro: O Sertão Nacionalizado" in: Sociedade e Cultura v 1 n 1 (Janeiro/Junho), Rio de Janeiro.

TAYLOR, Peter. 1994. "The state as container: territoriality in the modern world-system." in: Progress in Human Geography 18, 151-62.

TOTA, Antonio Pedro. O imperialismo sedutor: a americanização do Brasil na época da Segunda Guerra. São Paulo, Companhia das Letras, 2000. $235 \mathrm{p}$.

VALVERDE, Orlando. "Excursão à Região Colonial Antiga do Rio Grande do Sul”, Revista Brasileira de Geografia, n. 4, ano X, Rio de Janeiro, IBGE, 1948.

. Planalto Meridional do Brasil. Guia da Excursão n.o 9, realizada por ocasião do XVIII Congresso Internacional de Geografia. Rio de Janeiro, CNG, 1957c.

_ “A geografia agrária como ramo da geografia econômica”, Revista Brasileira de Geografia, ano XXIII, n. 2 (170172), abr.-jun. 1961.

- "Contribuição de Leo Waibel a Geografia Brasileira", in Revista Brasileira de Geografia, ano XXX, n. 1, janeiro/março, 1968.

VELHO, Otávio Guilherme. Frentes de Expansão e Estrutura Agrária . Rio de Janeiro: Zahar, 1972

Capitalismo autoritário e campesinato. São Paulo/Rio de Janeiro, Difel, 1979. 261 p.

VELLOSO, Monica Pimenta. A brasilidade verde-amarela: nacionalismo e regionalismo paulista. Textos CPDOC, 1, 1990.

VELLOSO, Mônica Pimenta. Cultura e poder político: uma configuração do campo intelectual. In: OLIVEIRA, Lúcia Lippi, VELlOSO, Mônica Pimenta; GOMES, Ângela Maria Castro. Estado Novo: ideologia e poder. Rio de Janeiro, Zahar Editores, 1982. p. 71-108.

VESSENTINI, José William, 1996, A Capital da Geopolítica, São Paulo: Ática. 
VLACH, Vânia R. Farias. A propósito do ensino de Geografia: em questão o nacionalismo patriótico. São Paulo, FFLCHUSP, 1988, 206 p. Dissertação de mestrado.

WAIBEL, Leo H.. "A teoria de von Thünen sôbre a influência da distância do mercado relativamente à utilização da terra: sua aplicação a Costa Rica", Revista Brasileira de Geografia. 10 (1): 3-40, Rio de Janeiro, IBGE, 1948.

_. "A vegetação e o uso da terra no Planalto Central", Revista Brasileira de Geografia, ano 10, n. 3 (335-380), Rio de Janeiro, IBGE, 1948.

. "Princípios da colonização européia no sul do Brasil", Revista Brasileira de Geografia, ano 11, n. 2 (159-222), Rio de Janeiro, IBGE, 1949.

. “O que aprendi no Brasil”, Revista Brasileira de Geografia, Rio de Janeiro, IBGE, jul.-set. 1950.

. “As zonas pioneiras do Brasil”, Revista Brasileira de Geografia, ano XVII, n. 4 (3-36), Rio de Janeiro, IBGE, out.dez. 1955.

. Capitulos de Geografia Tropical e do Brasil. Rio de Janeiro, IBGE, 1958.

. "Determinismo geográfico e geopolítica (contribuição ao problema da mudança

da capital)", Boletim Geográfico, n. 164 (612-617), Rio de Janeiro, IBGE, 1961.

WALLERSTEIN, Immanuel 1974, The Modern World System (tomo I), San Diego/Nova Iorque: Academic Press.

---------- , 2001, Capitalismo Histórico \& Civilização Capitalista, Rio de Janeiro: Contraponto.

WEGNER, Robert, 2000

WILSON, Thomas \& DONNAN, H., (org), 1998, Border Identities: Nation and State at International Frontiers, Cambridge: Cambridge University Press.

ZARUR, Jorge. "Geografia: ciência moderna ao serviço do homem”, Revista Brasileira de Geografia, Rio de Janeiro, IBGE, jul.-set. 1944. p. 5-18.

ZUSMAN, Perla Brígida Zusman, 1996, Sociedades Geográficas na Promoção do Saber ao Respeito do Território: estratégias políticas e acadêmicas das instituições geográficas na Argentina (1879-1942) e no Brasil (1838-1945), São Paulo, Dissertação de Mestrado, PROLAM/ USP.

Representaciones, imaginarios y conceptosen torno a la producción material de las fronteras. Reflexiones a partir del debate Hevilla-Escamilla. Biblio 3W. Revista Bibliográfica de Geografía y Ciencias Sociales. Universidad de Barcelona, $\mathrm{n}^{\circ}$ 149, 25 de marzo de 1999

ZUSMAN, Perla; PEREIRA, Sérgio Luiz Nunes. "Entre a ciência e a política: um olhar sobre a Geografia de Delgado de Carvalho" Terra Brasilis, ano 1, n. 1 (50-81), jan.-jun. 2000.

-----------, 2000, Tierras para El Rey. Tres Fronteras y la Construcción del Territorio del Rio de la Plata (1750-1790), Bellaterra: Tese de Doutorado, DG/Universidade Autônoma de Barcelona. 